UNIVERSIDADE DE SÃO PAULO

FACULDADE DE FILOSOFIA, LETRAS E CIÊNCIAS HUMANAS

DEPARTAMENTO DE LINGUÍSTICA

PROGRAMA DE PÓS-GRADUAÇÃO EM SEMIÓTICA E LINGUÍSTICA GERAL

Uma história serial e conceitual da gramática brasileira oitocentista de língua portuguesa

(versão corrigida)

Bruna Soares Polachini 


\author{
UNIIVERSIDADE DE SÃO PAULO \\ FACULDADE DE FILOSOFIA, LETRAS E CIÊNCIAS HUMANAS \\ DEPARTAMENTO DE LINGUÍSTICA \\ PROGRAMA DE PÓS-GRADUAÇÃO EM SEMIÓTICA E LINGUÍSTICA GERAL
}

\title{
Uma história serial e conceitual da gramática brasileira oitocentista de língua portuguesa
}

(versão corrigida)

Bruna Soares Polachini

Tese apresentada ao Programa de PósGraduação em Semiótica e Linguística Geral do Departamento de Linguística da Faculdade de Filosofia, Letras e Ciências Humanas da Universidade de São Paulo, para obtenção do título de Doutor em Letras.

De acordo

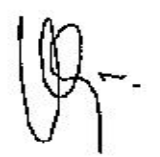


Autorizo a reprodução e divulgação total ou parcial deste trabalho, por qualquer meio convencional ou eletrônico, para fins de estudo e pesquisa, desde que citada a fonte.

Catalogação na Publicação

Serviço de Biblioteca e Documentação

Faculdade de Filosofia, Letras e Ciências Humanas da Universidade de São Paulo

Ph Polachini, Bruna brasileira oitocentista de língua portuguesa / Bruna Polachini ; orientadora Olga Coelho. - São Paulo, 2018 .

$458 \mathrm{f}$.

Tese (Doutorado)- Faculdade de Filosofia, Letras e Ciências Humanas da Universidade de São Paulo. Departamento de Linguística. Área de concentração: Semiótica e Lingüística Geral.

1. Historiografia Linguística. 2. Gramáticas Brasileiras. 3. Século XIX. 4. Verbo substantivo. I. Coelho, Olga, orient. II. Título. 


\section{Agradecimentos}

A todos que de alguma forma se moveram para que esta tese pudesse ser construída - do motorista do ônibus que me levou à USP tantas vezes aos editores dos livros que pude ler -, pois, certamente, ela é fruto de imensa generosidade proveniente de inúmeros gestos que, por seu aspecto rotineiro, poderiam facilmente passar despercebidos.

Ao CNPq pela bolsa concedida durante os quarenta e oito meses de pesquisa.

A Olga Coelho pela orientação certeira, precisa e essencial nesse longo período (e também à orientação anterior no mestrado).

A Pierre Swiggers e Ton Van Hal, que me orientaram por dois meses na KU Leuven (Bélgica), lendo meus relatórios e comentando-os detalhadamente, além de possibilitarem que eu tivesse acesso a diversos livros e textos presentes na biblioteca da universidade. A Peter Lauwers pela leitura cuidadosa de meu relatório e úteis apontamentos.

A Cristina Altman e a Maria Helena de Moura Neves pela leitura de meu relatório e pelos comentários valiosos realizados, quando banca de meu exame de qualificação.

À banca de defesa e, assim, novamente, a Pierre Swiggers e Cristina Altman, pelos gentis, estimulantes e, sem dúvida, interessantes comentários. A Marilza de Oliveira, pela pronta, cuidadosa e detalhada leitura da tese. A José Borges Neto pela gentileza de me trazer material que poderia acrescentar à tese. A Luiz Francisco Dias pelo olhar analítico e crítico que me deu sobre a análise direcionada para o conteúdo.

A Alessandro Beccari, Edgard Bikelis e Jaci Brasil Tonelli pelas traduções concedidas, respectivamente, do grego, do latim e do francês.

A Erica, Denise e Robson pelo pronto auxílio sempre que necessário.

A Renata Moreira e Fernanda Canever por me acompanharem na empreitada de ser RD do nosso Programa de pós; "trabalhar junto" é uma expressão que tomou novo (e melhor) valor após nossa experiência.

Aos colegas de organização do Tardes de Linguística Andressa Toni, Bruno Guide, Rodrigo Madrid, Suzana Fong, pelas nossas longas discussões a respeito de maneiras de tornar a pósgraduação em Linguística mais atrativa, interessante e prazerosa para nossos colegas.

Aos queridos, antigos e novos, colegas do $\mathrm{CEDOCH}$, pelas reuniões profícuas, pelos eventos realizados e pelas indispensáveis risadas: Edgard Bikelis, Ênio Sugiyama, José Bento Vidal Neto, Julia de Crudis Rodrigues, Karina Oliveira, Lygia Testa, Mariana Viel, Olívia Yumi, Patrícia Souza Borges, Roberta Ragi, Rodrygo Tanaka, Stela Maris Danna, Wellington Santos.

Às amigas e co-moradoras do Jaguaré, Janayna e Larissa, por me darem a experiência de viver com amigas, o que, agora, me parece imprescindível num período tão forçosamente introspectivo como é a pós-graduação. À Jaci por apoiar com carinho e atenção esse doutorado. Aos queridos amigos, pelos dias compartilhados: Aline, Amanda, Bianca, Cássio, Gustavo, Joyce, Jéssica, Julia, Júlia, Natália, Nathália, Patrícia, Renan, Stela, Ted.

Por último, mas certamente não menos importante, enfatizo meu agradecimento aos meus pais, Alita e Renato, aos meus irmãos, Íris e Renato, e à minha cunhada, Saarah, que sempre apoiaram (emocionalmente e financeiramente) minhas decisões profissionais sem quaisquer ressalvas, fomentando um especial sentimento de liberdade sem o qual eu não poderia realizar esta tese desta maneira (a parte boa, claro, as falhas são todas minhas). 
Tudo permanecerá

Do jeito que tem sido

Transcorrendo,

transformando

Tempo e espaço navegando

Em todos os sentidos

(Gilberto Gil) 
RESUMO: Nesta tese, que se propôs a explorar as gramáticas brasileiras do português publicadas no século XIX, tivemos três objetivos. O primeiro foi realizar um mapeamento exaustivo da produção gramatical brasileira do português do século XIX, o qual foi feito por meio de fontes secundárias e catálogos de bibliotecas. Tivemos conhecimento de 127 títulos e 77 reedições, o que resulta em duzentas gramáticas. A partir dos dados coletados, que, em geral, eram título, subtítulo, autor, ano de publicação, local e casa impressora, formalizamos unidades de análise para, ao relacioná-las, por meio da metodologia da História Serial (Furet 1991, Barros 2005), realizar um mapeamento descritivo e interpretativo dessa produção. Nosso segundo objetivo, tendo selecionado, com base em quatro critérios combinados (prestígio, emergência, institucionalização e diálogo), dezoito exemplares (16 títulos, 2 reedições) dos duzentos e quatro de que tivemos conhecimento, foi de realizar uma análise orientada para os conteúdos dessas obras, organizada em torno de uma possível rede conceitual. A hipótese dessa análise, baseada em Auroux (2009[1992]) e Swiggers (2010), é de que alguns conceitos poderiam ser eixo de uma rede conceitual devido à sua influência técnica e, eventualmente teórica, em uma determinada tradição de descrição linguística. Essa hipótese surgiu nos resultados de nossa pesquisa de mestrado, em que, ao notar a complexidade da dimensão técnica (cf. Swiggers 2004) de algumas obras dessa tradição, pensamos ser necessário procurar meios de tornar sua análise mais homogênea (cf. Polachini 2013, Polachini 2016). Para testá-la, examinamos o conceito-chave de 'verbo substantivo' apresentado nas obras selecionadas, que são amiúde influenciadas pela tradição da grammaire générale francesa, ao menos até 1880, quando passa a haver também influência do método histórico-comparativo (cf. Maciel 1910, Nascentes 1939, Elia 1975, Cavaliere 2001, Parreira 2011, Polachini 2013). Ademais, foi necessário formalizar uma metodologia a fim de reconhecer a rede conceitual em torno do 'verbo substantivo'. Primeiramente, definimos conceitos gramaticais como sendo formados por meio de processos classificatórios da cadeia falada. Tais processos têm como produto, por um lado, termos, e, por outro, conceitos. Estes últimos podem ser analisados intensionalmente, por meio de sua definição e seu lugar numa determinada taxonomia, ou extensionalmente, considerando o inventário de dados linguísticos eleitos como exemplos e eventuais ilustrações desses dados em uso. Cada conceito é, portanto, analisado por meio das seguintes categorias: definição, taxonomia, exemplos, ilustrações e por seus termos. Consideramos rede conceitual as relações travadas entre o conceito-chave, 'verbo substantivo', e conceitos que, na tradição da grammaire générale teriam já alguma relação com o 'verbo substantivo' (cf. Chevalier 1968; Colombat 1992; Raby 2000; Bouard 2007), a saber: gramática e linguagem, metaclasses e classes de palavras, modificadores do nome, verbo, oração (seus elementos e sua organização) apresentadas nas obras. Essas relações podem ser de quatro tipos: (1) equivalência; (2) intersecção (3) subordinação; (4) base teórica comum. Finalmente, distinguimos no texto gramatical a descrição linguística, que chamamos de texto, e as ampliações, reflexões ou críticas realizadas sobre essa descrição, que chamamos de metatexto. Tal metodologia nos permitiu uma visão mais clara e homogênea da dimensão técnica das obras (e de seu eventual ecletismo), além de proporcionar uma visão mais complexa de continuidades e descontinuidades dessa produção, que contrasta com aquelas das revisões históricas. Ademais, os resultados apontam também para: relações entre agendas dos autores ao publicarem suas gramáticas e seu ecletismo. Nossa terceira proposta foi de que esta tese fosse não apenas uma historiografia, mas também uma epihistoriografia dessa tradição. Assim, apresentamos dois apêndices: um com informações catalográficas das 204 gramáticas de que tivemos conhecimento, organizadas cronologicamente; e outro com os paratextos das dezoito obras analisadas.

Palavras-chave: Historiografia Linguística; Gramáticas brasileiras do século XIX; História Serial; Rede conceitual; Verbo substantivo. 
ABSTRACT: In this thesis, which approached the Brazilian grammars of Portuguese published in the 19th century, we had three objectives. The first one was to conduct a comprehensive mapping of the Brazilian grammatical production on Portuguese in the 19th century, which we carried out through secondary sources and library catalogs. We have acknowledged 127 titles and 77 re-editions, which total two hundred grammars. From the data collected, which generally consisted of title, subtitle, author, year published, publisher city and publisher name, we built standardized units of analysis so that, when analyzing their relations among one another, we conducted a descriptive and interpretative mapping of this production, adopting the methodology of Serial History (Furet 1991, Barros 2005). By selecting eighteen grammars (16 titles, 2 re-editions) out of the acknowledged two hundred works, based on four combined criteria (prestige, emergence, institutionalization and dialog), our second object was to carry out an analysis oriented to the content of these selected works, organized under a possible conceptual network. The hypothesis of this analysis, based on Auroux (2009[1992]) and Swiggers (2010), is that some concepts could work as an axis of a conceptual network due to their technical, and sometimes theoretical, influence on a specific tradition of linguistic description. This hypothesis was raised in the results of our master's research, in which, by realizing the complexity of some of this tradition's grammars' technical dimension (cf. Swiggers 2004), we thought it to be necessary to find ways of turning the analysis more homogeneous (cf. Polachini 2013, Polachini 2016). In order to test its effectiveness, we examined the key concept of 'verbo substantivo' (literally: 'substantive verb'), presented in the selected works, which are frequently influenced by the tradition of the French grammaire générale, at least until 1880, when the influence of the historical-comparative method started to take place (cf. Maciel 1910, Nascentes 1939, Elia 1975, Cavaliere 2001, Parreira 2011, Polachini 2013). Moreover, it was necessary to formalize a methodology in order to recognize the conceptual network around the 'verbo substantivo'. First, we defined the grammatical concepts as being formed through classifying processes of spoken speech. These processes have as products, on one side, terms and, on the other, concepts. The latter can be analyzed intentionally, through its definition and its places in a specific taxonomy, or extensionally, considering the inventory of linguistic data considered as examples and any illustrations of these data in use. Each concept is, therefore, analyzed through the following categories: definition, taxonomy, examples, illustrations and by its terms. We considered as conceptual network the relations between the key concept, 'verbo substantivo', and concepts that, in the grammaire génerale's tradition would already have some relation to the 'verbo substantivo' (cf. Chevalier 1968; Colombat 1992; Raby 2000; Bouard 2007), such as: grammar and language, metaclasses and parts of speech, noun modifiers, verb, clause (its elements and organization) presented in the grammars. These relations can be of three types: (1) identity; (2) intersection; (3) subordination; (4) shared theoretical background. Finally, in the grammatical text, we distinguished the linguistic description, which we called text, from its expansions, reflections and critical comments on this description, which we called metatext. Such methodology allowed a clearer and more homogeneous view of the technical dimension of the works analyzed (and their often eclecticism), in addition to providing a more complex view of continuities and discontinuities of this production, which contrasts with those of the historical reviews. Furthermore, the results also point to: relations between the authors' schedules when publishing their grammars and their eclecticism; and the metatext's role between teaching and linguistic reflection. Our third objective was to make this thesis not only a historiography but also a epihistoriography of this tradition. Thus, we presented two appendices: one with cataloging information of the two hundred grammars which we acknowledged, organized chronologically; and another one with the paratexts of the eighteen works analyzed.

Keywords: Linguistic Historiography; 19th-century Brazilian grammars; Serial History; Conceptual Network; Noun verb. 


\section{SUMÁRIO}

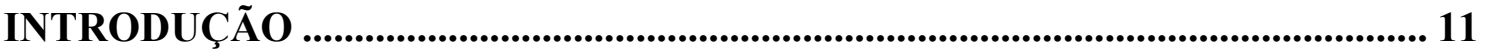

CAPÍTULO 1| Fundamentos teóricos........................................................................ 19

1.1. Lacunas e possibilidades da historiografia linguística........................................... 19

1.2. (Meta-)metalinguagem e conceptualização ........................................................ 24

1.3. Continuidade e descontinuidade, homogeneidade e heterogeneidade .................. 30

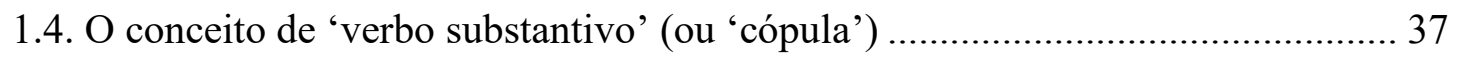

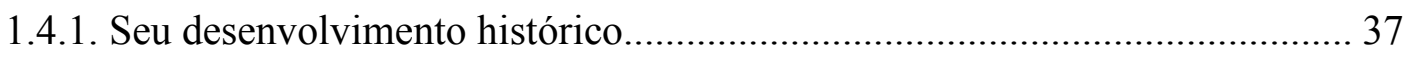

1.4.2. Relações do 'verbo substantivo' com outros conceitos na tradição da

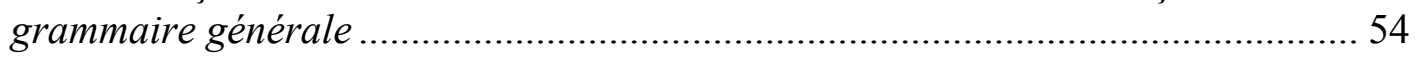

1.5. Sobre as revisões históricas da gramaticografia brasileira do português.............. 57

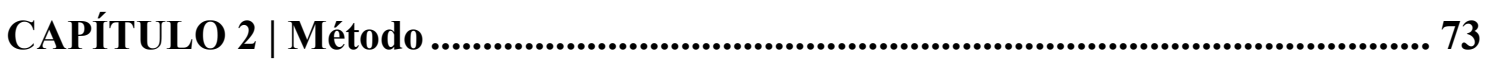

2.1. Levantamento de gramáticas brasileiras do português do século XIX .................. 73

2.1.2. A seleção de obras para análise: critérios combinados ................................. 74

2.2. Critérios para a análise orientada para o contexto …………………………......... 80

2.2.1. História Serial: concebendo um mapa........................................................ 80

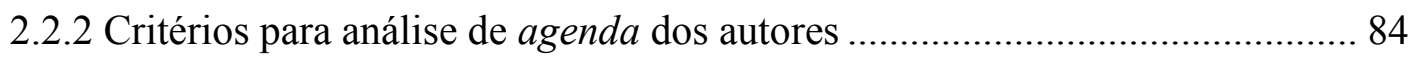

2.3. Critérios para análise direcionada para o conteúdo: conceitos e rede conceitual 85

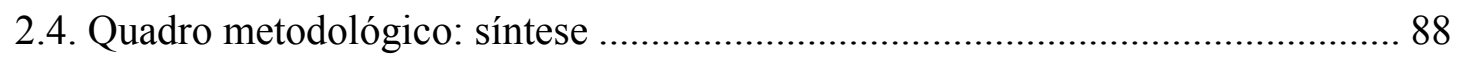

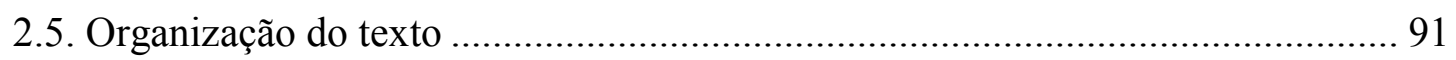

CAPÍTULO 3 | Análise orientada para contexto...................................................97

3.1. História Serial: mapeamento baseado em dados contextuais das gramáticas...... 97

R1. Gramáticas publicadas por década .............................................................. 98

R2. Reedições das gramáticas: prestígio e durabilidade .......................................... 98

R3. A publicação de gramáticas em diferentes regiões......................................... 108

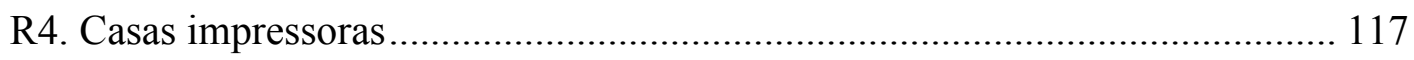

R5. Escolhas de títulos ao longo do século ..................................................... 120

R6. Subtítulos: formato, conteúdo e objeto das gramáticas .................................. 128

R7. Subtítulos: público-alvo e dedicatórias.......................................................... 132

3.2. Análise de agenda ….................................................................................. 138

3.2.1. Antonio Morais Silva, Epitome da grammatica de lingua portugueza (1806,

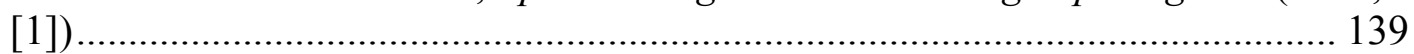

3.2.2. Ignacio Felizardo Fortes, Arte da grammatica portugueza (1816, [4]) ...... 142

3.2.3. Antonio da Costa Duarte, Compendio da grammatica portugueza (1829, [10]) e Compendio de grammatica philosophica da lingua portugueza (1859, [44])

3.2.4. Antonio Alvares Pereira Coruja, Compendio da Grammatica da Lingua Nacional (1835, [16]; 1873, [92]) ..................................................................... 146 
3.2.5. Raymundo Camara Bithencourt, Epitome da grammatica philosophica da lingua portugueza $(1862,[50])$

3.2.6. Francisco Sotero dos Reis, Grammatica portugueza accomodada aos princípios geraes da palavra seguidos de immediata aplicação pratica (1877, [106])

3.2.7. Ernesto Carneiro Ribeiro, Grammatica Portugueza Philosophica (1881, [120]) e Serões Grammaticaes ou Nova Grammatica Portugueza (1890, [171]) 151

3.2.8. Julio Cezar Ribeiro Vaughan, Grammatica Portugueza (1881, [123]; 1885, [143])

3.2.9. Maximino de Araujo Maciel, Grammatica Analytica (1887, [152]) e Grammatica Descriptiva (1895, [188]).

3.2.10. Pacheco da Silva Junior e Lameira de Andrade, Noções de grammatica portugueza $(1887$, [153])....

3.2.11. Fillipe Benicio de Oliveira Condurú, Grammatica Elementar da Lingua Portugueza (1888, [157])

3.2.12. João Ribeiro Fernandes, Exames de Portuguez - Grammatica Portugueza

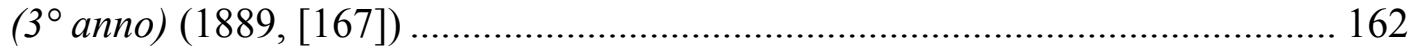

3.2.13. Alfredo Gomes, Grammatica Portugueza (1895, [187]) .......................... 164

CAPÍTULO 4 | Análise orientada para conteúdo

4.1. Epitome da grammatica de lingua portugueza (1806, [1]), de Antonio Morais Silva

4.1.1 Conceitos de gramática e de linguagem e organização da obra 169

4.1.2 Conceitos de metaclasses e classes de palavras 170

4.1.3 Conceitos modificadores do nome..... 172

4.1.4 Conceito de verbo 174

4.1.5 Conceito de sentença e seus elementos ..................................................... 176

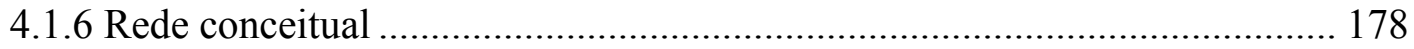

4.2. Arte da grammatica portugueza (1816, [4]), de Ignacio Felizardo Fortes ........ 180

4.2.1 Conceitos de gramática e de linguagem e organização da obra................... 180

4.2.2 Conceitos de metaclasses e classes de palavras ........................................... 180

4.2.3 Conceitos modificadores do nome ........................................................ 181

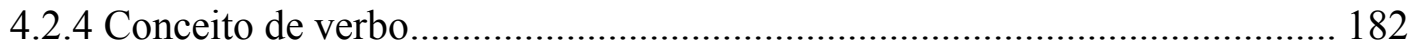

4.2.5 Conceito de oração e seus elementos ........................................................ 182

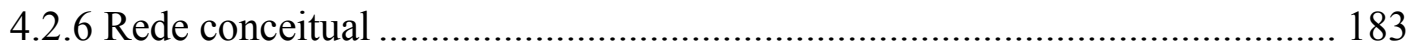

4.3. Compendio da grammatica portugueza (1829, [10]) e Compendio de grammatica philosophica da lingua portugueza (1859, [44]), de Antonio da Costa Duarte........ 183

4.3.1 Conceitos de gramática e de linguagem e organização da obra................... 183

4.3.2 Conceitos de metaclasses e classes de palavras ........................................... 185

4.3.3 Conceitos modificadores do nome ............................................................. 187

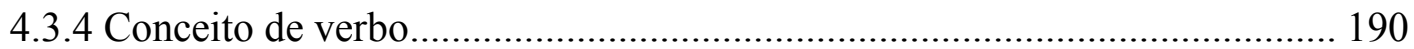




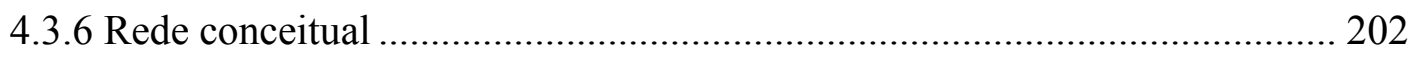

4.4. Compendio da Grammatica da Lingua Nacional (1835, [16]; 1873, [92]), de

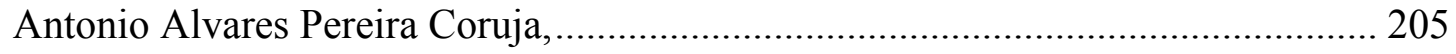

4.4.1 Conceitos de gramática e de linguagem e organização da obra ................... 205

4.4.2 Conceitos de metaclasses e classes de palavras .......................................... 206

4.4.3 Conceitos modificadores do nome ............................................................ 207

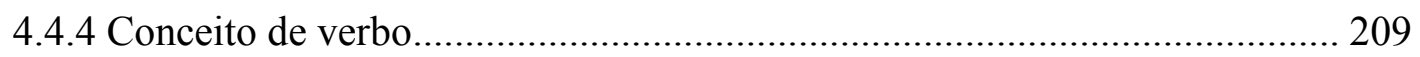

4.4.5 Conceito de oração e seus elementos ......................................................... 211

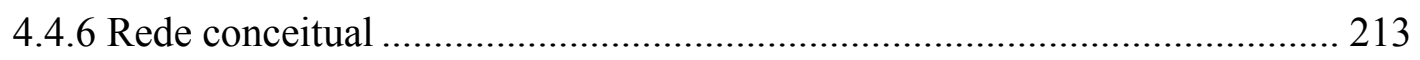

4.5. Epitome da grammatica philosophica da lingua portugueza (1862, [50]), de Raymundo Camara Bithencourt......................................................................... 215

4.5.1 Conceitos de gramática e de linguagem e organização da obra .................. 215

4.5.2 Conceitos de metaclasses e classes de palavras ........................................... 216

4.5.3 Conceitos modificadores do nome ............................................................ 217

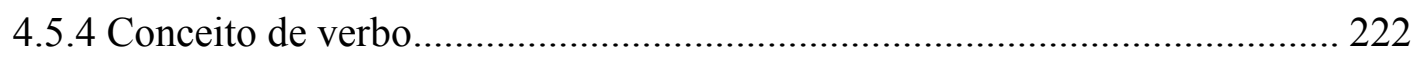

4.5.5 Conceito de oração e seus elementos ...................................................... 224

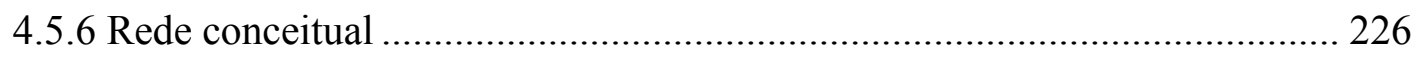

4.6. Grammatica portugueza accomodada aos princípios geraes da palavra seguidos de immediata aplicação pratica (1877), de Francisco Sotero dos Reis ................... 227

4.6.1 Conceitos de gramática e de linguagem e organização da obra ................... 227

4.6.2 Conceitos de metaclasses e classes de palavras ........................................... 228

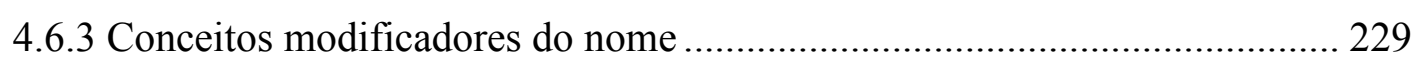

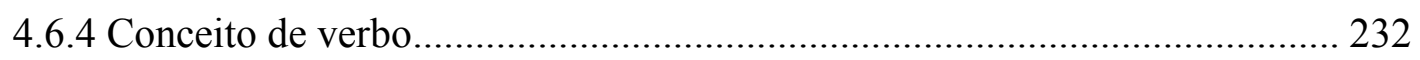

4.6.5 Conceito de oração e seus elementos ......................................................... 235

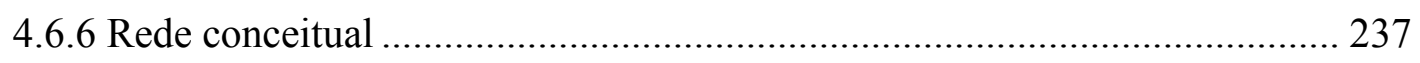

4.7. Grammatica Portugueza Philosophica (1881, [120]) e Serões Grammaticaes ou Nova Grammatica Portugueza (1890, [171]), de Ernesto Carneiro Ribeiro ............ 238

4.7.1 Conceitos de gramática e de linguagem e organização da obra ................... 238

4.7.2 Conceitos de metaclasses e classes de palavras .......................................... 241

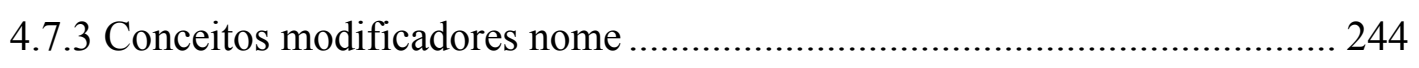

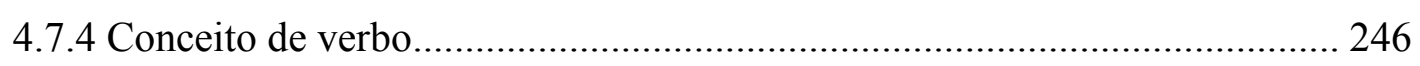

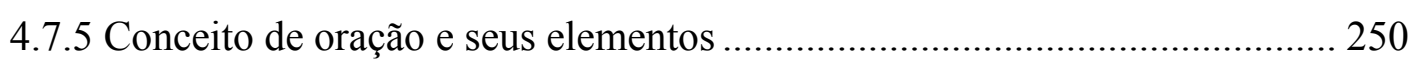

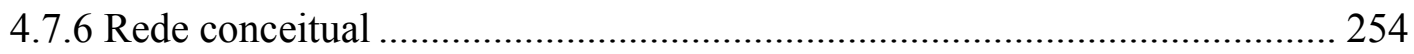

4.8. Grammatica Portugueza (1881, [123]; 1885, [143]), de Julio Cezar Ribeiro

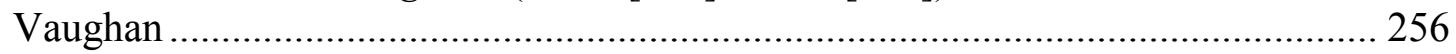

4.8.1 Conceitos de gramática de linguagem e organização da obra...................... 256

4.8.2 Conceitos de metaclasses e classes de palavras ....................................... 257 


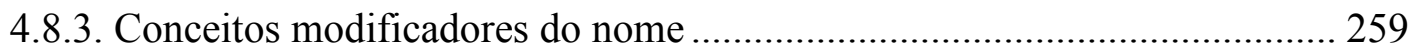

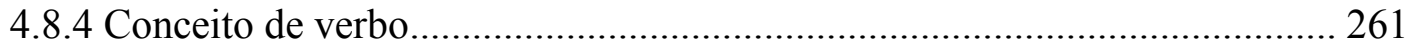

4.8.5 Conceito de sentença e seus elementos .................................................... 264

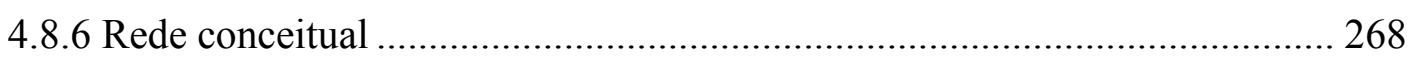

4.9. Grammatica Analytica (1887, [152]) e Grammatica Descriptiva (1895, [188]), de Maximino de Araujo Maciel........................................................................... 270

4.9.1 Conceitos de gramática e de linguagem e organização da obra ................... 270

4.9.2 Conceitos de metaclasses e classes de palavras ......................................... 272

4.9.3 Conceitos modificadores do nome ........................................................ 273

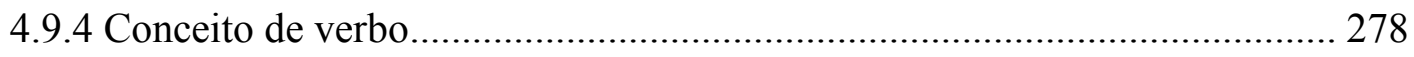

4.9.5 Conceito de sentença ou proposição e seus elementos ............................... 282

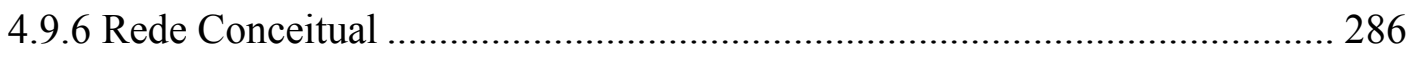

4.10. Noções de grammatica portugueza (1887, [153]), de Pacheco da Silva Junior e

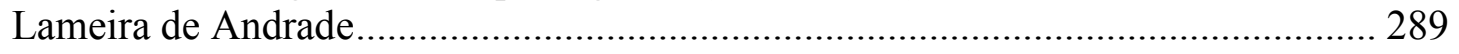

4.10.1 Conceitos de gramática e de linguagem e organização da obra ................ 289

4.10.2 Conceitos de metaclasses e classes de palavras ........................................ 290

4.10.3 Conceitos modificadores do nome ......................................................... 292

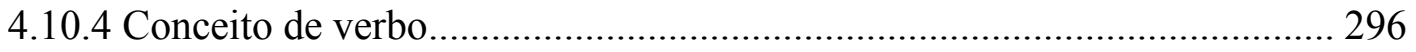

4.10.5 Conceito de proposição e seus elementos …............................................. 300

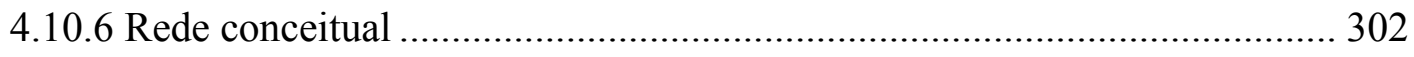

4.11. Grammatica Elementar da Lingua Portugueza (1888, [157]), de Fillipe Benicio

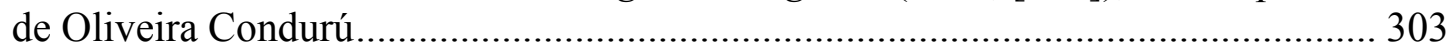

4.11.1 Conceitos de gramática e de linguagem e organização da obra ................. 303

4.11.2 Conceitos de metaclasses e classes de palavras ....................................... 303

4.11.3 Conceitos modificadores do nome .......................................................... 304

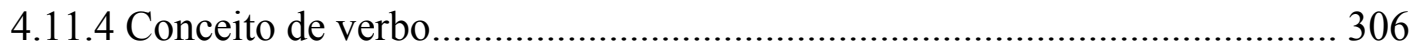

4.11.5 Conceito de oração e seus elementos ....................................................... 308

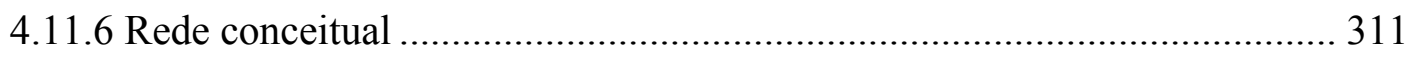

4.12. Exames de Portuguez - Grammatica Portugueza (3ªnno) (1889, [167]), de

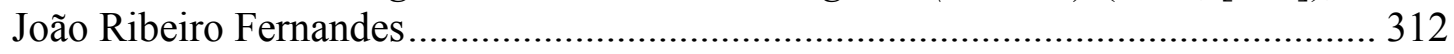

4.12.1 Conceitos de gramática e de linguagem e organização da obra ................ 312

4.12.2 Conceitos de metaclasses e classes de palavras ....................................... 314

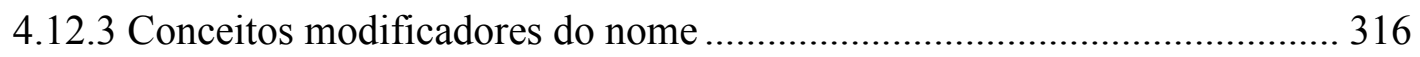

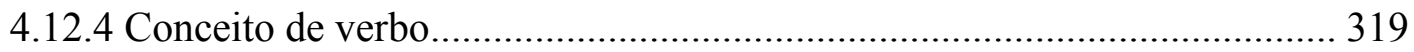

4.12.5 Conceito de proposição e seus elementos ................................................ 320

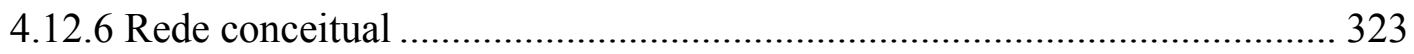

4.13. Grammatica Portugueza (1895, [187]), de Alfredo Gomes .......................... 323

4.13.1 Conceitos de gramática e de linguagem e organização da obra ................. 324 
4.13.2 Conceitos de metaclasses e classes de palavras ....................................... 325

4.13.3 Conceitos modificadores do nome ........................................................ 326

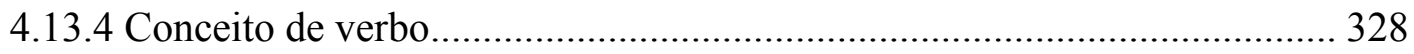

4.13.5 Conceito de proposição ou oração e seus elementos................................. 329

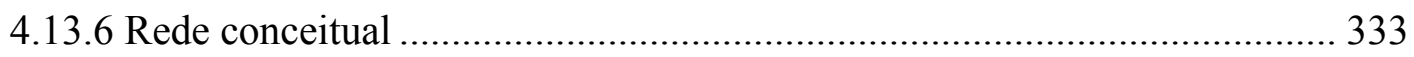

CAPÍTULO 5 | Resultados e contribuições .............................................................. 337

5.1. Exame longitudinal de redes conceituais: continuidades e descontinuidades.. 337

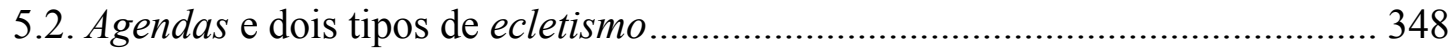

5.3. O ‘verbo substantivo' e a língua portuguesa: o debate entre ser e estar ........... 352

5.4. Resultados e contribuições da metodologia da História Serial........................... 353

5.5. Resultados e contribuições da metodologia da rede conceitual ........................ 357

REFERÊNCIAS BIBLIOGRÁFICAS .............................................................. 359

APÊNDICE A | Referência completa das gramáticas .............................................. 369

APENDICE B | Fichas Descritivas............................................................................. 393 


\section{Lista de abreviaturas e siglas}

A : Autor
Ex: Exemplo(s)

GGR-PR: Grammaire Generale et Raisonnée de Port-Royal

Il: Ilustração/ões de uso

MT: Metatexto (em oposição a texto)

NDR: Nota de rodapé

REF: Referência bibliográfica dada em gramática a alguma ilustração de uso.

T: Texto (em oposição a metatexto) 


\section{ÍNDICE DE QUADROS, TABELAS E FIGURAS}

Quadro 1. Doze conceptualizações de língua (Swiggers 2004) .................................... 27

Quadro 2. Programas de Investigação (Swiggers 2004)................................................. 28

Quadro 3. Relações lógicas entre termos (Swiggers 2010a) .......................................... 29

Quadro 4. Relações possíveis entre conceito-chave e conceitos da rede conceitual ..... 30

Quadro 5. Gramáticas oitocentistas citadas pelas revisões históricas ............................ 66

Quadro 6. Síntese de periodizações realizadas sobre a gramaticografia brasileira

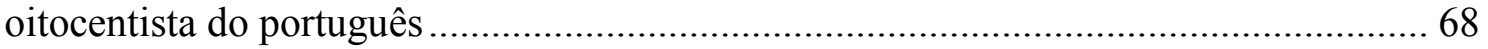

Quadro 7. Unidades e tipos de unidade analisados na História Serial .......................... 81

Quadro 8. Siglas e tipos de título analisados na História Serial ....................................... 82

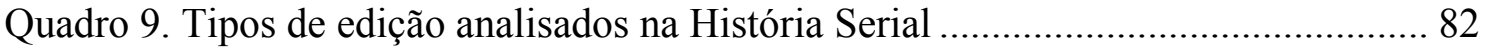

Quadro 10. Tipos de público-alvo analisados na História Serial ................................... 83

Quadro 11. Questões e relações realizadas no mapeamento descritivo-interpretativo... 84

Quadro 12. Dados biobliográficos e paratextos expostos nas FDs ............................... 85

Quadro 13. Conceitos analisados em intensão e extensão .............................................. 86

Quadro 14. Edições ausentes com base em número das edições conhecidas ................ 101

Quadro 15. Número de 'gramáticas' e 'edições específicas' por local e década ............. 110

Quadro 16. Casas impressoras de cada gramática em cada década e cada local.......... 119

Quadro 17. Gramáticas em cujo título não aparece referência à língua portuguesa .... 128

Quadro 18. Diferentes tipos de subtítulo ..................................................................... 130

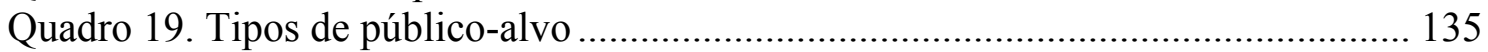

Quadro 20. Relação entre público alvo (grau de ensino) e título das obras .................. 137

Quadro 21. Metaclasses e classes de palavras de Morais Silva (1806)....................... 171

Quadro 22. Espécies de 'sentença' em Morais Silva (1806) ........................................ 178

Quadro 23. 'Casos' do 'artigo' em Fortes (1816) ............................................................ 181

Quadro 24. Natureza, pensamento e discurso em Costa Duarte $(1829,1859)$.............. 185

Quadro 25. Espécies de 'adjetivo' em Costa Duarte $(1829,1859)$............................... 187

Quadro 26. Objetos que os nomes podem ser e relações que podem ter na oração (Costa

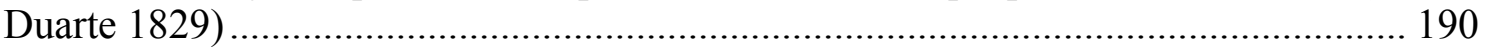

Quadro 27. Conceitos de 'verbo' em Costa Duarte $(1829,1859)$............................... 191

Quadro 28. Principais espécies de 'verbo' em Costa Duarte $(1829,1859)$................... 192

Quadro 29. Espécies de 'verbo adjetivo' em Costa Duarte $(1829,1859)$...................... 196

Quadro 30. Espécies de 'verbo transitivo' em Costa Duarte $(1829,1859)$................... 197

Quadro 31. Elementos da oração em Costa Duarte $(1829,1859)$.................................. 200

Quadro 32. Espécies de 'complementos' (Costa Duarte 1829, 1859) ........................... 200

Quadro 33. Espécies de 'proposição' em Costa Duarte $(1829,1859)$............................ 201

Quadro 34. Espécies de 'proposições parciais' em Costa Duarte $(1829,1859)$............ 202

Quadro 35. Metaclasses e classes de palavras em Coruja $(1835,1873)$...................... 207

Quadro 36. Espécies de 'verbo' em (Coruja 1835, 1873) ......................................... 210

Quadro 37. Elementos da 'oração' em Coruja $(1835,1873)$........................................ 211

Quadro 38. Espécies de 'complementos' em Coruja (1873) ....................................... 212

Quadro 39. Espécies de 'artigo' em Bithencourt (1862) ............................................... 219

Quadro 40. Espécies de 'adjetivos demonstrativos' em Bithencourt (1862)................. 220

Quadro 41. Espécies de 'verbo transitivo' em Bithencourt (1862) ............................... 224

Quadro 42. Espécies de 'complementos' em Bithencourt (1862) ................................. 225

Quadro 43. Espécies de 'oração' de acordo com sua 'natureza' em Bithencourt (1862) 226

Quadro 44. Espécies de 'adjetivo qualificativo' e 'adjetivo determinativo' em Sotero dos

Reis (1877) 
Quadro 45. Espécies de 'verbo atributivo' em Sotero dos Reis (1877)........................ 234

Quadro 46. Espécies de 'sujeito' e 'atributo' em Sotero dos Reis (1877) ...................... 235

Quadro 47. 'Complementos' de classes de palavras em Sotero dos Reis (1877) ......... 236

Quadro 48. Espécies de 'proposição' em Sotero dos Reis (1877) ................................. 237

Quadro 49. Espécies de 'gramática' em Carneiro Ribeiro $(1881,1890)$....................... 240

Quadro 50. Metaclasses e classes de palavras em Carneiro Ribeiro $(1881,1890)$..... 244

Quadro 51. Espécies do 'artigo indicativo' ou 'puro' e 'artigo conotativo' em Carneiro

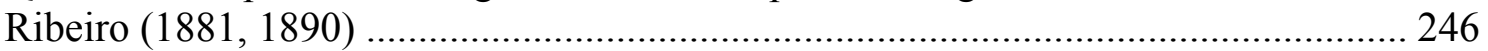

Quadro 52. Espécies de 'verbos' em Carneiro Ribeiro $(1881,1890)$............................ 249

Quadro 53. Metaclasses e classes de palavras em Ribeiro (1881) ............................. 258

Quadro 54. Metaclasses e classes de palavras em Ribeiro (1885) ..............................2259

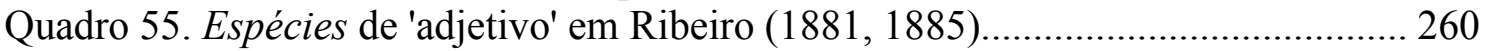

Quadro 56. Espécies de 'pronome adjetivo' em Ribeiro $(1881,1885)$......................... 261

Quadro 57. Principais espécies de 'verbo' em Ribeiro (1881) ..................................... 263

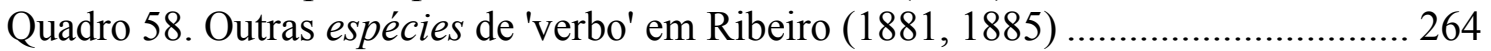

Quadro 59. Espécies de 'relação' em Ribeiro $(1881,1885)$.......................................... 266

Quadro 60. 'Relações' entre 'membros' e espécies de 'sentença' em Ribeiro (1881, 1885)

Quadro 61. Espécies de 'gramática' em Maciel $(1887,1895)$

Quadro 62. Diferentes 'modos' de 'manifestar o pensamento' em Maciel (1887, 1895)271

Quadro 63. Metaclasses, classes e epítetos em Maciel $(1887,1895)$......................... 273

Quadro 64. Espécies de 'adjetivo qualificativo descritivo' em Maciel $(1887,1895)$... 275

Quadro 65. Espécies de 'adjetivo designativo' em Maciel $(1887,1895)$..................... 277

Quadro 66. Principais espécies de 'pronomes' em Maciel $(1887,1895)$....................... 277

Quadro 67. Espécies de 'adjetivo substantivo' em Maciel $(1887,1895)$...................... 278

Quadro 68. Espécies de 'verbo atributivo' em Maciel (1887)....................................... 280

Quadro 69. Espécies de 'predicação' e 'verbo' em Maciel (1895).................................... 281

Quadro 70. Espécies de 'proposições coordenadas' ou 'membros' em Maciel (1887,

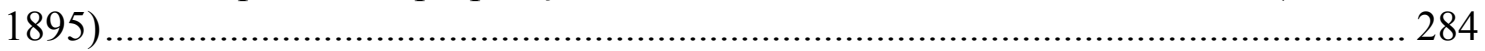

Quadro 71. Espécies de 'proposições subordinadas' ou 'cláusulas' em Maciel (1887,

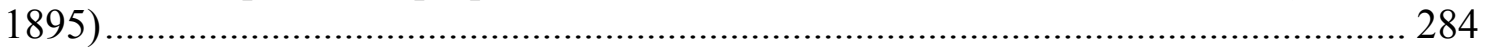

Quadro 72. Espécies de 'funções' em Maciel $(1887,1895)$........................................ 285

Quadro 73. Espécies de 'gramática' em Pacheco e Lameira (1887) ............................ 289

Quadro 74. Metaclasses e classes de palavras em Pacheco e Lameira (1887)............ 292

Quadro 75. Espécies de 'adjetivo' quanto à 'significação' em Pacheco e Lameira (1887)

Quadro 76. Espécies de 'pronome' em Pacheco e Lameira (1887)................................. 295

Quadro 77. Espécies de 'verbo' segundo diferentes critérios em Pacheco e Lameira

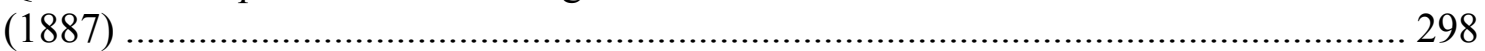

Quadro 78. Outras espécies de 'verbo' em Pacheco e Lameira (1887) ......................... 299

Quadro 79. Espécies de 'adjetivos determinativos' em Condurú (1888) ...................... 306

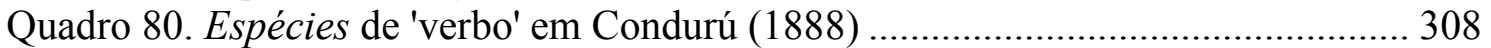

Quadro 81. Elementos essenciais da 'oração' em Condurú (1888) ................................ 309

Quadro 82. Espécies de 'complemento' em Condurú (1888)...................................... 309

Quadro 83. Espécies de 'oração' dentro de um 'período' em Condurú (1888) ............... 311

Quadro 84. Espécies de 'adjetivos' em Ribeiro (1889) .................................................. 317

Quadro 85. 'Vestígios de declinação' em 'pronomes pessoais' em Ribeiro (1889)....... 318

Quadro 86. Espécies de 'relação' e elementos 'da proposição' envolvidos em Ribeiro

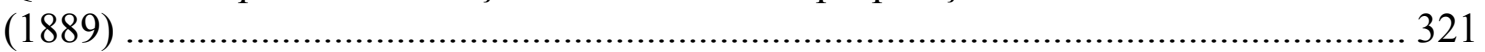

Quadro 87. Espécies de 'sujeito', 'predicado' e 'objeto' em Ribeiro (1889) .................. 322 
Quadro 88. Metaclasses e classes de palavras em Gomes (1895) .............................. 326

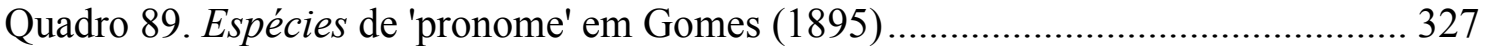

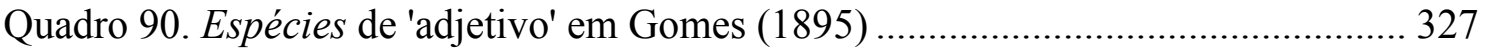

Quadro 91. Principais espécies de 'verbo' em Gomes (1895)..................................... 328

Quadro 92. Espécies de 'verbo' quanto à 'forma' em Gomes (1895) ............................ 329

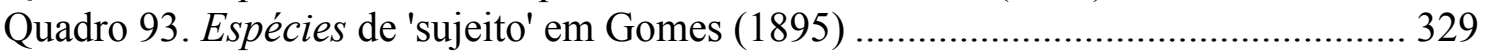

Quadro 94. Espécies de 'predicativo' em Gomes (1895) ............................................. 330

Quadro 95. Espécies de 'proposição' quanto à 'forma' em Gomes (1895).................... 331

Quadro 96. Elemento considerado na 'regência' em Gomes (1895) ............................ 332

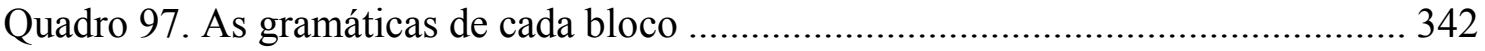

Tabela 1. Número de tipos de edição por década ........................................................... 99

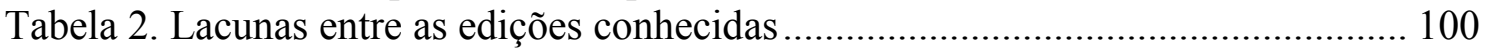

Tabela 3. Número de gramáticas de cada tipo de título por década ............................. 121

Tabela 4. Espécies de títulos Gx e número de ocorrências por década ......................... 122

Tabela 5. Títulos X e número de ocorrências por década .......................................... 123

Tabela 6. Espécies de títulos Xg e número de ocorrências por década ......................... 123

Tabela 7. Espécies de títulos Xgx e número de ocorrências por década ...................... 124

Tabela 8. Número de gramáticas dedicadas a cada tipo de público-alvo por década... 135

Figura 1. Partes do conceito

Figura 2. Representação do modelo "Mainstream-vs-Undercurrent" de Koerner (1989:52)

Figura 3. Representação do modelo "Discontinuity-vs.-Continuity" de Koerner (1989:53)

Figura 4. Termos da proposição, tradução de Itkonen $(1991: 178)$................................. 41

Figura 5. Gráfico do número de gramáticas publicadas por década............................... 98

Figura 6. Gráfico de número de edições publicadas por década ................................. 102

Figura 7. Mapa do Brasil com divisões territoriais históricas (Albuquerque, Reis,

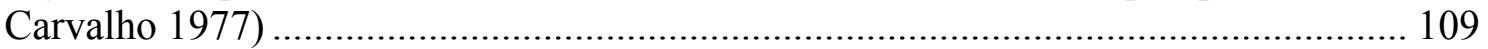

Figura 8. Gráfico de frequência de tipos de títulos ao longo do século ....................... 121

Figura 9. Gráfico de frequência de títulos G e XG-compêndio em edições específicas

Figura 10. Gráfico de frequência de títulos G e Xg-compêndio em gramáticas ........... 127

Figura 11. Modelo de continuidade vs. descontinuidade das gramáticas brasileiras oitocentistas 


\section{INTRODUÇÃO}

A ideia inicial para o projeto desta tese surgiu nos resultados de nossa dissertação de mestrado (Polachini 2013), em que avaliamos que houve dificuldades para determinar continuidades e descontinuidades da capa técnica, que, de acordo com Swiggers (2004), corresponde a técnicas de análise e métodos de apresentação dos dados, no tratamento da sintaxe apresentado em seis gramáticas brasileiras do português, a saber: Morais Silva (1806), Coruja (1873[1835]), Sotero dos Reis (1866), Freire da Silva (1875), Ribeiro (1881), Maciel (1902[1894]). Supomos que era possível olhar de maneira mais homogênea para a capa técnica se procurássemos por um problema específico da produção gramatical examinada.

Outra ideia decisiva de nosso projeto surgiu de comentários do Prof. Pierre Swiggers (KU Leuven, Bélgica), que visitava o Brasil em setembro de 2013 para o proferimento de conferências em dois eventos na Universidade de São Paulo ${ }^{1}$, à comunicação que realizamos no VII MiniEnapol de Historiografia Linguística, em que falávamos justamente sobre os resultados obtidos na dissertação de mestrado recémdefendida. Ele nos sugeriu examinar diferentes edições das obras já analisadas na dissertação a fim de observar se havia mudanças e qual seria o "prazo de validade" da veiculação dos conceitos apresentados, mapeável, por exemplo, pelo número de edições, em quanto tempo. Iniciamos, assim, um processo de busca (em fontes secundárias e catálogos de bibliotecas) por gramáticas brasileiras de língua portuguesa, no qual encontramos dados catalográficos de duzentas delas.

Desses dois impulsos iniciais surgiram duas de nossas propostas: (1) fazer um mapeamento descritivo e interpretativo com os dados encontrados sobre as 204 gramáticas (127 edições específicas, 77 reedições) de que tivemos conhecimento, que contribuísse para a historiografia dessa produção, indo além, no que concerne à

\footnotetext{
${ }^{1}$ Apresentou no Congresso Internacional 100 anos com Saussure a conferência "Not Waiting for Goblot: Saussure and the Place of Linguistics as a Science" e proferiu um minicurso de duas aulas, cujos temas foram "A Historiografia Linguística: Domínio, Objetivos, Princípios e Perspectivas. Reflexões Metodológicas e Epistemológicas" e "A Historiografia da Linguística Histórica: o problema da diacronia na linguística dos séculos XIX e XX", que ocorria junto ao VII MiniEnapol Historiografia Linguística, organizado pelo CEDOCH-USP. Ademais, a convite da comissão organizadora do evento VII MiniEnapol, escreveu dois capítulos para o primeiro volume dos Cadernos de Historiografia Linguística do CEDOCH, em que relata parte do evento, "Linguistic historiography in Brazil: impressions and reflections", e apresenta diretrizes para a historiografia linguística, "Directions for linguistic historiography" (cf. Polachini et al. 2015).
} 
quantidade de informações e a sua organização, das revisões históricas já realizadas; (2) arquitetar uma forma de examinar a capa técnica das obras de maneira homogênea a partir de um problema específico dessa tradição.

As revisões históricas realizadas para a produção gramatical brasileira (cf. Maciel 1910, Nascentes 1939, Elia 1975, Cavaliere 2001, Parreira 2011, Polachini 2013). citam, em geral, cerca de cinco obras, repetidamente, pois são as que, segundo esses autores, obtiveram maior prestígio ou promoveram alguma ruptura no tipo de conhecimento linguístico em circulação no Brasil, a saber: Morais Silva (1806), Sotero dos Reis (1866, ou edições posteriores), Grivet (1881), Ribeiro (1881) e Carneiro Ribeiro (1890); além disso, tais revisões costumam acrescentar o nome de gramáticos (e apenas eventualmente o título de suas obras) que escreveram gramáticas adequadas ao Programa de Estudos para exames do Colégio Pedro II de 1887, a saber: Maximino Maciel, Pacheco da Silva Junior, Lameira de Andrade, João Ribeiro e Alfredo Gomes. Algumas das revisões fazem listas mais longas de títulos, como é o caso de Castilho (1962), Parreira (2011) e Polachini (2013); no entanto, o número total de obras citado mesmo por estas não chega a trinta. Dessa forma, a obtenção de dados de 127 edições específicas e de 77 reedições dessa tradição nos proporcionou a possibilidade de realizar um mapeamento inédito. Para realizá-lo, dado que em geral tínhamos apenas os dados catalográficos das obras, utilizamos a metodologia da História Serial, a qual nos possibilitou perceber eventos a partir da flutuação de séries de unidades relativas a dados que tínhamos das duzentas obras. Assim, por exemplo, notamos que é entre a década de 1860 e 1880 que ocorre uma grande expansão na gramaticografia brasileira, notamos também que é no Rio de Janeiro que se concentra a maior parte da produção gramatical, em relação ao número de autores, de gramáticas e de edições específicas, de que tivemos conhecimento; ademais, observamos que gramáticas que não são, em geral, referidas pelas revisões históricas (cf. item 1.5) podem ter obtido bastante prestígio ao longo do século XIX.

Nossa segunda proposta fragmentou-se em duas partes: uma hipótese e uma metodologia para testá-la. Nossa hipótese, baseada em Auroux (2009[1992]) e Swiggers (2010), é de que alguns conceitos, que chamamos de conceito-chave, poderiam ser eixo de uma rede conceitual devido à sua influência técnica e, eventualmente teórica, em uma determinada tradição de descrição linguística. No caso da tradição gramatical oitocentista brasileira do português, supomos que 'verbo substantivo' seria um conceito-chave produtivo, visto que é frequentemente apresentado nas obras dessa tradição, que são, por sua vez, amiúde influenciadas pela tradição da grammaire générale francesa, ao menos 
até 1880 (cf. Maciel 1887, Nascentes 1939, Elia 1975, Cavaliere 2001, Parreira 2011, Polachini 2013). Sabemos, por meio de trabalhos que se debruçaram sobre a tradição da grammaire générale, que o 'verbo substantivo' estaria relacionado com outros conceitos (cf. Chevalier 1968; Colombat 1992; Raby 2000; Bouard 2007).

Foi, assim, necessário formalizar uma metodologia a fim de reconhecer a rede conceitual em torno do 'verbo substantivo'. Primeiramente, definimos conceitos gramaticais como sendo formados por meio de processos classificatórios da cadeia falada. Tais processos têm como produto, por um lado, termos, e, por outro, conceitos. Aqueles são os nomes dados aos conceitos, estes últimos podem ser analisados intensionalmente, por meio de sua definição e seu lugar numa determinada taxonomia, ou extensionalmente, considerando o inventário de dados linguísticos eleitos como exemplos e eventuais ilustrações desses dados em uso. Cada conceito é, portanto, analisado por meio das seguintes categorias: definição, taxonomia, exemplos, ilustrações e por seus termos. Consideramos rede conceitual as relações travadas entre o conceitochave, 'verbo substantivo', e conceitos que, na tradição da grammaire générale teriam já alguma relação com o 'verbo substantivo' (cf. Chevalier 1968; Colombat 1992; Raby 2000; Bouard 2007), a saber: gramática e linguagem, metaclasses e classes de palavras, modificadores do nome, verbo, oração (seus elementos e sua organização) apresentadas nas obras. Essas relações podem ser de quatro tipos: (1) identidade; (2) subordinação; (3) equivalência; (4) base teórica comum.

Temos também uma terceira proposta, que surgiu ao longo da escrita da tese, de que ela, levando em conta uma série de lacunas nas revisões históricas disponíveis sobre a gramaticografia brasileira do português, se tornasse também uma obra de consulta para que novos trabalhos sobre essa produção pudessem ser realizados com mais facilidade, isto é, que ela fosse não apenas uma historiografia, mas também uma epihistoriografia. Procuramos, portanto, dispor nosso texto de forma que ele oferecesse informações organizadas que, por um lado, permitissem montar um panorama dessa produção e, por outro, permitissem a busca e a leitura autônoma dos diferentes tipos de dados e de análises realizadas.

Adiante, descrevemos a estrutura desta tese, seu conteúdo, e a maneira como procuramos atingir nossos objetivos.

No Capítulo 1, de fundamentos teóricos e revisões da literatura, avaliamos inicialmente lacunas e possibilidades da historiografia linguística (1.1), isto é, perguntamo-nos em que medida e de que maneira descrevemos e interpretamos não 
coextensivamente a história que se passou na produção gramatical brasileira de língua portuguesa no século XIX. Em seguida, no item 1.2, discutimos sobre a cascata semiótica de metalinguagens (cf. Swiggers 2010) com a qual o historiógrafo da linguística deve lidar e sobre a conceptualização realizada necessariamente na descrição gramatical, visto que todo processo classificatório da cadeia falada tem como resultado um conceito carregado de teoria. No terceiro item desse capítulo (1.3), abordamos os inescapáveis pêndulos das oposições entre continuidade e descontinuidade e entre homogeneidade e heterogeneidade, com especial atenção à seleção realizada pelo olhar do historiógrafo e à suposição da existência de redes conceituais.

Tendo feito as observações teóricas, passamos nos itens 1.4 e 1.5 a revisões da literatura sobre o tema estudado e sobre nosso objeto de estudo. Em 1.4, tratamos do tema de nosso trabalho, a 'cópula' ou 'verbo substantivo': inicialmente, em 1.4.1, resenhamos uma breve história desse conceito, de Aristóteles ao século XIX, a fim de delinear as diversas formas que ele tomou na história da gramática ocidental; em seguida, no item 1.4.2, com base em trabalhos históricos realizados sobre a tradição da grammaire générale, que teve impacto sobre as gramáticas brasileiras oitocentistas, procuramos hipotetizar como seria uma rede conceitual ideal cujo conceito-chave fosse o "verbo substantivo'. Em 1.5 revisitamos os trabalhos que analisaram longitudinalmente a produção gramatical brasileira oitocentista, concentrando-nos em suas periodizações e no destaque dado, nessas revisões, a algumas gramáticas em detrimento de outras.

No Capítulo 2, tratamos dos métodos utilizados para executar nossa análise. Inicialmente, em 2.1, detalhamos os procedimentos realizados no levantamento, por meio de fontes secundárias e de catálogos de bibliotecas, das 204 obras gramaticais de que tivemos conhecimento; e justificamos a seleção, baseada em critérios combinados, de dezoito dessas gramáticas para análise vertical (2.1.1), a saber: Morais Silva (1806), Fortes (1816), Costa Duarte (1829, 1859), Coruja (1835, 1873), Bithencourt (1862), Sotero dos Reis (1877), Carneiro Ribeiro (1881, 1890), Ribeiro (1881, 1885), Maciel (1887, 1895), Pacheco \& Lameira (1887), Condurú (1888), Ribeiro (1889), Gomes (1895).

Em 2.2, delineamos os critérios definidos para nossa análise orientada para o contexto. Expomos detalhadamente a maneira como organizamos e cruzamos os dados que tínhamos de 204 gramáticas dessa produção a fim de, inspirados pela metodologia da História Serial (Furet 1991, Barros 2004), realizar um mapeamento descritivo e interpretativo da produção gramatical brasileira (2.2.1). Apresentamos também critérios 
para uma análise de agenda dos autores das dezoito gramáticas selecionadas por meio de seus dados biobibliográficos e paratextos, como folha de rosto, epígrafes, prólogo, dedicatórias e assinaturas, das obras (2.2.2). Na penúltima seção desse capítulo (2.3), abordamos os critérios para análise orientada para o conteúdo, em que explicamos nossa metodologia de exame da hipotética rede conceitual do 'verbo substantivo', à qual já nos referimos anteriormente. No item 2.4, sistematizamos um quadro metodológico em que procuramos sintetizar os critérios e a metalinguagem utilizados em nossa análise. Finalmente, em 2.5, explicitamos e justificamos a organização textual realizada nesta tese.

Nos Capítulos 3 e 4, realizamos as análises orientadas para o contexto e para o conteúdo com as ferramentas de nosso quadro metodológico. Em 3.1, analisamos as unidades (autor, título, tipo de título, ano de publicação, década de publicação, lugar de publicação, casa impressora, edição, subtítulos e público alvo) presentes nos dados catalográficos de 204 gramáticas brasileiras do português, observando: (1) o número de gramáticas publicadas por década; (2) reedições de gramáticas, seu prestígio e durabilidade; (3) a publicação de gramáticas em diferentes regiões do Brasil ao longo do século; (4) as casas impressoras em que foram publicadas essas obras; (5) a escolha de títulos ao longo do século; (6) os subtítulos que continham informações sobre o formato, conteúdo e objeto das gramáticas; (7) e, finalmente, os subtítulos que continham informações sobre público-alvo da obra ou dedicatórias.

No item seguinte (3.2), examinamos a agenda dos treze autores das dezoito gramáticas selecionadas ao publicá-las, ou seja, com base em seus dados biobibliográficos e paratextos das obras, analisamos, seu perfil profissional e eventual retórica revolucionária, de continuidade, mista ou mesmo ausência de retórica. No capítulo 4, analisamos os conceitos de gramática e linguagem, metaclasses e classes de palavras, modificadores do nome, verbo e oração apresentados nas gramáticas e observamos suas relações com o nosso conceito-chave, o 'verbo substantivo'. Examinando a rede conceitual formada em cada obra particularmente. Dividimos as subseções do item 3.2 e do capítulo 4 pelos treze autores das dezoito gramáticas analisadas. Com isso, intentamos, por um lado, realizar uma análise particular de cada autor, inicialmente, para apenas nos resultados cruzar esses dados; por outro, tendo como intuito que essa tese possa ser uma obra de consulta, preferimos oferecer informações organizadas de modo que permitam busca e a leitura autônoma dos diferentes tipos de dados e de análises realizadas. 
No quinto capítulo estão os resultados obtidos por meio da análise e as contribuições historiográficas e meta-historiográficas que o trabalho pôde alcançar. Em relação aos resultados, ressaltamos de forma mais holística aspectos observados particularmente na análise. Assim, inicialmente, em 5.1, fazemos um exame longitudinal das redes conceituais que foram analisadas particularmente no capítulo 4, chegando a uma nova observação de continuidades e descontinuidades da produção gramatical brasileira. Observamos também as relações possíveis entre o ecletismo das obras e a agenda dos gramáticos ao escrevê-las (5.2), e implicações teóricas da dificuldade que muitos gramáticos tiveram ao usar o conceito de 'verbo substantivo' para descrever a língua portuguesa, a saber, se ele é apenas "ser" ou é também "estar" (5.3). Ademais, fazemos uma balanço quanto às contribuições do trabalho para a historiografia da gramática brasileira oitocentista de língua portuguesa e para meta-historiografia no que diz respeito ao uso da metodologia da História Serial (5.4) e das noções de conceito e de rede conceitual (5.5).

Finalmente, oferecemos dois apêndices em que organizamos e disponibilizamos informações objetivas das obras: no apêndice A, estão dados catalográficos de todas as duzentas gramáticas encontradas, dispostos em ordem cronológica e alfabética; no apêndice B, estão as Fichas Descritivas (FDs) de cada uma das dezoito obras examinadas, nas quais constam dados bibliográficos dos autores, os paratextos (dados da folha de rosto, epígrafes, prólogos, prefácios e assinatura) e os sumários das obras. 
Esses eus de que somos compostos, um em cima dos outros como pratos empilhados na mão de um garçom têm relacionamentos em outros lugares, simpatias, pequenos códigos $e$ direitos próprios, como quer que os chamemos.

(Virginia Woolf) 


\section{CAPÍTULO 1| Fundamentos teóricos}

\subsection{Lacunas e possibilidades da historiografia linguística}

Silva (1975:46) sintetiza pensamentos de Paul Veyne numa pergunta que consideramos primordial para o fazer histórico: "como resolver a dificuldade criada pela existência de aspectos do passado que as fontes nos deixam ignorar e que ignoramos que elas nos deixam ignorar?". Formulamos outras questões, relacionadas a essa, que consideram o que não necessariamente ignoramos. Há maneiras de superar as lacunas conhecidas? E, visto que há lacunas (ignoradas e conhecidas), o que seria uma seleção consciente de objeto e de objetivo?

Tais questionamentos, que surgiam como uma espécie de advogado do diabo deste trabalho, não foram de todo solucionados (possivelmente porque isso não é concebível). Encontramos, no entanto, possibilidades de, de maneira reflexiva, superá-los. Swiggers, Desmet \& Jooken (1996:36) afirmam que o objeto da historiografia linguística é sempre "reconstruído", considerando que ele é o resultado de uma escolha ou de um conjunto de escolhas dentre várias possibilidades descritivas e, de maneira irrefutável, constitui uma visão parcial e seletiva do que chamamos de história. Seguindo o raciocínio de Swiggers (2004, 2009, 2013), existem os fatos e situações linguísticas, os quais, culturalmente, tornam-se objeto de reflexão humana, que, por sua vez, corresponde ao pensamento linguístico em suas diversas formas, nos diferentes tempos e espaços. Essa reflexão, que é a história por que nos interessamos, é o objeto de estudo da historiografia linguística, a qual é modalizada por dois aspectos: (1) organização e disponibilização dos documentos, que Swiggers chama de epihistoriografia; (2) organização e exposição de possibilidades teóricas e metodológicas de se observar e analisar esses documentos, chamada metahistoriografia linguística.

$\mathrm{O}$ autor distingue a historiografia da história, visto que têm necessariamente estatutos e dimensões diferentes, especialmente por não serem coextensivas; tal relação pode ser comparada àquela existente entre, respectivamente, uma gramática descritiva $\mathrm{e}$ a língua por ela descrita (cf. Altman 2012:27). Os aspectos modalizantes da historiografia ratificam que ela é uma possibilidade e que condicionamentos variados (inclusive lacunas) são parte integrante de sua natureza. 
Sendo tal modalização imprescindível (cf. Swiggers 2004:118-9), o melhor caminho a se tomar é o de uma historiografia linguística metodologicamente consciente, que, de acordo com Koerner (2014), propõe-se ao mesmo tempo a apresentar o passado linguístico como uma parte integral da disciplina linguística e ser uma atividade fundada em princípios bem definidos, havendo assim expressividade no método e rigor em sua aplicação. Diversas são as ferramentas fornecidas pela metahistoriografia linguística a fim de formar historiografias metodologicamente conscientes, dissolvendo, assim, inconsistências que poderiam passar despercebidas. Tais ferramentas vão desde noções mais abstratas e inexoráveis, como a consciência do fato de que se estuda uma determinada tradição dentro de outra tradição específica (cf. Alonso 2012), até elementos mais maleáveis e próprios da execução do fazer histórico, como seleção de dados e documentos, possibilidades de narrativa, intencionalidade do historiógrafo (cf., por exemplo, Swiggers 2013:44-5).

Assim, repetimos nosso leitmotiv do capítulo teórico (e de toda a tese), com base em Swiggers (2004), de que é recomendável abandonar a perspectiva puramente extensionalista da historiografia linguística; é mais favorável adotar a ideia de historiografia como reconstrução de "conteúdos significativos", os quais, sempre que possível, sobejam o quadro de observação direto. Nesse sentido, Lauwers (2004:35) enfatiza que o ponto de vista determina (em parte) os fatos recolhidos; entretanto, lembra que tais fatos devem passar por uma verificação intersubjetiva, a qual consiste na adequação dos fatos recolhidos em relação ao objeto estudado e aos objetivos selecionados. Observamos adiante como definimos cada um desses elementos neste trabalho.

O objeto estudado neste trabalho é a gramaticografia de língua portuguesa desenvolvida por brasileiros no século XIX. Em mais detalhes, a cobertura desse trabalho consiste, no que diz respeito à geografia, a aproximadamente o território que hoje é dado como Brasil e, mais especificamente, esse território ao longo século XIX, fosse ele do Brasil enquanto colônia, reino, império ou república; os autores das gramáticas do português analisadas devem ter nascido ou vivido por um longo período nesse território. No que diz respeito à periodização, podemos considerá-la de média duração, já que temos como objeto gramáticas publicadas ao longo de todo o século XIX. A escolha do período motiva-se pelo fato de a primeira gramática do português escrita por um brasileiro ter sido publicada somente em 1806; procuramos, assim, compreender como se deu a formação e o desenvolvimento dessa gramaticografia em seu primeiro século de vida. Entre edições 
e reedições (cf. Capítulo 2), selecionamos dezoito gramáticas por meio de critérios combinados de natureza externa (explicitados no capítulo 2), que visavam contemplar obras representativas dessa tradição.

Nem todas as obras de que tivemos conhecimento, porém, estavam disponíveis para leitura e análise, pois essa produção cresce bastante ao longo desse período e está esparsa em uma área territorial bastante grande (cf. Capítulo 3). É comum, inclusive, que as resenhas historiográficas a respeito dessa produção ignorem muitas obras, mesmo aquelas que parecem ter obtido certo prestígio no período (cf. item 1.5 e Capítulo 3). Parece-nos que isso é, por um lado, resultado do próprio condicionamento histórico referente à acessibilidade a determinados tipos de objeto, como falam Swiggers, Desmet \& Jooken (1996:36):

Esta seleção [de objeto] é parcialmente determinada pelo próprio legado histórico, isto é, os dados a nossa disposição, ou - de um ponto de vista negativo - os dados fora do nosso alcance. Em verdade, certos fatos nunca poderão ser retraçados (por exemplo, dados sobre as práticas de ensino de línguas na Antiguidade e na Idade Média). Acima de tudo, isto é determinado por limites intrínsecos da prática historiográficas, que nunca pode ser "totalitária" em sua natureza, isto é, recobrir a história em sua integridade. Em sua reconstrução, o historiógrafo primeiramente visa identificar problemas ou interesses temáticos. ${ }^{2}$

Por outro lado, parece-nos que é resultado também de falhas na fase heurística de pesquisa no que diz respeito, ao menos, à história externa dessa gramaticografia. Essa fase da pesquisa, segundo Swiggers (2013: 44), compreende, entre outras, as tarefas de informar-se a respeito de fontes e de sua disponibilidade, sendo, portanto, essencial ao recolhimento do objeto estudado. É também abarcada pela fase heurística a leitura dos textos-fontes e a catalogação de suas ideias, pontos de vista e terminologia; dessa forma, essa fase é pressuposta pela seleção dos objetivos do trabalho de que fala Lauwers (2004), visto que é necessário conhecer as obras antes de defini-los. Entretanto, é a fase hermenêutica que mais fortemente se relaciona com os objetivos, pois consiste em uma interpretação baseada em categorias (interpretativas), sejam elas de uso mais geral, correspondente à área do trabalho, ou mais específico, exclusivas daquele trabalho.

Temos três objetivos neste trabalho. O primeiro, orientado para o contexto (context-oriented, cf. Swiggers 1990), é o de realizar uma nova revisão da produção

\footnotetext{
${ }^{2}$ Tradução nossa do original: "This selectivity is partly determined by historical legacy itself, i.e. the data at our disposal, or - from a negative point of view - the data out of reach. As a matter of fact, a number of facts can never be retraced (e.g., data on the practice of language teaching in Antiquity and the Middle Ages). More important, it is determined by the intrinsic bounds of practicing historiography which can never be "totalitarian" in nature, i.e. recover history in its entirety. In his reconstruction the historiographer primarily aims at identifying thematical problems or interests."
} 
gramatical de língua portuguesa no Brasil do século XIX com base no grande número de gramáticas que encontramos em nossa fase heurística de pesquisa (Cf. Apêndice A) Para tanto, utilizamos a metodologia da História Serial: primeiramente, tomamos as informações que temos acerca das obras (como título, subtítulo, data e local de publicação), considerando-as como unidades, a fim de observá-las em série e, posteriormente, fazer diversos cruzamentos, com base em um questionário (cf. Capítulo 2), dos resultados obtidos acerca de tais unidades. A História Serial é uma abordagem

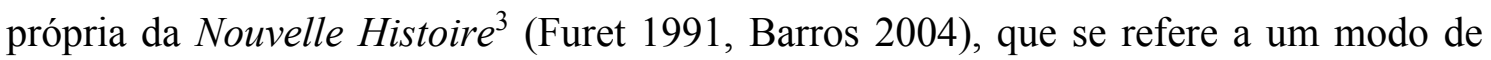
tratamento de fontes. Consiste na análise de documentos em série com certo nível de homogeneidade, observando unidades que se repetem e que se modificam ${ }^{4}$ ao longo do tempo. Os eventos são necessariamente construídos de acordo com as mudanças na série de unidades; não são dados a priori, dissolvendo, portanto, a narrativa baseada no "evento privilegiado". Como dizem Silva (2011) e Furet (1991) nas citações a seguir:

Uma História serial não se preocupa mais com eventos tipo Independência, Abolição, República, Revolução de 30; ela se debruçará por exemplo nos arquivos militares para estudar a série documental referente aos recrutamentos e dela extrair o máximo de informações. [...] Destruidora da narrativa histórica em torno do evento privilegiado, mesmo que essa narrativa se diga "estrutural" e não "factual", a História serial não recusa, pelo contrário, defende o evento quando inserido numa série, quando destituído de seus antigos privilégios. (Silva 2011:s.n)

\begin{abstract}
A história serial apresenta a vantagem decisiva, do ponto de vista científico, de substituir ao incompreensível «acontecimento» da história positivista a repetição regular de dados selecionados e construídos em função do seu carácter comparável. Mas ela não implica nem a pretensão à exaustão do conjunto documental descrito, nem sistema de interpretação global, nem formulação matemática, visto que, pelo contrário, o corte da realidade histórica em séries deixa o historiador perante um material decomposto em níveis, em subsistemas, cujas articulações ele é livre, em seguida, de propor ou não. (Furet 1991:62)
\end{abstract}

Por meio do cruzamento de unidades como o título das obras e as diferentes décadas do século ou os títulos relacionados ao público-alvo das obras, pudemos chegar a fatos

\footnotetext{
${ }^{3}$ Surgida na França na década de 1970 , a Nouvelle Histoire é definida pela via negativa, em relação ao que havia antes do predicado "nova", por Peter Burke (1992): (1) não diz respeito apenas à política, mas se interessa virtualmente por toda atividade humana; (2) não se considera uma simples narrativa, mas preocupa-se com a estrutura dos acontecimentos; (3) não oferece apenas a visão de cima, mas se interessa também por homens, feitos e ideias consideradas, por muito tempo, menos relevantes; (4) não se restringe a documentos oficiais, mas preocupa-se com uma maior variedade de evidências; (5) não apresenta modelos explicativos antes de uma análise cuidadosa de um fato; (6) não considera a história como uma narrativa dos fatos "como eles realmente aconteceram", mas pondera que percebemos o mundo através de uma estrutura de convenções, esquemas e estereótipos, que variam de uma cultura para outra.

${ }^{4}$ Os exemplos clássicos são análises de ciclos econômicos ou curvas demográficas a partir de documentos que explicitam condições de pagamento ou de nascimento e morte em certo período de tempo. Pode ser usada em campos como Histórica Econômica, História Demográfica ou História das Mentalidades, além de se aplicar a objetos como História das Práticas Religiosas, História da Família, entre outros (Barros 2005:236).
} 
globais significativos, os quais trazem informações novas a respeito dos caminhos cursados por essa produção.

Nosso segundo objetivo, também orientado para o contexto (context-oriented, $\mathrm{cf}$. Swiggers 1990), é de compreender a agenda em que se inseriam os autores quando publicaram as dezoito gramáticas que analisamos neste trabalho. Para tanto, observamos os dados biobibliográficos do autor e os paratextos das gramáticas para obter resultados nas categorias interpretativas de "treinamento", objetivos e autopercepção de cada gramático naquele momento (cf. Capítulo 2).

Finalmente, nosso terceiro objetivo, orientado para o conteúdo (content-oriented, cf. Swiggers 1990), é o de analisar a organização dos conteúdos das gramáticas e/ou seu possível ecletismo (cf. item 1.3) baseando-nos na hipótese de que há uma rede conceitual em torno do conceito-chave de 'verbo substantivo' nessa produção, isto é, que outros conceitos da gramática estariam conectados ao conceito de 'verbo substantivo', o que poderia ser evidenciado não apenas pelas relações entre os conceitos, mas também no momento de queda do conceito-chave, que acaba por carregar também os conceitos apresentados na rede.

Lauwers (2004:35) distingue fatos discretos de fatos globais. Os primeiros resultam de observações simples, da mera leitura das obras (como preto no branco), podem ser localizados e citados. Já os segundos não são tomados diretamente, mas são resultantes de uma série (concordante) de observações simples. De acordo com o autor, os fatos globais podem ser encontrados por meio de métodos quantitativos ou qualitativos. Em nossa história serial da produção gramatical brasileira oitocentista, utilizamos predominantemente métodos quantitativos. Ao passo que, na análise orientada para o contexto acerca da agenda dos gramáticos quando escreviam suas gramáticas e a análise orientada para o conteúdo das obras, utilizamos apenas de métodos qualitativos para a obtenção de fatos globais. No Capítulo 2 desta tese, apresentamos os métodos utilizados em detalhe.

Finalmente, tendo obtido fatos discretos e globais por meio da análise do objeto recolhido com vistas aos objetivos selecionados, resta delinear como deve ser a exposição deles em texto. Swiggers (2013: 45) chama a fase da pesquisa em que é realizada a demonstração dos resultados da investigação de executiva. Ressaltamos duas de suas dimensões, uma que se refere ao formato de exposição, que em nosso trabalho, é uma exposição combinatória (das formas narrativa e tópica), dado que se centra "entre o contexto e o conjunto de pontos de vista em determinada época da história linguística" 
(Swiggers 2013: 45). Outra dimensão diz respeito ao programa cognitivo, dependente, em parte, da disponibilidade do objeto, em parte, das aspirações do historiógrafo; adotamos neste trabalho o perfil de historiografia "narrativa" na medida em que relatamos, em sucessão cronológica, fatos discretos e fatos globais da história da gramática.

Enfim, em resumo, respondemos as perguntas com que iniciamos este item. Ainda que haja uma série de lacunas, se estivermos cientes delas, utilizarmos uma metodologia fundamentada teoricamente e a explicitarmos, parece ser possível realizar a historiografia (i.e., uma versão da história) de um determinado período, de uma determinada tradição, autor e ou problema linguístico.

\section{2. (Meta-)metalinguagem e conceptualização}

O pensamento linguístico, que se refere aos dados e fatos linguísticos é necessariamente uma metalinguagem, dado que falamos da linguagem utilizando outra linguagem; a metalinguagem é parte relevante da historiografia orientada para o conteúdo. Nesse sentido, a historiografia linguística, tendo como objeto o pensamento linguístico, é uma meta-metalinguagem, a qual, por sua vez, é modalizada, como vimos, pela metahistoriografia que não é nada mais do que uma meta-meta-metalinguagem. É justamente esse processo que Swiggers (2010a:9-10) chama de "cascata semiótica de 'metaníveis"”.

Entramos na cascata semiótica de "metaníveis", visto que tratamos de uma metalinguagem (construída), que não pode ser descrita senão em função de uma meta-metalinguagem (superposta), que, por sua vez, pressupõe uma ou várias meta-meta-metalinguagens (que servem de quadro construtivo/evolutivo/modificativo etc). ${ }^{5}$

Hjelmslev (2000[1943]), tendo como base a concepção de signo linguístico como um conteúdo em relação com uma expressão, afirma que no signo metalinguístico há signo(s) linguístico(s) no lugar do conteúdo. Assim, considerando a cascata semiótica, no conteúdo de um signo meta-metalinguístico, há signos metalinguísticos; dessa forma, se um signo linguístico é E R C (Expressão em relação com Conteúdo), o signo metalinguístico é E R(ERC), já o signo meta-metalinguístico é E R(ER(ERC)), e assim

\footnotetext{
${ }^{5}$ On est entrâné dans la cascade sémiotique de "méta-niveaux", vi qu'on traite d'un métalangage (construit), qui ne peut être décrit qu'en fonction d'un méta-métalangage (superposé), qui lui-même présuppose un (des) méta-méta-métalangage(s) (qui sert de cadre constructif/évaluatif/translatif, etc).
} 
por diante. Em suma, por exemplo, o signo linguístico "homem" estaria dentro do signo linguístico "substantivo", o qual, por sua vez, poderia estar dentro do signo metametalinguístico "conceito".

A escolha que fazemos da expressão ou do termo de nossos signos metametalinguísticos deve ser cautelosa para, por um lado, não causar confusão entre os níveis, e, por outro, para ser justa com seu conteúdo correspondente. A respeito desse tema, Swiggers, Desmet \& Jooken (1996:34) e Swiggers (2010a: 8-9) chamam atenção para a escolha do historiógrafo entre um nível de descrição êmico ou ético. No primeiro, foca-se numa análise interna e funcional de um sistema específico, ao passo que no ético, procura-se fazer uma metalinguagem compreensiva e ampla - é possível fazer uma analogia entre os conceitos supracitados e as áreas da fonética e da fonêmica. Em trabalhos que exigem comparação entre sistemas muito diferentes, torna-se um desafio atingir o nível êmico.

Neste trabalho, utilizamos a noção mais geral de conceito, o resultado de processos de classificação ou conceptualização da cadeia da linguagem, como metametalinguagem para observar a metalinguagem das gramáticas analisadas. De um ponto de vista estrutural, segundo Auroux, a gramática e os estudos linguísticos em geral são formados por, pelo menos, “a) uma categorização das unidades; b) exemplos; c) regras mais ou menos explícitas para construir enunciados (os exemplos escolhidos podem tomar seu lugar)" (Auroux 2009[1992]:65) ${ }^{6}$. Esses três procedimentos são reunidos e organizados dentro de uma metalinguagem, a qual é específica em cada gramática. Tendo como base os itens (a) e (b), organizamos da seguinte forma a noção de conceito.

\footnotetext{
${ }^{6}$ Assim, a gramática necessariamente repousa sobre uma análise da cadeia falada, seja ela sintagmática (formando uma cadeia em frases, as frases em palavras, as palavras em letras), seja ela paradigmática, em que a repartição das partes se dá por conta de propriedades imbricadas (há diversos tipos de frase/proposição, tal como há diversas espécies de palavras). Nesta última, surgem as partes do discurso. Estas são produto da decomposição da linguagem em palavras, que foi dominante nos estudos ocidentais da linguagem até, pelo menos, o século XX.
} 


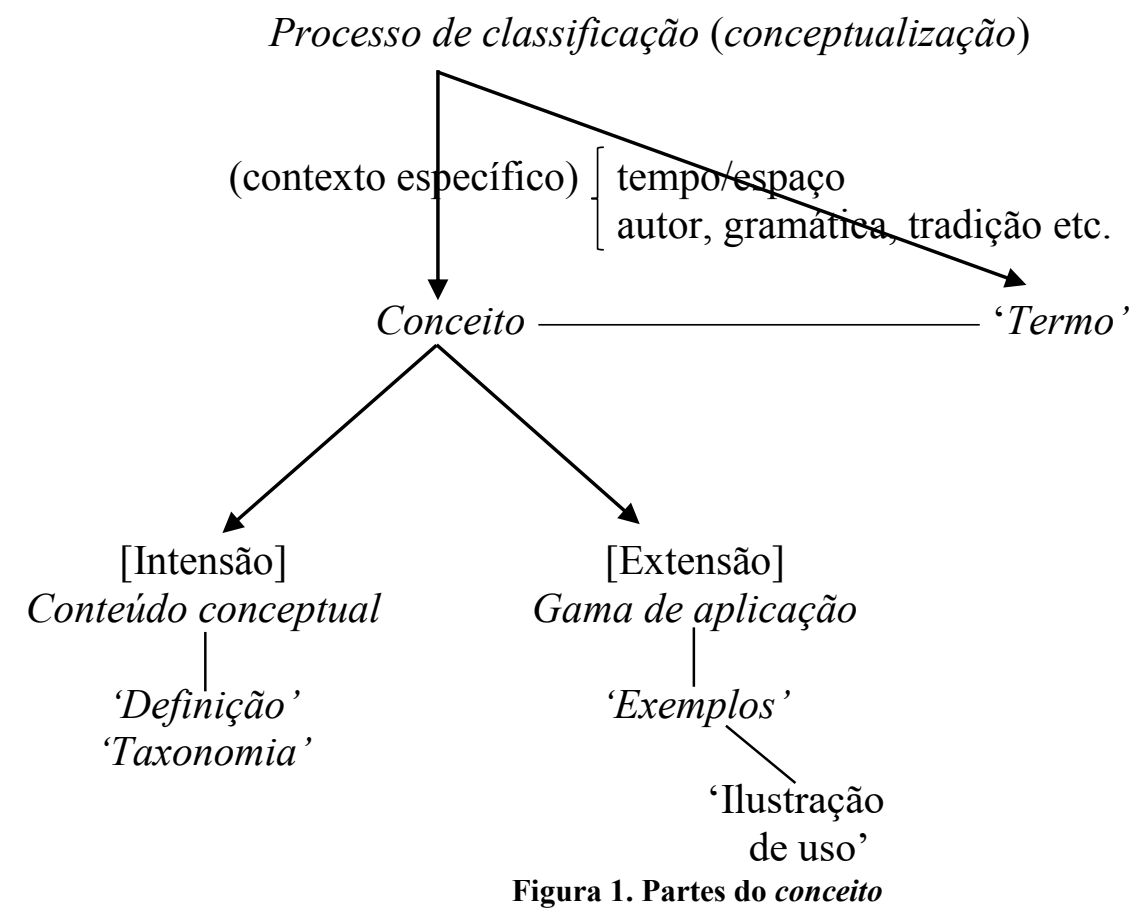

Os processos de classificação, os quais são teoricamente carregados (theoryladen, cf. Swiggers 2004) e realizados em um contexto especifico, resultam em conceitos justapostos a termos. Observamos o conteúdo do conceito em seus dois aspectos lógicos, isto é, a intensão e a extensão. O primeiro refere-se ao conteúdo conceptual enquanto o segundo é a gama aplicacional do conceito. O conteúdo conceptual pode ser distinguido em definição e taxonomia, esta última é a relação que o conceito tem com outros conceitos quando são gênero ou espécie. A gama aplicacional refere-se aos dados linguísticos representativos do conceito, que têm dois tipos, são exemplos, quando são apenas formas básicas do inventário de dados linguísticos que têm como escopo o conceito, são ilustrações de uso, quando o exemplo aparece em contexto de uso.

Exemplificamos o uso dessas noções com o conceito de 'artigo' apresentado por Dionísio Trácio em sua Tékhnē Grammatikē̄. O termo é 'artigo'; a definição é "parte da frase sujeita à variação de caso, preposta ou posposta à declinação dos nomes"; as espécies (que configuram sua taxonomia) são 'prepositivo' e 'pospositivo'; os exemplos, para a primeira espécie, "ho", e, para a segunda espécie, hós; e, por fim, as ilustrações de uso correspondem ao 'artigo' nos três diferentes 'gêneros' "ho poiētês", "he poiēsis", "tó poiēma" (tradução e gêneros: o poeta - masculino; a poesia - feminino; o poema neutro).

${ }^{7}$ Utilizamos a tradução para o português de Chapanski (2003: 32). 
Antes de passarmos à rede conceitual, vamos observar com mais atenção a ideia de que processos de classificação ou conceptualizações possuem carga teórica. A esse respeito, Swiggers (2004:127) lembra que historiógrafos, ao examinar teorias e modelos do passado, encontram formas muito variadas de conceptualização. Para exemplificar isso, apresenta doze conceptualizações do objeto central do pensamento linguístico, isto é, a língua (ou linguagem), a saber:

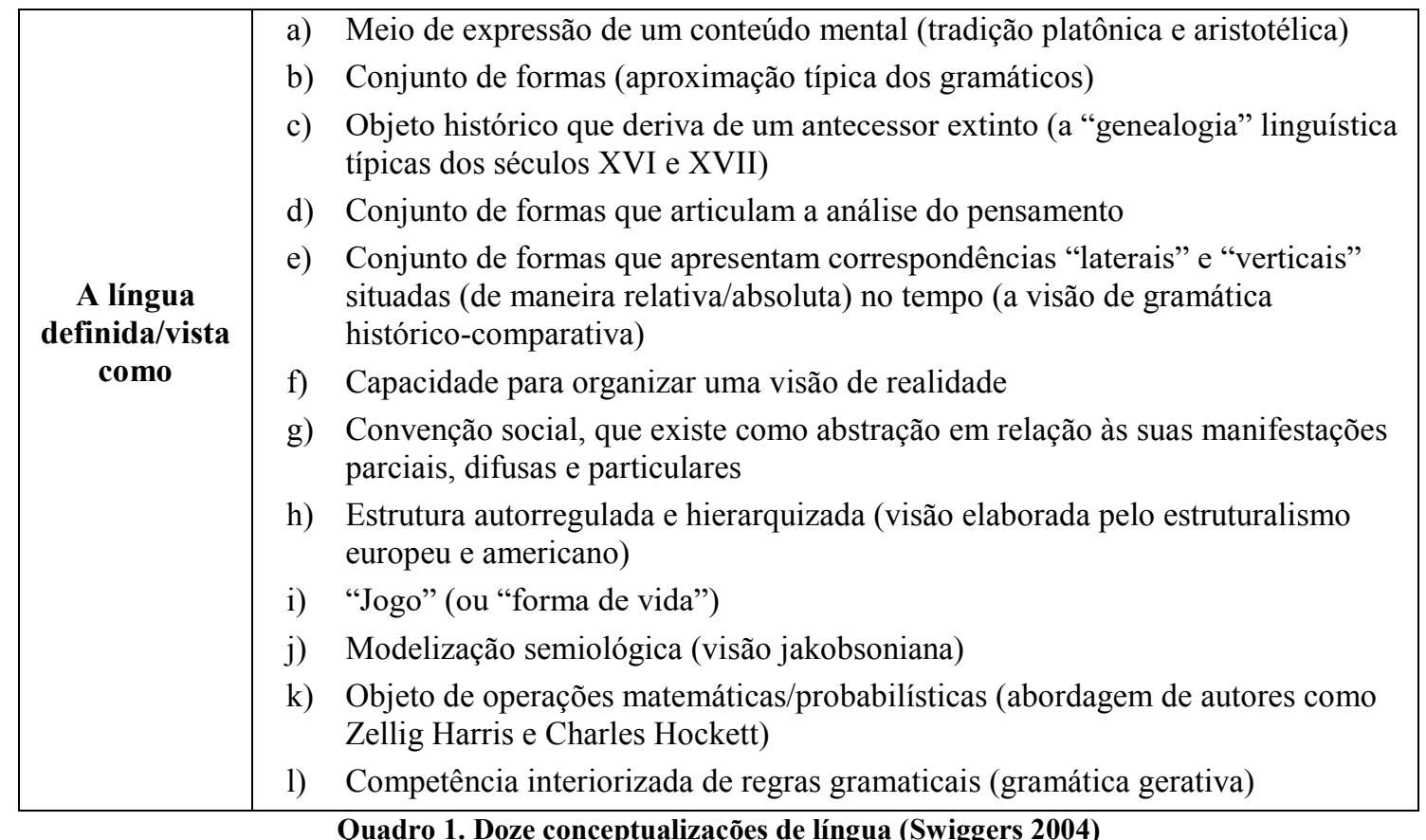

Embora, (b) tenha sido classificada como a "aproximação típica dos gramáticos" por Swiggers, ela é uma das possibilidades de conceptualização sobre a língua em gramáticas. Por outro lado, é verdade que a conceptualização de gramática enquanto manual descritivo de determinados níveis linguísticos é relativamente estável em seus mais de dois mil anos de existência. Ainda que tenha tido orientações diversas ao longo de sua história, as quais estavam conectadas a diferentes conceptualizações da língua ou da linguagem, é possível observar alguma estabilidade em sua divisão e nos conteúdos geralmente apresentados. Auroux (2009[1992]) em relação ao conteúdo relativamente estável da gramática, diz que nela devem constar: "ortografia/fonética (parte opcional), partes do discurso, morfologia (acidentes da palavra, compostos, derivados), sintaxe (frequentemente muito reduzida: conveniência e sintaxe), figuras de construção.” (Auroux 2009[1992]:65).

Os modelos de descrição linguística pressupõem ideias sobre o que é a linguagem, sua estrutura, unidades descritivas, técnicas de análise. A fim de canalizar estruturas 
conceptuais similares de uma visão global e de interesses específicos, Swiggers (2004:129) apresenta a noção de programa como sistema conceptual que abarca aproximações que compartilham a mesma visão, a mesma focalização e a mesma técnica quanto à linguagem. Há quatro programas de investigação, que expomos no quadro adiante:

\begin{tabular}{|c|c|}
\hline $\begin{array}{c}\text { Programa de } \\
\text { Correspondência }\end{array}$ & $\begin{array}{l}\text { Visão: correlação língua-pensamento-realidade } \\
\text { Incidência: relações entre estruturas morfossintáticas e conteúdos ou processos } \\
\text { mentais } \\
\text { Técnica: semantização de estruturas gramaticais (estabelecimento de classes } \\
\text { lógico-semânticas); estabelecimento de correlações entre os processos mentais e as } \\
\text { regras gramaticais. } \\
\text { Autores e grupos cujas propostas se vinculariam a esse programa: Platão, } \\
\text { Aristóteles, os modistas, os gramáticos filosóficos dos séculos XVII e XVIII, } \\
\text { Gustave Guillaume e Noam Chomsky (e seus discípulos). }\end{array}$ \\
\hline $\begin{array}{c}\text { Programa } \\
\text { Descritivista }\end{array}$ & $\begin{array}{l}\text { Visão: descrição das línguas como objetos } \\
\text { Incidência: análise (segmentação/colar em oposição/combinação) de formas } \\
\text { observáveis; comparação de formas de diversas línguas (para fins constrativos/para } \\
\text { fins comparativos; reconstrução); função de formas. } \\
\text { Técnica: determinação de contextos, segmentação, estudo de relações de proporção } \\
\text { entre os elementos; estabelecimento de relações entre formas linguísticas e funções } \\
\text { comunicativas. } \\
\text { Autores e grupos cujas propostas se vinculariam a esse programa: os gramáticos } \\
\text { sânscritos, os gramáticos alexandrinos (e seus comentadores bizantinos), os } \\
\text { gramáticos romanos e carolíngeos, os autores das gramáticas de uso da Renascença, } \\
\text { e, nos últimos séculos, os comparatistas e os linguistas estruturalistas (que } \\
\text { trabalham com sincronia ou com diacronia). }\end{array}$ \\
\hline $\begin{array}{c}\text { Programa } \\
\text { Sociocultural }\end{array}$ & $\begin{array}{l}\text { Visão: a língua como um fato social e cultural } \\
\text { Incidência: determinação dos usos linguísticos; a competência comunicativa; a } \\
\text { variação sociolinguística; a expressão de uma cultura através da língua. } \\
\text { Técnica: integrativa ou sintética; (inserção de fatos linguísticos em uma análise das } \\
\text { sociedades ou das culturas; inserção de análises linguísticas em uma teoria da } \\
\text { estratificação social ou da evolução social e cultural). } \\
\text { Autores e grupos cujas propostas se vinculariam a esse programa: discussões } \\
\text { sobre o uso linguístico e as reflexões filosóficas-linguísticas, desde a Renascença, } \\
\text { sobre a diversidade (social das línguas); linguística "idealista" neo-humboldtiana; } \\
\text { sociolinguística. }\end{array}$ \\
\hline $\begin{array}{l}\text { Programa de } \\
\text { Projeção }\end{array}$ & $\begin{array}{l}\text { Visão: línguas como conjuntos de fragmentos lógicos (predicativos) } \\
\text { Incidência: sub-sistemas gramaticais particulares } \\
\text { Técnica: tradução de estruturas linguísticas em linguagem formalisada. } \\
\text { Autores e grupos cujas propostas se vinculariam a esse programa: os trabalhos de } \\
\text { Montague, Hintikka, Cresswell, Dowty, Partee, }\end{array}$ \\
\hline
\end{tabular}

Quadro 2. Programas de Investigação (Swiggers 2004)

Swiggers canaliza em um mesmo programa diferentes porém similares conceptualizações de linguagem, técnicas de análise e incidências. Essa neutralização (ou homogeneização) é feita sobretudo paradigmaticamente ou verticalmente, ainda que haja três categorias 
sintagmáticas ou horizontais para se observar numa teoria, que são visão, incidência e técnica. Propomos neste trabalho outro modo de neutralização, realizada de maneira sintagmática ou horizontal, que pudesse ser aplicada a especificidades de textos gramaticais.

Consideramos, com base em Swiggers (2010a: 10), que termos têm conteúdo focal, isto é, a relação bilateral entre um termo e o que ele significa, e conteúdo contrastivo, isto é, a rede, implícita ou explícita, de conteúdo no interior da qual um termo assume seu conteúdo dinâmico. Tendo em conta que, neste trabalho, chamamos o conteúdo do termo de conceito, temos a hipótese de que seja possível encontrar redes conceituais em torno de conceitos que sejam observados como conceitos-chave. Estes seriam como uma pedra fundamental de uma determinada conceptualização de linguagem, o que acabaria por torná-los, idealmente, relacionados a outros conceitos e mesmo, por vezes, pressupostos por eles. Supomos que em nosso objeto, isto é, na gramaticografia brasileira oitocentista, o 'verbo substantivo' seja, na maior parte do século que a inicia, o conceito-chave do tratamento da sintaxe das obras e parte do tratamento das classes de palavras - essa seleção é explicada com mais demora no item 1.4 .

Swiggers (2010a:11) apresenta as relações lógicas que termos poderiam travar no interior de uma teoria ou na comparação de teorias, o qual reproduzimos abaixo:

\begin{tabular}{|cc|}
\hline Relações intensionais & Relações extensionais \\
Subordinação & Subsunção \\
Não-intersecção & Justaposição \\
Intersecção & Sobreposição \\
Contradição & Exclusão \\
Contrariedade & Oposição \\
\hline
\end{tabular}

Quadro 3. Relações lógicas entre termos (Swiggers 2010a)

No entanto, nosso objeto não são teorias, mas gramáticas que, embora tenham, na maior parte dos casos, uma conceptualização predominante de linguagem, apresentam muitas vezes certo ecletismo (cf. item 1.3); ademais, não procuramos relações entre termos quaisquer, mas entre um conceito-chave e outros conceitos que nos pareçam ter alguma relação com ele. Dessa forma, aproveitamos as relações expostas por Swiggers (2010a) da seguinte maneira: pensando idealmente na rede conceitual, parecem-nos interessantes as relações de subordinação/subsunção e de intersecção/sobreposição. Além disso, pensamos que pode haver entre os conceitos da rede conceitual outros dois tipos de relação, a de identidade, quando dois conceitos têm a mesma intensão e a mesma 
extensão, e a relação de base teórica comum, isto é, há entre os dois conceitos uma relação correspondente a, por exemplo, conceptualização de língua selecionada. No quadro adiante, sintetizamos as relações que concebemos haver entre os conceitos.

\begin{tabular}{|c|c|}
\hline Relaçães & Definição \\
\hline Subordinação & Relação de inclusão entre dois conceitos. Um contém outro. \\
\hline Intersecção & Relação na qual há parte comum entre os (conjuntos dos) dois conceitos. \\
\hline Equivalência & Relação em que os conceitos são equivalentes intensionamente e têm a \\
mesma extensão.
\end{tabular}

Quadro 4. Relações possíveis entre conceito-chave e conceitos da rede conceitual

Como vimos, tanto os programas de investigação de Swiggers (2004) quanto a hipótese de uma rede conceitual procuram, metodologicamente, neutralizar a diversidade. No item adiante, tratamos das oposições entre homogeneidade e heterogeneidade e entre continuidade e descontinuidade.

\subsection{Continuidade e descontinuidade, homogeneidade e heterogeneidade}

Como veremos ainda nesse capítulo (cf. 1.4), Itkonen (1991) e García (2004) têm visões diferentes acerca da continuidade ou descontinuidade do tratamento da 'proposição' realizado por Aristóteles no Peri Hermeneias (IV a.C.) e por Arnauld e Lancelot, autores da Grammaire Générale et Raisonnée de Port-Royal (1660). Enquanto o primeiro enfatiza a continuidade, García ressalta as diferenças, ainda que considere algumas similaridades. Isso não quer dizer que um deles esteja certo e o outro errado. Dado que a narrativa historiográfica é uma versão da história, a observação do pensamento linguístico contínuo ou descontínuo no tempo é, de certa forma, uma opção do(a) historiógrafo(a). Borges Neto (2012:88) comenta acerca disso:

Uma das questões epistemológicas centrais da historiografia linguística reside na decisão (prévia e determinante) de como encarar o fluxo dos eventos: se numa linha, mais ou menos cronológica, de eventos que se acumulam ou numa sucessão de momentos de ruptura e transformação.

Como já dissemos, a historiografia linguística é a escrita da história do pensamento linguístico em que há um recorte do número incontável de fatos e de eventos que esta oferece por meio de uma metodologia que realiza outros recortes e ainda tendências. Swiggers (1997:5), ao tratar do pensamento linguístico ocidental, afirma que há uma 
dinâmica interna de problemas nesses estudos, e que esta dinâmica não se manifesta sempre com a mesma intensidade, nem ao mesmo tempo. Citamo-lo:

É significativo que através da história do pensamento linguístico diferentes problemas estiveram no centro das preocupações dos estudiosos; a adequação ou não adequação da linguagem em relação à realidade ou às nossas representações mentais; a apresentação de um quadro descritivo para a língua que deve ser ensinada; a justificativa filosófica das categorias que são estabelecidas; a "genealogia" das línguas; a língua como organismo ligado a uma cultura, etc. ${ }^{8}$

Ainda assim, Swiggers captura nessa mesma história do pensamento linguístico alguns padrões de homogeneidade, os quais ele desenvolve nos programas de investigação, de que já tratamos (cf. item 1.2). Em suma, a escolha por uma historiografia que enfatize continuidades ou descontinuidades é, como disse Borges Neto, responsabilidade do estudioso na medida em que ele tem de estar consciente das tomadas de decisão que faz a fim de realizar sua historiografia para que possa explicitá-las ao leitor.

Lembramos, no entanto, que a ideia de que a ciência possa ou não ser analisada por meio de rupturas é recente, dado que até pouco tempo atrás havia na história da ciência (e também na história da linguística) uma tendência, praticamente exclusiva, para a continuidade, a qual, por sua vez, era denominada progresso (muitas vezes, unilinear, por constante aperfeiçoamento). No caso da historiografia da linguística, podemos encontrar exemplos desse tipo de análise de continuidade em textos como de Leroy (1977), Mounin (1967), Mattoso Câmara Jr. (1975) ${ }^{9}$. É, ao menos parcialmente, por conta do impacto do conhecido texto de Thomas Kuhn, A Estrutura das Revoluções Cientificas, que a ruptura ganha papel tão relevante quanto o papel da continuidade na história das ciências. $\mathrm{Na}$ metahistoriografia linguística, o modelo de Kuhn foi frequentemente adaptado (cf. Percival 1976, Hymes 1983, Koerner 1989, Murray 1994, Swiggers 2004, entre tantos outros).

\footnotetext{
${ }^{8}$ Il est significatif qu'à travers l'histoire de la pensée linguistique différents problèmes ont été au centre des préoccupations des savants: l'adéquation ou la non-adéquation du langage par rapport à la réalité, ou par rapport à nos représentations mentales; la présentation d'un cadre descriptif pour la langue qui doit être enseignée; la justification philosophique des catégories grammaticales qu'on établit; la "généalogia" de langues; la langue comme organisme lié à une culture, etc. (Swiggers 1997:5)

${ }^{9}$ Leonard Bloomfield, embora não tenha escrito uma história da linguística, inicia seu Language com a seguinte afirmação "The new version [of this book] is much larger than the old, because the Science of language has in the interval made progress, and because both men of Science and the educated public now atribute greater value to an understanding of human speech." (Bloomfield 1966[1933]: vii), a qual, em tradução livre, ficaria "A nova versão deste livro é muito mais longa do que a antiga, porque a Ciência da linguagem fez progressos nesse intervalo de tempo, e porque o homem, a Ciência e o público educado atribuem grande valor para a compreensão da fala humana". Koerner (1989) apresenta esse trecho como exemplo do do modelo de Progresso Unilinear, considerando "ingênuo".
} 
Kuhn (2009[1962]) procura explicar o desenvolvimento das ciências com base em um modelo estrutural, que considera que as ciências formam um paradigma ${ }^{10}$ por vez, os quais são incomensuráveis e têm um percurso cíclico constituído por algumas fases ${ }^{11}$.

Embora a proposta seja considerada positivamente, sobretudo por reconhecer as rupturas e o papel da comunidade científica na formação do paradigma, ela também recebeu diversas críticas. O conceito de ciência de que fala Kuhn é criticado, visto que seriam ciências amadurecidas apenas os conhecimentos que tivessem (tido) um paradigma, o que não ocorre na Linguística, por exemplo (cf. Percival 1976, Obregón 1982), e na maior parte das ciências humanas. As críticas também afirmam ser preciso modalizar a relação travada entre a comunidade científica e o paradigma, inserindo mais complexidade do contexto sociocultural. Para suprir essas faltas, Koerner (1989) apresenta, baseado em Hymes, o conceito de que cinosuras (estruturas similares aos paradigmas) estariam em competição pelo lugar de mainstream, tal como, na Sociolinguística, as variantes linguísticas competem pelo lugar de variante padrão, como no diagrama abaixo:

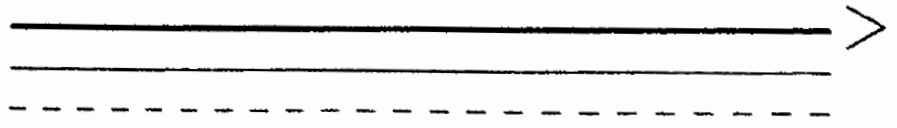

Figura 2. Representação do modelo "Mainstream-vs-Undercurrent" de Koerner (1989:52)

\footnotetext{
${ }^{10}$ Kuhn não define exatamente paradigma, mas o trecho a seguir pode delinear o conceito: "Homens cuja pesquisa está baseada em paradigmas compartilhados estão comprometidos com as mesmas regras e padrões para a prática científica. Esse comprometimento e o consenso aparente que produz são prérequisitos para a ciência normal, isto é, para a gênese e a continuação de uma tradição de pesquisa determinada." (Kuhn 2009[1962]:30)

${ }^{11} \mathrm{Na}$ primeira fase, chamada pré-paradigmática, o paradigma ainda não existe, pois há uma série de ideias que não entram em acordo entre si, impossibilitando a unidade própria do paradigma; portanto, ainda não há ciência, de acordo com Kuhn. Posteriormente, por meio de persuasão coletiva, uma das ideias ganha unidade de pensamento, dando surgimento ao paradigma e sua respectiva comunidade científica. A partir de então, temos a terceira fase, que Kuhn nomeou de ciência normal, na qual diversos cientistas, persuadidos pela eficácia do paradigma, trabalham num mesmo objeto, baseando-se em mesmos fundamentos teóricos e usando de técnicas similares. Nesse momento, segundo Kuhn, pode haver um progresso interno ao paradigma. Há, entretanto, um esgotamento desse progresso, que é revelado pelo interesse em respostas de perguntas que o paradigma não contempla, essa é a quarta fase, nomeada ciência extraordinária, momento em que, aos poucos, o paradigma passa a perder a confiança dos cientistas. Surge, então, a crise, que nada mais é que um novo espraiamento da ciência em diversas ideias e estudos que não se combinam entre si. Essa fase é bastante similar à fase pré-paradigmática, com a diferença de que já houve um paradigma e, portanto, falamos de uma ciência amadurecida. Logo, como havia acontecido no ciclo anterior, por meio de persuasão, é selecionado um paradigma e cria-se concomitantemente sua comunidade científica; esse último processo chama-se revolução científica.
} 
Outra questão em torno do modelo kuhniano é relativa à ruptura promovida numa revolução, as críticas tendem a afirmar que essa ruptura não seria necessariamente total, nem ocorreria num único momento. Nesse sentido, Koerner complexifica o modelo apresentado anteriormente, mostrando que cinosuras, sejam elas da tendência dominante ou de alguma corrente periférica, podem ser interrompidas, darem lugar a outras cinosuras e serem retomadas no futuro, seja como corrente periférica, seja como tendência dominante novamente, como vemos no diagrama abaixo:

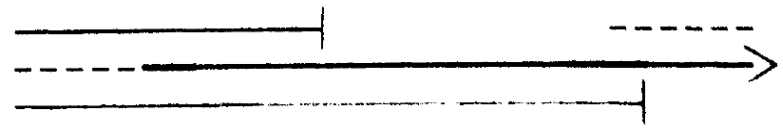

Figura 3. Representação do modelo "Discontinuity-vs.-Continuity" de Koerner (1989:53)

Os modelos de Koerner, enfatizam, por um lado, a descontinuidade no tempo, a qual já havia sido desenvolvida, ainda que de forma mais simples, por Kuhn, e, por outro, traz a novidade da diversidade (em oposição à unidade do paradigma) do pensamento linguístico, visto que há várias cinosuras num mesmo período.

Swiggers (2004), inspirado no modelo de Peter Galison, assumindo que a ruptura em si é complexa, não sendo ela una e total, propõe que a mudança de um paradigma seja observada em capas ou dimensões. Nesse sentido, a incomensurabilidade do paradigma kuhniano é novamente questionada. O autor distingue no todo do conhecimento linguístico quatro diferentes dimensões. A capa teórica, que diz respeito ao conceito global de linguagem e estatuto dos estudos realizados; a capa técnica, correspondente a técnicas de análise e métodos de apresentação dos dados; a capa documental, que abarca a documentação linguística e filológica, número de línguas, tipos de fontes de dados, por exemplo, sobre o qual se baseia o estudo linguístico; e, finalmente, a capa contextual e institucional, correspondente ao contexto cultural e à contextura institucional. Neste modelo, uma dimensão poderia passar por descontinuidade, enquanto as outras estariam em continuidade, por exemplo. Caso todas as dimensões se modificassem, haveria a uma mudança transversal, que seria similar à revolução kuhniana.

Murray (1994), por sua vez, enfatizando o papel da comunidade científica e da persuasão na formação de um paradigma, propõe que em vez da noção kuhniana de revolução científica fosse empregada noção de retórica revolucionária. Tal proposta desloca a ruptura do campo epistemológico para a dimensão discursiva da ciência. Segundo o autor, a escolha de retórica pode ser revolucionária ou de continuidade de acordo com a tomada de opinião do cientista. Murray observou que, na linguística 
antropológica norte americana do início do século XX, tal decisão, porém, dependeu de alguns fatores: condição de elite, idade profissional e acesso ao reconhecimento. Tanto pesquisadores de elite quanto os marginais podem ter uma postura inovadora, entretanto, os primeiros só fazem isso quando a inovação parece segura, ao passo que os pesquisadores marginais tendem a assumir mais riscos. A noção de idade profissional, que distingue estudantes de cientistas certificados, demonstra que quanto menor foi o treinamento e, portanto, menores os comprometimentos institucionais e científicos, maior a disposição para adotar a retórica revolucionária. Finalmente, a falta de acesso ao reconhecimento pode também ser uma razão para a adoção da retórica revolucionária em relação a grupos pré-estabelecidos. Dessa forma, Murray apresenta um desenvolvimento do papel da persuasão nas rupturas. Entretanto, ele limita seu estudo à retórica, não abarcando também questões epistemológicas.

Nosso objeto de estudo, a gramática, como já dissemos anteriormente, é um gênero textual bastante estável, mas que passou frequentemente por mudanças no que diz respeito à conceptualização de linguagem. Em suma, é um objeto que têm certo grau de continuidade e homogeneidade em seu formato e da seleção de níveis de análise ao mesmo tempo que sofre modificações e pode ser diverso num mesmo momento histórico devido à sua conceptualização de linguagem e, portanto, de abordagem dos dados (cf. item 1.1). Utilizamos a proposta de Swiggers (2004) em estudo anterior (cf. Polachini 2013), no qual procuramos fazer uma periodização "complexa", que considerava as quatro dimensões, do tratamento da sintaxe na gramaticografia brasileira do português do século XIX por meio da análise de seis obras ${ }^{12}$.

Obtivemos resultados bastante interessantes por meio da distinção de dimensões. Notamos, entretanto, que há dificuldade de lidar com a capa técnica devido sua complexidade interna. Assim, ainda que determinadas técnicas fossem continuadas de gramática para gramática, havia outras que não o eram, havendo um percurso de rupturas parciais na dimensão técnica entre cada par de gramáticas. Isso revelava, por um lado, que a maneira como estávamos analisando o tratamento da sintaxe priorizava o

\footnotetext{
${ }^{12}$ Em trabalho anterior (cf. Polachini 2013), analisamos o tratamento da sintaxe em seis gramáticas brasileiras do português, a saber: Morais Silva (1806), Coruja (1873[1835]), Sotero dos Reis (1866), Freire da Silva (1875), Ribeiro (1881) e Maciel (1902[1894]). O estudo, cuja metodologia baseava-se nas dimensões propostas por Swiggers (2004), demonstrou que a ruptura entre a tradição influenciada pela grammaire générale e a outra mais aproximada do método histórico-comparativo, não se deu de forma abrupta, mas gradual. Ademais, procuramos descrever o tratamento da sintaxe nas quatro dimensões, o que proporcionou uma análise mais detalhada.
} 
aparecimento da diversidade, e, por outro, levantava a suspeita de que havia certo ecletismo na gramaticografia brasileira do português.

Quanto à nossa metodologia em 2013, não procurávamos fazer generalizações na análise da dimensão técnica - diferentemente do que faz, por exemplo, Swiggers com os programas de investigação - e não procurávamos relacionar as técnicas entre si, como agora pretendemos fazer com a noção de rede conceitual. Neste trabalho, utilizamos uma metodologia que possibilite a observação, idealmente, da homogeneidade interna de cada material analisado, dezoito gramáticas brasileiras do português (cf. item 2.1), com objetivo de analisar com maior minúcia as continuidades e descontinuidades da capa técnica entre as obras, além do ecletismo presente na tradição brasileira do português.

Tradição e ecletismo são termos de nossa meta-metalinguagem que indicam, respectivamente, certa homogeneidade e certa heterogeneidade. Swiggers (2010b: 7n) apresenta quatro modos pelos quais a noção de tradição pode ser tomada: (1) de um ponto de vista nacional, étnico ou geograficamente definido; (2) conectada a um paradigma científico ou a um tipo de investigação científica - por vezes, é combinada com o foco nacional; (3) pode estar relacionada a um investimento linguístico, em função de um alvo cultural, ideológico e/ou político, como é, por exemplo, o caso da linguística missionária; (4) de forma mais ampla, definida pelo foco em um subgênero da prática linguística (lexicografia bilíngue, por exemplo) ou por se ocupar de uma língua específica.

Nesta tese, apresentamos algumas tradições cujo critério de homogeneidade é variável. Por vezes, nos referimos à tradição da grammaire générale francesa (16601883) (cf. Bouard 2007), que, sendo do tipo (2), por conceptualizar a língua como, grosso modo, expressão do pensamento, com acréscimo do foco nacional de (1), tem certos traços de (4) por ter como base o gênero textual gramatical. A tradição gramatical brasileira de língua portuguesa parte, como está no seu nome, dos critérios (1), pelo foco nacional, e (4), por ser do gênero textual gramatical e se direcionar para a língua portuguesa; o critério (2), relativo ao paradigma, no entanto, é modificado ao longo do tempo. Do início do século até a década de 1880, essa tradição é predominantemente influenciada (direta ou indiretamente) pela tradição da grammaire générale francesa supracitada; no último quartel do século têm início um processo de ruptura epistemológica, as gramáticas passam a conceptualizar a língua (2) como fatos linguísticos que deve ser comparados entre diferentes línguas e entre períodos diferentes da mesma língua e provinha, paradigma este que tem, sobretudo, mas não só, origem alemã (1) (cf. item 1.5). 
Sendo, porém, a tradição gramatical brasileira não apenas receptiva a conceptualizações realizadas por tradições paradigmáticas em diferentes momentos do século XIX, mas é também eclética por, algumas vezes, reunir elementos epistemológicos provenientes de diferentes tradições (ou paradigmas) que não compartilham da mesma conceptualização de linguagem, há nela uma tensão entre a homogeneidade - de tradição nacional, tradição relativa ao objeto de estudo (língua portuguesa) e tradição relativa ao formato de exposição dos conteúdos (gramática) - e a heterogeneidade. A rede conceitual é uma metodologia que observa a homogeneidade ou revela a heterogeneidade horizontal de conceitos; ela, portanto, nos parece um bom modo de compreender se havia e como se dava o ecletismo na formação e desenvolvimento da gramaticografia do português no Brasil, além de permitir uma visão diferente de como se deu a descontinuidade de uma tradição paradigmática para a entrada de outra no final do século.

Definimos ecletismo como reunião de conceptualizações (a respeito da língua e de suas partes) de origens diversas que não se articulam em uma unidade consistente. Isso pode se dar de duas maneiras: a horizontal, em que não há a articulação entre os conceitos de uma gramática, por exemplo, quando o 'verbo substantivo' é definido na obra como aquele que promove a união entre o ‘sujeito' e o ‘atributo', mas não aparece no conceito de 'oração'; e a vertical, quando a gramática apresenta mais de um conceito para o mesmo termo. Normalmente, o ecletismo vertical se dá quando a gramática é menos direta do que seria se fosse apenas um manual (grego téchne, latim ars, português arte), mas apresenta também reflexões acerca da linguagem e outras possibilidades conceituais para um mesmo termo.

Encontramos alguns tipos de reflexão nas obras, as quais chamamos de metatexto, visto que são em geral uma ampliação do que é dito no seu próprio texto gramatical, como quando apresenta (1) nota de rodapé ou nota dentro do próprio texto, por meio de diferenciação tipográfica ou (2) comentário meta-metalinguístico a respeito do próprio conceito. Consideramos também metatexto trechos em que os gramáticos se afastam da autoria de certos conceitos ou explicações e iniciam seu texto por (3) "dizem os gramáticos" ou "tal gramáticos diz que". Texto, ao contrário, seria o restante da obra, onde os termos e conceitos são apresentados.

Ademais, observando os elementos paratextuais das gramáticas, como título, subtítulos, epígrafes, prefácio e prólogo, analisamos, baseando-nos em Murray, a retórica do autor da gramática, isto é, em que medida ele apresenta uma retórica revolucionária, de risco ou segura, ou uma retórica de continuidade. Essa é parte da história externa das 
18 selecionadas que reunimos, posteriormente, à análise interna da rede conceitual para observar em que medida há coerência ou homogeneidade entre retórica e descrição gramatical ou não.

Em suma, no trabalho historiográfico, é preciso tomar uma série de decisões de acordo com nosso objeto e metodologia, as quais, envolvem as oposições entre continuidade e descontinuidade e entre homogeneidade e heterogeneidade. Neste trabalho, nossa metodologia se direciona para a compreensão da homogeneidade, sabendo que é possível também com ela encontrar a heterogeneidade.

\subsection{O conceito de 'verbo substantivo' (ou 'cópula')}

\subsubsection{Seu desenvolvimento histórico}

O conceito de 'verbo substantivo', por vezes, também denominado 'cópula', é tema relevante na gramaticografia oitocentista brasileira, pois está presente na grande maioria dessas gramáticas. Afinal, esta gramaticografia emerge e se mantém por décadas sob o prisma da tradição da grammaire générale. Como se sabe, nessa tradição, o 'verbo substantivo' é, em geral, associado à cópula entre os dois termos de uma 'proposição', 'sujeito' e 'atributo' (ou 'predicado'). Porém, esse conceito passou por diversas mudanças ao longo da história da gramaticografia ocidental, as quais procuramos, sumariamente, expor adiante.

A primeira citação de que se tem conhecimento do 'termo' 'verbo substantivo' é feita pelo gramático latino Prisciano, sem que ele, entretanto, faça relação com a cópula, mas se refira somente ao verbo esse, sum da língua latina (cf. García 2004). Ao longo da Idade Média, ele será denominado 'cópula' de uma 'proposição', ao modo aristotélico, em diversas obras, sobretudo as modistas (cf. Arens 1984, Itkonen 1991:263, García 2004:530). Também era visto na Idade Média como a raiz de todos os outros verbos, por isso esses eram então chamados de 'verbos adjetivos' - a partir de uma analogia terminológica com os conceitos de 'nome substantivo' e ‘nome adjetivo' (Itkonen 1991, Beccari 2013). Alguns dos latinistas renascentistas, que preconizavam a ratio apresentam o termo caracterizando-o, da mesma forma que os escolásticos, como raiz de todos os outros verbos (p. ex.: Sanctius 1587, Roboredo 1619). Houve, entretanto, ao longo dessa história, momentos em que o termo 'verbo substantivo' simplesmente referia o verbo 
"ser" (ou mesmo "fazer"), sem que houvesse um arcabouço epistemológico explicitamente conectado a ele, similarmente ao que ocorre nas Institutiones de Prisciano. Parece que o termo é utilizado dessa forma por alguns latinistas (ex.: Introducciones Latinas (1481), de Nebrija, cf. García 2004) e pelos primeiros gramáticos portugueses (ex.: Oliveira 1536, Barros 1540, Reis Lobato 1770; cf. Pessoa Santos 2010).

Dado esse longo percurso, com ênfase sobretudo na concepção aristotélica de 'cópula' e na de 'verbum substantivum' dos modistas, há certa polêmica acerca da originalidade do uso do termo na Grammaire Générale et Raisonnée de Port-Royal ${ }^{13}$ (1660), que é considerada o ponto inicial da tradição da Grammaire Générale francesa. Foucault (2007[1966]), no seu conhecido texto As Palavras e as Coisas, ao falar da mudança de episteme ocorrida no século XVII, apresenta um capítulo nomeado "Teoria do Verbo", em que ressalta a importância da concepção de 'verbo' como afirmação. De acordo com Foucault, nesta episteme, a 'proposição' seria o elemento fundamental da linguagem, ela formaria juízos partir da ligação de um 'sujeito' com seu 'atributo'. Daí adviria a importância do 'verbo', visto ser ele o responsável por essa ligação, afirmando uma coisa de outra coisa. Citamos uma síntese de como Foucault define o 'verbo', tendo em conta a teoria do verbo, na episteme clássica.

Há proposição - e discurso - quando se afirma entre duas coisas um liame de atribuição, quando se diz que isto é aquilo. A espécie inteira do verbo se reduz ao único que significa: ser. Todos os outros se servem secretamente dessa função única, mas a recobriram com determinações que a ocultam: acrescentaram-se-lhe atributos e, em vez de se dizer "eu sou cantante", diz-se "eu canto"; acrescentaram-se-lhe indicações de tempo e, no lugar de se dizer "outrora sou cantante", diz-se "eu cantava"; enfim, certas línguas integraram aos verbos o próprio sujeito e é assim que os latinos não dizem ego vivit, mas vivo. Tudo isso não passa de depósito e sedimentação em torno e acima de uma função verbal absolutamente tênue mas essencial, "há apenas o verbo ser... que se manteve nessa simplicidade". A essência inteira da linguagem se concentra nessa palavra singular. (Foucault 2007[1966]:131) ${ }^{14}$

Foucault defende que dar ao 'verbo' a significação de afirmação ou de ligação entre o 'sujeito' e o 'atributo' seria elemento específico da episteme clássica, e justifica essa afirmação a partir de uma síntese histórica, bastante breve e em parte retirada da própria Grammaire Générale et Raisonnée de Port-Royal (doravante: GGR-PR), publicada em 1660, sobre noções de 'verbo' na história dos estudos da linguagem. Foucault afirma que Aristóteles preocupou-se apenas com o fato de o 'verbo' significar

\footnotetext{
${ }^{13}$ Doravante GGR-PR.

${ }^{14}$ Foucault não se baseia somente na Grammaire de Port-Royal para fazer suas afirmações acerca da teoria do 'verbo', mas em diversas obras dos séculos XVII e XVIII; citemo-las: Logique, de Hobbes; Considérations sur l'origine et la formation des langues, de Adam Smith, Grammaire, de Condillac, a Logique de Port-Royal, de Arnauld e Nicole, Grammaire Générale, de Beauzée e Éléments d'ideológie, de Desttut de Tracy.
} 
tempo, o que também poderia ser feito por outras palavras como 'advérbios', 'adjetivos' e 'nomes'. Por outro lado, Scaliger ${ }^{15}$, segundo o autor, disse que o verbo significava a ação, mas isso seria, em verdade, função do 'nome'. Por fim, menciona que Buxtorf ${ }^{16}$ teria se preocupado com as 'pessoas' do 'verbo', mas que os 'pronomes' também as significam. A única, exclusiva e essencial característica do 'verbo' seria, portanto, a de afirmar.

Itkonen (1991:264), logo após citar o mesmo trecho do texto de Foucault acima transcrito, critica sua síntese histórica:

Devo interromper os saltos de fantasia de Foucault, apenas para avisar que nada do que ele diz justifica a visão da gramática de Port-Royal como tendo inaugurado uma nova era no estudo da linguagem. Sua visão de Aristóteles é completamente errada e ele não conhece Scaligero melhor do que conhece Aristóteles. ${ }^{17}$

Igualmente, Itkonen critica a pretensão de originalidade dos próprios autores da GGRPR, Antoine Arnauld (1612-1694) e Claude Lancelot (1615-1695), os quais, como dissemos, escrevem a síntese histórica parafraseada por Foucault. Citamo-la:

Assim, tendo Aristóteles parado na terceira das significações adicionadas àquela que é essencial ao verbo, ele a definiu: vox significans cum tempore: uma palavra que significa com tempo. Outros, como Buxtorf tendo adicionado-lhe a segunda, a definiram: Vox flexilis cum tempore \& persona. Uma palavra que tem diversas inflexões com tempo \& pessoa. Outros tendo parado na primeira dessas significações adicionadas, que é a do atributo, e tendo considerado que os atributos que os homens incorporaram à afirmação em uma mesma palavra, são, ordinariamente, ações e paixões, acreditaram que a essência do verbo consistia em significar ações ou paixões. E enfim Júlio César Scaliger acreditou achar um grande mistério em seu livro de princípios da Língua Latina, dizendo que a distinção das coisas em permanentes e fluentes, no que fica e no que passa; era a verdadeira origem da distinção entre os Substantivos e os Verbos : os substantivos servindo para significar o que fica e os verbos o que passa. Mas é fácil de ver que todas essas definições são falsas, e não explicam de maneira nenhuma a verdadeira natureza do Verbo. ${ }^{18}$

\footnotetext{
${ }^{15}$ Julius Caesar Scaliger (1484-1558), gramático renascentista, autor de De causis linguae latinae (1540).

${ }^{16}$ Johannes Buxtorf (1564-1629), gramático do hebreu.

${ }^{17}$ Tradução nossa. Original: I must interrupt Foucault's leaps of phantasy, just to note that nothing what he says justifies the view of the Port-Royal grammar as inaugurating a new era in the study of language. His view of Aristotle is completely wrong, and he does not know Scaliger any better than he does Aristotle.

18 Tradução do francês de Jaci Brasil Tonelli. Original: Ainsi Aristotle s'étant arrêté à la troisiême des significations ajoutées à celle qui est essentielle au Verbe, l'a défini: vox significans cum tempore: un mot qui signifie avec temps. D'autres, comme Buxtorf y ayante ajoutée la seconde, l'ont défini: Vox flexilis cum tempore \& persona. Un mot qui a diverses inflexions avec temps \& personne. D'autres s'étant arrêtés à la première de ces significations ajoutées, qui est celle de l'attribut, \& ayant consideré que les attributs que les hommes ont joint à l'affirmation dans un même mot, sont d'ordinaire des actions \& des passions, ont cru que l'essence du verbe consistoit à signifier des actions ou des passions. Et enfin Jules César Scaliger a cru trouver un grande mystère dans son livre des principes de la Langue Latine, en disant que la distinction des choses in permanentes \& fluentes, en ce qui demeure \& ce qui passe; étoit la vraie origine de la distinction entre les Noms \& les Verbes: les nom estant pour signifier ce qui demeure, \& les verbes ce qui passe. Mais il est aisé de voir que toutes ces définitions sont fausses, \& n'expliquent point la vraie nature du Verbe. (Arnauld \& Lancelot 1803: 334-335)
} 
E Itkonen, num tom claro de crítica, replica que

Ignorando dois mil anos de tradição gramatical, os autores da gramática de Port-Royal calmamente asseveram que inventaram a centralidade da cópula, sua capacidade de combinar os dois termos da sentença, sua força de afirmação, a reanálise de um verbo finito como 'cópula mais particípio', etc. Isso só pode ser um sinal de grande ignorância ou de grande desonestidade. Pessoalmente, eu não posso acreditar que Arnauld e Lancelot podem ter sido ignorantes acerca de toda a tradição precedente. (Por exemplo, a Grammatica Speculativa de Thomas de Erfurt foi publicada em Paris em 1605). ${ }^{19}$

Itkonen defende que a noção de cópula, tão relevante na episteme clássica tal como concebida por Foucault, era um conceito bem mais antigo, que estaria presente, no mínimo, em textos de Aristóteles e dos modistas. Em seu Peri Hermeneias ${ }^{20}$, ou De Interpretatione, Aristóteles, define 'verbo' como a palavra “que não apenas transmite um significado particular, como também possui referência temporal”, este significado particular, desvendado em seguida, refere-se ao 'verbo' "ser" "uma indicação de alguma coisa predicada de alguma coisa, quer dizer, alguma coisa predicada de um sujeito ou neste encontrada presente"; porém, Aristóteles deixa claro que o 'verbo' não possui significação se nada houver para ser predicado: “os verbos não chegam a expressar juízos positivos ou negativos, pois mesmo os infinitivos ser, não ser e o particípio sendo somente são indicativos de fato se e quando alguma coisa complementar é acrescida". Para compreender exatamente como o 'verbo' significa a cópula é preciso ver antes concepção de 'sentença' e 'proposição'.

A 'sentença', para Aristóteles, é uma reunião de palavras que pode expressar afirmação ou negação. Há um tipo específico delas chamadas 'proposições', as quais encerram, em si mesmas, verdades ou falsidades (julgamentos) - a prece, por exemplo, não é uma 'proposição'. Em suma: “Uma proposição simples, mais precisamente, é um enunciado falado com significado que afirma ou nega a presença de alguma coisa outra coisa no sujeito no tempo passado, presente ou futuro".

De acordo com Itkonen (1991:177-8 - cf. também Robins 1967, Swiggers 1997), a proposição aristotélica é composta por dois elementos: onoma e rhēma. O onoma possui uma significação simples: ele é o 'sujeito' da 'proposição' ou simplesmente um 'nome'. Já o rhēma tem uma significação complexa: ele possui um significado específico, ao

\footnotetext{
${ }^{19}$ Tradução nossa. Original: Ignoring two thousand years of grammatical tradition, the authors of the PortRoyal grammar calmly assert that they have invented the centrality of the copula, its capacity to combine the two terms of the sentence, its force of affirmation, the reanalysis of a finite verb as 'copula plus participle', etc. This can only be a sign of great ignorance or of great dishonesty. For my part, I cannot believe that Arnauld and Lancelot could have be ignorant of the whole preceding tradition. (For instance, Thomas of Erfurt's Grammatica Speculativa had been published in Paris in 1605.) (Itkonen 1991:263-4)

${ }^{20}$ Como se sabe, este texto é a segunda obra do Organon de Aristóteles, no qual também constam, em ordem: As Categorias, Analiticos Anteriores, Analiticos Posteriores, Tópicos, Elencos Sofisticos.
} 
mesmo tempo em que co-significa 'tempo'; indica que algo está sendo dito sobre outra coisa; sempre, portanto, contém a palavra einai (o verbo ser, a cópula). Mesmo nos casos em que isso não é aparente, pode haver análise por meio de 'cópula', como em badizei ([ele] anda) que é analisada como badizōn esti ([ele] é andante), e, a partir do momento em que se exclui a cópula do rhēma, ele se torna um onoma; é graças a esse tipo de análise, a qual é feita mentalmente, que se chega à noção de 'proposição' exposta anteriormente. Itkonen (1991:178) apresenta um esquema para explicar o significado dos dois termos na proposição, o qual traduzimos adiante:

rhēma

consignifica \& significa

Afirmação $=$

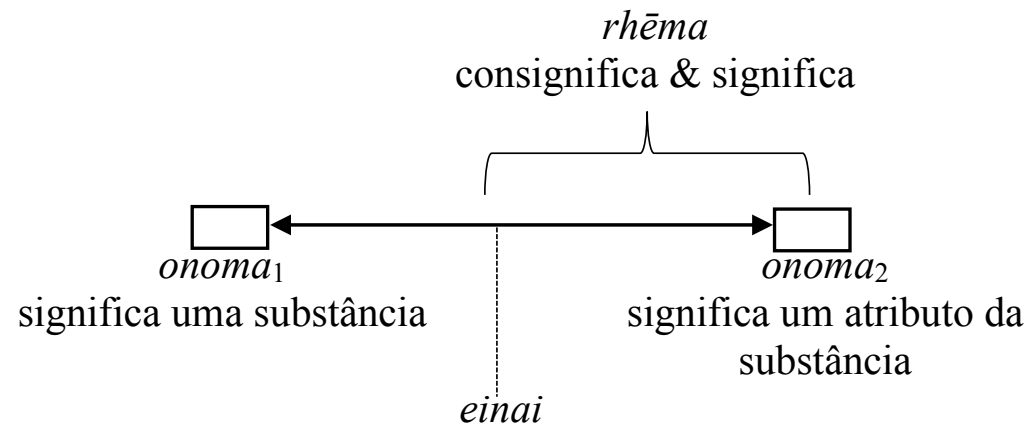

(a cópula)

consignifica: a) tempo presente

b) predicação

c) combinação (síntese) do

$o_{\text {onoma }}$ e onoma $_{2}$ pela mente.

Figura 4. Termos da proposição, tradução de Itkonen (1991:178)

Aristóteles confere singularidade ao 'verbo' "eînai" ("ser”), colocando-o, de acordo com García (2004:530), como o "verbo por antonomásia", ao menos no discurso apofântico; as ideias contidas nos textos de Aristóteles, sobretudo o Peri Hermeneias, foram relevantes para a exposição posterior de uma teoria similar na GGR-PR. Entretanto, ainda de acordo com García (2004:533-534), o conceito de ‘verbo substantivo' ou de 'verbo único' que é sustentado entre os séculos XVII e XIX, não aparece nos textos do filósofo de Estagira. García explica que o verbo grego "eînai” não era, para Aristóteles, nem 'substantivo', nem 'único', que são duas características frequentes do "être" na tradição grammaire générale; pois, apesar de "eînai" poder realizar um grande número de possibilidades predicativas, justamente por poder substituir os verbos em sua 'perífrase copulativa', que vimos anteriormente, ele não seria 'substantivo', na medida em que ele poderia não apenas predicar acerca da 'substância' do 'sujeito' (o que é), mas também 
acerca de qualquer uma das 'categorias' ${ }^{21}$. Esse verbo também não seria 'único' por não ser mais relevante entre os outros verbos, a não ser por proporcionar um outro modo de expressar a 'predicação'; isto é, não haveria diferenças relevantes entre a 'cópula' e os 'verbos léxicos', ambos seriam simplesmente equivalentes. Com essas afirmações, García, diferentemente de Itkonen, defende que haja diferenças relevantes entre o conceito que Aristóteles sustenta sobre "eînai" e aquele posterior, sustentado pela tradição da grammaire genérale, a qual tem como ponto inicial a GGR-PR ${ }^{22}$, a respeito do verbo francês "être". Como vimos no item 1.3, a continuidade e a descontinuidade têm relação com a escolha metodológica do historiógrafo.

A partir do que é indicado pelas leituras feitas não se pode dizer que a proposta teórica de que o verbo (correspondente no português a) "ser" junto de um 'predicado' pode substituir outros 'verbos' seja recente, nem que seja específica de um período da história da gramática ocidental. Por outro lado, notamos que é preciso distinguir as particularidades e observar as similaridades entre as ideias sustentadas ao longo da história, tendo em conta que um (mesmo) conceito ou proposta podem ser retomados, mas de forma (um pouco) diferente em momentos diferentes.

Como já mencionamos anteriormente, até onde se sabe, o termo 'verbo substantivo' aparece pela primeira vez nas Institutiones de Prisciano. Este termo, com novos significados, será ainda mencionado, ao menos, em gramáticas da tradição modista, em gramáticas renascentistas, fossem aquelas que privilegiavam a ratio ou aquelas que davam relevo ao usus, nas primeiras gramáticas de línguas vernáculas (cf. Nebrija 1492, Oliveira 1536, Barros 1540), e, mais especificamente, por um amplo conjunto de textos que surgiram na tradição de descrição da língua portuguesa ao longo dos séculos XVIII e XIX.

Parece-nos que o termo teve dois usos bastante gerais na gramaticografia ocidental. Um uso em que simplesmente denominava o 'verbo' "ser" (e, por vezes, o verbo "fazer"), e outro em que ele fazia parte de um arcabouço teórico que considerava que a(s) língua(s) possuiria(m) um nível subjacente. Para observar essas mudanças,

\footnotetext{
${ }^{21}$ As dez categorias de Aristóteles, apresentadas no texto As Categorias, primeiro do Organon, são: substância (o que), quantidade (o quanto), qualidade (o como), relação, lugar, tempo, estado (como está), hábito (em que circunstância), ação (atividade) e paixão (passividade). Benveniste (2005[1966]) descreve algumas possibilidades de interpretação da escolha feita por Aristóteles por essas dez categorias e ainda elabora uma hipótese estruturalista de que cada uma delas corresponderia a uma classe de palavra ou propriedade de palavra do grego antigo, isto é, Aristóteles teria criado uma teoria baseada em sua própria língua - sem notá-lo.

${ }^{22}$ Há hoje novos estudos que consideram que a gramática que inicia a tradição da grammaire générale seja a Grammaire Générale et Raisonée de Macé (1635) (cf. Bouard 2007).
} 
vamos, a partir de bibliografia secundária, fazer uma breve e panorâmica reconstrução do conceito de 'verbo substantivo' na tradição latina, em Prisciano, nas tradições modista, renascentista (em geral e portuguesa).

O texto Institutiones de Prisciano é bastante posterior (cerca de oitocentos anos) ao Peri Hermeneias de Aristóteles. No momento em que sai à luz o texto de Prisciano, acontecimentos relevantes já teriam ocorrido na historiografia linguística e gramatical do ocidente, como a produção da Téchné grammatiké de Dionísio de Trácia (170 a.C. - 90 a.C.), considerada a primeira gramática do ocidente, em que são descritas oito classes de palavras no idioma grego. Nela, o 'verbo' é definido como “a palavra não casual, capaz de tempos e também de pessoas e números, a qual apresenta ação e padecimento"23. Portanto, não há referência especial ao verbo "ser". Dionísio não descreve a sintaxe da língua grega, o que seria feito posteriormente por Apolônio Díscolo (século II d.C.) em sua Syntaxe, que tem sido considerada influência relevante para Prisciano.

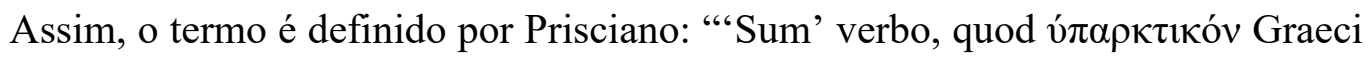
vocant, quod nos possumus 'substantivum' nominare; id enim omnium semper est perfectissimum, cui nihil deest" 24 , passagem que pode ser traduzida como "O verbo 'sou'

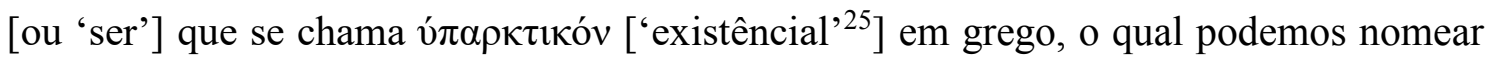
de 'substantivo', pois este é o mais perfeito de todos, sempre, a quem nada falta" ${ }^{26}$. Coxito

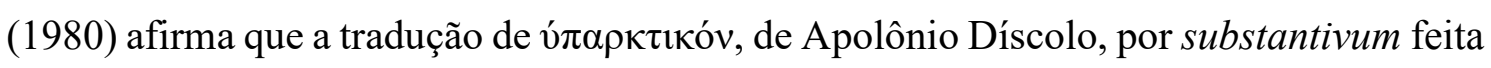
por Prisciano é polêmica, pois levaria gramáticos e lógicos posteriores a confundir os conceitos de substância e existência.

Houve uma série de comentários feitos ao texto de Aristóteles na Idade Média, como os de Amônio de Hérmias e Abelardo ${ }^{27}$ (cf. Itkonen 1991, Arens 1984), e grande parte deles referia-se a estudos lógico e filosóficos que também envolviam a linguagem. Vamos, porém, nos ater às gramáticas modistas do século XIII, especialmente a Grammatica Speculativa (1310), de Thomas de Erfurt, a qual é muitas vezes considerada uma síntese das anteriores e também a última gramática modista (cf. Itkonen 1991, Beccari 2013). Nela, assim é definido o 'verbum substantivum'

O verbo substantivo significa por meio do modo do ser de maneira geral, que é especificável por qualquer ser especial. Assim, ele não é chamado de substantivo por causa do modo de estar por si

\footnotetext{
23 Tradução de Martinho (2007:164).

${ }^{24}$ Prisciani, VIII, Cap. X 51, ed. Hertzii (1855), pp. 414, 14-15.

${ }^{25}$ Diversas possibilidades de tradução para esta palavra, como existência e substância.

${ }^{26}$ Tradução do grego para o português realizada por Alessandro Beccari.

27 Amônio de Hérmias (ca. 440- ca. 520) foi um filósofo grego que escreveu, sobretudo, sobre a obra aristotélica. Abelardo (1079-1142) foi um filósofo escolástico francês, considerou textos aristotélicos ao escrever sua filosofia da mente.
} 
mesmo, mas porque significa o ser geral, o qual pode ser especificado. Como resultado disso, o verbo substantivo é especificável por qualquer especificador que o especifique. ${ }^{28}$

Beccari (2013:423) explica, em termos gerais, essa definição:

TE [Thomas Erfurt] considera o verbo "ser" como o mais geral dos verbos. Nisso, ele baseia-se no princípio da metafísica medieval segundo o qual todas as coisas, sejam elas cadeiras, livros, estátuas, pessoas, etc., têm em comum o fato de existirem. Todavia, o fato das coisas serem $x$ ou serem $y$, segundo essa mesma interpretação, leva à conclusão de que o "ser" é especificado em cada entidade. Essa especificação seria replicada na linguagem e o verbo "ser" seria, ao mesmo tempo, o verbo mais geral e o mais específico de todos os verbos. Nesse sentido, para TE, o verbo ser, que ele chama de verbo substantivo, é "especificável por qualquer especificador que o especifique".

Antes de explicar esse processo em termos linguísticos, é preciso deixar claro que a metafísica medieval de que fala Beccari diz respeito a uma certa hierarquia das dez categorias aristotélicas, seja no plano ontológico, mental ou linguístico. Nessa hierarquia, a substância (ens) seria precedente aos seus acidentes (esse), porém os dois carregam o verbo "ser", um de forma geral, e outro de forma específica, e é justamente o verbo "ser" que promove a união entre a substância e o acidente. Ao explicar isso em termos linguísticos, Beccari diz que os gramáticos medievais viam o verbo "ser" como implícito em todas as construções de tipo "nome + verbo/particípio/adjetivo". Assim, Socrates est albus (Sócrates é/está pálido/branco) é a sentença com a explicitação do "ser" implícito em Albus Socrates (Sócrates pálido/branco), da mesma forma que de Socrates currit (Sócrates corre) são derivadas duas sentenças, Socrates est (= Sócrates existe) e est currens (= há um corredor), tornando-se Socrates est currens. Por um lado, há o ens, próprio da substância, e por outro, o esse, que se refere ao acidente dessa substância, sendo assim o verbo "ser", o mais geral e o mais específico, ao mesmo tempo (cf. Beccari 2013:118-9, Itkonen 1991:239-240). Ainda, de acordo com Thomas Erfurt, o verbo "ser" estaria presente na raiz de todos os verbos (cf. Beccari 2013:311). Ademais, aparecem menções ao verbum adiectivum, que, na tradução de Beccari (2013:308), é assim definido: “o modo do ser com distância é derivado de maneira especial para especificar a ação ou a paixão e, dessa forma, esse modo constitui o verbo adjetivo. Portanto, o verbo adjetivo significa a ação ou o sofrer uma ação.”29

\footnotetext{
${ }^{28}$ Tradução de Beccari (2013). Original: Verbum ergo substantivum est, quod significat per modum esse generaliter, specificabile per quodlibet esse speciale. Unde etiam dicitur substantivum, non ex modo per se stantis, sed quia significat esse generale specificabile; ideo potest stare specificativum cuiuscumque specificantis ipsum. (p. 307 - cap. XXVI)

${ }^{29}$ Iste modus essse cum distantia sumitur specialiter, prout stat in speciali pro esse actionis vel passionis; et sic iste modus constituit verbum adiectivum. Verbum ergo adiectivum est, quod actionem vel passionem significat. (Beccari 2013:308)
} 
Observamos, agora, seguindo a cronologia, algumas obras latinas renascentistas, tal como o início da gramaticografia de línguas vernáculas. Como se sabe, nesse período, entre os séculos XV e XVI, busca-se um distanciamento do latim medieval, visto então como corrupto, e também da gramaticografia tardia da Idade Média. É feito, portanto, um retorno às gramáticas de Donato e, sobretudo, de Prisciano. Por conta disto, o termo 'verbo substantivo' será frequentemente usado nas obras, porém, como destaca também García (2004), muitas vezes simplesmente como uma nomenclatura para o verbo "sum" ou "fieri" (fazer), sem ter consequências sobre a teoria de partes do discurso ou de sintaxe sustentada nas gramáticas. García (2004:541) cita como exemplos o espanhol António Nebrija, em seus Instituctiones latinae (1481), que nega "um papel sintáctico especial a esse (al margen de su uso como auxiliar), ya que queda equiparado al resto de verbos intransitivos", e em sua Gramática castellana (1492), em que nem sequer cita o termo. $\mathrm{Na}$ gramaticografia emergente do português, no século XVI, João de Barros (1540) apresenta a divisão entre "verbo sustantivo" e "verbo ajetivo" definindo-os

Os latinos partem os feus uęrbos, em fuftantiuos e aietiuos. Dos primeiros temos este fó uęrbo, fou, ao quâl chamámos fuftantiuo por que demóstra o fer peffoál da coufa, com quãdo digo, Eu fou criatura racionál. Vęrbo aietiuo podemos chamar todolos outros. (Barros 1540:18)

Já Fernão de Oliveira (1536), quatro anos antes, em suas anotações de gramática portuguesa, não define o 'verbo fuftãtiuo', apenas menciona algumas vezes o termo com unicamente uma referência ao verbo ser (todas as observações referentes ao som e sílabas desse verbo $)^{30}$.

Para além da gramaticografia portuguesa, o século XVI é relevante na produção de gramáticas latinas, sobretudo aquelas que envolvem a razão, e não somente o uso, a saber: Rudimenta Grammatices (1523), de Thomas Linacre, Grammaire Française (1562), de Petrus Ramus, De causis latinae libri XIII (1540), de Julius Caesar Scaliger e Minerva sive de causis linguae Latinae (1587), Franciscus Sanctius Brocensis. García (2004) destaca o posicionamento de Sánchez de las Brozas, por considerá-lo original. Ele diz que o latinista espanhol considera o verbo substantivo a raiz de todos os outros verbos, o que o assemelha aos modistas (ver acima); ele também considera o verbo "fiere" (em português, "fazer") como substantivo, algo que não era incomum no período ${ }^{31}$, negando depois essa ideia para dizer que o 'verbo substantivo' é realmente “esse”. Sua originalidade, porém, estaria no fato de que ele considera que o verbo "no sólo es

\footnotetext{
${ }^{30}$ Cf. Oliveira (1536: 39, 45, 71).

${ }^{31}$ Feito também por Valla, em seu De linguae latinae eleguantia (1471) (cf. García 2004).
} 
sustantivo porque transmite la sustancia de los verbos, sino también porque predica acerca de la sustancia y no de los accidentes de la realidad designada por el sujeto" (García 2004: 543). Assim, a sentença "Caesar est albus" contém uma 'elipse', visto que num nível subjacente seria assim "Caesar est albus Caesar".

No Methodo Grammatica para todas as lingvas do português Roboredo, publicado em 1619. No capítulo "Do Verbo fustantivo, Sum, que nem he Activo nem Palsivo", Roboredo assim define o 'verbo substantivo': “ESTE Verbo, Sum, he como fundamento de todos; \& com elle per rodeio fupprîmos as vozes pafsivas que lhes faltão. He irrigular; \& fignifica fuftancialmente, fer, ou ftar" (Roboredo 1619:30). Nota-se que o verbo é dado como fundamento de todos os outros, porém, é, ao mesmo tempo, o simples verbo "ser" ou "estar".

Retomemos agora a Grammaire de Port-Royal. Assim Arnauld e Lancelot definem o verbo:

\begin{abstract}
Pode-se dizer que o verbo ele mesmo devia ter outro uso senão que o de marcar a ligação que nós fazemos em nosso espírito de dois termos de uma proposição : mas não há senão o verbo ser (être) o qual chamamos de 'substantivo' que seja mantido nessa simplicidade, e ainda se poderia dizer que ele não é senão mantido na terceira pessoa do presente, $e$, e em alguns encontros [com atributos]. Pois como os homens têm costume de abreviar suas expressões, eles quase sempre juntaram a afirmação a outras significações em uma mesma palavra. Eles juntaram a ela [a afirmação] algum atributo, de maneira que duas palavras fossem uma proposição : como quando eu digo, Petrus vivit, Pierre vive; porque o atributo de ser vivente; e assim é a mesma coisa dizer Pierre vive e Pierre é vivente. Disso que vem a grande diversidade de verbos em cada língua; de maneira que, se é suficiente dar ao verbo a significação geral de afirmação, sem juntar a ele nenhum atributo particular, nos não teríamos necessidade, em cada língua, de nenhuma outro verbo senão aquele que chamamos substantivo. [...] Nós já dizemos que os homens tem uma infinidade de encontros entre um atributo particular e a afirmação, tendo feito esse grande número de Verbos diferentes do substantivo, que se encontram em todas as Línguas, e que podemos chamar Adjetivos, para mostrar que a significação que é própria a cada um é unida à significação comum a todos os verbos, que é aquela da afirmação. Mas é um erro comum crer que todos esses verbos significam ações e paixões. ${ }^{32}$
\end{abstract}

\footnotetext{
${ }^{32}$ Tradução nossa do francês. Original "On peut dire que le verbe de lui-même ne devoit point avoir d'autre usage que de marquer la liaison que nous faison dans notre esprit des deux termes d'une proposition; mais il n'y que le verbe être qu'on appelle substantif qui soit demeuré dans cette simplicité, \& enconre l'on peut dire qu'il n'y est proprement demeuré que dans la troisième du prefent, est, \& en de certaines rencontres. Car comme les hommes fe portent naturellement à abreger leurs expressions, ils ont joint presque toujours à l'affirmation d'autres significations dans un même mot. lls y ont join celle de quelque attribut, de sorte qu'alors deux mots font une proposition: comme quand je dis, Petrus vivit, Pierre vit; parce que l'attribut d'être vivant; et ainsi c'est la même chose de dire, Pierre vit, que de dire Pierre est vivant. De là est venue la grande diversité des verbes dans chaque langue; au lieu que, si ons'étoit contenté de donner au verbe la signification générale de l'affirmation, sans y joindre aucun attribut particulier, on n'aurout eu besoin, dans chaque langue, que d'un seul verbe, qui est celui q'on appelle substantif. [...]Nous avons déja dit que les hommes ayant joint en une infinité de rencontres quelque attribut particulier avec l'affirmation, en avoient fait ce grand nombre de Verbes différents du substantif, qui fe trouvent dans toutes les Langues, \& que l'on pourroit appeller Adjectifs, pour monftrer que la signification qui eft propre à chacun, est ajoutée à la signification commun à tous les verbes, qui est celle de l'affirmation. Mais c'est une erreur commune de croire que tous ces verbes signifient des actions ou des passions." (Arnauld \& Lancelot 1803 :332-333)
} 
Parece haver uma teoria por trás do conceito de 'verbo substantivo' na GGR-PR, visto que as noções de 'verbo' e de 'proposição' ficam intimamente conectadas - o 'verbo' significa a afirmação entre os dois itens da 'proposição', o ‘sujeito' e o 'atributo'. Isto é definido em termos de uma linguagem subjacente, condizente com o pensamento, já que na fala a construção com um ‘verbo substantivo' e um 'atributo' seria abreviada, tornando-se um 'verbo adjetivo'. De acordo com Graffi (2001), a pedra angular do sistema sintático de Port-Royal seria justamente a "teoria da cópula" (copula-theory), a qual está relacionada ao fato de que todas as sentenças poderiam ser resolvidas em três termos: 'sujeito', 'cópula/verbo', e 'atributo', resultando num julgamento. O julgamento, junto com a concepção e o raciocínio são as três operações do pensamento assumidas pela GGR-RR; essas três operações seriam expressadas pela linguagem.

Todos os filósofos ensinam que há três operações de nosso espírito : CONCEBER, JULGAR E RACIOCIONAR. CONCEBER não é outra coisa senão um simpler olhar de nosso espírito sobre as coisas, seja de uma maneira puramente intelectual, como quando eu conhece o ser, a duração, o pensamento, Deus ; seja com as imagens corporais, como quando eu me imagino um quadrado, uma roda, um cachorro, um cavalo. JULGAR é afirmar que uma coisa que nós concebemos é assim, ou não é assim : como quando tendo concebido que isto é a terra, e que isto é rendodo, eu afirma que da terra que ela é rendonda. RACIOCINAR é se serverir de dois julgamentos para fazer um terceiro : como quando tendo julgado que toda virtude é louvável, e que a paciência é uyma virtude, eu concluo que a paciência é louvável. De onde se dê que a terceira operação do espírito não é senão um extensão da segunda ; e assim bastará, para nosso assunto, considerar as duas primeira, ou o que existe da primeira na segunda. [...] O julgamento que nós fazemos das coiss, como quando eu digo que a terra é redonda, se chama PROPOSIÇÃO ; e assim toda proposição encerra necessariamente dois termos : um chamado sujeito, que é sobre o qual afirmamos, como terra; e o outro chamado atributo, que é o que afirmamos, como redonda; e há ainda a ligação entre os dois termos $e^{33}$

Tendo em conta que o pensamento seria anterior à linguagem, dizer "Pierre vivit" é não somente equivalente a dizer "Pierre est vivant", mas é uma abreviação do pensamento, logo, toda 'proposição' teria como base essa estrutura e assim deveria ser analisada. A GGR-PR situa o 'verbo substantivo' como primeiro e essencial. A partir de então, mencionar o 'verbo substantivo' implicava também mencionar a estrutura da

\footnotetext{
${ }^{33}$ Tradução nossa do francês. Original: Tous les philosophes enseignent qu'il y a trois opérations de notre esprit: CONCEVOIR, JUGER, RAISONNER. CONCEVOIR, n'est autre chose qu'un simple regard de notre esprit sur les choses, soit d'une manière purement intellectuelle, comme quand je connais l'être, la durée, la pensée, Dieu; soit avec des images corporelles, comme quand je m'imagine un carré, un rond, un chien, un cheval. JUGER, c'est affirmer qu'une chose que nous concevons est telle, ou n'est pas telle: comme lorsqu'ayant conçu ce que c'est que la terre, et ce que c'est que rondeur, j'affirme de la terre, qu'elle est ronde. RAISONNER, est se servir de deux jugements pour en faire un troisième : comme lorsqu'ayant jugé que toute vertu est louable, et que la patience est une vertu, j'en conclus, que la patience est louable. D'où l'on voit que la troisième opération de l'esprit n'est qu'une extension de la seconde; et ainsi il suffira, pour notre sujet, de considérer les deux premières, ou ce qui est enfermé de la première dans la seconde. (...) Le jugement que nous faisons des choses, comme quand je dis la terre est ronde, s'appelle PROPOSITION; et ainsi toute proposition enferme nécessairement deux termes : l'un appelé sujet, qui est ce dont on affirme, comme terre; et l'autre appelé attribut, qui est ce qu'on affirme, comme ronde; et de plus la liaison entre ces deux termes, est. (Arnauld \& Lancelot, 1803[1660], p.270-271).
} 
'proposição', levando à sua leitura lógica tripartite - técnica que, junto com a ideia de que ele era um verbo único e essencial, seria muito difundida e por um longo período (cf. García 2004, Bouard 2007).

Certamente, a tradição que se segue da grammaire générale não foi sempre a mesma (cf. Rosiello 1967), houve uma série de mudanças ao longo dos dois séculos de sua existência, isto é, de Port-Royal (1660) até os últimos gramáticos gerais, como Burggraff (1863) (cf. Bouard 2007). Há, entretanto, como afirma Graffi (2001:17), pontos em que essa tradição manteve unidade, como a existência de uma conexão estrita entre categorias de pensamento (também chamadas de categorias lógicas) e categorias de linguagem, e também a assunção de que a diferença entre as línguas seria somente superficial, havendo entre elas as mesmas categorias de pensamento. O 'verbo substantivo' é mantido durante quase toda essa tradição, mas sofre uma série de deslocamentos ou mudanças ao longo de dois séculos (cf. Rosiello 1967, Itkonen 1991, Raby 2000, Graffi 2001, García 2004, Bouard 2007).

A difusão do modelo de Port-Royal, seja no que diz respeito à cópula, seja em relação à sua rede conceitual - como a concepção de verbo, sua classificação, o conceito tripartite de proposição, entre outros -, ocorre não apenas dentro da gramaticografia francesa, mas, sobretudo no século XIX, com grande força nas gramaticografias hispânicas (cf. Vaquera 1986; Battista 2011), portuguesa (cf. Pessoa Santos 2010) e brasileira (cf. Parreira 2011; Polachini 2013). É certo também, porém, que a gramaticografia francesa, que modificava a GGR-PR, continuou tendo grande impacto nas outras gramaticografias supracitadas. Interessa-nos, portanto, recapitular brevemente alguns conceitos sustentados na tradição francesa ao longo dos séculos XVIII e XIX.

DuMarsais insere a 'cópula' da 'proposição' dentro do 'atributo':

Ele [o atributo] contem essencialmente o verbo porque o verbo é dito do sujeito e marca a ação do espirito que considera o sujeito como sendo dessa ou daquela maneira, como tendo ou fazendo tal coisa. Observem, portanto, que o atributo começa sempre pelo verbo. ${ }^{34}$

Beauzée mantém o 'verbo’ dentro do 'atributo', seguindo Dumarsais, porém, apresenta também algumas modificações. Substitui o significante 'verbo substantivo’ por 'verbo abstrato', e o significante 'verbo adjetivo' por 'verbo concreto', modificações estas que acompanham uma mudança de significado:

\footnotetext{
34 Tradução do francês de Jaci Brasil Tonelli. Original: "il [l'attribute] contiente essentiellement le verbe parce que le verbe est dit du sujet et marque l'action de l'esprit qui considère le sujet comme étant de telle ou telle façon, comme ayant ou faisant telle chose. Observez donc que l'attribut commence toujours par le verbe." (Dumarsais, 1729-1756, p. 441 Apud Bouard 2007:315).
} 
Eu acredito que seria mais razoável chamar o verbo de abstrato que nomeá-lo substantivo; porque, na verdade, ele prescinde de todo atributo determinado e enquanto esses que a existência e o atributo determinado, como amar, partir etc. ${ }^{35}$

Em relação aos significados desses termos, o ‘verbo substantivo' ou 'abstrato' é definido como "aquele que designa pela ideia precisa da existência intelectual, com relação a um atributo qualquer", já o 'verbo adjetivo' ou 'concreto' é “aquele que designa pela ideia precida da existência intelectual, com relação a um atributo determinado, que é cumprido na significação total do verbo"36, e então decompõe os verbos da forma clássica: Dieu VEUT [Deus DESEJA] e les hommes TREMBLERONT [os homens TREMERÃO] em Dieu est voulant [Deus é desejante] e les hommes seront tremblants [os homens serão trementes]. (Bouard 2007:386-7)

Condillac (1775), por sua vez, não deu continuidade às ideias dos enciclopedistas, retomando boa parte do que estava já na GGR-PR. 'Proposição' tem três partes, o 'sujeito', o ‘atributo' e o 'verbo substantivo'. O ‘verbo substantivo' seria “proprement le seul”, ao passo que os 'adjetivos' seriam sempre equivalentes ao 'verbo substantivo' e um 'adjetivo' ou 'particípio presente' (cf. Bouard 2007:409). Silvestre de Sacy (1799), mantém a proposição com três itens, 'sujeito', 'verbo' e 'atributo', mas traz inovações terminológicas. Chama o verbo adjetivo de 'verbo atributivo', devido à presença do atributo dentro dele - nova terminologia que se aproxima do conceito da nova terminologia de Beauzée (cf. Bouard 2007:430-1).

No século XVIII, há duas gramáticas do português, Regras da lingua portugueza, espelho da lingua latina (1721/1725), de P. Jerônimo Contador de Argote (1676-1749) e a Arte da Grammatica da Língua Portugueza (1770), de José Reis Lobato (? - ?). A primeira não menciona o 'verbo substantivo', já a segunda o define da seguinte forma:

"O verbo Ser, a que chamão fubftantivo, por affirmar a fubftancia, ou o fer do fogeito, que lhe exerce a fignificação, he auxiliar, porque dos feus tempos, modos, e pefloas fe fórma toda a voz pafliva de qualquer verbo activo, pofpondo-fe-lhe o participio paflivo do mefmo verbo. E com efte circumloquio fe fuppre a falta que tem (a mefma fe encontra nas outras linguas vulgares) a lingua Portugueza de verbos pallivos." (Lobato 1770:74)

\footnotetext{
${ }^{35}$ Tradução do francês de Jaci Brasil Tonelli. Original: "Je crois donc qu'il seroit plus raisonnable d'appeler abstrait le verbe que l'on nomme substantif; parce qu'en effet il fait abstraction de tout attribut déterminé et alors ceux que l'existence et l'attribut déterminé, comme aimer, partir etc." (Beauzée 1767 :44 Apud Bouard 2007:386)

${ }^{36}$ Tradução nossa. Originais: "celui qui désigne par l'idée précise de l'existence intellectuelle, avec relation à un attribut quelconque" e celui qui désigne par l'idée précise de l'existence intellectuelle, avec relation à un attribut déterminé, qui est compris dans la signification totale du verbe" (Beauzée 1767 Apud Bouard 2007:386-7)
} 
Para Lobato, o ‘verbo substantivo’ significava, por um lado, substância e o ser do sujeito, por outro, era auxiliar da 'voz passiva' dos 'verbos ativos' de língua portuguesa, que não tem 'verbos passivos' - com o tinha o latim.

No século XIX, a gramática portuguesa brasileira sofre alguma influência dos Principes de grammaire générale, ou, Exposition raisonnée des éléments du langage de Pierre Burgraff, de 1863. O autor ressalta que o 'verbo substantivo' promove uma relação entre duas ideias.

Quanto às ideias que representam a existência da relação e que são exprimidas pelas palavras que nós chamamos Verbos, está claro que o Verbo único ser com seus equivalente de outras línguas poderia servir para marcar essa existência de relação ou de nossa comparação entre dois objetos. Também, se existem nas línguas um grande número de outras palavra que portam o nome de Verbo, não é que a ideia que representa a existência seja tão variada e tão múltipla ela mesma, mas isso vem de que, para abreviar o discurso, formou-se, como eu explicarei mais tarde, palavras que exprimem a existência e ao mesmo tempo um dos dois termos da relação. Nos vemos deste modo que os Verbos podem igual se dividir em duas classe : $1^{\circ} \mathrm{O}$ Verbo substantivo ou abstrato, ser. $2^{\circ}$ Os Verbos atributivos ou adjetivos, que exprimente o Verbo ser com um atributo ; por exemplo : escrever, amar, etc., que querem dizer ser escrevente, se amante, etc. ${ }^{37}$

Ele, da mesma forma que nas gramáticas que vimos anteriormente, considera o 'verbo substantivo' algo geral, de todas as línguas. Os outros verbos, chamados 'atributivos', seriam a abreviação, própria das línguas. Essa concepção de que o 'verbo substantivo' promove a relação entre duas ideias é um ponto relevante para Burgraff, ele expressa isso mais adiante, em outra definição de verbo, em que compara sua definição com a de autores anteriores, inclusive a Grammaire de Port-Royal.

Da mais alta antiguidade até a nossa época, os gramáticos não puderam se entender sobre o caráter essencial e distintivo do verbo. Dentre as diversas definições que eles lhe deram, das quais três que nós podemos deixar de examinar o valor, as quais hoje ainda são usadas em muitos gramaticas particulares. ${ }^{38}$

\footnotetext{
${ }^{37}$ Tradução nossa do francês. Original: "Quant aux idées qui représentent l'existence du rapport et qui sont exprimées par les mots que nous avons appelés Verbes, il est clair que le seul Verbe être avec ses équivalents dans les autres langues pourrait suffire pour marquer cette existence de relation ou de notre comparaison entre deux objets. Aussi, s'il est dans les langues un grand nombre d'autres mots qui portent le nom de Verbe, ce n'est pas que l'idée qui représente l'existence de la relation soit si variée et si multiple en elle- même; mais cela vient de ce que, pour abréger le discours, on a formé, comme je l'expliquerai plus tard, des mots qui expriment l'existence et en même temps un des deux termes du rapport. Nous voyons par là que les Verbes peuvent également se diviser en deux classes: $1^{\circ}$ Le Verbe substantif ou abstrait, être. $2^{\circ}$ Les Verbes attributifs ou adjectifs, qui expriment le Verbe être avec un attribut; par exemple: écrire, aimer, etc., c'est-à-dire être écrivant, être aimant, etc." (Burgraff 1863 :185-186)

${ }^{38}$ Tradução do francês de Jaci Brasil Tonelli. Original: "Dans la plus haute antiquité et jusqu'à notre époque, les grammairiens n'ont pu s'entendre sur le caractère essentiel et distinctif du verbe. Parmi les diverses définitions qu'ils en ont données, il en est trois dont nous pouvons d'autant moins nous dispenser d'examiner la valeur, qu'aujourd'hui encore elles ont cours dans plusieurs grammaires particulières." (Burgraff $1863: 344$ )
} 
O gramatico belga afirma que Aristóteles definia o verbo como palavra que significava tempo, ideia que muitos seguiram, como os gramáticos gregos e romanos e também Jules César Scaliger, gramatico latino renascentista. Porém, Burgraff explica que o verbo pode perder sua característica de tempo e ainda ser verbo, portanto, este não seria um aspecto essencial. Outros gramáticos, por sua vez, dizem que o verbo é de ação efetuada pelo sujeito. Há, entretanto, uma série de verbos que não representam uma ação, como "estar", “dormir", "ser”. Por fim, apresenta a definição dada pela Grammaire de Port-Royal, em que o verbo é definido como afirmação. Burgraff rejeita essa definição porque acredita que a afirmação seja oposto da negação e o verbo possa, na verdade, tanto negar quanto afirmar, como vemos na citação adiante:

A definição do verbo dada pelo autor da Grammaire générale et raisonnée de Port-Royal: "o verbo é uma palavra que significa a afirmação", não se justifica [...] A definição de Port-Royal é consequentemente muito estreita; e deve-se definir o verbo como uma palavra que exprime a existência de uma relação qualquer entre duas ideias; [...] A definição de Port-Royal seria boa, se o homem pensasse e se exprimisse sempre de maneira afirmativa. ${ }^{39}$

É importante destacar que a 'cópula' não foi propriedade de autores de língua francesa. Ela esteve presente também em outras tradições, como a germânica e saxônica, nas quais nem sempre estava relacionada ao termo 'verbo substantivo', mas provavelmente com algum diálogo com a tradição que usava o termo. Dois autores oitocentista que são mencionados pelos gramáticos brasileiros e usam da cópula são Karl Ferdinand Becker (1775-1849), Charler Petes Mason (1820-1900).

Graffi (2001) afirma que a gramática da língua alemã de Karl Ferdinand Becker (1775-1849) é aquela que provoca, pela primeira vez, uma ruptura na concepção tripartite de 'sentença', proveniente da Grammaire de Port-Royal.

Como observado por Glinz (1947:52) essa atenuação da cópula força Becker a introduzir uma inovação teminológica, isto é, distinguir 'predicado' de 'predicativo': uma sentença como “O cachorro é preto" seria analisada, de acordo com a concepção tripartite da proposição, em 'sujeito', ‘cópula' e 'predicado'. Em vez disso, Becker distingue um sujeito (“o cachorro") e o predicado ("é preto"), que por sua vez deve ser analisado em cópula ("é") e predicativo ("preto"). ${ }^{40}$

\footnotetext{
${ }^{39}$ Tradução do francês de Jaci Brasil Tonelli. Original: La définition du verbe donnée par l'auteur de la Grammaire générale et raisonnée de Port-Royal: "le verbe est um mot qui signifie l'affirmation," ne se justifie pas [...] La définition de Port-Royal est conséquemment trop étroite; et on doit définir le verbe um mot qui exprime l'existence d'um rapport quelconque entre deux idées; [...] La définition de Port-Royal serait bonne, si l'homme pensait et s'exprimait toujours affirmativement. (Burgraff 1863:347-349)

${ }^{40}$ Tradução nossa do inglês. Original: As observed by Glinz (1947:52) this lessening of the copula role forces Becker to introduce a terminological innovation, i.e. to distinguish 'predicate' from 'predicative': a sentence like „The dog is black" would be analyzed, according to the tripartite conception of the proposition, into subject, copula and predicate. Becker would instead distinguish a subject (,the doge) and a predicate (,is black $\left.{ }^{\prime \prime}\right)$, which in turn should be analysed into copula (,,is") and predicative (,,black $\left.{ }^{\mathrm{ec}}\right)$. (Graffi 2001: 137).
} 
Entretanto, o gramático ainda usa da cópula, porém pensa em divisões dos constituintes da sentença sempre binárias. Adiante, citamos um trecho da versão inglesa da obra:

\begin{abstract}
Uma sentença é formada pela combinação de um Sujeito e Predicado [combinação predicativa]. O sujeito é a pessoa ou coisa de que se fala. O predicado é a ação, afirmada ser ou não ser uma ação do sujeito. O sujeito de uma sentença simples é expresso por um substantivo, ou pronome; e.g. der Mensch denkt [o homem pensa] ou er denkt [ele pensa]. O predicado é expresso por um verbo, ou por um adjetivo ou substantivo com a cópula ser; e.g. der Mensch lebt [o homem vive]; er ist sterblich [ele é mortal]; ich bin ein Mensch [ele é um homem]. O predicado sempre concorda com o sujeito em Pessoa e Número. O verbo predicativo, portanto, ou o verbo auxiliary é fleccionado por Pessoa e Número; [...] Quando o predicado é expresso por um adjetivo ou substantive com o verbo auxiliar ser, ou por uma das formas compostas da conjugação, o verbo auxiliary que pega as flecções de pessoa e número é chamado cópula. ${ }^{41}$
\end{abstract}

O norte-americano Charles Peter Mason (1820-1900) diz-se influenciado por Becker no prefácio do seu Essentials of English Grammar (1868). No trecho adiante, é notável a semelhança com o gramático alemão, inclusive no uso da cópula.

A cópula gramatical em toda sentença consiste em flexões pessoais [*nota: isto é, as flexões pelas quais número e pessoa são marcados, e pelas quais o verbo torna-se um verbo finito] do verbo. Na sentença "Time flies" [o tempo voa], o sujeito é Time; o que é predicado ou afirmado do tempo é flying [voar]: a terminação pessoal do verbo flies une a ideia ao sujeito. Na sentença "The rose is red", the subject is rose; o que é predicado acerca da rosa é being red; a flexão pessoa pela qual is torna-se terceira pessoa do singular é a cópula. [...] Na medida em que as terminações pessoais do verbo não têm existência separadas do verbo ele mesmo, é usual (e conveniente) na gramática tratar a cópula como uma parte do predicado. [...] mas deve ser compreendido que, doravante, ao usar a palavra predicado nos queremos dizer o predicado e a cópula combinados. ${ }^{42}$

Nota-se que ambos dão ou o verbo ser ou a flexão verbal como cópula. Não se observa mais uma língua subjacente. É interessante observar que esse ponto de vista, é apresentado pelo gramático português oitocentista que teve mais influência na

\footnotetext{
${ }^{41}$ Tradução nossa do inglês e dos exemplos em alemão. Original: "A sentence is formed by the combination of a Subject and Predicate [predicative combination]. The subject is the person or thing spoken of. The predicate is the action, asserted to be or not to be an action of the subject. The subject of a simple sentence is expressed by a substantive, or pronoun; e.g. der Mensch denkt, or er denkt. The predicate is expressed by a verb, or by an adjective or substantive with the copula to be; e.g. der Mensch lebt; er ist sterblich; ich bin ein Mensch. The predicate always agrees with its subject in Person and Number. The predicative verb, therefore, or the auxiliary verb is inflected by Person and Number; [...] When the predicate is expressed by an adjective or substantive with the auxiliary verb to be, or by one of the compound forms of conjugation, the auxiliary verb taking the inflections of person and number is termed Copula." (Becker 1845[1830]:712)

${ }^{42}$ Tradução nossa do inglês. Original: "The grammatical copula in every sentence consists of the personal inflections [*nota: That is, the inflections by which number and person are marked, and by which the verb is made a finite verb] of the verb. In the sentence "Time flies", the subject is Time; that which is predicated or asserted of time, is flying: the personal termination of the verb flies unites the idea to the subject. [...] Inasmuch as the personal terminations of a verb have no existence apart from the verb itself, it is usual (and convenient) in grammar to treat the copula as a part of the predicate. Thus in the sentence, "Time flies," time is called the subject, and flies the predicate. [...] but it must be understood that, henceforth, in using the word predicate we mean the predicate and copula combined." (Mason 1858:91-2)
} 
gramaticografia brasileira do mesmo século, a saber: Jerônimo Soares Barbosa. Citamos o trecho adiante:

Hum exemplo notavel destas reducções e expressões abbreviadas he o verbo adjectivo. Elle apanha em si não so a significação de existencia, propria ao verbo substantivo, com todas as suas modificações de modos, tempos, numeros, e pessoas; mas ajunta-lhe além disso a idea adjectiva de huma qualidade ou attributo, com a qual completa tudo, o que necessario he para qualquer oração. Para perceber isto melhor, dividamos qualquer verbo adjectivo em dous membros, partindo-o pelas suas terminações em ar, er, e ir deste modo, Am-ar, Tem-er, Ouv-ir. O primeiro membro, quer conste de huma, quer de mais syllabas, quer de huma letra so, he a parte Radical, e a unica propria do verbo adjectivo, pela qual elle exprime a qualidade, ou acção, que affirma da pessoa, ou pessoas, que são o sujeito, ou agente da Linguagem. $A m$, por ex., Tem, c Ouv servem de outros tantos adjcctivos, equivalentes aos verbaes Am-ante, Tem-ente, Ouv-inte. Esta parte radical e adjectiva he sempre a mesma e invariável em todos os tempos do verbo; porque exprime a mesma qualidade, que elle constantemente desde o principio até o fim enuncia, das pessoas, que fazem na oração. A segunda porém, que he a terminação em ar, ou er, ou ir, na qual está toda a força do verbo substantivo, e que, se pode dizer, he o mesmo verbo transformado; esta varia de continuo, e toma, como elle, todos as fórmas necessarias para exprimir a coexistencia da dicta qualidade nas pessoas, de quem a enuncia por differenres modos, e com relação a certos tempos, numero, e qualidade das mesmas pessoas. Na primeira parte pois do verbo adjectivo he que consiste toda a sua propriedade, pertencendo todo o resto ao verbo substantivo, do qual he huma reducção e expressão abbreviada. (Soares Barbosa 1822:239-240).

Assim, o gramático português apresenta duas maneiras de se analisar o verbo adjetivo, a primeira é pelo método tradicional, isto é, amar é ser amante, e outra é pela construção morfológica, em que o verbo substantivo é representado pela terminação do verbo, sua desinência. Esse segundo tipo de análise é bastante similar àquele de Becker e Mason, pois está focado na língua manifestada, em vez de uma projeção subjacente. Esse tipo de análise foi usado também por diversos gramáticos brasileiros, como veremos adiante, no capítulo 4.

Para finalizar nossa síntese histórica, apresentamos a maneira como o grande fundador do que viria a se chamar método histórico-comparativo apresentou análises que consideravam o 'verbo substantivo'. Franz Bopp, em Analytical Comparion (1820), de acordo com Graffi (2001) define verbo como "aquela parte do discurso pela qual o sujeito é conectado com seu atributo" ${ }^{43}$. Bopp também analisa algumas formas verbais da línguas Indo-Europeias baseando-se em assunsões gerais, como no trecho "o verbo latino, dat, expressa a proposição, he gives [ele dá], ou he is giving [ele está dando]: a letra $t$, que indica o a terceira pessoa, é o sujeito, $d a$ expressa o atributo de dar, e a cópula gramática é entendida"44. No entanto, de acordo com Graffi (2001) o 'verbo substantivo' já não

\footnotetext{
${ }^{43}$ Tradução nossa do inglês. Original: "that part of speech, by which a subject is connected with its attribute" (Bopp 1820:13[1989:22] Apud Graffi 2001:76)

${ }^{44}$ Tradução nossa do inglês. Original: "The Latin verb, dat, expresses the proposition, he gives, or he is giving: the letter $t$, indicating the third person, is the subject, $d a$ expresses the attribute of giving, and the grammatical copula is understood." (Bopp 1820:14[1989:23] Apud Graffi 2001:76).
} 
aparece com tanta relevância em publicações posteriores do autor, como no Vergleichende Grammatik (Bopp 1857-1861; a primeira edição é de 1833-1852). Isso mostra que era natural naquele momento haver certa hesitação em deixar esse modelo de análise, a qual só era realizada depois de alguma maturação no estudo dos dados.

Em suma, pudemos ver nessa breve síntese histórica, a qual ainda tem muitas lacunas a serem preenchidas, que além do 'verbo substantivo' não ser um conceito estático nem recente, ele obteve um grande impacto nas análises linguísticas de diversas obras posteriores à publicação da Grammaire Générale et Raisonnée de Port-Royal, fossem elas de diferentes tradições. No século XIX, como vimos, passa a haver, paulatinamente, certa hesitação ao utilizá-lo, fazendo com que ele perca o papel de prestígio que obteve por quase dois séculos. O conceito deixa de ser a parte principal da oração e torna-se uma mera parte morfológica dos verbos, não sendo mais o verbo primitivo e único. A gramaticografia brasileira nasce no momento em que essas questões estão surgindo no ocidente, ela absorve, ao longo desse século, parte dessas hesitações ao mesmo tempo em que cria outras, mais específicas da língua portuguesa. Nosso trabalho procurou observar atentamente como essa tradição nacional, no seu primeiro século de vida, tratou esse conceito.

\subsubsection{Relações do 'verbo substantivo' com outros conceitos na tradição da grammaire générale}

Nossa hipótese de que pode haver uma rede conceitual em torno do conceito de 'verbo substantivo' na produção gramatical brasileira do século XIX, isto é, que outros conceitos da gramática poderiam estar relacionados ao 'verbo substantivo', é baseada em relações que esse conceito mantém na tradição da grammaire générale. Selecionamos quatro aspectos do tratamento de línguas que poderiam ter alguma relação com o 'verbo substantivo': (1) conceito de gramática e de linguagem; (2) conceitos de metaclasses e classes de palavras; (3) conceitos de modificadores do nome; (4) conceito de verbo; (5) conceitos de oração/sentença/proposição e de seus elementos.

As relações (4) e (5) parecem mais óbvias, por duas razões: se o 'verbo substantivo' costuma ser uma espécie de 'verbo', ele tem já uma relação de inclusão em relação ao 'verbo'. No entanto, observamos também em que medida o 'verbo substantivo' trava relações com os conceitos de outras espécies de 'verbo', como 'transitivo', 'ativo', 'impessoal' etc. Quanto à 'proposição', 'sentença' ou 'oração', a relação primeira estaria 
na assunsão de que esta é tripartite, e que o nó que une o 'sujeito' ao 'atributo' é justamente o 'verbo substantivo'. Entretanto, nossa busca vai além, procuramos ver em que medida as partes da 'proposição', sua organização (seja por meio de conceitos como 'casos', 'complementos', 'funções'), e as outras diversas espécies de 'proposição' têm alguma relação com o 'verbo substantivo'. Nessa busca, chegamos a um conceito de linguagem e de gramática (1), porque as conexões entre 'verbo substantivo' e os conceitos supracitados se dá, em geral, porque se considera que os dados linguísticos devem ser analisados por meio de processos subjacentes, os quais são iguais ou similares a aspectos da lógica e acontecem em qualquer língua, é isso, afinal, que possibilita a existência de uma gramática geral naquele momento. Tendo em conta essa noção de linguagem, observamos como os autores tratavam da distinção entre classes de palavras e a eventual assunção de metaclasses que justificasse essa divisão (2), observando, sobretudo, se essa justificativa se dava com base numa concepção de linguagem que considerasse o pensamento ou uma linguagem subjacente, e em que metaclasse está o conceito de 'verbo' - em alguns casos, ele está numa metaclasse de relação, conjunção ou julgamento, por exemplo. Finalmente, observamos os conceitos dos modificadores do nome (2), analisando primeiramente a organização feita deles pelos gramáticos em termos de classes de palavras, em seguida, analisamos em que medida os autores utilizam os conceitos, originalmente da Logique de Port-Royal, da oposição entre 'intensão' e 'extensão', e, igualmente da oposição apresentada em 'termos complexos' (que contêm mais de uma ideia) entre 'determinação' e 'explicação' - ou mesmo a classificação posterior à Logique entre, primeiramente, 'determinação' e 'qualificação', sendo este último dividido em 'explicação' e 'restrição' - e observamos em que medida esses conceitos têm efeito não apenas para os modificadores do nome, mas também na distribuição das espécies de 'proposição', o que em geral se dava na distinção de duas espécies de 'proposição incidente', dado que os 'termos complexos' seriam, em verdade, 'proposições incidentes' (il.: O deus invisível criou o mundo invisível = $\mathrm{O}$ deus que é invisível criou o mundo que é visível). Consideramos que tal paralelismo configura base teórica comum em relação à assunção do 'verbo substantivo', visto que ambos não apenas consideram uma linguagem subjacente que pode ser elíptica na linguagem manifestada, mas também trabalham com conceitos lógicos ('cópula', 'intensão', 'extensão'). Essa seria uma visão geral de uma rede conceitual idealizada e hipotética; adiante observamos aspectos de diversas obras da tradição da grammaire générale. 
Uma importante novidade trazida pela GGR-PR (1660) foi de, considerando a linguagem uma expressão do pensamento, colocar a 'proposição' no centro do estudo da gramática e de considerá-la ponto de partida da análise gramatical, em detrimento da palavra e, consequentemente, das classes de palavras, (Bouard 2007, Chevalier 1968). Segundo Bouard (2007) é esse protagonismo da 'proposição' o que mantém a homogeneidade da tradição da Grammaire Générale, que tem cerca de duzentos anos de existência. Assim, nessa tradição, mesmo a definição das partes do discurso estavam baseadas na proposição ou, ao menos, nos aspectos do pensamento que levavam à 'proposição' (Raby 2000).

Como vimos, a GGR-PR adota uma representação da proposição de tipo lógico, isto é, há nela dois termos, o ‘sujeito’ e o ‘atributo', os quais são conectados pela 'cópula', ou o 'verbo substantivo', "ser" (em francês "être"), o qual faz parte de todos os outros verbos, denominados 'adjetivos'. Tal classificação inicial das espécies de 'verbo' acabou por influenciar, ao longo da tradição, a classificação das outras espécies de 'verbo', visto que elas eram subordinadas ao 'verbo adjetivo'.

Na Logique ou l'art de penser de Port-Royal (1662), Arnauld e Nicole assumem que toda ideia pode ser observada do ponto de vista de sua 'compreensão' ou 'entendimento'. A primeira diz respeito aos atributos específicos daquela ideia, o segundo aos sujeitos a que a ideia convém ${ }^{45}$. Daí surge a Lei de Port-Royal, em que intensão e extensão variam em proporção inversa (Auroux 1993). Na Logique, quando duas ideias são unidas ('termos complexos' exprimem uma 'ideia total' ${ }^{46}$ ), passa a haver dois tipos de adição: uma chamada 'determinação', que faz a restrição do extensão e aumento de sua compreensão (il.:les corps transparents; les hommes savants; un animal raisonnable [os corpos transparentes; os homens sábios; um animal racional]); outra chamada 'explicação', que nada altera na 'compreensão' da ideia, nem o restringe, apenas marca

\footnotetext{
45 “J'appelle compréhension de l'idée, les attributs qu'elle enferme en soi, et qu'on ne peut lui ôter sans la détruire; comme la compréhension de l'idée du triangle enferme extension, figure, trois lignes, trois angles, et l'égalité de ces trois angles à deux droits, etc. J'appelle étendue de l'idée, les sujets à qui cette idée convient, ce qu'on appelle aussi les inférieurs d'un terme général, qui à leur égard est appelé supérieur, comme l'idée du triangle en général s'étend à toutes les diverses espèces de triangles." (Arnauld \& Nicole $1662: 52)$

46 "On joint quelquefois à un terme divers autres termes qui composent dans notre esprit une idée totale, de laquelle il arrive souvent qu'on peut affirmer ou noer ce qu'on ne pourrait pas affirmer ou nier de chacun de ces termes étant séparés ; par exemple, ce son des termes complexes, un homme prudent, un corps transparent; Alexandre, fils de Philippe. Cette addition se fait quelquefois par le pronom relatif, como si je dis : Un corps qui est transparent; Alexandrre, qui est fils de Philippe ; le pape, qui est vicaire de JésusChrist. Et on peut dire même que si ce relatif n'est pas toujours exprimé, il est toujours en quelque sorte sous-entendu, parce qu'il peut s'exprimer, si l'on veut, sans changer la proposition. Car c'est la même chose de dire, un corps transparent, ou un corps qui est transparent. " (Arnauld \& Nicole $1662: 58$ )
} 
um atributo que é de todos os elementos que compartilham dessa ideia (il.: l'home (qui est un) animal doué de raison; 1'home (qui est) mortel [o homem (que é um) animal dotado de razão]) (cf. Raby 2000).

Posteriormente, Beauzée reformula essas ideias considerando que o 'entedimento' ou 'extensão' configura o número de indivíduos a que a ideia enunciada por um nome se aplica. Assim, considerando a união de uma ou mais ideias, oporiam-se a 'qualificação', que diria respeito à 'compreensão', e a 'determinação', que diria respeito à 'extensão' ou 'entendimento'. Há, desse ponto de vista, duas espécies de 'adjetivo', o 'qualificativo', um que modifica a compreensão do nome, e o 'determinativo', outro que modifica a extensão do nome, tal como haveria duas espécies de 'proposição incidente', também a 'qualificativa' e a 'determinativa' (Colombat 1992). Noël e Chapsal em sua gramática escolar, acrescenta outra oposição à já realizada inicialmente por Beauzée entre qualificação e determinação, os autores consideram também uma oposição entre os adjetivos que modificam a compreensão do nome e aqueles que não a modificam, o que geral a oposição, interior aos 'adjetivos qualificativos' entre 'explicativos' e 'restritivos'. (Colombat 1992). Como veremos mais adiante (cf. capítulo 4), as gramáticas brasileiras variaram entre esses dois últimos modelos, de Beauzée e Noël e Chapsal.

\subsection{Sobre as revisões históricas da gramaticografia brasileira do português}

Desde o início do século XX, houve revisões históricas da produção gramatical brasileira sobre a língua portuguesa. Descrevemos neste item sete delas, escritas entre 1910 e 2013. A primeira, cronologicamente, é o "Breve retrospecto sobre o ensino da Lingua Portugueza”, de Maximino Maciel, que é um apêndice da edição de 1910 de sua Grammatica Descriptiva. No texto, o autor, que escreveu duas gramáticas no final do século anterior, a Grammatica Analytica de $1887\left([152]^{47}\right)$ e a Grammatica Descriptiva de 1894 ([188]), relata a transição por que passavam os estudos da língua portuguesa no Brasil e em Portugal no final do século $\mathrm{XIX}^{48}$. Para tanto, ele opõe dois grupos de gramáticos, aqueles que utilizavam o modelo antigo, como Sotero dos Reis, Freire da

\footnotetext{
${ }^{47}$ Esses números entre colchetes e, por vezes, também entre parêntesis correspondem à numeração dada às 216 gramáticas que encontramos em nosso levantamento exaustivo, sendo 12 delas sem data. Elas são numeradas primeiramente, por ordem cronológica, e, secundariamente, por ordem alfabética de sobrenome do autor (cf. apêndice A).

${ }^{48}$ É interessante notar que desde a publicação de sua primeira gramática, em 1887, o autor já procurava traçar um relato do que acontecia, como veremos na análise do item 3.2. Na Ficha Descritiva 12 podemos ver isso no trecho introdutório à obra (cf. Apêndice B).
} 
Silva, Soares Passos, Grivet, Costa Duarte, Ibirapitanga, Massa, Carneiro Ribeiro, e outros que utilizariam um modelo mais recente para análise gramatical, o qual ele denominada de "criterio philologico, o methodo historico comparativo, applicado á aprendizagem das linguas, com especialidade ao da vernacula” (Maciel 1918[1910]:441), seriam Julio Ribeiro, que teria estreado esse novo método, Fausto Barreto, Hemeterio dos Santos, Alfredo Gomes, Silvio de Almeida, João Ribeiro, Pacheco Junior, Lameira de Andrade, Said Ali, Boscoli, Veríssimo Vieira, Vicente de Souza, Paranhos de Macedo, Aureliano Pimentel, entre outros.

Ressalta, porém, que ainda que Julio Ribeiro tenha sido o primeiro a trazer essa orientação para o Brasil ao publicar sua Grammatica Portugueza em 1881, o autor apressou-se, pois apresenta um conteúdo que, por ainda não ter sido completamente assimilado, é ora obscuro, ora mera adaptação de teorias estrangeiras à língua portuguesa. Um momento mais propício para essa mudança se deu, segundo Maciel, em 1887, quando é escrito o Programa de Estudos para exames preparatórios do prestigiado Colégio Pedro II, da capital - que teve, porém, influência em escolas de todo o país. Assim o descreve o autor "assignalou nova época na docencia das linguas e, quanto á vernacula, a emancipava das retrogradas doutrinas dos autores portuguezes [...] houve, pois, com a publicação do programma de 1887, uma como Renascença dos estudos da língua vernacula” (Maciel 1918 [1910]: 444, 446). Neste ano, diz Maciel, foram publicadas quatro obras a fim de preecher os requisitos do programa e servir de manual aos alunos, são elas as gramáticas de Pacheco e Lameira, João Ribeiro, Gomes e Maciel.

Outra revisão histórica importante do período é o artigo "A Filologia Portuguesa no Brasil (Esboço Historico)" de Antenor Nascentes (1939). O autor menciona o texto de 1910 de Maciel, demonstrando estar ciente dele. Entretanto, Nascentes traz uma proposta diferente, ele deseja fazer uma periodização da produção linguística brasileira do século XVI até a data em que escreve o texto. Assim ele define três períodos:

O primeiro, a que chamemos embrionario, vai dos tempos em começou a cultura brasileira até 1835, data da publicação do "Compendio da grammatica da lingua nacional" (sic), de Antonio Alvares Pereira Coruja. O segundo, a que podemos dar o nome de empirico, vai de 1835 a 1881 , data da publicação da "Gramatica Portuguesa" de Julio Ribeiro. O terceiro, que se pode apelidar de gramatical, vai de 1881 a 1939, ano da fundação da Faculdade Nacional de Filosofica da Universidade do Brasil. (Nascentes 1939: 22)

O primeiro período obedece, segundo Nascentes, exclusivamente a orientação portuguesa, seria só depois da independência do país que esse cenário se modificaria. 
Nascentes ainda justifica que deixou de lado o Epitome da Gramatica Portuguesa ${ }^{49}$ do brasileiro Antonio Morais Silva ([1]) porque, apesar da nacionalidade do autor, o texto seria, rigorosamente falando, português, já que não se deteria em apresentar as diferenças do falar brasileiro ${ }^{50}$.

O segundo período é iniciado com a publicação do Compendio de Coruja ([16]). Outras gramáticas do período são o Compendio da gramatica filosofica da lingua portuguesa, de Costa Duarte ([19][33]), o Resumo da gramatica portuguesa de 1855, de José Alexandre Passos ([37]), Novo sistema de estudar a gramatica portuguesa por meio da memoria, inteligencia e analise de 1862, de Ortiz e Pardal ([54]), as Postilas de gramatica geral aplicada à linguistica portuguesa pela analise dos classicos, de 1865 ([59 $\left.]^{51}\right)$, e a Gramatica Portuguesa de 1866 de Sotero dos Reis ([75]), a terceira edição da Gramatica Portuguesa de Augusto Freire da Silva ([111]), a Gramatica portuguesa filosofica ([120]) e os Serões Gramaticais de Ernesto Carneiro Ribeiro ([170]).

Finalmente, o terceiro período é iniciado pela publicação da Gramatica Portuguesa de Julio Ribeiro, em 1881 ([123]). Nascentes afirma que o autor se norteava por novos métodos, cita tanto trechos do prefácio à segunda edição da gramática do autor (para mais detalhes, cf. FD 10, Apêndice B), que ressaltam suas inovações em relação ao que havia antes na gramaticografia brasileira, quanto trechos de críticas a Ribeiro do texto de 1910 de Maciel. Outras gramáticas desse período são Nova Gramatica Analitica da Lingua Portuguesa de 1881, de Adrian Olivier Grivet ([120]) - lembra que o autor havia já publicado uma obra menor, nomeada Pequena gramatica da lingua portuguesa, de 1865 ([71]) -, os Principios de gramatica historica e comparada, de 1883, de Costa e Cunha ([134]). Menciona o Programa de Estudos para examens do Colégio Pedro II, de 1887, e cita, mais uma vez, o texto de Maciel, em que este lembra das gramáticas

\footnotetext{
${ }^{49} \mathrm{~A}$ grafia para os títulos das obras citadas refere-se àquela utilizada no texto referido, por isso, pode variar. No apêndice $\mathrm{A}$, apresentamos os títulos das gramáticas com a grafia que têm: na sua própria capa, nos catálogos de biblioteca, no texto em que tivemos conhecimento delas (que, em geral, são os dicionários bio-bibliográficos de Sacramento Blake).

${ }^{50}$ Estudos mais recentes, porém, observam, por um lado, que Morais Silva apresenta um dado de português ao qual ele se refere como "próprio das colônias", e, por outro, que a tendência de descrever dados de um português próprio do Brasil em oposição ao de Portugal apresenta-se na gramaticografia apenas nas duas últimas décadas do século XIX (cf. Vidal Neto 2008; Polachini 2013; Coelho, Danna \& Polachini 2014; Coelho \& Danna 2015; Polachini \& Danna 2016). Entretanto, anteriormente foram publicadas listas de palavras, dicionários e mesmo ensaios a respeito da diferença entre os falares (cf. Pinto 1978; Coelho 2008). Considerando que Nascentes não se baseia somente na gramaticografia para fazer sua periodização, mas cita também trabalhos como "Coleção de vocabulos e frases usados na provincia de S. Pedro do Rio Grande do Sul" de Coruja (1852) e o Vocabulario brasileiro para servir de complemento aos dicionario da lingua portuguesa" de Brás da Costa Rubim (cf. Nascentes 1939: 23-24).

${ }^{51}$ Não conhecemos a edição de 1865 , portanto a referência numérica é da primeira edição, de 1862 (Cf. Apêndice A).
} 
publicadas a fim de servir de manual para os alunos, as quais são de Pacheco e Lameira, João Ribeiro, Gomes e Maciel que, de acordo com Nascentes, foi reeditada em 1894, com o nome Grammatica Descritiva ([188]) - tivemos acesso a uma segunda edição de 1895 , porém. Finalmente, a última gramática do século XIX que o autor cita é a Gramatica Analitica da Lingua Portuguesa, do Padre José de Noronha Napoles Massa, de 1888 ([161]).

Observemos adiante a lista de gramáticas oitocentistas apresentadas por Ataliba T. de Castilho (1962) em seu texto "Estudos Lingüísticos no Brasil”. Os estudos linguísticos brasileiros, segundo o autor, teriam dois períodos, um dos séculos de colônia até a década de 1930, quando são fundadas as Faculdades de Filosofia de São Paulo (1934) e do Rio de Janeiro (1939) e outro período daí até 1962, data de publicação do artigo, assim, as gramáticas do século XIX estão num mesmo período. As gramáticas por ele citadas são: Compêndio da gramática da língua nacional, de Coruja (1835, [16]); Compêndio de gramática filosófica da língua portuguesa, de Costa Duarte $\left(1836^{52},[19]\right)$; Resumo de gramática portuguesa, José A. Passos (1855, [37]); Novo sistema de estudar a gramática portuguesa por meio da memória, inteligência e análise, de Ortiz e Pardal (1862, [54]); Postilas de gramática geral aplicada à linguagem portuguesa pela análise dos clássicos (1862, [59]) e Gramática Portuguesa (1865 53, [75]), de Francisco Sotero dos Reis; Gramática Histórica da Língua Portuguesa (1878, [108]), de M. Pacheco da Silva Jr; Compêndio de Gramática Portuguesa (1875, [96]), Augusto Freire da Silva; Gramática portuguesa filosófica $\left(1879^{54}\right.$, [111]) e Serões Gramaticais (1890, [170]), de Ernesto Carneiro Ribeiro; Gramática Portuguesa Julio Ribeiro (1881, [123]), que, segundo Castilho, "revolucionou o estudo da língua entre nós"; Nova gramática analítica da língua portuguesa (1881, [120]) e Pequena Gramática da língua portuguesa (1865, [71]), de Charles O. A. Grivet; Princípios de gramática histórica e comparada (1883, [134]), de A. Estêvão da Costa e Cunha; Gramática Analítica (1887, [152]) e Gramática Descritiva (1894, [188]), "refusão da primeira", de Maximino Maciel; Gramática analítica da língua portuguesa (1888, [161]), de Pe. José de N. N. Massa.

\footnotetext{
${ }^{52}$ Não conhecemos uma edição de 1836, por isso, apresentamos a referência numérica da edição de 1840 (cf. Apêndice A).

${ }^{53}$ Não conhecemos uma edição de 1865 , por isso, apresentamos a referência numérica da edição de 1866 (cf. Apêndice A).

${ }^{54}$ A obra de 1879 de Freire da Silva que conhecemos chama-se "Compêndio da Grammatica Portugueza" (cf. Apêndice A).
} 
Passamos agora para o artigo "Os estudos filológicos no Brasil”, de Sílvio Elia, publicado em 1975. O autor inicia o texto trazendo a periodização de Nascentes (1939) para em seguida apresentar os dois períodos de que vai tratar " $10^{\circ}$ vernaculista: de 1820 (data aproximada da nossa independência política) a 1880 (data aproximada da publicação da Gramática Portuguesa de Júlio Ribeiro); 2. ` científico, daí até 1960.” (Elia 1975:117). A respeito do período vernaculista, Elia ressala o chamado "Grupo Maranhense", que composto por Sotero dos Reis, de quem ele cita as seguintes gramáticas Postilas de Gramática Geral Aplicada à Língua Portuguesa pela Análise dos Clássicos (1862, [59]); Gramática Portuguesa (1886 ${ }^{55}$ [75]). Cita também desse período os Serões Grammaticaes de Ernesto Carneiro Ribeiro, de 1890 ([171]). O período científico, de acordo com Elia, pode ser dividido em duas fases, um que vai de 1880 a 1900 e outro de 1900 a 1960. Observemos as gramáticas que são citadas como parte do primeiro período. Começa com a Gramática Portuguesa de Julio Ribeiro (1881, [123]) cuja forma definitiva seria a segunda edição $\left(1884^{56}\right.$, [142]). Em seguida, menciona as críticas de Maciel à gramática de Ribeiro, lembrando também do seu mérito de trazer a nova orientação. Outras gramáticas do período são a Nova Gramática Analítica da Língua Portuguesa de 1881 ([120]), de Charles Grivet, que seria uma refundição de sua Gramática Analítica da Língua Portuguesa de 1865 ([71]); Princípios de Gramática Histórica e Comparada, de Costa e Cunha ([134]). Elia comenta o Programa de Exames do Colégio Pedro II, considerando-o um importante acontecimento, lembrando que João Ribeiro, Pacheco e Lameira e Alfredo Gomes escreveram gramáticas de acordo com ele, tal como é a Gramática Analítica de Maciel ([152]), que seria refundida e publicada com novo título Gramatica Descritiva da Língua Portuguesa em 1895 ([188]).

No artigo "Uma proposta de periodização dos estudos lingüísticos no Brasil", Ricardo Cavaliere inicia o texto expondo e discutindo as periodizações de Nascentes (1939) e Elia (1975), para em seguida lançar a sua, que é composta por três períodos. O primeiro chama-se embrionário e vai “das origens até 1802” (Cavaliere 2001:56). Não há gramáticas do português escritas nesse período no Brasil, embora haja aquelas de línguas indígenas, o autor cita, por exemplo, a Arte de gramática da língua mais usada na costa do Brasil, de José de Anchieta (1595). O próximo período, denominado racionalista, por

\footnotetext{
${ }^{55}$ Há duas possibilidades para essa data: há uma edição de 1886 que desconhecemos, houve um erro de digitação e o autor se refere à primeira edição da "Grammatica Portugueza" de Sotero dos Reis, de 1866 ([75]).

${ }^{56}$ Não conhecemos uma edição de 1884, acreditamos que o autor fale da que conhecemos de 1885 (cf. Apêndice A).
} 
conta da influência da grammaire générale, inicia-se em 1802 com a publicação do Epitome da grammatica portugueza, de Antonio Morais Silva ([1]), e vai até em 1881. O autor menciona as seguintes gramáticas como parte desse período: Grammatica Analytica da lingua portugueza de 1865 ([71]), de Grivet; a Grammatica portugueza de Sotero dos Reis, da qual ele indica a terceira edição, de 1877 ([106]). O período seguinte, denominado "científico" vai de 1881 a 1941 e tem influências do método históricocomparativo. Esse período se inicia com a publicação da Grammatica Portugueza de Julio Ribeiro, em 1881. Cavaliere o divide em duas fases, uma fundadora, que vai até o primeiro decênio do século XX e outra legatária que vai até a década de 1940. A respeito da primeira fase, o autor menciona o nome dos seguintes gramáticos oitocentistas Maximino Maciel, Pacheco da Silva Júnior, Lameira Andrade, Alfredo Gomes. Cita ainda Ernesto Carneiro Ribeiro como autor que por um período esteve mais próximo do racionalismo para posteriormente se aproximar do cientificismo.

Nas atas do Congresso Internacional de Lexicografia e Literaturas no Mundo Lusófono (17 a 21 de julho de 2000), publicado em 2002, encontramos o artigo de Leodegário A. de Azevedo Filho "Os estudos filológicos e lingüísticos no Brasil - uma tentativa de periodização", no qual o autor apresenta cinco períodos: o primeiro diz respeito ao tratamento de línguas indígenas em contato com o português e corresponde ao século XVI; o segundo é dado como período de imitação da gramática portuguesa, abarca os séculos XVII e XVIII; o terceiro período é o de purismo e diferenciação idiomática e compreende o século XIX; o quarto período, também ocorrido no século XIX, chama-se período vernaculista e de diferenciação idiomática; finalmente, o último período, nomeado de filológico e linguístico, compreende o século XX. Azevedo Filho cita gramáticas brasileiras oitocentistas do português em quatro diferentes períodos, o Epítome da gramática portuguesa que foi acabado pelo autor em Pernambuco em 1802 ([1]) é colocado dentro do segundo período, pois "não examina as diferenças já exitentes entre a fala brasileira e a fala portuguesa" (Azevedo Filho 2002:163) e não estava ainda "liberta" dos princípios da gramática filosófica.

O Compêndio da gramática da língua nacional de Antônio Álvares Pereira Coruja, publicado em 1835 ([16]), inicia o terceito período, porque, segundo Azevedo Filho, já havia centro interesse pelos problemas da língua portuguesa no Brasil, dado que o mesmo Coruja publica em 1856 o artigo Coleção de vocábulos e frases usados na província de São Pedro do Rio Grande do Sul. Cita também como sendo desse período a Gramática Filosófica da língua portuguesa de Costa Duarte (sem explicitar a data de 
publicação - possivelmente [19]), afirmando que não teria ainda havido a "libertação dos estudos gramaticais da filosofia e da lógica" (Azevedo Filho 2002:165). Outras gramáticas desse período são: as Postilas de gramática geral aplicada à língua portuguesa pela análise dos clássicos, publicada em São Luís, em 1852 ([59] $)^{57}$, e a Gramáticas portuguesa acomodada aos princípios gerais da palavra seguidos de imediata aplicação prática, publicada em São Luís, em 1866, ambas de Francisco Sotero dos Reis, e a Gramática portuguesa filosófica de Ernesto Carneiro Ribeiro, de 1879 $([120])^{58}$.

No terceiro período, denominado vernaculista e de evolucionismo linguístico, em que era "superado" o "velho logicismo gramatical em nome de princípios evolucionistas" (Azevedo Filho 2002:169), está a Gramática Portuguesa, de Júlio Ribeiro, publicada inicialmente em 1881, mas sua forma definitiva é de $1884^{59}$ ([123], [142]). São desse período também: a Nova gramática analítica da língua portuguesa do suíço Charles Grivet, de 1881, que é refundição de sua Gramática analítica da língua portuguesa, publicada em 1865 ([120], [71]); os Princípios de gramática histórica e comparada de Costa e Cunha, publicado em 1883 ([134]); as gramáticas de João Ribeiro, Pacheco e Lameira e Alfredo Gomes, as quais são baseadas no programa das línguas para os exames gerais e preparatórios escritos por Fausto Barreto em 1887; a Gramática Descritiva de Maximino Maciel de 190460; a Gramática da língua portuguesa, do Padre José de Noronha Massa, de 1888 ([161]); e, finalmente, os Serões Gramaticais publicado em 1890 ([170]) por Ernesto Carneiro Ribeiro.

A tese de Parreira Contrubución a la historia de la gramática brasileña del siglo XIX, defendida em 2011 na Universidade de Salamanca, Espanha, apresenta a análise ${ }^{61}$ de quatro gramáticas oitocentistas, as quais a autora considera inovadoras teórica ou metodologicamente. São elas: o Epitome da Grammatica Portugueza de Antonio Morais Silva, de 1806, publicado no Rio de Janeiro ([1]); a Grammatica Portugueza ${ }^{62}$ de Augusto Freire da Silva, de 1875, publicada no Maranhão, que teve 8 edições, segundo a autora

\footnotetext{
${ }^{57}$ Consideramos que sua primeira edição é de 1862, não de 1852 (cf. Apêndice A).

${ }^{58}$ Consideramos que essa gramática foi publicada ou em 1877 ou em 1881, pois a edição a que tivemos acesso tem duas folhas de rosto, cada uma com um ano de publicação diferente (cf. Apêndice A).

${ }^{59}$ Não conhecemos uma edição de 1884, acreditamos que o autor fale da que conhecemos de 1885 (cf. Apêndice A).

${ }^{60}$ Consideramos em nosso levantamento de obras (Cf. Apêndice I A) apenas obras publicadas durante o século XIX, assim temos nele apenas duas edições da Gramática de Maciel (1887 [149]; 1895 [183]).

${ }^{61}$ Baseada, segundo ela, em outros trabalhos como Gómez Asencio (1981), Calero Vaquera (1986) e García Folgado (2005), entre outros.

${ }^{62}$ Conhecemos apenas os "Compendios da grammatica portugueza" ([96], [112], [136], [144], [175]) de Freire da Silva, não há uma "gramática".
} 
([96]); a Grammatica Portugueza de Júlio Ribeiro, publicada em 1881 em São Paulo, que teve 11 edições ([123]); e, finalmente, a Grammatica Descriptiva de Maximino Maciel, publicada em $1894^{63}$ no Rio de Janeiro e que chegou a ter 11 edições, de acordo com Parreira, ([188]).

Ademais, a autora apresenta um quadro com outras dezessete gramáticas brasileiras do português, as quais não teriam promovido grandes mudanças. São elas: Breve Compendio de Grammatica Portugueza, de Frei J. do Amor divino Caneca, de 1817, Salvador ([100] $]^{64}$ ); Compendio de Grammatica Portugueza de Antonio da Costa Duarte, publicado em 1829 no Maranhão, 6 edições ([10]); Compendio da Grammatica da Língua Nacional de Antonio Álvares Pereira Coruja, publicado em 1835 em Porto Alegre, do qual a autora conhece duas edições ([16]); Breve Compendio de Grammatica Portugueza, de Salvador Henrique de Albuquerque, de 1844, Recife, 2 edições ([25]); Compendio de Grammatica Portugueza pelo methodo analytico, de José Alexandre Passos, publicada em 1848, no Rio de Janeiro ([28]); Compendio de Grammatica Portugueza, de Policarpo José Dias da Cruz, de 1859, Rio de Janeiro, 4 edições ([45] ${ }^{65}$ ); Compendio de Grammatica Philosophica de Manoel Soares da Silva Bezerra, de 1861, Ceará ([49]); Grammatica Portugueza de Francisco Sotero dos Reis, 1865, Maranhão $\left([75]^{66}\right)$; Nova Grammatica Anayticica da Lingua Portugueza de Charles Adrien Olivier Grivet, de 1865, Rio de Janeiro ([71]); Compendio de Grammatica da Lingua Portugueza de Laurindo José da Silva Rabelo, Rio de Janeiro, 1872 ([88]); Principios de Grammatica Historica e Comparada de A. Estevão da Costa e Cunha, de 1883 ([134]); Grammatica da Lingua Portugueza de Pacheco da Silva Jr. \& Lameira de Andrade, de 1887, Rio de Janeiro, 2 edições ([153]); Grammatica Portugueza de Alfredo Gomes, 1887, Rio de Janeiro, 15 edições ([151]); Grammatica Portugueza de João Ribeiro, 1887, Rio de Janeiro, 25 edições ([154]); e, finalmente, Serões Grammaticaes de Ernesto Carneiro Ribeiro, 1890, Bahia, 6 edições ([170]).

Finalmente, o último estudo que consideramos é a dissertação de mestrado $O$ tratamento da sintaxe em gramáticas brasileiras do século XIX: estudo historiográfico de Polachini, defendida na Universidade de São Paulo em 2013. Nela, baseando-se nas

\footnotetext{
${ }^{63}$ Não conhecemos uma edição de 1894, acreditamos que a autora fale da que conhecemos de 1895 (cf. Apêndice A).

${ }^{64}$ A qual, embora tenha sido escrita nos anos 1810, é publicada apenas em 1876.

${ }^{65}$ Conhecemos obra de título diferente de mesmo autor e mesmo ano "Postillas da grammatica portuguesa" (cf. Apêndice A).

${ }^{66} \mathrm{O}$ ano da edição que conhecemos é 1866 (cf. Apêndice A).
} 
periodizações anterior, procuramos primeiramente expandir o quadro de Parreira, e fazer uma análise de continuidades e descontinuidades de seis gramáticas do período baseandonos na metodologia de capas de Swiggers $(2014)^{67}$. Observamos as gramáticas que foram consideradas pontos de ruptura nas periodizações anteriores a fim de testar a metodologia de Swiggers e contribuir com a história dessa gramaticografia. Assim, analisamos o Epitome da Grammatica Portugueza, de Antônio Morais Silva, publicada em 1806 ([1]); a nova edição do Compendio da Grammatica da Lingua Nacional de Antônio Álvares Pereira Coruja, de 1873, publicada no Rio de Janeiro ([92]) - a primeira edição da obra, à qual não tivemos acesso então, é de 1835 e foi publicada em Porto Alegre ([16]); a Grammatica Portugueza de Francisco Sotero dos Reis, de 1866, Maranhão ([75]); o Breve Compendio da Grammatica Portugueza publicado em 1875 no Maranhão, de Augusto Freire da Silva ([96]); a Grammatica Portugueza de Júlio Ribeiro, publicada em 1881, em São Paulo ([123]); e, finalmente, a Grammatica Descriptiva de Maximino de Araújo Maciel, publicada em 1902 no Rio de Janeiro, que tinha edição anterior (à qual não tivemos acesso então) de 1895 ([188]), Rio de Janeiro.

Ademais, inspirados pelo trabalho de Parreira, fizemos um quadro similar ao da autora a fim de apresentar as gramáticas de que tínhamos conhecimento. Além das já expostas por ela, acrescentamos nove obras, a saber: Resumo da Grammatica Portugueza, de 1855, de José Alexandre Passos ([37]); Novo sistema de estudar a grammatica portugueza por meio da memoria, inteligencia e analyse, de Ortiz e Pardal, 1862 ([54]); Postillas de Grammatica Geral Aplicada à linguagegem portuguesa pela analyse dos classicos de Sotero dos Reis, 1862, Maranhão ([59]); Grammatica Portugueza Philosophica, de Ernesto Carneiro Ribeiro, publicada em 1881, na Bahia ([120]); a Nova gramática analítica da língua portuguesa de Charles Adrian Grivet, publicada em 1881 no Rio de Janeiro ([120]); Grammatica analytica da lingua portugueza, composta e offerecida aos brazileiros, de José de Noronha Nápoles Massa, publicada no Rio de Janeiro, em 1888 ([161]); Primeira Grammatica da Infância e Segunda Gramática da

\footnotetext{
67 "Na análise da capa teórica, correspondente a visão global da linguagem e concepção das tarefas e do estatuto dos estudos linguísticos, foram analisados os termos 'gramática' 'língua' e 'linguagem'. Na análise da capa técnica, relativa a técnicas de análise e métodos de apresentação dos dados, abordaram-se termos da seção de tratamento da sintaxe das obras presentes em seis temas: a definição mesma de 'sintaxe', 'sentença' e seus membros, 'concordância', 'hierarquia dos itens da sentença', 'sintaxe figurada' e 'vícios'. Já a capa documental, definida por Swiggers como a documentação linguística e filológica (número de línguas, tipos de fontes de dados, por exemplo) sobre o qual se baseia o estudo linguístico, permitiu a análise dos dados linguísticos eleitos como exemplos nas gramáticas e um exame, ainda que tangencial, das formas de incorporação do português do Brasil a esses trabalhos. Por fim, a capa contextual ensejou a exploração de elementos externos que tiveram algum impacto sobre o tratamento da sintaxe nas obras selecionadas." (Polachini 2013:5)
} 
Infância, de Francisco Ferreira de Vilhena Alves, de 1897, Pará ([194]); Grammatica da lingua portugueza de Zillah do Paço Mattoso Maia, de 1899, Rio de Janeiro ([203]); e, finalmente, a Grammatica Portugueza de José Ventura Boscoli, cuja segunda edição foi publicada em 1899 no Rio de Janeiro ([201]). Ademais, modificamos alguns dados expostos por Parreira (2011). A data de publicação do compêndio de Frei Caneca é 1876 ([100]), embora tenha de fato sido escrito entre 1817 e 1819, a gramática de Freire da Silva publicada em 1875 ([96]) chama-se Compendio da Grammatica Portugueza.

Vistas em detalhes as revisões históricas, adiante apresentamos um quadro síntese das obras e autores citados pelas por elas com o número correspondente da lista que apresentamos no apêndice A.

\begin{tabular}{|c|c|c|c|c|c|c|c|c|}
\hline Autor & $\begin{array}{c}\text { M. } \\
1910\end{array}$ & $\begin{array}{c}\text { N. } \\
1939\end{array}$ & $\begin{array}{c}\text { C. } \\
1962\end{array}$ & $\begin{array}{c}\text { E. } \\
1975\end{array}$ & $\begin{array}{c}\text { C. } \\
2001\end{array}$ & $\begin{array}{l}\text { A. F. } \\
2002\end{array}$ & $\begin{array}{c}\text { P. } \\
2011\end{array}$ & $\begin{array}{c}P . \\
2013\end{array}$ \\
\hline Morais Silva & & [1] & & & [1] & [1] & [1] & [1] \\
\hline Costa Duarte & A & [19] & [19] & & & [19]? & {$[10]$} & \\
\hline Coruja & & {$[16]$} & {$[16]$} & & & {$[16]$} & {$[16]$} & $\begin{array}{l}{[16]} \\
{[92]}\end{array}$ \\
\hline Albuquerque & & & & & & & {$[21]$} & [21] \\
\hline Passos & & {$[37]$} & [37] & & & {$[37]$} & {$[28]$} & $\begin{array}{l}{[28]} \\
{[37]}\end{array}$ \\
\hline Cruz & & & & & & & {$[45]$} & [45] \\
\hline Bezerra & & & & & & & [49] & [49] \\
\hline Ortiz e Pardal & & {$[54]$} & [54] & & & {$[54]$} & & [54] \\
\hline Sotero dos Reis & A & {$[75]$} & $\begin{array}{l}{[59]} \\
{[75]}\end{array}$ & $\begin{array}{l}{[59]} \\
{[75]}\end{array}$ & [106] & $\begin{array}{l}{[59]} \\
{[75]}\end{array}$ & {$[75]$} & $\begin{array}{l}{[59]} \\
{[75]}\end{array}$ \\
\hline Ibirapitanga & A & & & & & & & \\
\hline Grivet & A & $\begin{array}{c}{[71]} \\
{[120]}\end{array}$ & $\begin{array}{c}{[71]} \\
{[120]}\end{array}$ & $\begin{array}{c}{[71]} \\
{[120]}\end{array}$ & $\begin{array}{c}{[71]} \\
{[120]}\end{array}$ & $\begin{array}{c}{[71]} \\
{[120]}\end{array}$ & [120] & $\begin{array}{c}{[71]} \\
{[120]}\end{array}$ \\
\hline Rabelo & & & & & & & {$[88]$} & [88] \\
\hline Caneca & & & & & & & [100] & [100] \\
\hline Freire da Silva & A & [111] & $\begin{array}{c}{[96]} \\
{[112]}\end{array}$ & & & & {$[96]$} & [96] \\
\hline Carneiro Ribeiro & A & $\begin{array}{l}{[120]} \\
{[170]}\end{array}$ & [170] & {$[170]$} & A & $\begin{array}{l}{[120]} \\
{[170]}\end{array}$ & [170] & $\begin{array}{l}{[120]} \\
{[170]}\end{array}$ \\
\hline $\begin{array}{l}\text { Hemetério dos } \\
\text { Santos }\end{array}$ & A & & & & & & & \\
\hline (Júlio) Ribeiro & A & [123] & [123] & $\begin{array}{l}{[123]} \\
{[142]}\end{array}$ & [123] & $\begin{array}{l}{[123]} \\
{[142]}\end{array}$ & [123] & [123] \\
\hline Costa e Cunha & & [134] & [134] & [134] & & [134] & [134] & [134] \\
\hline Pacheco & A & A & [108] & A & A & A & [153] & [153] \\
\hline Lameira & A & A & & A & A & A & [153] & {$[153]$} \\
\hline Gomes & A & A & & A & A & A & [151] & [151] \\
\hline (João) Ribeiro & A & A & & A & A & A & [154] & [154] \\
\hline Maciel & A & $\begin{array}{l}{[152]} \\
{[188]}\end{array}$ & $\begin{array}{c}{[152]} \\
{[188]}\end{array}$ & $\begin{array}{c}{[152]} \\
{[188]}\end{array}$ & & [188] & [188] & $\begin{array}{l}{[152]} \\
{[188]}\end{array}$ \\
\hline Massa & A & [161] & [161] & & & [161] & & [161] \\
\hline Alves & & & & & & & & [194] \\
\hline Maia & & & & & & & & [203] \\
\hline Boscoli & A & & & & & & & {$[201]$} \\
\hline Vieira & A & & & & & & & \\
\hline
\end{tabular}


Observamos que certas gramáticas são frequentemente citadas, como é o caso das seguintes: Coruja (1835, [16]), Sotero dos Reis (1866, [75]), Ribeiro (1881, [123]), Grivet (1865, [71]; 1881, [120]), Maciel (1895, [188]), Carneiro Ribeiro (1890, [170]). Além disso, os autores que seguiram o Programa de Exames de Fausto Barreto são também citados frequentemente, ainda que sem o nome das obras, Pacheco \& Lameira (1887, [153]), Ribeiro (1887, [154]), Gomes (1887, [151]). É notável também que grande número das obras que encontramos não são citadas.

Outro ponto dos nove textos analisados a ser ressaltado são as rupturas, em geral epistemológicas, observadas pelos autores, sobretudo aquelas do século XIX. No quadro adiante, apresentamos uma síntese delas.

\begin{tabular}{|c|c|c|c|}
\hline$\gamma_{-}$Period. & Antes do século XIX & \multicolumn{2}{|c|}{ Século XIX } \\
\hline M. 1910 & & "Modelo antigo" até 1881 & $\begin{array}{l}\text { "Critério filológico, o método } \\
\text { histórico-comparativo" } \\
\text { Inicia-se com Ribeiro (1881), } \\
\text { que, entretanto, apressou-se } \\
\text { (copiou estrangeiros sem } \\
\text { assimilá-los). A consolidação } \\
\text { se dá em } 1887 \text { com Programa } \\
\text { de estudos do Pedro II, de } \\
\text { Fausto Barreto }\end{array}$ \\
\hline N. 1939 & $\begin{array}{l}1^{\circ} . \text { Embrionário } \\
\text { (1500-1835) } \\
\text { Orientação } \\
\text { portuguesa - Inclui } \\
\text { Morais Silva }(1806)\end{array}$ & $\begin{array}{c}2^{\circ} \text { Empírico (1835-1881) } \\
\text { Inicia-se com Coruja } \\
(1835)\end{array}$ & $\begin{array}{c}3^{\circ} \text { Gramatical (1881-1939) } \\
\text { Inicia-se com Ribeiro (1881), } \\
\text { consolida-se com Programa de } \\
\text { Estudos de } 1887 .\end{array}$ \\
\hline C. 1962 & \multicolumn{3}{|c|}{ Da colônia até 1939} \\
\hline E. 1975 & & $\begin{array}{c}1^{\circ} \text { Vernaculista } \\
(1820-1880) \\
\text { A data inicial corresponde } \\
\text { à independência do Brasil } \\
\text { aproximadamente. }\end{array}$ & $\begin{array}{c}2^{\circ} \text { Científico (1880-1960) } \\
\text { Inicia-se com Ribeiro (1881), } \\
\text { consolida-se com Programa de } \\
\text { Estudos de } 1887 .\end{array}$ \\
\hline C. 2001 & $\begin{array}{c}1^{\circ} \text { Embrionário } \\
\text { (Das origens até } \\
1802 \text { ) }\end{array}$ & $\begin{array}{c}2^{\circ} \text { Racionalista } \\
(1802-1881) \\
\text { Inicia-se com Morais Silva } \\
\text { (que finaliza seu Epitome } \\
\text { em 1802) }\end{array}$ & $\begin{array}{c}3^{\circ} \text { Científico } \\
(1881-1941) \\
\text { Inicia-se com Ribeiro (1881) }\end{array}$ \\
\hline A. F. 2002 & $\begin{array}{c}1^{\circ} \text { Tratamento de } \\
\text { línguas indígenas em } \\
\text { contato com o } \\
\text { português (século } \\
\text { XVI); } \\
2^{\circ} \text { Imitação da } \\
\text { gramática portuguesa } \\
\text { (séculos XVII e } \\
\text { XVIII) - Inclui } \\
\text { Morais Silva (1802). }\end{array}$ & $\begin{array}{c}3^{\circ} \text { Purismo e diferenciação } \\
\text { idiomática } \\
\text { (Século XIX - até 1881) } \\
\text { - Pautado pela gramática } \\
\text { filosófica e lógica. }\end{array}$ & $\begin{array}{c}4^{\circ} \text { Vernaculistas e } \\
\text { diferenciação idiomática } \\
\text { (Século XIX - depois de } \\
1881 \text { ) } \\
\text { - Pautada por princípios } \\
\text { evolucionistas. } \\
\text { Inicia-se com Ribeiro (1881) }\end{array}$ \\
\hline P. 2011 & & $\begin{array}{r}\text { uatro gr } \\
\text { Mor }\end{array}$ & $\begin{array}{l}\text { cos inovadores: } \\
\text { lva (1806) }\end{array}$ \\
\hline
\end{tabular}




\begin{tabular}{|c|c|c|}
\hline & \multicolumn{2}{|c|}{$\begin{array}{c}\text { Freire da Silva (1875) } \\
\text { Ribeiro (1881) } \\
\text { Maciel (1894) }\end{array}$} \\
\hline P. 2013 & $\begin{array}{l}1^{\text {a }} \text { gramática de LP escrita } \\
\text { por brasileiro: Morais } \\
\text { Silva (1806). Gramática } \\
\text { baseada na grammaire } \\
\text { générale francesa. }\end{array}$ & $\begin{array}{l}\text { Ruptura gradual com Ribeiro } \\
\text { (1881); que é continuada com } \\
\text { Maciel (1894). Gramáticas } \\
\text { baseadas no método histórico- } \\
\text { comparativo. }\end{array}$ \\
\hline
\end{tabular}

Quadro 6. Síntese de periodizações realizadas sobre a gramaticografia brasileira oitocentista do português

Exceto por Castilho (1962) todos os autores consideram uma ruptura epistemológica no século XIX. A maior parte deles ressalta o papel de Ribeiro (1881) nessa ruptura, outros ainda incluem o Programa de Estudos do Colégio Pedro II e as gramáticas publicadas em decorrência dele, em 1887. Essa ruptura se deu entre uma gramática denominada, por vezes, filosófica, racionalista, lógica, empírica ou baseada na grammaire générale, e uma gramática baseada no método histórico-comparativa, que é, por alguns, denominada científica, vernaculista ou gramatical. Adiante, no Capítulo 2, apresentamos nossa seleção de obras com base, sobretudo, em nossa história serial (Cf. Capítulo 3) e na análise das revisões históricas. 
Poemas apolíticos também são políticos,

e lá em cima a lua já não dá luar.

Ser ou não ser: eis a questão.

(Wislawa Szymborska) 


\section{CAPÍTULO 2 | Método}

\subsection{Levantamento de gramáticas brasileiras do português do século XIX}

Como já dissemos no capítulo teórico (cf. item 1.1), definimos a cobertura deste trabalho, isto é, o conjunto de recortes referentes à delimitação de um espaço, à periodização e à temática, como sendo o território brasileiro no que diz respeito à nacionalidade (ou naturalização) dos autores tratados; o século XIX como período de publicação das obras; e, por fim, quanto à temática, o tratamento, em gramáticas do português, do conceito de 'verbo substantivo' e da rede conceitual formada em torno dele.

Tivemos conhecimento, em nossa busca exaustiva, de 204 gramáticas, das quais, na maior parte, pudemos levantar as informações bibliográficas. Esse levantamento foi feito em catálogos de bibliotecas ou nas menções feitas por fontes secundárias (cf., entre outros, Sacramento Blake 1883-1902). Com esse conjunto de dados bibliográficos, organizamos uma história serial dessa produção.

Das 200, tivemos acesso e pudemos ler a somente quarenta, entre as quais estão as mais frequentemente mencionadas em fontes secundárias (por exemplo: Coruja 1835, [16] ${ }^{68}$; Sotero dos Reis 1866, [75]; Ribeiro 1881, [123]; Grivet 1881, [120]; Maciel 1887, [152], 1895, [188]; Carneiro Ribeiro 1881, [120] 1890, [170]; Pacheco \& Lameira 1887, [153]). Também lemos outras pouco ou nada citadas (por exemplo: Bithencourt 1862, [50]; Villeroy 1870, [81]; Rabelo 1872, [88]; Condurú 1888, [157]). Fizemos, dentre essas obras, uma seleção consciente de textos que fossem representativos para a tradição estudada, a fim de realizar a análise vertical a respeito do conceito de 'verbo substantivo'. Chegamos, ao final desse processo, ao número de 18 gramáticas (as quais são, nos critérios do Capítulo 3: 16 edições, 2 reedições), de 14 autores diferentes, sendo uma obra em coautoria.

Ainda que tivéssemos enfrentado a limitação relativa ao acesso a apenas certas obras $^{69}$, o princípio de nossa seleção era formar um corpus representativo da tradição nacional estudada. Assim, a fim de compreender o que de fato era representativo,

\footnotetext{
${ }^{68}$ Esses números entre colchetes correspondem à numeração em que cada gramática de que tivemos conhecimento foi colocada em nosso mapeamento. Todas as gramáticas estão em, primeiramente, ordem cronológica de publicação dos textos e, em segundo lugar, ordem alfabética de sobrenome dos autores no Apêndice A.

${ }^{69}$ Essa limitação se deveu-se, frequentemente, ao fato de que tivemos conhecimento de muitas gramáticas pelo Dicionário Biobibliográfico de Sacramento Blake, mas não as encontramos em sebos, arquivos ou bibliotecas.
} 
analisamos os dados contextuais que tínhamos acerca das 204 gramáticas. Tais dados referiam-se aos comentários feitos sobre essas obras por Sacramento Blake (1883-1902) e outras revisões históricas (cf. item 1.5) e a dados catalográficos das obras (por vezes, incompletos). Tendo em conta que muitas das gramáticas que encontramos foram omitidas pelas revisões históricas (cf. item 1.5; capítulo 3), procuramos criar nossa própria revisão e, dado que tínhamos sobretudo dados catalográficos das gramáticas, o que nos proporcionava uma fonte homogênea de dados, escolhemos a metodologia da História Serial para organizar um mapa dessa produção.

\subsubsection{A seleção de obras para análise: critérios combinados}

A fim de fazer uma seleção consciente das obras analisadas, operamos com critérios contextuais combinados. Certamente, o prestígio e impacto da obra formam um critério a ser considerado. Procuramos, assim, observar que gramáticas ao longo do século tiveram um grande número reedições, que obras foram adotadas por colégios (de prestígio), quais delas são citadas até hoje em revisões ou periodizações dessa produção (Cf. item 1.5). Além disso, notamos em algumas gramáticas, que não foram necessariamente prestigiosas, diálogos com aquelas que tiveram grande impacto; essas foram selecionadas com o objetivo de analisar a maneira como eram lidas e discutidas naquele período as gramáticas mais conhecidas.

Outro critério que tomamos como importante foram as rupturas nessa tradição. Dessa forma, num primeiro momento, procuramos observar sua emergência, perguntando-nos como e com que obras surgiu a tradição gramatical brasileira do português. Além da busca por esses marcos iniciais, consideramos que houve também, ao longo do século, uma ruptura retórica e epistemológica (como muitos revisores dessa produção também o fazem; cf. item 1.5; cf. Maciel 1910, Nascentes 1939, Elia 1975, Cavaliere 2001, Azevedo Filho 2002, Parreira 2011, Polachini 2013), a qual culminou, em 1887, na redação de um programa de estudos para o colégio mais importante da capital no período, o Colégio Pedro II, fator que, muito provavelmente, promove a primeira padronização da gramaticografia brasileira. Selecionamos, portanto, desse subperíodo, as gramáticas escritas explicitamente de acordo com esse programa. Dados esses critérios combinados (prestígio; diálogo com outras gramáticas; participação no processo de emergência da gramaticografia brasileira do português; inserção no movimento de ruptura 
característico do final do século e incorporação do Programa de Estudos de Fausto Barreto (padronização)), chegamos à seguinte seleção de dezoito obras gramaticais:

1. 1806 [1]. MORAIS SILVA, Antonio de. Epitome da grammatica portugueza. Lisboa: Off. de Simão Thaddeo Ferreira. $1^{\mathrm{a}}$. ed. $165 \mathrm{p}$.

2. 1816 [4]. FORTES. Ignacio Felizardo. Arte de grammatica portugueza que para uso dos seus discipulos compoz o padre... Rio de Janeiro: Imprensa Régia. $2^{\text {a }}$ ed. $95 \mathrm{p}$.

3. 1829 [10]. COSTA DUARTE, Antonio. Compendio da grammatica portugueza: para uso das escolas de primeiras letras, ordenado segundo a doutrina dos melhores grammaticos. Maranhão: Typographia Nacional. $1^{\mathrm{a}} \mathrm{ed} .100 \mathrm{p}$.

4. 1835 [16]. CORUJA, Antonio Alvares Pereira Coruja. Compendio da Grammatica da Lingua Nacional: dedicado á mocidade rio-grandense. Porto Alegre: V. F. de Andrade. $1^{\mathrm{a}}$ ed. $68 \mathrm{p}$.

5. 1859 [44]. COSTA DUARTE, Antonio. Compendio da grammatica philosophica da lingua portugueza. Maranhão: Typ. do Frias. $4^{\mathrm{a}}$ ed. $121 \mathrm{p}$.

6. 1862 [50]. BITHENCOURT, Raymundo Camara. Grammatica Philosophica da lingua portugueza. Rio de Janeiro: Eduardo \& Henrique Laemmert. $1^{\text {a }}$ ed. 144p.

7. 1871 [85]. SOTERO DOS REIS, Francisco. Grammatica Portugueza: accommodada aos principios geraes da palavra seguidos de immediata applicação pratica. Maranhão: Typ. de R. d'Almeida \& C. 1ª 304p.

8. 1873 [92]. CORUJA, Antonio Alvares Pereira Coruja. Compendio da Grammatica da Lingua Nacional: dedicado á mocidade rio-grandense. Rio de Janeiro: Esperança. "Nova edição". 99p.

9. 1881 [120]. CARNEIRO RIBEIRO, Ernesto. Grammatica Portugueza Philosophica. Bahia: Imprensa Economica. $1^{\mathrm{a}}$ ed. $447 \mathrm{p}$.

10. 1881 [123]. RIBEIRO, Julio. Grammatica Portugueza. São Paulo: Typ. de Jorge Seckler. $1^{a}$. ed. $298 p$.

11. 1885 [143]. RIBEIRO, Julio. Grammatica Portugueza. São Paulo: Teixeira \& Irmão, Editores. Segunda edição, refundida e muito augmentada. 362p.

12. 1887 [152]. MACIEL, Maximino de Araújo. Grammatica analytica baseada nas doutrinas modernas, satisfazendo ás condições do actual programma. Rio de Janeiro: Typ. Central, de Evaristo Rodrigues da Costa. $1^{\mathrm{a}}$ ed. $215 \mathrm{p}$. 
13. 1887 [153]. PACHECO \& LAMEIRA, Noções de grammatica portugueza de accordo com o programma official para os exames geraes de preparatorios do corrente anno. Rio de Janeiro: J. G. de Azevedo - Editor. $1^{\text {a }}$ ed. 537p.

14. 1888 [157]. CONDURÚ, Fillipe Benicio de Oliveira. Grammatica elementar da lingua portugueza. São Luiz do Maranhão: Typ. do Paiz. 13a ed. 103p.

15. 1889 [167]. RIBEIRO, João. Exames de portuguez - Grammatica Portugueza (3 anno). Rio de Janeiro: Livraria Classica de Alvez \& C. $3^{\text {a }}$ ed. 302p.

16. 1890 [170]. CARNEIRO RIBEIRO, Ernesto. Serões grammaticaes ou Nova Grammatica Portugueza. Bahia: Imprensa Popular. 369p.

17. 1895 [187]. GOMES, Alfredo. Grammatica Portugueza. Capital Federal (Rio de Janeiro): J. G. de Azevedo. $6^{\mathrm{a}}$ ed. 215p.

18. 1895 [188]. MACIEL. Grammatica Descriptiva baseada nas doutrinas modernas. Capital Federal: Typ. de Paso \& C. $2^{\mathrm{a}}$ ed. 335p.

As gramáticas de Morais Silva (1806) e Fortes (1816) foram selecionadas por serem as primeiras na gramaticografia brasileira do português. Consideramos Morais Silva (1755-1824) um autor cuja gramática pode fazer parte do nosso corpus, e, portanto,

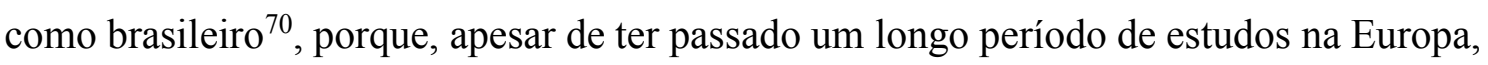
sobretudo em Portugal e na Inglaterra, ele nasceu e morou a maior parte de sua vida no Brasil colônia. Ademais, ao assinar a obra, ele apresenta sua localização como "Engenho Novo de Moribeca em Pernambuco". Morais Silva foi o primeiro brasileiro a escrever uma gramática da língua portuguesa. Fortes é considerado o primeiro autor brasileiro a publicar sua gramática no Brasil, após a chegada do príncipe regente e da corte portuguesa, e a subsequente implementação de uma imprensa local. Assim, ambos os textos nos ajudam a demarcar o início do processo de emergência da tradição. Além disso, é relevante ressaltar que ambos parecem ter tido também certo prestígio.

Sacramento Blake (1893) assinala que a gramática de Fortes (nascido no último quartel do século XVIII - 1846) teve diversas edições. Além da primeira, de 1810 ([2]), e da segunda, de 1816 ([4]), o autor ainda cita "a terceira, mais correcta e augmentada, de 1825 ([7]); a nona, do 1844 ([23]), igualmente mais correcta e augmentada; a décima segunda de 1851 ([31]); a décima terceira do 1855 ([36]); a décima quarta de 1862 ([53]), todas do Rio de Janeiro" (Sacramento Blake, vol. 3, 264). Entretanto, como já dissemos

\footnotetext{
${ }^{70}$ Cavaliere (2001) também argumenta nesse sentido. Alguns autores consideram-no português, como é o caso, por exemplo, de Nascentes (1939) e Pessoa Santos (2010).
} 
anteriormente, sua obra era praticamente desconhecida nos dias de hoje, não tendo sido citada em nenhuma das revisões históricas mencionadas no Capítulo 1 (cf. item 1.5); foi apenas, muito recentemente, incluída em Kemmler (2013). Selecionamos sua segunda edição por ter sido a única a que tivemos acesso.

Já Morais Silva é bastante conhecido por conta de seu dicionário da língua portuguesa, cuja primeira edição é de 1789. A segunda, de 1813 ([3]), apresenta o texto do epítome gramatical como um apêndice. Anos depois, em 1824 ([6]), o texto do epítome seria republicado com a supressão do capítulo inicial, chamado "ao leitor", na Grammatica Portugueza. Além disso, em 1832 ([12]), é reescrito em formato de diálogo e publicado em Porto Alegre, sem constar o autor que adaptou a obra a esse formato.

Em suma, ainda que essas gramáticas tenham sido escolhidas sobretudo por participarem da emergência da tradição brasileira de descrição do português, elas também poderiam ser aqui incluídas com base no critério de prestígio.

A Grammatica Portugueza de Júlio Ribeiro (1845-1890), publicada em 1881 em São Paulo, é muito prestigiosa; como vimos no Capítulo 1, ela é citada por todas as revisões históricas, além de ter tido um grande número de reedições (até 1899, foram seis reedições). Isso parece se dar, sobretudo, por ser considerada aquela que promove a transição da influência da gramática geral francesa para a influência do método históricocomparativo (cf. Maciel 1910, Nascentes 1939, Elia 1975, Cavaliere 2001). Ribeiro é bastante aberto a críticas e sugestões, colocando nas primeiras páginas de sua gramática a seguinte advertência

Peço á crtitica illustrada e hones o que ella não pode recusar - toda a severidade para com esta Grammatica. Não é um orgulho tolo que me leva a fazer tal pedido: é o desejo de melhorar o meu trabalho em bem dos que estudam Portuguez. Dos directores da imprensa espero uma fineza-que me sejam enviados todos os exemplares das suas folhas em que saiam noticias e apreciações desta obra. Endereço: Julio Ribeiro. S. João de Capivary, Província de São Paulo. Brazil. (Ribeiro 1881)

Acolhendo, assim, comentários diversos, Ribeiro promove uma série de mudanças na segunda edição de sua gramática, de 1885, que depois seria reimpressa e editada diversas vezes, apesar da morte prematura do autor em 1890. Analisamos, em vista disso, as duas primeiras edições da gramática, de 1881 e 1885 .

No rol das gramáticas sobretudo prestigiosas, incluímos Costa Duarte (1829, 1859), Coruja (1835, 1873), Sotero dos Reis (1871), Carneiro Ribeiro (1881, 1890), Condurú (1888) e Freire da Silva $(1875,1894)$. Lembramos, porém, que nossa seleção pode ser considerada um tanto arbitrária, já que não tivemos acesso a gramáticas talvez 
igualmente prestigiadas no século XIX, como as de Hemetério dos Santos ([113]) e de Alexandre Passos ([28], [37], [64], [84]). Adiante, explicamos a seleção de cada uma das gramáticas prestigiosas.

O Compendio da grammatica portugueza, do maranhense Costa Duarte (?-?), tem sua primeira edição publicada em 1829, mas é apenas a partir de sua segunda edição, publicada em 1840, bastante aumentada e com novo título, que ela foi adotada pelo Liceu do Maranhão para as aulas de primeiras letras até, pelo menos, o final da década de 1870 . Temos conhecimento de ao menos seis edições da obra: a terceira de 1853, a quarta de 1859, a quinta da qual não pudemos determinar a data e, por fim, a sexta de 1877 ([105]). Todas apresentam subtítulo que indica seu vínculo com o Liceu do Maranhão. Selecionamos, para o nosso corpus, a primeira edição, de 1829, e a quarta, de 1859. Isso porque, de acordo com os critérios apresentados mais adiante neste capítulo (cf. 2.2.1), embora pareça-nos que o autor tratou essas gramáticas como edições posteriores, nós as tratamos como diferentes obras, pois têm títulos diferentes. Assim, procuramos observar como Costa Duarte promoveu mudanças em diferentes gramáticas ao longo do século.

O compêndio gramatical de Coruja (1806-1889) tem sua primeira edição em 1835, publicada em Porto Alegre, província de origem do autor. As muitas edições posteriores foram publicadas no Rio de Janeiro, província para a qual Coruja se mudara, muito embora ele tenha mantido em todas elas o subtítulo "para a mocidade rio-grandense". A edição mais tardia de que temos conhecimento data de 1891([172]), o que ratifica o imenso prestígio da obra, que permaneceu por cerca de seis décadas em circulação. Há diversas modificações e acréscimos ao texto de acordo com as edições posteriores. Por conta disso, analisamos a primeira edição, de 1835 e a edição de 1873 .

Francisco Sotero dos Reis (1800-1871) foi considerado um dos integrantes da Atenas Brasileira ${ }^{71}$ maranhense. Sua gramática é muitas vezes dada como texto exemplar do período no qual as gramáticas brasileiras foram fortemente influenciadas pela grammaire générale francesa (cf. Maciel 1910). Embora só tenha tido três edições, de 1866, 1871 e 1877, a gramática é frequentemente mencionada em fontes secundárias (cf.

\footnotetext{
${ }^{71}$ Citamos os membros listados por Costa (2013:35-36): "Nesse contexto de efervescência cultural, formouse uma geração de intelectuais no Maranhão, composta por: Manuel Odorico Mendes, João Inácio da Cunha, Francisco Sotero dos Reis, José Cândido de Morais e Silva, Antônio Pedro da Costa Ferreira, Feliciano Antônio Falcão, Joaquim Franco de Sá, Joaquim Vieira da Silva e Sousa, João Pedro Dias Vieira, Joaquim Gomes de Sousa, Antônio Joaquim, Franco de Sá, João Duarte Lisboa Serra, Trajano Galvão de Carvalho, Belarmino de Matos, Francisco José Furtado, Antônio Gonçalves Dias, João Francisco Lisboa, Antonio Marques Rodrigues e Doutor Frei Custódio Alves Serrão todos eles foram biografados na obra Pantheon Maranhense, organizada pelo Dr. Antônio Henriques Leal42. Eles pertenceram à primeira geração (1846-1868) de intelectuais maranhenses."
} 
Maciel 1910, Nascentes 1939, Elia 1975, Cavaliere 2001) e também por outros gramáticos (cf., ao menos, Grivet 1881, Ribeiro 1881), o que revela que era uma obra conhecida no período. Analisamos a segunda edição, de 1871 ([85]), que é póstuma e contém um prefácio do autor que não constava na primeira edição, além de anotações de seus filhos, Francisco Sotero dos Reis Júnior e Américo Sotero dos Reis.

O baiano Ernesto Carneiro Ribeiro (1839-1920) publica em 1881 uma gramática que ele intitula como filosófica; essa gramática não tem reedições, mas é uma modificação dela que é publicada em 1890 sob o título Serões Grammaticaes ou Nova Grammatica Portugueza, a qual foi reeditada e modificada diversas vezes em vida do autor e republicada mesmo postumamente. Temos conhecimento das edições de 1915, 1919, 1950 e 1956, que são, respectivamente, a segunda, terceira, quinta e sexta. Analisamos as duas gramáticas publicadas no século XIX.

A última gramática do século que foi selecionada sobretudo por seu prestígio é a gramática de Condurú (1818-1879); é publicada em 1850 ([30]) pela primeira vez e, de acordo com Silva (2013), era parte do curso primário do ensino na província do Maranhão. Tivemos acesso, porém, somente a uma edição bastante adiantada, a décima terceira, de 1888 (de acordo com Nogueira (2009), visto que a cópia digitalizada da gramática não apresenta ano de publicação). Sabe-se que a gramática obteve muitas outras reedições, às quais também não obtivemos acesso; seu prestígio, porém, não pode ser negado. Assim, selecionamos a edição de 1888 como parte de nosso corpus.

Um terceiro tipo de obras foi selecionado, como já dissemos, por dialogar com obras de prestígio. Bithencourt publica seu epitome em 1862 afirmando no prólogo que tinha, primeiramente, o objetivo de substituir a Grammatica Philosophica da Lingua Portugueza, do lusitano Soares Barbosa (1822), pois essa se encontrava esgotada nas livrarias e era "demasiado difusa", sendo de difícil aplicação para os alunos. Ademais, ressalta que procurou notificar pontos em que discorda da gramática de Costa Duarte, que, segundo o gramático carioca, "se aparta do insigne Soares Barbosa, sustenta doutrinas que nos parecem pouco grammaticaes" (cf. Apêndice B). Na obra, o autor apresenta sobretudo em notas de rodapé um diálogo interessante de comparação entre o que escreveram Costa Duarte e Soares Barbosa.

Por fim, elencamos gramáticas que procuraram cumprir o programa de estudos redigido por Fausto Barreto, em 1887, para o Colégio Pedro II. A primeira edição da gramática de Maciel (1866-1923), intitulada Grammatica Analytica foi publicada em 
1887, mesmo ano em que também publicaram gramáticas João Ribeiro (1860-1934), Alfredo Gomes (?-?) e Pacheco (?-?) \& Lameira (?-1897). Todos pr. -

ocurando seguir as indicações do programa de estudos supramencionado. Tivemos acesso às primeiras edições de Maciel (1887) e Pacheco \& Lameira (1887) somente. Quanto às gramáticas de Ribeiro (1889) e de Gomes (1895) analisamos a edição mais próxima de 1887 a que tivemos acesso, as quais são, respectivamente, a terceira e sexta edições. Ademais, analisamos a segunda edição de Maciel (1895), dado que essa gramática poderia se colocar dentre as prestigiosas e também nos permite observar que mudanças o autor promoveu em sua gramática em relação ao que havia feito para o programa em 1887.

\subsection{Critérios para a análise orientada para o contexto}

Nossa análise externa consiste, primeiramente, de um mapeamento da produção gramatical brasileira oitocentista que é feito por meio da metodologia da História Serial, que explicamos em detalhes no item 2.2.1. Posteriormente, a fim de observar a agenda (i.e. as intenções ou motivações subjacentes de um indivíduo ou grupo) dos autores ao escreverem suas gramáticas, analisamos, por um lado, seus dados biobibliográficos, e, por outro, os paratextos (com atenção especial a prólogos ou prefácios e epígrafes) dos dezoito textos selecionados; nessa análise, nos inspiramos especialmente sobre o modelo de conflito de Murray (1994), a metodologia encontra-se em detalhe no item 2.1.2.

\subsubsection{História Serial: concebendo um mapa}

Para realizar um mapeamento de eventos baseado na abordagem da História Serial, primeiramente, coletamos informações sobre todas as gramáticas publicadas durante o século XIX de que tivemos notícia. Essa coleta se deu amiúde em fontes secundárias e em catálogos de bibliotecas. Dessa forma, em muitos casos, tivemos acesso a dados apresentados na contracapa das obras, como: autor, título, ano de publicação, número da edição, lugar de publicação e casa impressora. Para analisar esses dados formalizamos categorias que poderiam funcionar como unidades, a fim de observar repetições e mudanças no processo, são elas: autor, título, tipo de título, subtitulos, ano de publicação, década de publicação, lugar de publicação, casa impressora, edição (não 
em números, pois frequentemente não tivemos acesso a eles, mas de acordo com nosso conhecimento das obras fizemos tipos de edição, os quais são: edição mais antiga conhecida, nova edição, nova edição com novo título, única edição conhecida), público alvo (de acordo com título ou subtítulo explícitos: grau da educação, regional, institucional etc.). As unidades são fatos discretos (Lauwers 2004; cf. item 1.1) e estão resumidas no quadro abaixo:

\begin{tabular}{|c|c|}
\hline Unidades & Tipos de unidade \\
\hline Autor & - \\
\hline \multirow{4}{*}{ Título } & Tipos de título: \\
& G - ex.: gramática portuguesa \\
& X-ex.: manual de língua portuguesa \\
Gx - ex.: gramática elementar \\
Xg- ex.: compêndio da gramática portuguesa \\
Xgx: resumo da gramática filosófica
\end{tabular}

Quadro 7. Unidades e tipos de unidade analisados na História Serial

Dada a enorme diversidade de títulos, criamos categorias abstratas para sua organização, antes de analisá-los/comentá-los. Assim, os títulos foram agrupados em cinco categorias iniciais, as quais expomos no quadro abaixo: 


\begin{tabular}{|c|l|}
\hline Sigla & \multicolumn{1}{c|}{ Definição } \\
\hline G [nGp, nGlp, Gp, & $\begin{array}{l}\text { Títulos que se iniciem por "gramática" [G] ou "nova gramática" [nG] e que, } \\
\text { além disso, façam alguma referência à língua portuguesa [lp, p]. Exemplos: } \\
\text { Gramática Portuguesa; Gramática da Língua Portuguesa. }\end{array}$ \\
\hline $\begin{array}{c}\text { Gx [Gx, Gpx, Gxlp, } \\
\text { Gxb, Gxp] }\end{array}$ & $\begin{array}{l}\text { Títulos que contenham "gramática" [G] e, depois, alguma palavra [x] como } \\
\text { "elementar", "analítica", "prática", "fillosófica" etc. e, eventualmente, alguma } \\
\text { referência à língua portuguesa [p, lp] ou ao Brasil [b]. Exemplos: Gramática } \\
\text { elementar da língua portuguesa; Gramática analítica etc. }\end{array}$ \\
\hline $\mathbf{X}$ [X, Xlp, Xp] & $\begin{array}{l}\text { Títulos que não contenham "gramática" e que eventualmente façam referência } \\
\text { à língua portuguesa [p, lp] Exemplos: Manual do examinando de português; } \\
\text { Noções de língua portuguesa etc. }\end{array}$ \\
\hline Xg [Xg, Xgp, Xglp, \\
Xgln, Xgn] & $\begin{array}{l}\text { Títulos que se iniciem por uma palavra [X] que é seguida de "gramática" ou } \\
\text { "gramatical" [g] e façam referência à língua portuguesa [p, lp]. Exemplos: Arte } \\
\text { da gramática portuguesa; Compêndio gramatical do português; Rudimentos da } \\
\text { gramática portuguesa etc. }\end{array}$ \\
\hline Xgx [Xgpx, Xgxlp] & $\begin{array}{l}\text { Títulos que se iniciem por uma palavra [X] que é seguida de "gramática" [g] e, } \\
\text { depois, de outra palavra [x] e, eventualmente, façam referência à língua } \\
\text { portuguesa [p, lp]. Exemplos: Compêndio da gramática filosófica da língua } \\
\text { portuguesa; Epitome da Grammatica Philosophica de Língua Portugueza. }\end{array}$ \\
\hline
\end{tabular}

Essa divisão inicial pautada pela estrutura do título cujo eixo, exceto por uma das categorias, era o termo 'gramática' nos levou, em seguida, a observar os sentidos dos termos colocados em cada posição do título em cada um dos cinco tipos de título (cf. R5 no item 3.1)

Ademais, definimos cinco tipos de edição. Dada a instabilidade na ordem das edições encontradas (Cf. Capítulo 3), procuramos trabalhar com dados que consideravam apenas relações entre as edições encontradas. Dessa forma, temos primeiramente a divisão entre edições específicas, que são gramáticas cujos títulos são diferentes, e reedições, que têm o mesmo título. Dentro das primeiras, temos as seguintes subdivisões: a edição mais antiga conhecida, que pode ser a primeira ou não; a nova edição com novo título, que é uma nova edição, ou seja, há edições anteriores de que temos conhecimento, entretanto, o autor modificou o título e, possivelmente, parte considerável da obra; a única edição conhecida, nesse caso, pode ser que conheçamos somente a primeira ou somente uma edição já adiantada. Já as reedições referem-se às subdivisões: nova edição e a nova edição modificada, pois são um elemento posterior de uma série da qual conhecemos um outro elemento anterior (ainda que seja parcialmente modificado), que seria, por exemplo, a edição mais antiga conhecida. No quadro abaixo, sintetizamos essa diferença:

\begin{tabular}{|l|c|c|}
\hline \multirow{4}{*}{ Gramáticas } & \multirow{2}{*}{ Títulos } & Edição mais antiga conhecida \\
& & Nova edição com novo título \\
\cline { 3 - 3 } & & Única edição conhecida \\
\cline { 2 - 3 } & Reedições & Nova edição \\
\cline { 3 - 3 } & & Nova edição modificada \\
\hline
\end{tabular}

Quadro 9. Tipos de edição analisados na História Serial 
O público-alvo, também bastante diverso, foi agrupado em diferentes categorias. Assim, reunimos essas informações em tipos, sejam eles simples, porque apresentam apenas uma unidade para o público-alvo, sejam eles complexos, porque apresentam mais de uma unidade, tornando o público alvo mais específico. No quadro abaixo, apresentamos os tipos:

\begin{tabular}{|c|c|}
\hline Letra(s) & Tipo \\
\hline \multicolumn{2}{|c|}{ TIPOS SIMPLES } \\
\hline A & Alunos \\
\hline $\mathrm{B}$ & Instrução Primária \\
\hline $\mathrm{C}$ & $\begin{array}{l}\text { Graus de ensino posteriores à Instrução primária: } \\
\text { Curso Médio, Curso Superior, } 2^{\circ} \text { ano, } 3^{\circ} \text { ano }\end{array}$ \\
\hline $\mathrm{D}$ & Regional \\
\hline $\mathrm{E}$ & Nacional \\
\hline $\mathrm{F}$ & Institucional \\
\hline G & Programa Institucional \\
\hline $\mathrm{H}$ & Pessoa (dedicatória) \\
\hline I & Professor \\
\hline \multicolumn{2}{|c|}{ TIPOS COMPLEXOS } \\
\hline $\mathrm{ABF}$ & $\begin{array}{c}\text { Alunos } \\
\text { Instrução Primária } \\
\text { Institucional }\end{array}$ \\
\hline $\mathrm{ABE}$ & $\begin{array}{c}\text { Instrução Primária } \\
\text { Nacional } \\
\text { Alunos } \\
\end{array}$ \\
\hline $\mathrm{BDF}$ & $\begin{array}{c}\text { Instrução Primária } \\
\text { Regional } \\
\text { Institucional } \\
\end{array}$ \\
\hline BFG & $\begin{array}{c}\text { Instrução Primária } \\
\text { Institucional } \\
\text { Programa Institucional }\end{array}$ \\
\hline$\overline{\mathrm{DF}}$ & $\begin{array}{c}\text { Regional } \\
\text { Institucional }\end{array}$ \\
\hline $\mathrm{AB}$ & $\begin{array}{c}\text { Alunos } \\
\text { Instrução Primária } \\
\end{array}$ \\
\hline $\mathrm{BF}$ & $\begin{array}{l}\text { Instrução Primária } \\
\text { Regional }\end{array}$ \\
\hline $\mathrm{BH}$ & $\begin{array}{c}\text { Instrução Primária } \\
\text { Pessoa }\end{array}$ \\
\hline BG & $\begin{array}{l}\text { Instrução Primária } \\
\text { Programa Institucional }\end{array}$ \\
\hline $\mathrm{BI}$ & $\begin{array}{c}\text { Instrução Primária } \\
\text { Professor }\end{array}$ \\
\hline CG & $\begin{array}{l}\text { Curso Médio } / 2^{\circ} \text { ano } \\
\text { Programa Institucional }\end{array}$ \\
\hline $\mathrm{AD}$ & $\begin{array}{c}\text { Alunos } \\
\text { Regional } \\
\end{array}$ \\
\hline $\mathrm{AE}$ & $\begin{array}{c}\text { Alunos } \\
\text { Nacional }\end{array}$ \\
\hline
\end{tabular}

Quadro 10. Tipos de público-alvo analisados na História Serial 
Essas unidades foram relacionadas de maneira diversa a fim de que respondêssemos a perguntas para a história da formação da gramática de língua portuguesa no Brasil. Adiante, explicitamos nosso questionário e as unidades relacionadas a fim de respondê-las:

\begin{tabular}{|c|c|c|}
\hline Relações & Questões & Unidades \\
\hline 1 & $\begin{array}{l}\text { Quantas gramáticas foram publicadas no século e em } \\
\text { cada uma das décadas? }\end{array}$ & $\begin{array}{l}\text { - Número total de edições } \\
\text { conhecidas } \\
\text { - Décadas }\end{array}$ \\
\hline 2 & $\begin{array}{l}\text { Quantas, entre elas, tiveram reedições? Qual era a 'data } \\
\text { de validade' dessas gramáticas, considerando suas } \\
\text { reediçoes? }\end{array}$ & $\begin{array}{l}\text { - Tipos de edição } \\
\text { - Décadas }\end{array}$ \\
\hline 3 & $\begin{array}{l}\text { Quantas gramáticas foram publicadas em cada } \\
\text { província/estado? Em que províncias/estados a } \\
\text { publicação de gramáticas é mais frequente em cada } \\
\text { década? }\end{array}$ & $\begin{array}{l}\text { - Todas edições } \\
\text { - Títulos das obras } \\
\text { - Local de publicação } \\
\text { - Décadas }\end{array}$ \\
\hline 4 & $\begin{array}{l}\text { Por quais casas impressoras as gramáticas são } \\
\text { publicadas em cada região e período? }\end{array}$ & $\begin{array}{l}\text { - Tipos de edição } \\
\text { - Casa impressora } \\
\text { - Local de publicação } \\
\text { - Décadas }\end{array}$ \\
\hline 5 & $\begin{array}{l}\text { Que títulos e tipos de títulos eram mais comuns? Isto } \\
\text { pode estar conectado a diferentes momentos do século? }\end{array}$ & $\begin{array}{l}\text { - Tipos de título } \\
\text { - Títulos das obras } \\
\text { - Todas edições } \\
\text { - Edições especificas } \\
\text { - Décadas }\end{array}$ \\
\hline 6 & $\begin{array}{l}\text { Que subtítulos e tipos de subtítulos eram mais comuns? } \\
\text { Isto pode estar conectado a diferentes momentos do } \\
\text { século? Pode também estar conectado ao título das } \\
\text { obras? }\end{array}$ & $\begin{array}{l}\text { - Tipos de título } \\
\text { - Títulos das obras } \\
\text { - Subtítulos } \\
\text { - Todas edições } \\
\text { - Edições específicas } \\
\text { - Décadas }\end{array}$ \\
\hline 7 & $\begin{array}{l}\text { Qual é o público-alvo das gramáticas? Os públicos-alvo } \\
\text { são diferentes ao longo do século? Há relação entre o } \\
\text { título escolhido e o público-alvo? E entre público-alvo } \\
\text { e regiões? }\end{array}$ & $\begin{array}{l}\text { - Tipos de público-alvo } \\
\text { - Décadas } \\
\text { - Edições específicas } \\
\text { - Local de publicação }\end{array}$ \\
\hline
\end{tabular}

Quadro 11. Questões e relações realizadas no mapeamento descritivo-interpretativo

Operamos com a hipótese de que as respostas a essas perguntas permitiriam não só que fizéssemos um mapeamento dessa produção, como também uma (re)construção de eventos que só poderiam ser observados nesse nível de detalhamento de análise.

No Capítulo 3, apresentamos os resultados da aplicação dessas relações.

\subsubsection{Critérios para análise de agenda dos autores}

Delineamos a agenda dos autores quando escrevem suas gramáticas tendo, inicialmente, conhecimento do mapeamento descritivo-interpretativo que fizemos por meio da metodologia da História Serial e observando, por um lado, dados biobibliográficos de cada autor que colhemos de fontes secundárias, os quais incluem um 
resumo de sua biografia e informações acerca de suas publicações (incluindo as diferentes edições da gramática analisada), e, por outro lado, pelos paratextos da obra analisada, em que observamos o título da obra, subtítulos, dedicatória, epígrafes e, sobretudo, prefácios e prólogos quando existem. Nas Fichas Descritivas (FD) apresentadas no Apêndice B deste trabalho, esses dois lados da análise correspondem aos seguintes itens:

\begin{tabular}{|c|c|}
\hline Análise da agenda & Itens da FD (Apêndice B) \\
\hline \multirow{2}{*}{ Dados biobliográficos } & Informações sobre o autor (biografia) \\
\cline { 2 - 2 } & Outras publicações conhecidas do autor \\
\cline { 2 - 2 } & Outras edições e reimpressões de gramáticas conhecidas \\
\hline \multirow{2}{*}{ Paratextos } & Descrição da obra consultada \\
\cline { 2 - 2 } & Objetivos do autor \\
\hline
\end{tabular}

Quadro 12. Dados biobliográficos e paratextos expostos nas FDs

Para analisar esses dados, inspiramo-nos no modelo de conflito de Murray (1994), o qual mobiliza a noção de autopercepção que o autor tem de si e de sua obra por meio da observação de retórica revolucionária ou retórica de continuidade nos paratextos das obras. Entretanto, observamos que nem sempre essa oposição era suficiente para tratar das obras, consideramos, assim, também uma retórica mista, quando o autor percebe-se seguindo uma visão parcialmente, consideramos também a possibilidade de não haver retórica alguma nas obras. Quanto à análise dos dados biobliográficos, adaptamos a proposta de Murray (1994), considerando nosso contexto menos institucionalizado, assim, procuramos o perfil profissional anterior e concomitante à publicação da obra, pensando, sobretudo, em sua atuação profissional e acesso ao reconhecimento.

\subsection{Critérios para análise direcionada para o conteúdo: conceitos e rede conceitual}

Trabalhamos, como já dissemos anteriormente (cf. item 2.1) com 18 gramáticas, das quais 16 são edições específicas, 2 são reedições, e há 14 autores (sendo um trabalho em coautoria). $\mathrm{Na}$ análise orientada para o conteúdo procuramos analisar cada obra individualmente, observando o conceito-chave e os outros conceitos apresentados por ela a fim de checar suas relações e chegar (ou não) a uma rede conceitual. Preferimos, entretanto, analisar em uma mesma seção as obras (sejam edições propriamente ou reedições) de mesmo autor, comparando-as por vezes. No entanto, no Capítulo 4, não há uma análise geral de continuidades e descontinuidades, vemos isso apenas no capítulo de resultados e contribuições (cf. Capítulo 5). 
$\mathrm{Na}$ análise particular (ou comparada quando de mesmo autor) de cada obra, distinguimos cinco principais conceitos ou conjuntos de conceitos que supomos ser relacionados ao conceito-chave de 'verbo substantivo' (cf. item 1.4), a saber: (1) conceitos de gramática e de linguagem; (2) conceitos de metaclasses e classes de palavras; (3) conceitos modificadores do nome; (4) conceito de verbo; (5) conceitos de oração/sentença/proposição e seus elementos. Lembrando que definimos conceito como a junção entre a intensão, que corresponde à definição e à taxonomia, e a extensão, que corresponde aos exemplos e à ilustração de uso, esses cinco conceitos são analisados da seguinte forma:

\begin{tabular}{|c|c|c|}
\hline Conceitos & Intensão & Extensão \\
\hline (1) Linguagem, Gramática & Definição & Exemplos \\
$\begin{array}{c}\text { (2) (Meta)classes de palavras } \\
\text { (3) Modificadores do nome } \\
\text { (4) Verbo }\end{array}$ & $\begin{array}{c}\text { Taxonomia } \\
\text { (gênero/espécie) }\end{array}$ & Ilustração de uso \\
\cline { 2 - 3 } (5) Oração/sentença/proposição &
\end{tabular}

Quadro 13. Conceitos analisados em intensão e extensão

Quanto à extensão dos conceitos gramaticais, os exemplos correspondem ao inventário (parcial ou completo) de dados a que o conceito corresponde, já a ilustração diz respeito justamente àqueles dados colocados em uso. A distinção é feita para observarmos também que alguns conceitos podem ser tanto exemplificados quanto ilustrados e outros podem apenas ser ilustrados. Em relação à intensão dos conceitos, a definição é meramente a exposição do significado do conceito, normalmente é dada de forma bastante direta (reflexões mais abstratas tendem a estar em metatexto); a taxonomia, por sua vez, é uma noção mais complexa. Ela é a organização do(s) conceito(s) em relação a seus gêneros ou espécies. Por exemplo, o conceito de 'verbo' muitas vezes é gênero de algumas espécies, como, por exemplo, 'verbo substantivo' e 'verbo adjetivo', as quais podem se tornar gêneros de outras espécies, como, por exemplo, o 'verbo adjetivo' pode ser gênero das espécies 'verbo ativo', 'verbo neutro' e 'verbo passivo'. No caso da 'proposição', além de ser gênero de espécies diversas de 'proposição', ela também costuma incluir conceitos que existem apenas dentro dela (p. ex.: sujeito, atributo, predicado etc.). Todos os conceitos são analisados pelas quatro noções apresentadas no quadro supracitado.

$\mathrm{Na}$ análise orientada para o conteúdo, distinguimos no texto gramatical o texto em oposição ao metatexto. Como já dissemos (cf. Capítulo 1, item 1.3), consideramos que a gramática teria uma função essencial de manual (téchne, ars, arte), isto é, de definir 
conceitos e sua aplicação a dados da língua, aos fragmentos correspondentes a esses processos chamamos de texto. Em muitas das gramáticas analisadas, porém, há reflexões acerca do conceito apresentado no texto ou mesmo há conceitos que são apresentados de maneira indireta, a passagens desse tipo chamamos metatexto. Além disso, as reflexões ou conceitos apresentados em metatexto podem ser adotados, parcialmente adotados ou rejeitados pela obra, pois a natureza livre dos metatextos permite que o que se apresenta nele seja um acréscimo à gramática, seja uma observação a respeito de outra conceptualização ou mesmo seja uma crítica a alguma conceptualização diferente da que o autor faz em texto, ou mesmo, por vezes, uma crítica à conceptualização apresentada em seu próprio texto. Observamos ainda que os metatextos apresentam certo paralelismo com os paratextos na medida em que podem ter também alguma retórica revolucionária ou de continuidade. Mas esta retórica está sempre acompanhada de conceitos ou reflexões epistemológicas. Observamos todos esses aspectos quando falarmos de metatexto na análise orientada para o conteúdo.

O metatexto pode ser localizado pela sua forma editorial ou efetivamente pelo seu conteúdo, segundo esta tipologia: a) nota de rodapé ou nota dentro do próprio texto; b) texto iniciado por "dizem os gramáticos" ou "tal gramáticos diz que”, isto é, toda vez que houve referência a outro manual ou autor, fossem eles especificados ou não (exceto em caso de simples referência bibliográfica); c) comentário meta-metalinguístico a respeito do próprio conceito. Procuramos especificar, entre os três citados, o tipo de metatexto sempre que os mencionamos ao longo da análise.

Finalmente, a relação entre o conceito-chave, 'verbo substantivo', e os conceitos selecionados, como já mencionamos no Capítulo 1, pode se dar de quatro maneiras diferentes (cf. Quadro 4. Relações possíveis entre conceito-chave e conceitos da rede conceitual, página 30), a saber: subordinação, em que há relação de inclusão entre dois conceitos, ou seja, um contém outro, intersecção, que é a relação na qual há parte comum entre os (conjuntos dos) dois conceitos, equivalência, na qual os conceitos são equivalentes intensionamente e têm a mesma extensão, e, por fim, base teórica comum, quando há um conjunto maior de que ambos os conceitos fazem parte.

Finalmente, destacamos que procuramos distinguir textualmente nossa metametalinguagem da metalinguagem das próprias gramáticas. Assim, quando os termos forem nossos, eles estarão em itálico, quando são das gramáticas, estarão entre aspas simples. Ademais, os exemplos (dados linguísticos do inventário limitado de um conceito) e ilustrações (dados do conceito colocados em uso, por exemplo, dentro de 
orações/sentenças/proposições) estarão predominantemente entre parênteses, entretanto, por vezes podem vir como citações e, portanto, entre aspas duplas.

\subsection{Quadro metodológico: síntese}

No quadro adiante, apresentamos uma síntese de nossa metodologia e metalinguagem. 


\begin{tabular}{|c|c|c|c|c|c|}
\hline \multirow{2}{*}{ Análise } & \multicolumn{2}{|c|}{ Fatos discretos (Lauwers 2004) } & \multicolumn{3}{|c|}{ Fatos globais (Lauwers 2004) } \\
\hline & Dados/fontes & Critérios de análise & Relações de fatos discretos & Fatos $g$ & obais \\
\hline \multirow{2}{*}{$\begin{array}{c}\text { Orientada } \\
\text { para contexto } \\
\text { (Capítulo 3) } \\
\text { (Swiggers } \\
1990)\end{array}$} & $\begin{array}{l}\text { Informações catalográficas } \\
\text { sobre as } 216 \text { gramáticas } \\
\text { (cf. Apêndice A, Referência } \\
\text { completa das gramáticas) }\end{array}$ & $\begin{array}{c}\text { Unidades (História Serial): } \\
\text { Autor } \\
\text { Tipo de título } \\
\text { Tipo de subtítulo } \\
\text { Ano e década de publicação } \\
\text { Província/Estado de publicação } \\
\text { Casa impressora } \\
\text { Tipo de Edição } \\
\text { Público alvo } \\
\end{array}$ & $\begin{array}{l}\text { Relações seriais entre unidades } \\
\text { com base em questionário }\end{array}$ & \multirow{2}{*}{$\begin{array}{c}\text { Mapeamento } \\
\text { descritivo- } \\
\text { interpretativo da } \\
\text { produção gramatical } \\
\text { brasileira oitocentista } \\
\text { (considerando as } 204 \\
\text { gramáticas } \\
\text { conhecidas e datadas) }\end{array}$} & \multirow{2}{*}{$\begin{array}{l}\text { Agenda em } \\
\text { perspectiva (das } 18 \\
\text { gramáticas } \\
\text { estudadas) }\end{array}$} \\
\hline & $\begin{array}{c}\text { Dados biobibliográficos } \\
\text { Paratextos (das } 18 \text { gramáticas } \\
\text { estudadas) } \\
\text { (cf. Apêndice B, Fichas } \\
\text { Descritivas) }\end{array}$ & $\begin{array}{c}\text { Perfil profissional: } \\
\text { Atuação profissional; } \\
\text { Acesso a reconhecimento. } \\
\text { Autopercepção: } \\
\text { Retórica revolucionária vs. } \\
\text { Retórica de continuidade } \\
\text { (Murray 1994) }\end{array}$ & $\begin{array}{l}\text { Relações contextuais entre } \\
\text { perfil profissional, } \\
\text { autopercepção e mapeamento } \\
\text { descritivo-interpretativo. }\end{array}$ & & \\
\hline $\begin{array}{l}\text { Orientada } \\
\text { para conteúdo } \\
\text { (Capítulo 4) } \\
\text { (Swiggers } \\
1990)\end{array}$ & $\begin{array}{c}\text { Texto } \\
\text { Metatexto } \\
\text { Língua/linguagem } \\
\text { Gramática } \\
\text { (Meta)classes de palavras } \\
\text { Modificadores do nome } \\
\text { Verbo } \\
\text { Proposição }\end{array}$ & $\begin{array}{c}\text { Conceptualização: } \\
\text { Termo } \\
\text { Conceito } \\
\text { (Definição } \\
\text { Taxonomia } \\
\text { Exemplos } \\
\text { Ilustração de uso) } \\
- \\
\text { Conceito-chave vs. } \\
\text { Conceitos relacionados }\end{array}$ & $\begin{array}{c}\text { Relações conceituais entre } \\
\text { conceito-chave e conceitos } \\
\text { relacionados em texto e } \\
\text { metatexto }\end{array}$ & \multicolumn{2}{|c|}{$\begin{array}{c}\text { Rede conceitual / } \\
\text { Ecletismo (vertical e/ou horizontal) }\end{array}$} \\
\hline
\end{tabular}


Como se pode ver, nossa a análise foi dividida por ser orientada ao contexto ou ao conteúdo. Distinguimos em ambas os fatos discretos e os fatos globais. Os primeiros são facilmente capturados, pois são, como disse Lauwers (2004), preto no branco, e podem ser evidenciados por citações dos textos gramaticais (ou biobibliográficos); já os fatos globais são concebidos após série (concordante) de fatos discretos, a qual pode ser montada por meio de métodos quantitativos ou qualitativos.

Boa parte do material utilizado em para a observação de fatos discretos encontrase nos quatro Apêndices do trabalho. Para realizar a História Serial e, consequentemente, o mapeamento da gramaticografia brasileira oitocentista do português, reunimos no Apêndice A informações catalográficas acerca das 204 gramáticas de que temos conhecimento (e incluímos outras 12 de que não tivemos a data de publicação); e, para interpretá-las, criamos as unidades que se encontram no quadro (autor, título, ano de publicação, lugar de publicação, casa impressora, edição, subtítulo e público-alvo).

Para observar a agenda dos gramáticos, mobilizamos, além de nosso mapeamento, por um lado, os paratextos das gramáticas, e, por outro, os dados biobibliográficos obtidos a respeito dos autores das obras, ambos encontram-se no Apêndice B, onde estão as Fichas Descritivas de cada uma das 18 gramáticas analisadas. Interpretamos tais dados baseando-nos no modelo de conflito de Murray (1994), considerando o perfil profissional (atuação profissional e acesso a reconhecimento) e a autopercepção (retórica revolucionária ou de continuidade) do gramático. Finalmente, relacionamos esses itens com o fato global obtidos na História Serial, isto é, o mapeamento descritivointerpretativo da produção gramatical brasileira a fim de observar a agenda do autor ao escrever a obra relacionada ainda com os dados obtidos por meio das relações seriais.

Quanto à análise orientada para o conteúdo, tendo como hipótese que o conceito de 'verbo substantivo' é produtivo para a análise das gramáticas com vistas a observar sua homogeneidade (rede conceitual) ou heterogeneidade (ecletismo), selecionamos alguns outros conceitos que, de acordo com revisões historiográficas de outras tradições - sobretudo a da grammaire générale francesa (cf. item 1.4), pois esta teve um impacto considerável na gramaticografia que estudamos -, têm alguma relação com o conceitochave. Procuramos, na análise, ser fieis ao que escreveram os gramáticos em suas obras, inclusive quando descrevemos seus conceitos por paráfrases. Esses fatos discretos foram observados com base em nossa noção de conceito, que contém, em sua intensão, definição e taxonomia, e em sua extensão, exemplos e ilustrações de uso. Ademais, distinguimos a 
mera apresentação de um conceito, que denominamos texto, com a reflexão acerca dele, ou acerca da concepção que outros autores têm do mesmo dado, ou ainda simplesmente de conceitos apresentados como coadjuvantes em nota de rodapé, por exemplo, que denominamos metatexto. Tal análise tornou possível, por meio de metodologia qualitativa ao observar as quatro relações possíveis de serem travadas entre o conceito-chave e outros conceitos, o fato global da rede conceitual ou o ecletismo de cada obra.

Lembramos ainda que em nossos resultados, observamos as possíveis relações entre os fatos globais obtidos na história orientada para o contexto e na história orientada para o conteúdo, para, justamente, retirar esta do "vácuo" e "dar sentido" à análise de agenda em perspectiva dos autores. Essa reunião se deu nos resultados do trabalho, que se encontram no capítulo 5.

\subsection{Organização do texto}

Organizamos nosso texto tendo dois objetivos, o primeiro era que ele fosse uma tese; o segundo é que ele fosse, nos modestos limites de uma investigação individual com prazo estrito para conclusão, uma obra de consulta.

Quanto ao formato tese, nosso texto possui uma introdução, em que apresentamos o leitor à tese. Em seguida, há o capítulo inicial de fundamentação teórica, no qual expomos não apenas as teorias em que baseamos nossa hipótese e nossos objetivos (cf. itens 1.1, 1.2 e 1.3), mas também os justificamos historicamente (cf. itens 1.4 e 1.5). No capítulo seguinte, apresentamos os métodos utilizados a fim de realizar o teste de nossa hipótese e nossos objetivos (cf. itens 2.2, 2.3 e 2.4) tal como a seleção de nosso corpus (2.1) e o modo de exposição escolhido para o texto (cf. itens 2.5). O terceiro e o quarto capítulo correspondem às análises, respectivamente, de orientação para o contexto e de orientação para o conteúdo, em que debruçamos nosso quadro metodológico sobre nosso corpus. No quinto capítulo apresentamos, por um lado, os resultados obtidos por meio da análise, os quais ressaltam de forma mais holística aspectos observados em fatos discretos e fatos globais, e, por outro, as contribuições que este trabalho pode oferecer a respeito do objeto estudado, a gramaticografia brasileira do português, e no que refere ao que os métodos que testamos, da História Serial e da análise de conceitos, podem oferecer para a Historiografia Linguística em geral.

Quanto ao formato de obra de consulta, levando em conta uma série de lacunas nas revisões históricas disponíveis sobre a gramaticografia brasileira do português, assim como o seu caráter mais particular (interessado em certos autores, temas, escolas), 
procuramos organizar nosso texto de forma que ele permitisse: oferecer informações organizadas que permitam montar um panorama dessa produção; permitir a busca e a leitura autônoma dos diferentes tipos de dados e de análises realizadas; fosse não apenas uma historiografia, mas também uma epihistoriografia dessa tradição. Assim:

1) nos capítulos de análise, optamos por dividir uma organização por autores e, destes, de cada uma das obras, em vez de realizar um texto holístico e entrelaçado em que as informações de cada autor e de cada obra estariam diluídas;

2) em dois apêndices, organizamos e disponibilizamos informações objetivas das obras: no apêndice A, estão dados catalográficos de todas as 204 gramáticas encontradas dispostos em ordem cronológica e alfabética; no apêndice B, estão as Fichas Descritivas (FDs) de cada obra, nas quais constam dados biobibliográficos dos autores, os paratextos (dados da folha de rosto, epígrafes, prólogos, prefácios e assinatura) e o sumário da obra. 
As coisas duplicam-se em Tlön; propendem simultaneamente a apagar-se e a perder os detalhes, quando as pessoas os esquecem. É clássico o exemplo de um umbral que perdurou enquanto o visitava um mendigo e que se perdeu de vista com sua morte. As vezes, alguns pássaros, um cavalo, salvaram as ruinas de um anfiteatro.

(Jorge Luis Borges) 


\section{CAPÍTULO 3 | Análise orientada para contexto}

Conforme detalhamos no Capítulo 2, com vistas a produzir um mapeamento da produção gramatical brasileira oitocentista baseado na metodologia da História Serial, realizamos um estudo dirigido por critérios como das unidades e das relações entre elas. Neste capítulo, analiticamente, apresentamos um mapeamento de dados relativos à formação histórica da gramática do Português no Brasil, procurando preencher algumas lacunas e desfazer alguns equívocos frequentemente reiterados em revisões históricas dessa produção (cf. item 3.1). Também conforme detalhamos no capítulo anterior, procuramos definir a agenda de cada um dos dezesseis autores ao públicar sua(s) gramática(s), considerando o panorama mais geral do período apresentado pelo mapeamento, dados biobibliográficos e os paratextos das obras.

\subsection{História Serial: mapeamento baseado em dados contextuais das gramáticas}

Como vimos, considera-se que a gramaticografia brasileira do português se inicia no século XIX, no entanto, mais recentemente, se insinua uma discussão acerca de qual seria o seu marco inaugural; há duas hipóteses em disputa. A primeira considera a primeira gramática publicada por autor brasileiro de que temos conhecimento no ano de 1806, em Lisboa, por Antonio Morais Silva (1757-1824), natural do Rio de Janeiro; além do local de nascimento, leva-se em conta que o autor do Epitome da Grammatica Portugueza $([1])^{72}$ registra que o teria escrito em Pernambuco. A segunda hipótese considera que somente a partir de 1808 as casas impressoras passaram a ser permitidas na colônia (cf. Hallewell 2005), que, naquele ano, tornava-se residência da corte, nesse caso, o marco inaugural desloca-se para 1810, ano no qual o padre Ignácio Felizardo Fortes (? - ?) publicou a primeira edição de sua Arte da grammatica portugueza, para uso de seus discipulos ([2]). Nas décadas seguintes, como veremos, a produção gramatical brasileira cresce bastante, com um número cada vez maior de publicações, certamente em decorrência também da organização do Brasil como país independente. Adiante, observamos as unidades mencionadas no Capítulo 2 (autor, título, subtítulo, ano de publicação, lugar de publicação, casa impressora, edição, público-alvo) os dados a que

\footnotetext{
${ }^{72}$ Lembramos que ao mencionar qualquer gramática, apresentaremos ao lado seu número referente à lista apresentada no Apêndice A.
} 
chegamos e as relações que fizemos entre eles a fim de formular um mapa descritivointerpretativo dessa produção.

\section{R1. Gramáticas publicadas por década}

Inicialmente, buscamos verificar quantas gramáticas haviam sido publicadas ao longo desse século (1800-1899). Tivemos conhecimento de 216 gramáticas, das quais dez não têm data definida. Como grande parte de nossas análises consideram o ano de publicação da obra, as dez sem data foram excluídas da análise; suas referências estão, entretanto, no Apêndice A, juntamente com as referências das outras duzentas.

A produção, se observada de um ponto de vista quantitativo, cresce lentamente entre 1810 e 1850, com o acréscimo médio de duas a cinco gramáticas por década. Na década de 1860, contudo, a produção de gramáticas dobra em relação ao que tinha sido publicado em 1850, passando de 16 para 34. Depois disso, o crescimento, mais modesto mas ainda grande, continua: na década de 1870 são publicadas 38 gramáticas, e na década de 1880,50 . Entretanto, ocorre diminuição na década de 1890 em relação às três décadas anteriores, visto que são publicadas somente 33 gramáticas nesse último intervalo. Esses dados estão no gráfico abaixo.

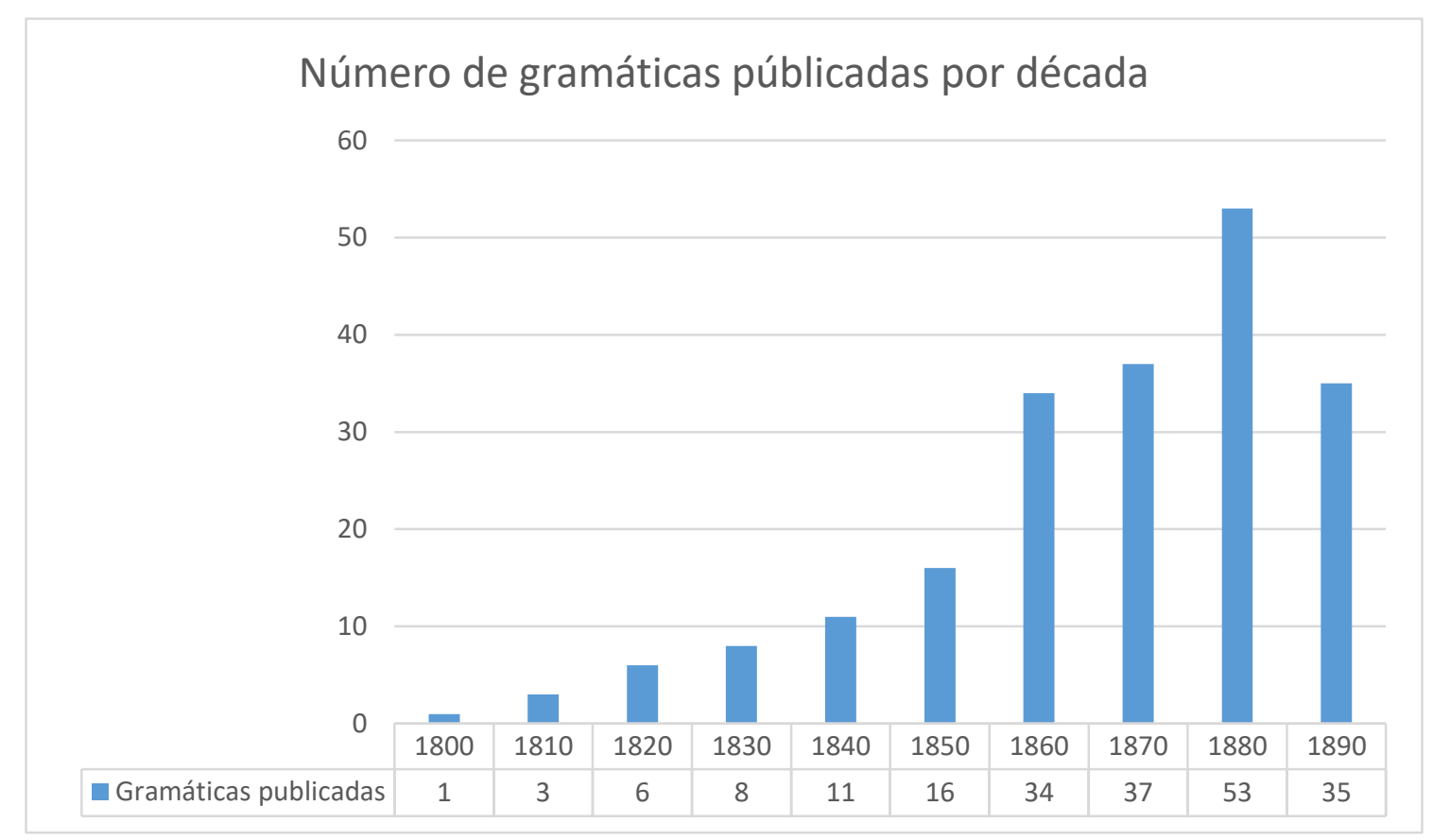

Figura 5. Gráfico do número de gramáticas publicadas por década

\section{R2. Reedições das gramáticas: prestígio e durabilidade}


Nossa pesquisa inicial em catálogos de biblioteca e em obras de referência, com destaque para Sacramento Blake (1883-1902), por vezes revelou importantes lacunas. Assim, por exemplo, o número da edição é raramente mencionado; além disso, por vezes, tivemos acesso a uma edição da obra que não é a primeira, sem que houvesse notícia de quando ela teria sido publicada pela primeira vez. Tendo isto em conta, como vimos no Capítulo 2, ao invés de usar os números das edições como parâmetro de unidade, preferimos reconstruir as relações "genéticas" apenas entre as 204 obras conhecidas. Distinguimos dois tipos de edições, que cobrem, alternadamente, cinco outros tipos: as edições específicas (única edição conhecida, edição mais antiga conhecida e edição posterior com título modificado) que se opõem às reedições (edição posterior modificada, edição posterior simples). Sempre que considerarmos todas os tipos de edições, usamos o termo gramáticas. Na tabela adiante, apresentamos os números de cada um dos tipos de edição por década, do século XIX.

\begin{tabular}{|c|c|c|c|c|c|c|c|c|}
\hline \multirow[b]{2}{*}{ Década } & \multirow[b]{2}{*}{ Gramáticas } & \multicolumn{3}{|c|}{ Edições específicas } & \multirow[b]{2}{*}{ Total } & \multicolumn{2}{|c|}{ Reedições } & \multirow[b]{2}{*}{ Total } \\
\hline & & $\begin{array}{c}\text { Única } \\
\text { edição } \\
\text { conhecida }\end{array}$ & $\begin{array}{c}\text { Edição } \\
\text { mais } \\
\text { antiga } \\
\text { conhecida }\end{array}$ & $\begin{array}{c}\text { Edição } \\
\text { posterior } \\
\text { com título } \\
\text { modifi- } \\
\text { cado } \\
\end{array}$ & & $\begin{array}{c}\text { Edição } \\
\text { posterior } \\
\text { simples }\end{array}$ & $\begin{array}{c}\text { Edição } \\
\text { posterior } \\
\text { modifi- } \\
\text { cada }\end{array}$ & \\
\hline 1800 & 1 & - & 1 & - & 1 & - & - & - \\
\hline 1810 & 3 & - & 1 & - & 1 & 2 & - & 2 \\
\hline 1820 & 6 & 4 & 1 & - & 5 & - & 1 & 1 \\
\hline 1830 & 8 & 4 & 2 & - & 6 & 2 & - & 2 \\
\hline 1840 & 11 & 3 & 2 & 1 & 6 & 2 & 3 & 5 \\
\hline 1850 & 16 & 6 & 5 & - & 11 & 5 & - & 5 \\
\hline 1860 & 34 & 18 & 6 & - & 24 & 8 & 2 & 10 \\
\hline 1870 & 37 & 14 & 7 & 2 & 23 & 10 & 4 & 14 \\
\hline 1880 & 53 & 20 & 11 & 1 & 32 & 15 & 6 & 21 \\
\hline 1890 & 35 & 12 & 3 & 3 & 18 & 13 & 4 & 17 \\
\hline \multirow[t]{2}{*}{ TOTAL } & \multirow[b]{2}{*}{204} & 81 & 39 & 7 & & 57 & 20 & \\
\hline & & \multicolumn{3}{|c|}{127} & & \multicolumn{3}{|c|}{77} \\
\hline
\end{tabular}

Tabela 1. Número de tipos de edição por década

Na tabela, temos, na coluna à esquerda, o número de gramáticas por década, cujo total é 200, à direita dela, em duas grandes colunas, temos os números de edições específicas e de reedições por década, dos quais apresentamos o número total (sombreado) e dividido nos cinco tipos de edições (única edição conhecida, edição mais antiga conhecida, edição posterior com título modificado, edição posterior simples, edição posterior modificada).

É notável que, das duzentas conhecidas, mais da metade seja de edições específicas, enquanto cerca de trinta e cinco porcento delas seja de reedições. Isso deixa 
claro que nem todas as gramáticas foram reeditadas; além disso, quando consideramos que muitas gramáticas têm mais de uma reedição, o número é de gramáticas reeditadas menor ainda. Em verdade, seria mais apropriado dizer que não tivemos conhecimento de suas reedições, a quais podem ou não ter existido, visto que conhecemos as lacunas desse levantamento - as quais, embora devam ser levadas em conta, não invalidam a importância interpretativa que o levantamento proporciona.

Tais lacunas, consequentes do fato de que diversos dados foram recolhidos em triagens em fontes secundárias e catálogos de biblioteca, ficam mais nítidas quando observamos que das 204 gramáticas de que temos conhecimento, 80 têm uma única edição conhecida e 32 são as edições mais antigas conhecidas, entretanto, entre essas 112 , tivemos conhecimento que algumas delas não são a $1^{\text {a }}$ edição da obra. Nas tabelas adiante, apresentamos dados a esse respeito, separados por década.

\begin{tabular}{|c|c|c|c|c|c|c|c|c|c|c|c|c|c|}
\hline \multirow[t]{3}{*}{ Década } & \multicolumn{13}{|c|}{ Número das edições } \\
\hline & \multicolumn{7}{|c|}{ Única edição conhecida } & \multicolumn{6}{|c|}{ Edição mais antiga conhecida } \\
\hline & $1^{\mathrm{a}}$ & $2^{a}$ & $3^{\mathrm{a}}$ & $4^{\mathrm{a}}$ & $8^{a}$ & $\overline{9^{a}}$ & $\overline{?^{73}}$ & $1^{\mathrm{a}}$ & $2^{\mathrm{a}}$ & $3^{\mathrm{a}}$ & $5^{a}$ & $6^{\mathrm{a}}$ & $?$ \\
\hline 1800 & & & & & & & & 1 & & & & & \\
\hline 1810 & & & & & & & & 1 & & & & & \\
\hline 1820 & 1 & & & & & & 3 & 1 & & & & & \\
\hline 1830 & & & 1 & & & & 3 & 1 & & & & & 1 \\
\hline 1840 & & & & & & & 3 & & & & & 1 & 1 \\
\hline 1850 & & 1 & & & & & 5 & 1 & 1 & & 1 & & 2 \\
\hline 1860 & 1 & 1 & & & 8 & 9 & 14 & 3 & & & & 1 & 2 \\
\hline 1870 & 3 & 1 & & & & & 11 & 4 & 1 & & & & 2 \\
\hline 1880 & 2 & 2 & & 4 & & & 14 & 4 & 1 & 1 & & & 5 \\
\hline 1890 & 3 & & 1 & 1 & & & 8 & & & & & & 3 \\
\hline $\begin{array}{l}\mathbf{N}^{\circ} \text { de edições } \\
\text { desconhecidas }\end{array}$ & - & 5 & 4 & 15 & 7 & $\overline{8}$ & $?$ & - & 3 & 2 & 4 & 10 & ? \\
\hline
\end{tabular}

Tabela 2. Lacunas entre as edições conhecidas

Chamam atenção as gramáticas de Martagão (1866, [74] - nona edição), Barker (1860, [46] - oitava edição), Albuquerque (1846, [25] - sexta edição) e Borges (1860, [47] - sexta edição), das quais desconhecemos, respectivamente, oito, sete, cinco e cinco edições anteriores e que também não são citadas nas revisões dessa produção (cf. item 1.5). Só por essa tabela, já é possível projetar, no campo das potencialidades, que há ao menos 58 edições que desconhecemos, isto é, cuja referência não temos. Se expandimos essa conta para as lacunas presentes entre reedições das quais conhecemos os números da edição, desconhecemos outras 44 edições, como se vê no quadro adiante, podendo, assim,

\footnotetext{
${ }^{73}$ A interrogação simboliza que a edição da obra é desconhecida por nós.
} 
pensar que o número de gramáticas de língua portuguesa publicadas por brasileiros no século XIX foi de 306 e, se considerarmos as não datadas, 318.

\begin{tabular}{|c|c|c|}
\hline $\begin{array}{c}\text { Edição mais antiga } \\
\text { conhecida }\end{array}$ & Reedições conhecidas & $\mathrm{N}^{\circ}$ de reedições desconhecidas \\
\hline Fortes $1810\left(1^{\mathrm{a}}\right)$ & $2^{\mathrm{a}}, 3^{\mathrm{a}}, 9^{\mathrm{a}}, 12^{\mathrm{a}}, 13^{\mathrm{a}}, 14^{\mathrm{a}}$ & $\begin{array}{c}7 \\
\left(4^{\mathrm{a}}, 5^{\mathrm{a}}, .6^{\mathrm{a}}, 7^{\mathrm{a}}, 8^{\mathrm{a}}, 10^{\mathrm{a}}, 11^{\mathrm{a}}\right) \\
\end{array}$ \\
\hline Coruja $1835\left(1^{\mathrm{a}}\right)$ & $4^{\mathrm{a}}, 5^{\mathrm{a}}$; e seis posteriores sem número & $\begin{array}{c}2 \\
\left(2^{\mathrm{a}}, 3^{\mathrm{a}}\right) \\
\end{array}$ \\
\hline $\begin{array}{c}\text { Andrade e Silva } \\
1847\left(3^{\mathrm{a}}\right) \\
\end{array}$ & $3^{\mathrm{a}}$ e $7^{\mathrm{a}}$ & $\begin{array}{c}3 \\
\left(4^{\mathrm{a}}, 5^{\mathrm{a}}, 6^{\mathrm{a}}\right)\end{array}$ \\
\hline Carvalho $1883\left(5^{\mathrm{a}}\right)$ & $\begin{array}{l}5^{\mathrm{a}} \text { e uma anterior e outra posterior sem } \\
\text { data }\end{array}$ & $\begin{array}{c}3 \\
\text { (edições entre a } 1^{\mathrm{a}} \text { e } 4^{\mathrm{a}} \text { ) }\end{array}$ \\
\hline Condurú $1850\left(1^{\mathrm{a}}\right)$ & $1^{\mathrm{a}}$ e $13^{\mathrm{a}}$ edições & $\begin{array}{c}11 \\
\left(2^{\mathrm{a}}, 3^{\mathrm{a}}, 4^{\mathrm{a}}, 5^{\mathrm{a}}, 6^{\mathrm{a}}, 7^{\mathrm{a}}, 8^{\mathrm{a}}, 9^{\mathrm{a}}, 10^{\mathrm{a}}\right)\end{array}$ \\
\hline Cruz $1863\left(3^{\mathrm{a}}\right)$ & Uma anterior, $3^{\mathrm{a}}, 4^{\mathrm{a}}, 6$ & $\begin{array}{c}2 \\
\left(1^{\mathrm{a}} \text { ou } 2^{\mathrm{a}} ; 5^{\mathrm{a}}\right)\end{array}$ \\
\hline $\begin{array}{l}\text { Freire da Silva } \\
1871\left(1^{\mathrm{a}}\right)\end{array}$ & $1^{\mathrm{a}}, 2^{\mathrm{a}}, 3^{\mathrm{a}}, 4^{\mathrm{a}}, 5^{\mathrm{a}}$, uma sem número, $8^{\mathrm{a}}$ & $\begin{array}{c}1 \\
\left(6^{\mathrm{a}} \text { ou } 7^{\mathrm{a}}\right)\end{array}$ \\
\hline Gomes $1887\left(1^{a}\right)$ & $1^{\mathrm{a}}, 6^{\mathrm{a}}, 7^{\mathrm{a}}$ & $\begin{array}{c}4 \\
\left(2^{\mathrm{a}}, 3^{\mathrm{a}}, 4^{\mathrm{a}}, 5^{\mathrm{a}}\right)\end{array}$ \\
\hline Marques $1875\left(2^{\mathrm{a}}\right)$ & $2^{a}$ e $4^{a}$ & $\begin{array}{c}2 \\
\left(1^{\mathrm{a}}, 3^{\mathrm{a}}\right)\end{array}$ \\
\hline $\begin{array}{c}\text { Ortiz \& Pardal } \\
1871\left(1^{\mathrm{a}}\right) \\
\end{array}$ & $1^{\mathrm{a}}, 2^{\mathrm{a}}, 3^{\mathrm{a}}, 5^{\mathrm{a}}, 6^{\mathrm{a}}$ & $\begin{array}{c}1 \\
\left(4^{\mathrm{a}}\right) \\
\end{array}$ \\
\hline Passos $1855\left(2^{\mathrm{a}}\right)$ & $\begin{array}{c}2^{\mathrm{a}} \text { e duas outras posteriores sem } \\
\text { número }\end{array}$ & $\begin{array}{c}1 \\
\left(1^{\mathrm{a}}\right)\end{array}$ \\
\hline Silveira $1872\left(4^{a}\right)$ & Uma anterior, $4^{\mathrm{a}}$ e $9^{\mathrm{a}}$ & $\begin{array}{c}6 \\
\left.\text { (Duas entre } 1^{\mathrm{a}} \text { e } 3^{\mathrm{a}} ; 5^{\mathrm{a}}, 6^{\mathrm{a}}, 7^{\mathrm{a}}, 8^{\mathrm{a}}\right)\end{array}$ \\
\hline Ribeiro $1887\left(1^{\mathrm{a}}\right)$ & $1^{\mathrm{a}}, 2^{\mathrm{a}}, 3^{\mathrm{a}}, 4^{\mathrm{a}}, 5^{\mathrm{a}}, 6^{\mathrm{a}}, 8^{\mathrm{a}}$ & $\begin{array}{c}1 \\
\left(7^{\mathrm{a}}\right) \\
\end{array}$ \\
\hline TOTAL & - & 44 \\
\hline
\end{tabular}

Quadro 14. Edições ausentes com base em número das edições conhecidas

Como apenas temos dados das gramáticas de que temos referências, excluiremos as 102 potenciais, levando em conta em nossa análise apenas as 204 gramáticas datadas de que temos conhecimento ( $\mathrm{cf}$. Apêndice A).

O gráfico adiante contrasta, dentre as 204 gramáticas cuja referência conhecemos, a publicação de gramáticas, de edições específicas e de reedições: 


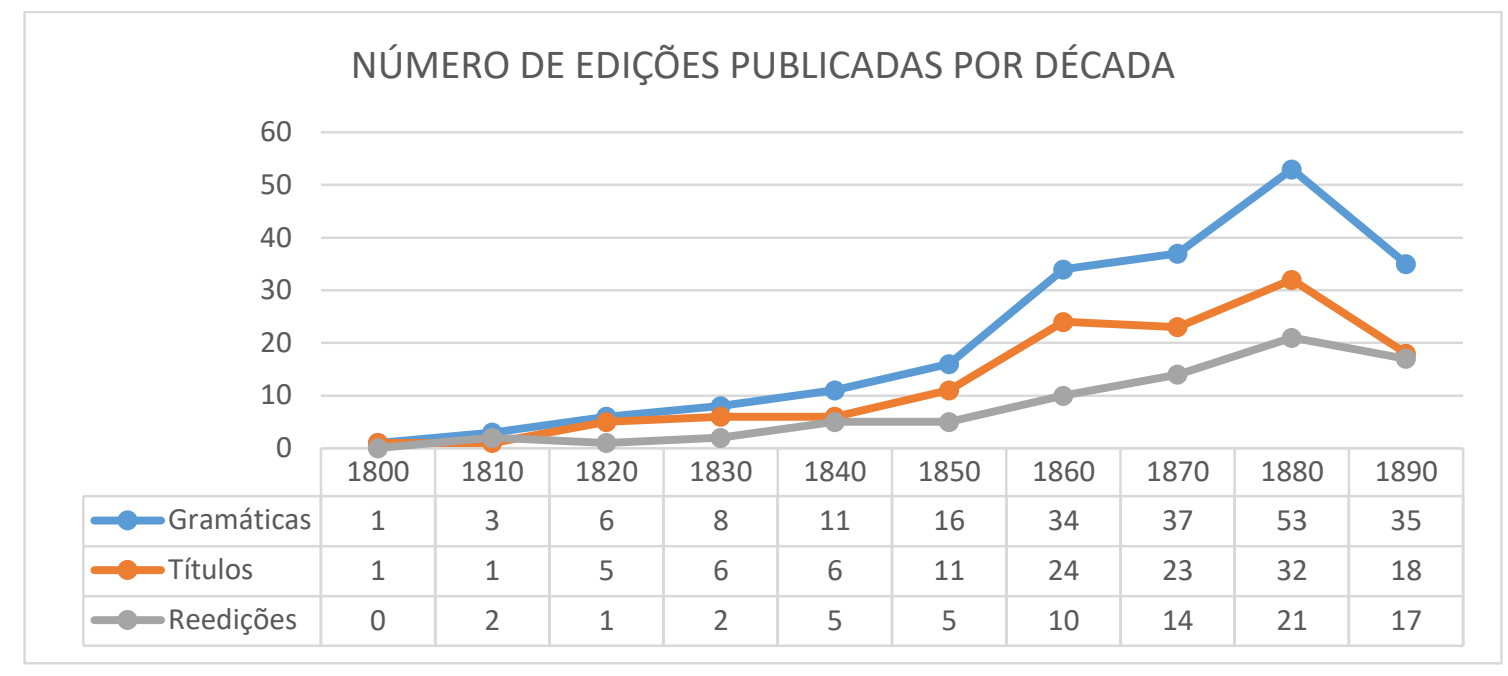

Figura 6. Gráfico de número de edições publicadas por década

De um ponto de vista quantitativo, observamos que a prática de elaboração de reedições de textos anteriormente publicados, ainda que sempre inferior à de edições específicas vai se tornando mais comum ao longo do século e cresce em ritmo similar ao de publicações de edições específicas.

De um ponto de vista qualitativo, no mapeamento das gramáticas que têm reedições, observamos que algumas se destacam bastante, seja por sua longa permanência como obras publicadas, seja pelo alto número de reedições em um curto período de tempo. Assim, vemos que Fortes (1810, [2]) e Coruja (1835, [16]) têm, ambos, uma longa vida de reedições. É curioso, entretanto, que o segundo autor e sua gramática tenham sido mencionados, nas diferentes revisões históricas a que tivemos acesso (ver item 1.5), ao passo que Fortes e sua Arte são mencionadados apenas por Sacramento Blake (1883) e, mais recentemente, por Kemmler (2013). Este autor, aliás, trata a existência da gramática de Fortes como uma descoberta, visto que, a julgar pela historiografia anterior a seu texto, não era um material conhecido. É por Sacramento Blake (1883) que somos informados de seis de suas reedições, entre 1810 e 1862, todas, segundo ele, publicadas no Rio de Janeiro (cf. Apêndice A:1816, [4]; 1825, [7]; 1844, [23]; 1851, [31]; 1855, [36]; 1862, [53]); tivemos acesso direto somente ao texto de 1816, a segunda edição da gramática. Por outro lado, Coruja é mencionado em muitas revisões históricas, inclusive Nascentes (1939) considera seu compêndio como gramática publicada do por um brasileiro ${ }^{74}$. Das

\footnotetext{
74 Nascentes (1939) considerava que Morais Silva (1806) era um autor português - como ele ainda é, até os dias atuais, considerado em algumas pesquisas (cf. Santos 2010); Nascentes apenas tinha conhecimento da segunda edição da gramática de Costa Duarte (1840), cuja primeira é de 1829, e não conhecia os outros títulos publicados antes de 1835. Tratamos com mais demora das concepções trazidas pelas revisões históricas já realizadas no item 1.5.
} 
diversas reedições que localizamos de seu compêndio, sobretudo em catálogos de biblioteca, as quais vão de 1835 a 1891 (Apêndice A: 1847, [27]; 1849, [29]; 1862, [52]; 1865, [69]; 1872, [87]; 1873, [92]; e 1891 [172]), tivemos acesso direto a três dessas edições: a primeira edição de 1835, a quarta, de 1846, e a edição sem número de 1873. A História Serial, nesse sentido, permite colocar em evidência que o prestígio que as gramáticas podem ter tido no século XIX não se tornou relevante para as revisões históricas novecentistas e mais recentes, na medida em que apresenta nos apresenta o prestígio por meio da recorrência de reedições.

O compêndio maranhense de Costa Duarte, publicado pela primeira vez em 1829, cujos título e conteúdo são modificados em 1840, tem "vida útil" de mais de três décadas, de 1840 a 1877 (cf. Apêndice A: 1829, [10]; 1840, [19]; 1853, [33]; 1859 [44]; 1862 [51]; e 1877, [105]) e é eventualmente mencionado em revisões históricas, como vimos em 1.5. O também maranhense Condurú, de acordo com Nogueira (2009), publicou seu compêndio pela primeira vez em 1850; esse compêndio teve ao menos doze reedições até 1888, visto que tivemos acesso a esta que era sua décima terceira edição (cf. Apêndice A: 1850, [30]; 1888, [157]). No entanto, de maneira similar a Fortes, não é um autor citado nas revisões históricas (cf. item 1.5). Por sua vez, outro maranhense ainda, Sotero dos Reis - conhecido sobretudo pelos volumes acerca de seu curso de literatura portuguesa e brasileira $^{75}$, e que teve sua gramática, publicada em 1866 ([75]), reeditada outras duas vezes, em 1871 e 1877 (respectivamente, [85] e [106]) - é, amiúde, enfaticamente mencionado nas revisões históricas (cf. item 1.5). Isso evidencia que há pelo menos dois diferentes modos de se pensar o prestígio dessas obras: um, via observação das séries de reedições, e outro via leitura de fontes secundárias, as quais podem coincidir ou não.

Outro autor pouco citado pelas revisões históricas é Salvador Henrique Albuquerque, cujo Compendio, publicado em 1846, tem reedições até, pelo menos, 1874 (cf. Apêndice A: 1846, [25]; 1858, [42]; 1874, [94]). Ele ainda publicou outros dois textos gramaticais, um Breve compendio, de 1841, reeditado em 1844, e Rudimentos, de 1873 (respectivamente, [20], [21] e [91]). A gramática analítica e explicativa da língua portuguesa, de Ortiz e Pardal, publicada primeiramente em Vitória e depois no Rio de Janeiro, tem ao menos seis edições, de 1871 a 1884 (cf. Apêndice A: 1871, [83]; 1873,

\footnotetext{
75 Além das Postillas de Grammatica Geral e da Grammatica Portugueza, o intelectual maranhense escreveu entre 1866 e 1868 os volumes de seu conhecido "Curso de litteratura portugueza e brazileira". Para mais detalhes, ver FD7, Apêndice B.
} 
[93]; 1876, [102]; 1884, [137]; 1888, [162]). A dupla de autores é citada por Nascentes (1939), mas numa menção a outra obra gramatical da dupla, chamada Novo systema de estudar a grammatica portugueza por meio de memória, intelligencia e analyse, ajudando-se mutuamente, de que temos conhecimento da edição de 1862 ([54]), sem saber se é a primeira e/ou se há reedições da obra. Policarpo José Dias Cruz, mencionado apenas por Parreira (2011) e Polachini (2013), publicou seu compêndio possivelmente pela primeira vez em 1853; ele seria reeditado até, pelo menos, 1879, sexta edição (cf. Apêndice A: 1853, [34]; 1863, [62]; 1865, [70]; 1879, [110]).

No final do século, principalmente nas duas últimas décadas, vemos diversas gramáticas serem reeditadas. A famosa gramática portuguesa de Ribeiro (1881), que foi considerada pela grande maioria das revisões históricas como aquela que promove tanto mudanças teórico-metodológicas (cf. Maciel 1910; Nascentes 1939; Elia 1975; Cavaliere 2001), quanto aquela que inicia a descrição de outro português, apresentando uma série de exemplos de fala usual do Brasil e, mais especificamente, do interior de São Paulo (cf. Vidal Neto 2008, Polachini 2013; Coelho, Danna \& Polachini 2014; Coelho \& Danna 2015; Polachini \& Danna 2016), é reeditada diversas vezes até o final do século. O autor, nascido em 1845, morre precocemente em 1890, e, após esse ano, sua gramática é reeditada com apontamentos ou revisão de outros estudiosos ${ }^{76}$. Conhecemos ao menos seis reedições, das quais cinco são publicadas no decênio de 1890 (cf. Apêndice A: 1881, [123]; 1885, [143]; 1893, [177]; 1896, [193]; 1899, [204]).

Observamos que algumas gramáticas, das quais a primeira edição (ou edição mais antiga conhecida) havia sido publicada em décadas ou anos anteriores a 1881, continuam a ser reeditadas após esse ano. Isso revela que a ruptura promovida por Ribeiro em (1881), embora tenha tido um grande impacto, como é possível ver sobretudo pelas revisões dessa produção (cf. item 1.5), não teve como resposta imediata a interrupção da circulação de obras anteriores, cuja inspiração teórica começava, naquele clima de opinião, a ser considerada ultrapassada. Na década de 1890, entretanto, que, não se veem reedições de obras anteriores à de Ribeiro (1881), com exceção de Coruja (em 1891) e Freire da Silva (em 1894). Este último, entretanto, parece ter modificado uma série de seus pressupostos (não todos, porém), pois é sabido que a edição mais antiga de seu compêndio, publicada em 1875, tem nas seções de 'etimologia' e 'sintaxe' um resumo da gramática “filosófica”

\footnotetext{
${ }^{76}$ Sabemos que foi revisada por João Vieira de Almeida, na quarta, de 1893, e quinta edição, de 1899; R. Lagoa, na sexta edição, de 1900. Não tivemos acesso à edição de 1896.
} 
de Sotero dos Reis (1866, 1871). Entretanto, ao analisar a edição de 1894 (e também a de 1906), Parreira (2011) afirma que o texto de Freire da Silva estaria mais próximo da metodologia utilizada no final do século, que difere daquela de Sotero dos Reis, o que seria uma evidência da tentativa do autor de se adaptar às novas tendências - o que pode ter possibilitado que a obra persistisse em circulação por mais tempo (edições da gramática de Freire da Silva, que muda de título em dois momentos, em Apêndice A: 1871, [82]; 1875, [96]; 1879, [111]; 1883, [136]; 1886, [145]; 1894, [180]).

No final da década de 1880, há algumas gramáticas, todas do Rio de Janeiro, que afirmam, em seu subtítulo, estar seguindo um programa de exames (ver mais detalhes adiante). Quatro do ano de 1887, a saber, Gomes, Maciel, Pacheco \& Lameira, Ribeiro (Apêndice A: respectivamente, [151], [152], [153], [154]) as quais são frequentemente mencionadas em revisões históricas, como inspiradas no Programa de Estudos do Colégio Pedro II, escrito por Fausto Barreto, no mesmo ano de publicação das gramáticas. Este programa apresenta quarenta e seis pontos que um estudante deveria saber para os exames preparatórios do Colégio Pedro II (cf. Ribeiro 2007:85-94), altamente prestigiado na época. Tais pontos poderiam vir ao encontro das mudanças que se promoviam na orientação das obras, que deixavam de seguir um modelo aproximado da filosofia aristotélica, via grammaire de Port-Royal, para seguir um modelo de inspiração históricocomparativo. As quatro gramáticas supramencionadas, tiveram reedições. Não tivemos acesso à primeira edição de Gomes (1887, [151]), mas apenas à sexta, de 1895 ([187] $)^{77}$, a qual é dada como modificada e já não menciona o programa, entretanto, o autor e a edição de 1887 de sua gramática são frequentemente citadas nas revisões históricas (cf. 1.5). Esta edição não apresenta os quarenta e seis itens como elementos organizadores da obra, os quais podem ter tido esse papel na sua primeira edição, tal como o têm na gramática de Pacheco \& Lameira (1887, [153]), primeira edição, e em Ribeiro (1889, [167]), terceira (não tivemos acesso à edição de 1887 ([154]), ambas organizadas de acordo com os pontos do programa (cf. Apêndice B, FD13 e FD15). Como se vê, a gramática de João Ribeiro foi reeditada muito rapidamente. Na década de 1890, temos conhecimento ainda de sua quinta edição, de 1893 ([176]), da sexta, de 1894 ([183]), e da oitava de 1898 ([198]). A gramática de Pacheco \& Lameira muda de título em 1894 ([181]) e passa ter outros critérios organizadores de conteúdos (que não os pontos do programa de 1887 ([153]). Maciel, da mesma forma, modifica o nome e a organização de

${ }^{77}$ Temos conhecimento também da sétima edição, de 1897 ([191]). 
sua gramática na edição posterior, também de 1895 ([188]), no entanto, já não utilizava os pontos do programa como índice da obra desde a primeira edição (1887, [152]), a qual ele afirma, no prefácio, que já estaria pronta havia dois anos, ou seja, em 1885. Notamos, portanto, que as gramáticas de Ribeiro e Gomes obtiveram certo prestígio e foram reeditadas com mais frequência logo após sua publicação, ao passo que Maciel e Pacheco $\&$ Lameira reformularam seus textos e os republicaram com títulos e conteúdos diferentes quase uma década depois.

João Ribeiro foi autor de outras gramáticas. A obra relativa ao Programa era direcionada ao terceiro ano do nível secundário, mas o autor publicou também uma gramática para segundo ano (1888, [164]), uma destinada à instrução primária (1894, $[182])^{78}$, e outra caracterizada como elementar (1888, [163]) - pouco sabemos das reedições delas. É notável a preocupação didática do autor, a qual pode estar relacionada à melhor organização institucional da escola e dos níveis escolares no período. Outros gramáticos, sobretudo do final do século, também escreviam gramáticas para diferentes níveis, ainda que isso não fosse colocado tão explicitamente em títulos, como o era por João Ribeiro. Um exemplo é Boscoli, que escreve uma gramática para a "puerícia" (1895, [185]) e outra para qual não há um nível específico (1893-4, [178]; 1899, [199]), mas que certamente é mais aprofundada que a primeira. O mesmo faz Costa e Cunha, que escreveu duas gramáticas para o primeiro grau (1880, [118]; 1895, [186]) e uma para o examinando de português (1883, [133]) - além dos seus Princípios de Gramática Histórica (1883, [134]). Francisco Ferreira de Vilhena Alves escreve também gramáticas para diferentes níveis, nomeados infância (1896, [190]; 1897, [194]) e curso superior (1895, [184]). O próprio Julio Ribeiro traduz e adapta uma gramática inglesa para a infância (1887, [155]). Parece ser uma tendência comum no final do século escrever gramáticas para diferentes níveis de aprendizagem, mas há casos anteriores, como o de Freire da Silva, que publica seu compêndio da gramática portuguesa em 1871 ([82]) e, dado seu aprofundamento em edições posteriores modificadas, publica em 1879 ([112]) os Rudimentos (cf. Sacramento Blake 1883). Mais adiante trataremos do público alvo das gramáticas, seja ele definido

\footnotetext{
${ }^{78}$ A popularidade da obra parece ter sido bastante alta, visto que em 1900, foi publicada sua décima oitava edição. Não temos dados exatos, entretanto, de outras edições senão a de 1894 (da qual não sabemos o número) e a de 1900, de que citamos a referência bibliográfica (nos moldes do Apêndice A) adiante: 1900. RIBEIRO Fernandes, João (Sergipe 1860-1934). Grammatica portugueza: curso primário, $1^{\circ}$ anno de portuguez [Gp] [Instrução Primária]. 18 a ed. "ref. e il. Com gravuras explicativas do emprego das preposições" [Edição posterior [174]]. Rio de Janeiro: Tip. Da Livraria Francisco Alves. 114p. - Sem menção em fontes secundárias, localizada em catálogos de bibliotecas.
} 
por faixa etária, por instituição, por região etc. Por agora, ainda acerca da publicação, resta falar daquelas gramáticas das quais conhecemos somente uma edição.

Chama a atenção o fato de que gramáticas com grande número de reedições não sejam comumente mencionadas nas revisões históricas, são elas: na terceira edição, César (1834, Bahia, [14]), e Carneiro Ribeiro (1890, Bahia, [170]) - que não são os Serões Grammaticais, cuja primeira edição é do mesmo ano, mas os "Elementos de grammatica portugueza"; na quarta edição, Walter (1881, Pelotas, [125]) e Costa e Cunha (1895, Rio de Janeiro, [186]); na sétima, Borges (1887, Bruxelas, [104]) e, finalmente, na oitava, Martagão (1866, Bahia, [74]). Como vemos, a maior parte dessas gramáticas não eram produzidas nem publicadas na capital; isso talvez seja uma justificativa do seu esquecimento em diferentes crônicas históricas. Talvez a localização de sua publicação também limitasse o seu campo geográfico de circulação. Há ainda a possibilidade de que o número de exemplares por edição fosse pequeno, exigindo novas impressões.

O tipo de edição que denominamos edição posterior com título modificado reúne textos que conhecemos e textos assim classificados com base em comentários de Sacramento Blake. Há no corpus sete edições desse tipo. A primeira do século é a reedição de 1840 ([19]) do Compendio de grammatica philosophica portugueza de Costa Duarte, que fora publicado inicialmente em 1829 ([10]) como Compendio de grammatica portugueza, seu título e boa parte do conteúdo foram modificados. De acordo com os relatos de Sacramento Blake, a Grammatica da lingua portuguesa de Borges (1860, [28]), foi posteriormente publicada com novo título de Resumo da grammatica portuguesa $(1877,[104])^{79}$. Ainda de acordo com Sacramento Blake, temos conhecimento de que o Compendio da grammatica portugueza de Freire da Silva, publicado em 1875, seria reedição da gramática introdutória nomeada Noções de prosódia e orthographia para uso da infancia que frequenta as aulas do primeiro grau do Instituto Santista, intercaladas de um resumo da etymologia e syntaxe, extrahido da Grammatica portugueza de Francisco Sotero dos Reis, que o autor publicou com Leal, em 1871 ([82]); e que depois de algumas edições teria uma segunda mudança de título na $8^{\mathrm{a}}$ edição de 1894, passando a se chamar apenas Grammatica Portugueza ([180]). Finalmente, duas gramáticas de final do século escritas de acordo com o Programa de Estudos do Colégio carioca Pedro II de 1887 e publicadas neste mesmo ano, são reeditadas sete e oito anos depois,

\footnotetext{
${ }^{79}$ Nas edições sem data, portanto, não considerada em nossas análises, há ainda outra edição da gramática de Borges, que, segundo Blake, anterior à grammatica de linguage portugueza, chamava-se Epitome da grammatica portugueza.
} 
respectivamente em 1894 e 1895, com novos conteúdos e títulos, mas ainda consideradas edições daquelas de 1887, a saber: a Grammatica analytica baseada nas doutrinas modernas ([152]) de Maciel, que é republicada como Grammatica descriptiva baseada nas doutrinas modernas em 1895 ([188]); e as Noções da grammatica portugueza ([153]) de Pacheco \& Lameira, que se tornam Grammatica da lingua portugueza ([181]). Todas as reedições mencionadas neste parágrafo, nos parece, configuram mudanças também no conteúdo das obras, o que faz com que as consideremos dentro da categoria de edições específicas e não como reedições.

\section{R3. A publicação de gramáticas em diferentes regiões}

Como se sabe, ao longo do século XIX, o Brasil passou por cinco estatutos políticos diferentes. No início do século, o território era colônia de Portugal. Em 1815, por conta da vinda da família real à colônia em 1808, passou a ser o Reino do Brasil, tornando-se parte do Reino Unido de Portugal, Brasil e Algarves. Pouco tempo depois, em 1822, foi proclamada a Independência do Brasil, por D. Pedro, filho do rei português D. João IV, tendo início o Império do Brasil. Com a ida de D. Pedro I a Portugal e menoridade de Pedro II, houve o conturbado Período Regencial, entre 1831 e 1840. Finalmente, em 1889, proclamou-se a República no país, quando se instituíram os Estados Unidos do Brasil. A instabilidade política não provinha apenas de transições estruturais, mas também de movimentos revolucionários regionais, quase sempre com reinvindicações de autonomia ${ }^{80}$, e de confrontos No mapa abaixo, retirado o Atlas Escolar do IBGE (Albuquerque, Reis, Carvalho 1977), podemos ter um panorama geral das mundanças territoriais ocorridas no século (indicadas pela data de criação de algumas províncias), há ainda indicação das revoltas e suas datas.

\footnotetext{
${ }^{80}$ Como foi o caso das seguintes revoltas: Guerra dos Cabanos (1832-1835), em Pernambuco; Cabanagem (1835-1840), no Pará; a Sabinada (1837-1838), na Bahia; a Balaiada (1838-1840), no Maranhão; e a Farroupilha (1835-1845), no Rio Grande do Sul. Em consequência delas e de mudanças de governo, o período da regência é considerado o de maior instabilidade no século XIX. Nesse mesmo período, entretanto, criaram-se dois importantes centros de cultura para o Brasil: o Colégio Pedro II, como um modelo para os colégios provinciais, em 1837, e Instituto Histórico e Geográfico Brasileiro, em 1838, que tinha como objetivo a descrição geográfica e histórica do país como uma forma de "criar" um passado e um futuro para o país recém-independente (cf. Reis 2000).
} 


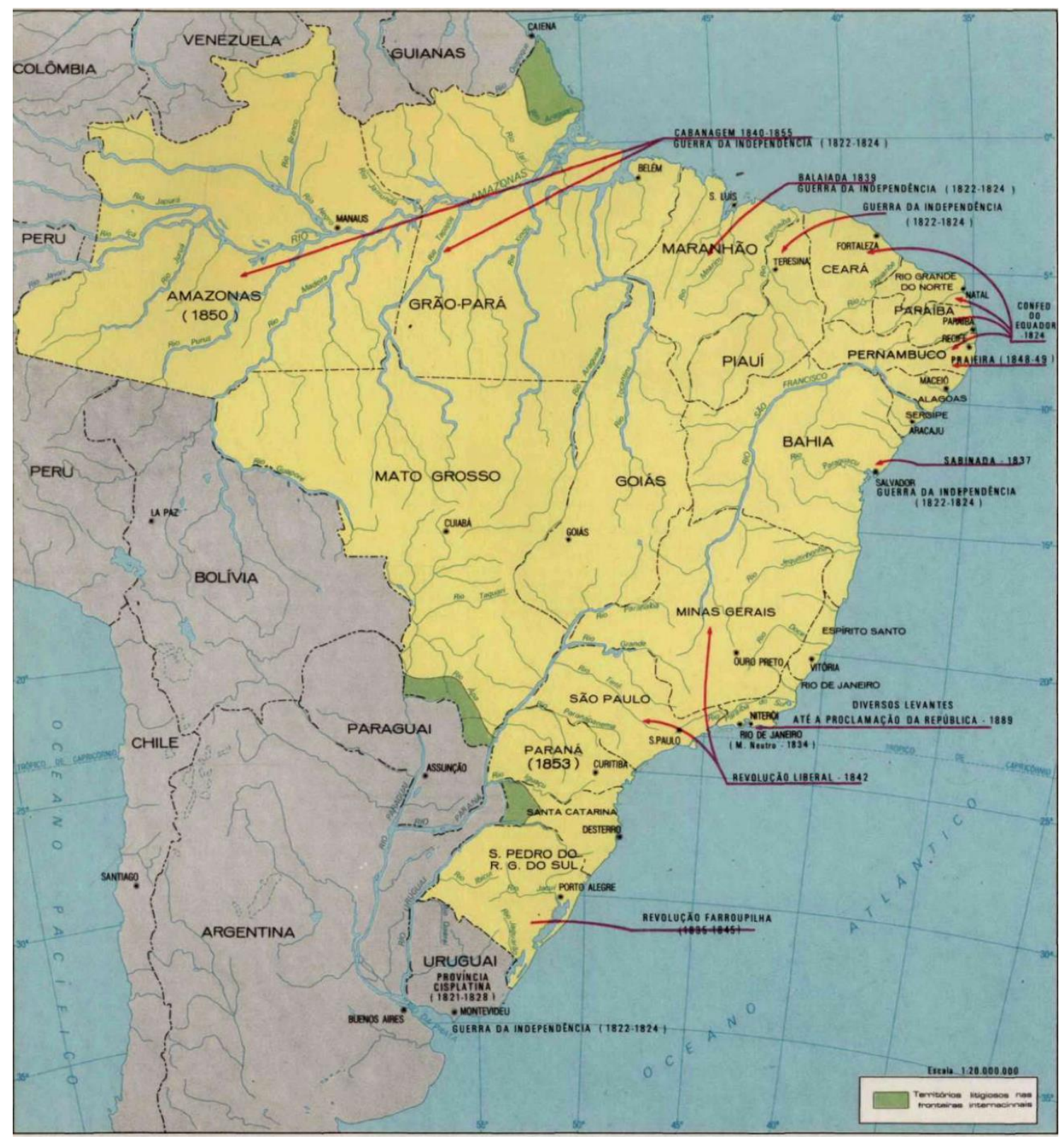

Figura 7. Mapa do Brasil com divisões territoriais históricas (Albuquerque, Reis, Carvalho 1977) 
$\mathrm{Na}$ tabela adiante, apresentamos dados relativos ao número de gramáticas e edições específicas (subescrito) publicadas em cada província em cada década do século XIX.

\begin{tabular}{|c|c|c|c|c|c|c|c|c|c|c|c|}
\hline & 1800 & 1810 & 1820 & 1830 & 1840 & 1850 & 1860 & 1870 & 1880 & 1890 & Total \\
\hline $\begin{array}{c}\text { Rio de } \\
\text { Janeiro / } \\
\text { Capital } \\
\text { Federal }\end{array}$ & - & 21 & $5_{4}$ & 32 & 73 & $10_{8}$ & $15_{9}$ & $15_{8}$ & $29_{21}$ & $16_{8}$ & $101_{63}$ \\
\hline $\begin{array}{l}\text { Maranhão / } \\
\text { São Luiz }\end{array}$ & - & - & $1_{1}$ & - & $1_{1}$ & $3_{1}$ & $3_{1}$ & $4_{1}$ & $1_{0}$ & - & $13_{6}$ \\
\hline $\begin{array}{l}\text { Rio Grande } \\
\text { (do Sul)/ } \\
\text { Porto Alegre } \\
\text { / Pelotas }\end{array}$ & - & - & - & $3_{3}$ & - & - & $22_{2}$ & $3_{3}$ & $2{ }_{2}$ & $1_{1}$ & $11_{11}$ \\
\hline $\begin{array}{c}\text { Bahia / } \\
\text { Salvador }\end{array}$ & - & - & - & $22_{2}$ & - & $2_{2}$ & $4_{4}$ & $1_{0}$ & $1_{1}$ & $2{ }_{1}$ & $12_{10}$ \\
\hline $\begin{array}{l}\text { Pernambuco } \\
\text { / Recife }\end{array}$ & - & - & - & - & $3_{2}$ & $1_{0}$ & $2_{2}$ & $4_{4}$ & - & - & $10_{8}$ \\
\hline $\begin{array}{c}\text { Ceará / } \\
\text { Fortaleza }\end{array}$ & - & - & - & - & - & - & $22_{2}$ & $1_{1}$ & - & - & $3_{3}$ \\
\hline $\begin{array}{l}\text { Vitória / } \\
\text { Espírito } \\
\text { Santo }\end{array}$ & - & - & - & - & - & - & $1_{1}$ & - & - & - & $\mathbf{1}_{1}$ \\
\hline $\begin{array}{c}\text { Alagoas / } \\
\text { Maceió }\end{array}$ & - & - & - & - & - & - & - & $1_{0}$ & - & - & $1_{0}$ \\
\hline Pará / Belém & - & - & - & - & - & - & - & $22_{2}$ & $2{ }_{1}$ & $4_{4}$ & $8_{7}$ \\
\hline $\begin{array}{l}\text { São Paulo / } \\
\text { Campinas }\end{array}$ & - & - & - & - & - & - & - & $3_{2}$ & $10_{4}$ & $6_{1}$ & $19_{7}$ \\
\hline $\begin{array}{c}\text { Santa } \\
\text { Catarina / } \\
\text { Desterro }\end{array}$ & - & - & - & - & - & - & - & - & $1_{1}$ & - & $1_{1}$ \\
\hline $\begin{array}{c}\text { Dupla } \\
\text { localização }^{81}\end{array}$ & - & - & - & - & - & - & $1_{0}$ & - & $1_{1}$ & - & 21 \\
\hline Exterior $^{82}:$ & $1_{1}$ & $1_{0}$ & - & - & - & - & - & $1_{0}$ & $1_{0}$ & - & $4_{1}$ \\
\hline $\begin{array}{c}\text { Sem } \\
\text { localização }\end{array}$ & - & - & - & - & - & - & $4_{2}$ & $2{ }_{1}$ & $6_{2}$ & $6_{2}$ & $18_{7}$ \\
\hline
\end{tabular}

Quadro 15. Número de 'gramáticas' e 'edições específicas' por local e década

${ }^{81}$ Rio de Janeiro e Ceará - Rubim (1862, [56]); Rio de Janeiro e Paris - Costa e Cunha (1883, [133]).

${ }^{82}$ Em ordem de publicação: Lisboa (1806), Lisboa (1813), Lisboa (1851), Bruxelas (1877), Porto (1880). 


\section{Rio de Janeiro}

É inegável que há predomínio da produção no Rio de Janeiro, que tem um número muito maior de obras publicadas e também uma maior diversidade de autores ao longo de todo o século. É no Rio de Janeiro também que ocorre a primeira impressão de uma gramática do Português no Brasil, em 1810, a Arte de grammatica portugueza, para uso de seus discípulos, de Fortes (cf. Kemmler 2013). São 51 autores diferentes na província/estado e 108 obras publicadas.

Na primeira década do século, temos somente a Arte de Fortes (1810, [2]) e sua reedição de 1816 ([4]). Na década de 1820, temos ainda reedições de Fortes (1825, [7]), e da, provável, primeira edição da Grammatica de Morais Silva (1824, [6]), além dos textos, menos conhecidos, de Tilbury (1823, [5]), Alencastro (1828, [8]) e Loureiro $(1828,[9])$. No decênio seguinte, há uma pequena diminuição no número de publicações, duas edições da Gramática Elementar de Paz (1833, [13]; 1836, [18]) e a da "Arte" de Soares $(1835,[17])$.

A partir de 1840, foram publicadas no Rio de Janeiro as reedições do Compendio de Coruja (1846, [26]; 1847, [27]; 1849, [29]), que inicialmente havia sido publicado em Porto Alegre (1835, [16]). A “Arte” de Fortes é também reeditada (1844, [23]). Ademais, são publicadas as gramáticas de Cordeiro (1844, [22]), Lopes (1845, [24]), Passos (1848, [28]).

No decênio de 1850, é publicada outra reedição de Fortes (1851, [31]), além de outras oito das quais não conhecemos edições anteriores, são elas: Susano (1851, [32]), Cruz (1853, [34]), Silveira (1855, [38]), Passos (1855, [37]), Andrade (1856, [39]), Graça (1857, [40]), Alberto Junior (1859, [43]), Cruz (1859, [45]).

$\mathrm{Na}$ década de 1860, há uma série de reedições, uma delas é a última de Fortes que conhecemos (1862, [53]), há também duas de Coruja (1862, [52]; 1865, [69]), e de gramáticas mais recentes (da década anterior): Passos (1863, [64]) e Cruz (1863, [62]; 1865; [70]). De textos novos (de acordo com nosso conhecimento), temos Barker (1860, [46]), Bithencourt (1862, [50]), Ribeiro 1862, [55]), Pinheiro (1864, [67]), Castilho (1864, [65]), Grivet (1865, [71]), Soares (1868, [76]), Morais (1869, [78]) e duas edições de Rubim (1860, [48]; 1862, [56]).

Nos anos 1870, temos duas outras edições de Coruja (1872, [87]; 1873, [92]), e a reedições de Silveira, que fora publicada na década 1850, de Rabelo (1872, [89]), publicada no fim da década anterior, e de Albuquerque, que havia sido publicado nas 
décadas de 1840, 1850 e 1870 em Recife ([20], [21], [42], [91]). Ademais, há duas edições da Gramática Analítica de Ortiz e Pardal (1871, [83]; 1876, [102]). Outras gramáticas publicadas no decênio são as de Pinheiro (1870, [80]), Frazão (1874, [95]), Pimentel (1875, [95]), Costa (1876, [101]), Vieira (1877, [107]), Carvalho (1879, [109]), Santos $(1879,[113])$.

A década de 1880 concentra 29 gramáticas, das quais 8 são reedições e outras 20 são novas. Aquelas consistem de duas reedições da gramática de Ortiz e Pardal (1884, [137]; 1888, [162]), de Alberto Junior (1887, [146]) que é reedição da década de 1850, e Vieira (1881, [124]) e Costa (1887, [149]), que são reedições de obras da década anterior. Os textos novos (de acordo com nosso conhecimento) são: Carvalho (1880, [117]), Costa e Cunha (1880, [118]), Grivet (1881, [120]) - que já havia publicado outra gramática na década de 1860 -, Nogueira (1881, [122]), Mello (1882, [129]), Carvalho (1885, [140]), Rabelo (1885, [140]) - embora seja um texto póstumo, tem título diferente da gramática publicada no fim de 1868 e início de 1872 -, Boscoli \& Paio (1887, [148]); gramáticas baseadas no programa de exames do Pedro II, que são Maciel (1887, [152]), Pacheco \& Lameira (1887, [153]), Gomes (1887, [151]) e Ribeiro (1887, [154]), esta que é reeditada em 1888 e 1889 ([165], [167]); Ribeiro escreve ainda gramáticas para outros níveis de ensino, uma gramática elementar (1888, [163]), outra para o segundo ano (1888, [164]); e continuando até o final do decênio, Boscoli \& Pacheco (1888, [156]); Lima (1888, [160]), Massa (1888, [161]), Vieira (1889, [168]) e, finalmente, Lacerda (188?, [169]).

Enfim, na última década do século, são publicadas no Rio de Janeiro apenas 15 obras, das quais 7 são novas e oito são reedições. Destas últimas, temos mais uma reedição de Coruja (1891, [172]), reedições da gramática para o $3^{\circ}$ ano de Ribeiro (1891, [174]; 1893, [176]; 1894, [183]), reedições de Gomes da década anterior (1895, [187]; 1897, [196]), de Carvalho (1896, [191]) e de Boscoli (1899, [201]). Das novas, temos mais uma gramática de Ribeiro, destinada à instrução primária (1894, [182]), duas gramáticas de Boscoli (1893-4, [178]; 1895, [185]), Costa e Cunha (1895, [186]), Vieira (1898, [199]), Maia (1899, [203]), e finalmente as reedições renomeadas de Pacheco \& Lameira (1894, [181]) e Maciel (1895, [188]), que haviam sido publicadas em 1887. Há ainda um número significativo de obras sem data, mas que provavelmente são do século XIX, são elas Costa ([209]) - que é reedição de obra das décadas de 1870 e 1880 -, Pimentel ([214]), Alberto Junior ([205]), Câmera ([207]), Cony ([208]), Muller ([212]). Após essa exaustiva lista de obras publicadas no Rio de Janeiro, veremos aquelas publicadas em outras províncias/estados. 


\section{Maranhão}

O Maranhão, pode-se dizer, é uma das províncias onde a publicação de gramáticas é precoce, pois é iniciada em 1829, com Costa Duarte ([10]). Os outros autores maranhenses são os gramáticos Condurú, Sotero dos Reis, Freire da Silva (que posteriormente iria para São Paulo) e Nunes Leal. Costa Duarte publica em 1829 a sua gramática, a qual seria bastante modificada (sobretudo por meio de longas e críticas notas de rodapé) e receberia um novo título em publicação de 1840 ([19]). Esta última seria reeditada até pelo menos 1877, como já foi dito anteriormente (reedições: [33], [44], [105]). Condurú publica a primeira edição de sua gramática em 1850 ([30]), mas tivemos acesso somente à décima terceira edição da obra, de 1888 ([157]). Assim, não nos foi possível observar eventuais modificações entre edições; é possível, entretanto, diante do número de reedições, atestar o prestígio da obra no período. Sotero dos Reis, conhecido também por seus volumes sobre a história da literatura brasileira e portuguesa, publica a primeira edição de sua gramática em 1866, a qual tem duas reedições póstumas (esparçamente corrigidas por seus filhos) em 1871 e 1877 (respectivamente: [75], [85] e [106]). Pedro Nunes de Leal, ao qual foram dedicadas as gramáticas de Sotero dos Reis, escreve junto com Freire da Silva uma gramática, publicada em 1871, na qual extrai e resume a 'Etimologia' e a 'Sintaxe' da gramática de Sotero dos Reis ([82]). Ressaltamos que a produção maranhense toda filia-se à grammaire générale francesa, mas as obras diferem entre si em diversos aspectos, como veremos no Capítulo 4; entretanto, Freire da Silva, anos depois, já morando em São Paulo, aproximou seus métodos da gramática histórico-comparativa.

\section{Rio Grande do Sul}

Outra produção precoce é a do Rio Grande do Sul, pois em 1832 publica-se em Porto Alegre uma reedição do Epitome de Morais Silva ([12]), cuja primeira edição havia sido publicada em Lisboa, em 1806. Esta reedição é modificada, visto que no catálogo da biblioteca há a seguinte observação "E agora mais resumido, e em fórma de dialogo, para uso dos meninos". Em 1834, é publicado o Compendio de grammatica da língua portugueza ordenado segundo a doutrina dos melhores grammaticos, de Lopes ([15]), da qual não temos informações acerca de possíveis reedições. Em 1835, Coruja publica seu 
célebre Compendio da grammatica da lingua nacional, dedicado á mocidade riograndense em Porto Alegre, em 1835 ([16]). Esta gramática posteriormente (ao menos desde a $4^{\mathrm{a}}$ edição, de 1846) foi publicada no Rio de Janeiro, para onde o gramático também se mudou; o título da obra, que faz referência à província do Rio Grande do Sul, entretanto, não foi modificado. A obra parece ter tido bastante sucesso, já que foi reeditada, com algumas revisões e modificações, ao menos até 1891 (edição sem número), quase sessenta anos após a primeira edição. A produção gramatical riograndense é, de acordo com os dados obtidos, descontínua, já que na década de 1830 são publicadas três gramáticas de diferentes autores, mas não há publicações de gramáticas até a década de 1860, na qual são publicadas as gramáticas de Tibault (1862, [60]) e Koeffer (1863, [63]); na década seguinte e início de 1880, Villeroy (1870 [81]) e Walter (1879 [115] e [116], 1881 [125]). Os sobrenomes sinalizam a imigração de estrangeiros de diferentes nacionalidades para a província naquele século. Há duas outras gramáticas publicadas até o final do século. Uma delas, cuja terceira edição (única que conhecemos) de 1882, chama-se Grammatica elementar, escrita por Hillario Ribeiro de Andrade e Silva ([131]), apresenta um subtítulo em que se diz, em subtítulo, adotada em diversas províncias do país, a saber: Rio Grande do Sul, Santa Catarina, Paraná, São Paulo, Rio de Janeiro e município neutro. Outra, publicada em fins do século, em 1899, é de Bibiano Francisco Almeida e chama-se Compendio de grammatica da lingua portugueza dedicado aos estudantes rio-grandenses ([200]), não sabemos se é a primeira edição. Dos nomes mencionados, Morais Silva e Coruja são os mais conhecidos, de acordo com a análise que fizemos das das revisões históricas (cf. item 1.5). Ressaltamos, entretanto, que o primeiro era natural do Rio de Janeiro (mas morava em Pernambuco) e faleceu em 1823; a gramática publicada no Rio Grande do Sul parece ser uma adaptação do original de 1806 feita por autores anônimos, os quais provavelmente residiam na província. Esta adaptação, entretanto, não é mencionada em nenhuma das revisões históricas que consultamos. Coruja, por sua vez, fugiu de Porto Alegre para a capital do país durante a revolução Farroupilha e lá publicou as edições subsequentes de sua gramática até o final de sua vida. Como vimos, a tradição riograndense de produção gramatical, embora seja precoce e tenha número de obras e autores considerável, é pouco lembrada nas revisões históricas.

\section{Bahia}


Na Bahia, as primeiras gramáticas publicadas, em 1832 e 1834, são de um mesmo autor, Casemiro Ferreira César. Chamam-se "Manual pratico ou methodo do ensino recopilado dos mais adoptados e mais próprios para as aulas da lingua nacional do Brazil" e "Grammatica portugueza" ([11] e [14]). A segunda é terceira edição, não sabemos ao certo se seria uma reedição de 1832 com texto modificado ou realmente outra obra.

Depois, em 1854, é publicada a gramática de José Ferreira dos Santos Cajá ([35]). Ainda da década de 1850, conhecemos a Grammatica ecletica-rudimentaria, de Philippe Jose Alberto Junior, da qual temos dados apenas da quinta edição, de 1858 ([41]); não temos informações sobre as edições anteriores, mas sabemos que foi reeditada até pelo menos 1887 ([146]).

Na década de 1860, quatro gramáticas de quatro autores diferentes são publicadas: Elementos de grammatica portugueza, de Carvalho (1863, [61]), Grammatica Geral, de Murici (1864, [66]), Compendio grammatical, reduzido a dialogo, para uso dos principiantes, de Ibirapitanga (1865, [72]) e Compendio da grammatica da lingua portugueza, de Martagão (1866, [74]).

Nas décadas seguintes, há uma reedição de Ibirapitanga (1875, [97]), outra obra de Martagão (s.d., [211]) e três gramáticas de Carneiro Ribeiro, duas mais amplamente conhecidas, Grammatica philosophica (1877, [120]) e os Serões Grammaticaes (1890, [170]), e outra não mencionada em revisões históricas, Elementos de grammatica portuguesa, cuja primeira edição é de 1885 (383).

\section{Pernambuco}

Pernambuco é a última província a iniciar sua produção gramatical na primeira metade do século. Um autor bastante popular da província é Salvador Henrique de Albuquerque, que publica ao menos quatro títulos entre as décadas de 1840 e 1870 (1841, [20]; 1844, [21]; 1846, [25]; 1858, [42]; 1873, [91]). Um deles, o Compendio de grammatica portugueza, está em sua sexta edição em 1846 (não tivemos conhecimento das edições anteriores). Dentre as outras gramáticas produzidas na província, está o Breve compêndio de Frei Caneca, que é publicado postumamente em 1876 ([100]). Também publicam na província Senna (1862, [57]), Taylor (1871, [86]) e Souza (1879, [114]), de cujas gramáticas conhecemos uma única edição.

\section{Outras localidades}


Seis províncias teriam publicações na apenas segunda metade do século, a partir de 1861, são elas (por ordem cronológica de aparecimento das obras): Ceará, Espírito Santo, Alagoas, Belém, São Paulo e Santa Catarina. Muitas dessas províncias, porém, concentram sua produção em um único autor e poucas obras: do Ceará temos conhecimento de duas gramáticas de Manuel Soares da Silva Bezerra (1861 [49], 1865 [68], 1877 [103]); do Espírito Santo, conhecemos somente o "Novo systema de estudar a grammatica portugueza", de 1862, de autoria de José Ortiz ([54]) -- que posteriormente publicaria gramáticas no Rio de Janeiro, junto com Candido Pardal; de Alagoas, temos notícia somente do "Resumo da grammatica portugueza", de 1871 (segunda edição), de José Alexandre Passos ([84]); finalmente, de Santa Catarina, temos notícia da Grammatica Portugueza de Lapagesse, nascido na França, de 1888 ([159]).

As províncias do Pará e de São Paulo, muito embora tenham um grande número de obras publicadas, têm produção tardia em relação a grande parte das regiões já mencionadas, uma vez que suas publicações se iniciam apenas na década de 1870 .

O Pará tem um número mais variado de autores, são seis. Souza publica sua gramática portuguesa em 1872 ([90]). Da gramática elementar de Marques temos conhecimento da segunda (1875, [98]) e quarta (1882, [128]) edições. Ainda na década de 1880, há o compêndio de Cardoso (1889, [166]). As outras quatro gramáticas são da última década do século, a saber: de Alves, a Grammatica Portugueza (1895, [184]) e a Primeira grammatica da infancia (1896, [190]); os Elementos de grammatica, de Luz (1896, [192]), e, finalmente, a Grammatica Primaria de Brito (1899, [202]).

São Paulo tem apenas autores nesse período, os quais produziram diversas obras, a saber: Freire da Silva, que publicou um Compendio da grammatica portugueza (1875, [96]; 1879, [111]; 1883, [136]; 1886, [145]; 1894, [180] - esta última edição com título modificado para Grammatica Portugueza), cuja primeira edição, como vimos, fora publicada no Maranhão, e os Rudimentos (1879, [112]), e Julio Ribeiro, considerado o gramático que promoveu a ruptura como o modelo filosófico ou geral de gramática em sua Grammatica Portugueza de 1881 ([123]), que e teve uma série de reedições (1885, [143]; 1893, [177]; 1895, [189]; 1896, [193]; 1899, [204]). Ressaltamos que as edições da gramática de Ribeiro da década de 1890 são corrigidas ou modificadas por outros estudiosos do período, dado que são edições póstumas. Ribeiro publicou também uma Grammatica Analytica, em 1885 ([142]), da qual não temos muitas informações; também traduziu e adaptou outra gramática, que nomeou de Holmer brazileiro ou grammatica da 
puericia, que seria tradução da Introduction to English Grammar de G. F. Holmes, em 1887 ([155]). O último autor é Feitosa, que cuja Grammatica das escolas, baseada em Pierre Larousse, foi bastante reeditada (1882, [127]; 1883, [135]; 1886, [144]).

Na maior parte das províncias e estados, a publicação de gramáticas concentra-se na segunda metade do século, o que não poderia ser diferente, visto que há 29 gramáticas publicadas até 1849, ao passo que são publicadas 171 entre 1850 e o final do século. A produção da segunda metade do século é cinco vezes maior do que a da primeira parte. Isso possivelmente se dá por razões bastante conhecidas na história social, política e econômica do Brasil, como a estabilização política a partir do Segundo Império e o crescimento da produção do algodão e, posteriormente, do café em regiões como Maranhão e São Paulo (para um resumo deste contexto cf. Polachini 2013).

É de se ressaltar a ausência de publicação de gramáticas em algumas províncias, são elas, em ordem alfabética, Amazonas (que existe como estado apenas a partir de 1850, antes seu território era predominantemente parte da província do Grão-Pará), Cisplatina (que está no mapa Brasileiro apenas entre 1821 e 1828), Goiás, Mato Grosso, Minas Gerais, Paraíba, Paraná (que entra no mapa apenas em 1853, antes o seu território era predominantemente parte de São Paulo), Piauí, Rio Grande do Norte e, finalmente, Sergipe (que passa a existir como tal apenas depois de 1821, antes era predominantemente parte da Bahia). Há, entretanto, uma gramática dedicada à província de Minas Gerais, Brandão (1882, [126]), da qual não temos informações acerca do local de publicação. Há também outra, de Andrade e Silva (1882, [131]), publicada em Porto Alegre, que é dedicada a alguns estados do Sul e Sudeste, incluindo o Paraná, como vimos.

\section{R4. Casas impressoras}

Das 204 gramáticas, pudemos determinar com precisão a casa impressora de 98. Separamos essas por local de publicação no quadro adiante:

\begin{tabular}{|c|c|c|c|c|}
\hline Local & Casa Impressora & Gramáticas & $\begin{array}{c}\mathbf{N}^{\circ} \text { de } \\
\text { obras }\end{array}$ & Período \\
\hline \multirow{3}{*}{$\begin{array}{c}\text { Exterior } \\
(4)\end{array}$} & $\begin{array}{c}\text { Lisboa: Off. De Simão Thaddeo } \\
\text { Ferreira }\end{array}$ & Morais Silva 1806 & 1 & 1806 \\
\cline { 2 - 5 } & Lisboa: Typographia Lacerdena & Morais Silva 1813 & 1 & 1813 \\
\cline { 2 - 5 } & Bruxelas: Tip. Guyot & Borges 1877 & 1 & 1877 \\
\cline { 2 - 5 } & Porto: Tip. Comercial Portuense & Rubim 1880 & 1 & 1880 \\
\hline & Imprensa Régia, Tipografia & Fortes 1810 & 4 & $1810-1863$ \\
& Nacional & Fortes 1816 & & \\
\hline
\end{tabular}




\begin{tabular}{|c|c|c|c|c|}
\hline \multirow{4}{*}{$\begin{array}{l}\text { Rio de } \\
\text { Janeiro }\end{array}$} & & $\begin{array}{c}\text { Loureiro } 1828 \\
\text { Passos } 1863\end{array}$ & & \\
\hline & $\begin{array}{l}\text { Typographia de Silva Porto, e } \\
\text { Comp. }\end{array}$ & Morais Silva 1824 & 1 & 1824 \\
\hline & Col. B. Ottoni & Cordeiro 1844 & 1 & 1844 \\
\hline & Typ. do G. Globo & Lopes 1845 & 1 & 1845 \\
\hline \multirow[t]{14}{*}{ (48) } & Tipografia Francesa & $\begin{array}{l}\text { Coruja } 1846 \\
\text { Coruja } 1847\end{array}$ & 2 & 1846,1847 \\
\hline & Tip. De M. A. Silva Lima & Passos 1848 & 2 & 1848 \\
\hline & Laemmert & $\begin{array}{c}\text { Susano } 1851 \\
\text { Bithencourt } 1862 \\
\end{array}$ & 2 & 1851,1862 \\
\hline & $\begin{array}{c}\text { Typ. do Commercio de Brito \& } \\
\text { Braga }\end{array}$ & Passos 1855 & 1 & 1855 \\
\hline & Morderna & Alberto Junior 1859 & 2 & 1859 \\
\hline & B. L. Garnier & $\begin{array}{l}\text { Pinheiro } 1864 \\
\text { Lacerda } 188 ?\end{array}$ & 2 & $1864-1880$ \\
\hline & $\begin{array}{c}\text { Francisco Alves, Nicolau Alves, } \\
\text { Livraria Clássica [de Alves] }\end{array}$ & $\begin{array}{c}\text { Pinheiro } 1870 \\
\text { Ortiz \& Pardal } 1873 \\
\text { Ortiz \& Pardal } 1876 \\
\text { Ortiz \& Pardal } 1884 \\
\text { Ribeiro } 1887 \\
\text { Ortiz \& Pardal } 1888 \\
\text { Ribeiro } 1888 \\
\text { Ribeiro } 1888 \\
\text { Ribeiro } 1888 \\
\text { Ribeiro } 1889 \\
\text { Coruja } 1891 \\
\text { Ribeiro } 1891 \\
\text { Ribeiro } 1893 \\
\text { Pacheco \& Lameira } 1894 \\
\text { Ribeiro } 1894 \\
\text { Ribeiro } 1894 \\
\text { Carvalho } 1896 \\
\text { Boscoli } 1899\end{array}$ & 18 & 1870-1899 \\
\hline & $\begin{array}{l}\text { Typographia de Esperança de } \\
\text { Gaspar João José Vellozo }\end{array}$ & $\begin{array}{l}\text { Rabelo } 1872 \\
\text { Coruja } 1873\end{array}$ & 2 & 1872,1873 \\
\hline & Typ. Quirino \& Irmão & $\begin{array}{l}\text { Silveira } 1872 \\
\text { Alberto } 1887 \\
\end{array}$ & 2 & 1872,1887 \\
\hline & Tip. Escola & $\begin{array}{l}\text { Costa } 1876 \\
\text { Costa } 1887 \\
\end{array}$ & 2 & 1876,1887 \\
\hline & Typ. de A. Santos & Nogueira 1881 & 1 & 1881 \\
\hline & $\begin{array}{l}\text { J. G. de Azevedo / Livraria } \\
\text { Academica de J. G. Azevedo }\end{array}$ & $\begin{array}{c}\text { Costa e Cunha } 1883 \\
\text { Pacheco \& Lameira } 1887 \\
\text { Costa e Cunha } 1895 \\
\text { Gomes } 1895 \\
\text { Gomes } 1897\end{array}$ & 5 & 1883-1897 \\
\hline & $\begin{array}{l}\text { Typ. Central de Evaristo } \\
\text { Rodrigues da Costa } \\
\end{array}$ & Maciel 1887 & 1 & 1887 \\
\hline & H. Lombaerts & Massa 1888 & 1 & 1888 \\
\hline \multirow{7}{*}{$\underset{\text { (8) }}{\text { Maranhão }}$} & Tipografia Nacional [?] & Costa Duarte 1829 & 1 & 1829 \\
\hline & $\begin{array}{c}\text { Livraria do Editor F. Fructuoso } \\
\text { Ferreira } \\
\end{array}$ & Costa Duarte 1853 & 1 & 1853 \\
\hline & Tipografia do Frias & Costa Duarte 1859 & 1 & 1859 \\
\hline & $\begin{array}{c}\text { Antonio Pereira Ramos } \\
\text { D'Almeida }\end{array}$ & Costa Duarte 1862 & 1 & 1862 \\
\hline & Tip. De B. de Matos & Sotero dos Reis 1866 & 1 & 1866 \\
\hline & Typ. de R. d'Almeida \& C. & Sotero dos Reis 1871 & 1 & 1871 \\
\hline & Livraria de Magalhães & Sotero dos Reis 1877 & 1 & 1877 \\
\hline
\end{tabular}




\begin{tabular}{|c|c|c|c|c|}
\hline & Typ. do Paiz & Condurú 1888 & 1 & 1888 \\
\hline \multirow{4}{*}{$\begin{array}{c}\text { Rio Grande } \\
\text { / Porto } \\
\text { Alegre } \\
\text { (4) }\end{array}$} & C. Dubreuil & Morais Silva 1832 & 1 & 1832 \\
\hline & V.F. Andrade & Coruja 1835 & 1 & 1835 \\
\hline & Typ. do Rio-grandense & Villeroy 187 & 1 & 1870 \\
\hline & Livreiro Rodolpho José Machado & Almeida 1999 & 1 & 1899 \\
\hline \multirow{4}{*}{$\begin{array}{c}\text { Recife / } \\
\text { Pernambuco } \\
\text { (6) }\end{array}$} & Tip. do Santos & $\begin{array}{c}\text { Albuquerque } 1841 \\
\text { Albuquerque } 1844 \\
\text { Taylor } 1871 \\
\end{array}$ & 3 & $1841-1871$ \\
\hline & Tip. Universal & Albuquerque 1858 & 1 & 1858 \\
\hline & Typ. Commercial & Albuquerque 1873 & 1 & 1873 \\
\hline & Typographia Mercantil & Caneca 1876 & 1 & 1876 \\
\hline \multirow{6}{*}{$\begin{array}{c}\text { Bahia } \\
\text { (6) }\end{array}$} & A. J. N. M. Bandeira: & Caja 1854 & 1 & 1854 \\
\hline & Tip. Poggetti: & Carvalho 1863 & 1 & 1863 \\
\hline & $\begin{array}{l}\text { Typ. Constitucional de França } \\
\text { Guerra }\end{array}$ & Murici 1864 & 1 & 1864 \\
\hline & Off. Litho-typ de J. C. Tourinho: & Ibirapitanga 1875 & 1 & 1875 \\
\hline & Economica & Carneiro Ribeiro 1890 & 1 & 1890 \\
\hline & Imprensa Popular & Carneiro Ribeiro 1890 & 1 & 1890 \\
\hline \multirow[t]{2}{*}{$\begin{array}{c}\text { Ceará } \\
\text { (3) }\end{array}$} & Tip. Social & $\begin{array}{l}\text { Bezerra } 1861 \\
\text { Bezerra } 1865\end{array}$ & 2 & 1861,1865 \\
\hline & Typographia Cearense & Rubim 1862 & 1 & 1862 \\
\hline \multirow{4}{*}{$\begin{array}{c}\text { Belém/ Pará } \\
\text { (4) }\end{array}$} & C. Seidl & Marques 1875 & 1 & 1875 \\
\hline & Tavares Cardoso & Cardoso 1889 & 1 & 1889 \\
\hline & Typ. de Pinto Barbosa e Ca.: & Alves 1895 & 1 & 1895 \\
\hline & Pacheco \& Barbosa: & Alves 1896 & 1 & 1895 \\
\hline \multirow{8}{*}{$\begin{array}{l}\text { São Paulo / } \\
\text { Campinas } \\
\text { (15) }\end{array}$} & Typ. do Frias [?] & Freire da Silva 1875 & 1 & 1875 \\
\hline & Tip. Jorge Seckler & $\begin{array}{c}\text { Freire da Silva } 1879 \\
\text { Ribeiro } 1881 \\
\text { Freire da Silva } 1883 \\
\text { Freire da Silva } 1888\end{array}$ & 3 & $1879-1888$ \\
\hline & Gazeta de Campinas & $\begin{array}{l}\text { Feitosa } 1882 \\
\text { Feitosa } 1883 \\
\text { Feitosa } 1886 \\
\end{array}$ & 3 & $1882-1886$ \\
\hline & Ty. de Leroy King: & Ribeiro 1885 & 1 & 1885 \\
\hline & Teixeira (\& Irmão): & $\begin{array}{l}\text { Ribeiro } 1885 \\
\text { Ribeiro } 1896 \\
\end{array}$ & 3 & $1885-1896$ \\
\hline & J. B. Endrizzi \& C & Freire da Silva 1894 & 1 & 1894 \\
\hline & Grande Livraria Paulista: & Ribeiro 1895 & 1 & 1895 \\
\hline & Miguel Melilo: & Ribeiro 1889 & 2 & $1899-1900$ \\
\hline
\end{tabular}

Quadro 16. Casas impressoras de cada gramática em cada década e cada local

Poucas casas impressoras imprimiram mais do que duas gramáticas, são elas: no Rio de Janeiro, a Imprensa Régia, que posteriormente passa a se chamar Tipografia Nacional e que imprime gramáticas ao menos de 1810 a 1863; Francisco Alves, que se destaca pelo grande número de gramáticas e reedições impressas, sobretudo de João Ribeiro, de 1870 ao fim do século; J. G. de Azevedo, que imprimiu quatro gramáticas nas últimas duas décadas do século; em Recife, há a Tipografia do Santos, que imprimiu pelo menos três gramáticas entre o início de 1840 e o início da década 1870; em São Paulo, 
destacam-se a Tipografia Jorge Seckler, entre o fim da década de 1870 e início de 1880, e a Gazeta de Campinas, na década de 1880.

É interessante notar que há pouca fidelidade dos autores com as casas impressoras. Exceto pelos casos de João Ribeiro e Feitosa, que imprimem apenas em uma casa (respectivamente, Francisco Alves (Rio de Janeiro) e Gazeta de Campinas (São Paulo)), todos os outros mudam de casas publicadoras a cada edição de suas gramáticas. Coruja, por exemplo, cujo compêndio tem uma longa vida, publica a primeira edição dele, de 1835, em Porto Alegre, na V. F. Andrade, as edições de, já no Rio de Janeiro, 1846 e 1847, na Tipografia Francesa, a de 1873 na Tipografia Esperança, e, finalmente, a última edição conhecida, já póstuma, de 1891, na Francisco Alves. A mudança de casas publicadoras também se dá quando há pouca diferença de tempo entre as publicações, como é o caso de Costa Duarte, que publica a edição de 1853 com Fl. Fructuoso Ferreira, e, em 1859, a imprime na Tipografia do Frias. Sotero dos Reis, similarmente, imprime em três tipografias diferentes as três edições de sua gramática: em 1866, na Tipografia de B. de Matos, em 1871, na Tipografia de R. d'Almeida \& C., e em 1877, na Livraria de Magalhães.

\section{R5. Escolhas de títulos ao longo do século}

Dada a enorme diversidade de títulos, criamos categorias abstratas antes de analisá-los e comentá-los. Assim, distinguimos cinco grandes tipos de título (as quais já expomos detalhadamente no capítulo 2), a saber: (1) que se iniciam e apresentam apenas o termo 'gramática' - cuja sigla é G; (2) que se iniciam por 'gramática' e contém algum outro termo em seguida, como 'elementar', 'analítica' - cuja sigla é Gx; (3) que não contém o termo 'gramática', como "noções de língua portuguesa" - cuja sigla é X; (4) que não se iniciam por um termo, como 'compêndio', e em seguida apresentam o termo 'gramática' - cuja sigla é Xg; (5) finalmente, que se iniciam por outro termo, como 'compêndio', em seguida apresentam 'gramática' e, finalmente, outro termo, como 'da infância', cuja sigla é Xgx. Todos esses podem ou não ser acompanhados por designações da língua descrita, no caso, o português, como: 'português', 'língua portuguesa' e 'língua nacional', cujas siglas são respectivamente: $p, 1 p$ e ln. Escolhemos a divisão estrutural a fim de observar os sentidos que cada palavra tem na ordenação do título, a qual analisamos adiante. 
Inicialmente, separamos os tipos mais gerais de título por décadas, obtendo os seguintes resultados, em tabela, em que distinguimos o número de gramáticas do número de edições específicas (subescrito), e em gráfico, este último considera somente o número de gramáticas:

\begin{tabular}{|c|c|c|c|c|c|}
\hline Década & $\begin{array}{c}\mathbf{G}[\mathrm{Gp}, \mathrm{Glp}, \\
\mathrm{nGp}, \mathrm{nGlp}]\end{array}$ & $\begin{array}{c}\text { Gx [Gx, } \\
\text { Gpx, Gxlp, } \\
\text { Gxb, Gxp] }\end{array}$ & $\begin{array}{c}\mathbf{X}[\mathrm{X}, \mathrm{Xlp}, \\
\mathrm{Xp}]\end{array}$ & $\begin{array}{c}\text { Xg [Xg, } \\
\text { Xgp, Xglp, } \\
\text { Xgln, Xgn] }\end{array}$ & $\begin{array}{c}\text { Xgx [Xgx, } \\
\text { Xgpx, } \\
\text { Xgxlp] }\end{array}$ \\
\hline 1800 & - & - & - & $1_{1}$ & - \\
\hline 1810 & - & - & - & $3_{1}$ & - \\
\hline 1820 & $1_{1}$ & $1_{1}$ & - & $4_{3}$ & - \\
\hline 1830 & $1_{1}$ & 21 & $1_{1}$ & $4_{3}$ & - \\
\hline 1840 & $1_{1}$ & - & - & $9_{4}$ & $1_{1}$ \\
\hline 1850 & $1_{1}$ & 22 & - & $11_{8}$ & 20 \\
\hline 1860 & 33 & 55 & - & $21_{13}$ & 53 \\
\hline 1870 & $5_{3}$ & $7_{5}$ & 22 & $22_{11}$ & $1_{0}$ \\
\hline 1880 & $11_{8}$ & $19_{11}$ & - & 199 & 33 \\
\hline 1890 & 198 & 55 & - & $9_{3}$ & $2{ }_{1}$ \\
\hline TOTAL & 4226 & $41_{30}$ & 44 & 10358 & 148 \\
\hline
\end{tabular}

Tabela 3. Número de gramáticas de cada tipo de título por década

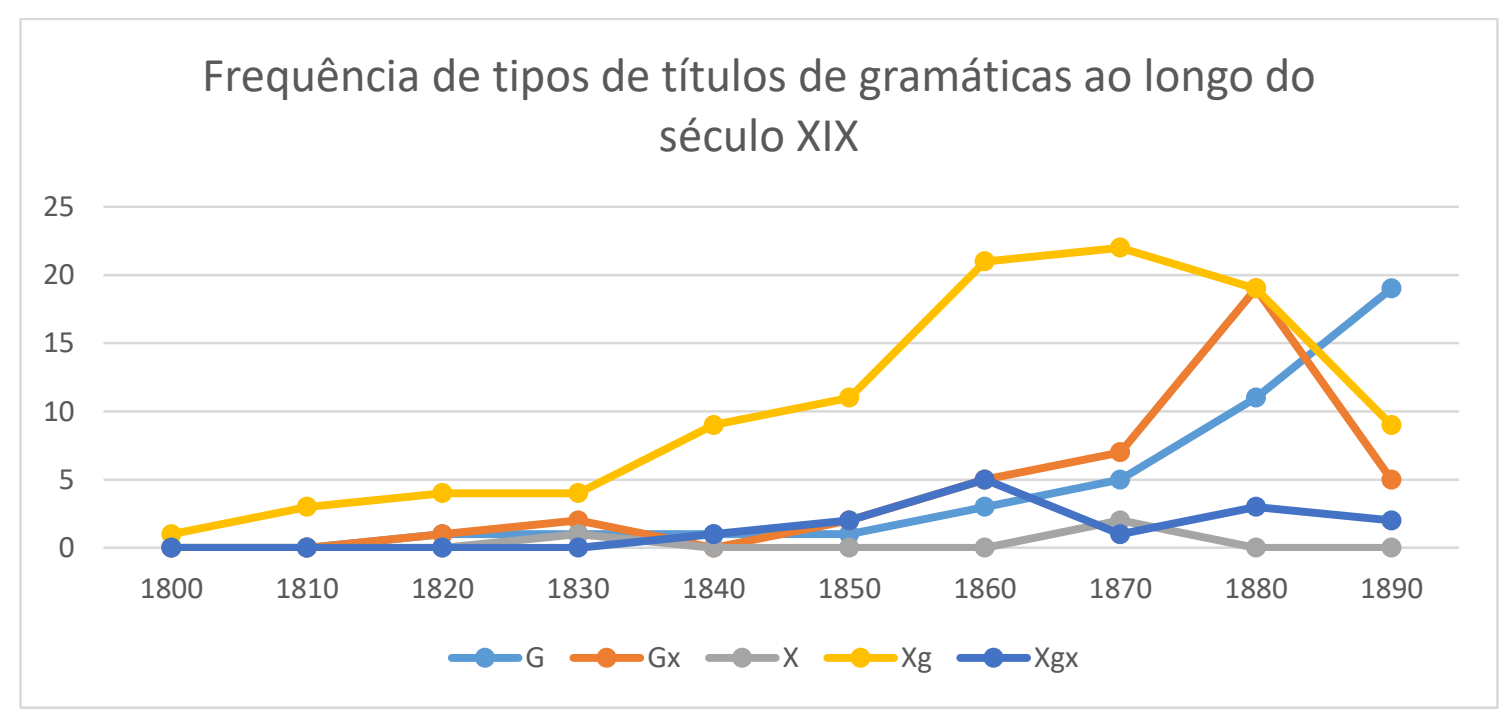

Figura 8. Gráfico de frequência de tipos de títulos ao longo do século

Os títulos de tipo Xg são os mais frequentes até a década de 1880, quando a incidência deles começa a diminuir, ao passo que os títulos de tipo Gx tornam-se os mais comuns, cresce também nessa década o tipo de título G, o qual, por sua vez, em 1890 torna-se o mais comum, dada a queda do tipo Gx. Há poucos títulos dos tipos X e Xgx ao longo de todo o século. 
Adiante, observamos em maior especificidade os títulos de cada tipo e sua frequência ao longo do século. O número de edições específicas está subescrito.

\begin{tabular}{|c|c|c|c|c|c|c|c|c|c|c|c|}
\hline Espécies & Gx Década & $\begin{array}{l}1800 \\
1810 \\
\end{array}$ & 1820 & 1830 & 1840 & 1850 & 1860 & 1870 & 1880 & 1890 & Total \\
\hline \multirow{5}{*}{ Público } & G. primária & - & - & - & - & - & - & - & - & $1_{1}$ & $1_{1}$ \\
\hline & G. da infância & - & - & - & - & - & $1_{1}$ & - & - & - & $1_{1}$ \\
\hline & G. da puerícia & - & - & - & - & - & - & - & $1_{1}$ & $1_{1}$ & $2_{2}$ \\
\hline & G. infantil & - & - & - & - & - & - & - & $1_{1}$ & - & $1_{1}$ \\
\hline & G. das escolas & - & - & - & - & - & - & - & $3_{1}$ & - & $3_{1}$ \\
\hline \multirow{8}{*}{$\begin{array}{l}\text { Método de } \\
\text { exposição }\end{array}$} & G. elementar & - & - & - & - & $1_{1}$ & - & 22 & 74 & - & $10_{7}$ \\
\hline & $\begin{array}{l}\text { G. elementar e } \\
\text { metódica }\end{array}$ & - & - & 21 & - & - & $1_{1}$ & - & - & - & $\mathbf{3}_{2}$ \\
\hline & G. descritiva & - & - & - & - & - & - & - & - & $1_{1}$ & $1_{1}$ \\
\hline & $\begin{array}{l}\text { G. eclético- } \\
\text { rudimentária }\end{array}$ & - & - & - & - & $1_{1}$ & - & - & $1_{0}$ & - & 21 \\
\hline & G. analítica & - & - & - & - & - & 22 & - & 33 & - & 55 \\
\hline & $\begin{array}{c}\text { G. analítica e } \\
\text { explicativa }\end{array}$ & - & - & - & - & - & - & 31 & $2_{0}$ & - & $5_{1}$ \\
\hline & G. prática & - & - & - & - & - & - & - & - & $22_{2}$ & 22 \\
\hline & $\begin{array}{l}\text { G. teórica e } \\
\text { prática }\end{array}$ & - & - & - & - & - & - & $1_{1}$ & $1_{1}$ & - & $1_{1}$ \\
\hline \multirow{4}{*}{$\begin{array}{l}\text { Base } \\
\text { teórica }\end{array}$} & G. filosófica & - & - & - & - & - & - & - & - & - & $1_{1}$ \\
\hline & G. geral & - & - & - & - & - & $1_{1}$ & - & - & - & $1_{1}$ \\
\hline & G. razoável & - & $1_{1}$ & - & - & - & - & - & - & - & $1_{1}$ \\
\hline & G. histórica & - & - & - & - & - & - & $1_{1}$ & - & - & $1_{1}$ \\
\hline
\end{tabular}

Tabela 4. Espécies de títulos Gx e número de ocorrências por década

É notável que a maior parte dos títulos é idiossincrática, isto é, apresenta-se uma única vez. As exceções estão em negrito, são elas: 'gramática da puerícia' (2 edições específicas), 'gramática elementar' (7 edições específicas), 'gramática analítica' (5 edições específicas) e 'gramática prática' (2 edições específicas).

Além disso, há três espécies de título Gx. Há aqueles que explicitam o público a que é direcionado a gramática, como é o caso das gramáticas primária, da infância, da puerícia, infantil e elementar - como é o caso das quatro primeiras, de cima para baixo, que aparecem na tabela. Há também aqueles que dizem respeito à maneira como se dá a exposição do conteúdo de obra, como é o caso das gramáticas 'elementar', 'elementar e metódica', 'descritiva', 'eclético-rudimentária', 'analítica', 'análitica e explicativa', 'prática', 'teórica e prática'. Finalmente, encontramos títulos que enfatizam a base teórica da gramática, como é o caso da 'filosófica', 'geral', 'razoável' e 'histórica'.

\begin{tabular}{|c|c|c|c|c|c|c|c|c|c|c|c|}
\hline X Década & 1800 & 1810 & 1820 & 1830 & 1840 & 1850 & 1860 & 1870 & 1880 & 1890 & Total \\
\hline $\begin{array}{c}\text { Manual ou } \\
\text { método }\end{array}$ & - & - & - & $1_{1}$ & - & - & - & - & - & - & $1_{1}$ \\
\hline
\end{tabular}




\begin{tabular}{|c|c|c|c|c|c|c|c|c|c|c|c|}
\hline Noções & - & - & - & - & - & - & - & $1_{1}$ & - & - & $1_{1}$ \\
\hline Explicador & - & - & - & - & - & - & - & $1_{1}$ & - & - & $1_{1}$ \\
\hline $\begin{array}{c}\text { Manual do } \\
\text { examinando }\end{array}$ & - & - & - & - & - & - & - & $1_{1}$ & - & - & $1_{1}$ \\
\hline
\end{tabular}

Tabela 5. Títulos X e número de ocorrências por década

Todos os títulos desse tipo são idiossincráticos. No caso dos títulos de tipo X, há apenas uma espécie, aquela que explicita a maneira como o conteúdo é exposto ('noções', 'método') e/ou o tipo da obra ('manual', 'explicador', 'manual do examinando'), em geral enfatizando o papel pedagógico da obra.

\begin{tabular}{|c|c|c|c|c|c|c|c|c|c|c|c|}
\hline Xg Década & 1800 & 1810 & 1820 & 1830 & 1840 & 1850 & 1860 & 1870 & 1880 & 1890 & Total \\
\hline Arte & - & $2{ }_{1}$ & $1_{0}$ & $1_{1}$ & $1_{0}$ & 20 & $1_{1}$ & - & - & - & $8_{3}$ \\
\hline $\begin{array}{c}\text { Breve } \\
\text { compêndio }\end{array}$ & - & - & - & - & $22_{1}$ & - & - & $1_{1}$ & - & - & 32 \\
\hline $\begin{array}{c}\text { Breve } \\
\text { explicação }\end{array}$ & - & - & $1_{1}$ & - & - & - & - & - & - & - & $1_{1}$ \\
\hline Compêndio & - & - & $1_{1}$ & 22 & $5_{2}$ & 54 & $10_{5}$ & $11_{3}$ & $4_{1}$ & 31 & $41_{19}$ \\
\hline Curso & - & - & - & - & - & - & $1_{1}$ & - & - & - & $1_{1}$ \\
\hline Elementos & - & - & - & - & - & $1_{1}$ & 22 & - & $3_{2}$ & $3_{2}$ & $9_{7}$ \\
\hline Epítome & $1_{1}$ & $1_{0}$ & - & $1_{0}$ & - & - & - & - & - & - & $3_{1}$ \\
\hline Lições & - & - & - & - & - & - & $1_{1}$ & - & $1_{1}$ & - & $1_{1}$ \\
\hline Noções & - & - & - & - & - & - & - & - & $1_{1}$ & - & $1_{1}$ \\
\hline $\begin{array}{l}\text { Noções de } \\
\text { análise }\end{array}$ & - & - & - & - & - & - & - & - & $1_{1}$ & - & $1_{1}$ \\
\hline $\begin{array}{c}\text { Novo } \\
\text { compêndio de } \\
\text { eloquência }\end{array}$ & - & - & - & - & - & $1_{1}$ & - & - & - & - & $1_{1}$ \\
\hline Novo método & - & - & - & - & - & - & 21 & - & - & - & 21 \\
\hline $\begin{array}{l}\text { Novo sistema } \\
\text { de estudar }\end{array}$ & - & - & - & - & - & - & $1_{1}$ & - & - & - & $1_{1}$ \\
\hline Postilas & - & - & - & - & - & $1_{1}$ & - & $22_{2}$ & - & - & $\mathbf{3}_{3}$ \\
\hline Preliminares & - & - & - & - & - & - & $1_{1}$ & - & - & - & $1_{1}$ \\
\hline $\begin{array}{l}\text { Primeiras } \\
\text { noções }\end{array}$ & - & - & - & - & - & - & - & $1_{1}$ & $1_{0}$ & - & $22_{1}$ \\
\hline $\begin{array}{c}\text { Primeiro / } \\
\text { Segundo / } \\
\text { Terceiro livro }\end{array}$ & - & - & - & - & - & - & - & $22_{2}$ & $1_{1}$ & - & 33 \\
\hline Rascunhos & - & - & - & - & - & - & - & - & $22_{1}$ & - & $2{ }_{1}$ \\
\hline Resumo & - & - & $1_{1}$ & - & - & $1_{1}$ & $22_{1}$ & $2{ }_{1}$ & $1_{1}$ & - & $6_{4}$ \\
\hline $\begin{array}{l}\text { Resumo } \\
\text { explicativo }\end{array}$ & - & - & - & - & $1_{1}$ & - & - & - & - & - & $1_{1}$ \\
\hline Rudimentos & - & - & - & - & - & - & - & 22 & $1_{1}$ & - & 33 \\
\hline Serões & - & - & - & - & - & - & - & - & - & $1_{1}$ & $1_{1}$ \\
\hline Tratado & - & - & - & - & - & - & - & $1_{1}$ & - & - & $1_{1}$ \\
\hline
\end{tabular}

Tabela 6. Espécies de títulos Xg e número de ocorrências por década

A grande maioria dos títulos são idiossincráticos, exceto por 'arte' (3 edições específicas), 'breve compêndio' (2 edições específicas), elementos (7 edições específicas), 'postilas' (3 edições específicas), 'resumo' (4 edições específicas), 
'rudimentos' (3 edições específicas) e o notável 'compêndio' (19 edições específicas). Ademais, no caso dos títulos $\mathrm{Xg}$, há certa similaridade com os títulos $\mathrm{X}$, visto que há apenas uma espécie, aquela que explicita a maneira como o conteúdo é exposto ('breve explicação', 'resumo explicativo', 'novo método', 'noções', 'noções de análise', 'postilas', 'primeiras noções', 'resumo', 'resumo explicativo', 'rudimentos', 'tratado') e o tipo da obra ('arte', 'breve compêndio', 'compêndio', 'curso', 'elementos', 'epítome', 'lições', 'novo compêndio', 'novo sistema de estudar', 'preliminares', 'rascunhos', 'serões'), em geral enfatizando o papel pedagógico da obra.

\begin{tabular}{|c|c|c|c|c|c|c|c|c|c|c|c|}
\hline Espécies & Xgx & 1810 & 1820 & 1830 & 1840 & 1850 & 1860 & 1870 & 1880 & 1890 & Total \\
\hline \multirow[t]{4}{*}{ Base teórica } & $\begin{array}{l}\text { Compêndio - } \\
\text { filosófica }\end{array}$ & - & - & - & $1_{1}$ & 20 & $22_{1}$ & $1_{0}$ & - & - & $5_{2}$ \\
\hline & $\begin{array}{l}\text { Epítome - } \\
\text { filosófica }\end{array}$ & - & - & - & - & - & $1_{1}$ & - & - & - & $1_{1}$ \\
\hline & $\begin{array}{c}\text { Postilas - } \\
\text { geral }\end{array}$ & - & - & - & - & - & $22_{1}$ & - & - & - & $22_{1}$ \\
\hline & $\begin{array}{l}\text { Princípios - g. } \\
\text { histórica e } \\
\text { comparada }\end{array}$ & - & - & - & - & - & - & - & $1_{1}$ & - & $1_{1}$ \\
\hline \multirow[t]{2}{*}{ Público } & $\begin{array}{l}\text { Pequena - da } \\
\text { infância }\end{array}$ & - & - & - & - & - & - & - & $1_{1}$ & - & $1_{1}$ \\
\hline & $\begin{array}{l}\text { Primeira - da } \\
\text { infância }\end{array}$ & - & - & - & - & - & - & - & - & $2{ }_{1}$ & 21 \\
\hline Exposição & $\begin{array}{l}\text { Método - } \\
\text { analítica }\end{array}$ & - & - & - & - & - & - & - & $1_{1}$ & - & $1_{1}$ \\
\hline
\end{tabular}

Tabela 7. Espécies de títulos Xgx e número de ocorrências por década

Apenas 'compêndio da gramática filosófica' aparece mais de uma vez, em 2 edições específicas. Quanto ao sentido dos termos, em títulos Xgx, encontramos as mesmas espécies encontradas no tipo $\mathrm{Gx}$ no que diz respeito ao $\mathrm{x}$ após o termo 'gramática', a saber: base teórica ('filosófica', 'geral', 'histórica e comparada'), público ('infância') e método de exposição ('analítica'). O X inicial, por outro lado, apresenta sempre aspectos relativos à maneira de exposição dos conteúdos da obra ou tipo de texto ('compêndio', ‘postilas', 'princípios', ‘pequena', 'primeira', ‘método'). É notável, portanto, que os termos que vêm após 'gramática' tendem a especificar a gramática quanto a três aspectos que, como acabamos de ver, são base teórica, público e modo de exposição de conteúdo. Os termos que vêm após o termo 'gramática' ou os títulos em que o termo 'gramática' não aparece significam apenas o modo de exposição de conteúdo e/ou o tipo tradicional de texto.

A maior parte dos títulos que tem termos com significado relativo a base teórica, de Gx e Xgx, referem-se à uma base filosófica (3 edições especificas), geral (2 edições 
específicas), razoável (1 edição específica), as quais estariam relacionadas à grammaire générale, que, como vimos no item 4.1, considerava a linguagem uma expressão do pensamento e não raro usava conceitos próprios da lógica e, portanto, da filosofia para basear suas técnicas de análise. Os títulos são uma evidência da grande influência que essa tradição na gramaticografia brasileira até, pelo menos, 1880. Os outros dois títulos com termos cujos significado refletem uma base teórica aproximam-se da gramáticas histórica e comparativa, visto que um chama-se 'gramática histórica' e outro 'princípios de gramática histórica e comparada', ambos do final do século - respectivamente das décadas de 1870 e 1880 -, momento em que esse modelo de descrição linguística ganhava estima no país (cf. item 1.5).

Ao fazer essa distribuição em cinco tipos de título e observar sua incidência na produção gramatical brasileira nas tabelas acima, pudemos, primeiramente, observar que a grande maioria dos termos " $\mathrm{X}$ ", estejam elas em títulos do tipo [Gx], [X], [XgX], são idiossincráticas, isto é, aparecem em um único título. Este é o caso dos seguntes títulos: do tipo [Gx], 'g. primária', 'g. da infância', 'g. da puerícia', 'g. das escolas', 'g. prática', 'g. filosófica', 'g. geral', 'g. razoável', 'g. descritiva', 'g. eclético-rudimentária'; do tipo [X], 'breve explicação', 'curso', 'diálogo', 'epítome', 'lições', 'noções', ‘novo método', 'novo sistema de estudar', 'postilas', 'preliminares', 'princípios', 'rascunhos'; e do tipo [Xgx] 'compêndio da g. filosófica', 'epítome da g. filosófica', 'postilas de g. geral', 'primeira g. da infância', 'método da g. analítica'.

Há, entretanto, tipos de título que se repetem com alguma frequência. Do tipo $[\mathrm{Xg}]$, temos, por exemplo, (em ordem de mais frequente para menos frequente): 'compêndio' (41 gramáticas, 19 edições específicas), 'elementos' (9 gramáticas, 7 edições específicas), 'resumo' (6 gramáticas, 4 edições específicas) e 'arte' (8 gramáticas, 3 edições específicas), 'rudimentos' (3 gramáticas e edições específicas), e "breve compêndio" (3 gramáticas, 2 edições especificas). A frequência de Xg-compêndio é tão alta que chega a ser similar àquela do tipo G (38 gramáticas, 24 edições específicas) (que inclui Gp. Glp. nGp, nGlp). Notamos, aliás, que há certa alternância de predominância entre esses dois tipos de título ao longo do século, a qual demonstramos nos gráficos adiante: 


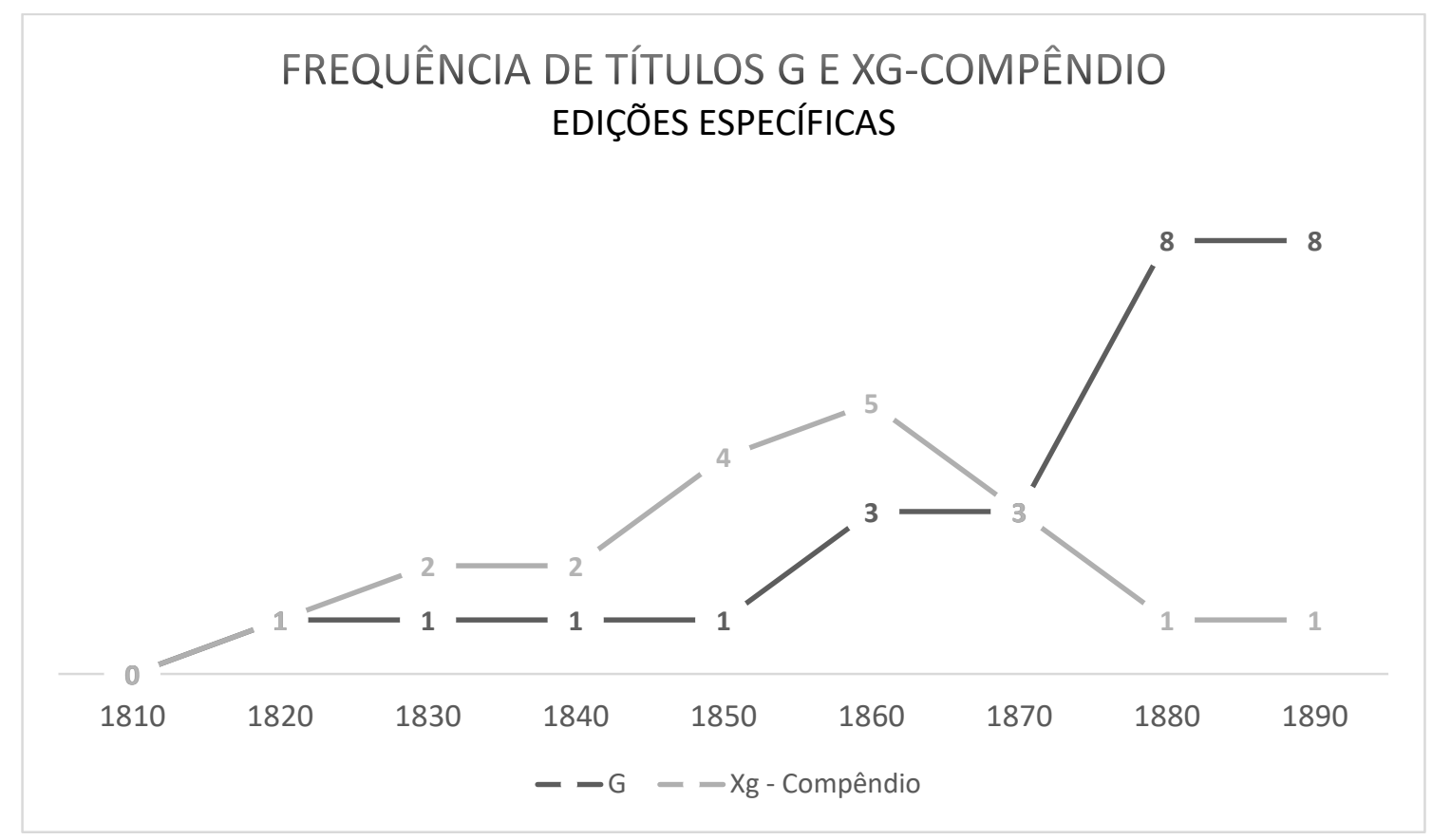

Figura 9. Gráfico de frequência de títulos G e XG-compêndio em edições específicas

Considerando apenas edições especificas, até a década de 1840, a frequência dos dois tipos de título é similar; na década de 1850 há um grande crescimento de Xgcompêndio, que se mantém até a década de 1860, a partir de então um número cada vez menor de gramáticas apresenta no título a palavra "compêndio", que aparece em uma única gramática nos dois últimos decênios do século. O título do tipo G, por outro lado, não era frequente no início do século, tendo uma gramática por década entre 1810 e 1850. Em 1860 passa a haver mais gramáticas com esse tipo de título, em 1870 tem o mesmo número de gramáticas de XG-compêndio publicadas, 3. No decênio de 1880, momento de decréscimo do título XG-compêndio, há amplo crescimento do número de gramáticas com título G. Enfim, na última década do século diferentemente do acontece com a produção gramatical brasileira, que descresce, o título G torna-se mas frequente.

As tendências de aumento e queda são similares quando tratamos de todas as edições, entretanto, por conta da durabilidade das reedições de Xg-compêndio, a sua queda ocorre apenas na década de 1880, quando também o número de títulos $\mathrm{G}$ dobra em relação à década anterior; finalmente, vemos que considerando todas as edições, há um grande crescimento do número de publicações com títulos de tipo $\mathrm{G}$ no último decênio do século, por conta da durabilidade de reedições das décadas de 1870 e 80 . 


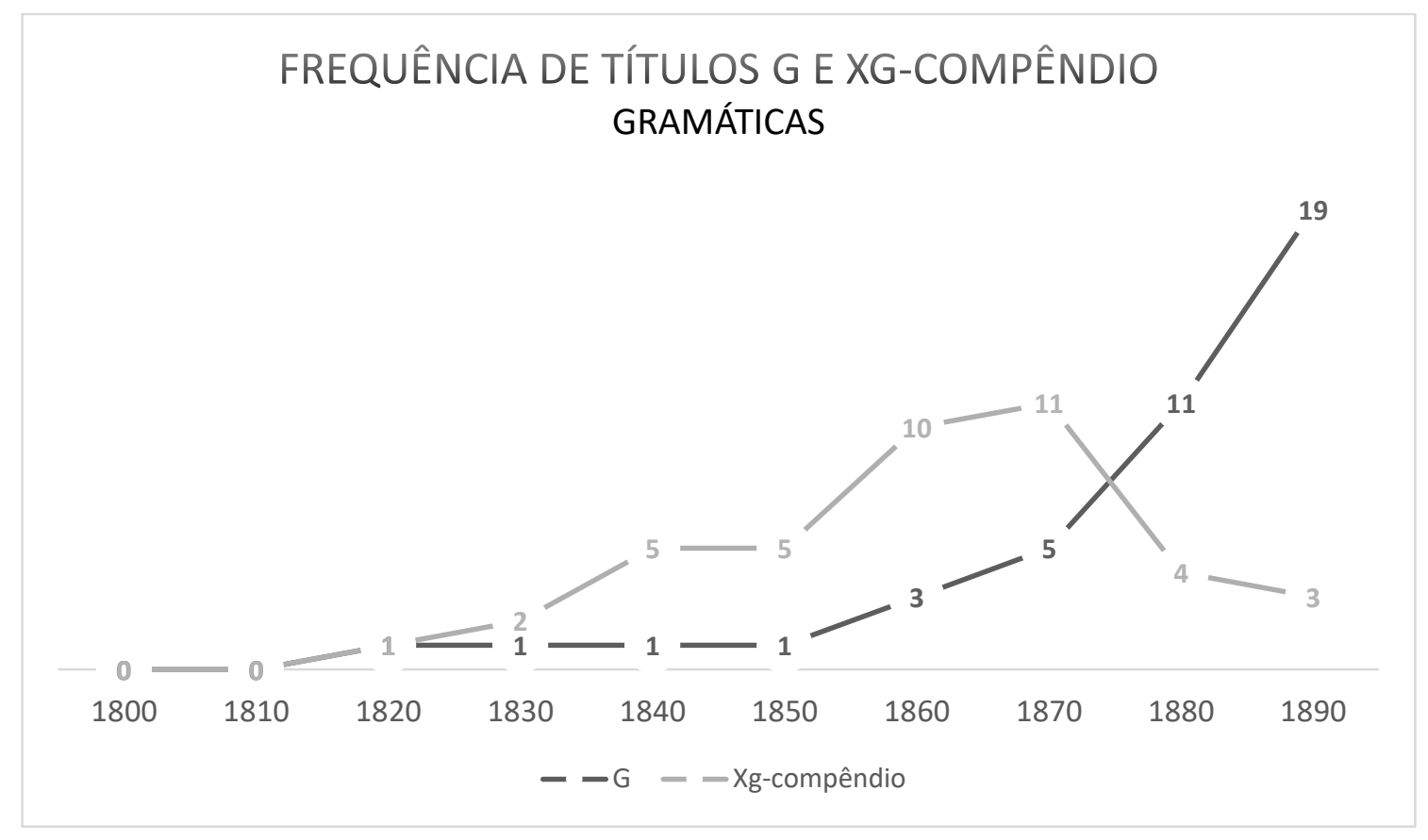

Figura 10. Gráfico de frequência de títulos G e Xg-compêndio em gramáticas

É difícil dizer qual seria a razão da alternância de títulos, mas nos perguntamos em que medida isso poderia estar atrelado ao público-alvo das obras. Para tanto, mais adiante, no item R6, analisamos as relações que pode haver entre os títulos e o públicoalvo.

Ademais, quanto aos títulos, ressaltamos outros dois pontos. Nem todos eles apresentam uma referência à língua portuguesa, deixando-a implícita, e outras obras apresentam como uma espécie de subtítulo algum complemento ao seu título que parece ser uma espécie de publicidade da obra, por falar de alguns de seus atributos.

Vinte e quatro gramáticas, das quais dezenove são títulos, não fazem referência à língua portuguesa em seus títulos, além disso, todas elas contêm um termo " $\mathrm{x}$ " no título, e foram publicadas entre 1864 e 1897. Por seu início tão adiantado no século, pensamos que possivelmente tal referência estava implícita. No quadro adiante, apresentamos os títulos:

\begin{tabular}{|c|c|}
\hline Autor Ano & Título \\
\hline Murici 1864 & Grammatica Geral \\
\hline Pinheiro 1864 & Grammatica da infância, dedicada aos senhores professores de instrucção \\
& primaria \\
\hline Castilho 1864 & $\begin{array}{c}\text { Preliminares de grammatica, dispostos em leitura apropriada para exercitar a } \\
\text { intelligencia dos principiantes e preparal-os para o estudo desta doutrina em obras } \\
\text { de maior desenvolvimento, representando o systema grammatical figurado por } \\
\text { meio da arvore da sciencia }\end{array}$ \\
\hline $\begin{array}{c}\text { Ibirapitanga } \\
1865\end{array}$ & Compendio grammatical, reduzido a dialogo, para uso dos principiantes do ensino \\
& das primeiras lettras \\
\hline
\end{tabular}




\begin{tabular}{|c|c|}
\hline $\begin{array}{l}\text { Freire da Silva } \\
\text { \& Leal } 1871\end{array}$ & $\begin{array}{c}\text { Noções de prosódia e orthographia para uso da infancia que frequenta as aulas do } \\
\text { primeiro grau do instituto santista, intercaladas de um resumo da etymologia e } \\
\text { syntaxe, extrahido da Grammatica portugueza de Francisco Sotero dos Reis pelo } \\
\text { doutor Pedro Nunes Leal. }\end{array}$ \\
\hline Walter 1879 & Segundo livro de grammatica, composto segundo o methodo Marcet \\
\hline Walter 1879 & Terceiro livro de grammatica, composto segundo o methodo Marcet \\
\hline Souza 1879 & $\begin{array}{l}\text { Tratado de analyse phonetica grammatical, syntaxica e lógica com seus } \\
\text { desenvolvimentos e applicações, seguido de um catalogo de palavras } \\
\text { diversificaveis em significação, para complemento do mesmo assumpto }\end{array}$ \\
\hline Walter 1881 & Primeiro livro de grammatica, composto segundo o methodo Marcet \\
\hline $\begin{array}{l}\text { Andrade e Silva } \\
\qquad 1882\end{array}$ & $\begin{array}{l}\text { Grammatica elementar e lições progressivas de composição, adoptada nas } \\
\text { províncias do Rio Grande do Sul, Santa Catharina, Paraná, S. Paulo, Rio de } \\
\text { Janeiro e municipio neutro. Terceira edição, melhorada e consideravelmente } \\
\text { augmentada com novos exercicios de lexicologia, orthographia e linguagem; } \\
\text { exercicios de invenção, estylo e sobre synonymos }\end{array}$ \\
\hline Feitosa 1882 & $\begin{array}{c}\text { Grammatica das escolas, dedicada à provincia de S. Paulo sobre o plano de Pierre } \\
\text { Larousse. }\end{array}$ \\
\hline $\begin{array}{c}\text { Costa e Cunha } \\
1883 \\
\end{array}$ & Principios de Grammatica Historica e Comparada \\
\hline Ribeiro 1885 & A grammatica analytica \\
\hline Carvalho 1885 & Methodo de grammatica analytica \\
\hline $\begin{array}{c}\text { Boscoli \& } \\
\text { Pacheco1888 }\end{array}$ & Noções de analyse grammatical, phonetica, etymologica e syntaxica \\
\hline Lacerda $188 ?$ & $\begin{array}{c}\text { Pequena grammatica da infancia composta para uso das escolas primarias (Nova } \\
\text { edição) }\end{array}$ \\
\hline $\begin{array}{l}\text { Costa e Cunha } \\
1895\end{array}$ & $\begin{array}{l}\text { Grammatica Pratica do } 1^{\circ} \text { Gráo contendo muito e variados exercicios praticos de } \\
\text { linguagem, lexiologia, syntaxe e recitação, regras de composição etc. } 4 \text { a edição. } \\
\text { Organisada de acordo com o novo plano de ensino primario do } 1^{\circ} \text { gráo. }\end{array}$ \\
\hline Alves 1896 & $\begin{array}{c}\text { Pequena grammatica da infancia composta para uso das escolas primarias (Nova } \\
\text { edição) }\end{array}$ \\
\hline
\end{tabular}

Quadro 17. Gramáticas em cujo título não aparece referência à língua portuguesa

Exceto por quatro títulos todos explicitam algum objetivo pedagógico, seja pelo público e grau de ensino a que são destinados, seja pelo método que seguem (Método Marcet, por exemplo), e, por terem o título em língua portuguesa, possivelmente são gramáticas dessa língua. Os quatro títulos que não têm essas informações são Grammatica Geral, Principios de Grammatica Historica e Comparada, Grammatica Analytica e Methodo de Grammatica Analytica. Os dois primeiros, sobretudo, podem tratar não apenas do português, mas de um grupo de línguas. Já os dois últimos carregam o termo " $\mathrm{x}$ " 'analítica', que não era incomum no século, tendo sido utilizado por outras quatro gramáticas da época que faziam referência ao português em seus títulos.

\section{R6. Subtítulos: formato, conteúdo e objeto das gramáticas}

São 39 as gramáticas e 30 as títulos ou títulos que apresentam algum um subtítulo que parece ser uma espécie de publicidade da obra, por falar de alguns de seus atributos, 
como aspectos do formato, conteúdo e objeto das gramáticas. No quadro adiante, os separamos por tipos:

\begin{tabular}{|c|c|c|}
\hline Tipos & Autor Ano & Título \\
\hline \multirow{7}{*}{$\begin{array}{l}\text { Conteúdo da } \\
\text { obra / } \\
\text { Programa de } \\
\text { Estudo }\end{array}$} & Tilbury 1823 & $\begin{array}{c}\text { Breve explicação sobre a grammatica, contendo quanto basta e } \\
\text { o que é de absoluta necessidade saber da grammatica } \\
\text { portugueza para aprender qualquer outra lingua }\end{array}$ \\
\hline & Pimentel 1875 & $\begin{array}{r}\text { Explicador de portuguez em conformidade com o programma } \\
\text { do } 1^{\circ} \text { anno do imperial collegio de Pedro II }\end{array}$ \\
\hline & Ribeiro 1887 & $\begin{array}{c}\text { Exames de portuguez. Lições de grammatica portugueza, } \\
\text { coordenadas segundo o programma de } 1887 .\end{array}$ \\
\hline & $\begin{array}{c}\text { Pacheco \& } \\
\text { Lameira } 1887\end{array}$ & $\begin{array}{c}\text { Noções da grammatica portugueza de accordo com o } \\
\text { programma official para os exames geraes de preparatorios do } \\
\text { corrente anno }\end{array}$ \\
\hline & Lima 1888 & $\begin{array}{l}\text { Resumo da grammatica portugueza. Pontos de portuguez, } \\
\text { segundo o novo programma de exames. }\end{array}$ \\
\hline & Vieira 1889 & $\begin{array}{c}\text { Grammatica elementar da lingua portugueza, dedicada á } \\
\text { instrucção primaria e organisada de accordo com o } \\
\text { programma vigente da instrucção primaria }\end{array}$ \\
\hline & Maciel 1887 & Grammatica analytica baseada nas doutrinas modernas \\
\hline \multirow{8}{*}{$\begin{array}{c}\text { Gramáticos, } \\
\text { autores ou } \\
\text { doutrinas em } \\
\text { que a obra se } \\
\text { baseia }\end{array}$} & Loureiro 1828 & $\begin{array}{c}\text { satisfazendo às condições do actual programma } \\
\text { Grammatica razoavel da lingua portugueza, composta segundo } \\
\text { a melhor doutrina dos grammaticos antigos e modernos de } \\
\text { differentes idiomas }\end{array}$ \\
\hline & Lopes 1834 & $\begin{array}{c}\text { Compendio de grammatica da lingua portugueza ordenado } \\
\text { segundo a doutrina dos melhores grammaticos }\end{array}$ \\
\hline & $\begin{array}{l}\text { Albuquerque } \\
1846 \\
\end{array}$ & $\begin{array}{c}\text { Compendio de grammatica portugueza, extrahido de diversos } \\
\text { autores e offerecido a seus alumnos }\end{array}$ \\
\hline & Passos 1848 & $\begin{array}{c}\text { Compendio da grammatica portugueza pelo methodo analytico, } \\
\text { recopilado especialmente das grammaticas de Moraes } \boldsymbol{e} \\
\text { Constancio, e accommodado á intelligencia dos meninos } \\
\text { dedicado á mocidade brazileira }\end{array}$ \\
\hline & Marques 1875 & $\begin{array}{c}\text { Grammatica elementar da lingua portugueza extrahida dos } \\
\text { melhores auctores }\end{array}$ \\
\hline & Santos 1879 & $\begin{array}{c}\text { Grammatica elementar da lingua portugueza extrahida dos } \\
\text { melhores auctores }\end{array}$ \\
\hline & Boscoli 1893-4 & $\begin{array}{l}\text { Grammatica portugueza: estudo raciocinado segundo os } \\
\text { principaes hodiernos da sciencia da linguagem. }\end{array}$ \\
\hline & Maciel 1895 & Grammatica descriptiva baseada nas doutrinas modernas \\
\hline \multirow{2}{*}{$\begin{array}{c}\text { Sistema ou } \\
\text { teoria em que } \\
\text { se baseia a } \\
\text { obra } \\
\end{array}$} & Andrade 1856 & $\begin{array}{c}\text { Novo compêndio de eloqüência grammatical da lingua } \\
\text { portugueza por systema philosophico }\end{array}$ \\
\hline & $\begin{array}{l}\text { Sotero dos Reis } \\
1866\end{array}$ & $\begin{array}{c}\text { Grammatica portugueza, accommodada aos principios geraes } \\
\text { da palavra, seguidos de immediata applicação pratica, } \\
\text { dedicada ao sr. Dr. Pedro Nunes de Leal }\end{array}$ \\
\hline \multirow{3}{*}{$\begin{array}{l}\text { Modo de } \\
\text { apresentação } \\
\text { do conteúdo }\end{array}$} & Barker 1860 & $\begin{array}{c}\text { Grammatica da lingua portugueza em forma de dialogo, que } \\
\text { para intelligencia da orthographia contem o que é } \\
\text { absolutamente indipensavel, etc. }\end{array}$ \\
\hline & Rubim 1860 & $\begin{array}{c}\text { Novo methodo da grammatica portugueza composto em verso } \\
\text { rimado, approvado e adoptado para as aulas da provincia do } \\
\text { Ceará e pelo Conselho director da instrucção publica da } \\
\text { mesma provincia. }\end{array}$ \\
\hline & Ortiz 1862 & $\begin{array}{l}\text { Novo systema de estudar a grammatica portugueza por meio de } \\
\text { memória, intelligencia e analyse, ajudando-se mutuamente. }\end{array}$ \\
\hline
\end{tabular}




\begin{tabular}{|c|c|c|}
\hline & Koeffer 1863 & $\begin{array}{c}\text { Resumo da grammatica nacional, adequado ao ensino } \\
\text { methodico dos principiantes }\end{array}$ \\
\hline & Castilho 1864 & $\begin{array}{l}\text { Preliminares de grammatica, dispostos em leitura apropriada } \\
\text { para exercitar a intelligencia dos principiantes e preparal-os } \\
\text { para o estudo desta doutrina em obras de maior } \\
\text { desenvolvimento, representando o systema grammatical } \\
\text { figurado por meio da arvore da sciencia. }\end{array}$ \\
\hline & $\begin{array}{l}\text { Ibirapitanga } \\
1865 \\
\end{array}$ & $\begin{array}{c}\text { Compendio grammatical, reduzido a dialogo, para uso dos } \\
\text { principiantes do ensino das primeiras lettras }\end{array}$ \\
\hline & Almeida 1866 & $\begin{array}{c}\text { Elementos de grammatica portugueza segundo um systema } \\
\text { mnemônico }\end{array}$ \\
\hline & Morais 1869 & $\begin{array}{c}\text { Grammatica analytica da lingua portugueza, ensinada por } \\
\text { meio de quadros analyticos, methodo facilimo para aprender a } \\
\text { lingua }\end{array}$ \\
\hline & Caneca 1876 & $\begin{array}{l}\text { Breve compêndio de grammatica portugueza, organisado em } \\
\text { fôrma systematica, com adaptação á capacidade dos alumnos }\end{array}$ \\
\hline & $\begin{array}{l}\text { Walter } 1879 \text { e } \\
1881 \\
\end{array}$ & $\begin{array}{c}\text { Primeiro, Segundo e Terceiro livro de grammatica, composto } \\
\text { segundo o methodo Marcet }\end{array}$ \\
\hline & Feitosa 1882 & $\begin{array}{c}\text { Grammatica das escolas, dedicada à provincia de S. Paulo } \\
\text { sobre o plano de Pierre Larousse. }\end{array}$ \\
\hline $\begin{array}{c}\text { Material } \\
\text { linguístico } \\
\text { sobre o qual se } \\
\text { debruça a obra }\end{array}$ & $\begin{array}{l}\text { Sotero dos Reis } \\
1862\end{array}$ & $\begin{array}{c}\text { Postillas da grammatica geral applicada á lingua portugueza: } \\
\text { pela analyse dos classicos, ou guia para a construcção } \\
\text { portugueza }\end{array}$ \\
\hline
\end{tabular}

Quadro 18. Diferentes tipos de subtítulo

Os conteúdos que seguem programas de estudos ou de exames surgem apenas no último quartel do século, ainda que, segundo Razzini (2000), os Programas de Ensino do Colégio Pedro II iniciem-se em $1850^{83}$. São seis obras destinadas a diferentes programas, Ribeiro, Pacheco \& Lameira e Maciel de 1887 e ainda, o menos conhecido de acordo com as revisões dessa produção (cf. item 1.5), Lima de 1888 têm conteúdo relativo ao Programa de Estudo para exames do Colégio Pedro II, escrito em 1887, esse Programa referia-se aos exames para o ensino superior, sendo ensinado, portanto, no ensino secundário.

Já as gramáticas de Pimentel (1875) e Vieira (1889) estão de acordo com Programas de Ensino da instrução primária, os quais, pela distância temporal de publicação das obras, devem ser programas diferentes. Tilbury (1823), por sua vez, explicita que sua Breve explicação sobre a grammatica contém o que é de absoluta necessidade saber de gramática portuguesa para aprender qualquer outra língua, explicitando, portanto, que seu objetivo não é exatamente o de ensinar a língua

\footnotetext{
${ }^{83}$ É curioso, ademais, que Razzini cite nos primeiros programas a Grammatica da Lingua Portugueza, de Cyrillo Dilermando, em diversos programas ( $1^{\circ}$ ano de: $\left.1858,1860,1865\right)$, a Grammatica Portugueza de Manoel Olimpio Rodrigues da Costa $\left(1^{\circ}\right.$ ano de: $\left.1877,1881,1882\right)$, a Grammatica Portugueza de Julio Ribeiro $\left(2^{\circ}, 3^{\circ}, 4^{\circ}\right.$ e $5^{\circ}$ anos de 1882$)$, a Grammatica Portugueza, curso médio de João Ribeiro ( $1^{\circ}$ ano de 1892 , de 1893 e de 1897), a Grammatica Portugueza, cuso superior de João Ribeiro ( $2^{\circ}$ ano de 1892 , de 1893 e de 1897), das quais não tivemos indicações no subtítulo referente aos Programas.
} 
portuguesa, mas permitir que outras línguas sejam aprendidas por meio da apreensão de sua gramática.

É notável modo de apresentação do conteúdo tenha tido tanto destaque na década 1860, mesma década que tem um grande aumento na produção gramatical, visto que ela mais do que dobra em relação ao que havia sido publicado até 1850. Como vimos, Barker (1860) e Ibirapitanga (1865) escrevem suas gramáticas em forma de diálogo; Rubim (1860) em verso rimado; Ortiz (1862) apresenta um novo sistema de estudar a gramática portuguesa por meio de memória, inteligência e análise; Koeffer (1863) escreve uma gramática adequada ao ensino metódico de principiantes; Castilho (1864) escreve preliminares de gramática dispostos em leitura apropriada para exercitar a inteligência dos principiantes e prepará-los para o estudo dessa doutrina em obras de maior desenvolvimento, representando o sistema gramatical figurado por meio da árvore da ciência; Almeida (1866) faz seus elementos de gramática segundo um sistema mnemônico; Morais (1869) ensina gramática da língua portuguesa por meio de quadros analíticos (o qual, diz ele, é um método facílimo para aprender a língua); o Breve Compêndio de Caneca, escrito, em verdade, entre 1817 e 19, mas publicado apenas em 1876, é organizado em forma sistemática, com adaptação à capacidade dos alunos; Walter e Feitosa seguem, respectivamente, o método de Marcet, possivelmente de conversações ${ }^{84}$, e o plano de Larousse, que não soubemos especificar.

Quanto às gramáticas, autores ou doutrinas em que a obra se baseia, no final do século, (Maciel 1887, Boscoli 1893-4, Maciel 1895) observa-se que a noção de modernidade e atualidade das gramáticas e doutrinas ganham destaque. No começo do século (Loureiro 1828), em oposição, fala-se da doutrina de gramáticos antigos e modernos, ou simplesmente de "melhores gramáticos" (Lopes 1836) ou "melhores autores" (Albuquerque 1846, Marques 1875, Santos 1879). Na metade do século, Passos, por sua vez, explicita os gramáticos em que se inspira, Morais Silva e Constâncio ${ }^{85}$.

\footnotetext{
${ }^{84}$ Jane Haldimand Marcet (1769-1858) foi autora britânica que escreveu uma série de textos científicos, em geral com o título de Conversations, como é o caso dos livros Conversations on Chemistry (1806), Conversations on Political Economy (1816), Conversations on Vegetal Phisiology (1829), entre outros. Eram livros escritos em forma de diálogo que procuravam levar dar informações básicas do tema aos leitores a fim de que pudessem compreender o assunto (cf. Baldinato \& Porto 2009)

${ }^{85}$ Antonio Morais Silva (1771- 1823), como vimos, é gramático brasileiro, nascido no Rio de Janeiro, e seu Epitome da Grammatica Portugueza é analisado neste trabalho. Francisco Solano Constâncio (1777-1846) é gramático português, nascido em Lisboa, cuja Gramática Analítica da língua portuguesa (1831) é dada por Schäfer-Prieß (2002) como a obra portuguesa que estaria entre a grammaire générale e o método histórico-comparativo.
} 
Em relação ao sistema ou teoria que baseiam a obra, Andrade (1856) afirma no título de sua obra que seu compêndio de eloquência gramatical é feito sob o sistema filosófico; Sotero dos Reis (1866) explicita que sua gramática portuguesa está acomodada aos princípios gerais da palavra.

Finalmente, quanto ao material linguístico sobre o qual a gramática se debruça, apenas Sotero dos Reis é realmente claro quanto a isso, afirmando que suas Postillas de grammatica geral aplicada á língua portugueza tem análise de textos clássicos.

\section{R7. Subtítulos: público-alvo e dedicatórias}

Além dos aspectos que observamos nos títulos, as obras têm subtítulos que explicitam a que contexto pretendem se destinar, seu público-alvo, ou, por vezes, são dedicadas em subtítulo, a alguma pessoa, a qual em geral tem algum cargo institucional. Neste item, além de observar os diferentes tipos de subtítulos das obras, também os relacionamos com seus títulos e com a região em que são publicadas.

Das 204 gramáticas, 107 apresentam subtítulos dessa maneira. Reunimos essas informações em tipos, sejam eles simples, porque apresentam apenas uma unidade para o público-alvo ou dedicatória, sejam eles complexos, porque apresentam mais de uma unidade, dando mais informações sobre a que se destina a obra. Todos os tipos e suas siglas encontram-se no Capítulo 2, mas podem também ser observados no quadro adiante, já com análise dos dados que temos. Nesse quadro, apresentamos a distribuição das obras segundo seus subtítulos, os quais apresentamos na coluna à direita, junto com a referência das gramáticas que os apresentam, indicando quando são reedições. 


\begin{tabular}{|c|c|c|c|}
\hline Sigla & Tipo & $\mathbf{N}^{\circ}$ & Subtítulos \\
\hline A & Alunos & $16_{5}$ & $\begin{array}{l}\text { - Para uso de seus discípulos (Fortes } 1810 \text { e todas reedições } 1816 \text {, } \\
1825,1844,1851,1855,1862) \\
\text { - Para uso dos meninos (reedição de Morais Silva 1832) } \\
\text { - Oferecido a seus alunos (Albuquerque 1846) } \\
\text { - Coligidos para uso de seus alumnos (Graça 1857) } \\
\text { - Com adaptação á capacidade dos alunos (Caneca 1876) } \\
\text { - Para uso de alunos de humanidades, que frequentam a aula de } \\
\text { portugues (algumas reedições de Freire da Silva 1879, 1886, 1891) } \\
\text { - Examinando de português (Costa e Cunha 1883) }\end{array}$ \\
\hline B & $\begin{array}{l}\text { Instrução } \\
\text { Primária }\end{array}$ & 1211 & $\begin{array}{l}\text { - Para uso das escolas de instrucção primaria (Lopes 1845) } \\
\text { - Para uso das escholas primarias (Susano 1851) } \\
\text { - Resumido para uso das escolas de primeiras lettras (Cajá 1854) } \\
\text { - Para uso das escolas de primeiras lettras (Passo 1855 e reedição de } \\
\text { 1871) } \\
\text { - Para uso das aulas de ensino primario (Tilbault 1862) } \\
\text { - Instrucção Primária (Castilho 1864) } \\
\text { - Adaptado ao ensino nas aulas de instrucção primaria (Taylor 1871) } \\
\text { - 1ªnno de português (Ribeiro 1894) } \\
\text { - Para uso das escolas primárias (Luz 1896) } \\
\text { Gramática Primária (Brito 1899) }\end{array}$ \\
\hline $\mathrm{C}$ & $\begin{array}{c}\text { Curso } \\
\text { posteriores } \\
\text { ao primário: } \\
\text { Médio; } 2^{\circ} \\
\text { ano; Curso } \\
\text { Superior; } 3^{\circ} \\
\text { ano }\end{array}$ & 83 & $\begin{array}{l}\text { - Curso médio. } 2 .^{\circ} \text { anno de Portuguez (Ribeiro 1888) } \\
\text { - Curso superior. } 3 .^{\circ} \text { anno de Portuguez (Ribeiro 1888) } \\
\text { - } 3^{\circ} \text { anno (reedições Ribeiro 1889, 1891, 1893, 1894, 1898) } \\
\text { - Curso superior (Alves 1895) }\end{array}$ \\
\hline $\mathrm{D}$ & Regional & $4 / 3$ & $\begin{array}{l}\text { - Adoptada nas províncias do Rio Grande do Sul, Santa Catharina, } \\
\text { Paraná, S. Paulo, Rio de Janeiro e município neutro (Andrade e Silva } \\
\text { 1882). } \\
\text { - Dedicada à província de São Paulo (Feitosa } 1882 \text { e todas as reedições } \\
\text { 1883, 1886). }\end{array}$ \\
\hline E & Nacional & $1_{1}$ & - Composta e offerecida aos brazileiros (Massa 1888) \\
\hline $\mathrm{F}$ & Institucional & 84 & $\begin{array}{l}\text { - Composta e offerecida à Sociedade Promotora da Instrucção, na } \\
\text { corte do Brazil (Soares 1835) } \\
\text { - Obra adoptada pelo conselho de instrucção publica (Silveira } 1855 \text { e } \\
\text { reedicões } 1862,1872,1884 \text {; Soares } 1868 \text { ) } \\
\text { - Alunos do mesmo estabelecimento } \\
\text { - Obra adoptada pelo governo imperial para uso das escolas } \\
\text { regimentaes do exercito e para o ensino dos aprendizes artilheiros. } \\
\text { - Para uso dos gymnasios, lyceus e escolas normaes (Pacheco \& } \\
\text { Lameira 1894) } \\
\text { - Adoptada no Gymnasio Nacional, Escola Normal, Collegio Militar, } \\
\text { Collegio Abilio, Collegio Moss (reedição Gomes 1895) }\end{array}$ \\
\hline G & $\begin{array}{l}\text { Programa } \\
\text { Institucional } \\
87\end{array}$ & $44_{4}$ & $\begin{array}{l}\text { - Satisfazendo às conduções do actual programma (Maciel 1887) } \\
\text { - De accordo com o programma oficial para os exames geraes de } \\
\text { preparatorios do corrente anno (Pacheco \& Lameira 1887) } \\
\text { - Lições coordenadas segundo o programma de } 1887 \\
\text { - Segundo o novo programma de exames (Lima 1888) }\end{array}$ \\
\hline $\mathrm{H}$ & $\begin{array}{c}\text { Pessoa } \\
\text { (dedicatória) }\end{array}$ & $3 / 1$ & $\begin{array}{l}\text { - Dedicada ao sr. Dr. Pedro Nunes de Leal (Sotero dos Reis } 1866 \text { e } \\
\text { reedições } 1871 \text { e 1877) }\end{array}$ \\
\hline I & Professor & & \\
\hline
\end{tabular}

${ }^{86}$ Não sabemos, porém, de que estabelecimento se trata, pois não tivemos indicações que o especificassem.

87 Já falamos de Programas Institucionais quando consideramos os títulos das obras, porque eles explicitavam um tipo de conteúdo. Quando os analisamos os Programas nesta seção, temos em conta que eles tinham um público-alvo, como alunos de uma instituição específica. 


\begin{tabular}{|c|c|c|c|}
\hline $\mathrm{ABF}$ & $\begin{array}{c}\text { Alunos, } \\
\text { Instrução } \\
\text { Primária, } \\
\text { Institucional }\end{array}$ & $1 / 1$ & $\begin{array}{l}\text { - Adaptada ao ensino das escolas da instrucção primaria, quer dos } \\
\text { menores, quer dos adultos, e bem assim dos collegios, lycêos, } \\
\text { escolas normaes e aulas preparatórias (Costa e Cunha 1880) }\end{array}$ \\
\hline $\mathrm{ABE}$ & $\begin{array}{l}\text { Instrução } \\
\text { Primária, } \\
\text { Nacional, } \\
\text { Alunos }\end{array}$ & $1 / 1$ & $\begin{array}{l}\text { - Para uso das aullas de primeiras lettras. Offerecido a mocidade } \\
\text { brazileira (Martagão 1866) }\end{array}$ \\
\hline $\mathrm{BDF}$ & $\begin{array}{l}\text { Instrução } \\
\text { Primária, } \\
\text { Regional, } \\
\text { Institucional }\end{array}$ & $9_{4}$ & $\begin{array}{l}\text { - Escolhida pela Congregação do Lycêo do Maranhão para o uso do } \\
\text { mesmo Lycêo, e das aulas de primeiras lettras da provincia } \\
\text { (reedições de Costa Duarte 1853,1859,1862,1877). } \\
\text { - Para uso do atheneu cearense e das escolas primarias (Bezerra 1865) } \\
\text { - Para uso da infancia que frequenta as aulas do primeiro grau do } \\
\text { instituto santista (Freire da Silva \& Leal 1871) } \\
\text { - Adoptada e premiada pelo conselho da instruç̧ão publica da } \\
\text { provincia do Pará (Souza 1872) } \\
\text { - Escolhida pela Congregação do Lycêo do Maranhão para o uso do } \\
\text { mesmo Lycêo, e das aulas de primeiras lettras da provincia } \\
\text { - Adoptada pela Inspeciona geral da instrucção publica de Minas- } \\
\text { Geraes para uso das escolas primarias (Brandão 1872) } \\
\text { - Approvada pelo inspector da instrucção pública para uso das escolas } \\
\text { de primeiras letras desta provincia e pelo conselho de instrucção } \\
\text { publica para uso do lyceu, collegios e aulas de instrucção primaria } \\
\text { (reedição de Condurú 1888) }\end{array}$ \\
\hline$\overline{B F G}$ & $\begin{array}{c}\text { Instrução } \\
\text { Primária, } \\
\text { Institucional, } \\
\text { Programa } \\
\text { Institucional }\end{array}$ & $1_{1}$ & $\begin{array}{l}\text { - Conformidade com o programma do } 1^{\circ} \text { anno do imperial collegio de } \\
\text { Pedro II (Pimentel 1875) }\end{array}$ \\
\hline $\mathrm{DF}$ & $\begin{array}{l}\text { Regional, } \\
\text { Institucional }\end{array}$ & $88_{5}$ & $\begin{array}{l}\text { - Escolhido pela congregação do Lyceu do Maranhão para uso do } \\
\text { mesmo Lyceu. etc (Costa Duarte 1840) } \\
\text { - Província do Ceará; Conselho diretor da instrução pública da mesma } \\
\text { provincia (Rubim 1860) } \\
\text { - Do lyceu provincial [Ceará] (Bezerra 1861) } \\
\text { - Approvado e adoptado para as aulas da provincia do Ceará e pelo } \\
\text { Conselho director da instrucção publica da mesma provincia } \\
\text { (reedições de Rubim 1862, 1880) } \\
\text { - Para uso das escolas publicas deste município [Rio de Janeiro] } \\
\text { (reedição de Cruz 1875) } \\
\text { - Adoptado para uso das escolas da provincia do Rio Grande do Sul } \\
\text { pelo respectivo Conselho Director da Instrucção Publica (Villeroy } \\
\text { 1870) } \\
\text { - Compêndio mandado adoptar pelo governo para uso das escolas } \\
\text { publicas de Santa Catharina por acto de } 26 \text { de outubro de } 1888 \text {, em } \\
\text { virtude do parecer do Conselho de Instrucção publica (Lapagesse } \\
\text { 1888) }\end{array}$ \\
\hline $\mathrm{AB}$ & $\begin{array}{l}\text { Alunos, } \\
\text { Instrução } \\
\text { Primária }\end{array}$ & $9_{5}$ & $\begin{array}{l}\text { - Destinadas ao uso dos alumnos de ambos os sexos que frequntam as } \\
\text { aulas de primeiras lettras (Senna 1862) } \\
\text { - Para principiantes (Koeffer 1863) } \\
\text { - Para uso dos principiantes do ensino das primeiras lettras } \\
\text { (Ibirapitanga } 1865 \text { e reedição 1875) } \\
\text { - Para uso dos alumnos de primeiras lettras (Freire da Silva } 1879 \text { e } \\
\text { reedição 1888) } \\
\text { - Para uso dos alumnos da instrucção primaria (Carvalho 1896) }\end{array}$ \\
\hline $\mathrm{BF}$ & $\begin{array}{l}\text { Instrução } \\
\text { Primária, } \\
\text { Institucional }\end{array}$ & $1_{1}$ & $\begin{array}{l}\text { - Destinada ao curso do } 1 .^{\circ} \text { anno do Imperial Collegio Pedro Segundo } \\
\text { (Costa 1876) }\end{array}$ \\
\hline
\end{tabular}




\begin{tabular}{|c|c|c|c|}
\hline $\mathrm{BH}$ & $\begin{array}{l}\text { Instrução } \\
\text { Primária, } \\
\text { Pessoa } \\
\text { (dedicatória) }\end{array}$ & $1_{1}$ & $\begin{array}{l}\text { - Para uso das escolas de primeiras letras, ordenado segundo a doutrina } \\
\text { dos melhores grammaticos, offerecido ao illmo. e exmo. Senhor } \\
\text { Cândido José de Araújo Vianna, presidente da provincia do } \\
\text { Maranhão, deputado ás cortes legislativas, etc. (Costa Duarte 1829) }\end{array}$ \\
\hline $\mathrm{BG}$ & $\begin{array}{l}\text { Instrução } \\
\text { Primária, } \\
\text { Programa } \\
\text { Institucional }\end{array}$ & $22_{2}$ & $\begin{array}{l}\text { - } 1^{\circ} \text { gráo - Organisada de acordo com o novo plano de ensino primario } \\
\text { do } 1^{\circ} \text { gráo (Costa e Cunha 1895) } \\
\text { - Dedicada á instrucção primaria e organisada de accordo com o } \\
\text { programma vigente da instrucção primaria (Vieira 1889) }\end{array}$ \\
\hline BI & $\begin{array}{l}\text { Instrução } \\
\text { Primária } \\
\text { Professor }\end{array}$ & $1_{1}$ & $\begin{array}{l}\text { - Dedicada aos senhores professores de instrucção primaria (Pinheiro } \\
\text { 1864) }\end{array}$ \\
\hline $\mathrm{CG}$ & $\begin{array}{l}\text { Curso Médio } \\
/ 2^{\circ} \text { ano, } \\
\text { Programa } \\
\text { Institucional }\end{array}$ & $1 / 1$ & $\begin{array}{l}\text { - Obra especialmente destinada ao curso secundario da lingua } \\
\text { portugueza e adaptada ao novo programma de exames (Carneiro } \\
\text { Ribeiro 1890) }\end{array}$ \\
\hline $\mathrm{AD}$ & $\begin{array}{l}\text { Alunos, } \\
\text { Regional }\end{array}$ & $11_{3}$ & $\begin{array}{l}\text { - Composta e oferecida á mocidade fluminense (Paz } 1833) \\
\text { - Dedicado à mocidade riograndense (Coruja } 1835 \text { e todas suas } \\
\text { reedições 1846,1847, 1849,1862,1865,1872,1873,1891) } \\
\text { - Dedicado aos estudantes rio-grandenses (Almeida 1899) }\end{array}$ \\
\hline $\mathrm{AE}$ & $\begin{array}{l}\text { Alunos, } \\
\text { Nacional }\end{array}$ & $22_{2}$ & $\begin{array}{l}\text { - Aulas da língua nacional do Brazil (César 1832) } \\
\text { - Accommodado á intelligencia dos meninos; dedicado á mocidade } \\
\text { brazileira (Passos 1848) }\end{array}$ \\
\hline
\end{tabular}

\begin{tabular}{|c|c|c|c|c|c|c|c|c|c|c|}
\hline Década & $\mathbf{1 8 0 0}$ & $\mathbf{1 8 1 0}$ & $\mathbf{1 8 2 0}$ & $\mathbf{1 8 3 0}$ & $\mathbf{1 8 4 0}$ & $\mathbf{1 8 5 0}$ & $\mathbf{1 8 6 0}$ & $\mathbf{1 8 7 0}$ & $\mathbf{1 8 8 0}$ & $\mathbf{1 8 9 0}$ \\
\hline Subtítulo & & & & & & & & & & \\
\hline A & - & $2_{1}$ & $1_{0}$ & $1_{0}$ & $2_{1}$ & $3_{1}$ & $1_{0}$ & $2_{1}$ & $3_{1}$ & $1_{0}$ \\
\hline B & - & - & - & - & $1_{1}$ & $3_{3}$ & $2_{2}$ & $2_{1}$ & - & $4_{4}$ \\
\hline C & - & - & - & - & - & - & - & - & $3_{2}$ & $5_{1}$ \\
\hline D & - & - & - & - & - & - & - & - & $4_{2}$ & - \\
\hline E & - & - & - & - & - & & & - & $1_{1}$ & - \\
\hline F & - & - & - & $1_{1}$ & - & $1_{1}$ & $2_{1}$ & $1_{1}$ & $1_{0}$ & $2_{1}$ \\
\hline G & - & - & - & - & - & - & - & - & $4_{4}$ & - \\
\hline H & - & - & - & - & - & - & $1_{1}$ & $2_{0}$ & - & - \\
\hline ABF & - & - & - & - & - & - & - & - & $1_{1}$ & - \\
\hline ABE & - & - & - & - & - & - & $1_{1}$ & - & - & - \\
\hline BDF & - & - & - & - & - & 20 & 21 & $3_{1}$ & $2_{1}$ & - \\
\hline BFG & - & - & - & - & - & - & - & $1_{1}$ & - & - \\
\hline DF & - & - & - & - & $1_{1}$ & - & $4_{2}$ & $1_{1}$ & $2_{1}$ & - \\
\hline AB & - & - & - & - & - & - & 33 & $2_{1}$ & - & - \\
\hline BF & - & - & - & - & - & - & - & $1_{1}$ & - & - \\
\hline BH & - & - & $1_{1}$ & - & - & - & - & - & - & - \\
\hline BG & - & - & - & - & - & - & - & - & $1_{1}$ & $1_{1}$ \\
\hline BI & - & - & - & - & - & - & $1_{1}$ & - & - & - \\
\hline CG & - & - & - & - & - & - & - & - & - & $1_{1}$ \\
\hline AD & - & - & - & 22 & $3_{0}$ & - & 20 & $2_{2}$ & - & $21_{1}$ \\
\hline AE & - & - & - & $1_{1}$ & $1_{1}$ & - & - & - & - & - \\
\hline
\end{tabular}

Tabela 8. Número de gramáticas dedicadas a cada tipo de público-alvo por década

Observamos que era muito comum, ao longo do século, oferecer a obra a alunos (A) como um público bastante geral, esse tipo simples foi bastante popular ao longo de todo o século. O mesmo se dá com textos direcionados à Instrução Primária (B), que, a partir do final dos anos 1820, passa a ter uma imensa popularidade, por vezes juntando- 
se a outros tipos (ABF, ABE, BDF, BFG, AB, BF, BH, BG, BI). O número total de textos dedicados à instrução primária, de tipos simples e complexos, é de 38 , considerando-se as gramáticas, e 28, contando apenas as títulos.

Vimos que outros níveis de ensino tiveram um alcance menos expressivo, como é o caso das obras para segundo ano, terceiro ano, médio e superior $(\mathrm{C}, \mathrm{CH})$, que contam 9 gramáticas e 4 títulos. Nota-se, portanto, que a gramaticografia brasileira do século XIX preocupava-se sobretudo com a instrução primária. É possível que isso seja um reflexo da escolarização do país que, nesse século, encontrava-se em formação.

Em relação à geografia, há quatro obras que, em seus subtítulos, se direcionam para o público brasileiro $(\mathrm{E}, \mathrm{AE}, \mathrm{ABE}){ }^{88} \mathrm{E}$ mais frequente, porém, que as gramáticas sejam dedicadas a regiões (províncias ou estados) do país, com subtítulos desse tipo (D, $\mathrm{DF}, \mathrm{AD}, \mathrm{BDF}$ ) temos conhecimento de 32 gramáticas das quais 14 são títulos. Destes últimos, 9 são também adotados ou dedicados a instituições - e quando contamos todas as edições (gramáticas), são 17 (BDF, DF). Dessas 17, 9 gramáticas (sendo 4 títulos) são explicitamente direcionadas à Instrução Primária (BDF), essa tendência pode ser reflexo da emenda constitucional de 1834 , que promovia a autonomia da província no que diz respeito à instrução primária. Há também aquelas gramáticas que apenas se referem a instituições, sem, entretanto, fazer referência a alguma região, essas contam ( $\mathrm{F}, \mathrm{BF}, \mathrm{ABF}$, $\mathrm{BFG})$, os quais em números são 13 gramáticas e 8 reedições. Há 8 gramáticas e títulos que satisfazem determinados programas de estudos ( $\mathrm{G}, \mathrm{BG}, \mathrm{CG}, \mathrm{BFG})$, todos eles do último quartel do século, mas que são sobretudo da década de 1880 - quatro deles faze referência ao Programa de Estudos escrito por Fausto Barreto para o Colégio Pedro II. Finalmente, temos aquelas que são dedicadas a alguma pessoa, seu número é bastante pequeno, são apenas duas títulos e quatro gramáticas: Costa Duarte 1829, que dedica ao governador de então da Província do Maranhão, e Sotero dos Reis (1866, 1871, 1877), que dedica sua obra a Pedro Nunes de Leal.

\section{R7.1. Público-alvo e título das obras}

Como vimos, o número de títulos $\mathrm{Xg}$-compêndio é quase igual o número de títulos G. Em busca de respostas para essa carcaterística da produção, procuramos sistematizar os dados relativos ao público-alvo da obra ou a que ela se destinava, dado que o número

\footnotetext{
${ }^{88}$ Não há gramáticas brasileiras, das encontradas por nós, que façam referência a Portugal.
} 
de obras direcionadas à Instrução Primária também era bastante alto. A tabela adiante sistematiza esses dados:

\begin{tabular}{|c|c|c|c|}
\hline \multicolumn{2}{|r|}{ Público-alvo } & $\begin{array}{c}\text { Instrução Primária (B, AB, } \\
\mathrm{BG}, \mathrm{BH}, \mathrm{BI}, \mathrm{ABE}, \mathrm{ABF}, \mathrm{BDF})\end{array}$ & $\begin{array}{c}2^{\circ} \text { ano, } 3^{\circ} \text { ano, Curso } \\
\text { Médio e Curso } \\
\text { Superior }(C, C G) \\
\end{array}$ \\
\hline \multicolumn{2}{|c|}{ Título G (Gp, Glp, nGp, nGlp) } & $\begin{array}{c}\mathbf{5 5} \\
\text { Taylor (1871), Souza (1872), } \\
\text { Costa (1876), Ribeiro (1894), } \\
\text { Vieira (1898) }\end{array}$ & $\begin{array}{c}\mathbf{8 3} \\
\text { Ribeiro (1888), Ribeiro } \\
(1888 \text { e reedições } \\
\text { 1889, 1891, 1893, } \\
\text { 1894, 1898), Alves } \\
(1895) \\
\end{array}$ \\
\hline \multirow[t]{10}{*}{$\begin{array}{c}\text { Títulos X (Gx, } \\
\text { X, Xg, Xgx) }\end{array}$} & $\begin{array}{l}\text { Compêndio } \\
\text { (filosófico) }\end{array}$ & $\begin{array}{c}\mathbf{1 1 6} \\
\text { Costa Duarte }(1829 \text { e reedições } \\
\text { 1853, 1859, 1862, 1877), Susano } \\
(1851) \text {, Cajá }(1854) \text {, Ibirapitanga } \\
(1865 \text { e reedição } 1875) \text {, Bezerra } \\
(1865), \text { Martagão }(1866) .\end{array}$ & - \\
\hline & Elementos & $\begin{array}{c}\mathbf{4 2} \\
\text { Carvalho (1880 e reedições } \\
\text { 1883, 1896) Luz }(1896)\end{array}$ & - \\
\hline & Explicador & $\begin{array}{c}1_{1} \\
\text { Pimentel (1875) } \\
\end{array}$ & - \\
\hline & $\begin{array}{l}\text { Gramática } \\
\text { elementar / } \\
\text { Elementar e } \\
\text { metódica }\end{array}$ & $\begin{array}{c}\mathbf{2} \mathbf{1} \\
\text { Tilbault (1862), Condurú } \\
\text { (reedição 1888) }\end{array}$ & - \\
\hline & Gramática infantil & $\begin{array}{c}11 \\
\text { Brandão (1882) }\end{array}$ & - \\
\hline & Lições & $\begin{array}{c}1 \mathbf{1} \\
\text { Senna }(1862) \\
\end{array}$ & - \\
\hline & Noções & $\begin{array}{c}\mathbf{1 1} \\
\text { Freire da Silva (1871) }\end{array}$ & - \\
\hline & $\begin{array}{l}\text { Preliminares de } \\
\text { gramática }\end{array}$ & $\begin{array}{c}11 \\
\text { Castilho (1864) }\end{array}$ & - \\
\hline & $\begin{array}{c}\text { Resumo } \\
\text { (explicativo) }\end{array}$ & $\begin{array}{c}\mathbf{4 3} \\
\text { Lopes }(1845), \text { Passos }(1855 \text {, } \\
\text { reedição 1863), Koeffer (1863). }\end{array}$ & - \\
\hline & Rudimentos & $\begin{array}{c}\mathbf{2}_{\mathbf{1}} \\
\text { Freire da Silva (1879 e reedição } \\
1888)\end{array}$ & - \\
\hline $\begin{array}{c}\text { Título duplo: } \\
\text { Gramática ou } \\
\text { X }\end{array}$ & $\begin{array}{c}\text { Serões } \\
\text { Gramaticais, Nova } \\
\text { Gramática }\end{array}$ & - & $\begin{array}{c}\mathbf{1 1} \\
\text { Carneiro Ribeiro } \\
(1890)\end{array}$ \\
\hline
\end{tabular}

Dos textos dedicados à Instrução Primária (B, AB, BG, BH, BI, ABE, ABF, BDF), como podemos ver no quadro, temos um alto número de títulos $\mathrm{X}$, esteja esse $\mathrm{X}$ iniciando o título ([X], $[\mathrm{Xg}],[\mathrm{Xgx}])$ ou após o termo "Gramática" ([Gx]). Temos, como os casos do primeiro tipo: "compêndio", "elementos", "explicador", "lições”, "noções”, "preliminares", "resumo", "rudimentos"; e do segundo tipo: gramática "elementar", 
“elementar e metódica”, “da infância”, infantill, e um número menor de textos do tipo G. Ao passo que os textos direcionados ao segundo e ao terceiro grau são majoritariamente do tipo G, há apenas uma exceção, que tem título duplo, chamado de Serões Grammaticaes ou Nova Grammatica Portugueza, de Carneiro Ribeiro (1890), direcionado ao segundo ano. Esses dados, portanto, demonstram que há conexão entre o título da obra e o grau para o qual ela é direcionada. O título de Gramática Portuguesa ou da língua portuguesa, é predominantemente em gramáticas de segundo e terceiro grau, já as gramáticas de instrução primária, apresentam um largo número de títulos que contém um termo " $x$ " e poucas do tipo G. Parece, portanto, haver alguma relação entre o título escolhido para a obras e o grau de ensino a que ela é destinada.

No capítulo de resultados e contribuições (cf. 5.4), por um lado, sintetizamos os aspectos que a metodologia da Historia Serial pôde elucidar sobre a historiografia da gramaticografia brasileira de língua portuguêsa do século XIX; por outro lado, observamos as contribuições dessa metodologia para a Historiografia Linguística em geral.

\subsection{Análise de agenda}

Nesta seção, observamos as agendas dos quatorze gramáticos analisados neste trabalho quando publicavam suas gramáticas ou reedições delas. Para tanto, como já dissemos no capítulo 2, inspirando-nos no modelo de conflito de Murray (1994), analisamos dados biobliográficos de cada autor, a fim de observar seu perfil profissional, e os paratextos das obras (título, subtítulo, dedicatórias, epígrafes, prólogos, assinaturas) a fim de observar que retórica ele pode estar neles transmitindo, revolucionária, de continuidade ou mista. Além disso, observamos a posição da obra de acordo com nosso mapeamento interpretativo-descritivo. As análises das diferentes obras não são homogêneas, sobretudo porque, além do fato de que algumas apresentam paratextos mais extensos e detalhados do que outras, não obtivemos informações biobibliográficas detalhadas de todos os autores. Finalmente, o leitor pode conferir dados bibliográficos e a transcrição dos paratextos das obras na Ficha Descritiva de cada uma delas, no Apêndice B. 


\subsubsection{Antonio Morais Silva, Epitome da grammatica de lingua portugueza $(1806,[1])$}

O primeiro gramático brasileiro conhecido é Antonio Morais Silva, nascido na cidade do Rio de Janeiro em 1755. Mudou-se, aos dezenove anos, para Coimbra, Portugal, para fazer o Curso Jurídico, pouco tempo depois de a Universidade ter sido reformada por Pombal, isto é, quando adentraram nela conhecimentos considerados iluministas. Não há certeza sobre se Morais Silva chegou a se formar como bacharel (cf. Sacramento Blake 1883, Murakawa 2006). Mas sabe-se que em 1779, que seria seu último ano na Universidade, foi denunciado à Inquisição junto com outros colegas; fugiu de Coimbra para Lisboa, e de lá para a Inglaterra, onde permaneceu até 1783. Em seguida foi para Roma, e depois para a França, de onde voltou para Portugal por ter recebido um indulto. No fim de 1785, porém, fez abjuração, abandonando publicamente a religião cristã. Em 1788 publicou a tradução da História de Portugal, escrita por um grupo de literatos ingleses. No mesmo ano foi publicada outra tradução sua, as Recreações de um homem sensivel, de François-Thomas-Marie de Baculard d'Arnauld. No ano de 1789, publicou a primeira edição de seu Dicionário da Língua Portuguesa, o qual tinha como base o Vocabulário Português e Latino (1712-1728, 8 vol., 2 supl.), de Raphael Bluteau (16381734), que, na versão do gramático brasileiro era monolíngue e tinha apenas dois volumes. Em 1794 casou-se, retornou ao Brasil, passando a residir em Pernambuco, e começou a advogar; no ano seguinte, 1795, foi nomeado pelo governo português Juiz de Fora e Provedor dos Ausentes na Bahia, contudo ficou apenas um ano no cargo. Comprou um engenho de cana-de-açúcar em Moribeca, Pernambuco, no qual, em 1802 terminou a redação de seu Epítome da Gramática da Língua Portugueza ([1]), o qual foi publicado em 1806.

Tendo em conta nosso mapeamento da produção gramatical brasileira, apresentado no item 3.1, o epítome de Morais Silva é um fato notável. Sua gramática é a única a ser publicada por um brasileiro na década que inicia o século. Entretanto, se pensarmos nas condições históricas do período, ele parece ter tido as ideais para realizar esse feito. Teve, como muitos outros brasileiros com boa situação financeira do final do século XVIII, possibilidade de estudar na Universidade de Coimbra, depois, por alguns anos, morou em diferentes países da Europa. A publicação da obra ocorreu quatro anos (1806) após sua finalização (1802), porque que teve de passar pelo Dezembargo do Paço e foi impressa em Lisboa, visto que até 1808 eram proibidas as prensas no Brasil. Não 
tivemos informação acerca de sua utilização em escolas, apesar de conhecer a supracitada edição póstuma e modificada de 1832, que parece ter um viés mais pedagógico.

No ano de 1813, publicou a segunda edição, bastante modificada e acrescentada, de seu Dicionário, ao qual anexou o Epitome nas primeiras quarenta e oito páginas, com texto idêntico ao da edição de 1806, mas disposto em páginas de tamanho maior e, portanto, em menor número de páginas; ademais, introduziu no dicionário um grande número de inovações lexicográficas, como apresentar a classe da palavra e indicar, com diacrítico, a sua sílaba tônica (cf. Murakawa 2006). Viu a publicação da terceira edição de seu Dicionário, ampliada por Pedro José Figueiredo, em 1823. Faleceu em 11 de abril de 1824.

Logo no início da obra analisada, apresenta uma citação de Condillac em epígrafe, que traduzimos adiante: “Complicamos nossa Gramática, porque desejamos fazê-la de acordo com a Gramática Latina. Não a simplificaremos até que retomemos a ligação entre as expressões e os elementos do discurso" (Cf. original na FD1, Apêndice B). Morais Silva parece querer expressar descrédito em relação às gramáticas baseadas no modelo da gramática latina. A primeira seção da obra chama-se "ao leitor benévolo" ${ }^{89}$, nela o gramático introduz ao leitor suas propostas ao escrever a gramática, não raro expondo também julgamentos acerca do seu horizonte de retrospecção. Morais Silva diz propor-se a dar ideias mais claras e mais exatas do que aqueles que se encontram em outras gramáticas, seja no que diz respeito às 'partes da oração', seja no que se refere à 'composição'. Critica a maneira como se tem descrito o 'artigo'; afirma que (exceto por $e u, t u, e l e)$ os 'nomes portugueses' não têm 'casos', e, a esse respeito, o autor completa que não há correspondências entre latim e português ${ }^{90}$ e que é absurdo querer explicar a 'sintaxe' ou ‘composição' com base em outras línguas; diz ainda que muitos gramáticos

\footnotetext{
${ }^{89}$ Esse título, muito provavelmente, tem influência do vocabulário português e latino de Raphael Bluteau, o qual foi, como sabemos, muito utilizado por Morais Silva na confecção de seu dicionário de língua portuguesa. Bluteau escreve nas primeiras 44 páginas do volume 1 de seu dicionário um "Prologo do autor a todo genero de leitores", no qual distingue dez gêneros de leitores, fazendo a cada um deles um prólogo, a saber: o leitor benévolo, o leitor malévolo, o leitor impaciente, o leitor português, o leitor estrangeiro, o leitor douto, o leitor indouto, o leitor pseudocrítico, o leitor impertinente e, finalmente, o leitor mofino. Ao leitor benévolo, diz Bluteau "Sem o merecer, eftou certo da tua approvação. No teu bom animo tenho a certeza defte beneficio. Tem a benevolencia afinidade com o amor; Se não é cega, he mal vifta. Não digo mais, LEITOR BENEVOLO; como tal, não veràs, o não quereràs ver os meus erros.” (Bluteau 1712:s.n.). Perguntamo-nos se seria essa a reação do leitor que esperava ou contava em ter Morais Silva.

${ }^{90}$ Citamos o exemplo que apresenta para fazer tal afirmação "tambem serião falsas noções as que se dessem de correspondencias entre o Latim, e Portuguez. Me v.g. parece se com o acusativo Latino, quando dizemos feriu $m e$, matou me: mas me tambem indica o termo da acção, quando esta tem paciente, e termo, v. g. matou me um Livro, as quaes relações no Latim se representão por outro caso diverso: (mihi e não me) e no Portuguez müitas vezes me, e a mim representão o mesmo.” (Morais Silva 1806: IV)
} 
engrossam seus livros com 'conjugações', mas reduzem o tratamento da 'composição' a muito poucas páginas; assim, procurará expor esta parte com mais demora. Depois, escreve um longo trecho acerca de suas fontes, afirmando que usa no Epítome textos “Clássicos", tanto para exemplificar o acerto, quanto para exemplificar o erro. Ao fim do prólogo, Morais Silva fala que mesmo distintos oradores podem não conhecer completamente a gramática e apresenta uma breve citação de Cícero em Latim que está traduzida adiante:

Pois falar Latim é algo que se deve ter em alta conta, não tanto por si mesmo, mas porque é negligenciado por muitos. De fato, não é tão admirável saber Latim como é torpe não o saber; e me parece que isto [i.e. sabê-lo] é mais próprio do Cidadão Romano que do Orador $^{91}$. (Brutus 140)

A retórica de Morais Silva é revolucionária, ele inicia, pois, seu prólogo com as palavras "propuz me nesta Grammatica dar te idéyas mais claras, e exactas, do que cómummente se achão nos livros d'est assumpto, que tenho visto no nosso idioma" (Morais Silva 1806: III). Tem, ainda, críticas a seus pares, ao dizer que não explicam bem o 'artigo', que usam a descrição do latim para descrever o português e que tratam pouco da 'sintaxe'. Sua crítica parece se destinar às gramáticas do português anteriores ${ }^{92}$, as quais usavam do latim com frequência para descrever a língua portuguesa; note-se que mesmo a Arte da grammatica da lingua portugueza de Reis Lobato, de 1770, já do período orientado pelo Marquês de Pombal, fez isso (cf. Crudis 2009). Entretanto, vale ressaltar que o gramático brasileiro apresenta, indiretamente, certa retórica de continuidade com ao menos parte da tradição da grammaire générale francesa, por conta da epígrafe de Condillac. Assim, sua retórica vai ao encontro de boa parte da tradição mainstream do período. Ademais, seu reconhecimento parece ter sido relativamente amplo, na medida em que sua gramática foi, no período, reeditada postumamente e posteriormente com modificações em Porto Alegre, e ainda que seja menos conhecida do que o dicionário nos dias atuais, sua primeira edição, de 1806, é constantemente citada pelas revisões históricas que se fizeram do período (cf. Nascentes 1939, Cavaliere 2001, Azevedo Filho 2002, Parreira 2011, Polachini 2013).

\footnotetext{
91 Tradução de Edgard Bikelis do original em latim: "Nam ipsum Latine loqui est illud quidem in magna laude ponendum, sed non tam sua spoute, quam quod est a plerisque neglectum. Non enunm tam praeclarum est scire Latine, quam turpe nescire; neque tam id mihi Oratoris, quam Civis Romani proprium videtur. Cicero." (cf. FD1, Apêndice B)

92 Não há muitas gramáticas exclusivamente do português até o século XVIII, temos conhecimento de: Oliveira (1536), Barros (1540), Argote (1721) e Reis Lobato (1770).
} 


\subsubsection{Ignacio Felizardo Fortes, Arte da grammatica portugueza (1816, [4])}

Tal como Kemmler (2013), lamentamos não dispor de muitas informações biográficas a respeito de Fortes. Sacramento Blake em seu Dicionário Bibliográfico, única fonte que temos a esse respeito, afirma a respeito do autor:

Presbítero do habito de São Pedro, nasceu no último quartel do século XVIII e faleceu em 1856 em Cabo Frio, província do Rio de Janeiro, onde exerceu o cargo de professor publico de latim da freguesia do Nossa Senha da Assumpção por muitos anos e também a advocacia. Era reputado como um grande latinista. (Sacramento Blake, vol. 3, 264-265)

Conhecemos também, via Sacramento Blake (1895) e buscas em catálogos de bibliotecas, algumas de suas outras publicações, todas posteriores à da gramática: Breve exame de pregadores pelo que pertence à arte retórica, publicada pela Tipografia Real em 1818; a tradução de dois tomos de História do Brasil desde a sua descoberta até 1810, originalmente escrita em francês por Mr. Affonso de Beauchamp, publicados em $1818 \mathrm{e}$ 1819; e de 1834, o texto Oração que, segundo Sacramento Blake, foi recitado por D. Pedro II. Como se pode ver, nenhuma das obras posteriores do presbítero eram gramáticas e tinham relação com estudos da linguagem. No entanto, sua Arte da Grammatica Portugueza, cuja primeira edição é de 1810 ([2]), foi reeditada durante toda a vida do autor e também postumamente. De acordo com Sacramento Blake, houve, ao menos, outras quatorze reedições, das quais ele cita cinco: a terceira, mais correta e aumentada, de 1825 ([7]); a nona de 1844 ([23]), igualmente mais correta e aumentada; a décima segunda de 1851 ([31]); décima terceira de 1855 ([36]); e, finalmente, a décima quarta, já póstuma, de 1862 ([53]). Neste trabalho, analisamos a segunda edição, de 1816 ([4]).

Concordamos e ressaltamos com Kemmler (2013) que a gramática seja uma "ilustre desconhecida", dado que, embora seja a primeira gramática escrita por um brasileiro e publicada no mesmo país e tenha tido diversas reedições ao longo de, ao menos, cinco décadas, não é mencionada em revisões históricas (cf. Capítulo 1, item 1.5). A razão de seu esquecimento não nos é clara. Na folha de rosto da obra, vemos seu título acompanhado de seu subtítulo: Arte da grammatica portugueza que para uso dos seus discípulos compoz o Padre Ignacio Felizardo Fortes, Professor de Lingua Latina. Notase que, embora seja uma gramática de língua portuguesa, Fortes era professor de língua latina, e, sendo a gramática destinada aos seus discípulos, espera-se que ela tenha alguma relação com o latim.

Há uma dedicatória na obra direcionada ao "Illustrissimo Senhor Luiz José de Carvalho Mello" que era, então, Desembargador do Paço, atribuição da Mesa do Dezembargo do Paço, instituição que funcionava como um tribunal de justiça de Portugal 
(do século XV a 1833) e era responsável pela concessão de licenças para impressão de livros relativos a matérias temporais. Nessa dedicatória, afirma que, no prólogo da obra, deixa claras as razões por que era importante publicá-la. No prólogo (cf. FD2, Apêndice B), Fortes explica a importância de se estudar a língua materna, ou seja, a língua portuguesa, lembrando que recentemente, em 1770, pelo Alvará do Senhor Rei D. José ${ }^{93}$, as Aulas de Língua Latina deveriam incluir também o ensino do português. Justifica tal decisão dizendo que, por mais que alguém estude a língua portuguesa (somente), jamais poderia falá-la ou escrevê-la corretamente sem ter os conhecimentos etimológicos que se encontram na língua latina. Com isso em mente e considerando que as artes portuguesas de então, ainda que ache algumas muito boas, não se acomodavam à língua latina, procurou, a fim de auxiliar os alunos a realizarem a conexão entre as regras das duas línguas, reduzir ao português regras de latim apresentadas pelo Padre Antonio Pereira de Figueiredo, cuja arte de gramática era utilizada nas aulas dessa língua no Reino Unido de Portugal, do Brasil e Algarves. Diz que seguiu sempre que foi possível as mesmas definições, regras e mesmos exemplos do Padre Pereira - as exceções, diz ele, estão, sobretudo, no detalhamento de 'declinações' de algumas classes de palavras e de 'conjugações' do 'verbo', a 'sintaxe', porém, é quase toda a mesma, segundo o autor.

Fortes, como vemos, afirma em seu prólogo estar realizando algo diferente do que havia no período ("vendo eu, que as Artes Portuguezas até aqui impressas, [sendo] algumas muito boas, são tão pouco accommodadas ás Latinas”); há, assim, uma sutil retórica revolucionária, com a qual procura mais apresentar a necessidade de sua obra para uma forma de aprender a língua portuguesa do que se mostrar uma nova maneira de analisar a língua. $\mathrm{O}$ autor, inclusive, afirma basear as técnicas de sua gramática quase que completamente em gramáticas setecentistas latinas do Padre Antonio Pereira (17251797) ${ }^{94}$. Quanto à atuação profissional de Fortes, ele afirma tê-la escrito com objetivo de auxiliar seus alunos a relacionar as línguas latina e a portuguesa; vemos que posteriormente não se interessou por escrever outras obras sobre língua latina ou língua portuguesa. Ademais, o autor encontrava-se atento ao contexto intelectual mais geral,

\footnotetext{
${ }^{93}$ Citamos de Mendonça (2013: 181) “Em 30/9/1770, El Rei D. José I assinava, no Palácio da Ajuda, a "Lei para que nas classes de latinidade sejam os mestres obrigados quando receberem discípulos a instruí-los previamente na gramática portuguesa", à qual se anexava alvará que explicitava que o ensino se faria com base na Gramática Portuguesa composta por Antonio Joze dos Reis Lobato.".

${ }^{94}$ De acordo com Kemmler (2012) e Moraes (2015), é possível encontrar traços de três obras do Padre Antonio Pereira na Arte de Fortes, a saber: Figuras da Sintaxe Latina (1761), Novo methodo da grammatica latina (1765) e Novo methodo de grammatica latina, reduzido a compendio (1814 - décima primeira edição). Há também traços similares ao da Arte da grammatica de lingua portugueza, de Reis Lobato (1770).
} 
dado que as justificativas para o modelo de sua gramática corroboram com determinações reais do último quartel do século anterior.

A gramática de Fortes, tal qual a gramática de Morais Silva, que vimos no item anterior (3.2.1), é uma das primeiras gramáticas de língua portuguesa escrita por brasileiro e, por isso, notável em seu contexto. Há apenas três gramáticas publicadas entre 1810 e 1819, das quais uma é reedição do Epítome de Morais Silva (1813), duas são edições de Fortes $(1810,1816)$. Era um período com baixa produção gramatical no Brasil; no entanto, havia já controvérsias explicitadas. Vimos na epígrafe e no texto introdutório "ao leitor benévolo" de Morais Silva que ele critica os textos gramaticais que davam ao português e ao latim as mesmas regras, que é justamente a proposta da Arte de Fortes, o qual, por sua vez, diz que então tais relações não eram feitas de forma satisfatória para que a língua portuguesa fosse incluída nas aulas de latim. É interessante notar que, entretanto, Morais Silva é anterior a Fortes e, portanto, falava de gramáticas que já realizam tal relação, como comentamos anteriormente (cf. item 3.2.1). As duas gramáticas não dialogam efetivamente entre si, mas tratam de temas de discussão próprios do clima de opinião daquele momento.

\subsubsection{Antonio da Costa Duarte, Compendio da grammatica portugueza $(1829,[10]) \mathrm{e}$ Compendio de grammatica philosophica da lingua portugueza (1859, [44])}

De acordo com o Sacramento Blake (1883:144-5), Costa Duarte nasceu na capitania, depois província, do Maranhão no final do século XVIII, foi presbítero de São Pedro e lente de gramática filosófica da língua portuguesa e análise dos clássicos. De suas publicações, Sacramento Blake conhece apenas as duas edições de sua gramática, a primeira de 1829 ([10]) e a segunda de 1840 ([19]), cujo título já havia sido modificado. Nós tivemos conhecimento ainda de quatro reedições, de 1853 ([33]), 1859 ([44]), 1862 ([51]), 1877 ([105]). Dentro de nosso mapeamento da produção gramatical brasileira de língua portuguesa, a gramática de Costa Duarte é uma das primeiras obras publicadasfoi, inclusive, dada por Nascentes (1939), que desconhecia sua primeira edição e outras obras, como a segunda obra publicada no Brasil, sendo posterior apenas à de Coruja (1835).

Além do título e do subtítulo, há outras diferenças nos paratextos das duas edições que analisamos. A primeira, intitulada, Compendio de grammatica portugueza: para uso das escolas de primeiras letras, ordenado segundo a doutrina dos melhores grammaticos, apresenta uma epígrafe, citação de Cícero, que diz "Que maior ou melhor serviço 
podemos oferecer à república que ensinar e instruir os jovens?"95, ademais, oferece e dedica a obra ao "Illm ${ }^{\circ}$ e Exm ${ }^{\circ}$ Sñr. Candido Joze de Araujo Vianna, Deputado nas Cortes Legislativas, Cavalleiro da Ordem de Christo, e Desembargador da Relaçaõ de Pernambuco" solicitando que este leia a obra e a corrija em sua doutrina no que for necessário para que seja interessante à instrução da mocidade (cf. FD3, Apêndice B). Esse senhor era então governador da província do Maranhão (ocupou o cargo de janeiro de 1829 a outubro de 1832). Costa Duarte parece pedir ao governante reconhecimento para que sua obra possa ser utilizada naquela província. Se era essa sua intenção, o gramático obteve sucesso, dado que o título e subtítulo da segunda edição, de 1840, eram Compendio da grammatica philosophica da lingua portugueza, escolhido pela congregação do lyceu do Maranhão para uso do mesmo lyceu; o liceu havia sido criado dois anos antes, em 1838 (Viveiros s.d.). Ademais, a partir da quarta edição, de 1859, é incluído ao subtítulo “e das aulas de primeiras lettras da província”. Nesta última já não há epígrafe nem dedicatória. A obra alcançou considerável sucesso, dado que foi reeditada por, pelo menos, as quatro décadas seguintes, sendo a última edição de que temos conhecimento a sexta, de 1877.

É curioso que essa gramática seja, na primeira edição, de 1829, oferecida e dedicada ao governador da província do Maranhão, e que o Ato Adicional à Constituição de 1824, que descentralizava a educação, tornando-a responsabilidade das províncias seja apenas 1834. Algo similar se dá com a Grammatica elementar e methodica de Paz, que foi publicada em 1833 ([13]) e é oferecida à mocidade fluminense também antes do Ato Adicional - todos os outros direcionamentos regionais em subtítulos de obras se dão após 1834. As edições seguintes da gramática de Costa Duarte, posteriores ao Ato Adicional, a partir de 1840, têm outra conexão com a província por meio de uma instituição, visto que em subtítulo é dito que ela é adotada no Liceu Maranhense e às escolas de primeiras letras da província.

Embora não haja prólogos que explicitem a maneira como o gramático se autopercebia em 1829 e depois em 1859, podemos, ao analisar os paratextos disponíveis, inferir algo acerca de sua agenda. Parece-nos que o Padre Antonio Costa Duarte procurou tornar sua gramática relevante em sua província por meio de dedicatória a seu governador no Brasil recém independente, e que o autor obteve o reconhecimento desejado e sua gramática foi reeditada e veiculada até o início do último quartel do século.

${ }^{5}$ Tradução do latim de Edgard Bikelis. Original: "Quod munus adferre majus meliusve reipublicae possumus, quam si docemus et erudimus juventutem? (Cic)" (cf. FD3, Apêndice B) 
Em suma, parece-nos que as duas títulos que analisamos da gramática de Costa Duarte têm um autor com agendas diferentes. Em 1829, o presbítero, que possivelmente era também professor de língua portuguesa, dedica sua obra ao então governador da província a fim de angariar reconhecimento. Pouco mais de dez anos depois, já com reconhecimento estabelecido, o gramático dá à luz uma nova edição com título modificado (e com diversas modificações internas, como veremos no capítulo 4), que é oficialmente utilizada no recém-aberto Liceu Maranhense e que, em edições seguintes, viria a ser utilizada nas escolas de primeiras letras da província. Assim, embora não tenhamos muitas informações biobibliográficas desse autor, é notável pela análise feita que há um percurso crescente de acesso a reconhecimento de acordo com as publicações de suas gramáticas, sobretudo entre a primeira e a segunda edição.

\subsubsection{Antonio Alvares Pereira Coruja, Compendio da Grammatica da Lingua Nacional (1835, [16]; 1873, [92])}

Da mesma forma que fizemos com Costa Duarte (cf. item 3.2.3), analisamos a agenda de dois Corujas, aquele de 1835 e outro trinta e oito anos mais tarde, em 1873. Nascido em agosto de 1806, em Porto Alegre, Coruja estudou, ao longo dos anos, latim, Filosofia Racional e Moral, francês, cantochão. Foi ainda, de acordo com Bastos (2006), um dos precursores do 'ensino mútuo' ou 'método lancasteriano' na Província de São Pedro, no Rio Grande do Sul:

\footnotetext{
"Em 18 de dezembro de 1825 firmou um contrato com o Conselho da Província de São Pedro do Rio Grande do Sul, pelo qual se comprometia a ir ao Rio de Janeiro habilitar-se na prática do método mútuo, para, posteriormente, assumir a primeira escola de ensino mútuo da Província. $\mathrm{O}$ contrato assinado estabelecia que se dispusesse ir à Corte do Rio de Janeiro, onde se doutrinaria no método lancasteriano, para, por este método, ensinar a mocidade" (Bastos 2006:7)
}

Ainda com base em Bastos (2006), sabemos que, em 1827, tendo já retornado à Província de São Pedro, fundou escola pública no método lancasteriano, chamada "Casa Queimada”. Em 1831, candidatou-se à cadeira de professor de Língua Latina, sendo aprovado. Em 1835, candidatou-se à cadeira de professor de Filosofia Racional e Moral, também sendo aprovado. (cf. Bastos 2006; Sacramento Blake 1983). No mesmo ano publicou a primeira edição da gramática que analisamos neste trabalho, no ano seguinte, porém, teve problemas e perseguições por conta de sua posição política na Revolta Farroupilha (1835-1845), tendo, inclusive, segundo Bastos (2006), sido preso. Em consequência disso, no ano de 1837, mudou-se com a família para o Rio de Janeiro, onde fundou o Liceu Minerva, em 1841, em que se ensinavam as primeiras letras, a Gramática 
da Língua Nacional e princípio de religião moral e cristã, dentre outras matérias; o Liceu, no entanto, foi transferido para Franklin Teodoro de Castro Menezes em 1856 e acabou por ser fechado em 1862. Foi membro do Instituto Histórico e Geográfico Brasileiro desde 1839, e seu tesoureiro por vinte anos. Em 1860, tentando um novo rumo, Coruja fundou a Companhia de Seguros Feliz Esperança, mas ela acabou por ser fechada em pouco tempo; posteriormente, em 1870, fundou a Caixa Depositária Sociedade Glória do Lavradio, que faliu em 1880. Ademais, Publicou diversos artigos para a Revista do IHGB, dos quais destacamos a "Coleção de Vocábulos de Frases usadas na Província de São Pedro do Rio Grande do Sul”, de 1852.

Grande parte de suas publicações é composta de livros escolares, evidentemente pelo forte vínculo profissional do autor com o ambiente pedagógico e educacional. Temos conhecimento dos seguintes livros, além do Compendio da Grammatica da Lingua Nacional, que foi reeditado diversas vezes por quase seis décadas (1835, [16]; 1846, [26];1847, [27]; 1849, [29]; 1862, [52]; 1865, [92]; 1873, [92]; 1891, [172]) (cf. FD4, Apêndice B), escreveu: Manual dos estudantes de latim (1838), Compendio de ortographia da lingua nacional (1848), Arithmetica para meninos (1850), Colleção de vocabulos e frases usados na provincia de S. Pedro do Rio Grande do Sul (1852), Lições de historia do Brazil (1855), A vida de José Bernardino de Sá depois de sua morte (1856), Annotações ás Memórias históricas de 'monsehor Pizarro (1858), Notas á memoria do tenente-coronel José dos Santos Viegas (1860), Antigualhas e reminiscencias de PortoAlegre (1881). Após seu Liceu falir e seus insucessos em outras carreiras, Coruja acabou por falecer, em 1889, segundo relatos, na miséria e morando em repúblicas de estudantes.

Ressaltamos que a primeira edição do Compendio de Coruja, de 1835, foi considerada por Nascentes (1939) e Castilho (1962) como a primeira gramática brasileira. Não há em ambas as edições prólogos que evidenciem o objetivo do autor ao escrevê-las. No entanto, há que se destacar aspectos de seu título e de seu subtítulo (que se mantêm nas reedições): Compendio da grammatica da lingua nacional: dedicado á mocidade riograndense. Nota-se que existe um direcionamento geográfico, relativo à província do Rio Grande do Sul, o qual se mantém até 1891, quase seis décadas após Coruja ter se mudado para o Rio de Janeiro. Ademais, o título é introduzido com o termo "compêndio", o qual, como notamos no mapeamento (cf. 3.1), estava relacionado ao ensino de primeiras letras e foi o tipo de título mais comum até as décadas de 1860 e 1870, quando os títulos iniciados por "gramática" tomam seu lugar. Além disso, tendo em conta o mapeamento, chama a atenção o fato de dizer que a gramática é de "língua nacional", pois tais termos 
para indicar a língua portuguesa não serão frequentes em gramáticas ao longo do século. Finalmente, a dedicação da obra à mocidade rio-grandense é um ponto interessante, na medida em que em 1834 houve um Ato Adicional sobre a Constituição de 1824, que tornava a educação básica responsabilidade das províncias. A continuidade desse título mesmo quando o autor muda-se para o Rio de Janeiro pode ser uma homenagem à sua província natal, é preciso considerar, porém, que seu compêndio foi recomendado para aulas de gramática portuguesa em São Pedro do Rio Grande do Sul em 1854.

Considerando os dados biobibliográficos e paratextos que temos de Coruja, notamos que seu perfil profissional quando escreve a primeira edição é de um jovem educador que elaborava seu primeiro livro. Na edição posterior, de 1873, que é similar à de 1835, exceto por acréscimos e pequenas mudanças, o autor, já teria escrito diversos livros direcionados para a educação e também já teria escrito seu famoso artigo a respeito de vocábulos e frases usados na província de São Pedro; no entanto, nesse momento, já abandonara a profissão de educador e procurava viver de outros empreendimentos.

\subsubsection{Raymundo Camara Bithencourt, Epitome da grammatica philosophica da lingua portugueza $(1862,[50])$}

De Raymundo Antonio Camara Bithencourt, sabemos, por Sacramento Blake (1902), que ele era natural do Rio de Janeiro, que talvez tenha exercido magistério na instrução primária e que, além de publicar o Epitome, traduziu diversas obras, entre peças e textos de fundo moral direcionados à infância, do francês (cf. FD6, Apêndice B), a maior parte do mesmo ano da publicação do Epítome, 1862, ou de anos próximos, como 1861 e 1863. O Epítome parece, portanto, ser seu único tratado gramatical, do qual só tivemos conhecimento da primeira edição, em cujo "Prefácio" temos algumas declarações do autor a respeito do momento que vivia e também dos objetivos que tinha ao escrever a obra.

Bithencourt inicia o prefácio dizendo que tem consciência do fato de que obra não seja perfeita. Ela, porém, segundo ele, não está abaixo daquelas que eram então publicadas; como exemplo, apresenta o compêndio de Costa Duarte como tendo muitas coisas aproveitáveis, mas que, por outro lado, tem doutrinas que, segundo Bithencourt, merecem reparo e não devem ser aceitas, sobretudo quando o gramático maranhense, Costa Duarte, se aparta da doutrina do gramático português Soares Barbosa, o qual era o modelo quase perfeito para o gramático carioca. Quase perfeito porque Bithencourt 
afirma reformular alguns pontos em que o "illustrado philologo nos [lhe] pareceu menos fundado". Há, em consequência disso, dois motivos que o autor lista para escrever sua gramática: estarem, então, esgotadas as edições da gramática de Soares Barbosa (1822), e considerar essa mesma gramática muito difusa e, por isso, inadequada ao ensino em aulas. Acrescenta, enfim, um terceiro motivo mais pessoal, que citamos adiante:

\begin{abstract}
"Um outro motivo, e perdôe-se-nos o orgulho, actuou tambem poderosamente em nós na composição deste epitome, a saber: a necessidade que tinhamos de provar solemnemente nossas habilitações, para bem exercermos um emprego em qualquer Repartição publica, um desses barateados á ignorancia, e arranjados pelo patronato; um emprego, emfim, que nos ponha a abrigo das primeiras necessidades da vida, já que o governo do paiz (não nos refirimos aos ministerios actual, ao qual por ora nada temos pedido) nunca se dignou de attender-nos. Acreditamos que o ministerio presidido pelo venerando Marquez de Olinda, tão amigo e protector das letras como é, nos fará justiça, e não consentirá que um moço que reune algumas habilitações, com as quaes póde até prestar bons serviões em uma secretaria d'estado, continue a viver sem um emprego e sem meios de prover á subsistencia de sua familia." (Bithencourt 1862: vii-viii)
\end{abstract}

Não podemos dizer com toda certeza, mas talvez essa motivação esteja, de modo geral, na intensa publicação de textos traduzidos pelo autor entre 1861 e 1863, da qual temos conhecimento por Sacramento Blake (1902). Como não sabemos ao certo que profissão exercia o autor e se, de fato, exerceu magistério, focaremos o desenho de seu perfil profissional baseando-nos em seu prefácio. O gramático evidentemente encontra-se numa posição de falta de reconhecimento, e parece escrever a gramática (e possivelmente traduzir outros textos na mesma época) a fim de acessar tal reconhecimento, o qual não necessariamente diz respeito à defesa de uma teoria ou doutrina, mas à ascensão social.

Ademais, o autor percebe-se ao mesmo tempo como continuísta e revolucionário, pois apresenta retórica mista em relação à gramática filosófica de Soares Barbosa, com alguns pontos corrigidos e em um formato mais didático. Ademais, afirma que corrige pontos em que Costa Duarte, outro gramático brasileiro, se distancia de Soares Barbosa. Bithencourt, assim, corrige pontos da gramática de Soares Barbosa ao mesmo tempo em que utiliza-a como base para refutar Costa Duarte.

Embora analisemos somente uma gramática da década 1860, vimos nessa década, no mapeamento que realizamos dessa produção, uma grande explosão de publicações de gramáticas do português por brasileiros (cf. item 3.1): em 1850 haviam sido publicadas 15 gramáticas (das quais 11 eram edições específicas), já em 1860 foram publicadas 33 obras (das quais 22 eram edições especificas). A gramática de Bithencourt, portanto, faz parte desse contexto de aumento de publicações. As intenções que o autor apresenta no prólogo demonstram que ele não pretendia criar uma gramática nova, mas adaptar uma antiga - criticando, também, as novas que não se enquadravam nos planos; tencionava 
também ser reconhecido e obter um emprego em alguma repartição pública. Assim, nesse contexto de grande aumento no número de gramáticas publicadas, temos um exemplo de gramática que, por um lado, dialoga vigorosamente com a tradição de descrição da língua portuguesa, e, por outro, foi usada como objeto de ascensão social.

\subsubsection{Francisco Sotero dos Reis, Grammatica portugueza accomodada aos princípios geraes da palavra seguidos de immediata aplicação pratica $(1877$, [106])}

Francisco Sotero dos Reis nasceu em 1800, em São Luís do Maranhão, local em que permaneceu até sua morte, em 1871. Teve ampla e diversa atuação profissional. Em 1821, foi nomeado pelo governador do Maranhão para lecionar latim em um colégio de instrução primária. Foi deputado provincial em 1832, e reeleito por várias legislaturas seguintes. Foi também o primeiro diretor do Liceu Maranhense, fundado em 1838, e primeiro inspetor da Instrução Pública do Maranhão. Além disso, desde 1825 participou ativamente da imprensa como jornalista (Martins 2010). Fundou uma série de periódicos, o mais importante deles, A Revista, foi fundado em 1840. Nelas estão seus mais célebres artigos de crítica literária. Escreveu para a Revista Trimestral do IHGB a biografia do falecido presidente da província do Maranhão, Eduardo Olímpio Machado (Sacramento Blake 1895).

Ao longo da década de 1860, já próximo ao fim da vida, publicou quatro livros. Em 1862, foram impressas as Postillas de Grammatica Geral applicada á lingua portugueza pela analyse dos classicos, obra que tratava especificamente de sintaxe e teve segunda edição em 1868. No ano de 1863, publicou tradução do texto Comentários sobre a Guerra Gálica, de Júlio César. Em 1866, a primeira edição de sua Grammatica portugueza accomodada aos princípios geraes da palavra seguidos de immediata aplicação pratica foi publicada, tendo duas reedições póstumas, de 1871 e 1877 analisamos a última. Entre os anos de 1866 e 1868, escreveu os volumes de seu conhecido Curso de litteratura portugueza e brazileira. (Sacramento Blake 1895, Nogueira 2006)

De acordo com a revisão historiográfica de Nascentes (1939), a Grammatica e as Postillas de Sotero dos Reis tiveram bastante prestígio no período de sua publicação, da mesma forma que seu Curso de Literatura. Ambos foram publicados em um dos períodos mais prósperos economicamente e intelectualmente da província do Maranhão. Nesse período, São Luís era conhecida como a "Atenas Brasileira”, principalmente por conta de 
suas 'Belas Letras', constituídas, dentre outros, por Gonçalves Dias, Odorico Mendes e Sotero dos Reis, os quais formavam o "Grupo Maranhense” (Nascentes 1939; Elia 1975).

É notável que Sotero dos Reis, embora tenha iniciado trabalhos com educação desde, pelo menos 1838, publique sua gramática, junto com outros livros, apenas no fim da vida, momento em que já se valia de grande reconhecimento intelectual e como homem de letras.

Não há prólogo do autor a nenhuma das edições da obra. O título Grammatica portugueza accomodada aos princípios geraes da palavra seguidos de immediata aplicação pratica é, como vimos em nosso mapeamento, um dos vários textos da década de 1860 que trazem em subtítulo algo relativo ao sistema em que se baseia a obra e ao seu modo de apresentação. Nota-se, assim, que a gramática se vincula à gramática geral, por considerar que a língua portuguesa poderia ser descrita por meio de princípios gerais da palavra; já a imediata aplicação prática pode tanto estar relacionada à exemplificação do português (que é muito frequente na obra e, ao que parece, os exemplos são em geral forjados pelo próprio gramático), quanto ao teor pedagógico da obra, que apresenta "modelos de análise" após os capítulos. Em suma, a Grammatica Portugueza de Sotero dos Reis parece ter sido escrita com uma agenda que fundia pedagogia e teoria, então, ao mesmo tempo que se apresentava como baseada na grammatica geral, tinha também objetivo de ser clara aos alunos que aprendiam português.

\subsubsection{Ernesto Carneiro Ribeiro, Grammatica Portugueza Philosophica (1881, [120]) e Serões Grammaticaes ou Nova Grammatica Portugueza (1890, [171])}

Nascido em 1839 em Itapacarica na Bahia e morto na mesma cidade em 1920, é um intelectual afrodescente relembrado até os dias atuais - seu $175^{\circ}$ aniversário foi celebrado pelo Doodle do Google Brasil, em 2014 ${ }^{96}$. Diplomou-se pela Faculdade de Medicina da Bahia em 1864, e, quando ainda era estudante, foi professor no Ginásio Baiano - de Abílio César Borges, então famoso educador e gramático (apresentamos duas gramáticas suas no Apêndice A, ver [47] e [104]). Da década de 1860, temos conhecimento, por meio de Sacramento Blake (1893), de alguns textos que escreveu para a área da medicina, Relações da medicina com as sciencias philosophicas; $O$ sulfato de

\footnotetext{
${ }^{96} \mathrm{Cf}$. nos sites: $\mathrm{http}: / /$ www.techtudo.com.br/noticias/noticia/2014/09/175-aniversario-do-ernesto-carneiroribeiro-e-celebrado-em-doodle.htm (Acessado em 21/06/2017) e https://www.google.com/doodles/ernestocarneiro-ribeiros-175th-birthday?hl=pt-BR (Acessado em 21/06/2017).
} 
quinino nas febres intermittentes; Do centeio espigado e sua applicação na obstetrícia; Theoria da respiração vegetal.

Em 1871, foi aprovado para a cadeira de Gramática Filosófica do Liceu Provincial. Em 1874, fundou o Colégio da Bahia com financiamento do Império Brasileiro, o qual durou até 1883. Em 1875, fundou o Ginásio Carneiro Ribeiro, do qual foi diretor por cerca de trinta e seis anos, sendo sucedido por seus filhos. Teve alunos famosos, como Ruy Barbosa, Euclides da Cunha e Rodrigues Lima. Publicou em 1877, a Grammatica Philosophica, que analisamos aqui. Em 1885, segundo Sacramento Blake (1893), escreveu Perturbações psychicas no domínio da hysteria. Em 1890, publicou outra gramática, chamada Serões Grammaticaes ou Nova Grammatica Portugueza, na qual procura se aproximar de estudos mais recentes sobre a linguagem, dado que ela inclusive, como é indicado pelo subtítulo, foi escrita de acordo com o programa de exames de 1887 do Colégio Pedro II. Sua gramática foi reeditada até meados do século $\mathrm{XX}$ e seu texto teve considerável aumento - houve duas outras edições em vida do autor, a segunda de 1915 e a terceira de 1919, da quarta não temos data, a quinta e sexta, póstumas, são respectivamente de 1950 e 1956. Ademais, já no início do século XIX, protagonizou, junto com seu ex-aluno, Ruy Barbosa, uma polêmica gramatical acerca da revisão do Projeto Civil.

A atuação profissional de Carneiro Ribeiro é dupla, já que exercia a medicina e o magistério. Sabemos pouco de sua carreira na medicina, mas é possível observar, por conta da fundação de colégios, que o autor teve reconhecimento no ensino. Sua primeira gramática, talvez por estar tão próxima da ruptura ocorrida em 1881 com a publicação da gramática de Ribeiro, não parece ter obtido grande reconhecimento. Foram os Serões Grammaticaes que obtiveram grande sucesso, sendo reeditados algumas vezes ao longo do século XX, e sendo citada por diversas revisões (cf. 1.5), ainda que possivelmente defendesse uma posição diferente do mainstream da época, como veremos adiante.

Não há prólogo na Grammatica Philosophica, mas seu título indica sua tendência a seguir, provavelmente, a doutrina veiculada pela grammaire générale. O autor apresenta uma epígrafe, citação de Francis Bacon em latim, que ressalta a importância da gramática: "Eu sou a lei do discurso, a regra verdadeira das línguas: "quem não me aprende não obterá mais nada" ${ }^{, 97}$. Curiosamente, essa mesma epígrafe seria usada dez anos mais tarde

\footnotetext{
${ }^{97}$ Tradução de Edgard Bikelis: Lex sum sermonis, linguarum regula certa; qui me non didiscit coetera nulla petat.
} 
na Grammatica Analytica de Maciel, de que também tratamos neste trabalho (cf. item 3.2.10).

Nos Serões Grammaticaes, Carneiro Ribeiro apresenta uma nova epígrafe e escreve longo prólogo em que são discutidas as novas tendências dos estudos da linguagem de então em relação aos mais antigos. Na epígrafre, em latim, o autor parece modestamente apresentar seu objetivo com a obra diz "não para que sejamos louvados, mas para que sejamos úteis"98. Quanto ao prólogo, Carneiro Ribeiro inicia-o dizendo que nos últimos anos os estudos gramaticais desenvolveram-se e foram esclarecidos com a gramática comparada. Assim, naquele momento, todo estudo que não considerasse a história no estudo da língua e sua evolução progressiva, como um organismo vivo, era considerado menor por ser abstrato e metafísico, dado que toda ciência aspirava então uma utilidade prática e real. Ainda que Carneiro Ribeiro valorize as novas direções que estavam tomando os estudos da linguagem, ele também era crítico a elas; diz no prólogo:

\begin{abstract}
Duas direcções differentes têm dado os escriptores ao estudo da sciencia da linguagem: na primeira o sentido das palavras é tudo, a sua função e o seo valor logico; a grammatica considerada sob esse aspecto é uma sciencia puramente abstracta como o é a logica, a que se vincula intimamente e com que se confunde; na segunda attentam mais nos elementos morphicos das palavras, consideram-nas sob seo aspecto material; a grammatica então se torna uma sorte de anatomia ou histologia: estudamse as palavras como compostas de orgãos; estudam-se para nos exprimirmos assim, os tecidos desses orgãos, os elementos desses tecidos, como nascem e vivem, como crescem e prolificam e definham, se encorpam e se apoucam, se engrazam e separam, se modificam, se transformam, estacionam, envelhecem e remoçam, apparecem e morrem. O grammatico não é mais um logico, senão um naturalista. Sob o primeiro aspecto estudaram a grammatica os Gregos e Romanos; sob o segundo, os grammaticos da India. Por muitos seculos foi aquella primeira a direcção que sempre se deo ao estudo da grammatica; a direcção, porem, a que se dá modernamente a preferencia é a segunda; mas por um excesso, a que tende sempre a humanidade quando duas opiniões se contrastam e parecem dividir os espiritos, á força de attentar na forma e no material das palavras; tem-se menosprezado o seo lado logico, o seo sentido e a sua funcção. O verdadeiro estudo da grammatica historica, como de qualquer grammatica especial, não é perfeito, se essas duas direcções se reputam incompatíveis, antagonicas e inconciliaveis, se não se approximam, auxiliando-se, compretando-se, robustecendose, amalgamando-se e fundido, encontrando uma na outra a saber em que se levanta e sustenta. (Carneiro Ribeiro 1890: II-III).
\end{abstract}

Vê-se que o gramático, apesar de valorizar os estudos mais recentes, os compreende como incompletos sem a abordagem mais antiga, preferindo, dessa forma, que ambos sejam reunidos. Assim, após ler tal prólogo, não esperamos que sua gramática, apesar de estar de acordo com o Programa de Estudos, tenha unicamente a abordagem das doutrinas mais recentes, mas que preserve ainda abordagens de doutrinas anteriores, as quais, possivelmente, Carneiro Ribeiro usou em sua gramática anterior, a Grammatica Philosophica. Finalmente, justifica o título Serões Grammaticaes, ao dizer que este foi

\footnotetext{
98 Tradução de Edgard Bikelis: Non ut laudemur, sed ut prosimus.
} 
escrito em subtraídas horas de repouso do autor, por conta de suas diversas ocupações, mas que essas foram horas bem ocupadas, dado que resultaram em uma grande e útil obra.

\subsubsection{Julio Cezar Ribeiro Vaughan, Grammatica Portugueza (1881, [123]; 1885, [143])}

Filho de uma brasileira e de um cidadão norte-americano, Júlio César Vaughan Ribeiro nasceu em 1845, na cidade de Sabará, em Minas Gerais. Em 1862, mudou-se para o Rio de Janeiro, onde fez três anos do curso da Escola Militar, deixando-o para se dedicar ao magistério e ao jornalismo. Posteriormente, foi nomeado professor de latim no curso anexo à Faculdade de Direito de São Paulo e deu aula em diversas escolas do interior do estado de São Paulo, como o Culto à Ciência, de Campinas. Morou também em Lorena, Sorocaba, Campinas, Capivari e Santos. Já no fim da vida, quando o Brasil tornou-se república, Ribeiro foi nomeado professor de retórica do Instituto de Instrução Secundária (cf. biografia em site da ABL).

Conhecemos quatro gramáticas escritas por ele, a Grammatica Portugueza, de 1881, a Grammatica Analytica (1885) o Holmes Brasileiro ou Grammatica da Puericia (1887) a Nova Grammatica de Lingua Latina, que não estava acabada no momento de sua morte e foi publicada em edição póstuma, em 1895. Ademais, escreveu também os Traços gerais de Linguística (1880). Sua gramática é dada, com frequência, como aquela que promoveu a primeira ruptura epistemológica na gramática brasileira do português (cf. item 1.5).

Além de escrever diversas obras gramaticais e linguísticas, Ribeiro foi também jornalista proprietário e diretor de jornais, como Sorocabano (1870-72), Procellarias (1887) e O Rebate (1888). Temido polemista, Julio Ribeiro escreveu as Cartas Sertanejas, as quais saíram ao longo de 1885 no Diário Mercantil como resposta a artigos que saíram no jornal A Província (atual Estado de São Paulo), da autoria de "Demócrito". Nelas, ele responde a diversos ataques à sua gramática e às filosofias ou aos teóricos que defendia. Em geral, o gramático respondia a essas críticas tanto com a resposta à questão ou crítica que lhe faziam quanto com crítica, nas quais afirmava haver erros na língua portuguesa escrita de seu oponente (cf. Ribeiro 2007).

Escreveu também dois romances, O padre Belchior Pontes (1876-1877) e A Carne (1888). Este, um romance naturalista, foi duramente criticado na época, por conta de suas acentuadas descrições sexuais. De uma dessas críticas surgiu a Polêmica Célebre entre 
Julio Ribeiro e o Padre Senna Freitas, na qual, além de trocar diversas ofensas, o gramático critica a escrita do Padre, afirmando que há erros nela.

Nas Cartas Sertanejas, Ribeiro descreveu-se como ateu que já havia sido católico e presbiteriano, e como republicano e intransigente (cf. Ribeiro 2007:15). Ademais, sustentava a tese de que um bom político devia ser "cientificamente preparado", o que significava, para ele, ter conhecimentos, ao menos elementares, nas seguintes áreas:

[M] athematicas, a physico-khimica, a bio-physiologia, a psykhologia-moral. Deve ter boas noções de arithmetica, de algebra, de geometria, de mekhanica, de cosmologia, de astronomia sideral e planetária, de geodesia, de geographia physica, de geologia, de mineralogia, de paleontologia, de botanica, de zoologia, de anatomia, de histologia, de linguistica, de historia e geographia-historica, de industria, de arte, de litteratura, de sociologia, de legislação, de politica (Ribeiro 2007:23)

Em diversos ponto das Cartas Sertanejas, considera os políticos do país atrasados, isto justificado pelo fato de a maior parte deles terem estudado Faculdades de Direito, as quais ele considerava "metafísicas", que era o oposto de "científico" e, dado o perfil de político por ele idealizado, o oposto do que um político deveria ser. Esse mesmo termo, “metafísica", é apresentado no prólogo à segunda edição, de 1885, e na assinatura da primeira. No início do prólogo à segunda edição, Ribeiro afirma que "as antigas grammaticas portuguezas eram mais dissertações de metaphysica do que exposições dos usos da lingua" (Ribeiro 1885: 10) e que para se afastar da "trilha batida", ele não poupou trabalhos. No final da primeira edição, há um pequeno trecho de finalização da obra em que ele diz que "subtilezas só engendram confusão: em metaphysica cada qual discreteia a seu modo, e ha sempre tantas sentenças quantas são as cabeças.” (Ribeiro 1881: 291).

É notável sua retórica revolucionária em relação à “metafísica”. Sabemos pelas Cartas Sertanejas que Ribeiro tinha uma espécie de rixa com os bacharéis em Direito, os quais eram, naquele momento, a grande maioria dos governantes do Império, além de serem considerados a alta classe intelectual. O gramático, assim, parecia se perceber numa condição de mais baixo reconhecimento por não ser bacharel em Direito, mas ter estudado no Colégio Militar. Entretanto, como vimos, ele acreditava que os estudos científicos, que ele fazia, eram a direção correta; além disso, e com a influência positivista no país no final do século, a ciência passou a ter mais espaço (Bastos 2005). Assim, parece-nos, seu acesso ao reconhecimento dependia de uma retórica revolucionária, a qual não apenas direcionava-se ao estudo da linguagem, mas a grande parte do estado de coisas do Brasil de então.

Seu acesso ao reconhecimento, entretanto, foi relativamente rápido, dado que sua primeira edição da gramática alcançou grande sucesso, sendo citada por todas as revisões 
históricas que observamos (cf. item 1.5) e também em trabalhos mais recentes que tratam especificamente de sua gramática e/ou de sua obra (cf., pelo menos, Vidal Neto 2008; Coan 2016; Aquino 2016). Além disso, na segunda edição, Ribeiro transcreve os pareceres e os comentários positivos feitos por Ruy Barbosa, Conselheiro Antônio José Viale e André Lefèvre à primeira edição da obra (cf. FD12, Apêndice B).

As três epígrafes da obra, que se mantêm nas duas edições analisadas, apresentam sobretudo a autopercepção do gramático. A primeira, de Duarte Nunes de Leão (1530?1608), que, além de historiador, foi pioneiro descritor da ortografia da língua portuguesa do século XVII, afirma ter tentado ensinar aos seus naturais o que de outrem não pôde aprender. Com essa citação, Ribeiro parece também se considerar de alguma forma pioneiro. A segunda é uma citação de Émile Littré (1801-1881), famoso lexicógrafo e filósofo francês, que afirma que a gramática moderna só pode ser explicada por meio do conhecimento da gramática antiga. Com essa fala, o autor se apresenta como estando mais próximo dos métodos da gramática histórico-comparativa, que era expoente naquele momento. Finalmente, a epígrafe com citação de François Guizot (1787-1874), político francês, parece ser de cunho pessoal, ela diz que a glória de um homem não está em atingir seu objetivo, mas de ter rumado ao encontro dele (cf. FD12, Apêndice B).

Na primeira edição, há uma dedicatória a diversos nome expoentes do estudo da linguagem de então como: Friedrich Diez, Emile Littré, William Dwight Whitney, Max Müller, Auguste Branchet, Gaston Paris, Michel Bréal, Theophilo Braga, Adolpho Coelho. Na segunda edição, Ribeiro dedica sua obra à memória de Luiz de Camões, Friedrich Diez e Émile Littré, aos "mestres” André Lefèvre, Michel Bréal e Adolpho Coelho, ao erudito polígrafo Theophilo Braga, ao escritor Camillo Castello Branco, que Ribeiro chama de "mais robusto manejador actual da Lingua Portugueza", e aos brasileiros Capistrano de Abreu, Vieira de Almeida, Thomas Galhardo e Serafim de Mello. É notável a entrega de intelectuais brasileiros na segunda edição e omissão de outros autores a quem a obra era dedicada quando em primeira edição.

Ademais, o autor pede nas duas edições à "critica illustrada e honesta" que seja severa em suas críticas à gramática, a fimm de melhorar a obra. O prólogo à segunda edição traz, entre outras coisas, comentários acerca das críticas e as mudanças realizadas pelo autor entre uma edição e outra. Diz Ribeiro que ainda que tenha acolhido certas críticas, exultou outras que eram "injustas e virulentas de gente atrabiliaria que, à mingua da sciencia, lança mão do insulto". A respeito das mudanças de conteúdo, afirma que deixou as definições que tomara de Burgraff, preferindo as de Whitney. Ressalta que o tratamento 
da sintaxe é baseado no sistema germânico de Becker, o qual foi modificado e introduzido na Inglaterra por C. P. Mason, e que foi adaptado ainda por Whitney, Bain e Holmes. Além disso, afirma que não tinha visto ainda A Higher English Grammar de Bain em 1881, mas que ambos os autores acabaram por seguir caminhos similares e análogos em suas gramáticas.

Em suma, considerando os dados cruzados, é certo que a agenda de Ribeiro era, explicitamente, promover uma mudança, a qual daria maior reconhecimento e prestígio aos viéses por ele defendidos. Tal desejo de mudança é acompanhado por uma forte retórica de ruptura, que se apresenta em diferentes âmbitos, inclusive a respeito do modelo usado para a descrição linguística.

\subsubsection{Maximino de Araujo Maciel, Grammatica Analytica (1887, [152]) e Grammatica Descriptiva (1895, [188])}

Em volume publicado em 1900, Sacramento Blake descreve Maximino de Araújo Maciel (1865-1923) como recém-formado em Direito que se encaminhava para se formar em Medicina.

Dr. Maximino Maciel - natural de Sergipe - Formado em medicina e em direito, professor cathedratico do Collegio Militar, membro da Sociedade de Medicina e Cirurgia do Rio de Janeiro, do Instituto Historico e Geographico de Sergipe. (Sacramento Blake 1900: 265)

Nas folhas de rosto dos dois títulos estudados, há uma breve descrição da atuação profissional de Maciel. Em 1887, é descrito como "natural de Sergipe, estudante do curso médico. Professor de Linguas no collegio Augusto, professor livre de philosophia, ex-professor de portuguez e frances da Associação Promotora da Instrucção". Já em 1894, descreve-se como "Natural de Sergipe. Formado em direito e em sciencias sociaes, professor cathedratico no Collegio Militar". Nota-se que é relevante a informação de que o autor é nascido em Sergipe, a qual está presente em ambas as folhas de rosto. Nota-se também que em 1887 Maciel destaca ser estudante do curso médico, o qual, de acordo com Sacramento Blake, concluiu; no entanto, em 1894, essa informação não aparece na folha de rosto, é colocada apenas sua formação em direito e ciências sociais (a primeira apresentada também por Sacramento Blake). Ademais, em 1887, Maciel apresenta uma série de empregos, inclusive ex-empregos; já em 1894, apresenta somente um, de grande prestígio, catedrático do Colégio Militar. Talvez possamos 
interpretar esses dados como uma busca por reconhecimento em 1887 e um acesso ao reconhecimento mais estabelecido em 1894. De fato, esse reconhecimento pode ser atestado pelo alto número de reedições que teria sua obra, chegando, até onde sabemos, à décima segunda edição em 1931.

As publicações do autor passam por diversos assuntos. Até 1900, temos conhecimento apenas de publicações relativas à língua portuguesa, as duas gramáticas citadas e o livro Philologia Portugueza, publicado em 1889 no Rio de Janeiro. Do século $\mathrm{XX}$, temos conhecimento das publicações relativas a outras áreas do conhecimento: Noções geraes de agronomia (1901), Lições de Botânica Geral (1903), Elementos de chimica geral (1913). Há ainda modificações e acréscimos realizados na Grammatica Descriptiva, como o da quarta edição, de 1910, que acrescenta ao final da obra uma revisão dos estudos gramaticais brasileiros do século XIX (cf. item 1.5).

$\mathrm{Na}$ primeira edição de sua gramática, intitulada Grammatica Analytica, publicada em 1887, consta no subtítulo que a obra foi escrita "baseada nas doutrinas modernas, satisfazendo ás condições do actual programma". Este "programa" de que fala Maciel é o Programa de Estudos do Colégio Pedro II, elaborado por Fausto Barreto, no mesmo ano. É notável, entretanto, que no texto que inicia a obra, Maciel revele que escreveu a obra em 1885 (quando, ressalta o autor, contava 20 anos). Nesse mesmo texto, Maciel trata extensivamente a respeito da transição que atravessava a ciência da linguagem. Afirma que o final do século XIX ficaria marcado nas páginas da história geral dos povos como o século das grandes evoluções científicas. Considerando, pois, que haveria uma harmonia reinante tanto no "mundo físico" como no "moral", haveria uma existência de relações recíprocas das ciências (cf. Apêndice B, FD15). Tal ênfase nas relações entre as ciências, que não aparece na edição seguinte, talvez justifique também a apresentação do curso médico na folha de rosto da obra.

Na segunda edição da obra, que aparece oito anos depois, o título é modificado para Grammatica Descriptiva baseada nas doutrinas modernas. Em nosso mapeamento observamos que esta é a única gramática em que consta o adjetivo "descritiva". Havia, porém, algumas obras que exibiam o adjetivo "analítica" em seu título, como Morais (1869), Ortiz \& Pardal (1871, 1873, 1876, 1884, 1888), Grivet (1881), Carvalho (1885), Ribeiro (1881) e Massa (1888). Não pudemos encontrar, porém, nenhuma correlação entre o conteúdo dos títulos e uma possível agenda do autor. No prólogo à segunda edição Maciel afirma que 
Em 1887 publicámos o nosso primeiro trabalho -- Grammatica Analytica em que, baseando-nos nas doutrinhas modernas, concorresmos de algum modo para romper com a velha tradição, quebrando os antigos moldes em que vasava a grammaticographia. E certo que esse trabalho nosso a que alludimos, posto que houvesse sido acceito pelos competentes e exaltado pela imprensa, se resentia de muitos defeitos, devidos á transição em que se achavam as doutrinhas d'então. Além disso, nós o escrevemos baseados mais no que haviamos lido do que na observação e até experimentação dos phenomenos da lingua, de sorte que actualmente discordamos de alguns pontos, graças á longa pratica do magisterio em que consolidamos o que sabiamos e adquirimos o que hoje se acha exarado no corpo dessa Grammatica Descriptiva. (Maciel 1902[1894]: VIII)

Vemos, portanto, que Maciel procurou desde a primeira edição de sua gramática, em 1887, renovar a tradição da gramaticografia brasileira do português. Essa atitude é similar em 1894, mas com o acréscimo da experiência pedagógica do autor juntamente com correções das partes que sofreram críticas. A retórica revolucionária é evidente em ambas as edições. Ademais, no mesmo prólogo, Maciel define que sua obra não era destinada exatamente a alunos, mas aos professores para que estes, por sua vez, repassassem os assuntos, seletivamente, aos alunos (cf. FD22, Apêndice B). Finalmente, na segunda edição apresenta uma citação de Francis Bacon como epígrafe (a mesma, coincidentemente ou não, anteriormente apresentada por Carneiro Ribeiro (1877)), que traduzida para o português quer dizer "sou a lei do discurso, a regra verdadeira das línguas; quem não me aprende não obterá mais nada" 99 , a qual parece querer enfatizar o valor positivo, senão necessário, da gramática.

\subsubsection{Pacheco da Silva Junior e Lameira de Andrade, Noções de grammatica portugueza $(1887,[153])$}

Noções de grammatica portugueza foi obra escrita por dois autores, Manuel Pacheco da Silva (? - ?), de quem temos mais informações, e Boaventura Plácido Lameira de Andrade (? - 1897), que conhecemos menos. O primeiro, de acordo com Sacramento Blake, dedicou-se desde jovem ao magistério, lecionou inglês no Liceu de artes e ofícios e foi nomeado lente de português e história literária do imperial Colégio Pedro II. Temos notícia de diversas publicações suas a respeito da língua portuguesa e inglesa. Em 1876, publicou o Novo methodo facil e pratico para aprender a linguage ingleza, uma adaptação do texto originalmente inglês. Em 1877, publicou o texto Estudo da lingua vernacula. Phonologia. Em 1878, a Grammatica litteraria da lingua portugueza, que teve segunda edição em 1883. Nesse mesmo ano, escreveu o Diccionario etymologico da

\footnotetext{
${ }^{99}$ Tradução do latim de Edgard Bikelis "Lex sum sermonis, linguarum regula certa; qui me non didiscit coetera nulla petat".
} 
lingua portugueza, o qual não sabemos se chegou a ser publicado. Enfim, em 1887, publicou, em co-autoria com Lameira de Andrade, o livro que analisamos neste trabalho, o qual é organizado segundo os quarenta e seis itens do Programa de Estudos de Fausto Barreto para o Collegio Pedro II; a segunda edição, de 1894, modificada, aumentada e com novo título: Grammatica da lingua portugueza para uso dos gymnasios, lyceus e escolas normaes desse já não tem os capítulos organizados com base nos itens do programa. Escreveu outro texto gramatical, as Noções de analyse grammatical, phonetica, etymologica e syntaxica, em co-autoria com Boscoli, outro gramático da época, temos conhecimento da edição de 1888. Além das obras gramaticais, publicou ainda, segundo Sacramento Blake, texto de história do Colégio Pedro II em 1880, chamado O collegio Pedro II, seu passado, presente e futuro.

Como dissemos, obtivemos poucas informações sobre o Boaventura Plácido Lameira de Andrade, sabemos apenas, por (Oliveira \& Matta 2011), que ele era responsável pela seção destinada aos estudos da Linguagem de um periódico de divulgação científica do século XIX intitulado "O Vulgarisador: O Jornal dos Conhecimentos Úteis", editado entre os anos de 1877 - 1880 por Augusto Emílio Zaluar (1825-1882), autor português naturalizado brasileiro; sabemos também que Lameira de Andrade era o professor, de escolas normais, e filólogo. Nota-se, portanto, que ambos os autores atuavam profissionalmente com ensino e reflexão sobre a língua portuguesa e ambos parecem também ter acesso a reconhecimento.

A gramática apresenta epígrafe em português sem indicação de autor, citamos: "ainda quando a grammatica histórica só désse em resultado tornar as grammaticas ordinarias mais logicas e mais simples, já não prestava pequeno serviço". Nessa epígrafe, os autores apresentam uma defesa da "gramática histórica", que, como vimos, é defendida também por outros autores do mesmo período em seus paratextos. Ademais, no prólogo, os autores apresentam seus objetivos ao escrever a gramática e também visão a respeito dos estudos da linguagem no Brasil então.

O objetivo inicial dos autores era "escrever uma grammatica completa da lingua portugueza, rompendo em lucta a tradição". Tal rompimento com a tradição, retórica revolucionária, parece-nos, está relacionado àquela tradição baseada na grammaire générale, pois, como vimos, ambos parecem engajados nos estudos da linguagem mais recentes, pois escrevem a obra de acordo com o Programa de Estudos de Fausto Barreto e, como vimos na epígrafe, defendem a abordagem da "gramática histórica". Seu objetivo inicial, entretanto, foi um tanto modificado quando souberam do programa e dos pontos 
nele exigidos, os quais não estavam presentes nas gramáticas brasileiras de então, assim, a fim de auxiliar a mocidade estudiosa e apressadamente escreveram a gramática que analisamos.

Afirmam que a única dificuldade que tiveram nessa empreitada foi a dosagem, para explicar o que quiseram dizer com isso, citam o pedagogo Alberto Brandão:

\footnotetext{
A grande difficuldade com que vão arcar os professores é a dosagem, porquanto, como disse Michel Bréal, não ha methodo mais perigoso do que o historico, quando mal applicado, e os autores do livro a apparecer têm de pôr de parte a vaidade natural aos que muito estudam para formularem um livro modesto e comprehendido pelos que começam a estudar.
}

Segundo o julgamento dos gramáticos, alguns dos pontos do programa deveriam ser tratados em "theses, não de exames de preparatórios, mas de concurso ao imperial Collegio [Pedro II]". Procuraram, assim, seguir o conselho de Brandão - afirmam em nota que colocaram em texto de tipo maior o que o aluno é obrigado a saber, já em tipo menor estão informações para os que desejam aprender mais; ademais, afirmam ter omitido informações de que os alunos já tinham conhecimento desde a escola primária.

Como vimos em nosso mapeamento, houve outras gramáticas publicadas nos anos de 1887 e 1888 que seguiam o programa de estudos de Fausto Barreto, o qual parece ter sido um divisor de águas no período, ao menos em relação à educação secundária. Nesse sentido, a retórica mista dos autores, que elogiam a transição por que passava a gramática brasileira naquele momento ao mesmo tempo em que vêm um problema de dosagem, se apresenta com um forte viés histórico e com algumas críticas pedagógicas parece ser um produto desse contexto de debate, próprio de um período de transição.

\subsubsection{Fillipe Benicio de Oliveira Condurú, Grammatica Elementar da Lingua Portugueza (1888, [157])}

Com o ato adicional de 1834, a responsabilidade pelo ensino primário e secundário passou para as províncias. Assim, começaram a surgir as primeiras Escolas Normais, de formação de professores. Condurú foi em 1838 enviado à França por dois anos, com despesas pagas pela província, a fim de lá estudar o método de ensino de Lancaster (ou ensino mútuo), e, na volta para o Brasil, dirigir uma Escola Normal, de formação de professores. De acordo com Viveiros (s.d.), Condurú, além do método Lancaster, aprofundou-se também línguas e geografia durane sua estadia na França.

Sua Grammatica Elementar da Lingua Portugueza, publicada pela primeira vez em 1850 (cf. Nogueira 2009), e, de acordo com Viveiros, obteve grande sucesso, 
chegando a ter mais de vinte reedições, e foi adotada em escolas do Maranhão e do Pará. A edição a que tivemos acesso é a da 1888 , que não tem data na impressão da obra, mas que é, segundo Nogueira (2009), de 1888. Em sua folha de rosto, está escrito que Condurú era então professor da Escola Normal do Maranhão, e que a obra fora aprovada pelo Inspetor da Instrução Pública para uso das escolas de Primeiras Letras da província do Maranhão, e que fora aprovada pelo Conselho de Instrução Pública para uso do Liceu, Colégos e Aulas de Instrução Primária na província do Pará.

Não há prólogo na obra, de Condurú. Pelas poucas informações que temos a respeito dele e de sua gramática, podemos supor que ela tenha um direcionamento pegagógico e que ela obteve grande reconhecimento por um longo período, dado que em 1888, 38 anos após a primeira edição, ainda era reeditada e usada em diversas escolas do país. Não temos conhecimento de sua retórica.

\subsubsection{João Ribeiro Fernandes, Exames de Portuguez - Grammatica Portugueza $\left(3^{\circ}\right.$ anno) $(1889,[167])$}

João Ribeiro, cujo nome completo era João Batista Ribeiro de Andrada Fernandes (cf. Rodrigues 2013), nasceu em Laranjeiras, na província do Sergipe, em 1860, e faleceu no Rio de Janeiro (RJ) em 1934. Inicialmente estudou medicina na Bahia, notando, porém, sua inaptidão para a profissão, mudou-se para o Rio de Janeiro em 1881, a fim de cursar a Escola Politécnica, mas, enfim, preferiu estudar Ciências Jurídicas e Sociais, curso que conclui na Faculdade do Rio de Janeiro em 1893 ou 1894 (cf. Sacramento Blake 1898; Rodrigues 2013).

Em 1885, foi aprovado para o cargo de oficial da Secretaria da Biblioteca Nacional. Escrevia, então, para alguns jornais, função que exerceria por toda vida. Nesse mesmo período, passou a escrever um curso de gramática em três volumes que foram impressos pela tipografia Francisco Alves, as obras são: Exames de portuguez. Lições de grammatica portugueza, coordenadas segundo o programma de 1887, de 1887 ([154]) (1ª edição); Grammatica portugueza elementar, 1888 ([163][164]) (não sabemos se é a primeira edição); Grammatica portugueza. Curso médio. $2{ }^{\circ}$ anno de Portuguez, de 1888 ([164]) (acreditamos ser a $2^{\mathrm{a}}$ edição). Essas obras alcançaram muitas reedições, a primeira, direcionada para os exames de português teve algumas novas edições com novo título, Grammatica portugueza. Curso superior. $3 .^{\circ}$ anno de Portuguez, ainda no século XIX, das quais tivemos das dos seguintes anos: 1888 ([165]), 1889 ([167]), 1891 ([174]), 1893 ([176]), 1894 ([183][182]), 1898 ([198]); todas as edições pela tipografia de 
Francisco Alves. Escreveu ainda outros textos relacionados ao estudo da linguagem e da literatura: Estudos philologicos: morphologia e funcciologia, de 1884; Diccionario Grammatical, de 1889; e no século XX escreveu muitos outros textos, dos quais destacamos: Autores contemporâneos (1923, 1931) ${ }^{100}$ e A lingua nacional (1921, 1933). Ainda quanto às Letras, é importante ressaltar que João Ribeiro entrou para a Academia Brasileira de Letras um ano após sua fundação, em 1898, e foi um dos promotores da reforma ortográfica de 1907. João Ribeiro também era poeta, escreveu Sensações (1879), Idilios Modernos (1880), Versos (1890). (cf. Leão 1954)

Realizou o concurso para entrar no Pedro II em 1887, ficando em segundo lugar com a tese "Morfologia e Colocação de Pronomes". Posteriormente, foi nomeado em novembro de 1890 como lente de história universal do Pedro II (cf. Biografia ABL) e, a partir de então, iniciou suas pesquisas na área de história que lhe rendeu algumas publicações, como Historia antiga: Oriente e Grécia (1892); e no século XX, História do Brasil: curso superior (1990), História Universal (1918), História da Civilização (1932) (cf. Rodrigues 2013).

Como vemos, o autor estudado obteve grande reconhecimento sobretudo nos estudos da linguagem e da literatura, mas também na área de história, visto que foi professor dessa disciplina no Colégio Pedro II. Seus livros, em geral publicados pela Francisco Alves - pois, como vimos no mapeamento, diferentemente de outros autores, Ribeiro tinha suas reedições sempre impressas pela mesma tipografia - obtiveram grande número de reedições e foram indicados em programas de estudo do Colégio Pedro II (cf. Razzini 2000). Ademais, por ter escrito uma gramática baseada no programa de estudos de Fausto Barreto, de 1887, é autor citado na maior parte das revisões da produção gramatical brasileira (cf. item 1.5).

Vê-se, portanto, que ainda que sua atuação profissional fosse de professor de história no prestigiado Colégio Pedro II, o gramático manteve intenso contato com os estudos da linguagem, pelo qual foi bastante reconhecido. Tal reconhecimento aparece também no prefácio à segunda edição da gramática (cf. FD15, Apêndice B). O autor relata que a primeira edição vendeu mais de dois mil exemplares, tendo se esgotado em quatro meses, e afirma que tal evento se deve aos elogios recebidos de seus generosos críticos: Carlos de Laet, então presidente do Instituto Filológico, de Sylvio Romero, que disse: “ou muito me engano, ou o livro do Sr. João Ribeiro está destinado á popularidade e ás

\footnotetext{
${ }^{100}$ Que de acordo com Razzine, foi frequentemente utilizado em Programas do Colégio Pedro II.
} 
successivas edições". Recebeu também elogios de Capistrano de Abreu, Felisbello Freire, Aureliano Pimentel. No prólogo à segunda edição, avisa sobre mudanças que realizou a fim de aprimorar a gramática e destaca alguns autores que utilizou como modelo, que são: Latham, Mason, Andres Bello, Adolpho Coelho e Karl von Reinhard Stoettner. Finalmente, vale ressaltar a advertência feita pelos editores na folha de rosto da obra, de que se o leitor precisasse de mais aprofundamento em algum tema, ele poderia procurálo no Diccionario Grammatical do mesmo autor e publicado igualmente pela Francisco Alves.

É notável o reconhecimento institucional de João Ribeiro, que estava: (1) trabalhando no prestigiado Colégio Pedro II, (2) publicando suas obras por uma também prestigiada tipografia da época, a Francisco Alves, (3) e, na reunião desses dois fatores, seus livros didáticos eram indicados nos programas do Colégio Pedro II, alcançando um grande número de reedições. Tal reconhecimento é fruto de um clima de opinião mais institucionalizado, que certamente influenciava sua agenda. O autor escrevia gramáticas para diferentes níveis de ensino, evidenciando sua preocupação pedagógica, que pela maior institucionalização era, possivelmente, igualmente uma preocupação do clima de opinião de então.

Sua agenda também estava relacionada com a visão que se tinha de língua naquele momento. Ribeiro expressa sua intenção, por meio de uma citação do prefácio à primeira edição, "de escrever um livrinho util e claro que desaffrontasse a glottologia elementar do imminente descredito que, a olhos profanos, parece entre nós ameaçal-a" (cf. FD18, Apêndice B). Ressalta que o "critério histórico" - já citado por outros autores, como vimos - não sendo mais novidade, não precisava de excessos para sua divulgação, mas defende que naquele momento seria impossível desterrar o "critério filológico" do estudo das línguas, convinha, assim, que o bom senso o consolidasse, ainda que alguns “devotos errados" procurassem desacreditá-lo. A retórica mista do autor é revelada em tal trecho, dado que mostra como Ribeiro, por um lado, exaltava o novo modelo de análise, ao mesmo tempo em que observava "devotos errados". Tal retórica nos parece pertinente num momento de transição em que haveria frequentes discordâncias entre os gramáticos.

\subsubsection{Alfredo Gomes, Grammatica Portugueza (1895, [187])}

Temos pouquíssimas informações sobre Alfredo Gomes, intelectual cujo nome não encontramos no dicionário biobibliográfico de Sacramento Blake. Sabemos por meio 
das revisões históricas da produção gramatical que ele escreveu uma gramática de acordo com o programa de estudos de 1887 (cf. Maciel 1910, Nascentes 1939, Elia 1975, Cavaliere 2001, Azevedo Filho 2002, Parreira 2011, Polachini 2013), em geral citando apenas seu nome ao lado de outros autores que escreveram gramáticas de acordo com esse programa, a saber: João Ribeiro, Pacheco e Lameira, Maximino Maciel. Conhecemos e tivemos acesso apenas à $6^{\text {a }}$ edição da obra, publicada em 1895, a qual, de acordo com Razzini (2000), foi recomendada para o primeiro e segundo ano do Colégio Pedro II nos Programas dos anos de 1895, 1897 e 1898.

Pela folha de rosto da obra, sabemos que Alfredo Gomes era então professor da Escola Normal, provavelmente do Rio de Janeiro, e que sua gramática era adotada no Ginásio Nacional, Escola Normal, Colégio Militar, Colégio Abílio, Colégio Moss. O autor, como vemos, não cita ainda o Colégio Pedro II, talvez porque sua adoção da obra seja posterior à sua impressão. Esses dados podem atestar reconhecimento da obra e, consequentemente, de seu autor, o qual trabalhava no magistério. Sua inserção no Colégio Pedro II também pode aludir ao fato de que era uma gramática que procurava tratar da língua por meio de doutrinas mais recentes, mais aproximadas do método histórico-comparativo, em detrimento aplicação de princípios gerais da grammaire générale. Não tivemos conhecimento, porém, de sua retórica. 
Palavra dócil

Palavra d'água pra qualquer moldura Que se acomoda em balde, em verso, em mágoa Qualquer feição de se manter palavra (Chico Buarque de Holanda) 


\section{CAPÍTULO 4 | Análise orientada para conteúdo}

Neste capítulo, fazemos a análise orientada para o conteúdo das dezoito gramáticas selecionadas (cf. item 2.1), que consiste na observação das relações que o conceito-chave 'verbo substantivo/abstrato' trava com outros a realizando uma rede conceitual em torno dele (cf. item 2.3). A análise é dividida, inicialmente, por autor, em seguida, por obra (em ordem cronológica). Como já vimos no item 2.3, na análise particular da rede de cada obra, distinguimos cinco principais conceitos ou conjunto de conceitos, os quais são, em suma: (1) conceitos de gramática e de linguagem; (2) conceitos de metaclasses e classes de palavras; (3) conceitos modificadores do nome ('artigo', 'pronome', 'adjetivo'); (4) conceito de verbo; (5) conceitos de 'oração', 'sentença', 'proposição' e de seus elementos ('sujeito', 'verbo', 'atributo', 'predicado', 'complementos', 'funções').

Em seguida, considerando a diferença entre texto e metatexto, analisamos as relações entre o conceito de 'verbo substantivo', nosso conceito-chave que está incluído no item (4) supracitado, com os outros conceitos apresentados. Como mencionamos anteriormente (cf. 1.2), essas relações podem ser de quatro diferentes naturezas: (1) subordinação; (2) intersecção; (3) equivalência; (4) base teórica comum.

\subsection{Epitome da grammatica de lingua portugueza (1806, [1]), de Antonio Morais Silva}

\subsubsection{Conceitos de gramática e de linguagem e organização da obra}

Como podemos ver na Ficha Descritiva da obra (cf. Apêndice B, FD1), Morais Silva, depois de apresentar uma "Introdução", divide a gramática em dois livros. O primeiro chamado "das palavras ou partes da sentença" em que trata de oito classes de palavras. O segundo, chamado "da composição das partes da sentença entre si ou sintaxe", em que trata das sintaxes de 'concordância', 'regência' e 'figurada'. Ademais, no segundo livro, fala de 'composições viciosas' e apresenta um capítulo sobre 'sinais ortográficos' e 'pontuação'.

$\mathrm{Na}$ "Introdução", define 'gramática' como a arte que ensina a declarar bem os nossos pensamentos por meio de palavras. Segundo Morais Silva, há duas espécies de 'gramática', a 'universal', que ensina os métodos e princípios de falar comuns a todas as 
línguas, e a 'particular de qualquer língua', que aplica os princípios comuns de todos os idiomas ao nosso, segundo os usos adotados pelos que melhor falam. Finalmente, diz que trata a gramática, de 'sentenças' e das diversas partes de que elas se compõem, isto é, 'palavras'. Em metatexto (nota de rodapé), completa que 'palavra' é uma quantidade de 'som articulado' que significa algum conceito em um determinado idioma, e acrescenta que quaisquer sons que não são articulados e não são significantes não seriam objetos da gramática, caso, diz o gramático, das 'partículas', como 'advérbio', 'interjeição' e 'preposição'. Entretanto, o gramático as descreve na seção relativa às classes de palavras.

O Epitome da Grammatica Portugueza de Morais Silva, como diz o título, é uma 'gramática particular', que seria fundamentada em princípios da 'gramática universal'. Como veremos adiante, o autor em geral sugere que a 'língua', isto é, as 'palavras' e as 'sentenças', seriam manifestação de movimentos da alma ou pensamento que são universais - o que nos mostra que a o conceito de linguagem do autor se enquadra no Programa de Correspondência (Swiggers 2004, cf. Quadro 2). O gramático apresenta um tom normativo ao dizer que, além disso, a 'gramática particular' apresenta os usos adotados pelos que melhor falam (p. 9). Há, dessa forma, com base nos conceitos de 'gramática' apresentados, um ponto de vista híbrido, em que se procura explicar a língua portuguesa com base em princípios sua universalidade ao mesmo tempo em que há intenção apresentar a língua usada pelos que melhor falam.

\subsubsection{Conceitos de metaclasses e classes de palavras}

Morais Silva (1806:15-18) apresenta oito classes de palavras, as quais, na ordem colocada pelo gramático, são: 'nomes' ou 'substantivos', 'adjetivos articulares', 'adjetivos atributivos', 'verbos', 'advérbios', 'preposições', 'conjunções', 'interjeições'. Dessas, cinco dividem-se em três metaclasses: os 'substantivos' e 'adjetivos atributivos' são “os objetos que se apresentam à nossa alma”; o 'verbo' "o que a alma julga, afirma ou quer acerca dos objetos"; e 'preposições' (correlações entre coisas) e 'conjunções' (correlações entre sentenças) "as correlações que a alma vê entre os juízos e a forma deles”. Quanto às outras três classes de palavras, afirma em metatexto (nota de rodapé) que 'advérbios' são 'palavras compostas' (ex.: 'agora = hac hora; ninguém - nenhuma pessoa"). Ainda em metatexto, em outra nota de rodapé, a respeito dos 'adjetivos articulares', que não se enquadram nas metaclasses, diz que indicam o modo em que a 
alma vê a extensão individual dos nomes de 'classes', 'gêneros', 'espécies', isto é, em quantos indivíduos estende a significação do nome (p. 17). A respeito da 'interjeição' explica, em texto, que essa classe de palavras seria própria à 'linguagem com sentenças sentimentais', pois expressam simplesmente 'paixões', ao passo que as outras sete classes de palavras fariam parte da 'linguagem analisada e discursada'.

Adiante, apresentamos um quadro síntese das classes de palavras e metaclasses expostas por Morais Silva:

\begin{tabular}{|c|c|c|c|}
\hline \multicolumn{3}{|c|}{ Conceitos em texto } & Conceitos em metatexto \\
\hline Linguagem & Metaclasses & Classes de palavras & Metaclasses \\
\hline \multirow{5}{*}{$\begin{array}{l}\text { Analisada e } \\
\text { discursada }\end{array}$} & $\begin{array}{c}\text { Objetos que se } \\
\text { apresentam à nossa alma }\end{array}$ & $\begin{array}{c}\text { Substantivos } \\
\text { Adjetivos atributivos }\end{array}$ & - \\
\hline & $\begin{array}{l}\text { O que a alma julga, } \\
\text { afirma, quer }\end{array}$ & Verbo & - \\
\hline & $\begin{array}{l}\text { Correlações que a alma } \\
\text { vê entre os juízos e a } \\
\text { forma deles }\end{array}$ & $\begin{array}{l}\text { Preposições } \\
\text { Conjunções }\end{array}$ & - \\
\hline & - & Adjetivo articular & $\begin{array}{c}\text { Modo como a alma vê a } \\
\text { extensão individual dos } \\
\text { nomes de classes, } \\
\text { gêneros e espécies, isto } \\
\text { é, a quantos indivíduos } \\
\text { se estende a significação } \\
\text { dos nomes. }\end{array}$ \\
\hline & - & Advérbio & Palavras compostas. \\
\hline $\begin{array}{c}\text { Com sentenças } \\
\text { sentimentais }\end{array}$ & - & Interjeição & - \\
\hline
\end{tabular}

O gênero 'linguagem analisada e discursada' tem como espécies três 'modos' principais da alma expressar ideias, seja por objetos, por juízos e vontade ou pela correlação entre juízos e sua forma. Esses três 'modos' são gêneros de espécies representadas por algumas das classes de palavras, que metodologicamente chamamos de metaclasses. O primeiro do 'substantivo' e 'adjetivo atributivo', o segundo do 'verbo', e o terceiro da 'preposição' e da 'conjunção'. Estão ausentes, entretanto, três das oito classes de palavras de que fala Morais Silva. O 'adjetivo articular' estaria dentro de um quarto 'modo', no qual a alma vê a extensão dos nomes, entretanto, esse modo é apresentado em metatexto. A ‘interjeição' não faz parte do gênero linguagem articulada e discursada, de que os modos são espécie, mas faz parte do gênero linguagem com 'sentenças sentimentais'. O 'advérbio', por sua vez, é dado, em metatexto (nota de rodapé), como uma 'classe de palavra composta' e, por isso, não figuraria nos 'modos' (ex.: agora, hac hora; hoje, hoc die; boamente, bona mente). Em texto, Morais Silva expõe 
palavras que declaram 'objetos', 'atributos' e outras 'circunstâncias' nas ilustrações: “eu” quer dizer "homem ou mulher que te falo", "amo" equivale a "eu sou amante agora", "teme" é o mesmo que "tu sê temente agora".

É notável que, exceto pela explicação dada ao 'advérbio', todas as outras são psicológicas, no sentido em que as quatro metaclasses propostas são expressão do pensamento ou alma, e a 'interjeição' é expressão do sentimento - esse modo de análise certamente estaria dentro do Programa de Correspondência de Swiggers (2004, cf. Quadro 2). Ademais, três das quatro metaclasses ('modos') estão relacionadas a processos sintáticos, o que é coerente com a ocupação da 'gramática' segundo a gramática, que vimos na seção anterior, como sendo a de tratar de 'sentenças' e de suas 'partes'. Assim, as classes de palavras estão sempre atreladas à 'sentença' e ao 'pensamento'. A ausência do 'advérbio' na classificação, porém, parece ser justificada em referência à forma da palavra, sem referência ao pensamento ou à 'sentença', dado que o gramático apresenta equivalências entre 'advérbios' da língua portuguesa e duas palavras da língua latina.

Adiante, observamos mais detidamente os conceitos modificadores do nome, que no caso de Morais Silva, são as classes de palavra 'adjetivo articular' e 'adjetivo atributivo'.

\subsubsection{Conceitos modificadores do nome}

O Epitome de Morais Silva é a única das gramáticas estudadas a apresentar dois diferentes conceitos de 'adjetivo', 'articular' e 'atributivo', como classes de palavras. $\mathrm{O}$ primeiro, define como elementos que se ligam aos 'nomes gerais' ou 'comuns' para determinar o número ou quantidade de indivíduos de que falamos. Suas espécies são: 'artigo simples', 'numerais', 'demonstrativos', 'possessivos', ‘conjuntivos' e ‘articulares' sem 'especificação'.

$\mathrm{O}$ 'artigo simples' tem como exemplos apenas “o, a”, em princípio, ele indica que o 'nome' se toma em toda a 'extensão' dos indivíduos que sua significação se aplica, como na ilustração de uso: "o homem é mortal". No entanto, pode ter diversas outras funções, listo-as adiante: determinar 'nome' extensivamente restrito a um só ‘sujeito' ou menos de todos da espécie junto com outras 'circunstâncias' (il.: o homem que ontem vimos, o velho da montanha); 'nomes próprios' não admitem 'determinativos', por terem já determinada sua 'extensão'; pode haver 'artigo posposto' junto com uma circunstância 
quando o nome individual não basta (il.: D. Afonso, o bravo); omite-se o 'artigo' toda vez que o 'nome comum' se usa atributivamente (il.: animal é boi, parede de ferro); parece trazer à memória o 'nome antecedente' (il.: Viste o cavalo de João? Vi-o), mas em verdade trata-se de 'elipse' ou falta do nome "cavalo" que facilmente se subentende Morais Silva ressalta que o 'artigo' não muda de natureza, nem é 'pronome' como “eu, tu”; finalmente, se usamos dos 'adjetivos' em vez dos 'nomes abstratos' (il.: o doce, o amargo) o 'artigo' refere-se e modifica ao "nome' "ser" subentendido ${ }^{101}$. O gramático afirma, em metatexto, que "a natureza do artigo parece que foi inteiramente desconhecida de nossos gramáticos". Algo similar é dito no prólogo da obra, como vimos anteriormente (cf. capítulo 3, item 3.2.1).

O 'numeral' tem os seguintes exemplos "um, dois, três" - Morais Silva comenta que "um” denota incerteza. Ademais, há uma espécie de 'numerais' chamados 'ordinais', que são exemplificados por "primeiro, segundo, terceiro". 'Demonstrativos', exemplificados por “este, esse, aquele", determinam a extensão do 'nome' a que se liga pela circunstância de estar o objeto, respectivamente, junto à primeira pessoa, à segunda pessoa ou distante das duas anteriormente citadas. Diz em metatexto (menção a gramáticos) que os gramáticos denominam esse conceito como 'pronomes demonstrativos', mas são, em verdade, 'adjetivos articulares demonstrativos', cujos 'substantivos' se calam ou se expressam. Ainda em metatexto (nota de rodapé, menção), ressalta que dizem alguns gramáticos que “isto, isso, aquilo" são 'variações neutras' de "este, esse e aquele", mas em verdade, segundo Morais Silva, equivalem a vários elementos da oração. 'Possessivos' são "meu, teu, seu, nosso, vosso". Em metatexto (menção a gramáticos), afirma que os gramáticos chamam-nos de 'pronomes possessivos', mas são 'articulares possessivos'. 'Relativos' são “que, qual, quem, cujo, onde, quando", trazem à memória o 'nome' antecedente ou tempo ou espaço e ajuntam a 'sentença' em que está o 'articular' com a antecedente.

Finalmente, há os 'articulares' sem denominação específica. O primeiro citado é “ele" que traz à memória um nome antecedente. Em metatexto (menção a gramáticos), diz que tem os casos "lhe, lhes" e que é impropriamente chamado de "pronome de terceira pessoa', entretanto, é 'adjetivo articular' por ser derivado do latino “ille, illa, illad” que em português usa-se frequentemente com 'elipse' do 'substantivo' a que pertence. Outros

\footnotetext{
101 Não há ilustrações de Morais Silva para esse caso, entretanto, supomos que seja algo similar a "o ser doce", "o ser amargo".
} 
‘articulares' são “todo”, que se usa sem o 'articular' e indica a totalidade de indivíduos e “algum, nenhum, cada, qualquer" cujo sentido, diz Morais Silva, é óbvio.

O 'adjetivo atributivo', outra classe de palavra, é definido como palavra que significam as qualidades existentes em algum objeto (ex.: branco, louro, manso, leal, amável). Por vezes, diz Morais Silva, podem ser usados por ‘nomes abstratos' (ex.: o agro dessa fruta; o doce do mel; o teso do monte). $\mathrm{O}$ autor se pergunta se não subentenderiam o 'nome verbal' "ser", que, em metatexto (nota de rodapé), ilustra com texto de Camões "o ser preso de tão formosos olhos, cantá-lo bastaria a contentar-me".

\subsubsection{Conceito de verbo}

Morais Silva define o 'verbo' como palavra com que se declara o que a alma julga ou quer acerca dos 'sujeitos' e dos 'atributos' das 'sentenças', com ele, portanto, afirmamos e mandamos (il.: eu sou amante; filho, sê temente a Deus). O gramático ressalta que a significação ou ofício principal dos 'verbos' anda anexa à significação de algum 'atributo' que existe ou que queremos que exista e as diversas épocas em que ele existe. Complementa que há usos que se equivalem e os ilustra: “amo" por si só equivale a "eu sou amante atualmente", e "ama a deus" a "sê tu amante de Deus". Essa é uma definição sintática, o 'verbo' é definido com base na 'sentença'; é também citada, secundariamente, sua função de exprimir 'tempo'.

Considerando-se a relação do 'verbo' com os elementos que vêm ao seu redor na 'sentença', há o 'verbo neutro', que não é nem 'ativo' nem 'passivo'. Segundo Morais Silva, em metatexto, os gramáticos chamam assim 'verbos' que não significam 'ação' (il.: o vento dorme; as ondas jazem; o cisne iguala a neve na candura) ou que significam uma ação que fica no mesmo 'sujeito' de quem se afirma (il.: eu ando, salto, respiro, corro, vivo). Ressaltamos, porém, que na definição de 'verbo' e da metaclasse que o engloba, o gramático não cita 'ação', mas apenas 'afirmação', 'julgamento' e 'mando' perguntamo-nos se seria essa 'ação' correspondente a um 'atributo' do 'verbo'. Os 'verbos ativos' têm em geral um 'paciente' ou 'objeto' em quem se emprega a 'ação' (il.: feri a Pedro; matei a lebre; remar o batel; remei meu remo; pelejar as pelejas do Senhor). Esses se dizem 'verbos transitivos' mas por vezes são usados sem 'paciente' (il.: não teme, não espera a consciência pura - isto é, não teme, não espera nada; primeiro haveis de alimpar como marmelo - isto é, ficar limpo; as minas da Espanha esgotaram). Por 
outro lado, pode-se juntar eventualmente aos 'verbos neutros' 'pacientes', como aos 'transitivos' (il.: viver vida feliz; correr carreiras; correr seu curso; o homem medroso tudo o estremece; deus chovia maná aos Israelitas; a planta malnascida o céu a geia, neva, abrasa e chove; entre outros). Alguns 'verbos neutros' usam-se com 'paciente' para designar espontaneidade e energia do 'sujeito' (il.: entrou o ano; entrou se o inimigo pela porta). Quando o ‘sujeito’ faz a ação em si mesmo (il.: Pedro feriu-se, cortou-se) dizem os gramáticos (metatexto) que isso se dá por 'verbos reflexos'. Já se os 'sujeitos' são reciprocamente 'agentes' e 'pacientes' (il.: Pedro e João amam-se; feriram-se). Menciona ainda que outras línguas têm propriamente, isto é, em 'sentido' e em 'figura', 'verbos médios', 'dobradamente ativos', que não há no português, dado que os 'reflexos' ou 'pronominais' e os 'recíprocos' são ‘ativos puros', usados com 'sujeito' e 'pacientes' idênticos. Ademais, a falta que a língua portuguesa tem de 'verbos passivos' é suprida de dois modos: usando dos 'verbos' "ser" e "estar" com os 'particípios passivos' (ex.: sou amado; estou ferido; il.: por ser justo e devido o dever se guardar tal como) ou ajuntar o 'caso' "se" aos sujeitos da 'terceira pessoas' que não podem fazer a ação em si mesmos (il.: cortam-se árvores; tecem-se sedas; edifica-se o edifício).

Morais Silva, fala, enfim, do 'verbo substantivo' ao dizer que os gramáticos (metatexto) chamam ao 'verbo' "ser" 'substantivo', porque a ele se ajuntam todos os 'atributivos' e ainda 'nomes' usados 'compreensivamente' ou 'atributivamente' (ex.: ser amado, ferido, amante; il.: o ser vosso, senhora, me condena [ref.: Camões]; o tempo ensina ser justo os pequenos [ref. Ferreira]; tudo é suspeito e pouco seguro para as mulheres até o serem virtuosas [ref. Menina e Moça]). Em metatexto (nota de rodapé), observa que por vezes o 'infinitivo substantivo' "ser" ou "serem” pode estar 'elíptico' (il.: de que maneira podiam escapar, de mortos ou cativos $=$ de serem mortos ou cativos [ref. Jornada d'África]; segundo os cavaleiros d'esta casa são poucos costumados a ociosos $=$ a serem ou estarem ociosos [ref.: Palmeirim]).

Morais Silva define os 'verbos impessoais' como aqueles que não têm variações correspondentes à 'primeira', nem à 'segunda pessoa', as quais são comuns ao homem, porque os 'atributos' desses 'verbos' não podem caber a homens, não se diz, por exemplo, "eu chovo", a não ser no sentido figurado (il.: tu nos choves altas doutrinas). A esses ‘verbos', diz Morais Silva, chamam os gramáticos (metatexto) ‘impessoais' ou carecentes de 'variações pessoais', mas eles as tem, ao menos das 'terceiras pessoas'. Além disso, por uso não se diz “eu fedo, eu brando, eu muno" por serem esses 'verbos defectivos'. 
Embora os termos e conceitos apresentados por Morais Silva priorizem a atividade e passividade do 'verbo', acima da transitividade, essa é contemplada muitas vezes na definição dos conceitos de 'verbo recíproco', 'reflexo', 'médio' e, sobretudo, 'ativo'. Ademais, notamos a utilização de conceitos da língua latina ao tratar das espécies de 'verbo', como se vê no caso de 'verbo passivo' e 'verbo médio' (os quais o autor diz não haver em português, mas ainda assim levanta o conceito) - embora o autor critique fortemente essa postura (cf. item 3.2.1). Ressaltamos que o 'verbo substantivo' é mostrado como apenas mais uma das espécies de 'verbo', sendo apresentado ao final do capítulo de tratamento dessa classe de palavra. Ademais, na definição dada ao 'verbo impessoal', o autor diz que o 'atributo' do 'verbo' não poderia corresponder a “homens”, por isso ele é usado sempre na 'terceira pessoa'. A noção de que existe um 'atributo' nos 'verbos' é explicitada por diversos gramáticos (por exemplo, Bithencourt 1862 e Caneiro Ribeiro 1881, 1890, cf. 4.5 e 4.7), entretanto, ela é baseada na noção de que todo 'verbo' é formado também pelo 'verbo substantivo'. Como Morais Silva apresenta um conceito alternativo de 'verbo substantivo' e não o coloca como essencial ao conceito de 'verbo', a definição de 'verbo impessoal' parece deslocada de outros conteúdos da obra.

\subsubsection{Conceito de sentença e seus elementos}

Morais Silva define a 'sentença', ou 'sentido perfeito', como a 'boa composição' das 'partes da oração' entre si com que nos fazemos entender, falando por 'palavras'. Toda 'sentença' declara o que julgamos das coisas (il.: este pomo é doce, João é virtuoso) ou o que queremos que as pessoas, coisas, sejam, façam, sofram (il.: filho, sê estudioso, sofre-te com os trabalhos). Nas 'sentenças' estão o 'sujeito', o ‘atributo', o ‘verbo' e, eventualmente, 'circunstâncias'. O ‘sujeito' é de quem se afirma, o qual é representado por um 'nome' sozinho ou modificado por 'articulares' e 'atributivos' ou por 'nomes' com 'preposições' (il.: este homem virtuoso foi infeliz; o templo de deus é lugar santo). O 'atributo' declara-se por 'adjetivos atributivos' ou 'nomes' com 'preposições' (ex.: infeliz; il.: Pedro é homem de honra, sem honra) - Morais não explica o papel do 'atributo' na 'sentença', apenas diz de que classes de palavras ele pode ser constituído. O 'verbo' afirma e conecta os 'atributos' aos 'sujeitos' ou exprime a vontade e mando (il.: tu é amante, sê amante). Por vezes, um único 'verbo' faz uma 'sentença perfeita' (il: amas, ama). $\mathrm{O}$ 'verbo' também pode significar ação que se emprega no 'paciente' e 'termina' em alguém (il.: feri a Pedro; dei um livro a Pedro; ensinei gramática aos 
meninos) - a noção de 'ação' não estava na definição da classe de palavra 'verbo', mas aparece na definição de 'verbo ativo'. Finalmente, o 'verbo' ou a ação que ele significa pode ser modificada e acompanhada de 'circunstâncias' de 'lugar', 'tempo', 'modo', ‘instrumento' e 'fim' (il.: dá esmolas aos pobres em segredo, com alegria, para consolação da sua aflição, sem vexame de sua vergonha e por satisfação da sua verdadeira liberalidade, sem mistura de vanglória).

O gramático afirma que o artifício de compor 'sentenças' consiste em mostrar as ‘conexões' ou ‘correlações' entre os 'nomes de coisas' e seus 'atributos' significados pelos 'adjetivos'; entre os 'nomes de coisas' e os 'adjetivos articulares', entre os 'nomes sujeitos'e os 'atributos' anexos aos 'verbos' com a afirmação ou querer. As 'correlações' entre os 'nomes' podem se dar de três maneiras: 1) variando a 'terminação' do 'nome' correlato com o seu antecedente, e isso principalmente nas línguas que tem 'casos'; 2) por meio de 'preposições' que indicam a 'correlação' que há entre os 'nomes' dos objetos; 3) pondo o 'nome correlato' junto do outro, que está em relação com ele, por meio de algum 'verbo' modificante do 'nome antecedente'.

Em metatexto (nota de rodapé) traz duas ilustrações, uma para (3) e outra para (2). Em relação ao terceiro modo como correlações podem se dar, Morais Silva apresenta as ilustrações de uso: em “Pedro ama João”, a ‘correlação' entre “João”, ‘objeto' amado por "Pedro", 'agente', resulta do 'atributo' “amante" que está unido ao 'verbo' “é”, pois "ama" equivale a "é amante"; para (2), apresenta a ilustração de uso "homem hábil para as letras", em que a 'correlação' entre “homem” e "letras” é mostrada pela 'preposição' "para" que indica o fim e que completa o sentido vago de "homem hábil". Em texto, apresenta ilustrações de uso da língua latina para mostrar como se daria (1).

Nenhuma das ‘correlações’ de Morais Silva está relacionada à 'afirmação', que é parte significativa da definição de 'verbo' e de 'sujeito'. Ademais, é de se notar que o gramático apresente a 'correlação' feita por meio de 'casos' e a exemplifique em latim, ainda que sua gramática tenha como objeto apenas a língua portuguesa.

Morais Silva é bastante conciso quando trata de espécies de 'sentença'. Diz que há 'sentenças' que modificam a 'sentença principal' explicando-a ou limitando-a a um ou mais indivíduos (il.: a virtude, que sempre é respeitável, nem sempre é amada; a casa que ontem vimos é minha; os livros, que eu tinha, perderam-se em um naufrágio). Essas 'sentenças' chamam-se 'incidentes', iniciam-se com 'articulares relativos conjuntivos' (ex.: que, quem, qual, onde, quando; il.: estive no teatro quanto tu lá estavas) e podem ser 'explicativas' ou 'determinativas' do sentido de uma palavra da 'sentença principal'. 


\begin{tabular}{|c|c|c|}
\hline \multicolumn{2}{|c|}{ Conceitos de espécies de 'sentença' } \\
\hline $\begin{array}{c}\text { Sentença } \\
\text { Principal }\end{array}$ & $\begin{array}{r}\text { Não há definição. Morais Silva diz apenas que ela pode ser modificada por outras } \\
\text { 'sentenças', sendo assim explicada ou limitada a um ou mais indivíduos. (il.: a } \\
\text { virtude, que sempre é respeitável, nem sempre é amada; a casa que ontem vimos é } \\
\text { minha; os livros, que eu tinha, perderam-se em um naufrágio) }\end{array}$ \\
\hline \multirow{2}{*}{$\begin{array}{c}\text { Sentença } \\
\text { Incidente }\end{array}$} & $\begin{array}{r}\text { Explicam ou limitam/determinam o sentido de uma palavra da 'sentença principal'. } \\
\text { Iniciam-se por 'articulares relativos conjuntivos' }\end{array}$ \\
\cline { 2 - 3 } & Explicativa & $\begin{array}{r}\text { Explicam o sentido de uma palavra da 'sentença principal' (il.: } \\
\text { a virtude, que sempre é respeitável, nem sempre é amada) }\end{array}$ \\
\cline { 2 - 3 } & Determinativa & $\begin{array}{c}\text { Determinam o sentido de uma palavra da 'sentença principal' } \\
\text { (il.: casa que ontem vimos é minha; os livros, que eu tinha, } \\
\text { perderam-se em um naufrágio) }\end{array}$ \\
\hline
\end{tabular}

Notamos alguma aproximação conceitual entre as espécies de 'sentença incidente' e as espécies de 'adjetivo' (cf. item 4.1.2), tal aproximação não chega, porém, a ser um paralelismo. Lembremos que o 'adjetivo articular' é definido como aquele que determina o número ou quantidade de indivíduos de que se fala e tem como espécies 'artigos', 'demonstrativo', 'possessivos', enquanto o 'atributivo' significa qualidades existentes em algum objeto. Finalmente, observamos que embora o autor traga um número considerável de dados linguísticos (exemplos e ilustrações de uso são frequentes), mostrando sua preocupação com a língua, a gramática por vezes parece não explorar todos os aspectos desses dados, visto que ele conceitua apenas duas espécies de 'sentença'.

\subsubsection{Rede conceitual}

O conceito de 'verbo substantivo' é definido como aquele a que se ajuntam todos os 'atributivos' e 'nomes' usados compreensivamente ou atributivamente (Morais Silva 1806: 60-61), seu exemplo é "ser", as ilustrações de uso provêm quase todas da literatura, seja para demonstrá-lo em uso, seja, em metatexto, para demonstrar sua ausência, quando ele está omitido. Em ambos os casos, as fontes de dados são textos literários portugueses do século XVI: cita autores como Bernadim Ribeiro (1482? - 1552?), por Menina e Moça, Francisco de Moraes (1500-1572), por Palmeirim, Luís Vaz de Camões (15241580), Antonio Ferreira (1528-1569), Jerônimo de Mendonça (1578-1607), por Jornada d'África, dos quais extrai ilustrações em que o 'verbo substantivo'.

Como vimos na breve história do conceito de cópula (cf. Capítulo 1, item 1.4), o 'verbo substantivo' era, em geral, na tradição da grammaire générale, próprio de uma língua em parte lógica, em parte subjacente, a qual nem sempre se apresentava na fala 
usual, isto é, ele fazia parte da análise e conhecimento da língua. Assim, Morais Silva foge a essa tradição ao apresentar exemplos cujas referências sejam literárias, consequentemente, usuais, não subjacentes.

Essa visão da língua como lógica e subjacente se apresenta, porém, com frequência na obra de Morais Silva, por exemplo, quando o gramático trata do conceito de linguagem e da distinção das metaclasses de palavras, e mesmo quando trata dos conceitos de 'verbo' e de 'sentença'. Esses últimos, aliás, são conceitos estritamente relacionados, pois envolvem definições que tratam de 'afirmação' ou 'mando' - o que se dá, muito provavelmente, proveniente da junção entre aspectos da grammaire génerale francesa e do Hermes (1751) do inglês James Harris (1709-1780) (cf. Capítulo 1, item 1.4.2), obra citada diversas vezes por Morais Silva na gramática. Ademais, as ilustrações de uso apresentadas na definição de 'verbo' chamam atenção na medida em que as duas primeiras (il.: eu sou amante; filho, sê temente a Deus) apresentam o verbo "ser", que podia facilmente ser suprimido nos dois casos. Posteriormente, emenda que há usos equivalentes e apresenta as seguintes ilustrações "amo" a "eu sou amante atualmente", "ama a deus" a "sê tu amante de Deus". No entanto, não é mencionado o "verbo substantivo' e, pelas ilustrações de uso apresentadas para esse conceito, parece que ele era considerado o verbo "ser" usual e não um item que se apresenta essencialmente em todos os outros verbos, chamados pela tradição, em geral, de 'adjetivos'. Logo, parecenos que, embora Morais Silva apresente análises que se assemelham àquelas que poderiam ser feitas com o conceito de 'verbo substantivo' costumeiro da tradição, o conceito de 'verbo substantivo' apresentado no final da seção de tratamento da classe de palavra 'verbo' e em metatexto não tem correspondência com essas análises. Ainda, em relação ao conceito de 'sentença', nota-se que o autor dá duas possibilidades estruturais para ela: uma em que o ‘verbo' significa ‘julgamento' ou 'mando' e outra em que é 'ação' e, nesse caso, costuma ter um 'paciente' e pode ter também um 'termo'. Em suma, Morais Silva apresenta ecletismo horizontal nos conceitos de 'verbo' e 'sentença', os quais ainda assim sustentam a noção de linguagem que predomina na obra, ao mesmo tempo em que seu conceito de 'verbo substantivo' é bastante particular e distancia-se mesma da concepção de linguagem.

Quanto à base teórica da obra, define 'gramática' no início como "arte que ensina a declarar bem os nossos pensamentos". Os 'modos' da 'linguagem analisada e discursiva' são sempre relativos à maneira como a 'alma' concebe e observa objetos, juízos, determinações e relações. As classes de palavras parecem, assim, ser expressão 
dos movimentos da alma. A 'sentença' também seria a expressão um movimento da alma, julgamento ou mando, regido pelo 'verbo'. Da mesma maneira, as espécies de 'sentença' e de 'adjetivos' são movimentos da alma que 'explicam' e 'determinam' objetos. Essa base teórica, portanto, seria aproximada do Programa de correspondência de que fala Swiggers (cf. Capítulo 1, item 1.2). Entretanto, o conceito ‘verbo substantivo’ no Epitome de Morais Silva contrai apenas relação de subordinação com o conceito de 'verbo'. É apenas mais uma dentre as espécies de 'verbo' e está apresentado em metatexto. Dessa forma, ele é coadjuvante entre as espécies de verbo.

\subsection{Arte da grammatica portugueza (1816, [4]), de Ignacio Felizardo Fortes}

\subsubsection{Conceitos de gramática e de linguagem e organização da obra}

A gramática de Fortes é dividida em oito livros (cf. Apêndice B, FD2). Os cinco primeiros referem-se às classes de palavras. O livro I trata do 'nome', do 'pronome', do ‘particípio', do ‘artigo' e de 'acidentes' dessas classes como ‘número' e ‘caso’; o livro II trata do 'acidente' 'gênero'; no livro III, o gramático disserta a respeito do 'verbo', suas espécies e suas 'conjugações'; o livro IV é dedicado a falar sobre o 'pretérito' e do 'particípio pretérito' nas três 'conjugações'; finalmente, o livro V trata das classes de palavras 'advérbio', 'conjunção', 'interjeição' e da 'proposição'. A 'prosódia' é tema do livro VI. No livro VII, dedicado à 'sintaxe', o gramático trata da 'sintaxe de regência' e da 'sintaxe de concordância', trata ainda dos casos 'dativo', 'acusativo' e 'ablativo'. Finalmente, o assunto do livro VIII é 'sintaxe figurada'.

Fortes define 'gramática portuguesa' como "uma arte que ensina a fazer sem erros a oração portuguesa” e que deve conter quatro partes, que são: 'ortografia', 'prosódia', 'etimologia' e 'sintaxe'.

\subsubsection{Conceitos de metaclasses e classes de palavras}

De acordo com o gramático, há nove 'partes da oração', que são colocadas na seguinte ordem: 'artigo', ‘nome', ‘pronome', ‘verbo', 'particípio', ‘advérbio', 'conjunção', 'interjeição', 'preposição'. Não são apresentadas metaclasses, nem há explicação para justificar a seleção de classes de palavras realizada. 


\subsubsection{Conceitos modificadores do nome}

As três classes de palavras que correspondem ao que temos chamado de modificadores do nome são 'artigo', 'nome' e 'pronome', as quais são anteriores ao 'verbo' e representam classes que, em diversas gramáticas, estariam juntas sob a classe “guarda-chuva” de 'adjetivo' (por exemplo, Morais Silva e Costa Duarte cf. 4.1 e 4.3), o qual, entretanto, na gramática analisada, é apenas uma espécie do 'nome'. O conceito de 'artigo' para Fortes é o de uma 'parte da oração' que serve para mostrar os 'gêneros' e os 'casos' dos 'nomes'. Exemplifica com duas palavras “o, a”, as quais podem ser colocadas nos cinco 'casos', nos dois 'gêneros' e no 'singular' e 'plural', como no quadro adiante:

\begin{tabular}{|c|c|c|c|c|}
\hline & Masc., sing. & Masc., plural & Fem., sing. & Fem., plural \\
\hline Nominativo & o & os & as & as \\
\hline Acusativo & do & dos & da & às \\
\hline Dativo & ao & aos & a/para a & as/para as \\
\hline Ablativo & o/ao/para o & os/aos/para os & da/na/pela & das/nas/pelas \\
\hline Genitivo & da/no/pelo & dos/nos/pelos & & \\
\hline
\end{tabular}

Quadro 23. 'Casos' do 'artigo' em Fortes (1816)

O nome divide-se em 'substantivo' e 'adjetivo'. Definem-se por sua oposição: o primeiro pode estar na 'oração' sem o 'adjetivo', ao passo que o segundo não pode estar na 'oração' sem o 'substantivo'. Ademais, o segundo divide-se em diversas espécies ( 'positivo', ‘comparativo', 'superlativo', 'partitivo', 'possessivo', 'pátrio', 'gentílico', 'numeral'), das quais enfatizamos o 'possessivo', que mostra o senhor ou possuidor de algo (il.: paço real), e o 'numeral', que significa número e tem as seguintes espécies: 'cardeal' (ex.: um, dois, três), o número absolutamente, e 'ordinal', número por ordem (ex.: primeiro, segundo, terceiro).

Finalmente, o 'pronome' é uma 'voz' que na 'oração' se põe em lugar de um 'nome', como é o caso de “eu, este”. Há diversas espécies de ‘pronomes', listamo-las com suas definições e exemplos a seguir: 'demonstrativo', é aquele que serve para mostrar qualquer coisa (ex.: este, esta); o 'relativo' traz à memória nome antecedente (ex.: aquele, o qual); o 'interrogativo' serve para perguntar (ex.: quem?, qual?); 'primitivo', aquele que não é 'derivado' de outro (ex.: eu, tu); 'derivado', aquele que deriva de outro (ex.: meu, teu); 'possessivo', o que mostra o senhor ou possuidor de algo (ex.: meu, teu); 'recíproco', refere-se à ação ao mesmo ‘sujeito’ de quem se fala (ex.: se; il.: Pedro feriu-se). 


\subsubsection{Conceito de verbo}

Fortes define o 'verbo' como 'voz' com que se significam as 'ações' e as 'paixões' de qualquer 'sujeito' declarando juntamente o tempo em que elas se exercem (il.: eu amo; eu sou amado). Há três espécies de 'verbo'. 'Ativo', que tem significação 'transitiva', emprega-se em ‘sujeito’ diverso de sua significação (ex.: louvar). 'Passivo', que significa ação obrada por outro ‘sujeito' e sofrida pelo ‘sujeito' do verbo (il.: eu sou louvado). 'Neutro', que tem 'significação permanente', que se emprega em si mesmo ou em ‘sujeito’ da mesma significação (ex.: morrer). Em metatexto (nota de rodapé), acrescenta os 'verbos auxiliares'; diz que o verbo “ter” é 'ativo', mas pode também se chamar 'auxiliar', porque ajuda a 'conjugar' todos os demais 'verbos'. A 'forma passiva', diz ele, conjuga-se ajuntando o particípio “tido, tida" (e de todos os outros 'verbos') ao 'verbo' "ser" em todos os tempos; é possível, também, formá-la colocando-se a partícula" "se" antes ou depois dos 'verbos ativos', conforme fizer melhor 'pronunciação' (ex.: se louva, louva-se). Como se vê, o autor não apresenta o 'verbo substantivo' nem faz qualquer alusão a ele; além disso, quando menciona o 'verbo' "ser”, coloca-o como 'auxiliar'.

\subsubsection{Conceito de oração e seus elementos}

O tratamento da sintaxe na gramática de Fortes é divido em 'sintaxe de concordância', 'sintaxe de regência' e 'sintaxe figurada'. As duas primeiras seções são compostas apenas de 'regras', não há definição de conceitos. Consequentemente, não há definição de 'oração'. Há, no total, 35 regras, as quais, afima o autor em metatexto (nota de rodapé), têm regras correspondente na língua latina (o que está de acordo com os objetivos de Fortes para a obra analisada, cf. item 3.1.2). Dessas, 24 são de 'regência', das quais transcrevo parte adiante a fim de demonstrar os conceitos que Fortes utiliza para tratar da sintaxe.

O 'sujeito' que exercita a significação do 'verbo do modo finito' vai para o 'nominativo', com o qual o ‘verbo' concorda em 'número' e 'pessoa' (il.: Antônio dorme; Os meninos brincam). Aquilo que se afirma ou se nega desse 'sujeito' ou a ele se refere também vai para o 'nominativo' (ilustração de uso: A velhice é doença; Eu sou chamado Antônio). O 'nome' que significa o senhor ou possuidor de alguma coisa ou a que ela pertence põe-se em 'genitivo' 'regido' da 'preposição' “de” (il.: Estou em casa de 
Francisco). Aos 'verbos' “confiar, dar, entregar, enviar, mandar, obedecer, remeter, recomendar", e outros, se ajunta o 'dativo', que significa a pessoa a que se confia, dá, entrega etc. (il.: todos devemos obedecer ao mestre). O 'verbo ativo' tem depois de si o 'acusativo', que é aquele 'sujeito' a quem se dirige a significação do 'verbo' (il.: Pedro matou a Antônio; o fogo queimou as casas.). O modo com que alguma coisa faz põe-se no 'ablativo' com a 'preposição' "com” ou “de" (il.: Leio com grande cuidado; o lobo investe a ovelha de salto.).

\subsubsection{Rede conceitual}

Sendo nosso conceito-chave o 'verbo substantivo', não pudemos encontrar rede conceitual estabelecida em torno dele nessa gramática. Entretanto, é notável observar o viés da obra, em que se desenvolvem técnicas de descrição da língua latina, sobretudo porque isso acaba por fazer com que nenhum dos seus conceitos aproximem-se do que seria uma rede conceitual hipotética (cf. item 1.4.2). O 'adjetivo' é espécie de 'nome' e é simplesmente definido como aquele que não pode aparecer sem o 'substantivo'. O 'verbo' é definido, semanticamente, como paixão ou ação. A 'oração' nem sequer é definida na obra, cujo tratamento da sintaxe se dá por meio de regras, as quais tratam sobretudo dos 'casos' latinos adaptados para língua portuguesa.

\subsection{Compendio da grammatica portugueza (1829, [10]) e Compendio de grammatica philosophica da lingua portugueza (1859, [44]), de Antonio da Costa Duarte}

\subsubsection{Conceitos de gramática e de linguagem e organização da obra}

Podemos ver que a divisão da gramática em quatro partes mantém-se a mesma nas duas gramáticas, são elas: 'ortoépia', 'etimologia', 'sintaxe', e 'ortografia' (cf. Apêndice B, FD3 e FD5). A única diferença entre as duas obras é a extensão de alguns subcapítulos, sendo os do Compêndio de 1859 mais longos, o que ocorre, provavelmente, pelas longas notas de rodapé inseridas.

$\mathrm{Na}$ 'Introdução' de ambas as gramáticas, Costa Duarte apresenta o seguinte trecho, no qual podemos identificar seu conceito de linguagem, que, por estar relacionado ao pensamento, que é uniforme, único e imutável: 
$\mathrm{Na}$ formação de seus pensamentos é uniforme, unico, e imutável o procedimento do espirito humano; pois que todo o homem, de qualquer Nação que seja, pensa porque tem ideias e comparando-as apreende a relação que entre elas ha; mas como entre as operações de nosso espírito e a Linguagem articulada, por meio da qual se exprimem, ha uma intima connexão e correspondencia; é forçoso que esta mesma immutabilidade se communique ás Linguas de todos os Povos. (1829: 7; 1859:5)

O autor define duas espécies de 'gramática', a 'universal' e a 'particular'. A primeira é a 'arte' que, analisando o pensamento, ensina com que 'espécies de palavras' se devem exprimir as ideias e as relações de que ele pode constar e, por isso, essa gramática é imutável e a mesma em todas as nações. A 'gramática particular' supriria a necessidade de acomodação dos princípios invariáveis da 'gramática universal' à índole de cada língua, visto que no seu aspecto material os vocábulos são diferentes (entre as línguas). Depois do estabelecimento dos preceitos gerais da linguagem, esses são aplicados aos usos da língua que se pretende ensinar. Acrescenta que a gramática trata tanto o aspecto físico e material dos vocábulos como de seu aspecto lógico e discursivo. Sobre o primeiro aspecto, ela observa os sons articulados elementares e fundamentais da linguagem, as sílabas que resultam de sua combinação, a pronunciação desses sons, os caracteres literais adotados pelo uso para representarem e fixarem esses mesmo sons e vocábulos na escrita; desses temas, tratam a 'ortoépia' e a 'ortografia' . Trata também, sobre o segundo aspecto, dos vocábulos como sinais representativos das nossas ideias e das suas relações, na 'etimologia' e na 'sintaxe', os quais:

para que representem clara, distincta, e fielmente as nossas ideias, é necessario primeiramente analysar o pensamento, reduzindo-o aos seus elementos, para distribuir em classes determinadas assim as ideias, como as relações de que elle póde constar; e depois assignar a cada uma destas classes outras tantas especies de palavras correspondentes que as enunciem; o que é dependente da observação das differentes propriedades, usos, e serventias, que as palavras tem no discurso; [...] resta saber coordenar e compor uma oração ou um encadeamento dellas, dando ás palavras já esta, já aquella terminação, subordinando umas as outras, de maneira que se accommodem ás differentes relações que as ideias tem entre si, ou sejão de identidade e coexistencia, ou de determinação e subordinação, e colocando em fim as palavras de um modo authorizado pelo uso, para de tudo isto resultar um sentido ao mesmo tempo ligado, e distincto. (1829: 8; 1859:6)

Assim, o gramático explicita na introdução da obra seus conceitos de linguagem e de gramática, além de separá-la em quatro partes. Notamos que há subordinação da linguagem ao pensamento, o qual sendo uno transmuta-se nos usos variáveis das diversas línguas. A gramática teria como base categorias do pensamento que seriam adaptadas à língua, visto que esta é considerada expressão daquele - tal maneira de ver a língua está claramente dentro do Programa de Correspondência definido por Swiggers (2004, cf. Quadro 2). 
No início do capítulo logo após a introdução, o autor, nas duas gramáticas, apresenta uma definição de caráter normativo para a 'gramática portuguesa': "arte que ensina a falar, ler, e escrever sem erros a Lingua Portugueza" (1829: 9; 1859: 7). Na gramática de 1859 conecta essa definição a uma nota de rodapé, metatexto, em que define 'arte' e 'língua'. 'Arte' é “um systema rasoado de operações proprias a produzir um effeito importante á vida, e que se não podia esperar da natureza só" (1859:7). 'Língua', por sua vez, é definida como um sistema de sinais que manifestam diretamente o pensamento, tal manifestação pode se dar por meio da linguagem articulada (com a língua e os vocábulos específicos de cada nação) ou por meio de gestos (movimentos do rosto e sons inarticulados). Finalmente, afirma que uma língua deve ser fácil para que seja entendida por ignorantes e sábios, mas para que seja bem feita e fácil, deve ser clara, precisa ou resumida, rica, e fundada na origem e geração de ideias.

\subsubsection{Conceitos de metaclasses e classes de palavras}

Na gramática de 1829, há uma introdução ao capítulo 'Da Etymologia' que se inicia com a seguinte afirmação: como em toda natureza há unicamente 'substâncias', 'qualidades' e 'relações', no pensamento há só 'ideias de substancias', 'de qualidades' e 'percepção de relações' ('de identidade', 'determinação', 'nexo' e 'ordem') entre as mesmas ideias e, enfim, sendo as palavras sinais de nossas ideias e de nosso pensamento, há em toda língua cinco espécies de palavras. Adiante, apresentamos um quadro com elas e o aspecto da realidade e do pensamento com que elas têm correspondência.

\begin{tabular}{|c|c|c|}
\hline Aspectos da natureza & $\begin{array}{c}\text { Ideias e relações do } \\
\text { pensamento }\end{array}$ & $\begin{array}{c}\text { Partes elementares da oração } \\
\text { e do discurso }\end{array}$ \\
\hline Substâncias & Ideias de substâncias & Nome substantivo \\
\hline Qualidades & Ideias de qualidades & Adjetivo \\
\hline \multirow{2}{*}{ Relações } & Relações de identidade & Verbo substantivo \\
\cline { 2 - 3 } & Relações de determinação & Preposição \\
\cline { 2 - 3 } & Relações de nexo e de ordem & Conjunção \\
\hline
\end{tabular}

Quadro 24. Natureza, pensamento e discurso em Costa Duarte $(1829,1859)$

As classes de palavras são justificadas por corresponderem a metaclasses relativas a 'ideias' e 'relações' do pensamento, as quais, por sua vez, correspondem a aspectos na natureza. Ao corresponder os recortes da realidade, do pensamento e da linguagem, Costa Duarte apresenta uma conceptualização específica de linguagem (mais uma vez, 
intimamente relacionada com o Programa de Correspondência definido por Swiggers 2004, cf. Quadro 2).

O capítulo de 'etimologia', que trata das 'partes elementares da oração e do discurso', é iniciado pela definição de 'oração' ou 'proposição', que é a união de um 'atributo' com um 'sujeito' (il.: o homem é racional), e de 'discurso', um encadeamento de 'proposições'. Apresenta, depois, seis partes do discurso, as cinco 'partes elementares' e a 'interjeição' que equivale a todas elas e passa a defini-las e explicá-las nas seções seguintes.

Na gramática de 1859, não apresenta introdução ao capítulo de 'etimologia'. Inicia-o pela definição de 'oração', que é a mesma exposta em 1829. Em metatexto (nota de rodapé), define 'juízo', 'ideia' e 'proposição', que são, respectivamente: a percepção da 'relação de conveniência' ou 'de repugnância' entre duas 'ideias'; o resultado da ação da alma sobre um sentimento único; e um ‘juízo enunciado' (este último equivale à definição dada em texto para 'oração', avisa o autor). Em texto, apresenta as mesmas cinco 'partes elementares da oração' que estavam na gramática de 1829, inclui ainda a 'interjeição', que não é considerada 'parte elementar do discurso', porque ela equivale a uma 'oração' ou a muitas. Em nota de rodapé, metatexto, apresenta parte do texto colocado na introdução do capítulo na gramática de 1829.

Emenda ainda, na gramática de 1859, observações sobre a 'interjeição', dizendo que nos exprimimos por ela quando enunciamos as "ideias em confusão". Assim, a 'interjeição' é equivalente a todas as cinco 'partes do discurso', mas o autor a contabiliza entre elas, somando seis. Costa Duarte sustenta que as 'partes do discurso', ainda que possam variar no material dos sons em diferentes povos, representam as mesmas ideias e as mesmas relações em todas as línguas (sejam, diz ele, cultas, selvagens, antigas e modernas). Observa ainda na mesma nota de rodapé que os termos 'nome substantivo', ‘adjetivo' etc. são invenções dos gramáticos, mas que são invenções necessárias para dar um nome a cada uma das diferentes classes de palavras, as quais correspondem às diversas espécies de ideias que existem no pensamento. Enfatiza que sempre houve nas línguas, palavras essencialmente diferentes, e ainda que palavras sejam iguais no material, pode haver variação quando são 'sinais de ideias'; ilustra isso dizendo que "head”, em inglês, significa "cabeça, chefe" quando é 'nome substantivo', mas significa "governar" quando é ‘verbo'; em português “tinha, capa, rio” são ‘nomes' e 'verbos'. 


\subsubsection{Conceitos modificadores do nome}

Nas gramáticas de Costa Duarte, os conceitos modificadores do nome estão na classe de palavra 'adjetivo'. Em 1829, Costa Duarte apresenta uma seção chamada “Dos nomes adjetivos", em que define o 'adjetivo' como palavra que significa acessórios e qualidades de um 'sujeito', a quem serve de 'atributo', e, consequentemente, não pode estar na 'oração' sem o 'sujeito'. Vê-se que a 'oração' tem papel central na análise do gramático (diferentemente, por exemplo, do que vimos na arte de Fortes em que o 'adjetivo' não pode aparecer sem um 'substantivo' (cf. 4.2)). Na edição de 1859, define 'nome adjetivo' (curiosamente dentro da seção de tratamento dos 'nomes substantivos') como palavra "que significa alguma qualidade, existente em algum sujeito; ou determina o nome substantivo, como: Virtuoso, Alegre, Todo, Este.” (p. 23). Quando inicia o tratamento de 'adjetivos' apresenta uma seção chamada "Divisão dos nomes adjetivos", na qual, sem definir a classe de palavra, porque já havia sido definida anteriormente, divide-a, tal como fizeram em 1829, em três espécies, mostradas no quadro adiante:

\begin{tabular}{|c|c|}
\hline Espécie de 'adjetivo' (termo) & Conceitos (iguais) apresentados em 1829 e 1859 \\
\hline Explicativo & $\begin{array}{c}\text { Significa algumas das qualidades incluídas na significação do nome } \\
\text { apelativo (il.: Homem racional) }\end{array}$ \\
\hline Restritivo & $\begin{array}{c}\text { Exprime alguma qualidade não incluída na significação do } \\
\text { apelativo (il.: homem virtuoso) }\end{array}$ \\
\hline Determinativo & $\begin{array}{c}\text { Junto ao apelativo, faz com que ele seja aplicado a compreender } \\
\text { todos os indivíduos da sua classe, somente alguns, um só, ou } \\
\text { nenhum (il.: todo o homem, alguns homens, este homem, nenhum } \\
\text { homem) }\end{array}$ \\
\hline
\end{tabular}

Quadro 25. Espécies de 'adjetivo' em Costa Duarte $(1829,1859)$

Observamos que muitos gramáticos apresentam essas espécies de 'adjetivo', como veremos neste capítulo, entretanto, é mais comum que façam duas divisões binárias, uma primeira que divide o 'adjetivo' em 'determinativo' e 'qualificativo' e outra que divide o 'qualificativo' em 'restritivo' e 'explicativo'.

Há três espécies de 'adjetivo determinativo' em ambas as edições, a saber: 'artigos, 'demonstrativo' e 'determinativo de quantidade'. Adiante, observaremos suas definições e taxonomia nas diferentes gramáticas de Costa Duarte.

No Compêndio de 1829, o 'artigo' é definido como: anteposto ao 'apelativo', mostra que ele compreende determinadamente todos os indivíduos da sua classe (ex.: o, a, os, as) (il.: o homem é racional). Quando é necessário que o 'artigo' compreenda apenas um indivíduo, ou menos dos da espécie, usa-se de alguma circunstância restritiva (il.: o café do Pará; viste o homem?). Além disso, é anteposto ao 'sujeito' da 'oração' il.: o 
estudo aperfeiçoa a razão) e quando é anteposto a qualquer 'elemento da oração' torna-o 'substantivo' (il.: o amar). Faz 'nomes próprios' ‘apelativos' (il.: a Bahia; o Porto; os Camões). Finalmente, não se usam anteposto a 'nomes próprios', quando assim usado, não pertence ao ‘nome próprio' (il.: o Brasil = o império Brasil) e não se usam antepostos a alguns 'demonstrativos'.

No Compêndio de 1859, Costa Duarte define 'artigo' simplesmente como: 'monossílabos' que, antepostos aos 'nomes apelativos' fazem com que eles se tomem: ou no sentido individual, ou determinadamente ou de modo vago. Distingue duas espécies de 'artigo': 'artigos definidos' (ex.: o, a, os, as) e 'artigos indefinidos' (ex.: um, uma, uns, umas), os primeiros - similares ao que foi denominado apenas 'artigo' em 1829 - são definidos aqueles que, antepostos ao 'apelativo', mostram que ele compreende determinadamente todos os indivíduos da sua classe (il.: o homem é racional). Porém sendo necessário que o apelativo compreenda um só indivíduo ou menos do da espécie, usa-se de alguma circunstância restritiva (il.: o café do Pará; viste o homem?). É anteposto a 'apelativos' que significam objetos conhecidos. Ademais, repete o que já havia sido dito em 1829 sobre: ser anteposto ao 'sujeito' da 'oração'; tornar substantivo qualquer elemento ao qual se antepõe; faz 'nomes próprios' 'apelativos'; não é usado antes de 'nomes próprios' e quando está nessa posição; não pertence a ele; finalmente, não é usado anteposto a alguns demonstrativos. O 'artigo indefinido', por sua vez, anteposto ao 'apelativo', dá-lhe sentido individual, porém, vagamente. (il.: um filho deve ser obediente ao pai). Ademais, antepõe-se a 'apelativos' que significam objetos desconhecidos.

Em ambas as gramáticas, os 'demonstrativos' dividem-se em três espécies: 'pessoais', 'puros' e 'conjuntivos'. Os 'pessoais' fazem com que os nomes a que se ajuntam, ou a que se referem, sejam uma das três pessoas ou coisas que lhes pertença (ex. de primitivos: eu, tu, ele, nós, vós, eles; ex. de derivados: meu, teu, seu, nosso, vosso).

Os 'puros' são os que fazem com que os apelativos mostrem os objetos no lugar e distância em que estão (ex.: este, esta, isto, esse, essa, isso, ele, ela, elo (antigo), aquele, aquela, aquilo, mesmo, o mesmo). Todos os 'demonstrativos puros' podem ser 'relativos', isto é, representar nomes antecedentes; mas não podem ser 'conjuntivos'.

Finalmente, os 'conjuntivos' mostram ou o 'sujeito', ou o 'atributo' de uma 'oração antecedente' e unem ao mesmo tempo as 'orações parciais' com as de que são parte (ex.: o qual, a qual, os quais, as quais, que, cujo, cuja, cujos, cujas, quem; il.: qual é a coisa que pode faltar a quem tem por seu um deus cujo é tudo quanto há no céu e na 
terra?). Ademais, todos os 'demonstrativos conjuntivos' podem ser 'interrogativos', mas nem por isso deixão de ser os mesmos 'conjuntivos' (il.: que hei de fazer? = dizei-me a coisa que eu hei de fazer.) Na gramática de 1859, Costa Duarte acrescenta em metatexto que há quem se oponha a que os 'interrogativos' sejam 'demonstrativos conjuntivos', e apresenta seu ponto de vista, contrário, com ilustrações: “dize-me que navios entraram hoje?" que é o mesmo que "dize-me o número e nome dos navios que entraram hoje", visto que, afirma o gramático, em ambas estas proposições se exprime o desejo de saber, e ambas são linguagem corrente.

A última espécie de 'adjetivo determinativo' são os 'determinativos de quantidade', que se definem, nas duas gramáticas, como aqueles que fazem com que os apelativos, a que se juntam compreendam ou todos os indivíduos da classe, ou somente alguns, ou nenhum, para sobre eles, ou sobre nenhum recair o atributo da oração (il.: todo o homem é mortal; alguns homens são virtuosos; nenhum homem é infalível). Há duas espécies de 'adjetivos determinativos', 'universais' e 'partitivos'. Em 1829, define os 'universais' como aqueles que fazem compreender todos os indivíduos da classe do apelativo juntos (ex.: todo, toda, tudo, todos, todas). Em ambas as obras esses universais podem ser 'afirmativos' (ex.: todo, toda, tudo, todos, todas) ou 'negativos' (ex.: nenhum, nenhuma, nada e ninguém). Na gramática de 1859, distingue os 'universais' em 'coletivos', que tem a mesma definição dos 'universais' de 1829, mas inclui nos exemplos também os 'artigos definidos' “o, a, os, as”, e em 'distributivos', que fazem compreender todos os indivíduos da classe do apelativo separadamente um por um (ex.: cada) (il.: cada homem tem seu gênio = todos os homens têm seu gênio, cada qual o seu). Os 'partitivos', em ambas as gramáticas, são os que fazem com que os 'apelativos' a que se unem, compreendam só uma parte, ou 'determinada' ou 'indeterminada', dos indivíduos da sua classe; e por isso fazer as 'orações particulares' (il.: alguns homens escaparam do naufrágio e quatro morreram afogados). Na gramática de 1859, acrescenta ainda uma espécie particular de 'determinativo de qualidade' chamada 'numerais', os quais determinam ao certo o número dos indivíduos. São 'cardiais', número das unidades (ex.: um, dois); 'ordinais' (ex.: primeiro, segundo), 'multiplicativos' (ex.: duplo, dobrado, triplicado) ou 'fracionários' (ex.: quinta parte, duas sesmas).

Em ambas as gramáticas, finaliza a seção destinada à descrição dos 'adjetivos' com um pequeno texto sobre as os 'objetos' que os 'nomes' juntos numa 'oração' podem ser ou as 'relações' que eles podem ter. Costa Duarte cita 'Sujeito', 'Atributo', 'Vocativo', 'Complemento Restritivo', 'Complemento Terminativo', 'Complemento 
Objetivo' e 'Complemento Circunstancial', os quais são brevemente explicados em 1829 (ver quadro adiante), já em 1859, o autor prefere apenas se referir ao capítulo de 'sintaxe', dizendo que lá tratará com mais detalhes desses conceitos.

\begin{tabular}{|c|c|}
\hline \multicolumn{2}{|c|}{ Costa Duarte (1829: 25-26) } \\
\hline Sujeito & Quem fala, ou de quem se fala na 'oração' \\
\hline Atributo & O que se afirma do sujeito, ou se lhe atribui \\
\hline Vocativo & O que exprime a pessoa com quem se fala \\
\hline C. Restritivo & Um nome precedido da preposição "de" \\
\hline C. Terminativo & O nome que exprime o termo de outra relação \\
\hline C. Objetivo & O nome que exprime o objeto imediato da ação do verbo \\
\hline C. Circunstancial & Os nomes circunstâncias, pertencentes aos termos da oração \\
\hline
\end{tabular}

Quadro 26. Objetos que os nomes podem ser e relações que podem ter na oração (Costa Duarte 1829)

Em seguida, define 'casos' como a 'terminação' diferente de um nome dentro do mesmo 'número'. Ressalta que na língua portuguesa, apenas os 'pessoais primitivos' têm casos, porque variam de terminação para exprimir as diferentes relações, as quais são indicadas nos outros nomes pela sua posição ou por meio de partículas antepostas a eles. Tal preocupação em já definir ou ao menos citar esses conceitos, próprios do tratamento da sintaxe, no capítulo 'Etimologia', que trata das classes de palavras, pode ser interpretada como uma centralização do tratamento da sintaxe.

\subsubsection{Conceito de verbo}

Chama atenção a diferença de leiaute entre as duas gramáticas quando tratam do ‘verbo', pois, enquanto em 1829, praticamente não há notas de rodapé, em 1859, as notas de rodapé são maiores do que o texto em muitas páginas. Em geral, esses longos metatextos de 1859 são reflexões ou discordâncias sobre o que havia na gramática de 1829 a respeito do 'verbo', e que o autor, mantém parcialmente no texto de 1859. Adiante, observamos essa tensão existente entre o conceito de 'verbo' entre as duas gramáticas de Costa Duarte e também entre texto e metatexto na gramática de 1859. Dessa forma, iremos sempre comparar os textos das duas edições para, depois, apresentar o metatexto de 1859. No quadro adiante, comparamos os dois conceitos de 'verbo' em texto.

\begin{tabular}{|c|c|}
\hline \multicolumn{2}{|c|}{ Conceito de 'verbo' em texto } \\
\hline Costa Duarte 1829 & Costa Duarte 1859 \\
\hline $\begin{array}{l}\text { 'Verbo' é uma 'parte do discurso' que une o } \\
\text { 'attributo' da 'oração' com o seu 'sujeito', } \\
\text { enuciando por diferentes modos a coexistencia de } \\
\text { um no outro, com relação a certos tempos e pessoas } \\
\text { (il.: eu sou, tu foste, elle será). A enunciação da } \\
\text { existência é o que é essencial ao 'verbo', assim, }\end{array}$ & $\begin{array}{l}\text { 'Verbo' é a palavra que anima os 'termos da } \\
\text { proposição', e por differentes modos, tempos, e } \\
\text { pessoas exprime a união de um 'atributo' com um } \\
\text { 'sujeito' (il.: Deus é justo: O homem não é } \\
\text { infalível: Aplico-me ao estudo). A essência do } \\
\text { 'verbo' consiste em animar os termos da }\end{array}$ \\
\hline
\end{tabular}


não podêmos admitir mais do que o 'verbo substantivo', porque só este pode enunciá-la; mas tendo nós em vista assim a enunciação da existência, como outras ideias acessórias, dividimos em geral o verbo em três espécies, a saber: 'verbo substantivo', 'verbos auxiliares' do mesmo, e 'verbo adjetivo'. 'proposição', e ao mesmo tempo enunciar a 'relação de conveniência' entre um e outro. Mas attendendo não só á essencia do 'verbo', e ao emprego que se lhe dá, mas tambem às ideias acessórias, nele muitas vezes concentradas, podemos dividir o 'verbo' em três espécies, a saber: verbo substantivo', 'verbos auxiliares', e 'verbo adjetivo'.

Quadro 27. Conceitos de 'verbo' em Costa Duarte $(1829,1859)$

Há pequenas diferenças de texto, em 1859, já não se chama o 'verbo' de 'parte do discurso' e ele 'anima' os 'termos' da 'proposição' em vez de apenas, como é definido em 1829,' 'unir o 'sujeito' e o 'atributo' da 'oração' e promover a 'coexistência' de um no outro. Além disso, em 1829, o 'verbo'. As ilustrações de uso apresentadas são diferentes, embora em ambos os casos apresente-se o 'verbo' "ser", em 1859, há também o 'verbo' “aplicar-se”. Em ambas as gramáticas, há uma essência do 'verbo', em cada uma delas, porém, é diferente. Em 1829, é a 'enunciação da existência', o que cabe ao 'verbo substantivo' apenas; já em 1859 consiste em 'animar' os termos da 'proposição', e ao mesmo tempo enunciar a 'relação de conveniência' entre um e outro - não há menção ao 'verbo substantivo'. Finalmente, ambas as obras, considerando também as ideias acessórias do verbo, apresentam três espécies de 'verbo': 'substantivo', 'auxiliares' (que em 1829 referem-se ao 'verbo substantivo' apenas), e 'adjetivos'. Costa Duarte parece ter desistido da definição de 'verbo' como palavra que promove a coexistência.

Em metatexto de 1859, nota de rodapé cujo índice está na definição de 'verbo', Costa Duarte repete a definição dada em texto; em seguida, defende que o 'verbo' signifique me 'relação', lembrando que sem os dois 'termos' da 'proposição', 'sujeito' e 'atributo' essa relação não pode existir. Acrescenta que essa 'relação' é tão simples que poderia ser significada sem o 'verbo’ por mera relação de concordância entre dois termos (il.: homem frágil, leão rugidor). Ressalta não faria sentido que significasse ação, ato ou estado, dado que esses são modos de existir do 'sujeito'. Finalmente, diz que o 'verbo' é 'palavra animada', pois dá vida aos 'termos' da 'proposição' e por conta disso os latinos teriam lhe chamado de "verbum", 'palavra por excelência'. Observa, no final da nota, que o 'verbo' não exprime relação de discordância, pois as 'proposições negativas' reduzemse às 'positivas', visto que a negação modifica o 'atributo', não o 'verbo' (il.: o homem não é infalível $=$ o homem é não infalível $=$ o homem é falível).

No quadro adiante, apresentamos os conceitos apresentados em texto de 'verbo substantivo', 'auxiliar' e 'adjetivo' nas duas gramáticas de Costa Duarte. 


\begin{tabular}{|c|c|c|}
\hline $\begin{array}{l}\text { Conceitos } \\
\text { (Termos) }\end{array}$ & $\begin{array}{c}\text { Conceito em texto - Costa Duarte } \\
(1829)\end{array}$ & $\begin{array}{c}\text { Conceito em texto - Costa Duarte } \\
(1859)\end{array}$ \\
\hline $\begin{array}{c}\text { Verbo } \\
\text { Substantivo }\end{array}$ & $\begin{array}{l}\text { Une o 'atributo’ da ‘oração' com seu } \\
\text { 'sujeito' e enuncia a 'coexistência' de } \\
\text { um em outro (ex.: ser). }\end{array}$ & $\begin{array}{l}\text { Não tem concentrado em si 'atributo' e } \\
\text { serve de ‘cópula' ou 'nexo' que une os } \\
\text { 'termos' da 'proposição', isto é, o } \\
\text { ‘atributo' e o ‘sujeito' (ex.: ser; il.: Pedro } \\
\text { é sabio). Há dois verbos na língua } \\
\text { potuguesa que exprimem a existência: } \\
\text { “ser”, que exprime existência habitual e } \\
\text { permanente, e “estar”, que exprime } \\
\text { existência atual e temporária (il.: eu sou } \\
\text { doente; eu estou doente). }\end{array}$ \\
\hline $\begin{array}{l}\text { Verbo } \\
\text { Auxiliar }\end{array}$ & \multicolumn{2}{|c|}{$\begin{array}{c}\text { Auxiliam o 'verbo' “ser" a tomar todas as 'formas compostas' e 'combinações } \\
\text { necessárias' ao discurso - para indicar as diferentes épocas da existência (ex.: haver, } \\
\text { estar, ter). Só quando conjugados com o infinito pessoal e particípio do verbo "ser" } \\
\text { esses verbos são 'auxiliares'. }\end{array}$} \\
\hline $\begin{array}{c}\text { Verbo } \\
\text { Adjetivo }\end{array}$ & \multicolumn{2}{|c|}{ 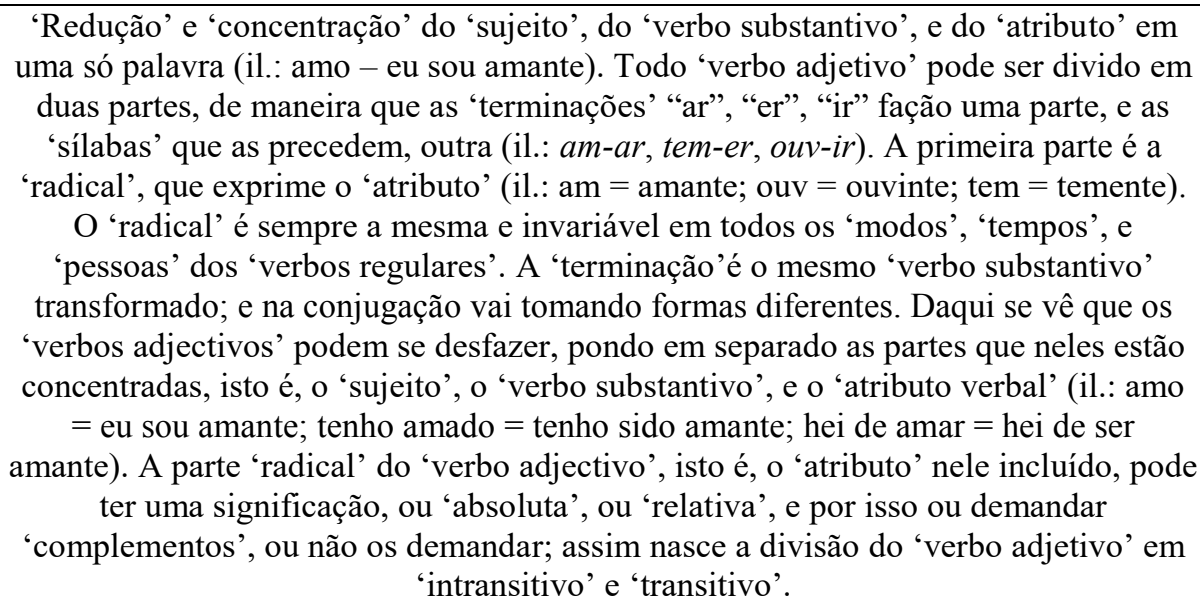 } \\
\hline
\end{tabular}

Como vemos, entre os textos das edições analisadas, apenas o 'verbo substantivo' tem um conceito que diverge, enquanto os conceitos de 'verbo auxiliar' e 'verbo adjectivo' são os mesmos. Em 1829, Costa Duarte define o 'verbo substantivo' simplesmente como aquele que une o 'atributo' da 'oração' ao 'sujeito' e enuncia a 'coexistência' de um no outro. Já em 1859, a definição de 'verbo substantivo' inicia-se dizendo que ele não contém 'atributo', em seguida, diz que esse 'verbo' serve de 'cópula' entre o 'sujeito' e o 'atributo'. Em seguida, apresenta um trecho que não deixa claro se tem relação ainda com o conceito de 'verbo substantivo'; Costa Duarte diz que há dois verbos que exprimem a existência na língua portuguesa, mas, como vimos, o 'verbo substantivo' não exprime a existência em seu conceito. Além disso, os textos diferem também quanto às ilustrações, em 1829, há apenas o exemplo "ser", ao passo que em 1859, há também a ilustração "Pedro é sábio" - e se considerarmos que Costa Duarte 
considerou que o 'verbo substantivo' era também 'verbo' que exprimia a existência, há outro exemplo, "estar", e outras duas ilustrações "eu sou doente" e "eu estou doente".

Em longas notas de rodapé (metatexto), Costa Duarte (1859), por um lado, acrescenta conteúdo ao conceito de 'verbo auxiliar', e, por outro, refuta os conceitos apresentados em texto para 'verbo substantivo' e 'verbo adjetivo'. Quanto ao metatexto relativo aos 'verbos auxiliares', o gramático acrescenta que "ser” nunca é 'auxiliar', porque na 'voz passiva' dos 'verbos adjetivos' ele é 'nexo' entre os dois 'termos' (il.: eu sou amado por Antônio), assim como em quaisquer 'proposições'. Acrescenta ainda outros exemplos de 'verbos auxiliares' (ex.: andar, ir, vir).

Em nota de rodapé (metatexto) que vem logo após a afirmação, em texto, de que há dois verbos que exprimem a existência em português, diz Costa Duarte acrescenta que também podem ser considerados verbos que significam 'existência' existir, ter e haver, possuir e gozar, como nos exemplos:

Amar a virtude, Ter amor á virtude, Possuir amor á virtude, Gozar do amor á virtude, Ser amante da virtude, Ser amador da virtude, tudo é o mesmo, pois as idéas são as mesmas, e só ha differença em as enunciar por nomes que significão ou qualidades, concretas, ou abstractas, ou por palavras que reunem em si o attributo e o verbo. (Costa Duarte 1859:43-4)

Completa dizendo que verbos como "estar", "existir", "ter" e "haver", tal como “ser”, também não têm 'atributo' em si; e que os verbos "estar" e "existir" podem também servir de 'nexo'. Ainda na mesma nota, o gramático maranhense apresenta alguns argumentos contra a consideração do verbo "ser" como único 'verbo substantivo': (1) tal como "ser", “estar", “existir", "ter” e "haver” não apresentam 'atributo' algum; (2) “estar” e "existir" podem servir de nexo, característica do 'verbo substantivo'; (3) o verbo "ser" não pode ser único, pois necessita de auxiliares para chegar a determinados tempos; (4) ou, em outros casos, depende de 'particípios imperfeitos' ('atributos') para exprimir esse tempo; (5) e, por fim, diz que nem sempre o verbo "ser" serve para exprimir a relação de conveniência com o 'sujeito', sobretudo quando isto precisa ser feito por meio de uma qualidade abstrata. O gramático, porém, não apresenta exemplos, deixando a cargo do leitor a interpretação dessas críticas no que diz respeito aos dados linguísticos.

Em nota que vem logo após a definição de 'verbo adjetivo', Costa Duarte refuta quase tudo que havia dito na definição de 'verbo substantivo' em texto. Ele inicia a nota da seguinte forma:

Dizem os Grammaticos modernos que Verbo Adjectivo é a reducção e concentração, ou expressão abbreviada, do sujeito, do verbo substantivo, e do attributo verbal em uma só palavra, como: Amo, em lugar de Eu sou amante; Durmo, em logar de Eu sou dormente etc. Parece-nos 
que nisto ha falta de reflexão, e que nem o sujeito, nem o verbo substantivo, nem o attributo verbal estão concentrados no Verbo Adjectivo. (Costa Duarte 1859:61)

No trecho, ele menciona os "Grammaticos modernos" como se fossem outros gramáticos, mas refere-se à mesma definição que deu em texto na mesma gramática, de 1859, e também na anterior, de 1829. Afirma, como vemos, que nem o ‘sujeito', nem o 'atributo', nem o 'verbo substantivos' estão concentrados no 'verbo adjetivo'. O 'verbo adjetivo' teria somente as "variações que mostram o caráter" dos 'sujeitos', mas não os próprios 'sujeitos'. Ao dizer que o 'atributo verbal' (ex.: amante) não poderia ser parte do 'verbo adjetivo', o gramático quer dizer que ele não existiria antes do 'verbo adjetivo' (ex.: amar) e, portanto, não poderia ser parte de sua composição. Isto porque Costa Duarte trabalha, nesse momento, com a ideia de que os 'nomes' são anteriores aos 'verbos' na formação da linguagem, assim o 'atributo' tem de ser um 'nome' e não um 'atributo verbal'. Dentro dessa lógica, se o 'atributo' for considerado um 'nome', dir-se-ia “Eu sou amor” em vez de "sou amante", o que é dado por ele como absurdo. Consequentemente, dentro dessa teoria de criação das classes de palavras numa ordem específica, não poderia haver dentro do 'verbo adjetivo' o 'verbo substantivo' "ser".

Vejamos: Eu sou olho, Eu sou prego, Eu sou mão. Ora bem se ve que isto e falso e ridículo, assim como tambem o é dizer: Eu sou olhante ou olhador, Eu sou pregante ou pregador, Eu sou maneante ou maneador; pois não foi desses attributos que se fizerão aquelles verbos, e alem disto elles são nómes verbaes, e porisso não podião existir antes dos seus verbos. Isto mesmo prova que todos os verbos nao são outra coisa mais do que nomes mais ou menos alterados, a que se ajuntarão significativas da relação de conveniencia desse mesmo attributo em um sujeito, as quaes vozes na nossa Lingua sao: $a r, \hat{e} r, i r$. (Costa Duarte 1859:62)

Ao fim dessa nota, o gramático conclui o que disse no início: não há ‘sujeito’, nem 'verbo substantivo', nem 'atributo verbal' dentro do 'verbo adjetivo'. É certo que há uma teoria evolutiva da linguagem por trás de suas afirmações, na qual os 'nomes' são anteriores ao 'verbo', mas há também uma aproximação dos dados observáveis por parte do gramático, dado que os 'verbos' são simplesmente 'nomes' a que se uniram as ‘terminações verbais', que no caso do português são "ar, er, ir”. Neste momento, o gramático parece excluir o conceito de 'verbo substantivo' de sua definição de 'verbo', mas ainda afirma que há um 'verbo' que se une ao 'atributo'.

Qual é pois o verbo que está unido ao attributo? Basta acreditar o testemunho dos sentidos e da razão, para conhecer que na 1a conjugação é $a r$, na 2 a $e r r$, e na $3^{\text {a }} i r$; verbos tão simples como a relação de conveniencia que elles exprimem; verbos que nunca andao sos mas sempre unidos a seus attributos, porque sos nada significão, pela mesma razão porque a relação que elles significão, per si so e inteiramente nada como já mostramos. Estes verbos vão crescendo em sons, á medida que se vão encarregando de exprimir as ideas accessorias de tempos, numeros, e o caracter dos sujeitos. Estes verbos exprimem a mesma cousa, isto e, a relaçao de conveniencia; mas disto não se segue que sejão um só verbo assim como por tres pessoas se empregarem cada 
qual em fazer uma cousa igual, se não segue que ellas não sejão tres individuos distinctos. Se os Grammaticos tivessem feito esta distincção; se tivessem attendido á differença que ha entre os indivíduos, e seu emprego; se não tivessem confundido o material do vocábulo Ser com o que elle significa; não teriao caido no erro de dizer que Ser é o unico verbo, e que se acha concentrado nos outros, contraindo e transformado. Virão elles que Ser enuncia a relação de conveniencia, e que os outros verbos a enuncião tambem, e assentárão logo em que o verbo Ser estava concentrado em todos os outros verbos; como se fosse impossivel haverem outras palavras que exprimissem a mesma relação, ou se o verbo Ser tivesse obtido algum privilegio, para elle só a enunciar. O verbo Ser tem seu uso no discurso, do mesmo modo que os outros o tem. (Costa Duarte 1859: 63)

Assim, acreditando nos "testemunhos do sentido e da razão", Costa Duarte afirma que o 'verbo' que unido ao 'atributo' são as terminações 'ar, er, ir”, as quais promovem a simples relação de conveniência e nunca estão separadas de seu 'atributo'. Refuta novamente a possibilidade de se considerar a existência do 'verbo substantivo' "ser", pois, diz o gramático, não se deveria confundir o 'material' do 'verbo' "ser" com o que ele 'significa', isto é, a relação de conveniência, que se apresenta em todos os verbos. Finaliza, assim, a longa nota de rodapé. Ressaltamos sua atenção aos 'sentidos' na primeira frase do trecho citado anteriormente, essa preocupação com a língua manifestada torna-se relevante na medida em que no final do século XIX, quando o conceito de 'verbo substantivo' é negado e omitido por diversas obras, a tendência das obras será, ao menos retoricamente, de se aproximar de dados manifestados e distanciar-se daqueles projetados ou subjacentes (cf. Polachini 2013).

Finalmente, em nota de rodapé (metatexto) que vem logo após ilustrações, que já citamos anteriormente, do 'verbo adjetivo' (il.: amo = eu sou amante; tenho amado = tenho sido amante; hei de amar $=$ hei de ser amante), Costa Duarte ressalta que tais ilustrações meramente se tratam de 'traduções' ou 'subtituições' de uma palavra por outras, visto que nem “ter", nem "haver”, nem “ser”, nem o 'atributo verbal' estão concentrados no 'verbo adjetivo', como já mostraram em nota anterior.

De volta ao texto, retomamos agora a afirmação de Costa Duarte acerca das diferentes espécies de 'verbo adjetivo' de acordo com o significado de sua parte 'radical', ou seu 'atributo', ser 'absoluto' ou 'relativo', demandando ou não 'complemento'. Há, assim, duas espécies de 'verbo adjetivo', o 'intransitivo' e o 'transitivo' cujos conceitos apresentados em cada gramática expomos no quadro abaixo:

\begin{tabular}{|c|c|c|}
\hline $\begin{array}{c}\text { Espécies de 'verbos adjetivos' } \\
\text { (termos) }\end{array}$ & Costa Duarte (1829) & Costa Duarte (1859) \\
\hline Intransitivo & $\begin{array}{c}\text { O que significa qualquer } \\
\text { 'estado', 'ação', ou 'qualidade' } \\
\text { absoluta e inseparável do } \\
\text { 'sujeito' do 'verbo', sem pedir }\end{array}$ & $\begin{array}{c}\text { O que não só exprime a 'relação } \\
\text { de conveniência', mas também } \\
\text { tem incluído em si um 'atributo' } \\
\text { que significa um 'estado' ou } \\
\text { 'ação absoluta' e 'inseparável' }\end{array}$ \\
\hline
\end{tabular}




\begin{tabular}{|c|c|c|}
\hline & $\begin{array}{l}\text { ‘complemento' algum (ex.: } \\
\text { dormir, arder, andar). }\end{array}$ & $\begin{array}{l}\text { do ‘sujeito', e por isso não pede } \\
\text { ‘complemento' algum; como: } \\
\text { (ex.: padecer, chorar, gemer, } \\
\text { suspirar). }\end{array}$ \\
\hline Transitivo & $\begin{array}{l}\text { Aquele cuja significação } \\
\text { incompleta e suspensa, pede um } \\
\text { ou mais 'complementos' (il.: } \\
\text { servir à patria, aplicar-se ao } \\
\text { estudo, dar o seu a seu dono). O } \\
\text { 'verbo transitivo' pode ser ou } \\
\text { 'ativo', ou 'passivo', ou 'médio' } \\
\text { e 'reflexo'. }\end{array}$ & $\begin{array}{l}\text { O que além de exprimir a } \\
\text { 'relação de conveniência' tem } \\
\text { incluído em si um 'atributo', } \\
\text { que significa um 'estado' ou } \\
\text { 'ação incompleta' e suspensa, e } \\
\text { por isso pede ou mais } \\
\text { ‘complementos' (il.: servir a } \\
\text { Deus, dar esmolas aos pobres). } \\
\text { O ‘verbo transitivo' divide-se } \\
\text { em 'relativo', 'ativo', 'ativo e ao } \\
\text { mesmo tempo relativo', } \\
\text { 'passivo', 'médio' 'reflexo'. }\end{array}$ \\
\hline
\end{tabular}

Quadro 29. Espécies de 'verbo adjetivo' em Costa Duarte $(1829,1859)$

Há algumas diferenças entre as gramáticas de Costa Duarte. Em 1829, o gramático não distingue o 'atributo' como sendo responsável pela significação do verbo, já o considerando um todo quando diz que sua significação é absoluta ou incompleta. Ao passo que em 1859, ele ressalta a expressão da 'relação de conveniência' (a qual, como vimos em seus longos metatextos, era considerada propriedade de todos os verbos) e parece enfatizar que o significado de 'estado' ou 'ação' completa ou incompleta é do 'atributo'. Vemos ainda que há espécies de 'verbo adjetivo', as quais apresentamos no quadro adiante em cada uma das gramáticas de Costa Duarte.

\begin{tabular}{|c|c|c|}
\hline $\begin{array}{l}\text { Espécies de 'verbos } \\
\text { transitivos' (termos) }\end{array}$ & Costa Duarte (1829) & Costa Duarte (1859) \\
\hline Relativo & - & $\begin{array}{l}\text { Pede uma 'preposição' com seu } \\
\text { ‘consequente', para lhe servir de } \\
\text { 'termo da relação' que elle } \\
\text { significa (il.: venho de casa). }\end{array}$ \\
\hline Ativo & $\begin{array}{l}\text { Aquele cujo 'sujeito' produz } \\
\text { uma 'ação' que 'outro' recebe } \\
\text { (il.: amo a deus). }\end{array}$ & $\begin{array}{l}\text { O que, em razão do ‘attributo' } \\
\text { nele incluído, significa uma } \\
\text { ‘ação' que deve ser exercitada } \\
\text { pelo ‘sujeito' do mesmo } \\
\text { ‘verbo', e 'empregada’ em um } \\
\text { ‘objecto', o qual pode ser o } \\
\text { mesmo ‘sujeito' (il.: eu amo a } \\
\text { Deus; Pedro ama-se). }\end{array}$ \\
\hline Ativo e Relativo & - & $\begin{array}{l}\text { O que, em razão do 'atributo' } \\
\text { nele incluído, pede não só um } \\
\text { ‘objecto' em que se empregue } \\
\text { na 'ação' que ele significa, mas } \\
\text { também um ‘termo' de sua } \\
\text { 'relação' (il.: dei um livro a } \\
\text { Pedro). }\end{array}$ \\
\hline Passivo & $\begin{array}{l}\text { Aquele cujo ‘sujeito' recebe e } \\
\text { padece uma 'ação' que outro } \\
\text { produz (il.: Deus é amado por } \\
\text { mim). }\end{array}$ & $\begin{array}{l}\text { O que, em razão do 'atributo', } \\
\text { significa uma 'ação' que deve } \\
\text { ser exercitada por um 'agente', } \\
\text { e empregada no 'sujeito' do }\end{array}$ \\
\hline
\end{tabular}




\begin{tabular}{|l|c|c|}
\hline & & $\begin{array}{c}\text { mesmo ‘verbo' (il.: Deus é } \\
\text { amado por mim). }\end{array}$ \\
\hline Médio Reflexo & $\begin{array}{c}\text { Aquele cujo ‘sujeito’ produz } \\
\text { uma acção e a recebe em si (il.: } \\
\text { Pedro ferio-se). }\end{array}$ & $\begin{array}{c}\text { É o mesmo ‘verbo ativo' } \\
\text { quando o ‘sujeito’ produz uma } \\
\text { 'ação' e a emprega em si (il.: } \\
\text { Pedro ferio-se). }\end{array}$ \\
\hline
\end{tabular}

Quadro 30. Espécies de 'verbo transitivo' em Costa Duarte $(1829,1859)$

Em 1859, Costa Duarte apresenta duas espécies de 'verbos adjetivos’ que não constavam em 1829: 'verbo relativo' e 'verbo relativo e ativo', que consideram um ‘termo de relação' do verbo' (il.: venho de casa, eu dei um livro a Pedro). Ademais, em relação as espécies que já eram concebidas em 1829, suas definições são mais longas em 1859. Isto se dá, por um lado, porque em 1859, ressalta em todas as definições que a significação do 'verbo' é proveniente de seu 'atributo' - em 1829, não fazia essa distinção na definição; além disso, se em 1829 o único conceito usado em todas as definições eram 'sujeito', em 1859, utiliza, além de 'sujeito', outros como 'agente', 'objeto' e 'termo'. Parece ter havido um acréscimo teórico às definições de Costa Duarte em 1859, visto que há novos conceitos de elementos da 'proposição' que não estavam presentes anteriormente, o que o faz conceber outras duas espécies de 'verbo adjetivo transitivo'. Finalmente, embora seja apresentado e definido, o conceito de 'verbo médio e reflexo' é dado apenas como uma variação do 'verbo ativo', na qual o 'sujeito' é o 'objeto' da ação em 1859.

No que diz respeito à descrição dos conceitos que acabamos de mencionar nas obras, há duas notas de rodapé (metatexto) em 1859 e apenas uma em 1829, a qual coincide com uma das de 1859. Esta última, conectada ao conceito de 'verbo médio e reflexo' adverte que as 'terceiras pessoas' desses 'verbos' tomam um 'sentido passivo', quando os 'agentes' são coisas que não tem 'ação' sobre si (il.: as cousas estimam-se pelo que valem $=$ As cousas são estimadas). A outra nota de rodapé, exclusiva de 1859, está conectada ao conceito de 'verbo passivo' e refuta, justamente, a existência desse conceito para a descrição da língua portuguesa. $\mathrm{O}$ autor afirma que a língua portuguesa, tem, em verdade, uma ‘voz passiva' que se mostra que o ‘sujeito' não é ‘agente', como o é na 'voz ativa', mas que é 'paciente' ou 'recipiente' da 'ação' - é possível ver que por meio dos conceitos novos, apresentados apenas em 1859, que Costa Duarte realiza essa reflexão que não estava em sua gramática anterior. Na mesma nota, afirma que em português não há também 'verbos neutros', dado que não há 'passivos' e, enfim, sugere que o melhor seria dizer que o 'verbo transitivo' tem três 'vozes': 'ativa', 'passiva' e 'média' ou 'reflexa'. É notável que nesse caso, tal como aconteceu na definição e ilustração dos 
conceitos de 'verbo substantivo' e 'verbo adjetivo', Costa Duarte está em conflito com a doutrina que apresenta em texto (o qual é, em geral, similar ao de 1829).

É curioso, entretanto, que no final da seção de tratamento do verbo, haja um parágrafo em texto que se mantém idêntico nas duas gramáticas e trata justamente da não adequação do 'verbo passivo’ e do ‘verbo médio e reflexo’ à língua portuguesa, do qual transcrevemos parte adiante

S.XVI. Conjugação do Verbo Adjectivo na sua Voz Passiva, e Media ou Reflexa. Na Lingua Portugueza não ha Verbos Passivos, mas nós os supprimos com grande facilidade, ajunctando a qualquer Linguagem do Verbo Substantivo o Participio Passivo do Verbo Adjetctivo, como: Eu Sou Amado, Tenho Sido Amado, Hei de Ser Amado, \&c. Quando os sujeitos dos verbos são cousas inanimadas e da terceira pessoa, tambem se fórma de repente a Voz Passiva, ajunctando o reciproco se ás terceiras pessoas dos verbos, como: Aqui premea-se a virtude; é o mesmo que dizer: Aqui é premiada a Virtude. Tambem a Lingua Portugueza não tem Verbos Reflexos em fórma simples, mas suppre-os, conjugando os verbos com os Demonstrativos Pessoaes Primitivos, postos ou antes, ou depois, ou no meio delles, como: Eu me amo, Tu te amas, Elle se ama, Nós nos amamos, Vós vos amais, Elles se amão. (Costa Duarte 1829: 51-52; Costa Duarte 1859: 75-76)

Embora seja o mesmo texto, há efeitos diferentes nas duas gramáticas. Em 1829, o gramático apresenta o título com o conceito de 'voz' sem antes tê-lo explicado e acaba refutando, em texto, o que havia dito anteriormente - como analisamos. Já em 1859, o autor corrobora com metatexto apresentado anteriormente, em que a noção de 'voz' já havia sido introduzida.

Em suma, pelo conceito de 'verbo', é possível ver que houve radicais mudanças no pensamento gramatical de Costa Duarte entre a escrita de um texto e de outro - a qual, porém, já estava, ao menos parcialmente, de alguma forma em seu pensamento em 1829, como vimos pela análise do parágrafo XVI. Em 1859, o autor parece preferir deixar observações que mostram tal mudança de pensamento em metatexto, as quais por vezes são bastante assertivas quanto à inadequação ou erro do conteúdo que se apresenta em texto. As pequenas modificações que há em texto entre as duas gramáticas são, em geral, pequenos acréscimos ou especificações.

Temos analisado também os conceitos de 'verbo impessoal' e 'defectivo' nas obras. Esses conceitos são definidos igualmente nas duas gramáticas, como expomos adiante. Nas duas gramáticas de Costa Duarte, 'defectivos' são verbos a que falta algum ‘tempo', 'número' ou 'pessoa' (ex.: precaver $(1829)$, prazer $(1859)$, munir $(1859,1879))$; ‘impessoais' são os que se usam só nas terceiras pessoas (ex,: chove, pesa-me). Em nota (metatexto) refere aos 'verbos impessoais', diz que os exemplificados são 'verbos propriamente impessoais', mas que há outros que nem sempre têm uso 'impessoal' (il.: ao cidadão cumpre ser útil à sua pátria, a esta convém premiá-lo). Na mesma nota, diz em 
ambas as gramáticas que alguns gramáticos dão nome de 'pronominais' a verbos que não se conjugam sem 'demonstrativos pessoais primitivos', pois sem eles mudam de significação (ex.: partir-se), enquanto são chamados 'recíprocos' os verbos que com os mesmos demonstrativos exprimem ação e reação entre dois ou mais 'sujeitos (il.: escrevome com Antonio (1829, 1859); as artes entre si se comunicam (1829); Antonio e João se abraçaram mutuamente (1859). Em 1859, acrescenta ainda na nota que alguns gramáticos chamam 'pronominais' e 'recíprocos' aos verbos conjugados na 'voz média'. Finalmente, em 1829, termina essa nota dizendo que não falará de outras divisões dos verbos por serem mais curiosas do que úteis; na gramática de 1859, porém, prefere citar, definir e exemplificar essas outras divisões do 'verbo' que são: 'frequentativos', 'continuativos' e 'incoativos'.

\subsubsection{Conceito de oração ou proposição e seus elementos}

Diferentemente do que vimos ao analisar o conceito de 'verbo' nas duas gramáticas de Costa Duarte, há grande, quase total, identidade entre o tratamento que se dá à sintaxe nas duas obras, quanto ao texto e ao metatexto.

Em ambas as obras, a ‘oração' ou 'proposição' é definida como enunciação de um 'atributo' em um ‘sujeito' ou a união de um 'atributo' com um ‘sujeito'. (il.: o homem é racional; o vício é detestável). Há três 'partes essenciais' da 'proposição': 'sujeito' que é pessoa ou coisa a que se atribui alguma qualidade, 'atributo' que é a qualidade que se atribui ao 'sujeito', e 'nexo' ou 'cópula' (termo usado apenas em 1859) que liga o 'atributo' com o 'sujeito' (il.: Deus é justo). Afirma que os 'termos essenciais da proposição' podem ser enunciados ou com três palavras, correspondentes a cada um (il.: eu sou amante), ou com duas (il.: eu amo) ou com uma só equivalente a todos os três (il.: amo). No quadro adiante, a que classes de palavras ou orações correspondem aos elementos da 'oração'.

\begin{tabular}{|c|c|c|}
\hline $\begin{array}{l}\text { Elementos da } \\
\text { oração }\end{array}$ & Costa Duarte 1829 & Costa Duarte 1859 \\
\hline Sujeito & \multicolumn{2}{|c|}{$\begin{array}{l}\text { Qualquer 'nome substantivo appelativo' com 'artigo', ou ‘nome substantivo próprio'; } \\
\text { uma 'proposição', ou qualquer parte elementar do discurso substantivada por meio do } \\
\text { 'artigo' (il.: O ser pobre não é deshonra) }\end{array}$} \\
\hline Atributo & \multicolumn{2}{|c|}{ Um 'adjectivo', ou cousa que o valha (il.: Pedro é homem). } \\
\hline $\begin{array}{l}\text { Nexo }(1829 \text {, } \\
\text { 1859) ou } \\
\text { Cópula } \\
\text { (1859) }\end{array}$ & $\begin{array}{l}\text { É sempre o ‘verbo substantivo' ou só, (il.: } \\
\text { Eu sou amante); ou incorporado com o } \\
\text { 'atributo' no ‘verbo adjectivo' (il.: como: } \\
\text { Eu amo). }\end{array}$ & $\begin{array}{l}\text { É sempre um 'verbo', ou só, (il.: Eu } \\
\text { sou amante); ou incorporado com o } \\
\text { 'atributo' no 'verbo adjectivo' (il.: } \\
\text { como: Eu amo). }\end{array}$ \\
\hline
\end{tabular}


Chama atenção a pequena diferença entre as duas gramáticas no que diz respeito ao 'nexo' ou a 'cópula'. Em 1829, era evidentemente o 'verbo substantivo', em 1859, é um 'verbo'; as ilustrações com o verbo "ser" mantém-se em 1859 as mesmas, porém.

$\mathrm{Na}$ seção em que trata de 'regência regular' Costa Duarte trata dos 'complementos' que são outros elementos que podem fazer parte da 'oração' ou 'proposição'. 'Complementos', definidos igualmente nas duas gramáticas, são palavras que estão completando a significação de outras (il.: abundante de frutos). No quadro adiante, apresentamos as quatro espécies de 'complemento' apresentadas pelas duas gramáticas.

\begin{tabular}{|c|c|}
\hline $\begin{array}{c}\text { Espécies de } \\
\text { Complemento (termos) }\end{array}$ & Costa Duarte 1829 e 1859 \\
\hline Objetivo & $\begin{array}{c}\text { Toda palavra ou oração, sobre que o 'verbo ativo' emprega a 'acção' que } \\
\text { significa (il.: Amo a virtude, Desejo instruir-me). }\end{array}$ \\
\hline Terminativo & $\begin{array}{c}\text { Toda palavra ou oração, pedida por outra palavra de significação relativa, } \\
\text { (il.: Ser util à pátria, Venho de casa, Abundante de frutos). Na Língua } \\
\text { Portuguesa as 'preposições' são os sinais destes 'complementos'. Só os } \\
\text { casos "me, nos, te, vos, se" não levam 'preposição' }\end{array}$ \\
\hline Restritivo & $\begin{array}{c}\text { Toda palavra ou oração com a 'preposição' "de" posta immediatamente } \\
\text { depois de um 'appelativo' de significação vaga e absoluta (il.: Livro de } \\
\text { Pedro). }\end{array}$ \\
\hline Circunstancial & $\begin{array}{c}\text { Qualquer palavra ou oração, regida de 'preposição', que se ajunta a algum } \\
\text { 'verbo' ou 'adjetivo', cuja significação não demanda complemento algum, } \\
\text { (il.: Pedro morreo em Agosto, por falta de tractamento, e á pura } \\
\text { necessidade, com grande mágoa de seus amigos). Os 'complementos } \\
\text { circunstanciais' indicam várias circunstâncias, como o 'Modo', 'Tempo', } \\
\text { 'Lugar', 'Preço', 'Causa', 'Companhia', o que facilmente se conhece pela } \\
\text { significação dos 'antecedentes' e 'consequentes' das 'preposições' (il.: } \\
\text { Moro com Antonio, Estuda com cuidado). }\end{array}$ \\
\hline
\end{tabular}

Ademais, Costa Duarte define o 'vocativo', dizendo que é destinado para chamar e excitar a atenção da pessoa com quem se fala (il.: Ó Melibeu ouve-me). Explica também que a 'regência irregular por elipse' se dá quanto falta alguma palavra ou algumas palavras necessárias para a integridade gramatical da proposição - a qual, além dos três termos essenciais ('sujeito', 'atributo', 'nexo'), deve conter também os complementos necessários - sem que isso afete sua compreensão.

Finalmente, observamos as espécies de ‘proposição’ apresentadas por Costa Duarte. Primeiramente, ele distingue duas espécies em 1829, 'simples', 'composta', e três em 1859, além das outras duas, 'proposições complexas'. No quadro adiante, cada uma delas é definida: 


\begin{tabular}{|c|c|c|}
\hline $\begin{array}{c}\text { Espécies de } \\
\text { 'proposição' }\end{array}$ & Costa Duarte 1829 & Costa Duarte 1859 \\
\hline Simples & Tem só um ‘sujeito' e um 'atributo' (il.: Pedro é sabio). \\
\hline Composta & $\begin{array}{c}\text { Tem mais de um 'sujeito', ou mais de um 'atributo', ou muitos ‘sujeitos' e } \\
\text { 'atributos' ao mesmo tempo (il.: A virtude, e a sabedoria são estimaveis, } e \\
\text { difficieis de se encontrar.) A 'Proposição Composta' inclui tantas } \\
\text { 'Proposisões Simples', quantos são os 'sujeitos', e 'atributos' que nela } \\
\text { estão. }\end{array}$ \\
\hline Complexa & $\begin{array}{c}\text { Aquela cujo 'sujeito' ou 'atributo' ou } \\
\text { ambos os 'termos' são modificados } \\
\text { por alguma 'proposição parcial', ou } \\
\text { por ideias a ela equivalentes (il.: O } \\
\text { homem sábio, ou que é sabio, } \\
\text { aborrece os vícios). }\end{array}$ \\
\hline
\end{tabular}

Quadro 33. Espécies de 'proposição' em Costa Duarte $(1829,1859)$

Nas relações entre si, quando ajuntam-se diversas proposições, como em um 'período', as quais podem ser 'principal', 'total subordinada' ou 'parcial'. 'Principal' é aquela que pode figurar sozinha no discurso porque faz um sentido completo e independente, sendo todas as outras 'proposições' dependentes dela - seu 'verbo' está sempre no 'modo indicativo'. A 'proposição total subordinada' não faz parte de outra, diferentemente da 'oração parcial', mas tem sentido suspenso e dependente da 'proposição principal - seu 'verbo' pode estar 'modo subjuntivo' ou no 'modo indicativo', quando com alguma 'conjunção' 'suspensiva de sentido' (il.: As delícias podem ter algum sabor, mas não podem ter utilidade alguma). Ambas essas 'proposições' podem ser 'modificadas' por outras palavras, que as expliquem, limitem ou completem. Daí surgem as 'proposições parciais', que são as que fazem parte de alguma palavra ou de outra proposição e têm ordinariamente em seu princípio algum dos 'demonstrativos conjuntivos' (ex.: que, quem, cujo), ademais, seus verbos devem estar no 'infinitivo', 'indicativo' ou 'subjuntivo' conforme demandar a significação do 'verbo determinante'. Há três espécies de 'proposições parciais', as 'explicativas', 'restritivas' ou 'integrantes'. No quadro adiante, definimos cada uma delas.

\begin{tabular}{|c|c|}
\hline $\begin{array}{c}\text { Espécies de } \\
\text { 'proposições } \\
\text { parciais' (termos) }\end{array}$ & Conceitos \\
\hline Explicativas & $\begin{array}{c}\text { 'Proposição' que desenvolve alguma qualidade, incluída já na significação de } \\
\text { alguma palavra de outra proposição (il.: Deus, que é justo, premeia a virtude) }\end{array}$ \\
\hline Restritivas & $\begin{array}{c}\text { 'Proposição' que limita alguma palavra de outra 'proposição', acrescentando- } \\
\text { lhe alguma idea, não incluida a significação dela (il.: O homem que é sabio } \\
\text { aborrece os vícios). }\end{array}$ \\
\hline Integrantes & $\begin{array}{c}\text { 'Proposição' que inteira e completa a significação 'transitiva' do 'verbo } \\
\text { adjetivo', isto é, do 'atributo' nele incluído (il.: Desejo ser virtuoso; Dizem } \\
\text { que Francisco é sabio; Espero que venhas hoje) As significações dos verbos }\end{array}$ \\
\hline
\end{tabular}




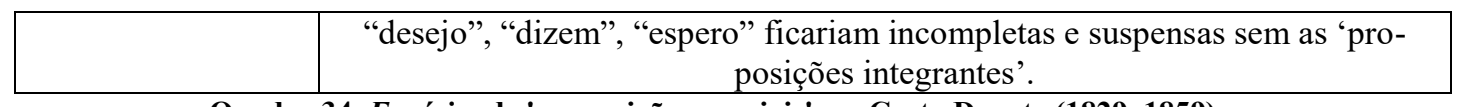

Quadro 34. Espécies de 'proposições parciais' em Costa Duarte (1829, 1859)

Embora o autor não explicite isso (como faz, por exemplo, Bithencourt 1862), há paralelismos entre os conceitos de duas espécies (das três) de 'adjetivo' e duas espécies (das três) de 'orações parciais', os quais usam termos iguais: 'explicativos' e 'restritivos'.

Finalmente, 'período' é definido como reunião de muitas 'proposições totais' ligadas entre si e terá tantas 'proposições' quantos forem seus 'verbos'. Se houver uma única 'proposição total' e várias 'parciais', não há 'período'.

\subsubsection{Rede conceitual}

Como vimos, as gramáticas de Costa Duarte são predominantemente similares entre si. No tratamento do 'verbo', porém, o gramático apresenta em 1859 uma série de mudanças, em texto e sobretudo em metatexto. Ademais, há conflitos entre conceitos apresentados em texto e em metatexto na obra de 1859. Mas antes de entrar nesse tema, observaremos a rede conceitual formada na edição de 1829 para depois compará-la com a rede conceitual formada na edição de 1859.

Em 1829, há clara rede conceitual em torno do 'verbo substantivo' que está em relação de identidade e equivalência com o conceito de 'verbo', porque, por um lado, as ilustrações de 'verbo' são todas com o 'verbo' “ser”, e, por outro, o 'verbo substantivo' tem o que é essencial ao verbo, isto é, sua 'enunciação da existência'; além disso, como vimos, o 'verbo substantivo' é considerado uma classe de palavra, que promove uma 'relação de identidade'. Entretanto, se levarmos em conta as outras duas principais espécies de 'verbo', o 'verbo substantivo' pode também ser considerado uma espécie de 'verbo' travando com ele uma relação de subordinação. Essas outras espécies de 'verbo' têm íntima relação com o 'verbo substantivo': os 'verbos auxiliares' servem para que este chegue a tempos a que não chegaria sozinho, os 'verbos adjetivos' contêm o 'verbo substantivo' dentro de si, já que são uma redução ou concentração deste com o 'atributo'; nosso conceito-chave, portanto, trava uma relação de subordinação com o 'verbo adjetivo'. Há ainda espécies de 'verbo adjetivo', como 'intransitivo', 'transitivo' (e as espécies deste último), as quais em 1829, diferentemente do que veríamos em 1859, não distinguem em sua definição o ‘verbo substantivo' e o ‘atributo' que estão concentrados 
em si. Dessa forma, a relação entre o ‘verbo substantivo’ e essas outras espécies de verbo é menos clara em 1829.

Costa Duarte define a 'proposição' como sendo a união de 'sujeito' com um ‘atributo' por meio do 'nexo' (em 1859 fala também ‘cópula'), este último é, em 1829, o 'verbo substantivo' e quando está incorporado ao 'atributo' torna-se 'verbo adjetivo'. Além dos três elementos essenciais, a 'proposição' pode ainda ser composta por outros quatro 'complementos', 'objetivo', 'terminativo', 'restritivo' e 'circunstancial', os quais acrescentam, obrigatoriamente ou não, informações aos elementos essenciais da 'proposição', como faz o 'complemento objetivo' ao ser 'palavra' ou 'oração' sobre que o 'verbo ativo' emprega ação.

Costa Duarte distingue as espécies de ‘proposição’ por dois critérios. O primeiro é pela sua composição, que, em 1829, teria as espécies 'simples' e 'composta' (quando tem mais de um 'sujeito' ou mais de um 'atributo') em cuja definição mantém a estrutura tripartite de 'proposição', sendo o 'verbo substantivo' subordinado também a essas espécies de 'proposição'. O segundo critério consiste em distinguir espécies de 'proposição' de acordo com as relações que travam entre si, não há referência ao 'verbo substantivo' nas proposições 'principais' e 'subordinadas totais'; há, entretanto, uma relação de paralelismo entre duas das espécies de 'proposição parcial' e espécies de 'adjetivo' 'explicativo' e 'restritivo'. Tal paralelismo, porém, não é comentado pelo gramático, que também não alude a uma possível elipse do ‘demonstrativo conjuntivo' e do 'verbo' "ser" que poderia tornar a 'proposição parcial' um 'adjetivo'. Ainda assim, podemos hipotetizar que existe uma relação justificada por base teórica comum entre essas espécies de 'adjetivo', as 'proposições parciais' e o 'verbo substantivo', na medida em que são todos conceitos provenientes de uma visão lógica da linguagem.

O 'verbo substantivo' tem, certamente, base teórica comum em relação aos conceitos de 'linguagem' e de 'gramática', pois estes consideram que ainda que as línguas variem entre si, existe uma base comum entre elas, a qual apresenta diferentes tipos de 'relações' e de 'ideias', os quais, por sua vez, como vimos, formam as classes de palavras. Assim, o 'verbo substantivo’ que, na língua portuguesa é frequentemente contraído com o 'atributo' formando o 'verbo adjetivo', é perfeitamente possível e mesmo necessário dentro da formulação de língua proposta pelo autor. Ademais, é notável que o autor insira aspectos do tratamento da sintaxe, como a definição de 'oração' e uma breve explanação sobre os 'complementos' respectivamente ao introduzir à obra e ao finalizar o tratamento 
dos 'nomes adjetivos'. Isso pode ser sinal do protagonismo da 'proposição', cujo eixo é o 'verbo substantivo', e do tratamento da 'sintaxe' na obra.

Em suma, em 1829, a rede conceitual do 'verbo substantivo' é formada por relação de equivalência e/ou de subordinação com o conceito de 'verbo'; relação de subordinação com os conceitos de 'verbo adjetivo', de 'proposição' e há base teórica comum entre o conceito de 'verbo substantivo', as espécies de 'adjetivo' e as 'proposições parciais', por ambos serem lógicos, e há base teórica comum com o conceito de linguagem e de gramática, por considerarem um nível subjacente e imutável da língua, do qual o 'verbo substantivo' é parte.

Quanto ao texto de 1859 , ele é bastante similar ao que vimos em 1829 . As mudanças principais estão no conceito de 'verbo' que deixa de promover a 'coexistência' entre ‘sujeito' e 'atributo' para ser apenas ‘cópula' entre ‘sujeito’ e 'atributo'. A essência do verbo torna-se 'animar' os termos da 'proposição'. Ademais, uma das ilustrações apresentadas tem o 'verbo' "aplicar-se", as outras apresentam "ser". O 'verbo substantivo' parece também ter uma relação mista de equivalência e subordinação com esse conceito de 'verbo'; da mesma forma que mantém próximas relações com as outras duas espécies de 'verbo': 'auxiliar' e 'adjetivo'. É notável que nessa edição Costa Duarte distinga o 'atributo' como responsável pela transitividade ou semântica na maior parte das espécies de 'verbo’ (as exceções são apenas ‘verbo relativo’ e ‘verbo médio reflexo’). No tratamento da 'proposição', o autor coloca como 'nexo' ou 'cópula' o 'verbo' - não fazendo mais referência ao 'verbo substantivo' como havia em 1829. Além disso, acrescenta a espécie 'proposição complexa', que é aquela cujos ‘sujeito’ ou 'atributo' são modificados por alguma 'proposição parcial'.

Finalmente, observamos que o metatexto de 1859 , sobretudo no tratamento do 'verbo', promove um ecletismo vertical, à medida que os conceitos que apresenta são alternativas aos conceitos apresentados em texto. Defende que o conceito de 'verbo' seja simplesmente 'relação de concordância' entre dois 'termos', a qual seria tão singela que poderia ser significada sem a presença do 'verbo' (il.: homem frágil); acrescenta que a negação recairia sobre o 'atributo', promovendo, assim, o 'verbo' sempre 'relações de concordância'. Neste momento, há apenas acréscimos concordantes com os conceitos apresentados em texto. Na nota que vem logo após a afirmação de que há dois 'verbos de existência' no português, o gramático começa a refutar a assunção de "ser" seja o único 'verbo'; um de seus argumentos, que ressalta que ele precisa de 'auxiliares' para chegar a certos tempos, refuta a relação de equivalência entre 'verbo substantivo' e 'verbo' 
apresentada em texto. Na nota de rodapé conectada à definição de 'verbo adjetivo', Costa Duarte, por meio de uma explanação da ordem de origem das classes de palavras, refuta novamente que o 'verbo' "ser" seja o 'verbo substantivo' e, mais, refuta que o 'verbo adjetivo' possa ser analisado pela distinção entre "ser" e um 'atributo verbal'. Sugere ele que os 'verbos' sejam unicamente as formas simples "ar, er, ir", pois essas formas promovem a simples 'relação de conveniência' com o 'sujeito', e tais formas juntam-se aos 'atributos', formando 'verbos atributivos'. Ademais, em outra nota, anexada a ilustrações do 'verbo adjetivo' (il.: hei de amar = hei de ser amante), afirma que essa são apenas 'traduções' e 'substituições' e não uma análise do 'verbo adjetivo'.

Assim, ainda que Costa Duarte, em metatexto, mantenha a conceito de 'verbo adjetivo', que contém um 'atributo', o autor parece eliminar o conceito de 'verbo substantivo' e substituí-lo pela simples forma do 'verbo' cujos exemplos são “ar, er, ir”. Tal concepção de 'verbo' entraria em conflito com conceitos assumidos em texto, por conta de sua intensão como também de sua extensão, em que apresenta com frequência o 'verbo ser' em seus exemplos e ilustrações (ainda que o gramático chame-os então de 'traduções'), como é o caso de: 'verbo', 'verbo auxiliar', 'verbo adjetivo’ e 'proposição'.

Em suma, Costa Duarte apresenta uma rede conceitual do 'verbo substantivo' na sua primeira gramática, de 1829, em que nosso conceito-chave é equivalente e/ou subordinado ao conceito de 'verbo', também é subordinado aos conceitos de 'verbo adjetivo', de 'proposição', e há base teórica comum com as espécies de 'adjetivo', as 'proposições parciais' e com o conceito de gramática e de linguagem da obra. Em 1859, há uma rede conceitual em texto, mas a gramática é eclética verticalmente, pois são apresentados conceitos alternativos em metatexto, os quais estão em discordância com a existência do 'verbo substantivo' que fora apresentado em texto. Consideramos, porém, que a eliminação do 'verbo substantivo' se dá em local de menor destaque e destinado à reflexão linguística, o metatexto, ao passo que ele se mantém na descrição linguística de destaque da obra, o texto.

4.4. Compendio da Grammatica da Lingua Nacional (1835, [16]; 1873, [92]), de Antonio Alvares Pereira Coruja,

\subsubsection{Conceitos de gramática e de linguagem e organização da obra}


Coruja $(1835,1873)$ define igualmente nas duas edições analisadas 'gramática' como uma 'arte' que ensina a declarar bem os pensamentos por meio de palavras; a qual compreende quatro partes: 'etimologia', 'sintaxe', 'prosódia' e 'ortografia' (cf. FD4 e FD8, Apêndice B).

O sumário das duas edições é bastante similar também, salvo pequenos acréscimos na edição posterior. Em ambas, vemos uma parte primeira de 'etimologia', em que constam as classes de palavras. Em seguida, está a parte segunda de 'sintaxe', onde se fala dos elementos da 'sentença' e da 'sintaxe figurada' na primeira edição (1835); na edição posterior (1873), são acrescidas seções relativa aos 'complementos' e às espécies de 'oração'. A terceira parte trata de 'prosódia' e 'figuras de dicção'. Finalmente, a quarta parte diz respeito à 'ortografia' e à 'pontuação'.

\subsubsection{Conceitos de metaclasses e classes de palavras}

De acordo com Coruja (1835), há nove 'partes da oração', que são, na ordem apresentada pelo autor: 'artigo', 'nome', 'pronome', 'verbo', 'particípio', 'advérbio', 'conjunção', 'preposição', 'interjeição'. Na primeira edição, os 'nomes substantivos' e 'adjetivo' fazem parte de uma mesma classe e não há metaclasses, o que seria modificado na edição posterior de 1873. Nela, encontramos dez 'partes da oração', porque o 'nome' ou 'substantivo' e 'adjetivo' tornam-se classes separadas. O autor ainda explicita as metaclasses de 'palavras variáveis' (as seis primeiras a apresentar: 'artigo', 'nome/substantivo', 'adjetivo', 'pronome', 'verbo', 'particípio') e 'invariáveis' (as quatro últimas: 'preposição', 'advérbio', 'conjunção', 'interjeição'), algo que não apresenta na edição de 1835, ainda que as palavras estejam em ordem similar.

Adiante, um quadro sintético comparativo das metaclasses e classes de palavras apresentadas por Coruja nas duas edições de seu Compendio.

\begin{tabular}{|c|c|c|}
\hline Coruja 1835 & \multicolumn{2}{|c|}{ Coruja 1873} \\
\hline Classes de palavras & Classes de palavras & Metaclasses \\
\hline Artigo & Artigo & \multirow{6}{*}{ Variáveis } \\
\hline \multirow[t]{2}{*}{ Nome } & Nome / Substantivo & \\
\hline & Adjetivo & \\
\hline Pronome & Pronome & \\
\hline Verbo & Verbo & \\
\hline Particípio & Particípio & \\
\hline Preposição & Preposição & \multirow{3}{*}{ Invariáveis } \\
\hline Advérbio & Advérbio & \\
\hline Conjunção & Conjunção & \\
\hline
\end{tabular}


\begin{tabular}{l|l} 
Interjeição & Interjeição \\
\hline
\end{tabular}

Quadro 35. Metaclasses e classes de palavras em Coruja $(1835,1873)$

A propósito, é possível observar em diversas gramáticas (por exemplo, Fortes (1816) e Condurú 1888 cf. 4.2 e 4.11) que a ordem em que as classes de palavras estão colocadas poderia ser dividida nesses dois conjuntos: um de 'variáveis' (ou ‘declináveis') e outro de 'invariáveis' (ou 'indeclináveis'), mesmo quando a gramática não menciona essas metaclasses, como faz Coruja (1835). Entretanto, quando for esse o caso, não levaremos essa suposição à análise, com ela expomos apenas que havia no período, como veremos em quase todos os gramáticos, essa preocupação em apresentar as classes de palavras em uma ordem específica eé compartilhada.

\subsubsection{Conceitos modificadores do nome}

Coruja 1835 e 1873 apresentam sutis diferenças entre a assunção dos três ou conceitos analisados nesta seção, que são 'artigo, 'pronome' e 'nome adjetivo' ou 'adjetivo'. Em 1835, define o 'artigo' como parte da oração que precedendo o nome mostra seu 'gênero' e 'número', como dá a entender que o nome se toma 'extensivamente' (e não 'compreensivamente'). O único artigo é “o”, que varia em “os, a, as”. Em 1873, sua definição torna-se mais enxuta, ao passo que os exemplos, mais abrangentes. 'Artigo' é, então, parte da oração que precedendo um nome, nos mostra seu 'gênero' e 'número'. Pode ser 'definito' (ex.: o, a, os, as) ou ‘indefinito' (ex.: um, uma - quando não são 'numerais').

O 'nome', em 1835, é definido como palavra com que significamos alguma coisa ou sua qualidade (ex.: homem, prudente). Classifica-se em 'substantivo', aquele que significa coisa ou pessoa, e 'adjetivo', que significa qualidade de coisa ou pessoa. Este último tem nove espécies ('positivo', 'comparativo', 'superlativo', 'partitivo', possessivo, pátrio, gentílico, numeral), das quais enfatizamos três, o 'partitivo', que significa parte de uma multidão (ex.: cada, qualquer, algum), o 'possessivo', que indica possessão (ex.: popular, nacional, imperial), e o 'numeral', que se define como mostradora do número, e divide-se em 'cardeal', o número simples e absolutamente, e ordinal, que designa por ordem. Em metatexto (nota), Coruja diz que alguns gramáticos chamam 'adjetivos articulares' não só aos 'artigos' “o, a” e aos 'pronomes' “ele, aquele, meu, teu, seu, vosso, nosso, que, qual”, mas também aos 'partitivos' “todo, algum, 
nenhum, cada, qualquer, outro" e ao 'advérbio' “onde". Entretanto, pelo que vemos no texto, ele não concorda com essa categorização ou, ao menos, não adere a ela.

Em 1873, Coruja define o conceito de 'adjetivo' como palavra que 'qualifica' ou 'determina' a coisa ou pessoa indicada pelo 'substantivo', dividindo-o em 'qualificativo', que indica a qualidade do 'substantivo', e 'determinativo', que 'determina' a quantidade do 'substantivo' a que se acha ligado na 'oração', declarando se sua significação se estende a todos, a alguns ou a quais. O 'determinativo' divide-se, ainda, em seis tipos, que são: 'universais' (ex.: nenhum, todo); 'partitivos' (ex.: alguns, muito); 'distributivos' (ex.: outro, cada, qualquer); 'relativos'/‘conjuntivos' (ex.: quanto, cujo); 'numerais', que se dividem em 'cardeais' (ex.: três, cinco, dez) e 'ordinais' (ex.: terceiro, quinto, décimo); 'articulares' (ex.: o, um), este último ele ressalta pertencer à classe dos 'adjetivos'. Entretanto, vemos que os exemplos dessa última espécie são os mesmos da classe de palavras 'artigo'.

Finalmente, no que diz respeito ao 'pronome', em 1835, Coruja o define como 'voz' que traz à memória 'nome antecedente' ou com ele tem relação (ex.: eu, tu, ele, aquele). Essa classe divide-se em sete espécies. 'Relativo', que traz à memória 'nome antecedente', ou com ele tem relação (ex.: aquele, o qual) - essa que é a mesma definição dada ao 'pronome'. Em metatexto, diz que “cujo" é o mesmo que "do qual”, por isso, é 'relativo' e 'possessivo', pois relata um 'nome antecedente' e concorda com um subsequente. 'Interrogativo', o 'pronome' que serve para perguntar (ex.: quem, que, qual). 'Possessivo', que denota possessão (ex.: meu, teu, nosso). 'Primitivo', que designa a pessoa de quem se fala e que não se deriva de outro (ex.: eu, tu, ele). 'Derivado', que se deriva do primeiro (ex.: teu, seu). 'Demonstrativo', que demonstra a pessoa ou coisa de se trata (ex.: isso, isto, aquilo). Finalmente, 'reflexivo', o 'pronome' "se” quando a ação do 'verbo' se emprega no mesmo sujeito de quem fala (il.: João riu-se), chama-se 'recíproco' quando os 'sujeitos' exercitando a ação do 'verbo' uns sobre os outros recebem deles ação igual (il.: Paulo e Maria amam-se).

Em 1873, o gramático define o 'pronome' como palavra que traz à memória pessoa e lugar a que se refere e que se põe na 'oração' no lugar do 'nome'. Divide-se em cinco espécies. 'Pessoal', que indica pessoa (ex.: eu, tu, ele). 'Relativo', que se refere a 'nome antecedente' (ex.: quem, que, qual). Em metatexto, nota de rodapé, afirma os 'relativos' também podem se chamar 'interrogativos', ainda que emende que perguntas podem ser feitas com muitas outras palavras. 'Demonstrativos', que limita a significação do 'substantivo' por circunstância de lugar, seja no discurso, seja fora de nós (ex.: este, 
esse, aquele). 'Possessivo', que indica possessão (ex.: meu, teu, vosso, nosso, seu). 'Reflexivo', que se une ao 'verbo' com referência ao 'sujeito' da 'oração' (ex.: se; il.: Domingos deita-se). Em metatexto, sobre o 'reflexivo', acrescenta que outros 'pronomes pessoais' são usados como 'reflexivos' (ex.: me, te, nos, vos) e que o 'pronome' "se" chama-se 'recíproco' quando se une ao 'verbo' com referência 'recíproca' a dois indivíduos que lhe servem de 'sujeito'. Observa ainda que alguns desses 'pronomes fazem' as vezes de 'adjetivo determinativo' quando vêm com 'substantivo claro'. Lembra também que os exemplos "o, a, os, as", quando vêm unidos a 'verbos' são considerados como variações de "ele", da mesma sorte é o "o" tomado invariavelmente.

Em 1835, as definições dos modificadores do nome de Coruja se aproximam das de Fortes (1816, cf. 4.2). Já em 1873, as definições e a própria taxonomia dos conceitos apresentam um conteúdo mais lógico, como quando Coruja apresenta as noções de 'compreensão' e 'determinação'.

\subsubsection{Conceito de verbo}

O conceito de 'verbo' em 1835 é simplesmente o de 'voz' com que na 'oração' significamos 'ação'. Em 1873, o autor acrescenta outros aspectos à definição, o 'verbo' é palavra com que na 'oração' significamos a ação 'afirmando' uma coisa de outra. Nesta edição, há uma nota de rodapé (metatexto) em que diz que o único e principal 'verbo' essencialmente falando é o 'verbo' "ser" que é, por excelência, chamado 'substantivo', ele exprime a existência de uma qualidade ou 'atributo' no 'sujeito' da 'oração'. Todos os outros 'verbos' chamam-se 'adjetivos' e são uma redução ou abreviação da 'linguagem substantiva', e 'afirmam', a partir do 'atributo' ou 'predicado', ação ('verbos ativos') e estados ('verbos neutros') do 'sujeito' da 'oração' (il.: eu amo = eu sou amante; eu vivo = eu sou vivente). Coruja finaliza a nota dizendo que tais explicações não são próprias de um 'compêndio' e, por isso, figuram apenas em nota. Na edição de 1835, não há menção ao 'verbo substantivo'.

As três principais espécies de 'verbo' apresentadas nas duas edições são as mesmas, com sutis diferenças em aspectos dos conceitos. Apresentamos no quadro adiante os conceitos de cada edição:

\begin{tabular}{|c|c|c|}
\hline $\begin{array}{c}\text { Espécies de } \\
\text { verbo } \\
\text { (termos) }\end{array}$ & Coruja 1835 & Coruja 1873 \\
\cline { 2 - 3 } & Conceito em texto e metatexto & Conceito em texto e metatexto \\
\hline
\end{tabular}




\begin{tabular}{|c|c|c|}
\hline Verbo ativo & $\begin{array}{l}\text { T: Tem uma significação ‘transitiva', } \\
\text { emprega-se em 'sujeito' diverso de sua } \\
\text { significação (ex.: amar, louvar, defender) } \\
\text { MT: Quando a ação do verbo recai sobre } \\
\text { o mesmo sujeito que a pratica chamam } \\
\text { alguns ‘verbo reflexivo' (il.: eu me } \\
\text { compadeço; tu te queixas). Chamam } \\
\text { também 'recíproco' quando os sujeitos } \\
\text { fazendo recair a ação do verbo sobre } \\
\text { sujeitos diversos recebem deles a mesma } \\
\text { ação reciprocamente (ex.: alegram-se; } \\
\text { defendem-se). }\end{array}$ & $\begin{array}{l}\text { T: Tem significação ‘transitiva' que se } \\
\text { emprega em ‘sujeito' diverso (ex.: amar, } \\
\text { louvar, defender). } \\
\text { MT: Quando a ação do ‘verbo' recai } \\
\text { sobre o mesmo 'sujeito' que a pratica } \\
\text { chamam alguns 'verbo reflexivo' (il.: eu } \\
\text { me compadeço; tu te queixas). Chamam } \\
\text { também 'recíproco' quando os sujeitos } \\
\text { fazendo recair a ação do verbo sobre } \\
\text { sujeitos diversos recebem deles a mesma } \\
\text { ação reciprocamente (ex.: alegram-se; } \\
\text { defendem-se). Contudo, nem por isso } \\
\text { perde a força de 'ativo'. }\end{array}$ \\
\hline $\begin{array}{c}\text { Verbo } \\
\text { neutro } \\
(1873: \\
\text { intransitivo })\end{array}$ & $\begin{array}{c}\text { T: Tem significação 'permanente', que se } \\
\text { emprega em si mesmo ou 'sujeito' de } \\
\text { mesma significação (ex.: voar, ir, vir, } \\
\text { morrer) }\end{array}$ & $\begin{array}{l}\text { T: Chama-se também 'intransitivo'. Tem } \\
\text { significação 'intransitiva' que se emprega } \\
\text { em si mesmo ou em sujeito de mesma } \\
\text { significação (ex.: voar, ir, vir, morrer). } \\
\text { MT: Quando o 'verbo neutro' tem por } \\
\text { 'paciente' palavras de sua mesma } \\
\text { significação, é considerado virtualmente } \\
\text { como 'ativo' (il.: vives vida feliz) }\end{array}$ \\
\hline $\begin{array}{c}\text { Verbo } \\
\text { passivo }\end{array}$ & $\begin{array}{l}\text { T: Aquele cuja ação é sofrida pelo mesmo } \\
\text { 'sujeito' do ‘verbo' (ex.: ser ferido, ser } \\
\text { louvado) } \\
\text { MT: No nosso idioma, não temos ‘verbos } \\
\text { passivo simples'. Todos são ‘compostos' } \\
\text { ou 'auxiliados' do ‘verbo' “ser” ou da } \\
\text { 'partícula' “se” (il.: João é amado; fia-se } \\
\text { lã). }\end{array}$ & $\begin{array}{l}\text { T: Aquele cuja ação é sofrida pelo mesmo } \\
\text { ‘sujeito' do ‘verbo' (ex.: ser ferido, ser } \\
\text { louvado). } \\
\text { MT: Em nosso idioma não temos 'verbo } \\
\text { passivo simples' (como no latim), todos } \\
\text { são' compostos' ou 'auxiliados' do verbo } \\
\text { "ser” ou da 'partícula' “se” (il.: João é } \\
\text { amado; fia-se lã). }\end{array}$ \\
\hline
\end{tabular}

Quadro 36. Espécies de 'verbo' em (Coruja 1835, 1873)

Em ambas as edições, Coruja optou por utilizar terminologia ligada ao conceito de ação ('verbo ativo', 'verbo neutro', 'verbo passivo'); e, como vimos, em ambas o 'verbo' é definido como palavra com que significamos ação. No entanto, nas definições, o autor apresenta o conceito de 'transitividade' para o 'verbo ativo' e de 'intransitividade' para o 'verbo neutro', apenas na edição de 1873 - em 1835, falava que este verbo tinha 'significação permanente'. É notável use o termo 'ativo' para a espécie do 'verbo', entretanto, sem apresentar a noção de 'ação' em sua definição - ela aparece aoenas ai tratar do 'verbo passivo'. Ademais, embora apresente o 'verbo passivo' em ambas as edições em texto, observa em metatexto (nota de rodapé) que a língua portuguesa não tem a forma 'passiva simples' (tal como há no latim, lembra Coruja apenas em 1873), assim, todos os ‘verbos passivo' são apresentados pelo verbo "ser" ou pela 'partícula' "se".

Em metatexto (nota relativa a 'verbos irregulares') em 1835, Coruja diz que os ‘verbos impessoais' só têm as ‘terceiras pessoas' (ex.: anoitece, apraz). A única diferença em relação à edição de 1875 é que nela o autor acrescenta que os verbos 'impessoais' melhor se chamariam 'unipessoais'. 


\subsubsection{Conceito de oração e seus elementos}

O conceito de 'oração' das duas edições é quase o mesmo, difere apenas porque na edição de 1873, acrescenta-se que a 'oração' consta também de 'predicado', elemento que não estava na edição de 1835. Assim, a ‘oração’ é união ou agregado de palavras com que afirmamos alguma coisa. Consta de 'sujeito', 'verbo', 'paciente' (ou 'predicado' em 1873) e 'circunstâncias' quando as há. Entretanto, ainda que não cite o 'predicado' na definição de 'oração' em 1835, Coruja o define posteriormente, junto com os outros elementos da 'oração'. No quadro adiante comparamos os conceitos de cada um deles.

\begin{tabular}{|c|c|c|}
\hline $\begin{array}{l}\text { Elementos da } \\
\text { 'oração' } \\
\text { (termos) } \\
\end{array}$ & $\begin{array}{c}\text { Coruja } 1835 \\
\text { Conceito em texto e metatexto }\end{array}$ & $\begin{array}{c}\text { Coruja } 1873 \\
\text { Conceito em texto e metatexto } \\
\end{array}$ \\
\hline $\begin{array}{c}\text { Sujeito } \\
\text { (1835: agente) }\end{array}$ & $\begin{array}{l}\text { T: Aquele que exercita a ação do } \\
\text { 'verbo'. (il.: Os meninos estudam; vós } \\
\text { aprendeis) } \\
\text { MT: Chama-se também 'agente'. }\end{array}$ & $\begin{array}{l}\text { T: Aquele que exercita a significação do } \\
\text { 'verbo' (vós aprendeis; os meninos } \\
\text { estudam). } \\
\text { MT: O ‘sujeito' da 'oração' nem sempre é } \\
\text { o 'agente' do ‘verbo', como se vê nas } \\
\text { 'orações' de ‘verbo passivo'. Nestas, o } \\
\text { 'sujeito' sofre a ação do 'verbo'. }\end{array}$ \\
\hline Verbo & - & - \\
\hline $\begin{array}{l}\text { Predicado } \\
\text { (1873: } \\
\text { atributo) }\end{array}$ & $\begin{array}{c}\text { T: Aquilo que se afirma ou se nega do } \\
\text { ‘sujeito'. (il.: João é bom; os estudos } \\
\text { são necessários) }\end{array}$ & $\begin{array}{l}\text { T: Pode se chamar 'atributo'. Aquilo que } \\
\text { se afirma ou se nega do 'sujeito'. (il.: João } \\
\text { é bom; os estudos são necessários) }\end{array}$ \\
\hline $\begin{array}{c}\text { Paciente / } \\
\text { Predicado } \\
\text { regido } \\
\text { (1873: } \\
\text { complemento } \\
\text { objetivo / } \\
\text { regimen } \\
\text { direto) } \\
\end{array}$ & $\begin{array}{l}\text { T: Aquele que sofre a ação do } \\
\text { 'verbo'. (il.: Vós aprendeis } \\
\text { gramáticas; o mestre instrui o } \\
\text { discípulo) }\end{array}$ & $\begin{array}{l}\text { T: A que também chamamos } \\
\text { ‘complemento objetivo' ou 'regimen } \\
\text { direto'. Aquele que sofre a ação do } \\
\text { ‘verbo'. (il.: vós aprendeis gramática; o } \\
\text { mestre instrui os discípulos) }\end{array}$ \\
\hline Circunstâncias & $\begin{array}{l}\text { T: São de lugar, fim, causa, modo, } \\
\text { companhia, qualidade, instrumento, } \\
\text { possessão, tempo, termo de ação, } \\
\text { aquisição, matéria, distância, preço, } \\
\text { princípio, 'objeto' a que se dá } \\
\text { oposição (muitos exemplos). } \\
\text { Sobre as preposições que devem reger } \\
\text { as 'circunstâncias' de uma 'oração' } \\
\text { não se pode estabelecer regra certa. } \\
\text { As ‘circunstâncias’ podem ser regidas } \\
\text { daquelas preposições que parecem } \\
\text { mais convenientes à 'oração'. (il.: } \\
\text { passão os soldados pela rua; as horas } \\
\text { são proprias para a lição; a lição } \\
\text { estuda-se com atenção) }\end{array}$ & - \\
\hline
\end{tabular}

Quadro 37. Elementos da 'oração' em Coruja (1835, 1873) 
Coruja não define 'verbo' nesse momento, observamos, porém, que de 1835 a 1873, ele modificou principalmente a definição deste e, consequentemente, do 'sujeito' da 'oração'. Este, que em 1835 também poderia se chamar 'agente', deixa de exercer a ação do 'verbo', então, para exercer simplesmente sua significação, em metatexto de 1873, a razão da mudança fica clara: o gramático diz que o 'sujeito' nem sempre é 'agente', pois no caso de 'verbos passivos' pode sofrer a ação do 'verbo'. Ademais, ele acrescenta o termo 'atributo' ao 'predicado' e os termos 'complemento objetivo' e 'regimen direto' ao 'paciente', que é, em ambas as edições, aquele que sofre a ação do 'verbo'. Finalmente, não apresenta definição, nem exemplos ou ilustrações para as 'circunstâncias', essas seriam contempladas quando falasse dos 'complementos' 'restritivo' e, sobretudo, 'circunstancial', os quais não constavam na edição de 1835.

Em 1873, o ‘complemento’ é definido como, gramaticalmente falando, a palavra ou as palavras que servem para completar o sentido de outra palavra, 'determinando-o' ou 'explicando-o'. Há quatro espécies de 'complemento', cuja definição e ilustrações de uso expomos no quadro adiante:

\begin{tabular}{|c|c|}
\hline $\begin{array}{c}\text { Espécies de } \\
\text { 'complemento } \\
\text { (termos) }\end{array}$ & Cpenas Coruja 1873 \\
\hline $\begin{array}{c}\text { Compl. } \\
\text { Objetivo }\end{array}$ & $\begin{array}{c}\text { Conceito em texto } \\
\text { 'regimen direto', para se distinguir do 'indireto' (il.: tenho sede; amo a deus; feriste- } \\
\text { me). }\end{array}$ \\
\hline $\begin{array}{c}\text { Compl. } \\
\text { Terminativo }\end{array}$ & $\begin{array}{c}\text { É a palavra que vai terminar a 'significação relativa' do 'verbo' ou 'adjetivo' a que } \\
\text { vem unido na 'oração' (il.: dei meus livros a Pedro; Francisco tem sido útil à sua } \\
\text { mãe; Horas próprias para a lição; Saudades da pátria; Contente com a sua sorte). }\end{array}$ \\
\hline $\begin{array}{c}\text { Compl. } \\
\text { Restritivo }\end{array}$ & $\begin{array}{c}\text { Palavra que restringe a 'significação vaga' do ‘substantivo' a que vem unido (il.: } \\
\text { filho de deus; homem de honra) quando esse 'complemento' se faz por 'pronome } \\
\text { possessivo' (il.: meu filho; vosso livro), ou por 'adjetivos qualificativo' (il.: homem } \\
\text { probo; senhora distinta). }\end{array}$ \\
\hline $\begin{array}{c}\text { Compl. } \\
\text { Circunstancial }\end{array}$ & $\begin{array}{c}\text { Todo aquele que não é essencialmente necessário à integridade gramatical da } \\
\text { oração. Tais são as circunstâncias que indicam relações de lugar, coisa, modo, } \\
\text { companhia, instrumento, tempo, matéria il.: passão os soldados pela rua; a lição } \\
\text { estuda-se com atenção -) }\end{array}$ \\
\hline
\end{tabular}

Quadro 38. Espécies de 'complementos' em Coruja (1873)

O ‘complemento objetivo' e o 'circunstancial' são os únicos a aparecerem como elementos da 'oração'. Entretanto, nota-se que o 'complemento terminativo', que parece corresponder ao 'regimen indireto' (citado na definição de 'complemento direito'), não é mencionado senão na seção relativa aos 'complementos', ainda que seja, por vezes, parte essencial da 'oração', como no caso da ilustração dada pelo próprio autor “dei meus livros 
a Pedro". Não havendo essa seção na edição de 1835, esse suposto (por nós) elemento da 'oração' não é mencionado na obra.

As espécies de 'oração' também não são apresentadas na edição de 1835 . Na edição de 1873, há dois critérios para os conjuntos de espécies de 'oração', o primeiro é as partes de que elas se compõem. Dentro desse critério, há as espécies 'simples' e 'composta', que exprimem respectivamente ‘juízo simples' e 'juízo composto', que correspondem a ter apenas um 'sujeito' ou 'atributo' ou mais de um; entretanto, Coruja não definiu a 'oração' como 'juízo' anteriormente, mas apenas como união ou agregado de palavras ou 'afirmação'. Ainda sob esse critério, a 'oração' pode ser 'perfeita' por ter claras todas suas partes necessárias, ou 'imperfeita'. O gramático, porém, ressalta que 'orações’ com ‘verbo intransitivo' são perfeitas, mesmo sem 'paciente’, e ‘orações’ com 'verbo impessoal' também o são, ainda que não tenham nem 'sujeito' nem 'paciente'.

O outro conjunto de espécies de 'oração' tem como base a relação entre elas. Há quatro espécies de 'oração', a 'principal' que é absoluta e independente, a 'incidente', que restringe ou explica o substantivo de outra 'oração, a 'subordinada' que tem sentido suspenso e por isso depende de uma oração 'principal', e a 'integrante' que integra outra 'oração' como ‘sujeito', 'predicado', 'paciente' ou 'complemento'.

\subsubsection{Rede conceitual}

Como vimos, os conceitos de 'verbo substantivo' e de 'verbo adjetivo' só são apresentados na edição de 1873 do Compêndio de Coruja e aparecem em metatexto (nota de rodapé). O gramático justifica não ter adotado o conceito em texto por seu manual se tratar de um 'compêndio'. Supomos, portanto, que Coruja considera 'compêndio' um texto elementar, do qual não faria parte a descrição da 'linguagem substantiva' e, consequentemente, os conceitos de 'verbo substantivo' e 'verbo adjetivo'. Assim, o 'verbo substantivo' não se apresenta na descrição linguística da obra, mas fica restrito à reflexão linguística que não condiz com a obra.

Se consideramos que discussões sobre 'linguagem substantiva' estariam conectadas à assunção de um nível subjacente da linguagem (cf. item 1.4), podemos interpretar que, quando Coruja define a 'gramática', em ambas as edições analisadas, como um manual que ensina a declarar bem os pensamentos por meio de palavras, ele está, em verdade, mais preocupado com a boa 'declaração' do que com o 'pensamento'. 
Em outras palavras, notamos que sua gramática é frequentemente baseada em dados linguísticos do nível manifesto, há bem poucos sinais de consideração de uma linguagem subjacente nas técnicas descritivas propostas pelo autor. Há entretanto, alguns conceitos que se aproximam da lógica, como de 'oração', que apresenta a estrutura tripartite, de ‘sujeito', 'verbo' e ‘atributo', mas acrescenta-se ela o 'paciente' e o papel do 'verbo' não é explicitado como a reunião entre 'sujeito' e 'atributo' (que, como vimos, era a definição de 'verbo subsantivo' dada em metatexto.

Quanto às diferenças entre as edições, notamos, primeiramente, que o conceito de 'verbo' é modificado. Em 1835, ele significa ação, já em 1873, continua definido como palavra com que se exprime ação, mas é acrescido do detalhe: "afirmando uma coisa de outra”. Como vimos, essa é a mesma definição que é dada para 'verbo adjetivo', que afirma, por meio do 'atributo', 'ação' ou 'estado', o que poderia gerar os 'verbos ativos' e 'neutros'. Não há, porém, qualquer referência à noção de 'afirmação' na definição dada para essas espécies de 'verbo', nem na edição de 1835, nem na de 1873.

Notamos diferenças na distribuição das classes de palavra nas duas edições. Vemos que em 1835 há nove classes enquanto que em 1873, há dez, isso porque na edição mais antiga a classe denominada 'nome' contém o 'substantivo' e o 'adjetivo', que são classes diferentes em 1873. Em 1835, o 'nome adjetivo' é definido como aquele que significa qualidade de pessoa ou coisa; já em 1873, ele pode qualificar ou determinar e, por isso, há duas espécies de 'adjetivo', o ‘qualificativo' e o 'determinativo'. O segundo contém uma espécie chamada 'articular', a qual tem como exemplos os mesmos dados linguísticos dados para 'artigo', o que não era incomum no período. É notável a mudança de papel do 'adjetivo', que de espécie de uma classe torna-se não apenas classe, e passa a ser definido, indiretamente, pelas noções lógicas de intensão e extensão, o que o leva conter dados de outra classe, a do 'artigo'.

Ademais, é somente na edição de 1873 que são apresentados os quatro diferentes 'complementos', os quais são definidos como responsáveis por completar o sentido de uma palavra. Finalmente, é também apenas na edição de 1873 que Coruja apresenta diferentes espécies de 'oração'. Chama atenção também a presença de 'orações incidentes' que podem ser 'restritivas' ou 'explicativas', como o eram em geral na tradição da grammaire générale (cf. item 1.4.2); não há, porém, espécies paralelas de 'adjetivo qualificativo' na obra.

Finalmente, quanto à edição de 1835, temos uma gramática que não apresenta os conceitos de 'verbo substantivo' e 'verbo adjetivo' (nem em metatexto) e que, de fato, em 
relação à edição de 1873 , tem poucos traços que poderiam ser observados como rede conceitual de nosso conceito-chave - as únicas exceções, dentro do que analisamos, estão no conceito de 'gramática' como uma 'arte' que ensina a declarar bem os pensamentos por meio de palavras (no qual ressaltamos a ideia de língua como expressão dos pensamentos) em que haveria base teórica comum, e no conceito de 'oração' que pode conter um 'sujeito', 'verbo' e 'atributo', em que haveria relação de subordinação do 'verbo substantivo' em relação à 'oração'. Os acréscimos à edição de 1873 tornam o conceito de 'verbo' parece mais próximo do conceito de 'verbo adjetivo', por "afirmar uma coisa de outra". Também são inseridos critérios lógicos que não estavam presentes na edição anterior, para a distinção de espécies de 'adjetivo' e de 'orações incidentes', o que poderia configurar como relação de base teórica comum com o 'verbo substantivo'. Entretanto, ainda que haja essas relações, deve-se considerar o distanciamento promovido entre o 'verbo substantivo' e esses outros conceitos por ele ser apresentado somente em metatexto, não fazendo parte da descrição linguística da obra. Portanto, consideramos o Compendio de 1873 eclético verticalmente, à medida que ela procura inserir elementos em metatexto que coadunam apenas parcialmente com aqueles apresentados em texto.

\subsection{Epitome da grammatica philosophica da lingua portugueza (1862, [50]), de Raymundo Camara Bithencourt}

\subsubsection{Conceitos de gramática e de linguagem e organização da obra}

Bithencourt define 'gramática' como a 'arte' que ensina a falar e escrever com acerto a própria língua, entretanto, diz ele, isso não basta. É preciso saber ou conhecer a razão por que se fala ou se escreve com acerto, por isso, é preciso conhecer a relação da linguagem com os preceitos da lógica. Dessa tarefa incumbe-se a 'gramática filosófica'. Em metatexto (nota de rodapé), ele acrescenta a distinção entre 'gramática geral' e 'gramática filosófica':

Parece-nos indispensavel essa divisão das duas grammaticas, da qual aliás não tratou ainda grammatico algum, nem mesmo o erudito Jeronymo Soares Barbosa, certamente o mais conspicuo philologo da lingua portugueza. Parece-nos tambem que já estamos ouvindo criticarnos pela differença que assignalamos, objetando-se-nos que, se a grammatica em geral é uma arte, dará ela os preceitos para bem se falar e escrever. É verdade, mas quando discriminamos a grammatica geral da philosophica, atendemos a que a primeira é estudada por meninos que, por assim dizer, acabam de aprender a soletrar, e, portanto, embora vejão escriptos os preceitos, todavia não os podem comprehender; entretanto que o estudo da grammatica philosophica presuppõe anteriores conhecimentos da parte daquellas pessoas que o começão e entre taes conhecimentos, o do latim e philosophia racional e moral. A differença, pois, que estabelecemos 
entre grammatica geral e grammatica philosophica, é muito procedente. Aliás, para que o estudo da segunda, tendo sido feito o da primeira? (Bithencourt 1862:1-2)

Assim, o autor considera a 'gramática geral' um manual mais simples e elementar da língua, que pode ser estudado por iniciantes, ao passo que a 'gramática filosófica' pressuporia conhecimentos de 'filosofia moral e racional' e de latim. Ao final da nota, pergunta-se se é realmente necessário aprender a 'gramática filosófica' no caso de já ter conhecimentos da 'gramática geral'. Observamos, em suma, que o gramático considera que há na língua uma razão, a qual pode ser explicada por meio de conteúdos da lógica e do latim. É curioso que, por um lado, o gramático apresenta um conceito de linguagem que se aproxima do Programa de Correspondência (Swiggers 2004, cf. Quadro 2), pois a língua seria analisada pelo conhecimento da razão. No entanto, por outro lado, afirma que o latim seria também necessário para compreender a gramática do português, o que aproxima Bithencourt, ainda que sutilmente, do Programa Descritivista, pois ele considera que a comparação entre as línguas, sendo o português filiado do latim, seria um bom meio para o aprendizado daquela.

Além disso, o gramático diz que a gramática deve se dividir em quatro partes: a 'ortoépia', a 'ortografia', a 'etimologia' e a 'sintaxe'. Essa é a mesma divisão de sua obra, que tem quatro capítulos (cf. FD6, Apêndice B).

\subsubsection{Conceitos de metaclasses e classes de palavras}

Bithencourt concebe sete classes de palavras ou 'partes elementares da oração', que são: 'nome substantivo', 'nome adjetivo', 'verbo', 'preposição', 'advérbio', 'conjunção' e 'interjeição'. Acrescenta numa longa nota de rodapé (metatexto) em que comenta a respeito da gramática do, também brasileiro, Costa Duarte (analisado neste trabalho, cf. Capítulo 4, item 4.3), diz que ele, acompanhando quase todos os gramáticos, não inclui a 'interjeição' no número das 'partes elementares da oração', pois ela equivaleria a uma 'proposição'. Bithencourt argumenta que, de fato, a 'interjeição' equivale a uma, senão mais de uma, 'proposição', mas afirma que isso também se daria com o 'advérbio', que é colocado por Costa Duarte no número das 'partes da oração', ainda que o próprio diga que essa classe é o mesmo que uma 'preposição' com seu 'complemento'. Bithencourt discorda de Costa Duarte, afirmando que se poderia dizer algo similar de quase todas as outras partes da oração (il.: Pedro é bom certamente = Pedro é bom, tenho certeza disso; pai = homem que tem filhos). Continua sua 
argumentação dizendo que na 'etimologia' não se deve considerar as palavras mecanicamente, mas a partir de sua lógica ou espírito.

Dessa forma, segundo o gramático, a classificação das classes de palavras não é mero arbítrio, mas é fruto de uma investigação verdadeira e genuína da aplicação dos 'vocábulos' e os empregam segundo a ideia ou ideias que eles representam; ressalta ainda

que não atender essa consideração pode ter como consequência a confusão entre o 'material' e o 'imaterial' dos 'vocábulos'. Exemplifica esse pensamento dizendo que não se confunde o 'substantivo' "bondade" com o 'adjetivo' "bom", no primeiro caso exprime-se uma 'ideia absoluta', no segundo, expressa-se uma 'ideia que necessita de outra', que deve a acompanhar necessariamente; igualmente, não se confunde a 'preposição' “entre” com o 'verbo' “entre”. A distinção, assevera o gramático, é tanto mais incontestável quanto o é a das ideias. Consequentemente, a etimologia da natureza das palavras deve ser apreciada sob um aspecto lógico ou filosófico, que é a maneira como gramático diz ter realizado na gramática analisada.

Não há metaclasses, entretanto, o autor traz um posicionamento em metatexto acerca da maneira como as classes de palavras devem ser distinguidas, isto é, sob o aspecto lógico ou filosófico, como vimos.

\subsubsection{Conceitos modificadores do nome}

Bithencourt define o 'adjetivo' como classe de palavra que não pode subsistir independente do 'substantivo', esteja este claro ou oculto na mesma 'oração'. Os 'adjetivos' são divididos em 'explicativos' ou 'restritivos' ou 'determinativos'. O primeiro exprime uma qualidade essencial do 'nome apelativo' (il.: homem frágil), o segundo é o que expressa alguma qualidade não essencial ao 'apelativo' (il.: homem virtuoso), finalmente, o 'determinativo' é aquele que, anteposto ao 'apelativo', faz com que ele compreenda totalidade de indivíduos da sua classe, apenas alguns, um só ou nenhum (il.: todo homem, alguns homens, este homem, nenhum homem). Em metatexto, Bithencourt assevera que "esta divisão é incontestavel, digão lá o que quizerem alguns grammaticos", na primeira ilustração "homem frágil” o 'adjetivo' representa algo próprio à humanidade, uma qualidade essencial; já na segunda ilustração "homem virtuoso" o 'adjetivo' é uma qualidade acidental do nome. Ainda em nota, o gramático contesta o ponto de vista que considera essas duas espécies de 'adjetivo' como uma única, a de 
'designativo', que, segundo ele, pretendem certos gramáticos, pois assim as qualidades essenciais e acidentais do 'apelativo' ficariam confundidas, além de que não haveria clareza sobre a 'determinação', isto é, a designação da 'extensão' do 'apelativo'. Por outro lado, há gramáticos brasileiros que criticam essa distinção (como é o caso, por exemplo, de Condurú 1888, item 4.11, e Maciel 1887, cf. 4.9).

Em outro metatexto (nota de rodapé), a respeito dos 'determinativos', Bithencourt reforça que esses devem ser antepostos ao 'apelativo', porque se pospostos mudariam absolutamente o pensamento (il.: todo homem é mortal; homem todo é mortal). Essa, afirma o gramático, é uma distinção entre os 'adjetivos qualificativos' e 'restritivos' em relação ao 'determinativo', os dois primeiros podem ser colocados antepostos ou pospostos ao apelativo sem que o sentido se altere (il.: homem virtuoso = virtuoso homem). Acrescenta o caso do 'determinativo' "algum" que considera notável, visto que se colocado anteposto afirma alguma coisa, se posposto, nega absolutamente (il.: algum homem é perverso, homem algum é perverso). Finaliza a nota citando, novamente, Costa Duarte, ao criticá-lo por não tratar da diferença de posicionamento do 'determinativo', acusa-o ainda de definir o 'determinativo' de forma confusa, sem apresentar exemplos.

Há três espécies de 'adjetivos determinativos': 'artigos', 'demonstrativos' e 'determinativos de quantidade'. No quadro adiante, apresentamos o conceito de cada um deles.

\begin{tabular}{|c|c|c|}
\hline $\begin{array}{l}\text { Espécies de } \\
\text { 'artigos' } \\
\text { (termos) } \\
\end{array}$ & Conceito em Texto & Conceito em Metatexto \\
\hline Artigo definido & $\begin{array}{l}\text { O artigo definido (ex.: o, a, os, as) } \\
\text { posto antes do apelativo mostra que este } \\
\text { compreende todos os indivíduos de sua } \\
\text { classe (il.: o homem é mortal); posto antes } \\
\text { de qualquer elemento da oração converte-o } \\
\text { em um nome substantivo (il.: o proibido, o } \\
\text { permitido, o louvar, o porquê). Os nomes } \\
\text { dos Estados têm ou podem deixar de ter } \\
\text { artigo. Não se usa do artigo quando o } \\
\text { apelativo já está determinado por } \\
\text { demonstrativo qualquer (il.: esta } \\
\text { gramática), mas deve ser anteposto aos } \\
\text { demonstrativos "mesmo, qual" e aos } \\
\text { ordinais "primeiro, segundo etc." quando } \\
\text { esses ordinais antecedem substantivo. } \\
\text { Deve-se também ser anteposto aos } \\
\text { demonstrativos "meu, teu, seu, nosso, etc." }\end{array}$ & $\begin{array}{l}\text { A palavra 'artigo', que tem sua derivação } \\
\text { de um 'verbo' grego, que quer dizer } \\
\text { adaptar, preparar, tem sido empregada } \\
\text { pelos gramáticos para que, anteposta aos } \\
\text { 'nomes apelativos', faça com que sejam } \\
\text { esses tomados 'determinadamente' ou de } \\
\text { 'modo indefinido'. } \\
\text { Segundo Costa Duarte, para mostrar que o } \\
\text { artigo não compreende todos os indivíduos } \\
\text { de sua classe é preciso usar-se uma alguma } \\
\text { 'circunstância restritiva' (il.: o café do } \\
\text { Pharoux). Parece-me que em tal caso o } \\
\text { artigo é um verdadeiro 'demonstrativo } \\
\text { puro' (il.: Pedro, dá-me os livros que te } \\
\text { emprestei = Pedro, dá-me aqueles livros } \\
\text { que te emprestei). Donde podemos definir } \\
\text { que o artigo pode também ser 'adjetivo } \\
\text { demonstrativo'. }\end{array}$ \\
\hline
\end{tabular}




\begin{tabular}{|c|c|c|}
\hline & & $\begin{array}{l}\text { No exemplo, "Filho, sê temente a Deus e } \\
\text { ama-o de todo coração" é fora de dúvida, e } \\
\text { nisso concordamos com Costa Duarte, que } \\
\text { o “o" neste caso é um verdadeiro } \\
\text { 'demonstrativo relativo' (il.: Filho, sê } \\
\text { temente a Deus e ama a Deus de todo o } \\
\text { coração; ou ama a ele de todo o coração). } \\
\text { Costa Duarte não concorda que o "o" } \\
\text { esteja em lugar de "ele" e a razão que dá } \\
\text { para isso é que, carecendo os latinos de } \\
\text { 'artigo definido', viria a estar incluído esse } \\
\text { artigo no demonstrativo ele ou ela, que é o } \\
\text { "ille, illa, illud" dos latinos. Não há } \\
\text { problema, podemos traduzir "ille" por "o". } \\
\text { O artigo "o" muda o "r" final do infinito } \\
\text { em "l" (il.: amá-lo); essa mudança se dá } \\
\text { apenas por 'eufonia', podia também ser o } \\
\text { relativo anteposto ao 'infinito' sem a } \\
\text { menor alteração no pensamento. } \\
\text { Não nos parece 'gramatical' que o 'artigo' } \\
\text { seja anteposto aos 'demonstrativos', ainda } \\
\text { que queiramos indicar uma coisa com mais } \\
\text { particularidade, caso este aceito por Costa } \\
\text { Duarte. O 'demonstrativo' por si só já } \\
\text { determina. }\end{array}$ \\
\hline $\begin{array}{c}\text { Artigo } \\
\text { indefinido }\end{array}$ & $\begin{array}{c}\text { Artigo indefinido (ex.: um, uma, uns, } \\
\text { umas). O artigo indefinido dá ao apelativo } \\
\text { a que é anteposto um sentido individual, } \\
\text { mas vago (il.: um discípulo deve obedecer } \\
\text { a seu mestre). }\end{array}$ & - \\
\hline
\end{tabular}

Quadro 39. Espécies de 'artigo' em Bithencourt (1862)

É notável que o metatexto a respeito do 'artigo' seja maior do que o texto sobre o mesmo assunto. Em nota, Bithencourt apresenta sua opinião a respeito de algumas polêmicas sobre a função do 'artigo'. Sumariamente, ele define o 'artigo' como 'adjetivo demonstrativo' quando está restrito por uma 'circunstância'; considera o “o" do 'período' "Filho, sê temente a Deus e ama-o de todo o coração" como um 'demonstrativo relativo', embora não haja definição dessa espécie de 'demonstrativo' na obra; finalmente, diz que não lhe parece gramatical que o 'artigo' seja anteposto aos 'demonstrativos'. Em todas as opiniões, cita o gramático maranhense Costa Duarte, na primeira discorda dele, na segunda, concorda e, na última, discorda novamente. Como temos visto, as comparações com a gramática de Costa Duarte são frequentes no metatexto de Bithencourt.

Além desses detalhes, o gramático distingue o 'artigo definido' do 'artigo indefinido', sendo este primeiro referente à 'compreensão' de todos os indivíduos de uma classe denominada pelo 'nome' (por conta disso, entra na primeira questão colocada em metatexto), já o 'indefinido' compreenderia um único indivíduo dessa classe de modo vago. 
Quanto aos 'demonstrativos', esses podem ser 'pessoais', 'puros' ou 'conjuntivos'. Em metatexto, acrescenta outras espécies, como 'demonstrativos neutros' e 'relativos'. No quadro adiante, apresentamos o conceito de cada uma:

\begin{tabular}{|c|c|c|}
\hline $\begin{array}{c}\text { Espécies de } \\
\text { 'demonstrativos' }\end{array}$ & Conceito em texto & Conceito em metatexto \\
\hline Pessoais & $\begin{array}{l}\text { Demonstrativos 'pessoais' são adjetivos } \\
\text { que determinam os nomes a que se } \\
\text { juntam ou a que se referem, pela } \\
\text { qualidade da personagem ou papel que } \\
\text { fazem no ato do discurso, ou da } \\
\text { propriedade e posse relativo à mesma } \\
\text { personagem (assim define S. Barbosa). } \\
\text { São também 'primitivos' (ex.: eu, tu, } \\
\text { ele, ela, nós, vós, eles, elas, se) ou } \\
\text { 'derivados' (ex.: meu, minha, meus, } \\
\text { minhas, nosso, nossa, nossos, nossas, } \\
\text { teu, tua, teus, tuas, vosso, vossa, } \\
\text { vossos, vossas, seu, sua, seus, suas) }\end{array}$ & $\begin{array}{l}\text { Costa Duarte diz que os 'demonstrativos } \\
\text { pessoais' são os únicos nomes que na } \\
\text { língua portuguesa têm ‘casos'. } \\
\text { Discordamos, pois a índole do idioma } \\
\text { repugna a existência de 'casos', mesmo } \\
\text { que parcial. Essa aberração, ou exceção à } \\
\text { regra geral, não tem fundamento algum } \\
\text { lógico ou filosófico, e, quando muito, se } \\
\text { poderia admitir como necessária à beleza } \\
\text { da língua. }\end{array}$ \\
\hline Puros & $\begin{array}{c}\text { Demonstrativo 'puro' é aquele adjetivo } \\
\text { que faz com que o apelativo mostre os } \\
\text { objetos assinalando diversas distâncias } \\
\text { e localidades (ex.: este, esse, ele, } \\
\text { aquele, o mesmo). }\end{array}$ & $\begin{array}{l}\text { Além dos cinco demonstrativos puros, há } \\
\text { também demonstrativos que podem ser } \\
\text { chamados de 'neutros' (ex.: isto, isso, } \\
\text { aquilo). São chamados de 'neutros' porque } \\
\text { judiciosamente observa Soares Barbosa, } \\
\text { esses demonstrativos exprimem coisas, } \\
\text { ações ou sentidos que não têm gênero. A } \\
\text { gramática portuguesa bem pudera } \\
\text { dispensar o emprego de tais } \\
\text { demonstrativos chamados neutros, pois que } \\
\text { eles poderiam ser plenamente substituídos } \\
\text { por alguns dos cinco mencionados. }\end{array}$ \\
\hline Conjuntivos & $\begin{array}{c}\text { Demonstrativos conjuntivos são } \\
\text { aqueles que atam as orações, na frente } \\
\text { das quais se encontram, com a } \\
\text { antecedente, como incidentes ou como } \\
\text { integrantes (il.: qual é a coisa que pode } \\
\text { faltar a quem tem por seu um Deus, } \\
\text { cujo é tudo quanto há no céu e na } \\
\text { terra?) (ex.: o qual, a qual, os quais, as } \\
\text { quais, que, cujo, cuja, cujos, cujas, } \\
\text { quem) }\end{array}$ & $\begin{array}{l}\text { Os 'demonstrativos conjuntivos' são ao } \\
\text { mesmo tempo 'relativos', as outro tanto } \\
\text { não sucede com os 'demonstrativos puros', } \\
\text { que podendo ser 'relativos', jamais são } \\
\text { 'conjuntivos'. }\end{array}$ \\
\hline
\end{tabular}

Quadro 40. Espécies de 'adjetivos demonstrativos' em Bithencourt (1862)

Em diversos momentos, cita o gramático português Soares Barbosa e também o brasileiro Costa Duarte. No caso desse último, critica seu posicionamento a respeito dos 'demonstrativos pessoais' por considerar que na língua portuguesa não há 'casos'. Ademais, em metatexto, embora concorde que com a classificação de 'demonstrativos neutros' de Soares Barbosa, opina que esses sejam dispensáveis para a língua portuguesa. Finalmente, em metatexto relativo aos 'demonstrativos conjuntivos', Bithencourt diz que esses podem também ser 'relativos', sem, entretanto, explicar o que são 'demonstrativos relativos', supomos por inferência que sejam aqueles que retomam 'nome' de 'oração' anterior. 
O gramático define, em texto, o 'determinativo de quantidade' como aqueles que fazem que os 'apelativos' abranjam todos os indivíduos de sua classe ou apenas parte (il.: todos os homens; alguns homens). Por isso, dividem-se em 'universais' (ex.: todo, o) e em 'partitivos' (ex.: alguns, certos) - é curioso observar que o exemplo que o gramático tinha, anteriormente, dado como 'artigo definido' consta nos exemplos de 'determinativos de quantidade universais'. Isso poderia ter alguma relação com o que o gramático disse anteriormente a respeito do 'material' e do 'imaterial' das palavras, entretanto, a definição de ambos é bastante similar, isto é, abranger todos os indivíduos da classe referida no 'apelativo'.

Apresenta em metatexto, nota de rodapé, o que dizem outros gramáticos sobre o 'determinativo de quantidade'. Dizem que também podem excluir e não abranger parte nenhuma dos indivíduos (il.: nenhum homem é infalível). Costa Duarte discorda dessa posição, ainda que ela seja a de todos os gramáticos que tem lido, inclusive Soares Barbosa. Em substituição dessa classificação, propõe que os 'adjetivos' supracitados, juntamente com o "algum" posposto ao 'nome', chamassem 'adjetivos exclusivos'.

Ademais, em texto, apresenta as espécies de 'determinativo' que apresentam números: 'numerais cardeais' (ex.: um, dois), 'numerais ordinais' (ex.: primeiro, segundo), 'numerais multiplicativos' (ex.: duplo, dobro, triplo), e 'numerais fracionários' (ex.: um quarto, um quinto).

Finalizado o conteúdo acerca dos 'adjetivos determinativos', entramos nas espécies de 'adjetivo qualificativo', o qual pode ser 'explicativo' e 'restritivo'. Os 'adjetivos explicativos' e os 'restritivos' modificam o 'substantivo', porém, não se confundem, porque os 'explicativos' não acrescentam ideia alguma nova ao 'substantivo', mas apenas desenvolvem aquelas que o mesmo ‘substantivo' contém, os 'restritivos', por sua vez, acrescentam ao 'substantivo' ideia nova que não se encontrava em sua significação. Os primeiros podem ser postos indiferentemente antes ou depois do 'apelativo' (il.: pedra dura, dura pedra); já os 'restritivos' devem ir depois do 'apelativo', porque às vezes, exprimem ideias diferentes se antepostos ou pospostos (il.: homem pobre, pobre homem).

Ambos são descritos como podendo ser substituídos por 'orações', o primeiro, quando posposto ao 'nome apelativo', pode ser convertido em uma 'oração incidente' ou 'causal' (il.: Deus é misericordioso perdoa os pecadores = Deus, que é misericordioso, etc.); o 'adjetivo restritivo' pode se converter em uma 'proposição condicional' (il.: O homem virtuoso detesta o pecado $=\mathrm{O}$ homem, se virtuoso, etc.). É interessante observar 
a relação que Bithencourt faz entre 'adjetivos' e 'orações', dado que na Grammaire Générale et Raisonnée de Port-Royal de Arnauld e Lancelot (1662), havia também tal relação, ainda que em diferentes moldes. Com esse posicionamento, o autor parece querer demonstrar que a língua pode expressar a mesma razão com diferentes materiais.

\subsubsection{Conceito de verbo}

'Verbo' é definido como a 'parte da oração' que serve para mostrar a relação do 'atributo' com o 'sujeito', exprimindo por diferentes 'modos' a coexistência e identidade de um com outro, segundo os diferentes tempos e maneira de existir. Além de compreender sua principal significação, de existência, o ‘verbo' compreende cinco ideias acessórias: 1) do 'sujeito' da 'oração'; 2) número; 3) diferentes 'modos' de exprimir a existência; 4) tempos da existência; 5) diferentes estados da existência. De acordo com o gramático, há na língua portuguesa três espécies de 'verbos': 'verbo substantivo' (ex.: ser), 'verbo auxiliar' (ex.: estar, haver, ter) e 'verbo adjetivo' (que é exemplificado por todos os outros).

'Verbo substantivo' é aquele que não tem concentrado em si 'atributo' algum (ex.: ser). Em metatexto (nota de rodapé), Bithencourt assevera que o 'verbo' "ser" é o único 'verbo substantivo', e exprime a existência de uma qualidade ou 'atributo' do 'sujeito' da 'oração'. Consequentemente, todos os mais 'verbos' podem se reduzir ao 'verbo' "ser" (il.: eu amo a Pedro = eu sou amante ou amador de Pedro). Ainda em nota, diz que há alguns gramáticos, cita Costa Duarte, que não concordam que "ser" seja o único "verbo substantivo', nem que "eu amo a Pedro" possa se converter em "eu sou mante de Pedro". Costa Duarte, nas palavras de Bithencourt, argumenta que dado que os 'infinitos' dos 'verbos' formam-se dos 'substantivos' correspondentes, para se admitir que todos os 'verbos' se pudessem converter no verbo “ser”, seria necessário juntar a esse 'substantivo' o 'verbo substantivo', e assim dizer "eu sou amor" em vez de "eu amo". Entretanto, segundo Bithencourt, é certo que os 'adjetivos verbais' 'restritivos' e 'qualificativos' são inseparáveis dos 'substantivos' e não é concebível assinalar a prioridade de existência de um sobre a de outro. Dessa forma, desde que houve a ideia de "amor", naturalmente também houve a de "amante". A opinião de Costa Duarte, conclui Bithencourt, não tem nada de filosófica, visto que o gramático maranhense, além do já mencionado, também discorda da maioria dos gramáticos, inclusive Soares Barbosa, de que todos os verbos possam se converter no 'substantivo" "ser", e sugere que "amo" possa se reduzir a "tenho 
amor”, o que, segundo Bithencourt, desvirtua a natureza dos 'verbos substantivos' e 'auxiliares'. Em outra nota, metatexto, ainda sobre o 'verbo substantivo', Bithencourt critica novamente Costa Duarte por este considerar o 'verbo' "estar", além do 'verbo' “ser”, como 'substantivo' e tendo como “ser” a significação de existência, embora atual e temporária. Bithencourt replica dizendo que todos os 'verbos' exprimem a existência, visto que todos são inseparáveis de "ser", diz ainda que Costa Duarte é totalmente refutado por Soares Barbosa em sua 'gramática filosófica'.

Define o 'verbo adjetivo' como a concentração do 'atributo' e o 'verbo' em uma só 'palavra' (il.: amo = sou amante). Todo 'verbo adjetivo' pode ser dividido em dois 'membros', partindo-o pelas suas ‘terminações' em “ar”, "er” e "ir” (ex.: am-ar; tem-er; ouv-ir). O primeiro 'membro' é a 'parte radical', a única própria do 'verbo adjetivo', pela qual ele exprime o 'atributo'. Essa parte pode ter uma 'significação absoluta' ou 'relativa' e, consequentemente, exige ou não exige 'complementos' após si. Por conseguinte, o 'verbo adjetivo' é 'intransitivo' e 'transitivo'.

O 'verbo intransitivo' é aquele que, enunciando a 'relação de conveniência' entre o 'sujeito' e 'atributo', e tendo em si concentrado esse mesmo 'atributo', não exige nenhum ‘complemento' (ex.: dormir, chorar, rir). O 'verbo transitivo', ao contrário, exige um ou mais 'complementos' (il.: louvar a Deus, amar a Pedro); e tem as seguintes espécies 'relativo', 'ativo', 'ativo e relativo', 'passivo', 'médio' e 'reflexo'. No quadro adiante, apresentamos o conceito de cada um deles.

\begin{tabular}{|c|c|}
\hline $\begin{array}{l}\text { Espécies de 'verbo } \\
\text { transitivo' } \\
\text { (termos) }\end{array}$ & Conceito em texto e metatexto \\
\hline Ativo & $\begin{array}{l}\text { T: Aquele que, tendo em si incluído o ‘atributo', enuncia uma ação que deve ser } \\
\text { exercida pelo 'sujeito' do mesmo 'verbo', ou, como se expressavam os antigos } \\
\text { gramáticos, aquele que tem um 'paciente' (il.: eu louvo a Deus). }\end{array}$ \\
\hline Relativo & $\begin{array}{l}\text { T: Aquele que depois de si demanda uma 'preposição' com seu 'consequente' } \\
\text { (il.: vou para casa) }\end{array}$ \\
\hline Ativo e relativo & $\begin{array}{c}\text { T: Aquele que não só tem 'paciente’, mas também ‘complemento' (il.: Dei } \\
\text { dinheiro a Pedro) }\end{array}$ \\
\hline Passivo & $\begin{array}{l}\text { T: Aquele que, em consequência do ‘atributo', enuncia uma ação que se deve } \\
\text { referir ao ‘sujeito' do mesmo ‘verbo' (il.: Pedro é louvado por Paulo). } \\
\text { MT: Segundo Costa Duarte, as ‘terceiras pessoas’ de tais ‘verbos’ tomam uma } \\
\text { significação passiva quando os ‘sujeitos da oração' são coisa que não podem } \\
\text { obrar sobre si (il.: as coisas são estimadas). Recomenda o citado gramático que } \\
\text { não se deve apassivar ‘verbos' deste modo quando os ‘sujeitos' podem obrar } \\
\text { sobre si (il.: mataram-se quatro homens). }\end{array}$ \\
\hline Médio e reflexo & $\begin{array}{l}\text { T: Não diversifica do 'verbo ativo', mas é este mesmo 'verbo' que, enunciando } \\
\text { a 'relação de conveniência' entre o ‘sujeito' e o 'atributo', faz que a ação recaia } \\
\text { sobre o mesmo ‘sujeito' (il.: Pedro matou-se) } \\
\text { MT: Entendem alguns gramáticos que os 'verbos médios e reflexos' devem ser } \\
\text { chamados 'pronominais', por conta do 'pronome' que às vezes se lhes pospõe, }\end{array}$ \\
\hline
\end{tabular}




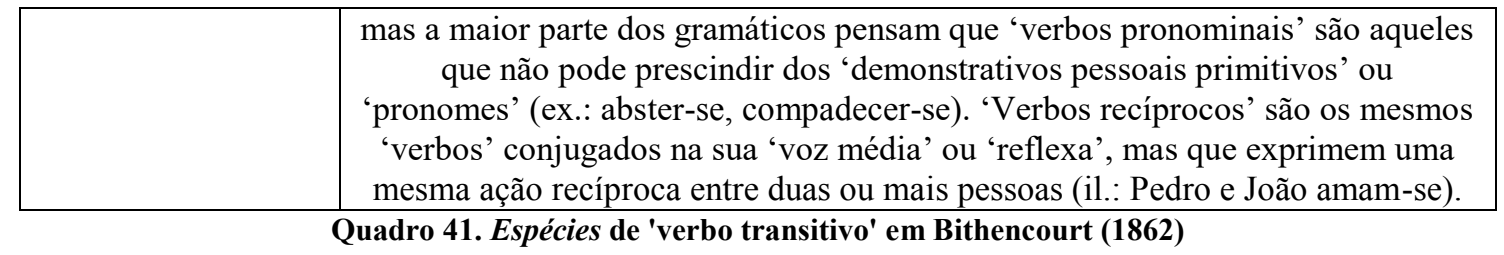

É notável que em quase todos os conceitos de espécies de 'verbo', Bithencourt ressalte o papel do 'atributo' na característica específica de cada um, sendo, dessa forma, coerente com a sua definição inicial de 'verbo'. Em metatexto, apresenta outras duas espécies, que se confundem com ou podem ser parte do 'verbo médio e reflexo', que são os 'verbos pronominais' e os 'recíprocos'. Em texto, Bithencourt define os 'defectivos' como aqueles aos quais falta algum tempo ou alguma pessoa (ex.: munir) e os ‘impessoais' como os que se conjugam somente nas terceiras pessoas (ex.: chover).

\subsubsection{Conceito de oração e seus elementos}

A 'oração' ou 'proposição' de Bithencourt é definida como qualquer juízo expresso ou mais detalhadamente, a 'conveniência' ou 'desconveniência' entre duas ideias expressadas por meio de palavras. Toda 'oração' consta necessariamente de três elementos: 'sujeito', 'atributo' e 'verbo', que também se chama 'cópula' ou 'nexo'. 'Sujeito’ e ‘atributo’ são ‘termos’ da 'oração'. O ‘verbo' exprime a relação entre ‘sujeito' e 'atributo'. O ‘sujeito' enuncia a pessoa ou coisa a respeito da qual se expressa alguma coisa; é um 'substantivo' ou 'nome substantivado' (il.: Deus é misericordioso; o ser virtuoso é muito difícil). O ‘atributo' é quase sempre um ‘adjetivo' ou 'apelativo'. Em metatexto (nota de rodapé), o autor ressalva, porém, que seria completa a 'oração" "louvo" porque o 'verbo adjetivo', que tem concentrado em si o 'atributo' ou qualidade, deixa claramente conhecer o 'sujeito'.

No que diz respeito a organização dos itens da 'oração', Bithencourt define 'regência regular' como quando estão igualmente expressas as palavras regentes e seus 'complementos'. De acordo com o gramático, reger quer dizer 'determinar' e 'demandar' alguma coisa. As palavras que regem outras palavras são os 'verbos adjetivos', os 'adjetivos transitivos' e as 'preposições'. A 'regência irregular' se dá, segundo o gramático, por 'elipse', isto é, quando falta alguma parte essencial à 'oração'; para que não seja viciosa é preciso que a 'elipse' seja justificada pela razão ou pela própria língua, quando, por exemplo, o elemento ausente já foi citado anteriormente. 
Há diferentes espécies de 'palavras' quando pensamos em 'regência'. Há 'palavras ativas' que exigem um 'objeto'; 'relativas' que exigem um 'termo'; 'ativas e relativas' ao mesmo tempo, as quais exigem um 'termo' e um 'objeto'; e, finalmente, há 'palavras absolutas' que nada demandam necessariamente. As palavras que completam a significação de outras chamam-se 'complementos'. Há quatro tipos deles: o 'objetivo' (que completa 'verbos ativos' e 'verbos ativos e relativos'), o 'terminativo' que (completa 'palavras relativas'), o 'restritivo' (que completa 'palavras absolutas') e o 'circunstancial' (que completa 'palavras absolutas'). No quadro adiante, definimos cada um dos 'complementos':

\begin{tabular}{|c|c|}
\hline $\begin{array}{c}\text { Espécies de } \\
\text { 'complementos' }\end{array}$ & Conteúdo em texto e metatexto \\
\hline C. objetivo & $\begin{array}{l}\text { T: Toda 'palavra' ou 'oração' sobre que recai a ação do ‘verbo ativo' (il.: amo a } \\
\text { Francisco; ambiciono instruir-me). } \\
\text { MT: É chamado por alguns gramáticos de 'paciente'. É o 'complemento' do } \\
\text { 'atributo' incluído no 'verbo' (il.: amo a Francisco = sou amante de Francisco). } \\
\text { Não se confunde com o 'atributo', como pensaram alguns gramáticos antigos, } \\
\text { quando diziam 'paciente' ou 'predicado' como se fosse a mesma coisa. Nem todos } \\
\text { os 'verbos' têm 'paciente' ou 'complemento objetivo', não há, entretanto, um só } \\
\text { que não tenha 'predicado' ou 'atributo' - porque não há um só 'verbo' que não } \\
\text { possa ser reduzido ao verbo “ser" seguido do 'adjetivo verbal'. }\end{array}$ \\
\hline C. terminativo & $\begin{array}{c}\text { T: ‘Palavra' ou 'oração' que completa ou termina a significação relativa das } \\
\text { 'palavras regentes', e do mesmo modo que as significações relativas são diferentes, } \\
\text { semelhantemente o são também as ‘preposições’ usadas nos 'complementos } \\
\text { terminativos' (il.: deu-me um livro = deu um livro a mim). }\end{array}$ \\
\hline C. restritivo & $\begin{array}{l}\text { T: Qualquer palavra precedida de 'preposição' "de" e posta imediatamente depois } \\
\text { de qualquer 'nome apelativo' para lhe determinar a significação vaga que de outro } \\
\text { modo teria (il.: dinheiro de Pedro). } \\
\text { MT: É chamado por alguns gramáticos de 'caso de possessão' ou 'complemento de } \\
\text { possessão'. Sobre a palavra "caso" nada mais diremos, porque já temos observado } \\
\text { mais de uma vez que ela não convém de maneira alguma à 'etimologia' e à } \\
\text { 'sintaxe' da 'Gramática Portuguesa'. Por vezes, esse 'complemento' denomina } \\
\text { posse, mas não sempre (il.: homem de virtudes, homem de honra). Sempre, } \\
\text { entretanto, restringe o indeterminado do 'apelativo', assim seu nome, 'restritivo', é } \\
\text { adequado. }\end{array}$ \\
\hline $\begin{array}{c}\mathrm{C} . \\
\text { circunstancial }\end{array}$ & $\begin{array}{l}\text { T: Toda 'palavra' ou ‘oração' precedida de uma ‘preposição' e junta a qualquer } \\
\text { 'verbo' ou 'adjetivo' cuja significação não exige ‘complemento algum' (il.: João } \\
\text { faleceu em dezembro por falta de tratamento). Indicam diversas circunstâncias, } \\
\text { como modo, causa, instrumento, tempo etc. (il.: Pedro feriu-me com a espada; leio } \\
\text { com atenção). }\end{array}$ \\
\hline
\end{tabular}

Ressaltamos o metatexto em que fala do conceito de 'complemento objetivo', pois explica que este é o 'complemento' do 'atributo' incluído no 'verbo', destacando novamente que o 'verbo' é dividido em 'atributo' e ‘verbo substantivo'.

As 'orações' têm diferentes espécies de acordo com a sua natureza ou de acordo com a sua graduação no 'período', este que é a reunião de tantas 'proposições totais' e de tal maneira atadas umas com outras que estas supõem necessariamente aquelas para que 
o sentido fique completo; o 'período' terá tantas 'orações' quantos forem os 'verbos'. No quadro abaixo, apresentamos as diferentes espécies de 'orações'.

\begin{tabular}{|c|c|}
\hline $\begin{array}{l}\text { Espécies de 'oração' } \\
\text { de acordo com sua } \\
\text { 'natureza' (termos) }\end{array}$ & Conceito em texto \\
\hline Simples & Tem só um ‘sujeito’ e um só ‘atributo’ (il.: João é mortal). \\
\hline Composta & $\begin{array}{l}\text { Consta ou de mais de um ‘sujeito' ou de mais de um 'atributo' (il.: Pedro e } \\
\text { João são mortais; Pedro é inteligente e virtuoso). Há nela tantas 'proposições } \\
\text { simples' quantos são os seus ‘sujeitos' e 'atributos'. }\end{array}$ \\
\hline Complexa & $\begin{array}{l}\text { Aquela cujo ‘sujeito' ou 'atributo’ é modificado por alguma 'proposição } \\
\text { parcial' (il.: Pedro, se é virtuoso, aborrece a intemperança.). Podendo, assim, } \\
\text { converter-se em 'orações simples' (il.: Pedro aborrece os vícios. Se Pedro é } \\
\text { virtuoso.). }\end{array}$ \\
\hline $\begin{array}{l}\text { Espécies de 'oração' } \\
\text { de acordo com sua } \\
\text { graduação no } \\
\text { 'período' (termos) }\end{array}$ & Conceito em texto \\
\hline Principal & É 'absoluta', isto é, não depende de outra (il.: Deus é misericordioso) \\
\hline Total dependente & $\begin{array}{l}\text { Embora não faça parte de outra, depende da 'proposição principal' (il.: os } \\
\text { vícios podem lisonjear os sentidos, mas são prejudiciais). }\end{array}$ \\
\hline $\begin{array}{l}\text { Parcial } \\
\text { (explicativa e } \\
\text { restritiva) }\end{array}$ & $\begin{array}{l}\text { Modifica qualquer dos 'termos da oração'. Como os termos da oração } \\
\text { podem ser modificados em 'sentido explicativo' ou 'sentido restritivo', } \\
\text { segue-se que a 'oração parcial' se subdivide em 'explicativa' e 'restritiva'. A } \\
\text { primeira desenvolve ou explica o 'predicado' já incluído em algum dos } \\
\text { termos da 'proposição principal' (il.: Deus, que é misericordioso, perdoa os } \\
\text { pecadores). A segunda restringe algum ‘vocábulo' de outra 'proposição', } \\
\text { apresentando ou enunciando alguma ideia não incluída na significação de } \\
\text { algum dos seus 'termos' (il.: o homem que é virtuoso detesta o pecado. }\end{array}$ \\
\hline Integrante & $\begin{array}{l}\text { É a mesma 'proposição simples' completando a 'significação transitiva' do } \\
\text { 'verbo adjetivo' (il.: Ambiciono ser sábio). }\end{array}$ \\
\hline
\end{tabular}

Quadro 43. Espécies de 'oração' de acordo com sua 'natureza' em Bithencourt (1862)

Nota-se que as 'orações parciais' assemelham-se com os 'adjetivos qualificativo', visto que ambos podem ser 'explicativos' ou 'restritivos'. Por outro lado, como vimos anteriormente, o gramático menciona os conceitos de 'oração causal' (que teria alguma equivalência com o conceito de 'oração incidente') e 'oração condicional' ao tratar dos 'adjetivos', mas não os apresenta na seção destinada ao tratamento das espécies da 'oração'.

\subsubsection{Rede conceitual}

Bithencourt apresenta em seu Epitome uma clara rede conceitual em torno do 'verbo substantivo'; consequentemente, seu texto pode ser considerado um exemplo de gramática em que há rede conceitual. Como vimos, a 'gramática filosófica' é definida como aquela que explica as 'razões' do falar correto, o que tem implícito um conceito de 
linguagem baseada em razões. Essa concepção de linguagem também se apresenta quando o autor trata da distinção entre as classes de palavras. Quanto aos conceitos modificadores do nome, nota-se um ponto de vista essencialmente semântico, onde são observadas sobretudo 'determinação', 'explicação' e 'restrição'. Esses dois últimos são também encontrados nos conceitos das espécies de 'oração incidente' - tal paralelismo, que é destacado pelo gramático, pode estar relacionado à assunção de uma 'razão' da linguagem ou nível subjacente. Assim, a base teórica desses conceitos é comum à do 'verbo substantivo'; possui ainda, historicamente, relação com a assunção do 'verbo substantivo' como protagonista da 'oração', como pudemos ver no capítulo 1 (item 1.4.2). As relações entre 'verbo substantivo', 'verbo' e 'oração' tripartite são mais próximas, ambas tratam da relação entre ideias ou da relação em 'sujeito' e 'atributo' e apresentam nas ilustrações o verbo "ser". Com ambos os conceitos, o 'verbo substantivo' trava relação de subordinação.

Vimos, ademais, que há longas reflexões do gramático em nota de rodapé, metatexto. Nelas, Bithencourt rejeita o conceito de 'verbo substantivo' proposto pelo gramático brasileiro Costa Duarte e, para isso, apoia-se no português Soares Barbosa. Costa Duarte (como já vimos no item 4.3) apresenta, em metatexto, um conceito, heterodoxo de 'verbo substantivo', se considerarmos a tradição da grammaire générale.

\subsection{Grammatica portugueza accomodada aos princípios geraes da palavra seguidos de immediata aplicação pratica (1877), de Francisco Sotero dos Reis}

\subsubsection{Conceitos de gramática e de linguagem e organização da obra}

Nos prolegômenos da obra, Sotero dos Reis afirma que a 'gramática' se divide em 'gramática geral' e 'gramática particular'. A primeira é a ciência dos princípios imutáveis e gerais da palavra pronunciada ou escrita em todas as línguas. A segunda, é a arte de aplicar aos princípios imutáveis gerais da palavra às instituições arbitrárias e usuais de qualquer língua. Depois dessa definição mais concisa, cita longo trecho traduzido que referencia como sendo de Du Marsais ${ }^{102}$ do qual citamos a parte final adiante:

\footnotetext{
Não obstante esta distincçào da sciencia e da arte grammatical, não pretendemos insinuar que se deva ou possa separar o estudo de uma do de outra. A arte nenhuma certeza poderá dar á pratica, si não fôr esclarecida e dirigida pelas luzes da especulação; a sciencia nenhuma consistencia poderá dar á theoria, si não observar os usos combinados e as differentes praticas, para leval-a
}

102 É possível, porém, que o texto seja de autoria de Beauzée, visto que consta na Letra G da Encyclopédie, pois diz-se que Du Marsais escreveu apenas até a letra F antes de falecer (cf. Polachini 2013). 
por gráos á generalisação de principios. Mas nem por isso é menos razoavel distinguir uma da outra; assignar a cada uma seu objecto proprio; prescrever-lhes os respectivos limites, e determinar-lhes a differença. (Sotero dos Reis 1877:VI]

Define 'gramática portuguesa' como a arte de aplicar aos princípios imutáveis e gerais da palavra os usos e idiotismos da língua portuguesa. Afirma que procurou desenvolver essa definição na gramática estudada, assim, tentou simplificá-la ao máximo na teoria, subordinando os usos da língua aos princípios gerais, visto que considera que o método e a clareza não têm maior inimigo que a multiplicidade de regras; e procurou apresentar exemplos tão logo apresentasse a teoria. Apresenta ainda outra definição para a 'gramática portuguesa' como arte de falar e de escrever corretamente a língua portuguesa.

Em nota (metatexto), diz que a GGR-PR, de forma geral, define a gramática como “arte de falar", que é, segundo o autor, a definição mais concisa, porque "falar" abrange tudo o mais. Além disso, divide em a gramática em quatro partes, que são: 'etimologia', 'sintaxe', 'ortografia' e 'prosódia'. Afirma ter dado muito mais desenvolvimento às duas primeiras partes, considerando que essas constituem a base de toda a 'ciência gramatical', são essencialmente especulativas e práticas. Completa dizendo que o consenso unânime de quase todos os gramáticos antigos e modernos vem em apoio dessa opinião, que, segundo o autor, é tão velha quanto a gramática.

Ainda nos prolegômenos, define 'palavras' como sinais com que representamos as simples noções das coisas, os quais, quando combinados em enunciados ou 'proposições', exprimimos 'operações do espírito'. Isso, porém, também pode ser representado, ainda que imperfeitamente, pelos 'gestos' e outras 'combinações intelectuais'. Por conta disso, a 'linguagem' pode ser em dividida naquela de 'sons articulados' e aquela que consta de 'gestos'. Sotero dos Reis lembra que o objeto da gramática é apenas a 'linguagem articulada'. Uma língua, diz ele, não é mais do que um 'sistema de sinais', que pode ser mais ou menos completo, segundo a língua se acha mais ou menos aperfeiçoada. Claramente, o conceito de 'gramática' e o conceito de 'linguagem' de Sotero dos Reis estejam dentro do Programa de Correspondência (Swiggers 2004, cf. Quadro 2), visto que baseia-se na relação entre as operações do espírito, de onde vêm os princípios imutáveis, e as línguas.

\subsubsection{Conceitos de metaclasses e classes de palavras}


Ainda nos Prolegômenos, Sotero dos Reis afirma que há duas 'espécies de palavras', nós, porém, as consideramos metaclasse, as 'palavras variáveis', que correspondem às classes de palavras 'nome', 'pronome', 'adjetivo' e 'verbo', e as 'palavras invariáveis', que correspondem às classes de palavras 'conjunção', 'preposição', 'advérbio', 'interjeição'. Em metatexto (nota), ele ressalta que nem todos os gramáticos estão de acordo com a divisão em oito classes de palavras. Cita o gramático latino Quintiliano e o gramático francês Tracy para exemplificar a divisão em apenas três classes de palavras 'nome', 'verbo' e 'conjunção'.

Na seção de 'Etimologia', algumas das classes de palavras recebem termos com pequenas variações em relação ao dado na seção “Prolegômenos”. O 'substantivo' e o 'adjetivo' tornam-se 'nome substantivo' e 'nome adjetivo' - embora não estejam sob o escopo de uma classe chamada nome, que não há na obra; ademais, o 'pronome' recebe a especificação de 'pronome pessoal'. Os termos das outras classes, 'verbo', 'conjunção', 'preposição', 'advérbio' e 'interjeição', são mantidos.

\subsubsection{Conceitos modificadores do nome}

$\mathrm{Na}$ gramática de Sotero dos Reis, são conceitos modificadores do nome 'pronome' ou 'pronome pessoal' e 'adjetivo' ou 'nome adjetivo'. O primeiro é definido, “como o está dizendo a fôrça dos termos, o que se põe em logar do nome, ou do sujeito, indicando ao mesmo tempo a pessoa gramatical deste e o papel que representa no discurso" (p. 5). O 'nome adjetivo' é "como soa a palavra, um nome que se ajunta ao substantivo, ou para qualificar, ou para determinar a pessoa ou cousa por ele designada" (p. 8-9), serve como acessório do 'substantivo' e não figura no discurso sem ele. Há duas espécies de 'nome adjetivo', o 'adjetivo qualificativo' que também pode se chamar 'atributivo', que exprime a qualidade do 'substantivo' e é o 'atributo' por excelência; o 'adjetivo determinativo', não exprime qualidade, "indica de um modo positivo o objeto significado pelo substantivo a que se junta” (p.16), e pode ser simples mostrador do 'atributo oculto'. O ‘adjetivo qualificativo' tem duas espécies, 'restritivo' e 'explicativo'; o 'adjetivo determinativo' tem sete espécies, 'articular', 'conjuntivo', 'interrogativo', 'numeral', 'quantitativo', 'possessivo' e 'pronominal'. No quadro adiante, apresentamos sua taxonomia.

Adjetivo qualificativo
Restritivo Explicativo 


\begin{tabular}{|c|c|c|c|}
\hline \multirow{12}{*}{$\begin{array}{c}\text { Adjetivo } \\
\text { determinativo }\end{array}$} & \multirow{5}{*}{ Articular } & \multirow[t]{2}{*}{ Artigo } & Definido \\
\hline & & & Indefinido \\
\hline & & \multirow[t]{3}{*}{ Adjetivo Demonstrativo } & Puro \\
\hline & & & Partitivo \\
\hline & & & Distributivo \\
\hline & \multicolumn{3}{|l|}{ Conjuntivo } \\
\hline & \multicolumn{3}{|l|}{ Interrogativo } \\
\hline & \multicolumn{3}{|l|}{ Numeral } \\
\hline & \multirow{2}{*}{ Quantitativo } & \multicolumn{2}{|c|}{ Ordinal } \\
\hline & & \\
\hline & \multicolumn{3}{|l|}{ Possessivo } \\
\hline & Pronominal & & \\
\hline
\end{tabular}

Quadro 44. Espécies de 'adjetivo qualificativo' e 'adjetivo determinativo' em Sotero dos Reis (1877)

A diferença das espécies do 'adjetivo qualificativo' é que o 'restritivo' exprime qualidade inerente ao objeto (il.: homem mortal), ao passo que o 'explicativo' exprime qualidade acidental ao objeto (il.: homem prudente). Como vemos no quadro, o 'adjetivo determinativo' divide-se em diversas espécies e muitas delas tornam-se gênero de outras espécies. O 'articular', que determina indicando gênero, espécie, lugar, identidade e distribuição, tem como espécies o 'artigo' e o 'adjetivo demonstrativo'. O primeiro, que põe-se antes do substantivo apelativo para determiná-lo (ex.: o, a, os, as, um, uma, uns, umas), tem ainda duas espécies, pode ser 'definido', quando, anteposto ao nome, indica objeto individualizando-o de modo certo (il.: o mestre); ou 'indefinido', quando, anteposto ao nome, indica objeto individualizando-o de modo vago (il.: um mestre). Em nota (metatexto), afirma que ainda que muitos gramáticos rejeitem o 'artigo indefinido', a língua portuguesa o admite, diferenciando-o do 'numeral cardeal' por possuir plural.

Tal como fazem diversos gramáticos, Sotero dos Reis também discute os usos do 'artigo'. Diz, por exemplo, que “o homem” pode individualizar a ideia geral de homem de modo determinado ou pode equivaler a toda humanidade. Afirma que a ausência do 'artigo' pode adjetivar certos 'nomes apelativos' (il.: o homem é homem de bem; o trigo é trigo sem joio) e ressalta que o 'artigo' nunca é posto antes de 'nome próprio', visto que este já está, por sua natureza, determinado, assim, sempre que é usado, há algum 'apelativo oculto' (o Manuel = o homem Manual; a Maria = a mulher Maria; o Amazonas $=\mathrm{o}$ rio Amazonas; o Brasil $=\mathrm{o}$ império Brasil). Em notas (metatexto), acrescenta que quando se junta o 'artigo' a 'nomes próprios' no plural, estes convertem-se em 'apelativos'; e que quando o 'artigo' se antepõe a qualquer 'parte da oração invariavel' ou 'orações inteiras', pode-se dizer que ele está em sua 'forma neutra', que tomou do hic, haec e hoc latino. 
O 'adjetivo demonstrativo', também espécie do 'articular', indica o objeto significado pelo 'nome substantivo', demonstrando-o sob alguma 'relação', como de lugar, identidade ou distribuição. São 'puros' (ex.: este, esta, isto, aquele, aquela, aquilo, esse, essa, isso, mesmo, mesma, o mesmo, a mesma) 'partitivos' (ex. outro, outra, al (antiquado), outro, outra, algo (antiquado), tal, qual, todo, toda, tudo, nenhum, nenhuma, outro) ou 'distributivos' (ex.: cada, cada um, qualquer, quaisquer, cada qual, quem quer). Todos os 'demonstrativos puros', exceto 'mesmo', postos sozinhos na 'oração' podem servir de 'sujeitos' (este afirmou, aquele negou, esse nada disse), por conta disso, afirma Sotero dos Reis, em metatexto (menção a gramáticos), que antigos gramáticos iludidos pela aparência denominaram-nos 'pronomes'. Não o são, porém, porque não substituem "eu, tu, ele", os quais não precisam ter sido tratados anteriormente no discurso. Diz, ainda em metatexto (menção a gramáticos), que alguns gramáticos incluem "ele, ela, elo (antiquado)" nos demonstrativos, mas hoje estes passaram a ser exclusivamente 'pronome pessoal'.

O 'adjetivo conjuntivo' conjunta 'proposições' fazendo as vezes de 'conjunção', pois liga 'proposições incidentes' (cf. 4.6.5) a outras por elas modificadas, por meio de dois termos de relação, um na 'proposição modificada', o 'antecedente', e outro na 'modificante', o 'consequente' (il.: o homem, que ama a Deus, vive isento do temor da morte: homem = antecedente, que (homem) = consequente). São 'adjetivos conjuntivos' “o qual, a qual, que, cujo, cuja, do qual, da qual, quem”, por vezes, os 'advérbios' colocam-se pelo ‘adjetivo conjuntivo' (ex.: onde, de onde, para onde).

O 'adjetivo interrogativo' serve para interrogar e liga 'proposições completivas' (il.: não diás quem és?; ex.: cujo?, cuja?, qual?, que?, quem?). Sotero dos Reis diz que como o primeiro termo da relação do 'adjetivo interrogativo' está sempre oculto ou é puramente mental, a 'proposição' que se liga à 'completiva' pode também estar oculta (il.: quem bate? = quem é que bate à porta?; que queres? que é o que queres?). O 'advérbio' “onde” também se coloca como 'adjetivo interrogativo', daí que tem também o nome de 'advérbios interrogativos'.

O 'adjetivo numeral' determina o objeto significado pelo 'substantivo' acrescentando-lhe a ideia de número, de modo positivo. Pode ser 'cardinal', que exprime simplesmente o número (ex.: um, dois, três, quatro), 'ordinal', que exprime o número por ordem (ex.: primeiro, segundo, terceiro, quarto). Já o 'adjetivo quantitativo' que também se chama 'numeral indefinido', determina o objeto significado pelo 'substantivo' juntando-lhe a ideia de quantidade numérica indeterminada (il.: muitos homens, mais 
soldados, tantas casas). O 'adjetivo possessivo' determina o objeto significado pelo 'substantivo', trazendo à lembrança a ideia de seu possuidor (il.: meu livro, teu chapéu, seu filho; ex.: meu, minha, meus, minhas, nosso, nossa, nossos, nossas, teu, tua, teus, tuas, vosso, vossa, vossos, vossas, seu, sua, seus, suas). Há também o 'adjetivo possessivo' derivado de ‘nome próprio' de pessoa (ex.: junonio (de Juno); manoelino (de Manoel), josefino (de José)).

Finalmente, o 'adjetivo pronominal' ou 'adjetivo pronome', como, segundo Sotero dos Reis, lhe chamam os franceses, tem este termo porque representa o 'nome' que indica e está sempre só na 'oração'. São “o, a" e vêm do "is, ea, id” latinos (il.: Copiaste a carta? Copiei-a $(\mathrm{a}=\mathrm{carta})$; $\underline{\mathrm{O}}$ que escreve deve pensar antes $(\mathrm{o}=$ homem)$)$. Embora pareça em forma e aparência com o 'artigo definido', o 'adjetivo pronominal' se distingue pelo seu emprego.

A classe de palavras 'pronome' ou, mais especificamente, 'pronome pessoal', como dissemos anteriormente, substitui o 'nome' ou o 'sujeito', indicando ao mesmo tempo a pessoa gramatical deste ou o papel que ele representa no discurso. As pessoas gramaticais, diz Sotero dos Reis, compreendem não só os indivíduos de nossa espécie, que são as pessoas por excelência, mas também, por extensão, os seres irracionais e mesmo coisas inanimadas. São 'pronomes pessoais' da 'primeira pessoa' “eu, me, mim, migo, nós, nos, nosco", da 'segunda pessoa' "tu, te, ti, tigo, vós, vos, vosco" e da 'terceira pessoa' "ele, ela, lhe, eles, elas, lhes, se, si, sigo".

\subsubsection{Conceito de verbo}

A classe de palavra 'verbo' é considerada a palavra por excelência porque dá vida ao discurso, que não pode existir sem ela. É a palavra que serve para afirmar a existência da qualidade na substância, pessoa ou coisa e, por conseguinte, o 'nexo' ou 'cópula', que une o 'atributo' ao 'sujeito' da 'proposição', 'frase', 'sentença' ou 'enunciado de juízo'. O 'verbo' tem como propriedade essencial a 'afirmação' (il.: Deus é eterno; Deus não é injusto), em que afirma que a qualidade de "ser eterno" e de "não ser injusto" existe no 'sujeito' 'Deus". Outra propriedade sua é a 'conjugação'.

Sotero dos Reis considera que a 'forma primitiva' do 'verbo' é única em todas as línguas, na portugueza é “ser”, que quer dizer "ser ente”. Por isso, o 'verbo' tem duas espécies, o ‘verbo substantivo' e o 'verbo adjetivo'. O primeiro é o 'verbo' em sua forma primitiva, "ser", que pode se apresentar dessa forma, separado do atributo, ou juntamente 
com o 'atributo' dentro do 'verbo atributivo' ou 'adjetivo'. O 'verbo substantivo' é o único que não é combinado com um 'atributo' (ex.: tu és estudioso; Pedro era sabio; Elle foi prudente; nós seremos amigos), todos os outros são 'verbos adjetivos'. O 'verbo substantivo' é também o único que significa a 'afirmação' e pode resolver todas as 'proposições'.

Em metatexto (menção a gramáticos), Sotero dos Reis relata que alguns gramáticos pretendiam também considerar “estar" 'verbo substantivo'. O gramático maranhense discorda dessa possibilidade, argumentando que "estar", que se resolve por "ser estante", envolve a significação ou ideia de existência modal, e, portanto, é um 'verbo substantivo' combinado com um 'atributo'. Enquanto “ser" exprime uma qualidade permanente, "estar" manifesta uma qualidade acidental.

O 'verbo atributivo' é, como já dissemos, o 'verbo' que tem o 'atributo' como parte de si. Ele existe, segundo o gramático, pela necessidade de abreviar o discurso para acompanhar o pensamento em sua rapidez. Assim, "ser criante" e "ser vivente" tornaramse "criar" e "viver". Sotero dos Reis apresenta ainda uma descrição sobre as 'terminações verbais', que citamos abaixo:

Todas estas tres terminações comprehendem o attributo grammatical e o verbo, Ser, que se torna patente na terminação em, er, da segunda conjugação. A terminação em, ar, é evidentemente uma terminação contracta de, aer, e a terminação em, ir, é tambem outra terminação contracta de, ier. Assim, Amar, quer dizer, amante ser, ou ser o que ama; Mover, movente ser, ou ser o que move; Unir, uninte ser, ou ser o que une. A terminação infinitiva em, ôr, que só se nota no verbo, Pôr, e seus compostos, não dá origem a uma conjugação especial, porque, Pôr, é a contracção de, Pôer, como se dizia antigamente. (Sotero dos Reis 1877: 55-6)

Há diversas tábuas em que Sotero dos Reis apresenta a conjugação verbal em diferentes tempos, modos e pessoas. Em uma delas, ele afirma que

para melhor se conhecer o verbo attributivo consta de um adjectivo, que é o attributo, e do verbo substantivo, que afirma a existencia d'elle no sujeito passarei a agora a conjugal-lo em seus tempos simples, pondo claras as fórmas mutiladas que representão o attributo e o verbo, das quaes a primeira se chama a radical ou raiz, e a segunda ou a terminação é o mesmo verbo. (Sotero dos Reis 1871: 72-3)

A tábua era organizada da seguinte forma. No presente do indicativo: Tem- $o$, temente sou; Tem-es, temente és; Tem-emos, tementes somos; Tem-eis, tementes sois; Tem-em, tementes são. No pretérito perfeito do indicativo: Tem- $i$, temente fui; Tem-este, temente foste; Tem-êo, temente foi; Tem-emos, tementes fomos; Tem-estes, tementes fostes; Temêrão, tementes fôrão. 
Entre as espécies do 'verbo', há também o 'verbo auxiliar' (ex.: haver, ter), que é usado pelo ‘verbo substantivo' (e, consequentemente, 'verbos adjetivo') alcance certos tempos.

O 'verbo adjetivo' ou 'atributivo' tem as seguintes espécies: 'transitivo', 'intransitivo', 'relativo', 'reflexo' e 'pronominal', cujo conceito apresentamos resumidamente no quadro adiante:

\begin{tabular}{|c|c|}
\hline $\begin{array}{l}\text { Espécies do 'verbo } \\
\text { atributivo' (termo) }\end{array}$ & Conceito \\
\hline Transitivo & $\begin{array}{l}\text { Passa a ação do ‘sujeito' a outro ‘sujeito’ diverso em que ela se emprega, e } \\
\text { que se denomina 'complemento direto' ou 'objetivo' do ‘verbo' (il.: Pedro } \\
\text { estuda a gramática). Pode passar facilmente para a voz passiva (il.: A } \\
\text { gramática é estudada por Pedro). }\end{array}$ \\
\hline $\begin{array}{l}\text { Transitivo }> \\
\text { Intransitivo }\end{array}$ & 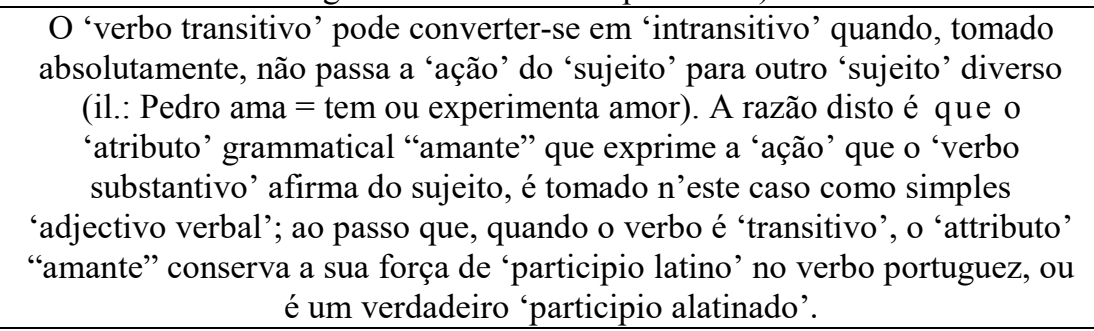 \\
\hline $\begin{array}{l}\text { Transitivo } \\
\text { relativo }\end{array}$ & $\begin{array}{l}\text { O'verbo transitivo', pode ser ao mesmo tempo ‘relativo', quando além do } \\
\text { 'complemento directo' ou 'objectivo', pede um ‘termo de relação', que se } \\
\text { denomina 'complemento indireto' ou 'terminativo'. (il.: dei um livro a } \\
\text { Pedro). }\end{array}$ \\
\hline Intransitivo & $\begin{array}{l}\text { O ‘verbo intransitivo' quando não passa a 'ação’ do ‘sujeito’ para outro } \\
\text { 'sujeito' diverso (il.: José fallou admiravelmente). }\end{array}$ \\
\hline $\begin{array}{l}\text { Intransitivo } \\
\text { relativo }\end{array}$ & $\begin{array}{l}\text { O ‘verbo intransitivo' pode se tornar relativo quando se dá um ‘termo' de } \\
\text { relação à 'ação' exercida pelo ‘sujeito' da 'proposição' (il.: Tu morreste para } \\
\text { o mundo; ficou-lhe a glória da ação). }\end{array}$ \\
\hline Relativo & $\begin{array}{l}\text { O ‘verbo attributivo', quando pede 'complemento indirecto' ou } \\
\text { 'terminativo', ou um ‘termo de relação' da 'acção' exercida pelo ‘sujeito'. } \\
\text { (il.: O mundo obedece a Deus; O sacerdote usa de vestes talares). }\end{array}$ \\
\hline Reflexo & $\begin{array}{l}\text { O ‘verbo atributivo', quando se lhe dá por ‘complemento directo' ou } \\
\text { ‘objectivo' o mesmo ‘pronome pessoal’ que representa o ‘sujeito' (il.: Tu te } \\
\text { feriste). }\end{array}$ \\
\hline Pronominal & $\begin{array}{c}\text { Quando habitualmente se conjuga com o referido ‘pronome’ por aquelle } \\
\text { ‘complemento’; porque então a 'ação’ exercida pelo ‘sujeito’ não passa para } \\
\text { outro ‘sujeito’ diverso, mas reflecte sobre ele proprio. (ex.: eu não me } \\
\text { queixo). }\end{array}$ \\
\hline Relativo & $\begin{array}{l}\text { O ‘verbo pronominal' é muitas vezes 'relativo' (il.: Condoo-me de ti; } \\
\text { Compunge-te de meus males). }\end{array}$ \\
\hline Atributivo composto & $\begin{array}{l}\text { Formado ordinariamente com os 'verbos' “estar”, “ficar”, “andar”, "ir”, } \\
\text { "vir”, e o 'gerundio' dos outros verbos (il.: estar orando; ficar esperando, } \\
\text { andar viajando, ir subindo, vir descendo) ou com o 'gerundio' próprio, } \\
\text { quando o ‘verbo' que com elle se combina exprime movimento (il.: andar } \\
\text { andando, ir indo, vir vindo). Esta especie de verbo composto pode ser, } \\
\text { transitivo, intransitivo, relativo, reflexo e pronominal, segundo a natureza da } \\
\text { significação do gerundio com que se compõe (il.: Estou escrevendo cartas; } \\
\text { Ficou expirando; Andou usando de banhos; Vou-me exercitando; se } \\
\text { queixando). }\end{array}$ \\
\hline
\end{tabular}

Quadro 45. Espécies de 'verbo atributivo' em Sotero dos Reis (1877)

Como vemos, exceto pela definição em que trata da transição de 'verbos transitivos' para 'verbos intransitivos', Sotero dos Reis, não trata da distinção entre 'verbo 
substantivo' e 'atributo' inserida nas espécies de 'verbo atributivo'. Na definição mencionada, o gramático explica que 'verbos transitivos' que se tornam 'intransitivos', por meio de uma distinção feita na língua latina, a qual, de acordo com o gramático, pressupõe duas análises diferentes do 'verbo adjetivo' (em 'verbo substantivo' mais 'adjetivo verbal' ou 'verbo substantivo' mais 'particípio').

\subsubsection{Conceito de oração e seus elementos}

Sotero dos Reis inicia seu capítulo de tratamento de sintaxe afirmando que o ‘discurso' consta de 'proposições' e as 'proposições' de 'palavras'; afirma também que a 'proposição' também é denominada por outros termos como 'oração', 'frase', 'sentença' e define-a como o enunciado do juízo ou ato do entendimento pelo qual afirmamos uma coisa de outra. Os três 'termos' da 'proposição' são ‘sujeito', 'atributo' e 'verbo', os dois primeiros são 'ideias acessórias, ao passo que o último é 'ideia principal' e promove o 'nexo' entre os outros dois 'termos' (il.: Deus é eterno).

'Sujeito' e 'atributo' podem ser 'gramaticais' ou ‘totais'. Quando gramaticais, são representados por 'nome substantivo', 'pronome' e 'oração', no caso do ‘sujeito', e 'nome adjetivo' ou equivalente, no caso do 'atributo'. Quando 'totais', são acompanhados por 'complementos', que são definidos como "toda palavra ou ação que completa o sujeito e atributo". Ademais, o 'sujeito' e o 'atributo' também são classificados em 'simples', 'compostos' e 'complexos'. No quadro abaixo, apresentamos o conceito de cada um:

\begin{tabular}{|c|c|c|c|}
\hline $\begin{array}{c}\text { Espécies de } \\
\text { 'sujeito' e } \\
\text { 'atributo' }\end{array}$ & Simples & Composto & Complexo \\
\hline Sujeito & $\begin{array}{c}\text { Representa apenas um } \\
\text { objeto ou objetos de } \\
\text { mesma natureza (il.: O } \\
\text { homem é mortal). }\end{array}$ & $\begin{array}{c}\text { Representa objetos } \\
\text { diferentes ou de natureza } \\
\text { diversa (il.: Pedro e João } \\
\text { são irmãos). }\end{array}$ & $\begin{array}{c}\text { Tem complementos (il.: O } \\
\text { homem que sabe regular } \\
\text { sua vida é prudente). }\end{array}$ \\
\hline Atributo & $\begin{array}{c}\text { Exprime uma só maneira } \\
\text { de existir do 'sujeito' (il.: } \\
\text { O homem é mortal). }\end{array}$ & $\begin{array}{c}\text { Exprime diversas maneiras } \\
\text { de existir do 'sujeito' (il.: } \\
\text { Cícero foi orador e } \\
\text { filósofo). }\end{array}$ & $\begin{array}{c}\text { Tem complementos (il.: O } \\
\text { mundo foi criado por } \\
\text { Deus). }\end{array}$ \\
\hline
\end{tabular}

Quadro 46. Espécies de 'sujeito' e 'atributo' em Sotero dos Reis (1877)

Sotero dos Reis distingue em seu capítulo de tratamento da sintaxe, uma sintaxe de 'palavras' e outra de 'proposições', em ambas há 'ligação' e ‘subordinação' (de palavras e de proposições). Lembramos que no 'prólogo' da obra, ele havia dito que a respeito das relações entre 'palavras' de que se compõe a 'proposição', assim como as 
relações entre as 'proposições' de que se compõem o 'discurso', são de três naturezas: 'nexo', 'concordância', 'dependência' ou 'subordinação'.

É quando trata das 'dependências' das palavras que Sotero dos Reis descreve diversos tipos de 'complementos' que pode haver nas 'proposições'. Antes, porém, ressalta a diferença entre línguas que têm 'casos', como latim e grego, e línguas que não têm, como o português. Enquanto aquelas expressam a 'subordinação' das palavras entre si por meio de 'casos' e independentemente de preposições claras ou subentendidas e sem "lei da posição", a língua portuguesa expressa essas subordinações por meio dos 'complementos diretos' ou 'objetivos' (sem preposição) e 'indiretos' ou 'terminativos' (com preposição) e deve-se observar a "lei da posição" das palavras.

Diferentemente da maior parte dos gramáticos, Sotero dos Reis não apresenta primeiro as espécies de 'complemento' e depois a que elas se referem, mas os apresenta distinguindo-os primeiramente pela palavra que complementam. Assim, há três 'complementos': do 'nome apelativo', do 'nome adjetivo' e do 'verbo atributivo', os quais podem ser das seguintes espécies, respectivamente, 'restritivo' ou 'terminativo', 'terminativo' ou 'circunstancial', 'objetivo' ou 'terminativo' ou 'circunstancial'. No quadro adiante, apresentamos sinteticamente o conceito de cada um:

\begin{tabular}{|c|l|}
\hline $\begin{array}{c}\text { 'Complementos' } \\
\text { de classes de } \\
\text { palavras }\end{array}$ & \multicolumn{1}{c|}{ Conceito } \\
\hline Nome apelativo & $\begin{array}{l}\text { Ordinariamente, 'restritivo', que designa propriedade, possessão ou fim (il.: Este } \\
\text { livro é de Pedro; As leis de Licurgo fizeram dos espartanos um povo guerreiro) } \\
\text { Mas pode também ser 'terminativo', que modifica o 'nome apelativo relativo' (il.: } \\
\text { inclinação às armas). Pode também ter os dois 'complementos' ao mesmo tempo } \\
\text { (il.: A inclinação às armas é evidente em Pedro; O amor ao estudo é feliz disposição } \\
\text { para aprender). }\end{array}$ \\
\hline Nome adjetivo & $\begin{array}{l}\text { Quando é 'relativo' o 'nome adjetivo' pode ser modificado pelo 'complemento } \\
\text { terminativo', e, sendo ou não 'relativo', pode ser modificado pelo 'complemento } \\
\text { circunstancial', que adiciona circunstância ao nome adjetivo, (il.: Este homem é } \\
\text { temente a Deus; Esta menina me é cara). }\end{array}$ \\
\hline Verbo atributivo & $\begin{array}{l}\text { Pode ser 'direto' / 'objetivo', quando o 'verbo' é 'transitivo' (il.: O homem fertiliza } \\
\text { com a cultura a terra ainda a mais ingrata; Estimo a Pedro que é um homem de } \\
\text { bem) ou 'indireto' / 'terminativo', quando o 'verbo' é 'relativo' (il.: O mundo } \\
\text { obedece a Deus; usa de armas defesas. Pode, por vezes, haver os dois } \\
\text { complementos quando o verbo é 'transitivo relativo' (Escrevi-te uma carta; Aquele } \\
\text { que primeiramente ensinou aos homens a arte de escrever, fez um grande bem à } \\
\text { humanidade). O 'complemento' do 'verbo atributivo' pode também ser } \\
\text { 'circunstancial', modificando-o ao acrescentar a ele um 'modo', 'meio', } \\
\text { 'instrumento', 'causa', 'origem', 'fim', 'companhia', 'ordem', 'oposição', } \\
\text { 'exclusão', 'matéria', 'preço', 'medida', 'espaço', 'distância', 'tempo' e 'lugar'. }\end{array}$ \\
\hline
\end{tabular}


É curioso que, ao tratar do 'sujeito complexo' e do 'atributo complexo', falou que esses teriam 'complementos', mas ao tratar dos 'complementos', o gramático não volta a citar o 'sujeito' e o 'atributo', mas apenas espécies de classes de palavras, as quais poderiam ter esses papéis na 'proposição', no caso do 'nome apelativo' e do 'nome adjetivo', mas há também a espécie de 'verbo' 'verbo atributivo' que também pode ter 'complementos'.

Finalmente, o gramático distingue as espécies de 'proposição', em três espécies: as 'absolutas', as 'subordinadas circunstanciais' e as 'subordinadas completivas'. Essas espécies, entretanto, surgem da oposição inicial entre 'proposições absolutas' e 'subordinadas'. As primeiras podem estar sozinhas no discurso (il.: Deu criou o mundo em seis dias) ou podem aproximar-se entre si, quando este último caso ocorre, ligam-se por 'conjunções' de 'aproximação' ou pela 'identidade' de 'sujeito' ou simplesmente pelo 'sentido'. Já as 'subordinadas' devem sempre estar acompanhadas de uma 'proposição absoluta', da qual dependem; quando estão unidas, a 'absoluta' chama-se 'principal' (il.: o homem pensa, porque é um ente dotado de inteligência). A união se dá por meio de 'conjunções de subordinação', 'adjetivos conjuntivos' (il.: Eneias fugia de Tróia, que tinha sido tomada), 'advérbios conjuntivos' (a terra, onde nos vai bem, é para nós a pátria) ou 'preposições' (no caso de 'proposição infinitiva'; il.: sem a cultivares, a terra não te produz bons frutos). No quadro adiante, apresentamos um resumo do conceito das duas espécies de 'proposição subordinada'.

\begin{tabular}{|c|c|}
\hline $\begin{array}{c}\text { Espécies de } \\
\text { 'proposição' (termos) }\end{array}$ & Conceitos \\
\hline $\begin{array}{c}\text { Subordinadas } \\
\text { circunstanciais }\end{array}$ & É ora equivalente do 'complemento restritivo', ora do 'terminativo', ora do \\
'objetivo'.
\end{tabular}

\subsubsection{Rede conceitual}

É possível notar em Sotero dos Reis uma rede conceitual em torno do 'verbo substantivo', sobretudo pela identidade e equivalência entre o conceito de 'verbo substantivo' e de 'verbo', além da clara subordinação do conceito de 'verbo substantivo' ao de 'proposição', visto que nosso conceito-chave é justamente o elo entre 'sujeito' e 'atributo'. Ademais, o conceito de 'verbo substantivo' parece ter base teórica comum com 
o conceito 'gramática' dado pelo autor, como princípios imutáveis da palavra que são aplicados às instituições das línguas, dado que o 'verbo substantivo' seria o 'verbo primitivo', presente em todas as línguas, enquanto que o 'verbo adjetivo' ou 'atributivo' seria já uma instituição, uma abreviação. Entretanto, diferentemente do que fazem outros gramáticos (Costa Duarte 1829, Bithencourt 1862 e até mesmo Ribeiro 1881, cf. 4.3, 4.5 e 4.8), ao tratar das diferentes espécies de 'verbo adjetivo' ou 'atributivo', o autor não distingue 'verbo substantivo' de 'atributo', ele apenas diz, por exemplo, que o 'verbo transitivo' passa uma 'ação' - conceito este não apresentado anteriormente como sendo do 'verbo', então provavelmente teria relação com 'atributo' - do 'sujeito' a um 'complemento objetivo'.

Ademais, Sotero dos Reis trata dos 'complementos' como complementando classes de palavra ('nome substantivo', 'nome adjetivo' e 'verbo atributivo') em vez de um papel sintático, como seria se complementasse o 'sujeito' ou o 'atributo', ainda que ao tratar de 'sujeito complexo' e 'atributo complexo', o autor considere que esses dois papéis sintáticos têm 'complemento'. Finalmente, dentre as espécies de 'proposição', as 'subordinadas' são equivalentes a quatro espécies de 'complemento', não havendo, assim, equivalência entre os conceitos de 'adjetivo restritivo' e 'adjetivo explicativo' e de espécies de 'proposição'.

Em suma, a gramática de Sotero dos Reis apresenta alguma rede conceitual em torno do 'verbo substantivo', mas por vezes não considera em descrições em que era comum considerá-lo, como a de espécies do 'verbo adjetivo' ou 'verbo atributivo'.

\subsection{Grammatica Portugueza Philosophica (1881, [120]) e Serões Grammaticaes ou Nova Grammatica Portugueza (1890, [171]), de Ernesto Carneiro Ribeiro}

\subsubsection{Conceitos de gramática e de linguagem e organização da obra}

Há similaridades e diferenças entres os conceitos apresentados nas duas obras de Carneiro Ribeiro. Em 1881, ele define gramática como 'ciência da linguagem' por ser a 'ciência' de enunciar os nossos pensamentos segundo as regras estabelecidas pela 'razão' e pelo 'bom uso'. Afirma ainda que ela deve ser estudada à luz da 'ideologia', que seria um estudo das 'ideias' no período. A linguagem para o gramático é, por um lado, aquilo que permite a análise das ideias, pois dá a elas um corpo fixo, separado do todo confuso 
e indistinto do pensamento. Por outro lado, define-a como um "verdadeiro organismo, tão dificil de inventar, quanto o organismo de um animal", sem o qual o pensamento ficaria preso, pois não teria o 'verbo' exterior. Em 1890, mais enxuto, define 'gramática' também como 'ciência da linguagem', mas modifica sutilmente restante, diz que a 'gramática' estuda leis ou normas segundo as quais se exprime o pensamento pela linguagem, quer escrita, quer falada. Portanto, já não cita a 'razão' como estabelecedora das regras, nem explicita o 'bom uso'. Em 1890, define 'linguagem' como um conjunto dos sinais pelos quais manifesta o homem seus pensamentos. Esses sinais são os músculos do rosto (mais próxima dos animais do que dos homens), os caracteres escritos (escritura) e os sons articulados (palavra). Finaliza definindo 'linguagem articulada' não é só um meio de comunicação, mas, como já havia dito em 1881, um poderoso instrumento por meio do qual se analisa, esclarece e desenvolve o pensamento, tornando realizáveis as operações do espírito.

Nas duas obras, são concebidas três espécies de gramática, cujos conceitos expomos nos quadros adiante.

\begin{tabular}{|c|c|c|}
\hline $\begin{array}{l}\text { Espécie de } \\
\text { 'gramática' }\end{array}$ & Conceito em 1881 & Conceito em 1890 \\
\hline Geral & $\begin{array}{l}\text { Tem por assunto os princípios invariáveis, } \\
\text { imutáveis e universais da linguagem. É } \\
\text { uma ciência, porque é a investigação } \\
\text { razoada dos princípios universais da } \\
\text { linguagem, os quais são comuns a todas } \\
\text { as línguas, e são as leis necessárias e } \\
\text { eternas do pensamento, constitutivas de } \\
\text { todos os espíritos. }\end{array}$ & $\begin{array}{l}\text { Tem por assunto os princípios universais } \\
\text { e invariáveis da linguagem. }\end{array}$ \\
\hline Particular & $\begin{array}{l}\text { Faz aplicação dos princípios da } \\
\text { 'gramática geral' aos usos e às } \\
\text { instituições arbitrárias de uma língua. } \\
\text { Comumente se define arte de ler, escrever } \\
\text { e falar corretamente uma língua. É } \\
\text { 'elementar' ou 'filosófica'. Quando } \\
\text { 'elementar', limita-se aos estudos das } \\
\text { regras sem elevar-se aos princípios gerais } \\
\text { de que se deduzem tais regras (arte); } \\
\text { quando 'filosófica' estuda as regras } \\
\text { gramaticais prendendo-as e ligando-as aos } \\
\text { princípios gerais que as explicam e } \\
\text { justificam (ciência-arte). }\end{array}$ & $\begin{array}{l}\text { Faz aplicação dos princípios da } \\
\text { 'gramática geral' aos usos e às } \\
\text { instituições arbitrárias de uma língua. É } \\
\text { 'elementar' (diz-se também expositiva, } \\
\text { descritiva, ou prática) ou 'filosófica'. No } \\
\text { primeiro caso, limita-se ao estudo das } \\
\text { regras e instituições mais ou menos } \\
\text { arbitrárias, sem se elevar aos princípios } \\
\text { gerais, de que se deduzem. No caso da } \\
\text { 'filosófica', estuda essas instituições } \\
\text { ligando-as aos princípios gerais, que são } \\
\text { os seus fundamentos, princípios de uma } \\
\text { verdade imutável comum a todas as } \\
\text { línguas. Expõe regras ou normas } \\
\text { observadas no emprego de um idioma } \\
\text { sem atender às suas transformações, nem } \\
\text { aos princípios gerais a que tais regras } \\
\text { obedecem. Geralmente é definida como a } \\
\text { arte de falar e escrever corretamente uma } \\
\text { língua. Assim, a gramática portuguesa é a } \\
\text { disciplina ou arte que ensina a falar e }\end{array}$ \\
\hline
\end{tabular}




\begin{tabular}{|c|c|c|}
\hline & & $\begin{array}{l}\text { escrever corretamente a língua } \\
\text { portuguesa. }\end{array}$ \\
\hline $\begin{array}{c}\text { Comparativa } \\
\text { (1890: ou } \\
\text { Histórica) }\end{array}$ & $\begin{array}{l}\text { É a que estuda dois ou mais idiomas, } \\
\text { investigando suas analogias e } \\
\text { semelhanças, comparando seus fatos, suas } \\
\text { transformações. É ciência que estuda os } \\
\text { idiomas aproximando-os, remontando-se } \\
\text { às etimologias, comparando todos os seus } \\
\text { elementos - tem sido cultivada neste } \\
\text { século [XIX] nos países civilizados, } \\
\text { nomeadamente a Alemanha. }\end{array}$ & $\begin{array}{c}\text { Estuda os idiomas investigando suas } \\
\text { analogias e semelhanças, suas feições } \\
\text { particulares, comparando seus fatos, suas } \\
\text { transformações, sua filiação, seu } \\
\text { desenvolvimento e sua evolução histórica. } \\
\text { Recebe o nome de 'histórica' porque não } \\
\text { é possível comparar dois ou mais idiomas } \\
\text { sem acompanhar seu desenvolvimento } \\
\text { histórico. }\end{array}$ \\
\hline
\end{tabular}

Quadro 49. Espécies de 'gramática' em Carneiro Ribeiro $(1881,1890)$

As espécies e os conceitos são bastante similares. A diferença entre as obras está no acréscimo de 'histórica' à gramática antes apenas 'comparativa' e na grande redução na definição de 'gramática geral' nos Serões; além disso, em 1890, não julga mais se algumas espécies de 'gramática' são ciência ou não. Ademais, nas duas obras, define as mesmas quatro partes constitutivas da gramática: 'fonologia' ou 'fonética', 'ortografia', 'lexicologia' e 'fraseologia' ou 'sintaxe'.

Observa-se, na definição das espécies de gramática, a mistura de aspectos do Programa Descritivista e do Programa de Correspondência (Swiggers 2004, cf. Quadro 2), pois considera, ao mesmo tempo, que gramática descreve a expressão do pensamento, fazendo, assim, uma relação entre linguagem e pensamento, ao mesmo tempo em que ela deve ser analisada enquanto objeto comparável. Como veremos nos próximos itens, essa é uma característica comum das gramáticas publicadas na década de 1880 e 1890 .

Além desse conteúdo, nas duas obras Carneiro Ribeiro apresenta uma breve reflexão (metatexto) a respeito da história da 'gramática' e cita gramáticos ou filósofos de diferentes períodos. Na Grammatica Philosophica de 1881, cita na Antiguidade Platão, Aristóteles, Ênio (latino), Dionísio da Trácia, que Carneiro Ribeiro considera responsável pela autonomia da gramática. Pula para o século XVI e XVII e cita gramáticos do latim e do francês renascentistas, como Pedro Ramos, Erasmo, Julio Cesar Scaligero, Vossio e Vangelas, e também os dois primeiros gramáticos da língua portuguesa Fernão de Oliveira e João de Barros. Menciona ainda o filósofo natural Francis Bacon, que, segundo o gramático, deu impulso às ciências experimentais. Menciona, em seguida, "os religiosos de Port Royal", Dangeau e, do século XVIII, Duclos, Dumarsais, Condillac, Predidente de Brosses, Beauzée, Court de Gébelin, Harris, Sylvestre de Sacy, Destutt de Tracy. Finalmente, do século XIX, menciona Adelung, Vater, Jones, Klaproth, Colebrooke, Burnouf, Bopp, Diez, Max Müller, Schlegel, Schleicher, Humboldt, Pott, Grimm, Benfey, Renan, Leo Meyer, A. Maury, Adolpho Coelho. 
Em 1890, apresenta um histórico mais enxuto, com um número menor de nomes. Menciona brevemente a Antiguidade, fala de gregos e romanos sem citar nomes, em seguida, fala muito brevemente da Idade Média (oculta na gramática anterior), salta os séculos XVI, XVII e XVIII e fala do XIX da seguinte forma:

Mas o verdadeiro methodo no estudo da sciencia gramatical ainda não se havia descoberto: subtilezas mais ou menos engenhosas, umas metaphysica futil e esteril, uma polyglottia pesada, inconsistente embaraçosa, substituia os verdadeiros processos no estudo da grammatica. O criterio historico e comparativo data da primeira metade do século 19. (Carneiro Ribeiro 1890: )

Cita desse último século: William Jones, Schlegel, Bopp, Pott, Maury, Benfey, Grimm, Burnouf, Diez, Max Müller, Bréal, Littré, Branchet, Adolpho Coelho.

É curioso que o histórico realizado pelo autor nas duas gramáticas seja, de alguma maneira, complementar. O que está apresentado em detalhe em 1881 é apenas retomado em 1890, e aquilo que não foi apresentado em 1881, como a idade média e um maior detalhamento do século XIX, são apresentados na gramática de 1890. O gramático parece querer demonstrar sua erudição e, sobretudo, seu conhecimento dos autores que mais tinham impacto no que, nos parece, é sua agenda ao escrever a gramática. Em 1881, cita, por exemplo, diversos gramáticos franceses da tradição da grammaire générale, em geral franceses, e alguns estudiosos oitocentista da gramática histórico-comparativa. Em 1890, Carneiro Ribeiro menciona apenas estes últimos, e já não cita os nomes da grammaire générale.

\subsubsection{Conceitos de metaclasses e classes de palavras}

A Grammatica Philosophica (1881) de Carneiro Ribeiro é, em geral, mais prolixa e traz comentários em metatexto mais longos do que os Serões Grammaticaes (1890). Na primeira, o gramático discute, em metatexto, diversas possibilidades de distribuir as classes de palavras em metaclasses (e seus respectivos autores) das quais discorda antes de apresentar o modelo com que concorda e que utiliza na obra. Adiante, apresentamos um breve resumo dessa discussão.

Diz Carneiro Ribeiro que Aristóteles, Varrão, Dionísio de Halicarnasse, Quitiliano e Plutarco, Sanchez de las Brozas, Lancelot e Gaultier dividiam todas as palavras em três classes: 'nomes', 'verbos' e 'partículas'. À luz da 'gramática filosófica', porém, esse modo não é aceito, dado que não tem 'fundamento lógico'. Muitas palavras de natureza diferentes são colocadas na mesma classe; por exemplo, os 'adjetivos' estão 
na mesma classe dos 'substantivos' quando grande diferença separa estes daqueles; ‘preposições', ‘conjunções’ e ‘interjeições' formam uma só ‘classe', quando a análise da natureza desses diversos elementos 'invariáveis'.

Harris, por outro lado, considera as palavras divididas em duas 'classes': 'palavras principais' ou de 'significação absoluta', que significam independentemente de outras palavras, e 'palavras acessórias' ou de 'significação relativa', que não têm significação senão unidas a outras palavras, como é o caso de 'preposições' e 'conjunções'. Algumas 'preposições' e 'conjunções', porém, têm por si mesmas uma significação, podendo, inclusive, ser reduzidas a 'nomes' e 'adjetivos'. Menciona ainda, baseado em Horne Tooke, que 'preposições', 'conjunções' e 'advérbios' acham-se em outras 'partes do discurso', como 'nomes' e 'verbos'.

Já U. Domergue distingue as palavras em duas classes: 'substantivos' e 'atributivos'. Parece, entretanto, a Carneiro Ribeiro que essa classificação é deficiente, na medida que julgamos que toda classificação de palavras deve ter uma correspondente à 'relação', que é um dos elementos integrantes da razão. O próprio Domergue apresenta esse elemento como parte da 'proposição': ‘judicando', 'judicato', ‘julgador' ou 'cópula' - este último exerceria a 'relação'. Lemare, por outro lado, concebe apenas 'substantivos' e 'adjetivos' revestidos ou privados de 'ideias acessórias'; considera que 'preposições' e 'advérbios' são 'substantivos' truncados'. Entretanto, Carneiro Ribeiro afirma que é difícil aplicar essa teoria quando se procura explicar todos os 'advérbios' e todas as 'preposições' e 'conjunções' sem recorrer a sutilezas que a razão e a lógica não aprovam. Ademais, a distinção entre 'palavras variáveis' e ‘invariáveis' não é, segundo o gramático brasileiro, extensiva a todas as línguas. No chinês, por exemplo, de acordo com Abel de Remusat, são 'invariáveis' em forma todos os vocábulos tomados separadamente, não admitindo inflexão nem mudança alguma.

A 'palavra', segundo Portalis, é o 'pensamento encarnado' e, sendo assim, toda classificação delas deve ter correspondência com a 'classificação de ideias'. A realidade é, de modo concreto, constituída por 'Deus', 'alma' e 'corpo', considerando-a abstratamente, há três elementos: 'substância', 'qualidade' e 'relação'. A razão humana, de acordo com Cousin, não concebia as coisas senão sob a razão de duas ideias: a 'unidade' e a 'pluralidade', o 'absoluto' e o 'relativo'. Posteriormente, Cousin acrescentou um terceiro elemento: a 'relação'. O filósofo Aristóteles já havia mencionado a 'substância', a 'qualidade' e a 'relação' entre suas dez categorias. Estabelecidos esses 
princípios filosóficos, bastaria, segundo o gramático, aplicá-los à classificação das palavras do discurso.

Enfim, apresenta suas metaclasses baseado nesses três elementos ${ }^{103}$. O gramático baiano afirma que a 'substância' corresponde à classe dos 'denominativos', a 'qualidade' à dos 'qualificativos' e a 'relação' à dos 'conjuntivos'. A primeira compreende os 'substantivos' e os 'pronomes', a segunda, os 'adjetivos', 'advérbios' e 'verbos', a terceira, finalmente, as 'preposições' e ‘conjunções'. Já a 'interjeição', embora tenha sido colocada pelos gregos como parte dos 'advérbios', forma uma 'classe de sinais' que não pertence à 'linguagem analítica', mas à 'linguagem sintética', visto que são sinais que por si sós indicam uma situação inteira de nossa alma. Ainda assim, o autor apresenta na gramática uma seção de tratamento dessa classe de palavra.

Mais direto nos Serões Grammaticaes (1890), Carneiro Ribeiro apresenta as mesmas metaclasses de 1881, com a mesma distribuição das classes de palavras. A diferença entre as duas obras é apenas terminológica, pois a metaclasse dos 'qualificativos' de 1881 passa a se chamar metaclasse dos 'modificativos' em 1890. Diz ele que os elementos gramaticais vulgarmente conhecidos pela denominação de "partes da oração' reduzem-se aos seguintes: 'substantivo', 'pronome', 'adjetivo', 'verbo', 'preposição', ‘conjunção' e 'advérbio'. Dividem-se em três classes: 'denominativos' ('substantivos' e 'pronomes'), 'modificativos' ('adjetivos', 'verbos', 'advérbios') e 'conjuntivos' ('preposições' e 'conjunções'). A respeito da 'interjeição', comenta que formam uma 'classe de sinais' que não pertencem à 'linguagem analítica', a linguagem registrada na 'gramática'. Entretanto, além dos 'sinais arbitrários' da 'linguagem analítica' há também os 'sinais afetivos', é relevante que a gramática estude e analise as 'interjeições' a fim de determinar-lhes a natureza.

Em metatexto (reflexão), o gramático fala brevemente sobre outras duas possibilidades de metaclasses, ao dizer que alguns gramáticos consideram que esses elementos podem ser divididos em 'variáveis' ou 'de flexão' e 'invariáveis' ou 'sem flexão', e que há, ainda, uma divisão antiga que distingue os 'elementos gramaticais' em 'nomes' ('substantivos', 'pronomes', 'adjetivos'), 'verbos' e 'partículas'. Carneiro Ribeiro, entretanto, diferente do que fez em 1881, não apresenta um julgamento a respeito dessas outras classificações, apenas não as adota.

\footnotetext{
${ }^{103}$ Assemelhando, nesse ponto, a Costa Duarte (1829, 1859 - cf. 4.3), dado que essa divisão distinguia as classes de palavras por estarem associadas a 'ideias', as quais podiam ser 'substância' ou 'qualidade, e a 'relações'.
} 
No quadro adiante, apresentamos os conceitos de classes e metaclasses de palavras realizado pelo gramático nas duas obras:

\begin{tabular}{|c|c|}
\hline Metaclasses & Classes de palavras \\
\hline Denominativos & Substantivos \\
\hline Qualificativos (1881) & Pronomes \\
\cline { 2 - 2 } Modificativos (1890) & Adjetivos \\
\cline { 2 - 2 } & Verbos \\
\cline { 2 - 2 } Conjuntivos & Advérbios \\
\cline { 2 - 2 } & Preposições \\
\hline
\end{tabular}

Quadro 50. Metaclasses e classes de palavras em Carneiro Ribeiro (1881, 1890)

\subsubsection{Conceitos modificadores nome}

Em ambas as gramáticas, Carneiro Ribeiro define os 'pronomes' como palavras que exprimem seres 'determinados' designando-os pela ideia de sua pessoa; afirma que na 'classe de pronomes' considera apenas os elementos gramaticais a que geralmente se dá a denominação de 'pronomes pessoais'. Em metatexto, afirma que Lemare os chamou de 'substantivos personativos'. Os exemplos dessa classe de palavra são “eu, mim, me migo, nós, nos, nosco, tu, ti, te, tigo, vós, vos, vosco, ele, ela, o, a, si, se, sigo, os, as, si, se, sigo". Afirma ainda que os exemplos “eu, tu, ele, ela, eles, elas, nós, vós”, correspondentes ao 'caso nominativo' dos 'pronomes' latinos, chamam-se 'variações diretas', ao passo que as outras variações pronominais chamam-se 'oblíquas'. Explica, na gramática de 1881, que 'casos' são as diversas 'terminações' ou 'inflexões' que tomam as 'palavras' para exprimir os diferentes intuitos do espírito ou as diversas relações dos objetos entre si e que, na língua portuguesa, só os 'pronomes' têm 'casos'.

Em metatexto, na edição de 1881, apresenta uma reflexão acerca da classificação feita pelo 'pronome'. Primeiramente, critica o gramático português Jerônimo Soares Barbosa por ter colocado os 'pronomes' dentro da classe dos 'adjetivos' (algo que, como vimos, muitos gramáticos brasileiros também fazem. Ademais, diz que muitos gramáticos se atêm à 'etimologia' do vocábulo 'pronome' e, por isso, acabam por defini-lo como palavra que se coloca em lugar do nome, mas argumenta que se assim fosse, todas as palavras empregadas 'metaforicamente' e grande número de 'adjetivos' estariam incluídos nessa classificação (il.: aquela cidade tem trinta mil almas; código napoleônico; leis julianas). Por outro lado, elogia os gramáticos franceses Dumarsais e Beauzée, aquele por ter sido o primeiro a reconhecer bem a natureza do 'adjetivo', o segundo por segui-lo e aperfeiçoá-lo. Em suma, segundo esses gramáticos, os 'substantivos' 'designam' os 
seres pela ideia de sua natureza, ao passo que os 'pronomes' os 'determinam' pela ideia precisa de uma relação com o 'ato da palavra'.

Por fim, ainda em metatexto, em ambas as obras destaca que muitas outras gramáticas (1881) ou que a 'gramática tradicional' (1890) distingue diversas espécies de 'pronome', como 'possessivos', 'demonstrativos', 'relativos' ou 'conjuntivos' e ‘indefinidos', mas rejeita essa opção. Em 1881, é enfático na crítica, dizendo que essa distinção é "completamente falsa" (1881:175), ao passo que em 1890 é mais brando e afirma simplesmente que parte dos dados que corresponderiam a essas espécies ficam nos 'nomes' e outra parte nos 'adjetivos' (ex.: isso, aquilo, tudo, outrem, quem, ninguém, nada, que, o qual, cujo, meu, teu, seu).

Antes de tratarmos dos 'adjetivos', ressaltamos que ainda na seção de tratamento dos 'substantivos' das duas gramáticas, Carneiro Ribeiro menciona que esses têm em seu significado a 'compreensão' e a 'extensão'. A primeira corresponde à totalidade das ideias parciais que se encerram na ideia total que ele exprime, já a 'extensão' é o número de indivíduos a que se aplica o 'substantivo'. Esses, diz Carneiro Ribeiro, estão em razão inversa, assim, quanto mais for a extensão, tanto menor será a compreensão e vice-versa (como vimos em 4.1.2, esta observação tem origem na Logique de Port-Royal). Ressalta, em seguida, que essa distinção será relevante para a distribuição dos 'adjetivos' em espécies diferentes.

Nas duas gramáticas, define 'adjetivos' como palavras que indicam seres indeterminados, designando-os por uma ideia acidental à natureza comum indicada pelo 'apelativo'. Lembra ainda o leitor que os 'adjetivos' pertencem à metaclasse dos 'modificativos', a qual compreende igualmente 'verbos' e 'advérbios'. Em 1881, afirma ainda que, como sinal de uma das categorias do espírito humano, o 'adjetivo' é uma categoria gramatical essencial a todas as línguas - o que torna explícito sua visão de que as classes de palavras são expressões de categorias já presentes no pensamento. Em metatexto, menciona pesquisas que indicavam a falta absoluta desse elemento gramatical no vocabulário dos Mohegans e Hurões, que, no entanto, não podem sustentar que o os falantes dessas línguas não distingam o 'sujeito' do 'predicado' ou a 'substância' da 'qualidade'.

Há duas espécies de 'adjetivo': ‘qualificativos' (ex.: bom, mau, justo, bonito, belo, grande, honesto, mole, duro, quente, frio, doce, amargo, verde, branco, negro, útil, necessário, possível, perfeito, infinito, eterno) e 'determinativos' ou 'artigos' (ex.: o, a, os, as, todo, nenhum, cada, um, uma, algum, dois, três, quatro, primeiro, segundo, 
terceiro, este, esse, aquele, meu, teu, seu, que, qual, cujo). Os 'qualificativos' modificam a compreensão dos 'nomes apelativos' sem lhes determinar a 'extensão'; 'determinativos' determinam a 'extensão' dos apelativos sem nada lhes ajuntar à 'compreensão'.

Em metatexto, apenas em 1881, cita Tracy, gramático francês, dizendo que em nossas línguas não modificamos uma ideia em sua compreensão sem que primeira a modifiquemos em sua extensão. Assim, não dizemos simplesmente "homem pobre", mas "o homem pobre" ou "todo homem pobre", "alguns homens pobres".

Nas duas gramáticas o ‘adjetivo determinativo' ou 'artigo' divide-se em: ‘artigo indicativo' ou 'puro', que apenas indica de um modo vago que a natureza comum significada pelo apelativo se deve aplicar aos indivíduos (ex.: o, a, os, as), e 'artigo conotativo', 'combinado' ou 'especial', que são todos os outros, que a essa ideia de indicação geral e vaga dos indivíduos ajuntão mais alguma ideia, determinando mais ou menos precisamente a quantidade dos indivíduos (ex.: nenhum, todo, algum, dois, segundo, suplo, oitava, meu, estes, que). No quadro adiante, apresentamos sua taxonomia:

\begin{tabular}{|c|c|c|c|c|}
\hline $\begin{array}{c}\text { Artigo indicativo / } \\
\text { puro }\end{array}$ & & & & \\
\hline \multirow{9}{*}{ Artigo conotativo } & \multirow[b]{2}{*}{ Universais } & Positivo & & \\
\hline & & Negativo & & \\
\hline & \multirow{7}{*}{ Partitivo } & Indefinitos & & \\
\hline & & \multirow{6}{*}{ Definitos } & \multirow[t]{3}{*}{ Numerais } & Cardeais \\
\hline & & & & Ordinais \\
\hline & & & & Dual \\
\hline & & & Possessivo & \\
\hline & & & \multirow[t]{2}{*}{ Demonstrativos } & Puros \\
\hline & & & & Conjuntivo \\
\hline
\end{tabular}

Quadro 51. Espécies do 'artigo indicativo' ou 'puro' e 'artigo conotativo' em Carneiro Ribeiro (1881, 1890)

\subsubsection{Conceito de verbo}

Nas duas gramáticas, 'verbo’ é definido como uma classe de palavras que indica seres indeterminados designando-os pela ideia de uma existência intelectual com relação a um 'atributo'. Ressalta Carneiro Ribeiro que o 'verbo' é a palavra por excelência; e que está dentro da metaclasse dos qualificativos (1881) ou 'modificativos' (1890) porque sua ideia primordial e característica é a ideia de existência, e esta é atributo universal dos seres - afirma ainda que se o verbo indica também uma relação, faz isso secundária e posteriormente (em 1890, acrescenta que somente as 'preposições' e 'conjunções' constituem a metaclasse dos 'conjuntivos'). Como já temos visto na análise das obras, frequentemente os autores não concordam a respeito da metaclasse que inclui o 'verbo'; 
há alguns que o encaixam em uma metaclasse de relação (cf. Ribeiro 1881, Maciel 1887), enquanto há outros que negam isso, como fez Carneiro Ribeiro.

A descrição das espécies do 'verbo' é bastante similar nas duas obras; diferem sobretudo porque em 1890 Carneiro Ribeiro apresenta poucos exemplos e ilustrações e porque em 1881 há reflexões mais longas sobre alguns aspectos. Afirma em 1890 que, considerados quanto à sua 'natureza', os verbos dividem-se quanto a conter ou não um 'atributo'. Em 1881 não há essa introdução, mas as duas espécies principais de 'verbo', nas duas gramáticas, são as mesmas: o 'abstrato’ e o ‘concreto'. O primeiro, que também se chama 'substantivo', 'lógico', 'metafísico' ou 'copulativo', designa o ser pela ideia precisa de uma existência intelectual com relação a um atributo qualquer. O segundo, que também pode se chamar 'atributivo' ou 'adjetivo', é o que designa o ser pela ideia de uma existência intelectual com relação a um 'atributo determinado', 'concentrado' e contido no 'radical verbal'. Afirma ainda que só há um 'verbo abstrato', o ser; todos os mais são 'concretos'. Em metatexto, destaca que o 'verbo' “estar” não é abstrato, porque quer dizer "ser" em um determinado lugar, em uma certa posição, em um certo estado ou situação (o que o torna um 'verbo concreto'). Em 1881, apresenta em texto ilustrações das duas espécies, 'verbo abstrato' (il.: a caridade é amável; a virtude é estimada; o justo será recompensado no céu; os homens são frágeis) e ‘verbo concreto' (il.: Pedro ama a virtude; Francisco dança; eles cantam; teus irmãos farão essa viagem).

Ainda em 1881, reflete acerca do 'verbo' "ser", afirmando que "racionalmente falando", esse verbo é anterior a todos os outros verbos; porque, sendo existência o atributo universal dos seres e indicando todos os verbos a existência simples combinada com um 'atributo', tem o 'verbo' "ser" a prioridade lógica relativamente aos outros pela razão de ser o único que designa a "existência simples e abstrata", desacompanhada de 'ideia atributiva'. Em ambas as gramáticas, assume que todos os 'verbos concretos', "racionalmente considerados", contém a ideia exprimida pelo 'verbo abstrato" "ser" combinada mentalmente com um 'atributo'. Ressalta, entretanto, apenas em 1881, que não seria exato "cronologicamente falando" considerar o "verbo" "ser" anterior a todos os outros, isto não apenas porque o verbo "ser" ("esse" latino) não teve sempre essa significação abstrata, mas, ao contrário, indicou a princípio uma ideia material e concreta, como porque não poderia ser o ‘verbo primitivo' da linguagem, visto que é a abstração um processo ulterior do espírito. Nesse segundo ponto, o cronológico, Carneiro Ribeiro parece basear suas ideias numa teoria evolutiva da linguagem, que era relativamente difundida no período e foi mencionada também por outros gramáticos brasileiros (cf. 
Costa Duarte 1859, cf. 4.3 - mas foi rejeitada por outros, cf. Bithencourt 1862, cf. 4.5), em que as classes de palavras tiveram uma ordem de surgimento, do mais abstrato ao mais geral.

Outra espécie de 'verbo', não apresentada como espécie do 'abstrato' ou do 'concreto', é a dos 'verbos auxiliares', definidos nas duas gramáticas como certas formas verbais que se ajuntam ao 'verbo abstrato' ou 'concreto' para exprimir diversos aspectos sob que se considera a ideia fundamental por ele enunciada. Em 1890, apresenta exemplos (ex.: estar, ter, haver, dever, ir, vir, andar), mas salienta que esses exemplos nem sempre são 'auxiliares', pois só o são quando formam 'linguagens compostas'. Em 1881, tece uma reflexão (que se configura como metatexto) acerca da natureza desses verbos. Afirma que são resultado dessa marcha incessante em que se movem os idiomas da 'síntese' para a 'análise' e que essa espécie de verbo é grande recurso nas 'línguas neolatinas', pois por meio deles, torna-se mais clara, mais precisa e completa a enunciação da existência considerada não já em si mesma, senão por diferente luz, debaixo dos variadíssimos aspectos por que o pensamento encara, concebe e representa. Torna-se cada vez mais visível que em 1890, o gramático procurou tornar sua obra mais enxuta, retirando diversas reflexões apresentadas em 1881.

Antes de 'distinguir' as espécies de 'verbo concreto', que são as mesmas apresentadas nas duas obras, isto é, 'absoluto', 'relativo' e 'bitransitivo', tece em 1881 longa reflexão, omitida na gramática de 1890, acerca de outra possibilidade de classificação das espécies de 'verbo concreto'. Assim, diz em metatexto (reflexão) que o 'atributo' concentrado na 'ação verbal' indica ou uma ação do próprio 'sujeito', uma 'ação' ou um 'simples estado' que não é propriamente 'ação' nem 'paixão', tais características se configurariam como as espécies 'verbo ativo' (ex.: amar, andar, matar, correr, vir), 'passivo' (ex.: padecer, sofrer, cair, morrer), e 'neutro' (ex.: existir, durar, ficar, permanecer). Afirma que os "gramáticos modernos", considerando os verbos mais pelo modo como o 'atributo' é neles enunciado, pelo 'papel' que representam na 'frase' e pelo modo pelo qual se ajuntam aos outros 'elementos da oração', do que pela 'natureza' do 'atributo' neles encerrado, os dividem em 'absolutos' ou 'intransitivos' e 'relativos' ou 'transitivos'. Observa que esta divisão é menos filosófica que a primeira (sem justificar a razão disso), mas que é a que usará na gramática a fim de estar de acordo com o uso geral dos gramáticos. Carneiro Ribeiro é o único gramático que discute essa distinção, observando suas diferenças e optando explicitamente por uma das opções; como vimos e veremos na análise das outras dezesseis obras, era frequente que os gramáticos 
misturassem as duas visões ou optassem por uma delas sem trazer justificativas. É notável também que, no exame de ambas as 'classificações', o gramático apresente o 'atributo' como responsável pelas distinções entre espécies.

As espécies de 'verbos concretos' são definidas da seguinte forma nas duas obras. 'Absolutos' ou 'intransitivos' são 'verbos' que em si mesmos têm um 'sentido determinado ou completo' (ex.: brincar, existir, morrer, nascer, permanecer, durar, ficar, cair, viver, amanhece, alvorecer, dormir). 'Relativos' ou 'transitivos' são 'verbos' que não têm em si um 'sentido completo', sendo necessário um 'complemento' para 'determiná-lo' e 'completá-lo' (ex.: amar, receber, defender, matar, admitir, estimar, encher, trazer, saber, conhecer, ter, levar, conduzir, colocar, perder, ganhar, meter, possuir, concluir, terminar, completar). Os 'verbos transitivos' ou 'relativos', quando pedem um 'complemento direto' ou 'imediato' denominam-se 'transitivos diretos' (ex.: amar, colher, possuir, perder, ganhar; il.: amo a virtude, colho flores e frutos, possuo um chácara, perdi um conto de reis, ganhei a sorte grande), quando pedem um 'complemento indireto' ou 'mediato' dizem-se 'transitivos indiretos' (ex.: obedecer, carecer, precisar, tender, resistir, depender, pertencer, descender, emanar, emergir; il.: obedeço à voz de minha consciência; careço de dinheiro; preciso de tuas luzes; os corpos tendem a seu centro; resistiu aos maus impulsos; este negócio depende de muita prudência e discrição; pertence este livro a Paulo; descende de uma boa família; esta autoridade emana de um poder legítimo; a luz vai emergindo destas trevas). Há também entre os 'transitivos' aqueles que pedem dois 'complementos', um 'direto' e outro 'indireto', que chamam-se 'bitransitivos' (ex.: dar, entregar, remeter, oferecer, atribuir, contar, dizer, referir e relatar; (1890) il.: dar esmolas a um mendigo; entregar uma carta a alguém; remeter uma carta a um amigo; oferecer um jantar a um homem; atribuir a alguém a autoria de um crime; contar, dizer, referir, relatar um fato a alguém). No quadro adiante, sintetizamos a taxonomia das espécies de 'verbo' mencionadas até o momento:

\begin{tabular}{|c|c|c|}
\hline Espécies de 'verbo' & Espécies de 'verbo concreto' & Espécies de 'verbo transitivo' \\
\hline Verbo abstrato & & \\
\hline \multirow{2}{*}{ Verbo concreto } & Intransitivo & Direto \\
\cline { 2 - 3 } & \multirow{2}{*}{ Transitivo } & Indireto \\
\cline { 2 - 3 } & & Bitransitivo \\
\hline Verbo auxiliar & & \\
\hline
\end{tabular}

Quadro 52. Espécies de 'verbos' em Carneiro Ribeiro $(1881,1890)$ 
Os 'verbos concretos' ainda podem ser divididos em outras espécies de acordo com sua 'forma' e 'conjugação', as quais são 'regulares', 'irregulares', 'defectivos' e 'pronominados'. 'Defectivos' são 'verbos' a que faltam tempos, modos, números ou pessoas, podem ter 'sujeito indeterminado' ou 'sujeito determinado'. Os primeiros chamam-se 'impessoais', e podem ser 'essencialmente impessoais' (ex.: chover, gear, trovejar, relampejar) ou 'acidentalmente impessoais' (il.: dança-se; brinca-se; corre-se; dorme-se). Alguns 'impessoais' podem algumas vezes ser empregados com 'sujeito determinado' no sentido figurado (il.: chovem-me lágrimas dos olhos; a ida de deus que do céu chove; relampagueie a estes olhos a verdade). Os que têm 'sujeito determinado' podem ser 'unipessoais', quando só se empregam na terceira pessoa do singular (ex.: importa, releva, convém, cumpre), ou 'pessoais', quando carecem de algumas pessoas nos tempos e modos de que usa a língua (ex.: feder, carpir, brandir, remir) ou se empreguem em todas as pessoas desses mesmo tempos e modos (ex.: poder, querer).

Como observamos no início desta seção, há poucas diferenças entre as duas gramáticas, as quais colocam-se sobretudo na observação de que em 1881, era mais comum o autor apresentar reflexões em metatexto, nas quais disserta sobre aspectos teóricos, conectados a uma visão de linguagem, como ao examinar acerca da anterioridade do 'verbo substantivo' em relação a outros 'verbos' 'racionalmente falando' ou 'cronologicamente falando' ou mesmo ao discorrer sobre a 'marcha incessante' em que se movem os idiomas da 'síntese' para a 'análise' ao tratar dos 'verbos auxiliares', e sobre diferentes possibilidades de análise, como quando trata da outra maneira de distinguir espécies do 'verbo concreto'. Tais reflexões, como vimos, estão omitidas da gramática de 1890, o que pode ser uma tentativa do autor de tornar os Serões Grammaticaes um texto mais enxuto e direto. Vemos que no texto há poucas diferenças entre as edições, ela se apresenta na maior ou menor presença de ilustrações e exemplos. Como vimos, Carneiro Ribeiro apresenta em 1881 uma série de ilustrações para as espécies 'verbo abstrato' e 'verbo concreto', ao passo que em 1890 não há nenhuma.

Em suma, vemos que em ambas as obras considera o 'verbo' uma palavra 'conjuntiva', mas prefere colocá-lo nas metaclasse de 'modificativos' por considerar a 'existência' um 'atributo universal'.

\subsubsection{Conceito de oração e seus elementos}


A 'oração' ou 'proposição', que em 1890 também podia ser chamada de 'sentença', é definida em ambas as obras como a 'enunciação de um juízo', que nada mais é do que uma 'afirmação mental enunciada': ao perceber a 'relação de conveniência' entre a 'ideia' de "Deus" e a de “justiça”, formamos em nosso espírito o ‘juízo': “Deus é justo".

Carneiro Ribeiro distingue, também nas duas gramáticas, duas maneiras diferentes de se considerar a 'oração' quanto às partes que a compõem. Quando logicamente considerada, ela compõe-se de três partes: ‘sujeito', 'verbo' e 'atributo' ou 'predicado' que são os 'elementos essenciais' ou 'lógicos' da 'oração'. Considerada, porém, gramaticalmente compõe-se de tantas partes, quantas são as 'palavras' de que consta que são os 'elementos gramaticais' da 'oração'.

Afirma, nas duas gramáticas, que os dois 'termos' da 'proposição', o ‘sujeito' e o 'atributo', reunidos constituem o que em 'linguagem lógica' denomina-se 'matéria da proposição', enquanto o 'verbo' constitui a sua 'forma' - em 1881 acrescenta que esses termos 'termos' e 'matéria' são provenientes dos 'escolásticos'. Ademais, define 'sujeito' como o 'objeto' de que se 'afirma' ou 'nega' alguma coisa; 'atributo' ou 'predicado' como aquilo que se afirma ou nega do 'sujeito'; e 'verbo' como palavra que, exprimindo a 'existência intelectual' com relação a um 'atributo', 'liga' este ao 'sujeito'. Exemplifica os três elementos da 'proposição': “a caridade é língua universal” em que o vocábulo “caridade” é o ‘sujeito', “língua universal” é o ‘atributo' ou ‘predicado', “é”, o ‘verbo', por ser a palavra que liga o 'atributo' ao 'sujeito' - como vimos na definição de 'verbo' este exerce também relação, mas faz isso apenas secundariamente.

Toda a 'proposição' consta essencialmente destes três elementos, estejam todos eles explícitos (il.: Deus é bom), esteja o ‘atributo’ combinado com o ‘verbo' (il.: o sol brilha, odio velho não cansa), ou seja a ‘proposição' exprimida por um só ‘vocábulo', que contém ao mesmo tempo o 'sujeito', o ‘atributo' e a “palavra que indica a relação destes dois termos" (il.: chove, chuvisca, troveja, neva), há ainda varias outras 'proposições' assim, como sucede ainda em todas as 'orações' que são exprimidas por 'interjeições'.

O 'sujeito' e o 'atributo' podem ser 'simples', quando exprimem uma unidade de 'ideia', ou 'compostos', quando não exprime uma unidade de ideia; podem ser também 'complexos', quando são modificados por algum 'acessório' ou 'incomplexos', quando nenhum 'acessório' os modifica.

Ainda nas duas gramáticas, além dos três elementos essenciais, uma 'proposição' também pode ter 'complementos', 'apostos' e 'completivos'. Os primeiros são palavras que se unem a outra para completar seu sentido (il.: amar a pátria; obedecer à lei; proceder 


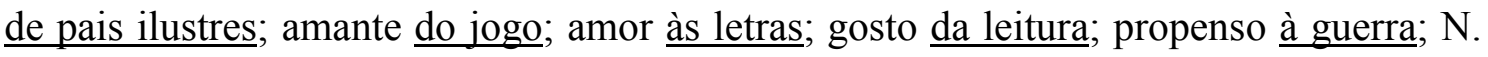
Bonaparte morreu em Santa Helena em 1821). Segundo Carneiro Ribeiro, há duas espécies de 'complemento': o ‘complemento direto' ou 'imediato' e o 'complemento indireto' ou 'mediato'. O primeiro é pedido imediatamente pela significação do 'verbo', completando seu o ‘sentido' sem interposição de 'preposição' - em metatexto afirma que são chamados por outros gramáticos de 'complemento passivo' ou 'regimen direto'. Apresenta ilustrações apenas nos Serões (il.: amo a virtude, admiro a caridade, respeito a ciência, venero a velhice). O segundo completa, com a interposição de uma 'preposição', o 'sentido' do 'verbo' ou de qualquer palavra suscetível de 'complemento'. [- em metatexto afirma que são chamados por outros gramáticos de 'regimen indireto'. Apresenta ilustrações apenas nos Serões (il.: obedeço a meu dever; assistiu à sessão; presidiu à cerimônia; agradou a todos aquele discurso). Acrescenta em metatexto que quando o 'complemento indireto' exprime circunstância de 'lugar', 'tempo', 'modo', 'instrumento', 'preço', 'causa', 'meio', 'fim' etc., é denominado por alguns gramáticos de 'circunstancial' (il.: A vitória de Trafalgar foi ganha pelo almirante Nelson em 1805; granharam os turcos as casas, pelas quais foram descendo a fortaleza [ref: Jac. de Andrade]).

‘Aposto' é qualquer palavra que vindo imediatamente após outra, exprime com esta uma só e mesma pessoa ou coisa (il.: Tito, delícias de Roma; Átila, flagelo de Deus; Pedro, o venerável; Afonso, o batalhador). Chama-se 'compelativo' a palavra que serve para exprimir a pessoa ou coisa a que nos dirigimos falando (il.: (apenas 1881) Terra da minha pátria! abre-me o seio, na morte ao menos [ref.: Garrett]; (em 1881 e 1890) Orgulho humano, qual es tu mais? feroz, estúpido ou ridículo? [ref.: A. Herculano]).

Vistos os elementos essenciais e não essenciais da 'proposição', observaremos agora a classificação realizada por Carneiro Ribeiro no que diz respeito a espécies de 'proposição', a qual difere parcialmente nas duas gramáticas. Distingue, inicialmente (em ambas as obras), duas espécies, a 'absoluta', que para integridade de seu sentido não necessita de outra. (il.: Deus é eterno; a caridade é língua universal), e a 'relativa' quando supõe outra para lhe completar o sentido (il.: não há corpo fraco onde o espírito é forte).

Ademais, afirma que uma 'frase' (o que também chama de 'período') é uma 'proposição composta', isto é, a reunião de duas 'proposições relativas', uma delas se chama 'principal' ou 'primordial' e a outra 'subordinada' ou 'secundária' (il.: o soldado generoso estima a guerra, porque deseja a vitória). Pode haver também 'principais coordenadas', quando na 'frase' há várias 'proposições' da mesma natureza, as quais 
seguem a mesma ordem de ideia, podendo cada um ser principal em relação às outras (il.: cresce a cegueira com a luz; é o dia noite aos olhos dos morcegos [ref.: Lucena]).

As 'orações secundárias' ou 'subordinadas' dividem-se em 'secundárias de primeira ordem' e 'secundárias de segunda ordem'. As primeiras indicam um sentido parcial que, não sendo complemento de algum dos termos de outra oração, depende todavia de uma principal que lhe determine e subordine (il.: logo que Rumecão teve posta em perfeição a mina, determinou à sombra dela dar um geral assalto [ref: Andrade]). As 'secundárias de segunda ordem', são de duas espécies 'incidentes' e 'integrantes'. As primeiras são as que fazem parte de outra, ampliando ou restringindo algum de seus 'termos', podendo ser 'ampliativas' ou 'explicativas' e 'restritivas' ou 'determinativas'. As primeiras desenvolvem o 'sentido' do 'sujeito' ou do 'atributo' da 'oração principal' sem lhe restringir a 'extensão’ (il.: Deus, que é onipotente, é infinitamente bom e justo). As 'restritivas', por sua vez, acrescentam uma 'ideia' ao 'termo' por ela modificado que não convém a este 'termo' em toda a sua 'extensão' (il.: o homem que é justo respeita os direitos de seus semelhantes). Apesar de fazer essa distinção, Carneiro Ribeiro reflete (em metatexto) que é, muitas vezes, difícil distinguir as duas espécies de 'orações incidentes', pois o caráter 'ampliativo' ou 'restritivo' de tais 'orações' dependem amiúde de “certas circunstâncias extrínsecas apenas conhecidas daquele que fala ou escreve ou do número limitado de indivíduos para quem se fala ou escreve" (1881:380). Tal discussão, como veremos adiante, é feita também por outros gramáticos ${ }^{104}$

Definimos adiante as 'orações integrantes', cuja definição é similar nas duas gramáticas, mas a terminologia é diferente. Podem ser de duas espécies: 'puras'(1881) ou 'simplesmente integrantes'(1890) e 'comparativas' (1881 e 1890) ou 'correlativas' (1881 e 1890). As primeiras são as que fazem parte da outra 'oração' servindo-lhe de 'sujeito', 'atributo' ou 'complemento' (il.: não sei se Francisco chegou da Europa; penso que estás enganado; julgo seres o autor daquele escrito; começa a sair e a crescer o sol, eis o gesto agradável do mundo e a composição da mesma natureza toda mudada [ref: Vieira]). Já as 'comparativas' completam o sentido de outra 'oração' ou de 'palavra' de outra 'oração' que se repetem ou correlacionam. (il.: Tal mulher me sejas tu, qual te eu sou marido [ref.: Ferreira]; vi o quanto ali se fez em seu benefício; tem mais espírito que ciência).

${ }^{104}$ Como Condurú (1888) e Maciel (1887). 
Considerada quanto à forma ou à totalidade, a oração é: 'plena' quando não se omite nenhuma de suas partes (il.: Deus é eterno); 'elíptica' quando lhe falta uma ou muitas dessas partes (il.: venho da Bahia; aqui d'el-rei; Adeus; Até logo; Hoje por mim; Amanhã por ti); 'implícita:' quando em si contém o ‘sujeito', o 'verbo' e o 'atributo', sendo todas essas partes resumidas numa só, que desaparece, reduzida a implícita uma oração plena (i.l.: sus! ora, sus!; oxalá!; holá!). Denomina-se 'período' a enunciação de um sentido completo e acabado por meio de uma reunião de orações que, não sendo partes integrantes umas das outras, se ligam todavia de tal modo entre si, que umas supõem as outras para a plenitude do 'sentido parcial'; e são 'membros do período' as orações que fazem no período um sentido parcial.

\subsubsection{Rede conceitual}

Carneiro Ribeiro apresenta o conceito de 'verbo abstrato' ou 'substantivo' nas duas gramáticas, as quais, a propósito, são bastante similares entre si. Como vimos, a grande diferença entre as duas está, sobretudo, em metatexto, por conta dos comentários que o autor faz a respeito de outras perspectivas gramaticais do passado e do presente na Grammatica Philosophica, de 1881, e também, eventualmente, pela presença ou ausência de ilustrações ou exemplos de algum conceito.

As duas obras apresentam clara rede conceitual em torno do 'verbo abstrato', a qual é um tanto diferente das redes conceituais que vimos em outras obras porque o autor tem, na verdade, um conceito diferente de 'verbo abstrato' (que nas outras gramáticas é, geralmente, denominado 'verbo substantivo'). Carneiro Ribeiro define-o como palavra que designa o ser pela ideia precisa de uma existência intelectual com relação a um atributo qualquer, o que tem relação de intersecção com o conceito de 'verbo', pois este não identifica se o atributo é 'qualquer' ou 'determinado', tendo uma relação de subordinação com as espécies 'verbo abstrato' e 'verbo concreto', cuja definição é designa o ser pela ideia de uma existência intelectual com relação a um 'atributo determinado').

Quanto às espécies de 'verbo concreto', as duas classificações, aquela feita em texto e a outra feita em metatexto, observam que há um 'atributo' no 'verbo', distinguindo apenas sua função. Assim, ambas estão numa relação de intersecção com o 'verbo abstrato', visto que ele é também, por definição, parte do 'verbo' que contém o 'atributo'. 
Quanto à 'proposição', ainda que Carneiro Ribeiro apresente duas possibilidades de defini-la, a 'lógica' e a 'gramatical', a que ele realmente descreve é a 'lógica', em que a 'proposição' é composta por três elementos: 'sujeito', 'verbo' e 'atributo'. Esse verbo é, justamente, o 'verbo abstrato', dado que é a “palavra que indica a relação destes dois termos". Como vimos, ainda que Carneiro Ribeiro trate do verbo como se não fosse de ‘relação', pois essa é uma característica secundária dele, trata-o dessa maneira e no conceito de 'proposição', e estando o 'atributo' separada desse 'verbo', ele deve ser o 'verbo abstrato'. Assim, nosso conceito-chave está em relação de subordinação com a 'proposição'. Esta última, a propósito, pode conter, além dos três elementos essenciais também 'complementos', os quais pode ser 'diretos' ou 'indiretos', e 'apostos'.

Quanto às espécies de 'oração', Carneiro Ribeiro apresenta as 'subordinadas de segunda ordem' chamadas 'incidentes', que podem desenvolver o 'sentido' (o que interpretamos como 'compreensão', pois está em oposição a 'extensão') dos 'termos' da 'oração principal' sem restringir a 'extensão', quando 'ampliativas' ou 'explicativa', ou podem acrescentar uma 'ideia' ao termo por ela modificado que não convém a este 'termo’ em toda sua 'extensão', o que acaba por restringi-la, daí seu nome de 'incidente 'restritiva' ou 'determinativa'. 'Adjetivo qualificativos', que modificam a 'compreensão' dos 'nomes apelativos' e os 'adjetivos determinativos', que determinam a 'extensão' dos 'nomes apelativos' sem nada ajuntar à sua 'compreensão'. Como vemos, as relações entre ‘compreensão' e 'extensão' promovidas nos conceitos de 'adjetivo' e de 'oração incidente' não são paralelas - elas são, na verdade, as duas oposições de Noël e Chapsal (cf. 1.4.2). - no entanto, tem base teórica comum com o 'verbo substantivo'.

As duas gramáticas de Carneiro Ribeiro são, dentre todas as que analisamos neste trabalho, possivelmente as que apresentam sua organização baseada em uma linguagem lógica subjacente e proveniente do pensamento de maneira mais explícita, pois usa com frequência termos da lógica para definir os conceitos. Assim, o 'verbo abstrato' forma rede conceitual a grande parte dos conceitos investigados. É notável, porém, que o gramático apresente mais de um conceito para diversos termos, havendo com frequência reflexões em metatexto acerca dessas possibilidades, com atenção aos conceitos das espécies de 'verbo atributivo' e o conceito de 'proposição'; nesse sentido, a gramática apresenta ecletismo vertical. Além disso, quando define as espécies de 'gramática', reúne visões de linguagem bastante diferentes, o que proporcionaria à obra também ecletismo horizontal. 
A entrada na década de 1880, com Carneiro Ribeiro e, posteriormente, com Julio Ribeiro, marca um período de transição na gramaticografia brasileira. Assim, não é de se admirar que a gramática de Carneiro Ribeiro oscile entre as possibilidades descritivas da língua, vagueando por conceptualizações diversas. Nesse momento do século, isso passa a ser comum, como já vimos na análise das gramáticas de Carneiro Ribeiro e veremos nas obras observadas adiante.

\subsection{Grammatica Portugueza (1881, [123]; 1885, [143]), de Julio Cezar Ribeiro Vaughan}

\subsubsection{Conceitos de gramática de linguagem e organização da obra}

$\mathrm{Na}$ introdução das duas edições analisadas de sua gramática, Ribeiro define 'gramática' como exposição metódica dos fatos da linguagem. Em nota (metatexto), faz referência ao texto Essentials of English Grammar, de Whitney, de 1881. Em seguida, afirma que a gramática não faz leis e regras para a linguagem, mas expõe os fatos dela, ordenados de modo que possam ser aprendidos com facilidade. Não tem, assim, por objetivo a correção da linguagem, visto que ouvindo bons oradores e conversando com pessoas instruídas, lendo artigos e livros bem escritos, muita gente consegue falar e escrever corretamente sem ter feito estudo especial.

Há, entretanto, segundo o gramático, muitos pontos de vista sob os quais é útil o estudo da gramática. Como para exprimir o pensamento oralmente ou na forma escrita, é preciso usar da linguagem não só com correção, mas também de modo que agrade aos outros, e sobre eles exerça influência. Há ainda pessoas que precisarão aprender línguas estranhas. Ademais, afirma o autor que é bom conhecer as formas várias por que passou a língua, para que, por meio da comparação, compreenda-se melhor a atual e como veio a ser o que é. Não basta usar a linguagem, mas saber o que a constitui, pois tal estudo nos diz muito sobre a natureza e história do homem. Sendo a linguagem instrumento e meio principal das operações da mente, para conhecê-la, é preciso estudar a linguagem. Finalmente, afirma que o conhecimento gramatical se inicia, mas nunca acaba, sempre há algo a acrescentar mesmo aos homens mais inteligentes. Define 'linguagem' como expressão do pensamento por meios articulados. Anteriormente, ao falar da gramática, disse que a 'linguagem' era também o instrumento e meio principal das operações da mente. 
Tal como veremos em muitos gramáticos do final do século, Ribeiro, ao definir linguagem, mistura aspectos dos Programas Descritivista e de Correspondência (Swiggers 2004, cf. Quadro 2), pois afirma que chegamos ao conhecimento da gramática de uma língua por meio de comparação da língua atual com o que ela já foi, por outro lado, essa mesma língua é expressão de um pensamento.

A 'gramática', segundo o autor, pode ser 'geral' ou 'particular'. A primeira é uma exposição metódica dos fatos da linguagem em geral. A segunda, a exposição metódica dos fatos de uma língua determinada, como, no caso da gramática portuguesa de Ribeiro, é a língua portuguesa. As definições utilizadas por Ribeiro são bastante vagas, não deixando claro a que Programa pertenceriam. Finalmente, apoiado em ampla bibliografia $^{105}$, Ribeiro divide a gramática em duas partes: 'lexecologia' e 'sintaxe' (cf. FD10, FD11 Apêndice B)

\subsubsection{Conceitos de metaclasses e classes de palavras}

A taxonomia, segundo a primeira edição da Grammatica Portugueza de Ribeiro (1881), é a distribuição das palavras em grupos correspondentes aos grupos de ideias de que se compõe o pensamento. Há três metaclasses: na primeira, as palavras representam objetos ou coisas sobre que se exerce comparação ou juízo; na segunda, as palavras representam a existência da comparação ou a relação; finalmente, na terceira, as palavras representam a natureza da relação. Dessa maneira, pode-se pensar que há também somente três classes de palavras, as quais, correspondendo às metaclasses, são, respectivamente, 'nomes', 'verbos' e 'partículas'. Na ilustração de uso "Pedras não são sensíveis", "pedras" e "sensíveis" são “nomes', "são" é ‘verbo', e "não" é uma 'partícula'.

Ribeiro, porém, apresenta outra possibilidade de distribuir as palavras, selecionando oito espécies: 'substantivos', 'artigo' 'adjetivo', 'pronome', 'verbo', 'preposição', 'conjunção', 'advérbio'. Em metatexto, diz que a maior parte dos gramáticos ainda acrescenta o 'particípio' e a 'interjeição', algo que ele não faz porque o

\footnotetext{
${ }^{105}$ Ribeiro cita diversos textos em nota de rodapé para sustentar essa visão. Transcrevemos a nota adiante: "BURGRAFF, Principes de Grammaire Générale, Liège, 1863, pag. 11. ALLEN AND CORNWELL, English Grammar, London, 1865, pag. 9. AYER, Grammaire Comparée de la Langue Francaise, Paris 1876, pag. 12. BASTIN, Étude Philologique de la Langue Française. St. Petersbourg, 1878, vol. 1, pag. 1. CHASSANG, Nouvelle Grammaire Grecque, pag. 1 e 131." Outro gramático brasileiro a sugerir essa divisão da gramática é Ribeiro (1889), sem usá-la, no entanto, já que seguia a divisão e 'lições' de acordo com os pontos de Programa de Estudos de Fausto Barreto.
} 
primeiro é parte integrante do verbo, e, por conta disso, não deve ser categoria à parte, e a segunda é um grito involuntário, instintivo, animal e, como não representa 'ideia', não constitui 'parte do discurso'.

O gramático procura reunir as duas classificações realizadas, como demonstramos no quadro abaixo. Ele ainda acrescenta as metaclasses de 'palavras variáveis' e ‘invariáveis', as quais incluímos também no quadro.

\begin{tabular}{|c|c|c|}
\hline Metaclasses 1 & Classes de palavras & \multirow{2}{*}{ Metaclasses 2 } \\
\hline \multirow{3}{*}{ Nome } & Substantivo & \multirow{2}{*}{ Variáveis } \\
\cline { 2 - 2 } & Artigo & \\
\cline { 2 - 2 } & Adjetivo & \\
\cline { 2 - 2 } & Pronome & \multirow{2}{*}{ Invariáveis } \\
\hline Verbo & Verbo & \\
\hline \multirow{3}{*}{ Partículas } & Preposição & \\
\cline { 2 - 2 } & Conjunção & \\
\cline { 2 - 2 } & Advérbio & \\
\hline
\end{tabular}

Quadro 53. Metaclasses e classes de palavras em Ribeiro (1881)

Emenda, em metatexto, que as palavras hoje consideradas 'invariáveis' já gozaram de vida no passado, visto que já tiveram formas móveis nas línguas matrizes. Em seguida, faz uma analogia com as ciências naturais, ao dizer que "são, se é permitido o símile, organismos inferiores cujas juntas ankylosaram-se, cujas partes fluidas solidificaram-se por uma cristalização linguística" (Ribeiro 1881: 52). Ressalta, porém, que no advérbio, há ainda vestígios de flexão. Vemos que muitas vezes Ribeiro discute, em metatexto,a história das línguas.

Na segunda edição, de 1885, são mantidas as metaclasses de palavras 'variáveis' e 'invariáveis' e as mesmas oito classes de palavras apresentadas em 1881. Entretanto, as metaclasses relativas a 'nome', 'verbo', 'partícula' são substituídas por outras, as quais descrevemos adiante: 1) há três classes de palavras que são 'independentes' das outras e capazes de formar sentenças, são 'substantivo', 'pronome', 'verbo'; 2) três classes de 'palavras qualificadoras', que são sempre dependentes de outra palavra que elas descrevem ou limitam, são 'artigo', 'adjetivo' e 'advérbio'; 3) finalmente, há duas espécies de 'palavras conectivas', que juntam uma palavra a outra ou uma sentença com outra, são 'conjunção' e 'preposição'. Dessa forma, considerando as duas possibilidades de metaclasses e as oito classes de palavras, o quadro da taxonomia de 1885 fica assim:

\begin{tabular}{|c|c|c|}
\hline Metaclasse 1 & Classes de palavras & \multirow{2}{*}{ Metaclasse 2 } \\
\hline \multirow{3}{*}{ Palavras independentes } & Substantivo & \multirow{4}{*}{ Variáveis } \\
\cline { 2 - 2 } & Pronome & \multirow{2}{*}{} \\
\cline { 2 - 2 } & Verbo & \\
\hline \multirow{3}{*}{ Palavras qualificadoras } & Artigo & \\
\cline { 2 - 2 } & Adjetivo & \\
\cline { 2 - 2 } & Advérbio & \\
\hline
\end{tabular}




\begin{tabular}{|l|l|l|}
\hline \multirow{2}{*}{ Palavras conectivas } & Preposição & Invariáveis \\
\cline { 2 - 2 } & Conjunção & \\
\hline
\end{tabular}

Quadro 54. Metaclasses e classes de palavras em Ribeiro (1885)

Repete, em metatexto, na edição de 1885, que as palavras invariáveis já gozaram de "vida" em outro momento.

\subsubsection{Conceitos modificadores do nome}

Em ambas as edições, o 'artigo' é definido como palavra que se antepõe ao substantivo para particularizar sua significação. Em metatexto (nota de rodapé), completa a definição dizendo que o 'artigo' é a palavra átona que nada exprime por si, mas contribui poderosamente para a clareza da expressão; em seguida, cita o latim, língua que não possui o 'artigo' tal qual o português, dizendo que este fica muito abaixo das línguas neolatinas, justamente por lhe faltar o artigo, ilustra isso ao comparar as frases portuguesas “dá-me pão, dá-me um pão, dá-me o pão" que são traduzidas igualmente por "da mihi panem" em latim.

Em 1881, o 'artigo' pode ser 'definido' ou 'indefinido'. O primeiro (ex.: o) particulariza a definição do substantivo de modo certo (il.: o menino deu-me o pêssego) e é frequentemente utilizado antes de substantivos que denotam espécies (il.: o tigre é animal veloz; o hipopótamo é vagaroso). Já o 'indefinido' (ex.: um) particulariza a definição do substantivo de modo vago (il.: o menino deu-me um pêssego; vieram-lhe uns cães da Espanha). Em 1885, não apresenta essa divisão, simplesmente exemplifica o 'artigo' como “o”. Em metatexto (nota de rodapé), acrescenta a observação de que Chassang (Nouvelle Grammaire Française, Paris, 1881) elimina o chamado 'artigo indefinido' que, diz ele, vai com toda razão ocupar lugar de 'adjetivo determinativo indefinido'.

O 'adjetivo' definido, em 1881, como palavra que 'descreve' ou 'limita' o substantivo; em 1885, a definição é modificada para palavra que 'descreve' ou 'determina' o substantivo. Em ambas as edições, há uma nota de rodapé, na qual que faz referência à gramática de Grivet de 1865 ([71]). Nesse metatexto, é afirmado por Ribeiro que o 'adjetivo' é terminantemente discriminado de outras espécies de palavras por sempre andar ligado a um 'substantivo' ou 'pronome' na qualidade de 'atributo' ou 'predicado', pois sempre que exerce outra função ('complementos direto' e 'indireto', 
'sujeito'), deixa de ser 'adjetivo' para tornar-se 'substantivo' (no caso do 'adjetivo descritivo') ou 'pronome' (no caso do 'adjetivo determinativo').

O 'adjetivo' é primeiramente classificado em 'qualificativo' ou 'descritivo', que denota ou denomina qualidade ou propriedade da coisa significada pelo substantivo a que ele se refere, e 'determinativo' ou 'limitativo', que denota o número, a posição ou qualquer outra limitação da coisa significada pelo substantivo a que se refere. Em metatexto, na edição de 1885, Ribeiro ressalta que o 'adjetivo qualificativo' não tem significação própria e supõe a existência de um 'sujeito', além de ser convertido facilmente em 'substantivo'. Essas duas espécies de 'adjetivo' são gênero de outras espécies, cujo conceito expomos no quadro adiante. As espécies de 'adjetivo' e suas definições são iguais nas duas edições, entretanto, são acrescidas notas de rodapé à edição de 1885 , que especificamos no quadro como metatextos.

\begin{tabular}{|c|c|c|}
\hline $\begin{array}{l}\text { Espécies de } \\
\text { 'adjetivo' }\end{array}$ & $\begin{array}{l}\text { Espécies dos itens } \\
\text { da coluna anterior }\end{array}$ & Conceito \\
\hline \multirow{2}{*}{$\begin{array}{l}\text { Adjetivo } \\
\text { qualificativo / } \\
\text { descritivo }\end{array}$} & Restritivo & $\begin{array}{l}\text { Denota ou denomina qualidade acessória do 'substantivo' } \\
\text { (il.: homem bom; cavalo preto). }\end{array}$ \\
\hline & Qualificativo & $\begin{array}{l}\text { Denota ou denomina qualidade essencial que já se inclui na } \\
\text { ideia do objeto (il.: diamante duro; homem mortal) }\end{array}$ \\
\hline \multirow[t]{6}{*}{$\begin{array}{l}\text { Adjetivo } \\
\text { determinativo } \\
\text { / limitativo }\end{array}$} & Numeral & $\begin{array}{l}\text { Adjetivo empregado para expressar limitação numérica. } \\
\text { - cardial (ex.: um, dois) } \\
\text { - ordinal: (ex.: quarto, décimo) } \\
\text { - multiplicativo: (ex.: duplo, triplo, cêntuplo) } \\
\text { MT (1885): Há formas numéricas que não pertencem ao } \\
\text { 'adjetivo', mas são ‘substantivos' (ex.: metade, dobro, } \\
\text { milhão), 'verbos' (ex.: dobrar, centuplicar) e advérbios (ex.: } \\
\text { primeiramente). }\end{array}$ \\
\hline & Demonstrativo & $\begin{array}{c}\text { Designa pessoas ou coisas, distinguindo-as de outras no que } \\
\text { diz respeito a lugar ou a tempo (ex.: este, esse, aquele, } \\
\text { estoutro, esseoutro, aqueloutro) }\end{array}$ \\
\hline & Distributivo & $\begin{array}{l}\text { Indica que os indivíduos que compõem um todo ou agregado } \\
\text { devem ser considerados separadamente (ex.: cada, cada um, } \\
\text { cada qual) (il.: cada terra tem seu uso) }\end{array}$ \\
\hline & Conjuntivo & Conecta cláusulas (il.: um homem, o qual eu vi) \\
\hline & Possessivo & $\begin{array}{l}\text { Indica senhorio ou posse em referência às coisas } \\
\text { significadas pelos substantivos a que ele se junta (meu, teu, } \\
\text { seu, nossa, vossa, próprio, alheio) (il.: minha espingarda; teu } \\
\text { cavalo). Muitos 'adjetivos qualificativos' envolvem uma } \\
\text { ideia de possessão (il.; fazenda nacional, família imperial). }\end{array}$ \\
\hline & Indefinido & $\begin{array}{l}\text { Limita pessoa ou coisa sem indicação de individualidade } \\
\text { particular (ex.: algum, certo, mais, menos, mesmo, muito, } \\
\text { nenhum, outro, pouco, qualquer, quanto, quejando, só, tal, } \\
\text { tanto, todo) (il.: alguns homens, ... negócios) }\end{array}$ \\
\hline
\end{tabular}


Ressaltamos que o 'adjetivo indefinido' não apresenta o antigo 'artigo indefinido' (ex.: um) em seus exemplos ou ilustração de uso, ainda que em metatexto o gramático tenha, anteriormente, citado a reclassificação dos dados linguísticos "um, uma”.

Ribeiro define 'pronome' como palavra usada em lugar de um 'substantivo'. Há dois tipos de 'pronome', o 'substantivo' e o 'adjetivo'. O primeiro aparece em lugar do substantivo, sem limitá-lo por maneira nenhuma; podem se chamar também 'pronomes pessoais' (ex.: eu, tu, ele, nós, vós, eles) (il.: ele fala; em vez de Pedro fala). O 'pronome adjetivo' toma lugar do 'substantivo' e o limita de alguma maneira (ex.: este, esse, aquele, este outro, esse outro, aquele outro) (il.: este relógio é bom, aquele é ruim). Em metatexto (nota), afirma que o 'pronome adjetivo' nada mais é do que o 'adjetivo determinativo' empregado na oração sem substantivo claro. Todavia, nessa classe, há também 'pronomes essenciais' que não são empregados como 'adjetivos' (como é o caso dos 'pronomes adjetivos indefinidos'). Ademais, ainda em nota, com base em Grivet (1865), Ribeiro diz que há gramáticos que consideram como 'pronomes' os 'adjetivos numerais' quando estão sozinhos na 'oração'.

No quadro adiante, apresentamos as espécies de 'pronome adjetivo' e seu conceito segundo Ribeiro (1881, 1885):

\begin{tabular}{|c|c|}
\hline $\begin{array}{c}\text { Espécies de 'pronome } \\
\text { adjetivo' (termo) }\end{array}$ & Conceito em texto \\
\hline Demonstrativo & $\begin{array}{r}\text { Idem 'adjetivo determinativo demonstrativo' sem sujeito claro, além de } \\
\text { 'pronomes essenciais' (ex.: isto, isso, aquilo) }\end{array}$ \\
\hline Distributivo & Idem 'adjetivo determinativo distributivo sem sujeito claro. \\
\hline Conjuntivo & $\begin{array}{c}\text { Idem 'adjetivo determinativo conjuntivo' sem sujeito claro, além de } \\
\text { 'pronomes essenciais' (ex. de 1881: que, quem), (ex.: de 1885: que, } \\
\text { quem, o que quer que, quem quer, quem quer que). }\end{array}$ \\
\hline Possessivo & Idem 'adjetivo determinativo possessivo' sem sujeito claro. \\
\hline Indefinido & $\begin{array}{c}\text { Idem 'adjetivo determinativo indefinido' sem sujeito claro, além de } \\
\text { 'pronomes essenciais' (ex.: al, algo, alguém, beltrano, fulano, homem, } \\
\text { nada, ninguém, outrem, sicrano, tudo). }\end{array}$ \\
\hline
\end{tabular}

Quadro 56. Espécies de 'pronome adjetivo' em Ribeiro $(1881,1885)$

Em 1885, apresenta ainda duas 'observações', que se configuram como metatexto. Na primeira, observa que "que" em frases interrogativas e exclamativas emprega-se também adjetivamente (il.: que homem aquele?; que mulher!). Na segunda, disserta, baseando-se no filólogo português Theófilo Braga, sobre o uso de "homem" como "pronome indefinido'.

\subsubsection{Conceito de verbo}


O conceito de 'verbo' é bastante divergente nas duas edições da Grammatica Portugueza, de Ribeiro. Na edição de 1881, Ribeiro define o 'verbo' como uma palavra que exprime a existência de uma relação entre duas ideias. Em seguida, inicia uma pequena crônica ${ }^{106}$ acerca do conceito de 'verbo' em diferentes momentos da história: primeiramente, aborda a visão aristotélica do 'verbo', definido por expressar tempo, que foi também utilizada por gramáticas posteriores; em segundo lugar, apresenta e contesta a concepção de verbo como palavra que exprime 'ideia de ação'; finalmente, apresenta argumentos contrários à concepção de 'verbo' como 'afirmação' (citando, inclusive, a Grammaire Générale de Port-Royal). No primeiro caso, afirma que o 'verbo' não é a única classe de palavra que expressa tempo; no segundo, considerando que todo verbo possa ser divido em "ser" acompanhado de um 'predicado', diz que nem sempre este representa uma 'ação', como é o caso de verbos como "descansar, sentar, dormir"; finalmente, diz que o verbo não apenas 'afirma', mas também pode 'negar'. Por essa razão, o autor dá preferência à definição de 'relação' entre duas 'ideias'. Finalmente, junta essa definição, à de Whitney, de que o 'verbo' é palavra que diz ou declara.

Adiante, apresenta as espécies de 'verbo'. Primeiramente, o 'verbo' divide-se em 'substantivo' e 'predicativo', posteriormente, o 'verbo predicativo' divide-se em 'intransitivo' e 'transitivo'. Adiante, apresentamos seus conceitos em texto e em metatexto.

\begin{tabular}{|c|c|c|}
\hline $\begin{array}{c}\text { Espécies de } \\
\text { 'verbo' } \\
\text { (termo) }\end{array}$ & Conceito em texto & Conceito em metatexto \\
\hline $\begin{array}{c}\text { Verbo } \\
\text { substantivo }\end{array}$ & $\begin{array}{c}\text { É o que indica a relação entre uma ideia } \\
\text { qualquer e a ideia simples de substância } \\
\text { (il.: Deus é, foi, e será) (ex.: ser). } \\
\text { Quando relaciona a uma ideia qualquer } \\
\text { a ideia de substância modificada por um } \\
\text { predicado, é considerado simples }\end{array}$ & $\begin{array}{c}\text { (Nota) Verbo 'estar' não é substantivo } \\
\text { porque não indica a existência em } \\
\text { absoluto, mas já modificada por um } \\
\text { estado ou uma posição }\end{array}$ \\
\hline $\begin{array}{c}\text { 'cópula' (il.: Pedro é bom; esses } \\
\text { meninos são inteligentes). }\end{array}$ & \\
predicativo & $\begin{array}{c}\text { Indica existência de uma relação entre } \\
\text { uma ideia qualquer e a ideia de } \\
\text { substância, modificada por um } \\
\text { predicado expresso pela raiz verbal (il.: } \\
\text { Pedro ama = Pedro é amante). } \\
\text { Subdividem-se em 'intransitivos' e } \\
\text { 'transitivos. }\end{array}$ & \\
\hline$>$ V. & $\begin{array}{c}\text { O predicado apresenta-se ao nosso } \\
\text { espírito: (1) como simples estado, puro } \\
\text { modo de ser, como simples mudança }\end{array}$ & (Nota) Os Estoicos chamaram ao verbo \\
transitivo em voz ativa 'kategórema
\end{tabular}

\footnotetext{
${ }^{106}$ Ribeiro cita ao fim da crônica, em nota de rodapé, Burgraff (1883). Ao comparar as duas obras, notamos que que o gramático brasileiro praticamente apenas traduziu essa crônica do gramático belga.
} 


\begin{tabular}{|c|c|c|}
\hline & $\begin{array}{l}\text { que um ser de um lugar para outro (ex.: } \\
\text { andar, tombar) - esses são os 'verbos } \\
\text { intransitivos' }\end{array}$ & $\begin{array}{l}\text { orthón', ‘verbum rectum', ‘verbo } \\
\text { direito'; ao ‘verbo transitivo' em voz } \\
\text { passiva deram o nome de_-'yption’ }\end{array}$ \\
\hline $\begin{array}{c}>\mathrm{V} . \\
\text { Transitivo }\end{array}$ & $\begin{array}{l}\text { O predicado apresenta-se ao nosso } \\
\text { espírito: (2) como estado de um objeto, } \\
\text { como um modo de ser desse objeto, que } \\
\text { produz ou pode produzir efeito sobre } \\
\text { outro objeto (ex.: ferir, quebrar, amar, } \\
\text { odiar) - esses são os 'transitivos'. Os } \\
\text { verbos transitivos estão na 'voz ativa' } \\
\text { quando a 'ação' é exercida pelo } \\
\text { ‘sujeito' da 'oração', e na 'voz passiva' } \\
\text { quando a 'ação' é exercida sobre esse } \\
\text { 'sujeito'. }\end{array}$ & $\begin{array}{c}\text { 'verbum supinum', 'verbo deitado de } \\
\text { costas'; ao verbo intransitivo } \\
\text { classificavam eles como ‘oydéteron', } \\
\text { 'verbum neutrum', verbo que não era } \\
\text { direito, nem deitado de costas. Estas } \\
\text { denominações foram tomadas, ao que } \\
\text { parece, das atitudes diversas dos atletas } \\
\text { ao darem e receberem golpes. } \\
\text { (Referência: R. Schmidt - Stoicorum } \\
\text { Grammatica) }\end{array}$ \\
\hline
\end{tabular}

Quadro 57. Principais espécies de 'verbo' em Ribeiro (1881)

Alguns aspectos desses conceitos merecem destaque. Primeiramente, observamos, que o 'verbo substantivo' pode, de acordo com Ribeiro, estar numa 'sentença' sem que haja 'predicado', indicando apenas "a relação entre uma ideia qualquer e a ideia simples de substância", a ilustração apresentada é "Deus é, foi, será". Em metatexto, o gramático mineiro ressalta que o 'verbo' “estar" não pode ser substantivo, por não significar 'existência absoluta', mas modificada por um ‘estado' ou 'posição' - alguns gramáticos, a partir de um certo momento do século, passam a apresentar refutações à classificação de "estar" como 'verbo substantivo', enquanto outros gramáticos apresentavam "ser" e “ser” como 'verbo substantivo' (cf.5.3). Ademais, é notável que na definição dada para as espécies do 'verbo atributivo', 'verbo intransitivo' e 'verbo transitivo', o gramático destaque o 'predicado' como responsável pela transitividade verbal.

Na segunda edição da Grammatica Portugueza de Ribeiro, de 1885, ele define 'verbo' como palavra que enuncia, diz ou declara alguma coisa e que implica sempre uma 'asserção' ou 'predicação'. Em seguida, já divide o 'verbo' em 'transitivo' e em ‘intransitivo'. O primeiro é definido como 'verbo' que enuncia um estado ou mesmo uma ação que não se exerce diretamente sobre um 'objeto'. O segundo, como 'verbo' que enuncia uma ação que se exerce diretamente sobre um 'objeto'. Como vemos, essas definições não destacam o 'predicado' e tratam de 'ação', noção que não era tratada nas definições dadas em 1881. Essas definições, porém, são apresentadas em metatexto (nota) na edição de 1885, nelas é dado, como vimos anteriormente, destaque para o 'predicado', como descrevemos anteriormente; na edição de 1885 , entretanto, Ribeiro já não apresenta os conceitos de 'verbo substantivo' e 'verbo predicativo'. Ademais, mantém, em nota de rodapé (metatexto) a observação sobre a transitividade verbal de acordo com os Estoicos.

No que vimos acima, as diferenças entres as edições são notáveis: o autor modifica seu conceito de 'verbo', retira a crônica baseada em Burgraff, retira as espécies de 'verbo 
substantivo' e 'verbo predicativo' e modifica sutilmente a definição em texto de 'verbo transitivo' e 'verbo intransitivo', mantendo em metatexto o que já estava na edição anterior.

Há ainda outros 'verbos' citados por Ribeiro nas duas edições de maneira quase idêntica (ressaltamos a única diferença no quadro), são eles: 'auxiliar', 'regular', 'irregular, 'impessoal' 'defectivo', 'perifrástico', 'frequentativo', 'terminativo' e 'pronominal'. No quadro adiante, o conceito de cada um deles.

\begin{tabular}{|c|c|}
\hline $\begin{array}{l}\text { Outras espécies de } \\
\text { 'verbo' (termo) }\end{array}$ & Conceito em texto e metatexto (MT) \\
\hline \multirow[t]{2}{*}{ Auxiliar } & $\begin{array}{c}\text { É empregado como elemento subsidiário na formação dos tempos compostos de } \\
\text { todos os verbos, de todos os tempos de verbos passivos, de todos os tempos dos } \\
\text { verbos perifrásticos (ex.: haver, ter, ser). }\end{array}$ \\
\hline & $\begin{array}{l}\text { Apenas na edição de 1881: Podem entrar na classe de 'auxiliares' os verbos } \\
\text { “cessar de", "deixar de", “acertar de", “dever de", "tornar a" e "dar" (il.: deixar } \\
\text { de fazer alguma coisa; não cessava de importunar e amesquinhar-se; acertou de } \\
\text { passar (casualmente passou); os autos devem de ser perdidos (provavelmente se } \\
\text { perderam); não tornes a pecar (não peques outra vez); muitos que já estavam } \\
\text { para quebrar, deram em dar (começaram a dar) para que deles tal se não } \\
\text { presumisse [Manoel Bernardes]). }\end{array}$ \\
\hline Regular & Segue exatamente seu paradigma de conjugação (ex.: louvar, defender) \\
\hline Irregular & Não segue exatamente seu paradigma de conjugação (ex.: dar, caber) \\
\hline Impessoal & $\begin{array}{c}\text { Em acepção própria não pode ter por sujeito um nome de pessoa (ex.: trovejar, } \\
\text { acontecer). }\end{array}$ \\
\hline Defectivo & Não é empregado em todas as formas (ex.: feder, colorir) \\
\hline Perifrástico & $\begin{array}{l}\text { Ao seu infinito ligam-se por meio da preposição “de” os tempos dos verbos } \\
\text { "haver”, chamado 'promissivo' (il.: eu hei de comprar), ou “ter”, chamado } \\
\text { 'obrigativo' (il.: eu tenho de comprar). }\end{array}$ \\
\hline Frequentativo & $\begin{array}{l}\text { Ao particípio imperfeito ajuntam-se tempos seus ou de outro verbo para denotar } \\
\text { duração e progresso do estado de movimento ou atividade, marcado pelo seu } \\
\text { predicado (il.: ir indo; vir vindo; estar caindo; andar estudando) }\end{array}$ \\
\hline Terminativo & $\begin{array}{l}\text { O predicado nele contido exige um termo indireto de ação. "Dar" e "usar" são } \\
\text { verbos terminativos porque os predicados neles contidos "dante" e "usante" } \\
\text { (palavras fictícias) requerem termos indiretos de ação (il.: dar alguma coisa a } \\
\text { alguém; usar de alguma coisa). }\end{array}$ \\
\hline Pronominal & $\begin{array}{c}\text { Por uso da língua, emprega-se sempre com um 'pronome' objetivo que } \\
\text { representa o ‘sujeito' (ex.: queixar-se, condoer-se). }\end{array}$ \\
\hline & $\begin{array}{l}\text { MT: A distribuição da ação do verbo em 'recíproca' e 'reflexiva' está mais no } \\
\text { domínio da lógica do que no da gramática, diz Garret. “O verdadeiro sistema de } \\
\text { gramática deveria ser o de simplificar, mas parece que acintemente não tratam } \\
\text { senão de aumentar entidades e fazer dificultoso o que é simples e fácil, } \\
\text { multiplicando termos e categorias de divisões e subdivisões em coisas que as } \\
\text { não precisam. Que quer dizer, por exemplo, 'verbo recíproco'? É um ‘verbo } \\
\text { ativo', nem mais, nem menos, com um pronome objetivo, assim como podia ter } \\
\text { um nome." }\end{array}$ \\
\hline
\end{tabular}

\subsubsection{Conceito de sentença e seus elementos}

A 'sentença' é definida quase igualmente nas duas edições, a diferença entre elas está apenas na troca de uma ilustração. Ambos dizer que o termo 'sentença', proveniente 
do termo latino 'sententia' (que significa pensamento, juízo, expressão completa) é preferível ao termo 'período', pois esteve, proveniente do grego 'periodos' (que significa caminho em volta, rodeio) não traduz bem a noção de pensamento e de juízo - Aristóteles e Cícero usaram esse último termo com a significação de 'sentença retórica', 'figurada', 'ornada'. Ademais, toda 'sentença' tem dois elementos, o 'sujeito', que representa a coisa a cujo respeito se fala, e o 'predicado', que representa o que se diz do sujeito. Este último ainda se subdivide em dois elementos, o 'predicado propriamente dito', que é a ideia que se liga ao 'sujeito', e a 'cópula', o laço que prende o 'predicado propriamente dito' ao 'sujeito'. Ressaltamos as diferenças entre o papel a 'cópula' que ocupava na relação à estrutura tripartite de 'sentença' parecia mais relevante, dado que ela não mais era o 'nexo' entre os 'termos' da 'sentença', do que o que ela ocupa nessa organização binária dos elementos da 'sentença', visto que tornou-se uma parte do 'predicado'.

A diferença entre as duas edições está na ilustração de 'sentença'. Há um primeiro exemplo que é idêntico nas duas, "Rosas são flores", em que "rosas" é 'sujeito', "são flores", 'predicado', em que "são" é a 'cópula' e "flores", o 'predicado propriamente dito'. O exemplo seguinte é "Pedro ama", em que "Pedro" é o 'sujeito' e "ama”, o 'predicado'. Este último elemento é divido de duas maneiras. Em 1881, “ama” decompõese em “é amante”, sendo “é” a 'cópula' e “amante”, o ‘predicado'. Já em 1885, Ribeiro decompõe "ama” em “am” que é ‘tema' e "a" que é ‘terminação'. O ‘tema' é o 'predicado propriamente dito', a 'terminação' é ‘cópula'. Ribeiro apresenta, em seguida, uma nota, metatexto, dizendo que baseando-se em Mason (English grammar, London, 1864, pág. 95) a 'cópula gramatical' de todas as 'sentenças' consiste na 'flexão' do 'verbo'. Nessa mesma nota, afirma que o ato da mente de conectar um 'predicado' ao 'sujeito' chamase ‘juízo', que o resultado de um ‘juízo’ é um 'pensamento’ e, por fim, que a expressão de um 'pensamento' é a 'sentença'.

Como vemos, Ribeiro mantém os conceitos nas duas edições, mas ao modificar a ilustração de 'sentença' em 1885, deixa de assumir que haja projeção de um dado linguístico na análise da 'sentença' "Pedro ama" em que o verbo "ser" seja a 'cópula' acompanhada do 'predicado propriamente dito' "amante", para apenas fazer a simples segmentação do verbo "ama" em 'radical' "am” e 'tema' “a”, tornando a 'cópula' a 'flexão do verbo'. Assim, ainda que, como vemos em sua nota, ainda considere a 'sentença' o resultado de um 'juízo' e que mantenha o conceito de 'cópula', o autor modifica a maneira de examinar os dados linguísticos de forma decisiva. Do ponto de vista técnico, podemos dizer que o gramático deixou de lado uma análise linguística 
baseada num Programa de Correspondência para se aproximar do Programa Descritivista (cf. Swiggers 2004 - cf. Quadro 2). Ademais, tal mudança pode, justamente, corresponder à eliminação do conteúdo vinculado ao conceito de 'verbo substantivo' na segunda edição.

No tratamento da sintaxe de ambas as edições, Ribeiro, a fim de explicar a organização dos itens da 'sentença', considera cinco 'relações' que as palavras ou grupos de palavras têm entre si. No quadro adiante, apresentamos o conceito de cada uma delas.

\begin{tabular}{|c|c|}
\hline $\begin{array}{c}\text { Espécie de } \\
\text { 'relação' (termo) }\end{array}$ & Conceito em texto \\
\hline Subjetiva & $\begin{array}{l}\text { Relação que o ‘sujeito’ de uma 'sentença' está para com seu 'predicado’ (il.: } \\
\text { Pedro é rico). Pode ser 'nome’, 'pronome', 'parte da oração substantivada', } \\
\text { 'cláusula', 'sentença'. }\end{array}$ \\
\hline Predicativa & $\begin{array}{l}\text { Relação em que o ‘predicado’ de uma ‘sentença’ está para com seu ‘sujeito’. Há } \\
\text { ‘verbos de predicação completa' (il.: o vegetal vive); ‘verbos de predicação } \\
\text { incompleta' (il.: Antônio está doente) - estes últimos são ‘verbo substantivo’, } \\
\text { ‘estar', alguns 'intransitivos’ (ex.: ficar, parecer) todos os ‘intransitivos’. (il.: A } \\
\text { França parece rejuvenescida; o rei ama-vos). }\end{array}$ \\
\hline Atributiva & $\begin{array}{l}\text { Relação em que a palavra que representa alguma qualidade, alguma circunstância } \\
\text { da coisa de que se fala está para a palavra que representa tal coisa - isso sem que } \\
\text { haja asserção, sem que se fala uso do verbo para mostrar tal conexão. (il.: } \\
\text { Homens prudentes). Somente 'substantivos' travam relação com o 'atributo', este } \\
\text { pode ser 'artigo', 'substantivo', 'adjetivo descritivo', 'adjetivo determinativo', } \\
\text { 'particípio', 'substantivo' precedido por 'preposição', 'cláusula adjetivo' (il.: o } \\
\text { homem; um homem; Afonso; rei; maça grande; este livro; cada casa; soldado } \\
\text { ferido; a casa de Pedro; a carta que escrevi). }\end{array}$ \\
\hline Objetiva & $\begin{array}{l}\text { Relação que está para com um ‘verbo' de 'ação transitiva' o ‘objeto' a que se } \\
\text { dirige ou sobre o que exerce essa ação (il.: o cão levantou a cabeça). Podem servir } \\
\text { de 'objeto' 'substantivos' e 'palavras', 'frases', ‘sentenças' tomadas como } \\
\text { 'substantivo'. Não é indicada por 'preposição', a não ser em caso anfibologia. }\end{array}$ \\
\hline Adverbial & $\begin{array}{l}\text { Relação em que está para com um 'substantivo', 'adjetivo', 'verbo' ou 'advérbio' } \\
\text { a palavra que modifica as relações entre eles existentes. É expressa por } \\
\text { 'advérbio', ‘substantivo’ precedido por 'preposição', 'pronomes substantivos', } \\
\text { ‘cláusulas advérbio' (ex.: ele combateu esforçadamente; Pedro escreve com } \\
\text { gosto; Pedro veio comigo; Deu-me o presente; Antônio estava lendo quando } \\
\text { cheguei). }\end{array}$ \\
\hline
\end{tabular}

Quadro 59. Espécies de 'relação' em Ribeiro (1881, 1885)

Ao tratar de 'relações', o gramático inclui os elementos essenciais da 'sentença', isto é, o 'sujeito' e o 'predicado', diferentemente do que vimos nos gramáticos até agora, que, em geral, apresentavam 'complementos' aos três elementos essenciais da 'proposição', 'oração' ou 'sentença'. Esse é um ponto crucial da mudança que se iniciava nesse momento, pois a noção de 'proposição lógica' parece começar a perder seu protagonismo, e, dessa forma, passa a ser analisada nos mesmos termos que eram analisados os outros elementos que fazem parte da 'sentença', como é o caso, por exemplo, do 'objeto' e as palavras que promovam 'relações adverbiais'. Além disso, 'predicado' e 'atributo' 
passam a ser conceitos diferentes. O primeiro contém necessariamente um 'verbo', ao passo que o segundo pode ser colocado numa 'sentença' sem ele.

No exame das espécies de 'sentença' os conceitos apresentados para 'sentença simples' e 'composta' são idênticos nas duas edições. A 'sentença simples' (também se chama 'oração' ou 'proposição') é aquela que contém uma só 'asserção', sejam ou não ampliados seu ‘sujeito' e seu 'predicado' (il.: abelhas fazem mel). A 'sentença composta' contém mais de uma 'asserção' (il.: Pedro é feliz, mas eu sou desgraçado; se me abandonas, considero-me perdido). Quando uma 'sentença' se compõe de duas ou mais 'asserções' cada uma delas se chama 'membro' (il.: o plano foi bem concebido / e produziu efeito). Chamam-se 'cláusulas' os 'membros' da 'sentença' quando são tão conexos entre si que um depende do outro ou até o modifica (il.: foge o veado / se o acossa o cão). 'Frase' é uma combinação de 'palavras coordenadas' (il.: o orador excedeu a expectação do público). A ‘frase' construída com um 'infinito' chama-se 'frase infinitiva' (il.: obedecer a lei é dever do cidadão). A 'frase' construída com o 'particípio' chama-se 'frase participial' (il.: negreiros são traficantes de escravos).

Duas são as relações que podem manter entre si os 'membros' de uma 'sentença composta': 'coordenação', quando os 'membros' são independentes entre si; 'subordinação' é quando um ou mais 'membros' da 'sentença composta' dependem de outro membro da mesma 'sentença'. Os 'membros' de que dependem outros 'membros' chamam-se 'cláusulas principais', os 'membros' dependentes têm o nome 'cláusulas subordinadas'. No quadro adiante, definimos as diversas espécies de 'sentença', aquelas relativas à 'coordenação' e à 'subordinação', de acordo com as duas edições da gramática de Ribeiro.

\begin{tabular}{|c|c|c|}
\hline $\begin{array}{l}\text { Relação entre } \\
\text { membros } \\
\text { (termos) }\end{array}$ & $\begin{array}{l}\text { Espécies } \\
\text { (termos) }\end{array}$ & Conceito em texto \\
\hline \multirow{4}{*}{ Coordenação } & Copulativa & Não há oposição entre elas (il.: Pedro é tenente e Antônio é capitão). \\
\hline & Adversativa & Há oposição entre elas (Pedro é conservador e Antônio é liberal). \\
\hline & Contratas & $\begin{array}{l}\text { Sentenças coordenadas com o mesmo ‘sujeito', 'predicado' ou } \\
\text { 'adjunto adverbial' (il.: Pedro furtou um relógio e foi pilhado em } \\
\text { flagrante; Pedro está bêbado e Antônio, louco). }\end{array}$ \\
\hline & Colaterais & $\begin{array}{l}\text { Sentença que estando a par umas das outras não se acham ligadas por } \\
\text { conjunção (il.: vim, vi, venci). }\end{array}$ \\
\hline Subordinação & $\begin{array}{c}\text { Cláusula } \\
\text { substantivo }\end{array}$ & $\begin{array}{l}\text { Aquela que em sua relação com o resto da 'sentença' equivale a um } \\
\text { 'substantivo. Começa sempre por “'de”" ou 'que”. Pode ser 'sujeito' } \\
\text { do 'verbo' da 'cláusula principal'; 'objeto' desse mesmo 'verbo'; } \\
\text { 'predicado' dele; 'adjunto atributivo' do sujeito ou do 'objeto' do } \\
\text { mesmo 'verbo', 'complemento de preposição' (il.: que eu caísse, era } \\
\text { o que ele desejasse; eu disse-te que fosses; Pedro é exatamente oque }\end{array}$ \\
\hline
\end{tabular}




\begin{tabular}{|c|c|c|}
\hline & $\begin{array}{c}\text { parece ser; a ideia de que partirás sem mim, tortura-me o coração; } \\
\text { arrependo-me de que lhe tivesse dito). }\end{array}$ \\
\cline { 2 - 3 } & $\begin{array}{c}\text { Cláusula } \\
\text { adjetivo }\end{array}$ & $\begin{array}{c}\text { Aquela que em sua 'relação' com o resto da 'sentença' equivale a um } \\
\text { 'adjetivo'. Está sempre em 'relação atributiva' o o 'substantivo' } \\
\text { expresso ou subentendido ao qual se por meio de um 'pronome } \\
\text { relativo' (il.: veja este lenço que eu bordei). }\end{array}$ \\
& $\begin{array}{c}\text { Cláusula } \\
\text { advérbio }\end{array}$ & $\begin{array}{c}\text { Aquela que em sua relação com o resto da 'sentença' equivale a um } \\
\text { 'advérbio'. Está sempre em relação adverbial para com um } \\
\text { substantivo, para com um 'adjetivo', ou para com um 'verbo' (il.: } \\
\text { Bayard, leão quando combatia, era cordeiro quando perdia; Pedro te } \\
\text { escrevia uma carta quando chegaste). Há 'cláusulas advérbio' de } \\
\text { tempo (quando, antes que), lugar (onde), ordem (antes que, depois } \\
\text { que), modo (como, assim como, porque), dúvida (se, se bem que). }\end{array}$ \\
\hline
\end{tabular}

Como vemos, diferentemente da maior parte dos gramáticos anteriores, Ribeiro já não trata de 'orações incidentes' ou 'parciais'.

\subsubsection{Rede conceitual}

Na edição de 1881, há uma rede conceitual que, tendo o 'verbo substantivo' como eixo, envolve divisão das metaclasses de palavras e os conceitos de 'verbo' e 'sentença'. Nas metaclasses de palavras, o 'verbo' se encaixa como 'palavra de relação'. Isso corresponderia ao conceito de 'verbo' que se definia como palavra que exprimia a existência de uma relação entre duas ideias. Nosso conceito-chave, o 'verbo substantivo' é uma das duas principais espécies de 'verbo' e define-se como aquele que indica a relação entre uma ideia qualquer e a ideia simples de substância; a outra espécie principal de 'verbo' é o 'predicativo' que indica a existência de uma relação entre uma ideia qualquer e a ideia de substância modificada por um 'predicado expresso' ou pela 'raiz verbal'. Há, assim, claramente, relação de intersecção entre os conceitos de 'verbo', de 'verbo predicativo' e de 'verbo substantivo'. Os verbos 'transitivo', 'intransitivo' e 'terminativo' incluem a noção de 'predicado' em sua definição, consequentemente, tendo relação de interseção com o 'verbo substantivo'. Ao definir a 'sentença', o gramático diz que ela consta de dois elementos, o 'sujeito' e o 'predicado', mas este último pode se dividir novamente em dois elementos, a 'cópula' e o 'predicado propriamente dito' e dá como ilustrações de uso "Rosas são flores" e "Pedro ama" que poderia ser fragmentado em "Pedro é amante", essa fragmentação evidencia a função do 'verbo substantivo', cujo único exemplo é "ser”, dentro das 'sentenças'. O conceito de 'verbo substantivo' trava, portanto relação de subordinação com os conceitos de 'sentença' e de 'verbo' suas espécies. 
É interessante observar que essa rede se perca quase completamente na segunda edição da obra, de 1885 , sobretudo porque isso não se dá apenas pelo fato do autor excluir os conceitos de 'verbo substantivo' e 'verbo predicativo' da obra. As metaclasses já são outras, o 'verbo' é parte daquela que abriga palavras 'independentes', como também o são o 'substantivo' e o 'pronome'. O 'verbo' é definido, com base em Whitney, como palavra que diz ou declara alguma coisa. As definições de verbos 'transitivo' e 'intransitivo' não apresentam mais o conceito de 'predicado' em texto, mas apenas em metatexto (o conceito de 'verbo terminativo', porém, mantém a noção de 'predicado' em texto). A definição de 'sentença' se mantém a mesma, mas uma das ilustrações de uso é modificada, "Pedro ama" é fragmentado em "Pedro am-a", sendo "am", 'radical', o predicado propriamente dito, enquanto "a" 'tema', que corresponderia também à 'cópula'. Vemos, portanto, que Ribeiro ao retirar o 'verbo substantivo' da obra, procurou eliminar os elementos a ele relacionados. Com isso, temos, na análise das gramáticas de Ribeiro, comprovação de nossa hipótese, de que o 'verbo susbtantivo' tem uma rede conceitual em torno de si, a qual é frequentemente eliminada junto com o conceito.

Ademais, quanto aos modificadores do nome, ainda que o autor apresente a distinção entre duas espécies de 'adjetivo', o ‘qualificativo' e o 'determinativo', e também distinga duas espécies de 'adjetivo qualificativo', 'restritivo' e 'explicativo' nas duas edições da obra, realizando as duas oposições de Noël e Chapsal (cf. item 1.4.2), não apresenta relações entre estes conceitos e as espécies de 'sentença', tal como comumente fizeram gramáticos anteriores.

Finalmente, é possível analisar a gramática de 1881 de Ribeiro como eclética, na medida em que, ao encaixar o conceito de 'verbo substantivo' e sua rede, o gramático apresenta, por um lado, ecletismo vertical, por apresentar dois conceitos de 'sentença' bastante diferentes, um baseado em Burgraff e outro em Whitney, e, por outro, ecletismo horizontal, na medida em que as espécies de 'sentença' e as 'funções' não tem relação com a noção de 'cópula' (como verbo "ser"). 
4.9. Grammatica Analytica (1887, [152]) e Grammatica Descriptiva (1895, [188]), de Maximino de Araujo Maciel

\subsubsection{Conceitos de gramática e de linguagem e organização da obra}

Em 1887, a gramática é definida como disciplina que trata das normas do pensamento humano pelo estudo analíticos dos fatos da linguagem. Há três espécies de gramática: 'descritiva', 'histórica' e 'filosófica'. Em 1895, a gramática é definida como sistematização lógica dos fatos e normas de uma língua qualquer - o conceito de pensamento desaparece da definição. Maciel apresenta quatro espécies, a 'descritiva', a 'histórica', a 'comparativa' e a 'geral'.

\begin{tabular}{|c|c|c|}
\hline $\begin{array}{l}\text { Espécies de } \\
\text { 'gramática' } \\
\text { (termo) }\end{array}$ & Conceito em 1887 & Conceito em 1895 \\
\hline $\begin{array}{l}\text { Descritiva / } \\
\text { Expositiva / } \\
\text { Particular } \\
\text { (1887) }\end{array}$ & $\begin{array}{l}\text { Trata praticamente das normas ou fatos } \\
\text { de uma língua qualquer. }\end{array}$ & $\begin{array}{l}\text { Sistematização orgânica dos fatos e } \\
\text { normas próprios de uma língua, } \\
\text { isoladamente considerada. } \\
\text { 'Gramática portuguesa': sistematização } \\
\text { orgânica das normas e fatos da língua } \\
\text { portuguesa, isoladamente considerada. }\end{array}$ \\
\hline $\begin{array}{l}\text { Histórica ou } \\
\text { Comparativa } \\
\quad(1887) \\
\text { Histórica } \\
(1895)\end{array}$ & $\begin{array}{l}\text { Trata dos fatos de uma língua em } \\
\text { diferentes épocas ou compara os fatos de } \\
\text { uma língua com os de outras, para }\end{array}$ & $\begin{array}{c}\text { Sistematização das normas e fatos da } \\
\text { língua desde a sua origem até nossos } \\
\text { dias, isto é, aquela que trata da evolução } \\
\text { da língua nos seus diversos períodos de } \\
\text { formação. }\end{array}$ \\
\hline $\begin{array}{l}\text { Comparativa } \\
\text { (1895) }\end{array}$ & conhecer as suas relacões & $\begin{array}{l}\text { Sistematização das normas e fatos de } \\
\text { duas ou mais línguas comparadas entre } \\
\text { si, isto é, nas suas diversas relações e } \\
\text { divergências. }\end{array}$ \\
\hline $\begin{array}{l}\text { Filosófica } \\
(1887) / \\
\text { Geral }\end{array}$ & $\begin{array}{l}\text { Aquela que procura ou investiga as } \\
\text { diferentes leis e princípios que dirigem } \\
\text { os fatos gerais da linguagem. }\end{array}$ & $\begin{array}{l}\text { Poderia se chamar 'glossologia', isto é, o } \\
\text { tratado das normas gerais e abstratas que } \\
\text { é possível aplicar à expressão do } \\
\text { pensamento ou à linguagem. De acordo } \\
\text { com Sayce, "linguagem é a manifestação } \\
\text { exterior do pensamento consciente". }{ }^{107}\end{array}$ \\
\hline
\end{tabular}

A gramática de 1895 apresenta maior detalhamento nas definições, ao ponto mesmo de distinguir duas espécies de 'gramática' onde 1887 havia apenas uma. Ademais, em 1887, Maciel preocupava-se em demonstrar de que assuntos tratava cada espécie de gramática, já em 1895, exceto pela 'gramática geral', especifica que as gramáticas são sistematizações. É curioso que, quando define 'gramática geral', em 1895, o gramático a

${ }^{107}$ Referência a La science du Language, de Max Müller; Philologie Comparée de Sayce. 
equivale a outro conceito, o de 'glossologia' 108 , algo que é feito também por Pacheco e Lameira (1887), que usa outro termo 'glotologia' (cf. 4.10); esta gramática, diferentemente das outras, não é definida como 'sistematização', mas como 'tratado', o qual corresponde a normas gerais da 'linguagem' enquanto 'expressão do pensamento'.

Ao definir 'linguagem', o autor apresenta diferentes "modos de manifestar o pensamento" em 1887; já em 1895 considerara-a a manifestação mediante sinais cuja teorização constitui a 'sêmica' (nota de rodapé com referência a A língua portugueza, de Adolpho Coelho). Há três espécies de modos de expressar o pensamento: 'linguagem', 'escritura' e 'gesticulação' ou 'mimica' ou 'accionação'; esses três parecem equivalentes às espécies de 'sêmica': 'fonética', 'gráficas' e 'mímica'. No quadro adiante, apresentamos conceitos dessas espécies.

\begin{tabular}{|c|c|c|c|}
\hline \multicolumn{2}{|c|}{ Conceitos em 1887 } & \multicolumn{2}{c|}{ Conceitos em 1895 } \\
\hline $\begin{array}{c}\text { Modos de } \\
\text { manifestar o } \\
\text { pensamento } \\
\text { (termos) }\end{array}$ & Conceito & $\begin{array}{c}\text { Manifestação do } \\
\text { pensamento: } \\
\text { Sêmica } \\
\text { termos) }\end{array}$ & Conceito \\
\hline Linguagem & $\begin{array}{c}\text { Manifesta o pensamento por } \\
\text { meio da voz humana. }\end{array}$ & Fonética & $\begin{array}{c}\text { Manifesta o pensamento por } \\
\text { meio da voz humana, isto é, } \\
\text { sons articulados. A linguagem } \\
\text { no rigor do termo, a palavra } \\
\text { viva. (Ref. a Gram. Franc. } \\
\text { d'après l'histoire, de Delon) }\end{array}$ \\
\hline Escritura & $\begin{array}{c}\text { Manifesta o pensamento via } \\
\text { 'caracteres significativos' }\end{array}$ & Gráfica & $\begin{array}{c}\text { Manifesta o pensamento via } \\
\text { 'símbolos literais'. Constitui o } \\
\text { que vulgarmente se chama } \\
\text { 'linguagem escrita'. }\end{array}$ \\
\hline $\begin{array}{c}\text { Gesticulação/ } \\
\text { Mímica / } \\
\text { Accionação }\end{array}$ & $\begin{array}{c}\text { Manifesta o pensamento por } \\
\text { meio de certos movimentos } \\
\text { fisiológicos ou sinais } \\
\text { mímicos. }\end{array}$ & Mímica & $\begin{array}{c}\text { Manifesta o pensamento por } \\
\text { meio de certos movimentos } \\
\text { fisiológicos ou gesticulações. }\end{array}$ \\
\hline
\end{tabular}

Quadro 62. Diferentes 'modos' de 'manifestar o pensamento' em Maciel $(1887,1895)$

Embora a terminologia seja diferente, o conceito dos modos de manifestar o pensamento é similar nas duas gramáticas de Maciel. Há mais acréscimo no conceito de ‘linguagem', que é seguido de referência bibliográfica. Em 1887 e 1895 a gramática é

108 É provável que na referência que faz a Max Müller, Maciel esteja considerando este trecho : La science du langage est de date très-récente : elle ne remonte pas beaucoup au-delà du commencement de notre siècle, et les autres sciences, ses soeurs ainées, l'admettent à peine sur un pied d'égalité. Son nom même est encore indéterminé, et les dénominations diverses qu'elle a reçues en Angleterre, en France et en Allemagne, sont si vagues et si mobiles qu'elles ont donné lieu, dans le public, aux idées les plus confuses sur les sujets réls de cette nouvelle science. Nous l'entendons appeler la Philologie comparée, l'Étymologie scientifique, la Phonologie et la Glossologie. En France, elle est connue sous le nom commode, mais un peu barbare, de linguistique. (Max Müller 1867 :4-5). (cf. Polachini 2013: 69). 
dividia em quatro 'partes', que são 'phonologia', 'lexeologia', 'syntaxologia' e 'semeiologia'. (cf. Apêndice B, FD12 e FD18).

Da mesma forma que outros gramáticos do período, Maciel parece, em seus conceitos de 'gramática' e 'linguagem', misturar os Programas de Investigação de Correspondência, por enfatizar que a língua seja manifestação do pensamento, e o Programa Descritivista, em que a língua é segmentada e comparada com outras ou com diferentes estágios de seu desenvolvimento.

\subsubsection{Conceitos de metaclasses e classes de palavras}

Em ambas as gramáticas (Maciel 1887, 1895), as classes de palavras aparecem na seção denominada 'taxionomia' da gramática de Maciel, seção essa que é definida em 1887 como "classificação das palavras em categorias correspondentes ás idéas que exprimem" (Maciel 1887:73) e em 1895 como a "classificação das palavras em grupos segundo as categorias lógicas a que correspondem" (Maciel 1895: 90) - uma diferença sútil entre as obras, portanto.

Nas duas gramáticas, há as mesmas três metaclasses de palavras (as quais, em 1895, Maciel diz ter retirado da Gram. Supérieure de Larouse), são elas: 'nominativas', 'modificativas' e 'conectivas'. As primeiras correspondem, nas duas gramáticas, ao 'substantivo', ao 'pronome' e, em 1895, também ao 'verbo'; as 'modificativas', ao 'adjetivo' e ao 'advérbio' e, em 1887, também ao 'particípio'; as 'conectivas' são a 'preposição' e a ‘conjunção', e, em 1887, também ao ‘verbo'. O gramático ainda observa, nas duas gramáticas, que os 'pronomes relativos' entram no grupo das 'conectivas' (apesar da classe do 'pronome' estar nas 'nominativas'), pois ligam as 'proposições', o 'particípio', por sua vez, em 1895, pode ser 'modificativo' ou 'nominativo' de acordo com a sua função de 'verbo' ou de 'adjetivo', finalmente, em ambas as obras, Maciel afirma que a ‘interjeição' não é classe de palavra - por ser “o grito synthetico e organico que, arrancado sob um impulso violento do nosso ser, exprime syntheticamente o sentimento subito que nos afeta [...] vale por uma proposição implícita" (1887:74) ou por ser "mais um grito, uma phrase latente e instantenea do que propriamente palavra" (1895:90). Além disso, na seção destinada ao tratamento de cada classe de palavra da Grammatica Descriptiva (1895), Maciel dá um epíteto a elas. No quadro adiante, apresentamos uma síntese das metaclasses, classes de palavras apresentadas por Maciel em texto com também os nomes que ele dá a cada classe. 


\begin{tabular}{|c|c|c|c|}
\hline Metaclasse & Classes 1887 & Classes 1895 & $\begin{array}{c}\text { Epíteto dado à classe } \\
\text { em } 1895\end{array}$ \\
\hline \multirow{4}{*}{ Nominativas } & Substantivo & Substantivo & Palavra de entidade \\
\hline & Pronome & Pronome & Palavra de substituição \\
\hline & - & Verbo & Palavra de afirmação \\
\hline & - & \multirow{2}{*}{ (Particípio) } & \multirow{2}{*}{-} \\
\hline \multirow{3}{*}{ Modificativas } & Particípio & & \\
\hline & Adjetivo & Adjetivo & Palavra de modificação \\
\hline & Advérbio & Advérbio & Palavra de circunstância \\
\hline \multirow{4}{*}{ Conectivas } & Verbo & - & - \\
\hline & Preposição & Preposição & Palavra de relação \\
\hline & Conjunção & Conjunção & Palavra de ligação \\
\hline & Pronome relativo & (Pronome relativo) & - \\
\hline- & (Interjeição) & (Interjeição) & - \\
\hline
\end{tabular}

Quadro 63. Metaclasses, classes e epítetos em Maciel $(1887,1895)$

Como se pode ver, é notável que o 'verbo' muda de metaclasse de uma gramática para outra de Maciel. Na primeira, faz parte das palavras 'conjuntivas', ao passo que na segunda, enquadra-se nas palavras 'nominativas'. Observaremos mais adiante as relações que tal mudança pode ter com o próprio conceito de 'verbo'. Ademais, o 'particípio faz parte das palavras 'modificativas' em 1887 e, em 1895, fica entre a 'categoria' das 'modificativas' e das 'nominativas'.

Em metatexto (menção a outros gramáticos) de 1895 apenas, o gramático observa que a “velha divisão clássica” (p. 90) em 'nome', 'verbo' e 'partícula' e a divisão de Mason em 'palavras nocionais' e 'palavras relacionais' não condizem com as condições atuais das línguas - em nota de rodapé, apresenta a seguinte referência: La trossiéme année de Grammaire, de Larrive et Fleury. Como vimos, outros gramáticos brasileiros também refletem a respeito das primeiras metaclasses ${ }^{109}$.

\subsubsection{Conceitos modificadores do nome}

O 'adjetivo', denominado como 'palavra de modificação’ em 1895, define-se em ambas as gramáticas como a 'compreensão' ou a 'extensão' de um 'nome apelativo' (1887) 'substantivo’ (1895). Na gramática mais antiga (1887:87), subdividem-se em 'qualificativo' e 'determinativo'. O primeiro, também chamado 'descritivo', modifica a

${ }^{109}$ Carneiro Ribeiro (1881), tal como Maciel, rejeita as metaclasses de 'nome', 'verbo' e 'partícula', em sua gramática posterior, de 1890, cita essa possibilidade de metaclasses mas não a aplica. Ribeiro (1881), por outro lado, aplica essas metaclasses, as quais são retiradas da edição seguinte, de 1885, da gramática (cf. 4.7 e 4.8$)$. 
'compreensão' do 'nome apelativo', juntando-lhe uma ideia de qualidade (ex. de 1887: casa nova, homem louco). O 'determinativo', por sua vez, modifica a extensão do 'nome apelativo', limitando-o a um maior ou menor número de indivíduos. Na gramática de 1895, vemos mudança terminológica, mas sútil diferença no conceito das espécies de 'adjetivo', o qual é 'descritivo' quando modifica a 'compreensão' de um 'substantivo' mediante uma ideia de qualidade ou propriedade (il.: homem, alto, magro, pálido, nervoso, inteligente, sagaz, sábio), e 'designativo' quando limita a 'extensão' do 'substantivo' definida ou indefinidamente. Em metatexto (reflexão), explica, de certa forma, a mudança terminológica de uma obra para outra, afirmando que esses nomes estão mais de acordo com a 'gramática moderna' do que os termos 'qualificativo' e 'determinativo' (os quais, como vimos, foram usados por um número considerável de gramáticas ao longo do século); tal mudança terminológica se deve, segundo Maciel (1895), ao aprofundamento dos estudos dos fatos.

Acrescenta ainda, nas duas gramáticas, cinco aspectos que fazem as duas principais espécies de 'adjetivo' diferir entre si: (1) enquanto o número de 'determinativos'/'designativos’ é limitado e conhecido, há grande número de 'adjetivos 'qualificativos'/'descritivos'; (2) os 'adjetivos qualificativos'/‘descritivos' podem se antepor ou se pospor ao 'substantivo', ao passo que os 'determinativos'/'designativos' normalmente se antepõem (il.: branca neve, neve branca; este livro); (3) a maior parte dos 'qualificativos'/‘descritivos' podem formar 'advérbio' (na forma feminina, com acréscimo do 'sufixo' -mente), já os 'designativos' não podem formar 'advérbios', salvo alguns 'ordinais' ${ }^{110}$ (il.: grandemente; perfeitamente; primeiramente); (4) grande parte dos 'descritivos' têm 'grau', ao passo que os 'designativos' não o tem ${ }^{111}$; (5) todo 'qualificativo'/'descritivo' sem 'substantivo' torna-se 'substantivo' ('substantivo acidental', em 1887), já os 'determinativos'/‘designativos' passam ao estado de 'pronome' ('pronome adjetivo', em 1887). Exemplifica em 1887: “o justo” e "este é meu”. Conclui em 1895 que, assim, os 'descritivos' são 'adjetivos nominais' e os 'designativos', 'pronominais'.

\footnotetext{
${ }^{110}$ Em 1887 (p.88), ele afirma, em metatexto (nota), que os 'determinativos ordinais' devem, antes de formar um 'advérbio', passar pelo estado de 'qualificativos' (ex.: primeira-mente). Não há essa afirmação na obra de 1895 .

${ }^{111}$ Em 1887 (p. 88), Maciel observa, em metatexto (nota), que por vezes podem ser encontrados na língua as expressões "muitíssimo" e "mesmíssimo", mas não devem ser empregadas, dado que não têm autoridade clássica para tal. Comenta também que não raro escutamos a expressão "esse objeto é mais meu do que seu", mas que nelas a comparação não se exerce no determinativo, mas nas expressões "é meu" e "é seu" que, diz o gramático, "são verdadeiras locuções que os determinativos formam com o verbo 'ser', significando 'pertencer”" (Maciel 1887:88).
} 
Essas duas espécies também são gêneros de outras espécies, cujos conceitos que apresentamos nos quadros adiante, comparando as duas gramáticas:

\begin{tabular}{|c|c|c|c|}
\hline Gênero & Espécies & Conceito em texto de 1887 & Conceito em texto de 1895 \\
\hline \multirow{3}{*}{$\begin{array}{l}\text { Qualificativo } \\
\text { Descritivo }\end{array}$} & Restritivo & $\begin{array}{l}\text { Modifica a ‘compreensão’ do } \\
\text { ‘nome apelativo', juntando-lhe } \\
\text { uma ideia de qualidade } \\
\text { 'acidental', isto é, não incluída } \\
\text { na própria significação do } \\
\text { 'nome apelativo' (ex.: homem } \\
\underline{\text { sábio, mesa redonda, árvore }} \\
\text { alta). }\end{array}$ & 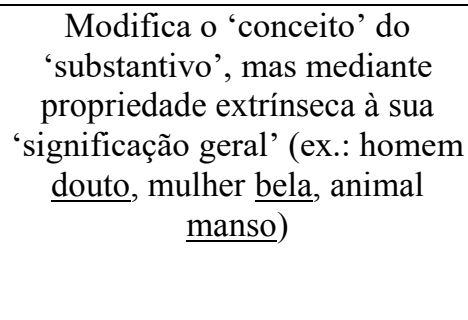 \\
\hline & $\begin{array}{c}\text { Explicativo } \\
\text { (Latente, 1895) }\end{array}$ & $\begin{array}{l}\text { Modifica a 'compreensão' do } \\
\text { 'nome apelativo', juntando-lhe } \\
\text { uma ideia de 'qualidade } \\
\text { essencial', isto é, incluída na } \\
\text { própria significação do 'nome } \\
\text { apelativo' (ex.: homem mortal, } \\
\text { sol brilhante, leite branco). }\end{array}$ & $\begin{array}{c}\text { Modifica o ‘conceito’ do } \\
\text { ‘substantivo’, mas mediante } \\
\text { uma ideia de propriedade } \\
\text { intrínseca112 à sua significação } \\
\text { geral (ex.: homem moral, sol } \\
\text { brilhante, neve branca, mármore } \\
\underline{\text { duro). }}\end{array}$ \\
\hline & $\begin{array}{l}\text { Específicos } \\
\text { (1895) }\end{array}$ & - & $\begin{array}{l}\text { Restringem-se a exprimir } \\
\text { sempre uma ideia de pessoa ou } \\
\text { de lugar. Há duas espécies: } \\
\text { - Personativos: calcados no } \\
\text { radical de um 'substantivo } \\
\text { personativo' (il.: leis } \\
\text { manuelinas, ordenações } \\
\text { afonsinas, mês mariano). } \\
\text { - Locativos: calcados no radical } \\
\text { de um nome de lugar (ex.: } \\
\text { americano, brasileiro, sergipano, } \\
\text { lisboense, paraense) }\end{array}$ \\
\hline
\end{tabular}

Alguns metatextos são acrescentados aos conceitos supracitados. Em ambas as obras, Maciel observa que se o 'adjetivo' será de uma espécie ou outra a depender do 'substantivo', dado que o mesmo 'adjetivo' pode ser 'explicativo' em relação a um ‘substantivo' e 'restritivo' em relação a outro (ex.: neve branca; saia branca) ${ }^{113}$. Ressalta ainda que os 'adjetivos explicativos' ou 'latentes' possam, indiferentemente, se pospor ou antepor ao 'substantivo', ao passo que os 'restritivos' geralmente se pospõem, pois podem ter significados diversos quando antepostos (il.: simples coisa, coisa simples; santa casa, casa santa; pobre homem, homem pobre). $\mathrm{Na}$ edição de 1895, apresenta duas observações, diz primeiramente que Sotero dos Reis (cuja gramática é analisada no item 4.6) considerou os 'adjetivos específicos' erradamente como ‘adjetivos possessivos' - em

\footnotetext{
112 No texto está escrito "extrínseca", entretanto, acreditamos que isso foi um engano da tipografia, pois, caso a palavra seja mesmo "extrínseca" as duas espécies de 'adjetivo' têm o mesmo significado.

${ }^{113}$ Esse tipo de discussão parece se tornar comum no fim do século, estando presente também em Condurú (1888).
} 
nota de rodapé apresenta não apenas a referência da gramática de Sotero dos Reis, mas também a de Carneiro Ribeiro (analisada neste trabalho no item 4.7), dado que o gramático baiano fez essa mesma afirmação sem, porém, se remeter especificamente a Sotero dos Reis. A citação de outras gramáticas brasileiras revela o conhecimento que Maciel tinha dessa tradição. Observa também que os 'específicos' têm sido chamados de 'gentílicos', 'pátrios' ou 'nacionais', mas afirma estarem essas denominações em desacordo com os fatos, por isso é preferível o termo mais genérico de 'locativo'.

\begin{tabular}{|c|c|c|c|}
\hline Gênero & Espécies & Conceito em texto de 1887 & Conceito em texto de 1895 \\
\hline \multirow[t]{4}{*}{ Designativos } & Articulares & $\begin{array}{l}\text { Limitam a extensão do nome } \\
\text { apelativo particularizando-lhe a } \\
\text { significação. Há duas espécies: } \\
\text { - Definito: modifica a extensão } \\
\text { do 'nome apelativo' } \\
\text { particularizando-lhe a } \\
\text { significação de modo certo e } \\
\text { positivo (ex.: o, a, os, as) } \\
\text { - Indefinito: Modifica a } \\
\text { extensão do nome apelativos } \\
\text { particularizando-lhe a } \\
\text { significação de um modo } \\
\text { incerto e vago (ex.: um, uma) }\end{array}$ & $\begin{array}{l}\text { Chama-se também 'artigo } \\
\text { definito'. É o 'designativo } \\
\text { monossilábico' que } \\
\text { individualiza a significação do } \\
\text { 'substantivo' de modo positivo } \\
\text { e certo (ex.: o, a, os, as). }\end{array}$ \\
\hline & Demonstrativos & $\begin{array}{c}\text { Modificam a extensão do } \\
\text { 'nome' limitando-o a um } \\
\text { ‘indivíduo' situado no espaço } \\
\text { ou na 'proposição'. São } \\
\text { 'simples' (ex.: este, esse, } \\
\text { aquele) ou } \\
\text { ‘compostos'/‘combinados' (ex.: } \\
\text { est'outro, ess'outro, } \\
\text { aquel'outro). }\end{array}$ & $\begin{array}{l}\text { Modificam a extensão do } \\
\text { ‘nome' mediante uma ideia de } \\
\text { lugar no espaço ou na } \\
\text { 'proposição'. São 'simples' } \\
\text { (ex.: este, esse, aquele) ou } \\
\text { 'compostos' (ex.: est'outro, } \\
\text { ess'outro, aquel'outro). }\end{array}$ \\
\hline & Possessivos & $\begin{array}{l}\text { Modificam a extensão do 'nome } \\
\text { apelativo' limitando-o sob uma } \\
\text { relação definida de posse (ex.: } \\
\text { meu, teu, seu, nosso, vosso, } \\
\text { seus). São cognatos dos } \\
\text { 'pronomes pessoais'. }\end{array}$ & $\begin{array}{l}\text { Modificam a extensão do } \\
\text { ‘substantivo' mediante uma } \\
\text { relação definida de posse (ex.: } \\
\text { meu, teu, seu, nosso, vosso, } \\
\text { seus) São cognatos dos } \\
\text { 'pronomes pessoais'. }\end{array}$ \\
\hline & Indefinitos & $\begin{array}{l}\text { Modificam a extensão do 'nome } \\
\text { apelativo', limitando-o de um } \\
\text { modo mais ou menos vago ou } \\
\text { geral (ex.: algum, certo, pouco } \\
\text { quanto etc.). Há duas espécies: } \\
\text { - Universais: estendem a } \\
\text { significação do 'nome } \\
\text { apelativo' a todos os indivíduos } \\
\text { de uma 'classe' (ex.: todos, } \\
\text { nenhum, cada, qualquer, algum } \\
\text { (posposto)). } \\
\text { - Partitivos: estendem a } \\
\text { significação do nome apelativa } \\
\text { a uma parte dos indivíduos de } \\
\text { uma 'classe' (algum } \\
\text { (anteposto), pouco, outro, } \\
\text { quanto, tal). }\end{array}$ & $\begin{array}{l}\text { Modificam a extensão do ‘nome } \\
\text { apelativo', porém de um modo } \\
\text { mais ou menos vago ou geral } \\
\text { (ex.: algum, alheio, cada, } \\
\text { menos, nenhum, outro, qual). } \\
\text { Às vezes também as palavras } \\
\text { “que, certo, vários, diversos” } \\
\text { precedendo geralmente ao } \\
\text { 'substantivo'. Há duas espécies: } \\
\text { - Universais: estendem a } \\
\text { significação do 'substantivo' a } \\
\text { todos os indivíduos de uma } \\
\text { 'classe' (ex.: todos, nenhum, } \\
\text { cada, qualquer, algum } \\
\text { (posposto)). } \\
\text { - Distributivos: estendem a } \\
\text { significação do substantivo a }\end{array}$ \\
\hline
\end{tabular}




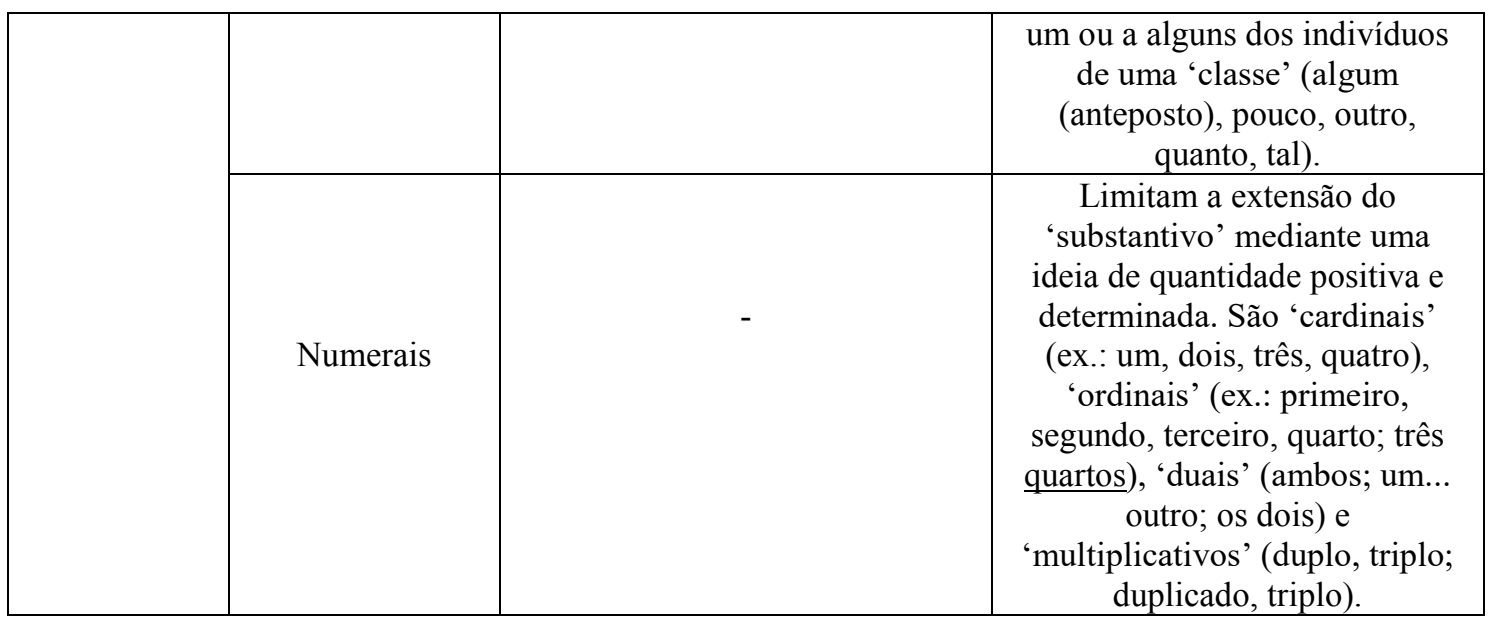

Quadro 65. Espécies de 'adjetivo designativo' em Maciel $(1887,1895)$

Em metatexto (reflexão), na gramática de 1887, observa que as formas "um, uma, uns, umas" devem passar para 'adjetivos indefinitos', são consideradas 'artigos' simplesmente por serem 'proclíticas' e 'monossilábicas'. Parece esta ser uma observação que faz referência à gramática de 1887, na qual, como vimos, "um” e "uma” eram considerados 'adjetivos articulares'.

O 'pronome', denominado em 1895 como 'palavra de substituição', é definido como qualquer palavra substituta dos nomes ou "de qualquer parte da oração tomada nominativamente" (1887:80) ou "de qualquer expressão nominativa” (1895: 101). Há duas espécies principais, os 'pronomes substantivos' e os 'pronomes adjetivos'. No quadro abaixo, apresentamos o conceito das espécies em cada uma das gramáticas.

\begin{tabular}{|c|c|c|}
\hline Espécie & Conceito em texto de 1887 & Conceito em texto de 1895 \\
\hline Substantivo & $\begin{array}{c}\text { Chama-se também 'essencial'. Aquele } \\
\text { que na 'proposição' é sempre empregado } \\
\text { como pronome (ex.: eu, tu, isto, quem). } \\
\text { Há quatro espécies: 'pessoais', } \\
\text { ‘demonstrativos', 'conjuntivos'e } \\
\text { 'indefinitos'. }\end{array}$ & $\begin{array}{l}\text { Substituem sempre os 'nomes', pois não } \\
\text { exercem outra função (ex.: eu, ele, tu, } \\
\text { nós, vós, eles, ninguém). Há cinco } \\
\text { espécies: 'pessoais', 'demonstrativos', } \\
\text { 'articulares', 'conjuntivos' e 'indefinitos'. }\end{array}$ \\
\hline Adjetivo & $\begin{array}{c}\text { Chama-se também 'acidental'. Qualquer } \\
\text { 'adjetivo determinativo' empregado na } \\
\text { 'proposição' sem 'substantivo' } \\
\text { enunciado. }\end{array}$ & $\begin{array}{l}\text { Não substituem propriamente o nome, } \\
\text { mas apenas lhes evitam a repetição (ex.: } \\
\text { este homem e aquele; teu livro e o meu). } \\
\text { Constituem uma função dos 'adjetivos } \\
\text { designativos', até mesmo os 'numerais' } \\
\text { têm força pronominal (ex.: eu tenho um } \\
\text { livro, tu dois) })^{114} \text {. }\end{array}$ \\
\hline
\end{tabular}

Quadro 66. Principais espécies de 'pronomes' em Maciel $(1887,1895)$

No quadro adiante, apresentamos os conceitos das espécies de 'adjetivo substantivo’ nas duas gramáticas.

${ }^{114}$ Em nota de rodapé, apresenta referência da Grammatica Analytica da Lingua Portugueza de Grivet. 


\begin{tabular}{|c|c|c|}
\hline $\begin{array}{l}\text { Espécie de 'adjetivo } \\
\text { substantivo' (termo) }\end{array}$ & Conceito em texto de 1887 & Conceito em texto de 1895 \\
\hline Pessoais & $\begin{array}{l}\text { Aqueles que substituem as pessoas } \\
\text { gramaticais (ex.: eu, tu, ele, ela, nós, } \\
\text { vós, eles, elas). Os pronomes } \\
\text { assumem diferentes formas, para } \\
\text { enunciação de funções sintáticas } \\
\text { distintas. as quais se chamam } \\
\text { 'declinação dos pronomes pessoais' } \\
\text { (ex.: me mim, migo, te, ti, tigo, se, si, } \\
\text { sigo, lhe, o, a, nos, nosco, vos, vosco, } \\
\text { se, si, sigo, lhes, os, as). }\end{array}$ & $\begin{array}{l}\text { Aqueles que substituem as pessoas } \\
\text { gramaticais. (ex.: eu, tu, ele, ela, nós, } \\
\text { vós, eles, elas). A cada um dos } \\
\text { pronomes correspondem outras } \\
\text { formas pronominais, de acordo com } \\
\text { as relações sintáticas (ex.: me mim, } \\
\text { migo, te, ti, tigo, se, si, sigo, lhe, o, a, } \\
\text { nos, nosco, vos, vosco, se, si, sigo, } \\
\text { lhes, os, as). }\end{array}$ \\
\hline Demonstrativos & $\begin{array}{c}\text { Substituem o 'nome', limitando-o } \\
\text { mediante alguma relação de situação } \\
\text { no espaço ou na proposição (isto, } \\
\text { isso, aquilo). }\end{array}$ & $\begin{array}{l}\text { Substituem o ‘nome’, indicando uma } \\
\text { relação de posição no espaço ou na } \\
\text { proposição (isto, isso, aquilo, o } \\
\text { (quando significa “aquilo”); il.: o que } \\
\text { é útil é caro). }\end{array}$ \\
\hline Articulares & - & $\begin{array}{l}\text { Próprio ‘artigo definito', substituindo } \\
\text { na proposição a um substantivo } \\
\text { anteriormente expresso (il.: este livro, } \\
\text { melhor que o (livro) que compraste } \\
\text { não é o livro da tua irmã). }\end{array}$ \\
\hline $\begin{array}{c}\text { Conjuntivos / } \\
\text { Relativos }\end{array}$ & $\begin{array}{l}\text { Conjuntivos, também chamados } \\
\text { 'relativos' ou 'memorativos', são } \\
\text { aqueles que conjuntam duas } \\
\text { proposições e se referem } \\
\text { rigorosamente a um nome } \\
\text { antecedentemente enunciado (ex.: } \\
\text { que, qual, quem, cujo). }\end{array}$ & $\begin{array}{l}\text { Relativos são aqueles que conjuntam } \\
\text { duas proposições e sempre se referem } \\
\text { a um nome anteriormente expresso } \\
\text { (ex.: que, o qual, quem, cujo, onde, } \\
\text { (em alguns casos) quando). Também } \\
\text { se dizem 'conjuntivos' porque } \\
\text { servem de conectivo a preposições. }\end{array}$ \\
\hline Indefinitos & $\begin{array}{l}\text { Substitui o 'nome', porém de um } \\
\text { modo vago, mais ou menos geral } \\
\text { (ex.: tudo, nada, ninguém, alguém, } \\
\text { outrem, fulano, sicrano, beltrano, al, } \\
\text { algo). }\end{array}$ & $\begin{array}{l}\text { Substitui o 'substantivo', porém de } \\
\text { modo vago e indeterminado (ex.: } \\
\text { tudo, nada, ninguém, al, algo, } \\
\text { alguém, outrem, etecetera, fulano, } \\
\text { beltrano, sicrano) }\end{array}$ \\
\hline
\end{tabular}

Quadro 67. Espécies de 'adjetivo substantivo' em Maciel (1887, 1895)

Há metatextos (notas) diferentes nas gramáticas para 'pronome pessoal'. Na de 1887, acrescenta que há a palavra "você”, considerada 'pronome pessoal de uso familiar'. Nas duas gramáticas, Maciel observa que os 'pronomes' "migo, tigo, sigo, nosco, vosco" são de uso limitado, pois só se usam pospostos à 'preposição' "com”. Em 1895, o autor comenta em metatexto (nota) que os 'pronomes' "ele" e "ela" são mais 'pronomes demonstrativos' do que propriamente 'pessoais'.

\subsubsection{Conceito de verbo}

Como vimos, o 'verbo' está em metaclasses diferentes nas duas gramáticas de Maciel. Em 1887, é 'palavra conjuntiva', ao passo que em 1895 é 'palavra nominativa'. A definição também difere nas duas obras. Em 1887, é definido como "a palavra conjuntiva que sob a noção de tempo exprime a existencia de um facto abstracto ou concreto, ex.: amo, quebro, etc.” (Maciel 1887: 107). Além disso, em 1887, enfatiza que 
o 'verbo' é 'palavra por excelência', dado que é elemento essencial ao 'juízo' e sempre exprime 'afirmação', que é declarar se uma coisa é ou deixa de ser. Em 1895, é "palavra de tempo destinada a affirmar e a exprimir simultaneamente os factos" (Maciel 1895: 104).

As espécies de 'verbo' são diferentes de uma gramática de Maciel para outra. Em 1887, ele distingue, inicialmente, o 'verbo substantivo' ou 'abstrato' do 'verbo atributivo' ou 'predicativo'. O primeiro não tem 'atributo' incluído em si e exprime uma noção de existência em absoluto (ex.: ser). Em metatexto, explica que o 'verbo' "estar" não pode ser 'substantivo', pois tem um 'atributo', visto que "estar" significa existir em um certo estado (il.: Maria stabat ad crucem). É curioso que o gramático, falando da língua portuguesa, apresente uma ilustração de uso em latim, sobretudo considerando que o verbo latino "stabat" talvez não corresponda exatamente ao que significa "estar" em português. Acrescenta, ainda, que se “estar” for 'verbo substantivo' outros 'verbos' que exprimem uma noção de existência modificada também o serão, como é o caso de "andar, ficar, permanecer”. O ‘verbo substantivo’ tem duas espécies: é 'abstrativo' quando limitase a exprimir a existência um 'sujeito' sem 'modificação predicativa' (il.: era no outono; Deus é, foi e será); é 'conectivo' quando limita-se a exprimir a existência de um sujeito com modificação predicativa (il.: as flores são belas; Deus é onisciente). ${ }^{115}$

O 'verbo atributivo', também chamado 'predicativo' ou 'concreto', tem o predicado incluído no 'radical' e exprime uma noção de 'existência relativa'. Todos os 'verbos' dessa espécie equivalem ao 'verbo' "ser” e um 'predicado' expresso pelo 'radical verbal' (il.: as estrelas brilham, isto é, as estrelas são brilhantes; o sol luz, isto é, o sol é luzente). O 'verbo atributivo' concentra duas ideias em uma só palavra: a ideia de 'qualidade' incluída no 'radical' e a ideia de 'relação' incluída na 'flexão', sendo esta última traduzida 'materialmente' pelo 'verbo' "ser" (ex.: brilhar = brilhante ser; dizer = dizente ser; punir = puninte ser). Enfim, o autor conclui a definição dessas duas espécies de 'verbo' com uma observação (metatexto) explicando que pelo fato de todo verbo equivaler a “ser”, que liga o ‘sujeito' ao 'predicado', ele é uma 'palavra 'conjuntiva'.

\begin{tabular}{|c|c|c|}
\hline $\begin{array}{c}\text { Espécies de } \\
\text { 'verbo } \\
\text { atributivo' }\end{array}$ & $\begin{array}{c}\text { Espécies de } \\
\text { 'verbo transitivo' }\end{array}$ & Conceito em texto \\
\hline
\end{tabular}

115 Chama atenção o conceito de 'verbo substantivo abstrativo' apresenta a mesma ilustração dada por Ribeiro (1881 - cf. 4.8) “Deus é, foi e será”; em que o 'verbo substantivo' pode, na língua em uso, exprimir existência do sujeito sem a presença de um predicado. A definição de 'existência em absoluto' aparece também em Ribeiro 1889 (cf. 4.12). 


\begin{tabular}{|c|c|c|}
\hline $\begin{array}{c}\text { Intransitivo / } \\
\text { Subjetivo }\end{array}$ & - & Sua ação, não exigindo ‘objeto externo', fica no ‘sujeito'. \\
\hline \multirow{3}{*}{$\begin{array}{c}\text { Transitivo / } \\
\text { Objetivo }\end{array}$} & - & Sua ação exige um ‘objeto externo' sobre que recaia. \\
\cline { 2 - 3 } & Direto/ Imediato & $\begin{array}{c}\text { Sua ação se transmite a um 'objeto externo' sem intervenção } \\
\text { de 'preposição' (il.: tenho amigos, amos as rosas) }\end{array}$ \\
\cline { 2 - 3 } & Indireto / Mediato & $\begin{array}{c}\text { Sua ação se transmite a um 'objeto externo' mediante uma } \\
\text { 'preposição' (il.: usamos de café, precisamos de criados) }\end{array}$ \\
\cline { 2 - 3 } & Bitransitivo & $\begin{array}{c}\text { Sua ação se transmite a dois 'objetos externos', um ‘direto' e } \\
\text { outros 'indireto' (il.: mandei livros a Pedro; comprei limas a } \\
\text { João; concedi licença aos meninos) }\end{array}$ \\
\hline
\end{tabular}

Quadro 68. Espécies de 'verbo atributivo' em Maciel (1887)

Em metatexto, afirma que, para seu 'verbo bitransitivo', a maioria dos gramáticos dá o nome de 'verbo transitivo-relativo', que, à luz de uma análise semiológica, seria uma expressão altamente pleonástica, visto que tanto 'transitivo' quanto 'relativo' querem dizer que o 'verbo' tem uma ação revestida de certa 'relação' para com seu 'complemento necessário', assim seria o mesmo dizer 'verbo transitivo-transitivo' ou 'verbo relativorelativo'. Concorda com o gramático brasileiro Carneiro Ribeiro (cujas gramáticas são analisadas no item 4.7) que dá ao ‘verbo transitivo' o nome de 'verbo relativo'.

Enfim, apresenta um comentário acerca das mudanças por que passava a 'ciência da linguagem' no período, que transcrevemos completo adiante:

Abandonemos certas expressões taxeonomicas legadas pelas falsas observações do grammaticos antigos e consideremos os fatos da língua sob aspecto racional e scientifico. A sciencia da linguagem está atravessando uma época de transição, tendendo amplamente a estabelecer definitiva e positivamente as suas modernas theorias. (Maciel 1887:111).

Na Grammatica Descriptiva, de 1895, Maciel afirma que o 'verbo' tem uma 'predicação', sua 'significação' ou 'ação', uma 'personalidade', a integralidade de suas formas, e uma 'conjugação', a sistematização de suas formas regulares e irregulares. A 'predicação' determina espécies de 'verbos', as quais são similares às que vimos anteriormente na gramática de 1887. Há uma espécie de 'verbo de predicação completa', cuja significação não exige nenhum 'objeto' ou 'adjunto predicativo' (ex.: nascer, durar, morrer, correr). Há também três espécies de 'verbo de predicação incompleta', os quais exigem, em sua significação, um 'objeto' ou 'adjunto predicativo', e duas espécies de 'verbos de predicação dupla', cuja significação exige ao mesmo tempo dois 'objetos', um 'direto' e outro 'indireto'. No quadro adiante, apresentamos o conceito de cada uma dessas seis espécies de 'verbo'.

\begin{tabular}{|c|c|c|}
\hline Predicação & $\begin{array}{c}\text { Espécie de ‘verbo' } \\
\text { (termo) }\end{array}$ & Conceito em texto e metatexto \\
\hline Completa & - & $\begin{array}{c}\text { Sua significação não exige nenhum 'objeto' ou 'adjunto } \\
\text { predicativo' (ex.: nascer, durar, morrer, correr). }\end{array}$ \\
\hline
\end{tabular}




\begin{tabular}{|c|c|c|}
\hline \multirow[t]{3}{*}{ Incompleta } & Transitivo direto & $\begin{array}{c}\text { Sua significação se transmite a um ‘objeto’ imediatamente, } \\
\text { isto é, sem 'preposição' (ex.: estimar, mover, impelir, } \\
\text { depor). }\end{array}$ \\
\hline & Transitivo indireto & $\begin{array}{l}\text { Sua significação se transmite a um ‘objeto’ mediatamente, } \\
\text { isto é, com preposição (ex.: precisar (de); depender (de); } \\
\text { provir (de); obedecer (a); tender (a); corresponder (a); } \\
\text { acreditar (em)). As preposições são, em geral, "a”, “de” e } \\
\text { "em”. }\end{array}$ \\
\hline & Adjuntivo & $\begin{array}{l}\text { Sua significação, em vez de 'objeto’, exige um ‘adjunto } \\
\text { predicativo' (ex.: ser, estar, andar, ir, vir, ficar, } \\
\text { permanecer, continuar). }\end{array}$ \\
\hline \multirow[t]{2}{*}{ Dupla } & $\begin{array}{l}\text { Biobjetivo / } \\
\text { Bitransitivo }\end{array}$ & $\begin{array}{l}\text { Sua significação exige ao mesmo tempo dois ‘objetos’, um } \\
\text { ‘direto’ e outro ‘indireto' (ex.: dar, atribuir, contar, unir, } \\
\text { comprar, tirar). }\end{array}$ \\
\hline & Objetivo adjuntivo & $\begin{array}{l}\text { Exige não apenas o ‘objeto direto', mas também um } \\
\text { ‘adjunto predicativo' que modifica o ‘objeto’ e integra sua } \\
\text { significação (il.: fazer alguém feliz, julgar alguém bom). }\end{array}$ \\
\hline
\end{tabular}

Acrescenta em nota de rodapé conectada ao 'verbo adjuntivo', que, com base na English Grammar de Murray, é na sintaxe que se pode estatuir a classe a que se filia o 'verbo', de acordo com as condições em que está empregado. Em outra nota de rodapé, conectada ao 'verbo objetivo adjuntivo', Maciel apresenta uma série de referências bibliográficas, as quais: Grammatica Portugueza, de Epiphanio Dias; Grammatica Portugueza, de Júlio Ribeiro; Sintassi latina comp. con la Greca, de Giovanni Giordano; e Latin Grammar de Zumpt.

Após apresentar essas espécies de 'verbo', inicia uma seção chamada "a antiga classificação", que é iniciada pela seguinte frase "a doutrina do verbo substantivo e adjectivo cahiu por estar provado que” (Maciel 1895:105). Assim, observamos que nessa seção, o gramático apresenta seis razões para não conceber o ‘verbo substantivo', as quais são: (1) "ser" tem forma de três verbos latinos (ex.: sedere, esse, fui); (2) considerandose o estado atual da língua, os 'verbos adjuntivos' supracitados também seriam 'substantivos', pois exercem igual função; (3) “ser” aparece na 'acepção primitiva' de "existir" e na de "acontecer" (il.: Aqui foi a cidade que Meliapor se chama; previmos os fatos e assim foi); (4) a maioria dos pretensos 'verbos adjetivos' não são sempre equivalentes a "ser" seguido de um 'adjetivos' terminado por "nte" (ex.: ter = ser tenente; vir $=$ ser vinte; agir = ser agente; morrer = ser morrente); (5) "ser" por sua "quase imprestabilide syntactiva e significativa" (p.106) é, em geral, sujeito à elipse, mesmo que ainda não tenha sido expresso (il.: não há mais novidade (não seja) arder o palácio do Lavra); (6) com base em Whitney (La vie du langage) afirma que "ser" tem por vezes apenas função gramatical, puramente formal, é quase destituído de significação, limitando-se a ligar o ‘adjunto predicativo’ ao ‘sujeito’ e não existe em diversas línguas. 
Vistas essas duas maneiras de conceber o 'verbo' e suas espécies fica claro que Maciel passou por uma transição de sua primeira gramática, escrita em 1887, e da segunda, publicada oito anos depois. Essa transição é marcada pela exclusão do conceito de 'verbo substantivo' e, consequentemente, também do conceito de 'verbo adjetivo'. O 'verbo' assim, deixa de ser palavra 'conjuntiva', para tornar-se palavra 'nominativa' e, como vimos nas justificativas para a queda do 'verbo substantivo', sua função de ligação é renegada a algo de menor importância e até mesmo desnecessário. Ademais, é perceptível que a preocupação terminológica, acompanhada de certa instabilidade, visto que diversos conceitos eram nomeados por mais de um termo, justificada pela transição por que passavam os estudos a respeito da língua, é diminuída consideravelmente na gramática de 1895 .

\subsubsection{Conceito de sentença ou proposição e seus elementos}

Há diferenças entre o conceito de 'sentença' ou 'proposição' de 1887, e o conceito de 'proposição' de 1895. Na Grammatica Analytica, Maciel (1887), chama-se 'sentença' uma 'proposição' ou agregado de 'proposições' formando um 'pensamento completo'. A 'sentença', 'logicamente considerada', contém três elementos essenciais: 'sujeito', 'verbo' e 'predicado'. 'Sujeito' é a pessoa ou coisa que atribuímos o 'predicado', o ‘objeto de juízo', a 'ideia de substância' e a 'ideia principal'; 'verbo' é o elemento conectivo que liga formalmente o 'predicado' com o ‘sujeito', a base da afirmação e a 'ideia intermédia'; finalmente, 'predicado' é a qualidade que atribuímos ao 'sujeito', o 'atributo' é a ideia secundária e de qualidade.

Em 1895, diz que a 'proposição' - que também se diz 'cláusula', 'frase', 'sentença' ou 'oração', mas é preferível o 'termo' 'proposição', por ser mais geral e estar mais de acordo com a teorizações da lógica - é um pensamento expresso por palavras. Mais especificamente, é um pensamento expressado por dois 'termos': 'sujeito' e 'predicado' (il.: os céus / ressoam do Senhor a glória [ref.: Poesias, Padre Caldas]; o Douro / é bem carregado e triste [ref.: L. e Narrativas, A. Herculano]). O 'sujeito' é o ser de quem se diz alguma coisa (il.: os céus). O predicado é o que se diz a respeito do 'sujeito' (il.: ressoam do céu a alegria). Há 'proposições' constituídas pelo 'verbo' "ser” em que os dois termos têm a mesma extensão, isto é, o 'adjunto predicativo' pode 
substituir ao 'sujeito' (il.: o maior dos males é a subversão dos princípios [ref: L. de Cultos, Bispo do Pará.]).

A diferença entre o conceito de 'proposição' ou 'sentença' das duas gramáticas é evidente. Em 1887, ela é tripartite, composta por 'sujeito', 'verbo' - que é relacional - e ‘predicado'. Em 1895, o ‘sujeito’ permanece, não há menção ao 'verbo' porque ela faz parte do 'predicado'. Além disso, em 'proposições' com o 'verbo' "ser" haveria o ‘sujeito’ e o ‘adjunto predicativo'. Não há ilustrações em 1887, já em 1895, há ilustrações extraídas de textos literários, como podemos ver pelas referências dispostas pelo próprio autor. Ademais, em 1887, a 'sentença', que também poderia ser uma 'proposição' ou um 'agregado de proposições', corresponde a um pensamento completo. Ao passo que em 1895, a 'proposição' (que também poderia ter outros vários nomes como 'cláusula', 'frase', 'sentença' ou 'oração'), é a expressão de um pensamento.

Em ambas as obras, essas seriam as 'sentenças' ou 'proposições simples'. Em 1887, especifica que é 'simples' a 'sentença' que contém uma só 'proposição' ou 'asserção' (ex.: todos geralmente o adoram com vários ritos e cerimônias [ref.: Bernardes]); é por sua vez 'composta', quando contém duas ou mais 'proposições' ou 'asserções' (ex.: logo porém teve Sara anúncio direto que conceberia, e com efeito Abraão teve dela Isaac [ref.: J. J. da Rocha]). Nas sentenças compostas, cada uma das 'proposições' com seus acessórios chama-se 'membro' ou 'cólon'. Os 'membros' tomarão o nome de 'cláusulas' se estiverem ligados mutuamente por uma 'relação de dependência' (il.: e tanto que a corneta deu o sinal, partem as carroças de Italico, como se foram setas sacudidas do poderoso arco [ref.: Bernardes]).

Em 1895, em texto um pouco diferente, diz que a 'sentença composta' é aquela que é constituída por duas ou mais 'sentenças simples'. As 'sentenças simples' chamamse 'proposições' e são consideradas 'membros' da 'sentença composta'. Há dois tipos de 'proposições', as 'coordenadas' e as 'subordinadas'. A 'proposição composta', também chamada 'período composto', é constituída por duas ou mais proposições simples. Ela pode ser 'composta' por 'coordenação', quando as 'proposições' são independentes entre si (il.: levantou-se o cardeal e subiu ao estado de príncipe), ou por ‘subordinação', quando as 'proposições' são dependentes entre si (il.: eu amo seus olhos que choram sem causa um pranto sem dor [ref: Clássicos, de Fr. Luiz de Souza]).

Adiante, um quadro com os conceitos das espécies de 'proposição' nas duas gramáticas de Maciel de acordo com o seu conectivo. 


\begin{tabular}{|c|c|c|}
\hline $\begin{array}{c}\text { Espécies de } \\
\text { 'proposições } \\
\text { coordenadas' ou } \\
\text { 'membros' de acordo } \\
\text { com o conectivo } \\
\end{array}$ & Maciel 1887 & Maciel 1895 \\
\hline $\begin{array}{l}\text { Copulativa (1887) } \\
\text { Aproximativa (1895) }\end{array}$ & $\begin{array}{l}\text { Indica juízo independente, está apenas } \\
\text { liga a outra por meio de uma conjunção } \\
\text { ‘copulativa' (il.: as estrelas douram o } \\
\text { espaço e a luz retrata-se no mar) }\end{array}$ & $\begin{array}{l}\text { Ligadas por conjunção } \\
\text { aproximativa (il.: era eu vestida } \\
\text { de riquissimas galas; (e) alva } \\
\text { coroa de rosas me tocava [ref: } \\
\text { Garret) }\end{array}$ \\
\hline Explicativa (1887) & $\begin{array}{c}\text { Aquela que explica e desenvolve o } \\
\text { sentido de outra, ligando-se por meio } \\
\text { de uma conjunção explicativa (il.: o } \\
\text { orvalho suaviza a flor como a virtude } \\
\text { suaviza as ações) }\end{array}$ & - \\
\hline $\begin{array}{l}\text { Disjuntiva (1887) } \\
\text { Alternadas (1895) }\end{array}$ & $\begin{array}{l}\text { Aquela que indica uma alternação de } \\
\text { pensamento, ligando-se a outra por } \\
\text { meio de uma conjunção disjuntiva (il.: } \\
\text { pastora virá falar-me, ou então irei ter } \\
\text { com ela) }\end{array}$ & $\begin{array}{l}\text { Ligadas por conjunção } \\
\text { alternativa (il.:os monarcas } \\
\text { indultam ou toleram facilmente } \\
\text { a republica americana [ref: Lat. } \\
\text { Coelho]) } \\
\end{array}$ \\
\hline $\begin{array}{l}\text { Conclusiva (1887) } \\
\text { Ilativas }(1895)\end{array}$ & $\begin{array}{l}\text { Aquela que se liga a outra por meio de } \\
\text { uma conjunção lógica (il.:a virtude é } \\
\text { louvável, logo a caridade é louvável) }\end{array}$ & $\begin{array}{c}\text { Ligadas por conjunção ilativa } \\
\text { ou conclusiva (il.:Jesus Cristo } \\
\text { nasceu do Espírito Santo, logo } \\
\text { era espírito [ref: Bittencourt } \\
\text { Sampaio]) } \\
\end{array}$ \\
\hline Adversativa & $\begin{array}{l}\text { Aquela que indicando oposição de } \\
\text { pensamento liga-se a outra por uma } \\
\text { conjunção adversativa (il.: eu sou } \\
\text { trabalhor, porém tu és vadio) }\end{array}$ & - \\
\hline Correlativa & $\begin{array}{c}\text { Aquela que indica um pensamento } \\
\text { independente, confrotando-o com outro } \\
\text { também independente mediante uma } \\
\text { conjunção correlativa (il.:assim como o } \\
\text { orvalho vivifica a flor, assim a virtude } \\
\text { vivifica o espírito) }\end{array}$ & - \\
\hline
\end{tabular}

Quadro 70. Espécies de 'proposições coordenadas' ou 'membros' em Maciel $(1887,1895)$

\begin{tabular}{|c|c|c|}
\hline $\begin{array}{c}\text { Espécies de } \\
\text { 'proposições } \\
\text { subordinadas' ou } \\
\text { 'cláusulas' de acordo } \\
\text { com o conectivo }\end{array}$ & Maciel 1887 & Maciel 1895 \\
\hline $\begin{array}{c}\text { Conjuntiva (1887) } \\
\text { Conjunccionais (1895) }\end{array}$ & $\begin{array}{c}\text { Está relacionada com a principal por } \\
\text { meio de uma conjunção (il.: Não sei se } \\
\text { voltes; Cumpra que partas) }\end{array}$ & $\begin{array}{c}\text { Ligam-se mediante conjunção } \\
\text { subordinativa (ex.: o padre } \\
\text { Cristiano tomou depressa a } \\
\text { porta, porque não podia reprimir } \\
\text { o riso [ref: Manoel Bernardes]) }\end{array}$ \\
\hline $\begin{array}{c}\text { Pronominal conjuntiva } \\
\text { (1887) }\end{array}$ & $\begin{array}{c}\text { Relacionada com a principal por meio } \\
\text { de pronome conjuntivo (il.: Vi o } \\
\text { homem que passou) }\end{array}$ & $\begin{array}{c}\text { Ligam-se mediante pronome } \\
\text { relativo (il.: O berço é a barca } \\
\text { que encalhou na vida [ref: } \\
\text { Castro Alves]) }\end{array}$ \\
\hline Indefinita & - & $\begin{array}{c}\text { Ligam-se mediante pronome ou } \\
\text { adjetivo indefinido (il.: qual a } \\
\text { materia seja não se enxerga } \\
\text { [ref:Camões]) }\end{array}$ \\
\hline
\end{tabular}

Quadro 71. Espécies de 'proposições subordinadas' ou 'cláusulas' em Maciel $(1887,1895)$ 
São notáveis as mudanças entre as duas gramáticas, as quais ocorrem no que diz respeito aos termos, às definições, e às ilustrações. É notável também o rigor descritivo de Maciel. O gramático ainda define, em 1887, as 'subordinadas' por sua natureza, daí existem as 'substantivas' (il.: quero que venhas), as 'adjetivas' (il.: o negócio que favorece deve ser empreendido) e as 'adverbiais' (il.: partirei antes que ele venha). Afirma que as 'adjetivas' chamam-se também 'incidentes', porque interrompe o sentido de outra proposição, e divide-a em 'explicativa' e 'restritiva', conforme valha por um 'adjetivo restritivo' ou 'explicativo'. Em 1895, apresenta essa mesma classificação, mas não distingue as 'adjetivas' em 'restritivas' e 'explicativas', nem a chama também de 'incidente'.

Em ambas as gramáticas, Maciel afirma que as 'palavras' podem exercer diferentes 'funções’ na 'proposição' como resultado de suas diversas relações. No quadro adiante, expomos os conceitos de cada espécie de ‘função' em cada uma das gramáticas de Maciel.

\begin{tabular}{|c|c|c|}
\hline $\begin{array}{l}\text { Espécies de } \\
\text { 'funções' } \\
\text { (termos) }\end{array}$ & Definição em 1887 & Definição em 1895 \\
\hline Subjetiva & $\begin{array}{l}\text { Aquela exercida pelo ‘sujeito’ em } \\
\text { relação ao seu ‘verbo'. Exercida pelo } \\
\text { 'sujeito'. }\end{array}$ & $\begin{array}{c}\text { Sujeito, que é o ser de quem se diz } \\
\text { alguma coisa. }\end{array}$ \\
\hline Predicativa & $\begin{array}{l}\text { Aquela exercita pelo 'predicado’ em } \\
\text { relação ao ‘sujeito'. Exercida pelo } \\
\text { 'predicado expresso' ou é encerrada na } \\
\text { 'raiz verbal'. }\end{array}$ & $\begin{array}{l}\text { Predicado, que é aquilo que se diz a } \\
\text { respeito do 'sujeito'. }\end{array}$ \\
\hline Atributiva & $\begin{array}{l}\text { Aquela que é exercida por uma palavra, } \\
\text { exprimindo qualidade, determinação ou } \\
\text { restrição sem formar proposição. }\end{array}$ & $\begin{array}{l}\text { Adjunto atributivo, que é toda palavra } \\
\text { ou expressão modificando ao } \\
\text { 'substantivo', mas não constituindo } \\
\text { 'asserção'. }\end{array}$ \\
\hline Objetiva & $\begin{array}{l}\text { Aquela que é exercida por uma palavra } \\
\text { sobre que recai imediatamente a ação } \\
\text { do 'verbo transitivo direto'. Exercida } \\
\text { pelo 'complemento objetivo'. }\end{array}$ & $\begin{array}{l}\text { Objeto direto ou objeto indireto, que é } \\
\text { a palavra ou expressão a que se } \\
\text { transmite imediata ou mediatamente a } \\
\text { ação do 'verbo transitivo'. }\end{array}$ \\
\hline Vocativa & $\begin{array}{c}\text { Aquela que é exercida por uma palavra } \\
\text { a que se dirige o discurso. }\end{array}$ & $\begin{array}{l}\text { Vocativo, que é palavra ou expressão } \\
\text { que, posta interjetivamente na } \\
\text { proposição indica a pessoa ou a coisa a } \\
\text { que nos dirigimos. }\end{array}$ \\
\hline Terminativa & $\begin{array}{l}\text { Aquela que é exercida por uma palavra } \\
\text { inteirando mediatamente o conceito } \\
\text { significativo de outra. Exercida pelo } \\
\text { 'complemento terminativo' ou } \\
\text { 'necessário'. }\end{array}$ & - \\
\hline Adverbial & $\begin{array}{l}\text { Aquela que é exercida por uma palavra } \\
\text { que mediante uma circunstância } \\
\text { modifica o verbo, o adjetivo, o } \\
\text { substantivo ou o advérbio. Exercida } \\
\text { pelo 'complemento circunstancial'. }\end{array}$ & $\begin{array}{l}\text { Adjunto adverbial, que é palavra ou } \\
\text { expressão que, mediante uma } \\
\text { circunstância, modifica o verbo, o } \\
\text { adjetivo e até outro advérbio. }\end{array}$ \\
\hline
\end{tabular}

Quadro 72. Espécies de 'funções' em Maciel $(1887,1895)$ 
Em 1887, ele apresenta o conceito de 'função' (também chamado de 'relação'), o qual é bastante similar ao conceito de 'relação' que vimos em Ribeiro (1881 e 1885 - cf. 4.8). Maciel (1887) concebe sete 'funções'. Como vemos no quadro, apenas nas definições de 1887 apresenta outro conceito, pelo qual a função denominada "é exercida" (como é o cada da 'função subjetiva', exercida pelo 'sujeito', ou a 'função adverbial', exercida pelo 'complemento circunstancial'). Já em 1895, há sempre um outro conceito que, parece-nos, é equivalente ao da 'função', pois inicia a definição. Assim, na definição de cada uma das 'funções', um outro 'conceito' inicia-a, como se pode ver no quadro acima; por exemplo, a definição de 'função subjetiva' inicia-se por 'sujeito', a de 'função atributiva' inicia-se pelo 'adjunto atributivo'. Maciel parece, portanto, estar concebendo dois conceitos com termos diferentes, mas cujo conteúdo é equivalente; talvez isso seja motivado pela grande variedade terminológica do período, a qual encontramos não apenas em Maciel, mas também em outras gramáticas ${ }^{116}$.

Ademais, tal como comentamos acerca de Ribeiro (1881 e 1885 - cf. 4.8), esse outro modo de observar os elementos da 'proposição', em comparação com o conceito de ‘complemento' (utilizado por muitos gramáticos brasileiros, sobretudo por aquele que publicam antes de 1880), diminui a importância dada anteriormente àqueles que eram os elementos essenciais da 'proposição' tripartite, isto é, o ‘sujeito' e o ‘atributo'.

\subsubsection{Rede Conceitual}

Maciel faz um percurso similar ao que vimos em Ribeiro (1881, 1885), visto que ambos apresentam o conceito de 'verbo substantivo' em uma obra e o retiram de outra ulterior. Esse comportamento talvez seja característico do período de transição que se passava na gramaticografia brasileira de então. Ademais, tal como vimos em Ribeiro, a eliminação do conceito de 'verbo substantivo' parece ser o gatilho para mudanças em outros aspectos da obra.

A respeito da gramática de 1887 , consideramos que o conceito de 'verbo substantivo' concebido por Maciel trava relação de subordinação com o conceito de 'verbo', pois enquanto aquele é definido semanticamente como expressão da existência em absoluto, este definido como existência de um fato abstrato ou concreto, sendo, ao que parece, que esse fato é o 'atributo' do 'verbo predicativo', que exprime a existência

\footnotetext{
${ }^{116}$ Veja-se, por exemplo, Pacheco e Lameira (1887, cf. 4.10) e Gomes (1895, cf. 4.13).
} 
relativa - haveria, assim, relação de equivalência entre 'verbo' e 'verbo predicativo'. Este último divide-se em duas espécies: 'verbo intransitivo’ e ‘verbo transitivo', mas não há, em sua definição, qualquer referência à distinção entre ‘verbo substantivo' e 'predicado'.

O 'verbo substantivo' também trava relação de subordinação com o conceito de 'proposição' tripartite apresentado, em que 'verbo' é o elemento conectivo entre o 'sujeito' e o 'predicado - o que corresponderia, ao menos, à espécie de 'verbo substantivo' chamada 'conectivo'. Ao tratar das 'funções', Maciel mantém o conceito anteriormente expresso do 'predicado' na 'função predicativa' pois esse pode estar expresso ou encerrado na 'raiz verbal'. Além disso, afirma que as funções 'objetiva', 'terminativa' e 'adverbial' são exercidas, respectivamente, pelos 'complementos' 'objetivo', 'terminativo' e 'circunstancial'. Parece haver, assim, certo ecletismo do gramático, na medida em que equivale algumas das 'funções' a 'complementos', os quais são justamente aqueles que se aplicavam aos elementos da 'proposição' em gramáticas anteriores.

Quanto aos modificadores do nome e às espécies de 'proposição', há paralelismo entre elas, Maciel utiliza terminologia e definições lógicas, de 'compreensão' e 'extensão', para distinguir diferentes espécies de 'adjetivo'. Consideremos, portanto, que há base teórica comum com 'verbo substantivo'. Finalmente, em 1887, o autor define gramática misturando aspectos dos Programas Descritivista e de Correspondência (cf. Quadro 2), pois, por um lado, apresenta a língua como manifestação do pensamento, já, por outro, considera-a como objeto suja análise se faz por meio de comparação. Dessa forma, o autor apresenta certo ecletismo vertical.

Quanto à gramática de 1895, como vimos, Maciel não somente elimina o 'verbo substantivo' de sua gramática como também apresenta uma crítica a ele em metatexto. $\mathrm{Na}$ crítica, ressalta que "ser" teve três formas em latim e aparece na acepção primitiva de “existir” e "acontecer”, que os 'verbos adjuntivos' (il.: fazer alguém feliz, julgar alguém bom). têm mesma função que o 'verbo substantivo', que nem sempre é possível transformar um “pretenso" 'verbo adjetivo’ na junção entre um ‘verbo substantivo' e um 'adjetivo' terminado em "nte”, e finalmente que a função de relação exercida por "ser" pode ser facilmente elipsada, sendo apenas necessária quando se junta o 'sujeito' ao 'adjunto predicativo' em português, mas que em verdade não existe em diversas línguas. 
Observemos, adiante, como ele tratou os conceitos que na gramática de 1887 travavam relação com o 'verbo substantivo'. O primeiro traço, bastante marcante, é o fato do 'verbo' deixar de ser palavra 'conjuntiva' para tornar-se 'nominativa'. Ademais, a 'proposição' encerra somente o 'sujeito' e o 'predicado', sendo tudo aquilo que se diz a respeito do 'sujeito', incluindo o 'verbo' seus 'objetos' e eventuais 'adjuntos', como se vê pelas ilustrações apresentadas pelo gramático. Finalmente, ao tratar da funções, já não equivale três delas as três 'complementos', e, especificamente, ao tratar da 'função predicativa', elimina trecho em dizia que o 'predicado' poderia ser 'expresso' ou estar 'encerrado na raiz verbal'. Quanto ao tratamento dos modificadores do nome, ainda que as critique (de maneira parecida com a que faz Condurú 1888, cf. 4.11), Maciel mantém as espécies apresentadas na gramática anterior, modificando sua definição, mas mantém, sobretudo, as definições baseadas em conceitos da lógica. Finalmente, não faz mais relação com o pensamento em sua definição de gramática, que é definida como sistematização lógica dos fatos e normas de uma língua qualquer. No entanto, ao tratar da gramática geral, ainda se refere ao pensamento - o que, em verdade, parece ser uma característica daqueles que queriam unir o conceito de língua como expressão do pensamento com o conceito de língua como objeto comparável, pois Sayce, que ele cita, tem esse pensamento, o mesmo ocorre com na obra Pacheco e Lameira (cf. 4.10 e 3.2.10). 


\subsection{Noções de grammatica portugueza (1887, [153]), de Pacheco da Silva Junior e Lameira de Andrade}

\subsubsection{Conceitos de gramática e de linguagem e organização da obra}

A gramática de Pacheco \& Lameira, tal como a de Ribeiro (1889) por ser baseada no Programa de Estudos escrito por Fausto Barreto, é dividida em capítulos que correspondem a cada um dos itens colocados no programa, os quais os autores da gramática chamam de lições (cf. Apêndice B, FD 13 e FD 15). Na lição 1, dividem a gramática quatro espécies 'geral', 'histórica' ou 'comparativa', 'descritiva' e 'portuguesa'. No quadro adiante apresentamos o conceito de cada uma delas, em texto e metatexto.

\begin{tabular}{|c|c|}
\hline $\begin{array}{l}\text { Espécies de } \\
\text { 'gramática' }\end{array}$ & Conceito em texto e metatexto \\
\hline Geral & $\begin{array}{l}\text { T: Estudo dos fatos e das leis da linguagem em toda sua extensão; conjunto dos } \\
\text { processos comuns a muitas línguas comparadas. Seu fim é coordenar } \\
\text { semelhanças e divergências dos vários processos orais, seguidos no maior } \\
\text { número de línguas conhecidas, para a expressão dos sentimentos e ideias, } \\
\text { estabelecendo ao mesmo tempo: regras gerais, princípios fundamentais, leis } \\
\text { comuns e positivas. Nessa acepção, a gramática geral é o próprio estudo da } \\
\text { linguagem ou 'glotologia'. } \\
\text { MT (nota): Há duas orientações no domínio da gramática geral: (1) uma } \\
\text { tendência lógica, que impõe a priori uma teoria do pensamento a todas as } \\
\text { modalidades linguísticas; (2) outra tendência exclusivamente mórfica, que } \\
\text { procura explicar o sentido pela estrutura, isto é, o interno pelo externo. Quando } \\
\text { exclusivas, essas orientações tornam-se viciosas, pois a linguagem é composta } \\
\text { de ideia e forma. Para perfeita constituição da glotologia, é pois mister a íntima } \\
\text { combinação dos dois processos. }\end{array}$ \\
\hline $\begin{array}{l}\text { Histórica ou } \\
\text { Comparativa }\end{array}$ & $\begin{array}{l}\text { T: Aquela que emprega a história e a comparação como instrumentos } \\
\text { verificadores da linguagem. Ela nos ensina a dissecação científica dos } \\
\text { vocábulos e permite remontar ao passado obscuro, pode reconstituir a forma } \\
\text { típica das palavras desfiguradas e gastas pelas migrações e pelos séculos. }\end{array}$ \\
\hline $\begin{array}{c}\text { Descritiva ou } \\
\text { Expositiva }\end{array}$ & $\begin{array}{c}\text { T: Codificação empírica e exposição analítica dos fatos da linguagem. Não } \\
\text { investiga causadas nem explica leis; seu fim é apenas classificar, definir e } \\
\text { exemplificar os materiais linguísticos. } \\
\text { MT: Ainda que estude a linguagem muito incompletamente, esse método } \\
\text { gramatical é de grande utilidade por sua clareza didática e ainda é acrescido por } \\
\text { muitos respingos de provas cumulativas. }\end{array}$ \\
\hline Portuguesa & $\begin{array}{l}\text { O objeto dessa gramática é o estudo geral, descritivo, histórico, comparativo e } \\
\text { coordenativo, mas tão somente no domínio da língua portuguesa. }\end{array}$ \\
\hline
\end{tabular}

É notável que as definições em texto se aproximem do Programa Descritivista (cf. Quadro 2), pois tratam a língua como objeto e a comparação entre elas é um ponto crucial. Em metatexto relativos à 'gramática geral', porém, o autor ressaltam que há dois modos de abordá-la, os quais deveriam se unir, a saber, um modo a posteri, que viria por meio 
da segmentação mórfica, e outro a priori, que seria baseado em princípios da relação entre linguagem e pensamento. Nesse sentido, os gramáticos aproximam o Programa Descritivista do Programa de Correspondência (cf. Quadro 2).

É certo que a 'gramática portuguesa' não se encontra no mesmo nível que as outras espécies. Enquanto as outras três são abstrações a respeito da visão e das técnicas de análise da linguagem, a 'portuguesa' tem como especificidade seu objeto, a língua portuguesa, e, pela definição dada pelos gramáticos Pacheco e Lameira, ela coaduna as técnicas das gramáticas 'geral', 'histórica' ou 'comparativa' e 'descritiva' ou 'expositiva' para esse fim, visto que apresenta o estudo geral, descritivo, histórico, comparativo e coordenativo da língua proposta.

Além disso, quanto à 'gramática descritiva', afirma em metatexto que seu objetivo é ser didática, não científica; mas acrescenta em que há nela muitos respingos científicos. Sendo sua gramática nomeada de 'noções de gramática portuguesa' e sendo ela direcionada para alunos que desejam realizar um exame (cf. 3.2.10), não fica claro se ela se aproxima mais da 'gramática portuguesa' ou da 'gramática descritiva'.

Os gramáticos, ao falar da 'gramática geral' citam a 'glotologia' (que parece ser uma variação do termo 'glossogia', citado por Maciel, cf. 4.9). Em metatexto, afirmam que há duas maneiras de se realizar 'glotologia', uma por meio de princípios a priori detectados na relação entre pensamento e linguagem e outra por meio da análise mórfica do dado externo, as quais em vez de se polarizarem devem, segundo os gramáticos, reunirem-se, dado que a língua é 'ideia' e 'forma'.

Finalmente, a 'gramática portuguesa' é constituída por duas partes: 'lexicologia' e 'sintaxe'. Na primeira, a palavra é estudada individualmente, em seus aspectos 'fonológicos' (que incluem 'fonética', 'prosódia' e 'ortografia'), 'morfológicos', e 'semiológicos'. Na segunda, trata da 'palavra coletiva', isto é, da 'frase' e da 'proposição' (divide-se em 'gramatical' e 'literária').

\subsubsection{Conceitos de metaclasses e classes de palavras}

Na sétima lição da gramática, Pacheco \& Lameira apresentam a 'classificação das palavras', que se entende pela distribuição das palavras em suas várias 'espécies' ou 'partes do discurso'. Dizem ainda que outros gramáticos (metatexto), definem essa classificação como conjunto das ideias ordenadas por 'gêneros' e 'espécies', o que 
corresponde à 'taxonomia'. Ressaltam que a "teoria das partes do discurso ou da oração" é antiga. Em nota (metatexto), afirmam que de acordo com Thomson ${ }^{117}$ classificam-se as palavras em três classes: 'substantivos', 'adjetivos' e 'preposições', já do ponto de vista de Beeker distinguem-se apenas duas classes, a de 'palavras nocionais', que exprimem ideias de seres ou ações formadas no espírito (como é o caso de 'substantivo', 'adjetivo', 'verbo', 'advérbio de modo', 'tempo' e 'lugar'), e a de 'palavras relacionais', que não exprimem noção ou ideia, mas apenas indicam a relação entre palavras (como é o caso de 'verbos auxiliares', 'artigos', 'pronomes', ‘numerais', 'preposições', ‘conjunções', e 'advérbios de relação'). Afirmam ainda, com base em Ticknor, que aplicar os princípios de 'classificação de palavras particulares' é uma tarefa difícil, dado que é possível que eles mudem de classe em certo período da história, além de poderem pertencer a diferentes classes em um mesmo período.

No português, segundo Pacheco e Lameira (1887:75), classificam-se as palavras, de acordo com sua significação em oito classes: 'substantivo', 'adjetivo', 'pronome', ‘verbo', 'advérbio', 'preposição', 'conjunção' e ‘interjeição' - esta última quando não é considerada simplesmente forma rudimentar e instintiva. Quanto às suas 'funções naturais', as palavras dividem-se duas categorias: 1) 'nominativas' ou 'ideais', dependentes ou independentes, "servem para distinguir os seres, as substâncias reais ou abstratas, as qualidades e ações, os diversos estados das pessoas e coisas e todas as manifestações da vida" (Pacheco \& Lameira 1887: 76) como 'nome' e 'verbo'; 2) 'conectivas' e 'relativas' são as palavras que exprimem as numerosas relações de tempo, lugar, número, quantidade, causa, efeito" (Pacheco \& Lameira 1887: 76), como 'preposição' e ‘conjunção'. O 'advérbio', por sua vez, participa de ambas as classes, pois, por sua natureza especial, é, por vezes, adjetivo e, outras, partícula; é também a classe de palavra que marca a transição das 'palavras de flexão' para as 'invariáveis'. Dado que, quanto à 'forma', as ‘categorias' de palavras dividem-se em 'variáveis', que são o 'nome' (que compreende 'substantivo', 'adjetivo' e 'pronome') e o verbo, e em 'invariáveis', que são as 'partículas' ('destroços orgânicos' ou 'organismos inferiores'), muitas delas sem existência independente (Pacheco \& Lameira 1887:76-77).

Adiante, apresentamos um quadro sintético das diversas possibilidades de divisão de classes de palavras apresentadas por Pacheco \& Lameira.

\footnotetext{
117 Thompson, Beeker e Ticknor são citados por Pacheco e Lameira (1887) para tratar de diferentes modos de descrever as metaclasses. Não os descrevemos em mais detalhe para o leitor por desconhecê-los.
} 


\begin{tabular}{|c|c|c|c|c|}
\hline \multicolumn{2}{|c|}{ Metatexto } & \multicolumn{3}{|c|}{ Texto } \\
\hline $\begin{array}{c}\text { Segundo } \\
\text { Thompson }\end{array}$ & Segundo Beeker & $\begin{array}{l}\text { Divisão por suas } \\
\text { 'funções naturais' }\end{array}$ & $\begin{array}{l}\text { Divisão por } \\
\text { 'forma' }\end{array}$ & $\begin{array}{c}\text { Divisão do } \\
\text { Português } \\
\text { quanto à } \\
\text { significação }\end{array}$ \\
\hline Substantivos & \multirow[t]{2}{*}{ Palavras nocionais } & \multirow{4}{*}{$\begin{array}{l}\text { Nominativas / } \\
\text { Ideais }\end{array}$} & \multirow{4}{*}{ Variáveis } & Substantivo \\
\hline Adjetivos & & & & Adjetivo \\
\hline- & Palavra relacional & & & Pronome \\
\hline- & $\begin{array}{l}\text { Palavra nocional / } \\
\text { relacional (verbos } \\
\text { auxiliares) } \\
\end{array}$ & & & Verbo \\
\hline- & $\begin{array}{l}\text { Palavra nocional (de } \\
\text { modo, tempo e lugar) } \\
\text { / relacional (de } \\
\text { relação) }\end{array}$ & $\begin{array}{l}\text { Está nas duas } \\
\text { classes }\end{array}$ & $\begin{array}{l}\text { Marca a } \\
\text { transição }\end{array}$ & Advérbio \\
\hline Preposições & \multirow{3}{*}{ Palavras relacionais } & \multirow{3}{*}{$\begin{array}{c}\text { Conectivas / } \\
\text { Relativas }\end{array}$} & \multirow{3}{*}{ Invariáveis } & Preposição \\
\hline- & & & & Conjunção \\
\hline- & & & & Interjeição \\
\hline
\end{tabular}

Quadro 74. Metaclasses e classes de palavras em Pacheco e Lameira (1887)

Nota-se que o 'advérbio' é uma palavra diferenciada das outras, na medida em que não se enquadra nas 'divisões' por 'funções naturais' e por 'forma', que funcionam como metaclasses da 'divisão do português', nem pode se encaixa em uma única metaclasse na divisão de Beeker. A propósito, nota-se que a divisão feita por Beeker pensa nas classes de palavras como permeáveis, na medida que podem-se colocar determinadas espécies de um gênero de classe de palavra como sendo 'palavras nocionais', ao passo que outras espécies desse mesmo gênero de classe de palavra corresponderiam a 'palavras relacionais' - como vemos ocorrer com o 'verbo' e o 'advérbio'. Algo similar (menos explícito, porém) parece ocorrer com o 'advérbio' nas duas 'divisões' supracitadas de Pacheco e Lameira. Ademais, observamos que o 'verbo', de um ponto de vista mais geral', é considerado, por sua função, 'nocional' ou 'nominativo/ideal' em oposição, respectivamente, a palavras 'relacionais' ou 'conectivas'.

\subsubsection{Conceitos modificadores do nome}

As classes de palavras de modificadores do nome são o 'adjetivo' e o 'pronome', que analisamos adiante. Pacheco e Lameira (1887:85-86) definem o 'adjetivo', na 'oitava lição', como aquele que se junta - dada sua etimologia "lat. adiectivum, de ad-icere, por a par, que ajunta” (p. 85) - ao 'substantivo' para qualificá-lo ou determiná-lo. Por designar as propriedades de um ser ou de um objeto, de pessoa ou ideia, o 'adjetivo' torna

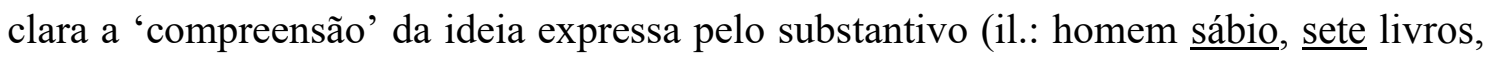


esta pena). Ademais, o 'adjetivo' não pode, sozinho, ser o 'sujeito' da 'proposição', mas com o 'verbo' “ser”, pode formar o 'predicado' (il.: Deus é justo; o homem é mortal), ainda que o 'adjetivo' possa ser empregado ‘substantivadamente' (ex.: grego: ho sophos; latim: sapiens - o sábio).

Em metatexto (nota), acrescentam que antigamente o 'adjetivo' não era considerado uma classe de palavra, mas simples 'substantivo comum' (ou 'apelativos) que indicavam mais 'qualidade' que 'substância'. Na 'classificação moderna', entretanto, o 'adjetivo' é classe separada porque sempre vem ligado a 'substantivo' ou 'pronome' na qualidade de 'atributo' ou 'predicado' - e, quando não for assim considerado, é 'substantivo' ou 'pronome'.

Há duas espécies principais de 'adjetivo', os 'qualificativos' (que também se chamam 'atributivos' ou 'descritivos') exprimem uma qualidade ou condição, já os 'determinativos' (que também se chamam 'circunstanciais' ou 'definitos') definem e limitam a significação do nome a que se unem. Os gramáticos acrescentam que, por vezes, quando o 'adjetivo' se torna um 'substantivo' ou 'pronome', o 'adjetivo atributivo' é aquele que pode se tornar um 'substantivo' (ex.: chão, frio), enquanto o 'adjetivo circunstancial', torna-se um 'pronome' (ex.: o, este, aquele).

As espécies de 'adjetivos' podem ser distinguidas por dois pontos de vista: quanto à 'significação' ou quanto à 'forma'. No quadro adiante, apresentamos as espécies de 'adjetivo' de acordo com cada perspectiva.

\begin{tabular}{|c|c|}
\hline \multicolumn{2}{|c|}{ Quanto à significação } \\
\hline Qualificativo / Atributivo & Essenciais / Explicativos \\
\cline { 2 - 2 } & Acidentais / Restritivos \\
\hline \multirow{4}{*}{ Determinativo / Circunstancial } & Possessivos \\
\cline { 2 - 2 } & Demonstrativos \\
\cline { 2 - 2 } & Conjuntivos \\
\cline { 2 - 2 } & Quantitativos / De números \\
\cline { 2 - 2 } & Artigos \\
\hline
\end{tabular}

Quadro 75. Espécies de 'adjetivo' quanto à 'significação' em Pacheco e Lameira (1887)

A oscilação terminológica é evidente, na medida em que diversos conceitos têm mais de um termo. Quanto ao 'qualificativo' ou 'atributivo', há uma divisão inicial em duas espécies: 'essenciais' ou 'explicativos' e 'acidentais' ou 'restritivos'. Os primeiros exprimem uma 'qualidade' ou 'condição' (p. 86) indicam propriedades essencialmente características da pessoa ou coisa (il.: branca neve; o cavalo é quadrupede) (p. 89). Os 'acidentais' ou 'restritivos', por sua vez, 'definem' e 'limitam' a significação do 'nome' ao qual estão ligados (p. 86) e indicam propriedades não essencialmente características 
da pessoa ou coisa (ex.: chapéu alto; cavalo náfego). Em metatexto, afirma que alguns gramáticos contemporâneos não aceitam essa divisão, adiante citamos a nota:

Alguns grammaticos hodiernos rejeitam a moderna classificação dos adjectivos em determinativos e qualificativos, apoiados nas duas seguintes ponderações: $1 .^{\circ}$, que todos os adjetivos ajuntando-se aos nomes para determinar-lhes ou restringir-lhes a significação á idéa da especie particular, são forçosamente determinativos; $2 .^{\circ}$, que tal classificação obriga a considerar, ora na classe dos adjectivo, ora na cathegoria do pronome, certas palavras da mesma natureza, posto não exerçam as mesmas funcções no discurso (meu, qual...). (Pacheco \& Lameira 1887: 86).

Segundo um aspecto ressaltado por Pacheco e Lameira, a crítica de outros gramáticos é baseada na suposição de que os 'adjetivos' sempre seriam 'determinativos', visto que sempre restringiriam a significação do nome de alguma maneira, algo que é efetivamente contrário à definição de 'adjetivo explicativo' de muitos gramáticos do período, inclusive na gramática analisada nesta seção ${ }^{118}$.

Pacheco e Lameira (1887:87) definem espécies de 'adjetivo determinativo' da seguinte maneira. 'Possessivos' são 'adjetivos pronominais' e exprimem ideia de posse (ex.: meu, teu, seu, nosso, vosso); 'demonstrativos' indicam pessoa ou coisa com ideia de lugar ou tempo (ex.: este, esse, aquele); 'conjuntivos' conjuntam 'cláusulas' (ex.: que, qual, cujo); 'quantitativos' ou 'de número' determinam todos os indivíduos de uma 'classe', ou parte dela. Esse último divide-se em duas espécies 'universais' ou 'gerais', aqueles, por sua vez, subdividem-se em 'coletivos' (ex.: todo, nenhum) e estes em 'distributivos' (ex.: cada, cada um), e 'partitivos', que podem ser 'definidos' (ex.: um, dois) ou 'indefinidos' (ex.: algum, certo, pouco) que exprimem um número ou quantidade indeterminada, seja em 'unidade' e 'pluralidade' (ex.: alguma, certo, muitos), seja em 'totalidade' ou 'universalidade' (ex.: cada, nenhum, todos). Emenda em metatexto (nota) que "qualquer, todos, cada, nenhum" têm 'valor pronominal' quando são empregados 'absolutamente'. Em texto, os 'partitivos' definidos' dividem-se em cardinais, que representam números formadores de qualquer numeração (ex.: um, dois, vinte), e 'ordinais', que, sendo verdadeiramente adjetivos, exprimem ordem (ex.: primeiro, quinto, vigésimo).

De acordo com os gramáticos (Pacheco \& Lameira 1887: 88), o 'artigo' é o "verdadeiro adjetivo determinativo" que individualiza o 'nome' ou designa uma 'espécie' geral ou particular. Citamos nota (metatexto) do autor a respeito do 'artigo' adiante:

\footnotetext{
${ }^{118}$ Entre as dezoito gramáticas analisadas, vimos críticas a respeito dessa divisão em Bithencourt (1862 cf. 4.5) e Condurú (1888 - cf. 4.11). Os argumentos usados por eles, entretanto, não são os mesmos citados por Pacheco e Lameira (1887).
} 
Tirou origem na necessidade que tem o povo de nomear claramente as cousas da vida commum, de individualisar a significação do nome. Sobre a origem do artigo como categoria grammatical, é erronea a hypothese de consideral-o resultante da obliteração do sentido vivo das raizes indicativas ou relacionaes. De feito, o zend, o sanskrito, o grego homerico, e o latim classico, conservam mais clara a consciencia dos elementos de relação; mas as linguas semiticas - que mais conservam a significação primitiva concreta e material de seus typos radicaes (Renan) possuiam o artigo, e desde o mais remoto periodo historico. (Pacheco \& Lameira 1887: 88)

O 'pronome' é palavra que substitui o nome (Pacheco \& Lameira 1887: 92), entretanto, diferentemente do 'substantivo', que exprime uma ideia e designa pessoas ou coisas por suas qualidades distintivas, características e naturais, o 'pronome' exprime apenas uma 'relação oracional'. São 'substantivos', quando exercem funções de ‘substantivo' tendo lugar de 'sujeito', 'objeto' (il.: ele (o professor); deu-lhe um livro), e 'adjetivos', quando determinam o 'substantivo' juntando-lhe uma relação de posse, indicação ou ideia de espaço ou distância (il.: este quadro é de Pedro; o teu (escrito) é de mais valor; aquele (autor) é mais clássico que este). No quadro adiante, apresentamos os conceitos das espécies de 'pronome' de Pacheco e Lameira (1887:92-94).

\begin{tabular}{|c|c|c|}
\hline $\begin{array}{l}\text { Espécies de } \\
\text { 'pronome' } \\
\text { (termos) }\end{array}$ & $\begin{array}{l}\text { Espécie do gênero da } \\
\text { coluna à esquerda } \\
\text { (termos) }\end{array}$ & Conceito em texto \\
\hline \multirow[t]{2}{*}{$\begin{array}{c}\text { Pronome } \\
\text { substantivo }\end{array}$} & Pessoal & $\begin{array}{c}\text { Designa a pessoa que fala, a com quem se fala, e a } \\
\text { pessoa ou coisa de que se fala (ex.: eu, nós; tu, vós; ele, } \\
\text { ela, eles, elas, o, a, os, as; il.: tinha essa obra, mas já } \underline{\text { a }} \\
\text { dei). }\end{array}$ \\
\hline & Indefinido & $\begin{array}{c}\text { Essencialmente pronominais, ou seja, não podem ser } \\
\text { construídos com ‘substantivos' ‘claros' (ex.: alguém, } \\
\text { ninguém, se, outrem, tudo, nada; fulanos, sicrano, } \\
\text { beltrano). }\end{array}$ \\
\hline \multirow{3}{*}{$\begin{array}{l}\text { Pronome } \\
\text { adjetivo }\end{array}$} & Demonstrativos & Essencialmente pronominais (ex.: isso, isto, aquilo) \\
\hline & Distributivos & - (não há definição, apenas menciona o termo) \\
\hline & $\begin{array}{l}\text { Conjuntivos / relativos } \\
\text { (interrogativos) }\end{array}$ & $\begin{array}{l}\text { Essencialmente pronominais (ex.: que, quem, quem quer } \\
\text { que, o que quer que). Referem-se a alguma coisa já } \\
\text { expressa em outra proposição. São 'interrogativos' } \\
\text { quando perguntam a 'relação demonstrativa' em } \\
\text { 'orações interrogativas' e 'interjectivas' (ex.: que flor é } \\
\text { essa? ; que menino!). }\end{array}$ \\
\hline
\end{tabular}

Em metatexto (notas e menção a outros autores), Pacheco e Lameira fazem observações etimológicas a respeito dos 'pronomes' 'pessoal' e 'indefinido' e reflexões teóricas acerca da classe 'pronome'. Quanto ao primeiro, consideram que o 'pessoal' é o "verdadeiro pronome". Ademais, com base em Bleeck ${ }^{119}$, afirmam que os 'pronomes' teriam derivado de 'substantivos' com significado, por exemplo, de "senhor", sendo uma

${ }^{119}$ Desconhecemos também o autor dessa referência feita por Pacheco e Lameira (1887). 
amostra desse fato, na língua portuguesa, a transformação gradual de "Vossa mercê" em "você". Quanto aos 'indefinidos', os gramáticos observam que "homem" e "gente" são empregados na linguagem popular de Portugal e do Brasil como verdadeiros 'pronomes' desde o século XV, tendo como evidências textos de autores dessa época, cita ainda exemplos similares de outras línguas: francês (ex.: on), alemão (ex.: mann) e inglês (ex.: man e people). Finalmente, afirmam que o 'pronome' é uma diferenciação lógica do nome, sua origem repousa na dupla modalidade psicológica do 'subjetivo' e do ‘objetivo', constituem os traços entre a gramática e o vocabulário, além de serem os primeiros ensaios da passagem do 'abstrato' para o 'concreto'.

Observamos que Pacheco e Lameira distinguem os 'adjetivos', indiretamente, pelos critérios lógicos de intensão e extensão. Há, assim, os 'determinativos' e 'qualificativos', estes ainda dividem-se em 'explicativos' ou 'restritivos', os quais se adequam nas duas divisões de Noël e Chapsal (cf. item 1.4.2). A grande variação terminológica nesse momento pode se. Ademais, como vimos, os autores observam em nota que nem todos os gramáticos estão de acordo com a distinção entre 'explicativos' e 'restritivos'; é notável que Pacheco e Lameira, em todos os aspectos examinados, frequentemente apresentem notas (metatexto) em que apresenta outras possibilidades de se pensar o dado linguístico quando tomam em texto um posicionamento que na época não era unânime.

\subsubsection{Conceito de verbo}

O verbo é assunto da décima lição, em que é definido como "palavra que exprime uma acção, uma affirmação" (p. 96). Em nota de rodapé (metatexto), ressalta que todos os verbos exprimem noção de atividade, mesmo os aparentemente 'inativos' já exprimiram originariamente uma ação. Em longa nota (metatexto), disserta acerca de sua definição de 'verbo' dada anteriormente, inicia-a com a afirmação "sem asserção não pode haver comunicação de pensamento" (p. 95). Ademais, nega que a noção de tempo deva constar na definição de 'verbo', visto que em grande parte das línguas os verbos têm formas que excluem essa noção (como o 'infinitivo'), e também porque as formas gramaticais que expressam tempo são, em proposições gerais, empregadas aoristicamente ou sem referência a tempo (ex.: os pássaros voam) - o emprego do presente pelo futuro seria uma prova dessa hipótese (il.: vou amanhã; je vais demain). Conclui dizendo que 
chamar o verbo de 'palavra de tempo' como fazem os alemães (Zeitwort) é denominá-lo não por uma característica essencial, mas por uma propriedade ocasional.

De volta ao texto, os autores consideram que o 'verbo' consta de dois elementos, um 'material', o 'tema', que corresponde à 'ação enunciada', e um 'formal', a 'desinência', que refere-se à 'afirmação' ou 'cópula lógica'. A divisão do 'verbo' em espécies se dá segundo três critérios de 'significação', o quais expomos no quadro abaixo.

\begin{tabular}{|c|c|c|}
\hline Critério & $\begin{array}{c}\text { Espécies de } \\
\text { 'verbo' (termo) }\end{array}$ & Conceito em texto e metatexto \\
\hline \multirow{3}{*}{$\begin{array}{l}\text { Segundo a natureza do } \\
\text { 'sujeito' }\end{array}$} & Pessoal & - \\
\hline & Unipessoal & $\begin{array}{l}\text { T: Aquele que não tem expresso seu 'sujeito lógico' (ex.: } \\
\text { trovejar, chover). Só se emprega na 'terceira pessoa do } \\
\text { singular', constitui sozinho uma 'proposição' cujo ‘sujeito' } \\
\text { é a ideia de uma 'ação' ou de um 'fenômeno natural' } \\
\text { expresso pelo 'verbo'. }\end{array}$ \\
\hline & & $\begin{array}{l}\text { MT: De acordo com Egger, é um ‘nome’ com 'terminação } \\
\text { verbal'. No sentido figurado, tornam-se 'pessoais' (il.: } \\
\text { choveram empenhos; Deus choverá sobre os maus as } \\
\text { penas, tormentos [ref.: H.P.]; em nossas almas choves } \\
\text { certas e altas doutrinas [ref.: Cam.]; troveja o orador, } \\
\text { relampague a estes olhos a verdade [ref.: Esc. da Verd.]). }\end{array}$ \\
\hline \multirow{3}{*}{$\begin{array}{l}\text { Segundo a natureza da } \\
\text { 'ação' dividem-se os } \\
\text { 'pessoais' } \\
\text { MT: essa classificação } \\
\text { tem por fundamento o } \\
\text { 'predicado' incluído no } \\
\text { 'verbo' }\end{array}$} & $\begin{array}{c}\text { Transitivos / } \\
\text { Objetivos }\end{array}$ & $\begin{array}{l}\text { T: Exprimem ações que passam de um ‘sujeito’ a um } \\
\text { ‘objeto’. Sua ideia é incompleta sem a noção } \\
\text { complementar de um ‘objeto'. Muitos verbos ativos são } \\
\text { empregados intransitivamente e vice-versa. }\end{array}$ \\
\hline & $\begin{array}{l}\text { Intransitivos / } \\
\text { Subjetivos }\end{array}$ & $\begin{array}{l}\text { T: Afirmam ações limitadas aos sujeitos que as fazem (ex.: } \\
\text { dormir, chorar, morrer, cair). Sua ideia é completa sem a } \\
\text { noção complementar de um 'objeto'. Não podem, por sua } \\
\text { natureza, ser conjugados na 'forma passiva'. Há entre os } \\
\text { 'verbos intransitivos' os 'incoativos' que exprimem } \\
\text { princípio de ação ou ação sucessiva (ex.: empalidecer, } \\
\text { envelhecer) }\end{array}$ \\
\hline & & $\begin{array}{l}\text { MT: As ações dos verbos intransitivo por vezes exprimem } \\
\text { modos de ser ou estado, por isso o ‘verbo' é muitas vezes } \\
\text { definido como palavra que exprime ação ou estado. } \\
\text { Entretanto, há muitos 'verbos intransitivos' que indicam } \\
\text { movimento (ex.: correr, andar), mas as ideias neles } \\
\text { contidas não representam os 'objetos' de que são } \\
\text { 'predicados' as qualidades (ex.: andante, corrente) como } \\
\text { exercitando uma ação sobre outro objeto. }\end{array}$ \\
\hline \multirow{4}{*}{$\begin{array}{l}\text { Segundo a natureza da } \\
\text { 'afirmação', dividem- } \\
\text { se os 'transitivos' }\end{array}$} & Ativos & \multirow{2}{*}{$\begin{array}{c}\text { T: A relação existente entre ‘sujeito’ e ‘predicado’ pode } \\
\text { ser 'ativa' ou 'passiva' - daí os ‘verbos ativos' e } \\
\text { 'passivos'. }\end{array}$} \\
\hline & Passivos & \\
\hline & Neutros & - \\
\hline & Reflexos & $\begin{array}{l}\text { 'Verbos pronominais' cuja ação recai na mesma pessoa } \\
\text { que a pratica (il.: ele feriu-se; arrependeu-se). } \\
\text { São consequência da 'voz reflexa' ou 'média' em que o } \\
\text { ‘sujeito' é ao mesmo tempo 'ativo' e 'passivo'. Conjugam- } \\
\text { se com um 'pronome objetivo' da mesma pessoa do } \\
\text { 'sujeito'. }\end{array}$ \\
\hline
\end{tabular}




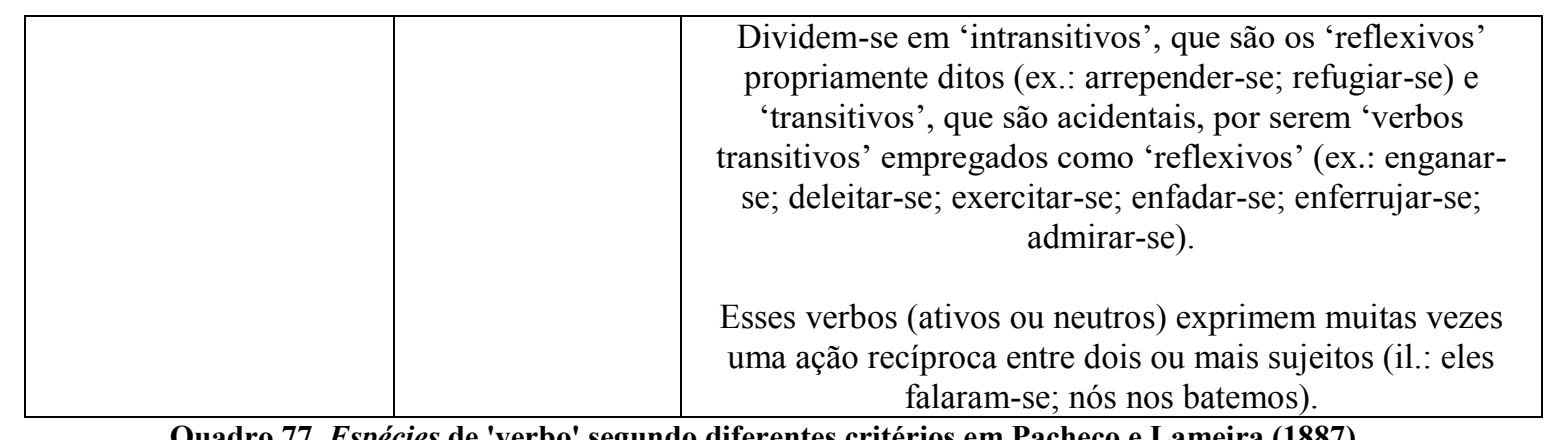

Quadro 77. Espécies de 'verbo' segundo diferentes critérios em Pacheco e Lameira (1887)

Embora os mencionem, Pacheco e Lameira não definem nem exemplificam os 'verbos' 'pessoais' e 'neutros'. No início do capítulo, como vimos, os gramáticos distinguem no 'verbo' duas partes, o 'tema', que significa a 'ação' e a 'desinência', que corresponde a 'afirmação' ou 'cópula lógica', visto que o 'verbo' exprime ao mesmo tempo 'afirmação' e 'ação'. Ao classificar as espécies, distingue dois (dos três) critérios com base nessas duas partes do verbo. Dessa forma, os 'verbos' são 'transitivos' ou 'intransitivos' com base no segundo a natureza de sua 'ação', que pode ou não ser passada a um 'objeto'; essa ‘ação' corresponde ao ‘tema' do 'verbo', o qual ele corresponde, em metatexto, a 'predicado'. Os 'verbos' são 'ativos', 'passivos', 'neutros', 'reflexos' de acordo com a natureza de sua 'afirmação', isto é, a relação (de 'cópula lógica') estabelecida entre 'sujeito' e 'predicado', como especificam ao definir os 'verbos' 'ativo' e 'passivo'. É curioso que o autor tenha colocado o 'verbo' na metaclasse de palavras 'nominativas' ${ }^{120}$, que estava em oposição à metaclasse de palavras 'conectivas', mas ressalte nessa definição que ele promove a relação entre ‘sujeito' e 'predicado'.

Além dos verbos supracitados, que são chamados pelos gramáticos de 'principais', há também os 'verbos auxiliares', que são elementos formadores dos 'tempos compostos', da 'voz passiva', dos 'verbos perifrásticos' e 'frequentativos'. São 'verbos relacionais', só exprimem o tempo ou modalidade e a 'voz passiva' dos 'verbos principais' ou 'nocionais'. Em metatexto (nota), ressalta que há também os 'verbos semiauxiliares', que podem auxiliar, mas conservam parte da sua significação própria (ex.: tornar, ir, dever, vir).

Os verbos ainda podem ser classificados, de acordo com a sua natureza, em cinco diferentes espécies:

\begin{tabular}{|c|c|}
\hline Espécies de 'verbo' & Conceito em texto \\
\hline Concretos & $\begin{array}{r}\text { Exprimem uma ideia de ação (ex.: ler, matar). Pode formar a 'cópula' } \\
\text { ou o 'predicado' de uma 'proposição'. }\end{array}$ \\
\hline
\end{tabular}

\footnotetext{
${ }^{120}$ Como fazem também Maciel (1895 - cf. 4.9) e Gomes (1895 - cf. 4.13).
} 


\begin{tabular}{|c|c|}
\hline Abstratos & $\begin{array}{c}\text { Exprimem simples 'relação' da 'proposição', só podem formar } \\
\text { 'cópula', nunca o 'predicado'. }\end{array}$ \\
\hline Terminativos & $\begin{array}{r}\text { Verbos sujo predicado requer um termo indireto de ação (il.: dar } \\
\text { esmola aos pobres). Podem ser 'transitivos' ou 'intransitivos'. }\end{array}$ \\
\hline Frequentativos & $\begin{array}{c}\text { Seu particípio imperfeito junta-se aos tempos dos mesmos verbos ou } \\
\text { de outro, a fim de indicarem com mais colorido a ação expressa pelo } \\
\text { 'predicado' (il.: vir vindo, vou indo, andar caindo). }\end{array}$ \\
\hline Perifrásticos & $\begin{array}{c}\text { Locuções complexas formadas dos tempos dos verbos "haver" e "ter" e } \\
\text { do infinito do 'verbo principal' ligados pela 'preposição' "de" (il.: tu } \\
\text { tens de escrever (verbo principal obrigatório); havemos de estudar } \\
\text { (verbo principal promitente). }\end{array}$ \\
\hline
\end{tabular}

Quadro 78. Outras espécies de 'verbo' em Pacheco e Lameira (1887)

'Concretos' e 'abstratos' são espécies de 'verbo' do ponto de vista das relações que promovem dentro de uma 'proposição', seja ela de 'cópula' e de 'predicado', no caso do primeiro, ou apenas de 'cópula' no caso do segundo. Ademais, lembramos que a terminologia 'concreto' e 'abstrato' para 'verbos' foi usada como equivalente, respectivamente, aos termos de 'verbo substantivo' e 'verbo adjetivo' ou 'atributivo', por Beauzée (e por diversos gramáticos; dentre os brasileiros, vemos Carneiro Ribeiro 1881, 1890 - cf. 4.7). Os gramáticos, porém, não exemplificam ou ilustram tais espécies de 'verbo', não permitindo, assim, que observemos se o 'verbo abstrato' correspondia ao 'verbo' "ser".

Pacheco e Lameira finaliza o tratamento do 'verbo' com uma pequena nota (metatexto), que, parece-nos, é um elogio a essa classe de palavra, a qual transcrevemos adiante:

Verbo $=$ palavra. $\mathrm{O}$ chinez chama aos verbos - palavras vivas, aos nomes = palavras mortas. $\mathrm{E}$, de feito. $\mathrm{O}$ verbo é o termo essencial da proposição, a palavra por excelencia, o elemento vital do discurso, "o verdadeiro sinal do juízo". "Onde há um verbo há um juízo e uma proposição; sempre que elle falta, ha apenas noções isoladas, ideias sem ligação - ou pelo menos incompletas. É de creação muito mais moderna que o nome, e seu desenvolvimento flexional é de origem mais recente que as flexões nominais. (p. 103)

No trecho, é enfatizado, o papel para a formação da 'proposição', sua natureza de 'sinal do juízo' e também sua importância para o 'discurso', por promover a 'ligação' entre ideias. Ademais, os gramáticos tocam no tema da ordem de criação das palavras, dado que, em comparação com 'nome', o 'verbo' é mais moderno, tal como também o são seu 'desenvolvimento flexional' em relação às 'flexões nominais' ${ }^{121}$.

É curioso, como já mencionamos anteriormente, que Pacheco e Lameira coloquem o 'verbo' em metaclasses que dizem respeito a nomes e ideias, visto que, embora sua

\footnotetext{
${ }^{121}$ A discussão acerca das evolução histórica das classes de palavras não é exclusiva de Pacheco e Lameira, sendo encontrada também nas gramáticas de Costa Duarte (1859), Bithencourt (1862) e Carneiro Ribeiro $(1881,1890)$.
} 
definição de 'ação' realmente seja compatível com essa classificação, o 'verbo' é também definido como 'afirmação', o que promoveria relações entre 'sujeito' e 'predicado' e o que, provalmente, é mencionado quando os gramáticos, na nota citada, dizem que sem os 'verbos' há apenas noções isoladas e ideias sem ligação. Ademais, no tratamento do ‘verbo' observamos, por um lado, que são poucos os exemplos e ilustrações, e, por outro, que é frequente a variação terminológica e rica a taxonomia.

\subsubsection{Conceito de proposição e seus elementos}

$\mathrm{Na}$ trigésima lição, Pacheco e Lameira definem 'proposição' como uma 'afirmação', a qual contém dois 'termos essenciais', o ‘sujeito' e o 'predicado', mas pode conter também ‘termos acessórios'. O ‘sujeito’ é expresso por um ‘substantivo’ ou por outra palavra ou 'expressão substantivada'. O 'predicado' é representado simplesmente pelo ‘verbo de predicação completa' ou 'intransitivo' ou pelo de 'predicação incompleta', mas nesse caso também é composto por seus ‘modificadores' ou 'termos acessórios'. Essa noção de 'predicado' parece não ser equivalente àquela apresentada anteriormente, no tratamento do 'verbo', quando os gramáticos, em metatexto, afirmam que essa classificação tem por fundamento o 'predicado' incluído no 'verbo', dado que o conceito de 'predicado' exibido dentro da 'proposição' contém o ‘verbo' e não o contrário.

Em metatexto, os gramáticos observam que há exceções (il.: ele é bom, eu estou bom, tu pareces contente). Os 'modificadores' ou 'determinadores' dos 'termos essenciais' da 'proposição' são: para o 'sujeito': 'adjetivos', 'palavras' ou 'expressões adjetivas' às quais se dá o nome de 'atributos'; já para o 'predicado': eles são 'objeto' e 'complemento adverbial', conforme são representados por 'substantivo', 'palavra' ou 'expressão de natureza substantiva', ou ainda pelo 'advérbio' e 'palavra' ou 'expressão adverbiada'. Pacheco e Lameira definem o 'objeto' mais detidamente, dividindo-o em 'direto' ou 'indireto', conforme modifica imediatamente ou meditamente (com ou sem 'preposição') o sentido do 'predicado' (il.: Deus recompensa os justos; ele matou-se; vivo do trabalho; preciso de ti). Observam, entretanto, que em alguns casos, o 'objeto direto' é precedido de preposição (il.: amo a Deus, arrancam das espadas). Ademais, comentam que o 'complemento adverbial' não é necessário para o perfeito sentido do elemento que ele modifica, pode ser substituído por outro termo acessório (il.: comprei há dias um bom livro; ele escreve corretamente, ele escreve com correção). 
A 'proposição' é dividida em 'simples', se tem apenas uma 'afirmação' e 'composta', se é composta por duas ou mais 'proposições simples'. Outras espécies de 'proposição' se dividem de acordo com diferentes critérios: quanto à 'forma', elas podem ser 'completas', 'incompletas' ou 'elípticas'; quanto à 'lógica', são 'principais' e 'subordinadas'. Vemos que é frequente a distinição entre 'forma' e lógica' na obra.

As 'proposições', dentro de um 'período composto', podem travar duas relações entre si, a 'coordenação' e a 'subordinação'. Nas primeiras, as 'proposições' que, por serem de "igual categoria intelectual ou força significativa", juntam-se por meio de 'justaposição' ou de 'conjunções conectivas' formando o 'período composto' (il.: o homem pensa, fala e ri). Como há simplesmente 'coordenação', as 'proposições' são sempre 'principais'. Ademais, no caso de haver 'conectivo', se são 'sindéticas', para junção das proposições, elas podem ser 'copulativas', 'adversativas', 'disjuntivas', 'conclusivas'. No caso de haver mera justaposição, chamam-se 'assindéticas'.

Quando há relação de 'subordinação' num 'período composto', uma das 'proposições' determina outra que passa a ser um dos seus 'termos' ou serve-lhe de 'complemento'. As 'orações subordinadas' dividem-se: quanto ao 'conectivo', podendo ser 'conjuncionais' e 'relativas', conforme for ele uma 'conjunção', 'adjetivo' ou 'pronome relativo'; quanto à natureza, dividem-se em 'substantivas', 'adjetivas' e 'adverbiais', conforme representam uma dessas três categorias gramaticais; quanto à 'função', podem ser 'subjetivas', 'objetivas', 'atributivas', ou 'adverbiais', conforme preenchem as funções de 'sujeito', 'objeto', 'atributo' ou 'adjunto adverbial' (il.: noticiaram que ele morreu, isto é, a sua morte; a mulher de pudor, isto é, a mulher pudica, pudenta, pudibunda; chegou depois que saímos, isto é, depois de nossa saída). As ‘subordinadas adverbiais' podem exprimir diversas circunstâncias, de tempo, fim, lugar, causa, consequência, comparação, conclusão.

Em metatexto, acrescentam que 'proposições subordinadas' ainda são classificadas por alguns gramáticos em: 'completivas', quando encerram um 'complemento essencial' para o sentido de outra proposição'; 'incidentes', quando se unem ao 'sujeito' ou 'atributo' de uma outra 'proposição' por um 'pronome relativo', podendo ser 'explicativas' ou 'terminativas'; e, finalmente, 'circunstanciais', quando exprimem 'circunstância' (de tempo, modo, causa etc.) complementar do sentido de outra 'proposição'. 


\subsubsection{Rede conceitual}

Pacheco e Lameira não tratam exatamente do conceito de 'verbo substantivo' tal qual esse era apresentado na tradição da grammaire générale, há, porém, o 'verbo abstrato', que parece estar em oposição ao 'concreto', pois o primeiro apenas forma 'cópula' enquanto o segundo exprime também 'ideia de ação'. Não há ilustrações ou exemplos para o 'verbo abstrato'.

Como vimos, no início da obra, ao definir 'glotologia', os gramáticos ressaltam a importância de analisar dois aspectos da língua, a 'ideia' e a 'forma', algo que de fato segue ao realizar sua descrição da língua portuguesa. Nos trechos que analisamos, vemos que o autor opõe a noção de 'forma' a alguns outros termos como 'natureza', para tratar da metaclasses de palavras, e 'lógica', ao tratar do 'verbo' e da 'proposição'.

Os gramáticos consideram que o 'verbo' exprime 'ação' e 'afirmação' e que tem duas partes, o tema, que corresponde à 'ação', e a desinência, que corresponde à 'afirmação' ou 'cópula lógica'. Tal distinção é utilizada para distinguir as espécies de 'verbo', visto que os 'transitivos' e 'intransitivos' o são segundo a natureza de sua 'ação', isto é, se ela passa ou não para outro e os 'ativos', 'passivos', 'neutros' e 'reflexos' o são de acordo com a natureza de sua 'afirmação'. Esta 'afirmação', também chamada de ‘cópula lógica', é estabelecida entre o ‘sujeito' e o 'predicado'.

É possível, certamente, pensar que o 'verbo abstrato' corresponderia à 'cópula lógica' e, por isso, estaria presente em todos os outros 'verbos' - os quais seriam 'verbos concretos'. No entanto, os gramáticos não fazem essa relação explicitamente, eles também, como vimos, não apresentam exemplos para o 'verbo abstrato'. Parece-nos, portanto, que essas noções servem mais aos aspectos da língua, 'ideia' e 'forma', que os gramáticos expuseram no início da obra, do que propriamente a uma rede conceitual em torno do 'verbo abstrato'. Esses mesmos aspectos, 'lógica' e 'forma', como vimos, aparecem na definição as espécies de 'proposição'.

Ademais, ainda que a 'proposição' seja definida como 'afirmação', o 'verbo abstrato' não é dado como parte de sua constituição. Há nela apenas os 'termos essenciais' 'sujeito' e 'predicado', sendo este último representado pelo 'verbo de predicação completa' ou 'incompleta' e, no último caso, há também 'termos acessórios' na 'proposição'. É interessante que, enquanto definem a 'proposição' como 'afirmação', os gramáticos considerem a 'predicação' do 'verbo' ao falar de 'predicado', muito embora tenham dito anteriormente que as espécies de 'verbo' 'intransitivo' e 'transitivo' são 
definidas de acordo com sua 'ação' e não por sua 'afirmação', como era o caso das espécies 'ativo', 'neutro' etc.

Finalmente, vemos que o gramático trata dos 'adjetivos' em termos lógicos, isto é, distinguindo-os, indiretamente, pela sua extensão e intensão. O que teria relação de base teórica comum com o 'verbo abstrato', visto que este é uma 'cópula lógica'. No entanto, não trata da 'proposição' tripartite. Ademais, não trata das sentenças incidentes senão em metatexto. Em conclusão, consideramos a gramática de Pacheco e Lameira eclética, na medida em que apresentam um conceito similar ao 'verbo abstracto', mas também outros que não estão relacionados a ele, como a 'proposição'.

\subsection{Grammatica Elementar da Lingua Portugueza (1888, [157]), de Fillipe Benicio de Oliveira Condurú}

\subsubsection{Conceitos de gramática e de linguagem e organização da obra}

Condurú inicia a décima terceira edição de sua gramática elementar definindo a 'gramática portuguesa' como arte que ensina a falar, escrever e ler com acerto a língua portuguesa. Diz ainda que divide-se em quatro partes, que são: 'etimologia', 'prosódia', 'ortografia' e 'sintaxe', que exatamente os quatro capítulos de sua obra.

\subsubsection{Conceitos de metaclasses e classes de palavras}

De acordo com o gramático maranhense, há sete classes de palavras, as quais não são divididas por metaclasses, são elas: 'substantivo', 'adjetivo', 'verbo', 'preposição', 'advérbio', 'conjunção', 'interjeição'. Em metatexto, Condurú afirma que o 'advérbio' e a 'interjeição' não são 'partes elementares' e 'representativas' de 'ideias simples', mas são 'partes constitutivas' da 'proposição', que podem ser de natureza 'simples', 'composta' ou 'complexa'. Ainda assim, ele ressalta que não pretende omiti-las, pois classificar as 'palavras' que existem no uso vivo da língua e omitir as que têm propriedades especiais não lhe parece razoável. 


\subsubsection{Conceitos modificadores do nome}

Todos os conceitos modificadores do 'nome' concentram-se na classe de palavra 'adjetivo', que é definida como a palavra que exprime as 'qualidades' do 'substantivo' ou o representa de um 'modo determinado' (il.: o menino dócil é estimado de seus mestres). Há dois tipos principais de 'adjetivo', o 'determinativo', que determina 'apelativos', fazendo com que sejam considerados de maneira particular, e o 'qualificativo' ou 'atributivo', que exprime 'qualidades' ou 'atributos' dos 'substantivos'.

Em metatexto, o autor ressalta que a divisão de 'adjetivos' em três espécies, 'explicativos', 'restritivos' e 'determinativos', não lhe parece razoável, porque a propriedade de explicar e de restringir o substantivo é geral à classe dos 'qualificativos' e não pode, por conseguinte, caracterizar uma parte deles somente para constituir divisão da espécie - um mesmo 'qualificativo' pode ser ora 'restritivo', ora 'explicativo' (il.: alma racional, animal racional; branca neve, mulher branca). Finaliza a nota dizendo que os que adotam essa divisão confundem com caracteres distintivos as 'relações de conveniência' ('inerente' ou 'acidental') que podem ter os 'adjetivos' com os 'substantivos' que eles qualificam. ${ }^{122}$

Os 'determinativos' são divididos em quatro espécies, 'artigos', 'pronomes' 'pessoais', 'demonstrativos' e 'quantitativos'. No quadro adiante apresentamos os conceitos espécies de cada um deles.

\begin{tabular}{|c|c|c|}
\hline $\begin{array}{c}\text { Conceito de espécies } \\
\text { de "adjetivos } \\
\text { determinativos' } \\
\text { (termo) }\end{array}$ & Conceito em texto & Conceito em metatexto \\
\hline Artigo & $\begin{array}{c}\text { Determinativo que se antepõe ao } \\
\text { 'apelativo' para indicar que sua } \\
\text { significação geral é tomada em } \\
\text { sentido individual. } \\
\text { Espécies: } \\
\text {-Artigo definido: indivíduos } \\
\text { determinados (ex.: o, a) } \\
\text { - Artigo indefinido: indivíduos } \\
\text { indeterminados (ex.: um, uma) }\end{array}$ & $\begin{array}{c}\text { Também ‘substantiva' quaisquer } \\
\text { ‘partes da oração’ e mesmo } \\
\text { ‘orações’ inteiras (il.: o justo; o } \\
\text { porquê; o amar a Deus sobre todas } \\
\text { as coisas) }\end{array}$ \\
\hline Pronome pessoal & $\begin{array}{l}\text { Determinativo que na oração } \\
\text { representa a pessoa que fala, a quem } \\
\text { se fala e de quem se fala ou coisas } \\
\text { tomadas no sentido de pessoa. }\end{array}$ & $\begin{array}{l}\text { ‘Pronome' é a palavra na oração que } \\
\text { se põe em lugar do nome de pessoa } \\
\text { ou coisa. Os verdadeiros pronomes } \\
\text { da língua portuguesa são, além dos }\end{array}$ \\
\hline
\end{tabular}

${ }^{122}$ Ressaltamos que diversos gramáticos brasileiros distinguiram essas duas espécies de 'adjetivo', como, por exemplo, Costa Duarte (1829, 1859 - cf. 4.3), Carneiro Ribeiro (1881, 1890 - cf. 4.7), Gomes (1895 cf. 4.13). Bithencourt (1862), porém, asseverou em metatexto que ela “incontestável”. 


\begin{tabular}{|c|c|c|}
\hline & $\begin{array}{l}\text { (ex.: eu/nós, tu/vós, ele/eles - que } \\
\text { variam/declinam em mim, me, migo, } \\
\text { nós, nos, nosco, ti, te, tigo, vós, vos, } \\
\text { vosco, lhe, o, a, elas, eles, os, as) }\end{array}$ & $\begin{array}{l}\text { pessoais, “alguém, ninguém, outrem, } \\
\text { quem, cada qual, este", que se } \\
\text { referem a pessoas, e os "algo, al, } \\
\text { isto, aquilo, tudo, nada, o mesmo" } \\
\text { que se referem a coisas. O relativo } \\
\text { "o" quando representa uma ideia já } \\
\text { expressa por palavras com que não } \\
\text { pode concordar, deve ser } \\
\text { considerado pronome (il.: há } \\
\text { verdades que o não parecem, as feias } \\
\text { nem por o serem deixam de } \\
\text { agradar). } \\
\text { Todos esses são formas indefinidas } \\
\text { de diversos determinativos quando } \\
\text { exprimem ideias concretas, por isso, } \\
\text { não lhe demos lugar distinto na } \\
\text { classificação das partes da oração, } \\
\text { entretanto, mestres minuciosos o } \\
\text { poderão fazer. }\end{array}$ \\
\hline Demonstrativos & $\begin{array}{c}\text { São os que mostram as pessoas ou } \\
\text { coisas de que falamos. } \\
\text { Espécies: } \\
\text { - Puros: aplicam-se a objetos } \\
\text { presentes à vista ou à imaginação } \\
\text { (ex.: este, esse, aquele, o mesmo) } \\
\text { - Possessivos: Designam objetos } \\
\text { pertencentes às pessoas que, a quem } \\
\text { ou de quem se fala (ex.: meu, teu, } \\
\text { seu, cujo) } \\
\text { - Relativos: referem-se a pessoas, } \\
\text { coisas ou juízos enunciados em frase } \\
\text { antecedente (ex.: o, a, quem, que, o } \\
\text { que, a que, a qual, o qual; il.: o } \\
\text { tempo que tão breve passa é } \\
\text { preciso)' }\end{array}$ & $\begin{array}{l}\text { Costumam os gramáticos } \\
\text { compreender “cujo" não entre os } \\
\text { 'possessivos', mas entre os } \\
\text { 'relativos' por ele se derivar } \\
\text { diretamente de “cujus”, genitivo de } \\
\text { “qui, quoe, quod” latino, que em } \\
\text { português equivale a “de que, de } \\
\text { quem, do qual, da qual”. Incluímo- } \\
\text { lo, não obstante, entre os } \\
\text { possessivos, por isso mesmo que o } \\
\text { genitivo latino exprime possessão ou } \\
\text { restrição, e o ofício que este } \\
\text { demonstrativo exerce na língua } \\
\text { portuguesa, bem como o dos } \\
\text { possessivos pessoais é sempre o de } \\
\text { restringir o apelativo que ele } \\
\text { determina. } \\
\text { 'Demonstrativos puros' e } \\
\text { 'possessivos' podem se tornar } \\
\text { 'relativos' quando referem-se a } \\
\text { substantivos expressos } \\
\text { antecedentemente. } \\
\text { 'Relativos' são chamados } \\
\text { 'interrogativos' quando por meio } \\
\text { deles se faz uma pergunta. }\end{array}$ \\
\hline Quantitativos & $\begin{array}{l}\text { Ajuntam à definição do apelativo } \\
\text { uma ideia de quantidade (il.: todo } \\
\text { homem é mortal; ninguém é } \\
\text { perfeitamente sábio) } \\
\text { Espécies: } \\
\text { - Universais: Fazem compreender na } \\
\text { significação do substantivo todos os } \\
\text { indivíduos de sua classe (il.: a alma } \\
\text { é racional, nenhum cidadão deve } \\
\text { eximir-se de servir a pátria; ex.: } \\
\text { todo, toda, tudo, nenhum, nenhuma, } \\
\text { ninguém, nada, quemquer, qualquer, } \\
\text { cada) }\end{array}$ & $\begin{array}{l}\text { O artigo definido converte-se em } \\
\text { quantitativo universal quando, } \\
\text { individualizando uma ideia geral, } \\
\text { faz compreender na significação de } \\
\text { um apelativo todos os da mesma } \\
\text { espécie (il.: o tigre é feroz; o } \\
\text { pensamento é os olhos da alma). }\end{array}$ \\
\hline
\end{tabular}




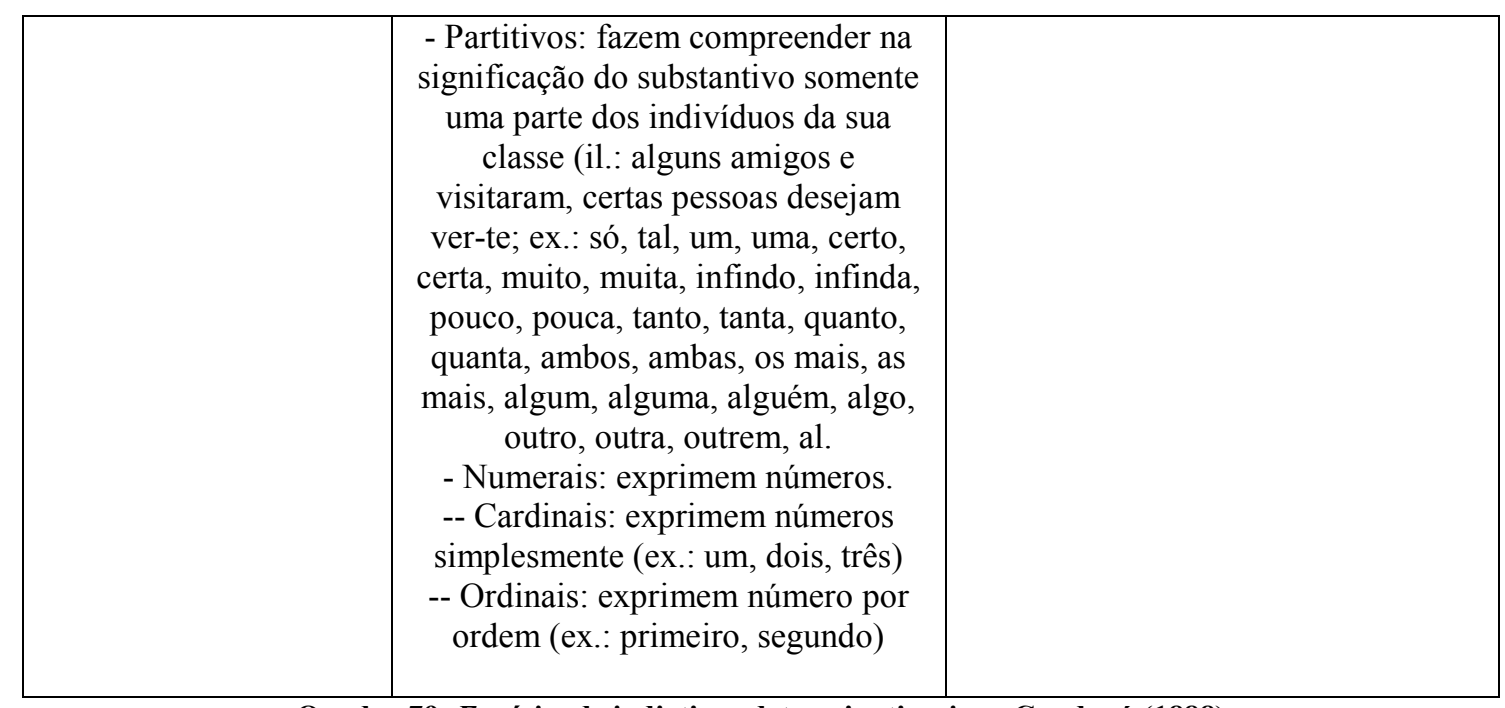

Quadro 79. Espécies de 'adjetivos determinativos' em Condurú (1888)

Os 'adjetivos qualificativos' ou 'atributivos' são os que exprimem qualidades ou atributos do substantivo (il.: Sol brilhante, terra fértil). Entre os qualificativos, distinguem-se os gentílicos, pátrios e particípios.

\subsubsection{Conceito de verbo}

Em texto, define 'verbo' como palavra que exprime a existência, estado ou ato de algum sujeito por diferentes modos, tempos, números e pessoas. Em seguida, diz que os verbos são ou 'de existência' ou 'de ação'. A primeira espécie, que também pode ser chamado de 'verbo substantivo', é definido como aquele que afirma a existência de um sujeito modificada por algum 'atributo' (il.: Deus é onipotente; o Brasil está situado na América). 'Verbos de ação' são definidos como aqueles que exprimem o estado de um sujeito praticando alguma ação (il.: eu escrevo; tu lês; ele brinca).

Em metatexto, ele diz que preferiu a definição dada em texto por considerá-la mais conforme a natureza dos verbos portugueses e, consequentemente, mais adaptada à compreensão dos meninos do que a definição lógica. Entretanto, apresenta esta última em nota para que o leitor siga a que preferir. Define, primeiramente, o 'verbo lógico' como palavra que exprime a relação de conveniência entre os termos da proposição, encontrese em sua forma simples, como 'verbo substantivo', ou incorporado ao atributo, como 'verbo adjetivo'. O primeiro tem seu nome por subsistir sem ideias acessórias e seria o único necessário, visto que por meio dele pode-se enunciar todas as proposições (ex.: ser, estar). O segundo tem seu nome porque o atributo nele incluído é exprimido, em geral, por 'adjetivo'. Todos os verbos, exceto por “ser" e “estar”, são 'adjetivos' e podem ser 
substituídos por esses com o 'atributo' expresso (il.: amar $=$ ser amante $=$ estar amando; folgar $=$ estar folgando). Finaliza a nota dizendo que essa doutrina, verdadeira para as línguas formadas segundo os princípios da Ideologia, apresenta dificuldades de análise naquelas em que não seja possível substituir verbos por outros termos sem alteração de sentido ou sem recorrer a palavras estranhas ao uso vivo da língua.

Em nota seguinte (portanto, metatexto) relativa às ilustrações dadas para 'verbo de existência', Condurú emenda que além de "ser" e "estar" tem a língua portuguesa vários outros verbos que por vezes também pedem 'atributo' (il.: ficar (contente); parecer (alegre); permanecer (triste)), os verbos “existir" e "haver", na mesma significação, são incontestavelmente 'verbos de existência', e se não pedem atributo expresso é porque na sua significação, que é "ser existente", já o compreendem.

De volta ao texto, Condurú divide o 'verbo de ação' em 'absoluto' ou 'intransitivo', 'transitivo' e 'relativo' - para os quais também apresenta um metatexto didático ("convindo muito que os principiantes distingam desde logo essas espécies de verbos, damos nessa nota a maneira prática de os conhecer”). Há também os verbos 'pronominais', 'auxiliares' e 'impessoais', conceitos que distribuímos e explicitamos no quadro adiante.

\begin{tabular}{|c|c|c|}
\hline $\begin{array}{c}\text { Espécies de verbo } \\
\text { (termos) }\end{array}$ & Conceito em texto & Conceito em metatexto \\
\hline \multirow[t]{2}{*}{$\begin{array}{l}\text { Absoluto / } \\
\text { Intransitivo / } \\
\text { Neutro }\end{array}$} & $\begin{array}{c}\text { Exprime uma ação que não passa do } \\
\text { sujeito que a pratica (il.: vós velais, } \\
\text { eles dormem) }\end{array}$ & $\begin{array}{l}\text { Todas as vezes que depois dele não se } \\
\text { poder dizer "alguém" ou "alguma } \\
\text { coisa" (ex.: suspirar). }\end{array}$ \\
\hline & & $\begin{array}{l}\text { Contudo, às vezes tomam os verbos } \\
\text { significação diversa da que lhes é } \\
\text { própria (il.: Estuda se queres saber; } \\
\text { este homem reflete bem; viver vida } \\
\text { alegre). Nessas ilustrações de uso, os } \\
\text { 'verbos transitivos' "estudar" e } \\
\text { "saber" e o 'relativo' "refletir" têm } \\
\text { significação de 'absolutos,' e o } \\
\text { 'absoluto' "viver", a de transitivo. }\end{array}$ \\
\hline Transitivo & $\begin{array}{c}\text { Exprime uma ação que pode ser } \\
\text { empregada diretamente em algum } \\
\text { objeto (il.: Deus criou todas as coisas) }\end{array}$ & $\begin{array}{l}\text { Pode-se perguntar a ele: “o que?" ou } \\
\text { “a quem?” (ex.: amar, saber). } \\
\text { (Cf. metatexto de v. absoluto) }\end{array}$ \\
\hline Relativo & $\begin{array}{c}\text { Pede depois de si um termo precedido } \\
\text { de alguma preposição para completar } \\
\text { seu sentido (il.: a virtude não precisa } \\
\text { de adorno) }\end{array}$ & $\begin{array}{c}\text { Todo verbo que é sempre seguido de } \\
\text { certa preposição, sem a qual ele deixa } \\
\text { de fazer sentido (ex.: rivalizar, } \\
\text { recorrer). }\end{array}$ \\
\hline & & (Cf. metatexto de v. absoluto) \\
\hline $\begin{array}{c}\text { Transitivo e } \\
\text { Relativo }\end{array}$ & $\begin{array}{c}\text { Pedem não só o objeto sobre que recai } \\
\text { a ação, mas também o termo a que ela } \\
\text { se refere (il.: Deus ordenou a caridade } \\
\text { a todos os homens) }\end{array}$ & \\
\hline
\end{tabular}




\begin{tabular}{|c|c|c|}
\hline Pronominais & $\begin{array}{c}\text { Certos verbos que são sempre } \\
\text { acompanhados de algumas variações } \\
\text { dos 'determinativos pessoais' (ex.: } \\
\text { me, te, se, nos, vos; il.: apoderar-se, } \\
\text { obstinar-se, condoer-se). }\end{array}$ & - \\
\hline Auxiliares & $\begin{array}{c}\text { Verbos que auxiliam os outros em } \\
\text { alguns de seus tempos (ex.: ter, haver, } \\
\text { ser). }\end{array}$ & $\begin{array}{l}\text { Na classe dos verbos auxiliares } \\
\text { compreende-se os que, conjugados em } \\
\text { todos ou em alguns tempos somente } \\
\text { com os particípios ou infinito de } \\
\text { outros, servem para dar-lhes uma } \\
\text { significação particular (il.: ando } \\
\text { trabalhando, vamos vivendo). O verbo } \\
\text { "poder", seguido quase sempre de } \\
\text { outro no infinito, parece-nos auxiliar } \\
\text { deste, porque na mudança das } \\
\text { proposições ativas ou passivas, ele, } \\
\text { assim como o "ter" e "haver", } \\
\text { conserva sua forma primitiva (il.: } \\
\text { podes-te alcançar um emprego - um } \\
\text { emprego pode ser alcançado por ti). }\end{array}$ \\
\hline Defectivos & $\begin{array}{l}\text { Verbos que não se prestam a todas as } \\
\text { variações de uma conjugação (ex.: } \\
\text { feder e munir - que só têm as } \\
\text { terminações em que o "d" e o “n” não } \\
\text { são seguidos de "o"). }\end{array}$ & - \\
\hline $\begin{array}{c}\text { Impessoais }< \\
\text { defectivos }\end{array}$ & $\begin{array}{l}\text { Só se empregam na terceira pessoa do } \\
\text { singular (ex.: chover, nevar, trovejar). }\end{array}$ & - \\
\hline
\end{tabular}

Quadro 80. Espécies de 'verbo' em Condurú (1888)

\subsubsection{Conceito de oração e seus elementos}

Em texto, Condurú define a 'oração' ou 'proposição' como enunciação de um 'sujeito' de quem se afirma ou se nega alguma coisa. Tem necessariamente duas partes, o ‘sujeito' e o ‘verbo', quando este é 'absoluto' (il.: a Terra gira); quando o 'verbo' é 'de existência', consta também de 'atributo' (il.: o sol é brilhante); finalmente, se for 'verbo' de ação 'transitiva', há um termo chamado 'paciente' ou 'complemento objetivo' (il.: a lua tem dois movimentos). No quadro adiante, apresentamos a definição de cada um dos elementos essenciais da 'oração':

\begin{tabular}{|c|c|}
\hline $\begin{array}{c}\text { Elementos } \\
\text { essenciais da } \\
\text { 'oração' (termo) }\end{array}$ & Conceito em texto \\
\hline Sujeito & $\begin{array}{c}\text { Pessoa ou objeto de quem se afirma ou nega alguma coisa, cujo caráter e número } \\
\text { são indicados pelo verbo (ex.: terra, sol, lua). Pode ser qualquer substantivo, } \\
\text { alguns dos pronomes pessoais ou dos demonstrativos relativos, algum verbo no } \\
\text { infinito, ou outra oração. }\end{array}$ \\
\hline Verbo & Palavra que exprime a existência, estado ou ato do sujeito \\
\hline Atributo & $\begin{array}{c}\text { Aquilo que se afirma ou nega do sujeito, por meio dos 'verbos de existência' (il.: } \\
\text { o sol é brilhante). Pode ser um adjetivo qualificativo, substantivo ou qualquer }\end{array}$ \\
\hline
\end{tabular}




\begin{tabular}{|c|c|}
\hline & $\begin{array}{l}\text { frase que modifique o sujeito. (il.: tu és feliz; João foi advogado; a minha } \\
\text { ocupação é instruir a mocidade). }\end{array}$ \\
\hline Paciente & $\begin{array}{l}\text { Objeto sobre o qual recai a ação do sujeito por meio do verbo transitivo (il.: a lua } \\
\text { faz seu movimento). Tudo quanto pode ser sujeito, pode também ser paciente } \\
\text { (que fazer aí?; vós aprendeis a ler; vejamos se eles estudam). }\end{array}$ \\
\hline
\end{tabular}

Nota-se que há pequenas incoerências nas definições, pois falta ao 'sujeito' realizar uma ação, visto que o 'paciente' é aquele sobre o qual recai a ação do ‘sujeito'. Fala-se também de 'afirmar' na definição do 'sujeito' e do 'atributo' e mesmo na definição de 'oração', mas não fica claro que elemento da 'oração' seria responsável por isso, pois o 'verbo' é definido apenas como palavra que exprime existência, estado ou ato do sujeito.

Em metatexto, apresenta outro conceito de 'proposição' que, sendo analisada logicamente, teria como elementos o ‘sujeito', o ‘verbo' e o ‘atributo', como nas seguintes ilustrações de uso "deus é espírito" e "creio", que pode ser analisado como "eu sou crente". Acrescenta ainda, em metatexto, que pode ser necessário haver 'palavras modificativas' na 'proposição', como 'atributos continuados', 'complementos restritivos', 'terminativos', 'objetivos' e 'circunstanciais'.

Quanto à organização dos elementos por 'regência', Condurú afirma que há palavras chamadas 'membro regente' que pedem que outra lhe complete o 'sentido', a qual é nomeada de 'regimen' ou 'complemento'. Os 'membros regentes' são 'verbos transitivos', 'preposições' e todas as palavras de 'significação relativa' que demandam alguma 'preposição' que, com seu 'regimen', lhe complete o sentido (il.: superior aos mais; abundante de frutos; propensão para o estudo).

Os ‘complementos' são dados somente em metatexto (os gramáticos dizem) e são de quatro espécies: 'objetivo', 'terminativo', 'restritivo' e 'circunstancial', sendo os dois primeiros necessários, ao passo que os dois últimos são acidentais. No quadro adiante, apresentamos o conceito de cada um.

\begin{tabular}{|c|c|}
\hline $\begin{array}{l}\text { Espécies de } \\
\text { 'complemento' }\end{array}$ & Conceito em metatexto \\
\hline Objetivo & $\begin{array}{c}\text { 'Palavra' ou 'frase' sobre que recai diretamente a ação do 'verbo transitivo' (il.: } \\
\text { cultivar as letras; dizem que és estudioso). }\end{array}$ \\
\hline Terminativo & $\begin{array}{l}\text { Palavra ou frase precedida de alguma preposição, pedida por força da } \\
\text { significação de outra palavra (aplica-te ao trabalho; foge da ociosidade). }\end{array}$ \\
\hline Restritivo & $\begin{array}{l}\text { Palavra ou frase que, precedida da proposição "de", serve de restringir a } \\
\text { significação geral do apelativo antecedente, tornando-a particular (il.: o amor da } \\
\text { gloria; o desejo de tornar-se útil à sociedade). }\end{array}$ \\
\hline Circunstancial & $\begin{array}{l}\text { Qualquer palavra ou frase que, à maneira dos advérbios, modifica o nome ou } \\
\text { verbo com que se relaciona por meio de alguma preposição, clara ou oculta (il.: } \\
\text { aplicado com afinco a seu trabalho; não atendia (em) muitas vezes ao que se } \\
\text { passava em sua vizinhança). }\end{array}$ \\
\hline
\end{tabular}

Quadro 82. Espécies de 'complemento' em Condurú (1888) 
Fala ainda de 'subatributos' ou 'palavras continuadas' e de 'apóstrofe' ou 'vocativo' como outros elementos possíveis da 'oração'. As primeiras se pospõem a outras para acrescentar-lhes alguma ideia ou explicar-lhes alguma qualidade (Gama, o descobridor da navegação da Índia, foi feito conde da Vidigueira por D. Manoel, rei de Portugal; o brilho da virtude torna-se mais vivo quando luta com a adversidade), a segunda é a pessoa ou coisa personificada por quem chamamos ou a quem exortamos por meio da 'interjeição' “ó”, expressa ou subentendida (il.: Lembra-te, ó homem, que é de pó formado; correi, lágrimas, que o pranto a dor embota).

As espécies de 'oração' podem ser consideradas sob dois critérios, de acordo com seus próprios termos ou de acordo com as relações que mantêm entre si dentro do 'período'. Dentro do primeiro critério, ela pode ser 'simples', quando consta de apenas um 'sujeito', de um único 'atributo' ou somente um 'paciente' (il.: o vício é feio; eu amo a virtude). Pode ser 'composta' quando tem mais de um 'sujeito', 'atributo' ou 'paciente' (il.: e Paulo são probos; Francisco é grato e generoso; João e Antônio estudam gramática e geografia); há na 'oração composta' tantas 'simples' quantos forem seus 'sujeitos', 'atributos' ou 'pacientes'. Finalmente, a 'oração' é 'complexa' quando o 'sujeito', o 'atributo' ou 'paciente' é modificado por outra 'proposição' ou por ideias equivalentes (il.: Deus justo (ou que é justo) não deixará sem prêmio o virtuoso (ou o homem que é virtuoso). É curioso que essa ilustração apresente certa equivalência entre 'adjetivos' e 'orações' (sobretudo as 'incidentes', que vemos a seguir).

Quando as 'orações' fazem parte de um 'período', há várias 'orações subordinadas' e uma delas que é a 'principal', da qual dependem todas as outras. No quadro adiante apresentamos as espécies de ‘oração’ selecionadas por Condurú.

\begin{tabular}{|c|c|c|}
\hline $\begin{array}{l}\text { Espécies de } \\
\text { 'oração' dentro do } \\
\text { 'período' (termos) }\end{array}$ & & Conceito em texto \\
\hline Principal & \multicolumn{2}{|c|}{$\begin{array}{l}\text { Aquela que por si só faz sentido completo no 'período', é sempre enunciada por } \\
\text { 'verbo' do 'indicativo' ou do 'imperativo', sem 'conjunção' que a torne } \\
\text { dependente de outra. }\end{array}$} \\
\hline Subordinada & \multicolumn{2}{|c|}{$\begin{array}{l}\text { Depende de outra por meio de alguma 'conjunção', por isso não faz por si só } \\
\text { sentido completo. Pode ser enunciada por verbo de qualquer modo. }\end{array}$} \\
\hline \multirow[t]{2}{*}{ Parcial } & \multicolumn{2}{|c|}{$\begin{array}{l}\text { Aquela que faz parte de outra, ou modifica algum de seus membros } \\
\text { (il.: a dor que nos causa o arrependimento de nossos erros traz consigo um } \\
\text { germe de consolação, porque já a consciência, que é inspiração divina, começa } \\
\text { a dirigir nossa reflexão - a dor traz consigo um germe de consolação > } \\
\text { principal; porque já a consciência começa a dirigir a nossa reflexão > } \\
\text { subordinada; que nos causa o arrependimento de nossos erros, que é inspiração } \\
\text { divina, a dirigir a nossa reflexão > parciais). } \\
\text { As 'orações parciais' dividem-se em 'integrantes' e 'incidentes'. }\end{array}$} \\
\hline & Integrante & $\begin{array}{l}\text { Aquela que faz parte de outra como 'sujeito', 'atributo' ou } \\
\text { 'complemento necessário' (il.: convém que nos entendamos; teu }\end{array}$ \\
\hline
\end{tabular}




\begin{tabular}{|c|c|c|}
\hline \multirow{1}{*}{ Incidente } & $\begin{array}{c}\text { prazer é andares vagando; sabei que sou vosso amigo). Sendo ela } \\
\text { suprimida, deixa suspenso o sentido da frase. }\end{array}$ \\
\cline { 2 - 3 } & $\begin{array}{c}\text { Aquela que se refere a algum membro de outra por meio dos } \\
\text { relativos “que, qual, quem" ou do 'possessivo' "cujo" e pode ser } \\
\text { 'explicativa' ou 'restritiva'. }\end{array}$ \\
& $\begin{array}{c}\text { - 'Explicativa' é a que desenvolve alguma qualidade } \\
\text { compreendida na significação do mesmo que ela modifica (il.: } \\
\text { explicativa' pode ser suprimida sem alterar o sentido da frase. } \\
\text { - 'Restritiva' é a que ajunta alguma ideia não incluída na } \\
\text { significação do membro por ela modificado (il.: o homem que é } \\
\text { modesto não louca suas próprias ações). A 'oração restritiva' não } \\
\text { pode ser tirada da frase sem alteração do sentido. }\end{array}$ \\
\hline
\end{tabular}

Era comum entre as gramáticas ${ }^{123}$ apresentar um paralelismo entre as espécies de 'adjetivo qualificativo' e de ‘oração incidente', mas, como vimos anteriormente, Condurú nega a possibilidade de 'adjetivos' poderem ser distinguidos dessa maneira, afirmando que isso seria uma confusão entre caracteres distintivos e 'relações de conveniência inerente' ou 'acidental' que pode haver entre 'substantivos' e 'adjetivos'. Entretanto, na ilustração que vimos acima, o autor parece possibilitar certa equivalência entre 'adjetivos' e 'orações', sobretudo as 'incidentes'.

\subsubsection{Rede conceitual}

Consideramos a gramática elementar de Condurú eclética verticalmente. Isso porque os conceitos que formam rede conceitual com o 'verbo substantivo' da tradição estão em metatexto, tal como está o próprio 'verbo substantivo', que é considerado pouco adequado, ao menos, para a língua portuguesa. No entanto, em texto, os conceitos apresentados fogem a essa rede. Talvez isso seja consequência do momento de transição, o qual pudemos notar em outras obras, como as já analisadas de Ribeiro $(1881,1885)$ e Maciel (1887 e 1895) (cf. 4.8 e 4.9), com a diferença de que analisamos duas obras de cada um desses autores, assim, eles apresentavam a o 'verbo substantivo' e sua rede na obra mais antiga, os quais eram eliminados em obra ulterior. No caso de Condurú, cuja edição que analisamos é a décima terceira, o gramático parece optar por apresentar a rede conceitual do 'verbo substantivo' apenas em metatexto, ou seja, em lugar de menos destaque; preferindo apresentar em texto outros conceitos de 'verbo' e 'oração'.

123 Ver, por exemplo, Bithencourt (1862) que, explicitamente, estabelece esse paralelismo. Outros gramáticos que o apresentam de maneira menos explícita são Costa Duarte (1829, 1859), Maciel (1887), Alfredo Gomes (1895). 
Em metatexto, o 'verbo substantivo' está em relação de subordinação com o conceito de 'verbo lógico', o conceito de 'proposição' apresentando em metatexto. Observamos, aliás, que a ilustração de uso do conceito de 'verbo adjetivo', que inclui o 'verbo substantivo', “amar = ser amante”, é equivalente à ilustração apresentada para o conceito de "proposição lógica' "creio = eu sou crente".

Ademais, haveria certo paralelismo entre as espécies de 'adjetivos qualificativos' e as espécies de 'oração incidente’ em decorrência apenas de uma ilustração apresentada pelo autor. Condurú, entretanto, mostra-se em metatexto contrário à distinção entre 'adjetivos qualificativos restritivos' e 'explicativos'. Afirma que um mesmo 'adjetivo' seria ora 'explicativo', ora 'restritivo'. Finalmente, a definição de gramática do autor não faz referência a diferentes níveis da linguagem. A base teórica comum que pressupõe uma língua subjacente parece, portanto, não ter tanta relevância.

Ainda a respeito do 'verbo substantivo', é notável que ele seja considerado inadequado, especificamente, para a língua portuguesa, que não ser uma língua formada de acordo com os "princípios da Ideologia”. Como vimos, Condurú, ao definir gramática, ressalta somente a correção, não define linguagem como expressão do pensamento. Dessa forma, podemos supor que sua base teórica não contenha esse conceito de linguagem, o que possibilitaria que o 'verbo substantivo' fosse adequado a certas línguas, enquanto impróprio para outras. Em suma, o gramático parece mais focado em dados linguísticos, nesse caso, do que em abstrações sobre a língua, mas está ainda atado à tradição e, por isso, apresenta conceitos relativos a ela em metatexto.

\subsection{Exames de Portuguez-Grammatica Portugueza ( $3^{\circ}$ anno) (1889, [167]), de João Ribeiro Fernandes}

\subsubsection{Conceitos de gramática e de linguagem e organização da obra}

A gramática de Ribeiro, por ser baseada no Programa de Estudos escrito por Fausto Barreto, é dividida em capítulos que correspondem a cada um dos itens colocados no programa, os quais ele chama de lições (cf. Apendice B). Na lição 1, define gramática como coordenação das fórmulas, leis ou regras segundo as quais uma língua é falada ou escrita. Em metatexto (nota), diz ainda que

Esta definição é deduzida da observação dos fatos da linguagem. A analyse revela que toda a lingua tem grammatica, porque os vocabulos que servem para a expressão das ideias, affectam variações de fórma, de collocação e de sentido susceptiveis de serem generalizadas, isto é, de 
serem construidas sob o typo de leis ou regras. O systema geral e abstracto destas leis constitue a grammatica. (Ribeiro 1889:1)

A 'gramática', desse ponto de vista, não é apenas um manual que descreve a linguagem, mas também leis intrínsecas a cada língua. A língua, assim, por conter uma gramática, pode ser vista como um sistema geral e abstrato de tais 'leis'.

Ribeiro divide a 'gramática', enquanto manual, em 'geral' e 'particular'. A primeira é aquela que expõe princípios lógicos comuns a todas as línguas, ao passo que a 'particular' expõe princípios e particularidades especiais de um idioma. Em metatexto (nota), afirma que "actualmente o progresso da philologia proscreveu a sciencia da grammatica geral" e que ela existe apenas quando para análise de uma classe, família ou grupo de língua de mesma filiação. Expõe, nesse trecho, que a base teórica abstrata, normalmente baseada em uma língua subjacente, da 'gramática geral' não era mais aceita, por isso, teria sido substituída por uma base teórica voltada para dados, mais próxima do Programa Descritivista (cf. Quadro 2), em que a generalidade da gramática seria observada por razões históricas e relações genéticas entre línguas.

Define ainda outros quatro tipos de 'gramática': 'histórica', 'comparativa', 'descritiva' e 'portuguesa'. A primeira é aquela que estuda os fatos de uma língua em diversos períodos, de sua origem e formação até a época presente. A ‘comparativa' estuda fatos comuns ou diversos em um grupo de línguas cuja origem é a mesma. Em metatexto (nota) diz que os estudos histórico e comparativo são, em geral, inseparáveis e constituem o 'método histórico-comparativo', que é, segundo Ribeiro, essencial à ciência das línguas. Acrescenta que, no caso da língua portuguesa, os elementos históricos são fornecidos pelo 'português antigo', o 'latim' e por influência de 'línguas estranhas', já os elementos comparativos encontram-se na análise de 'línguas românicas', como 'italiano', 'francês' e 'espanhol', que originaram-se do 'latim bárbaro’ da Idade Média.

Em texto, define a 'gramática descritiva' ou 'expositiva' ou 'prática' como arte que ensina a falar e a escrever corretamente uma língua. Em metatexto, observa que como essa gramática é 'arte', contém amiúde 'preceitos anticientíficos' e procura meios mecânicos e mnemônicos que facilitem o estudo. Ela, por exemplo, denomina como 'verbos irregulares' aqueles que, cientificamente, "no sentido de sua filiação historica, conservam a regularidade primitiva" (Ribeiro 1889: 2).

A respeito da 'gramática portuguesa', em texto, explicita sua divisão em quatro partes principais, que são 'fonologia', 'morfologia', 'classificação' ou 'taxonomia' e 'sintaxe'. As três primeiras são relativas ao estudo do vocábulo, a última, ao da 'frase' ou 
'proposição'. Em seguida, em metatexto (nota), o gramático afirma que as três partes supracitadas que se referem ao estudo do vocábulo têm, no conjunto, a denominação de 'lexilogia'. Ademais, afirma que o 'sentido' do 'vocábulo' é estudado na 'semântica', e sua origem e formas primitivas, na 'etimologia', estudos esses que apesar de dependentes da 'gramática', em geral, não fazem parte dela, antes representam divisões da 'filologia geral'.

Finaliza, assim, a introdução da lição 1, que dizia respeito, segundo o nome do capítulo (e o programa de Fausto Barreto) a "observações geraes sobre o que se entende por grammatica geral, grammatica historica ou comparativa e por grammatica descriptiva ou expositiva; objeto da grammatica portugueza e divisão do seu estudo".

Chamam atenção, sobretudo, os metatextos do autor, que revelam de certa forma que algumas coisas não eram óbvias e, por isso, precisavam ser ressaltadas. Isso acontece, primeiramente, na nota que explicita que todas as línguas têm 'leis' ou 'regras' que constituem a 'gramática' de cada língua, as quais são apresentadas no manual 'gramática' a partir da observação de fatos linguísticos. Em outra nota, trata da proscrição da 'gramática geral', que seria agora apenas a análise da relação histórica e genética entre as línguas. Finalmente, observa que há aspectos anticientíficos da 'gramática' e procura explicar que o estudo do vocábulo se dá na 'lexilogia', sendo a 'etimologia' e a 'semântica' mais próprias da filologia.

Todos esses comentários apresentam alguma ruptura com a tradição anterior, que: (1) observava a língua por meio de categorias do pensamento e da razão, não estando preocupada necessariamente com os fatos linguísticos; (2) tinha como sua base a 'gramática geral', uma abstração das categorias do pensamento e da razão que poderia ser aplicada a todas a línguas; (3) que a gramática não é uma ciência, mas tem objetivo de ensinar a língua, mais de métodos mnemônicos do que de uma explicação científica acerca dos fatos linguísticos; (4) era comum que gramática anteriores nomeassem a seção destinada ao estudo dos vocábulos, suas definições e espécies como 'etimologia', que, de acordo com Ribeiro, seria um estudo histórico das palavras e se aproximaria da 'filologia'.

\subsubsection{Conceitos de metaclasses e classes de palavras}

Ainda na introdução da obra, lição 1, o autor define 'taxionomia' ou ‘classificação' como a distribuição dos vocábulos por famílias e espécies, segundo o 
sentido. Em metatexto (nota), afirma que essa classificação tem por base a 'idéia', por ser esta o atributo mais notável do 'vocábulo' - a partir disso, as palavras são classificadas em 'famílias' como 'substantivos', 'verbos' etc. Diz ainda que a 'taxionomia' refere-se também à classificação de 'frases' e 'preposições', segundo a função que representam no 'discurso'.

Na lição VII, apresenta a 'classificação de palavras'. Inicia-a definindo novamente 'taxionomia' como a parte da gramática que nos ensina a classificar as palavras. Em metatexto (nota), diz que "na boa classificação a logica determina que se observe a subordinação dos caracteres" dos vocábulos, sendo a 'ideia' o mais importante deles. Pode-se, entretanto, classificar os vocábulos tomando por base outros caracteres ou atributos. Um deles é a 'forma histórica', os vocábulos classificam-se em 'primitivos', que não se originam de outra palavra (ex.: trovão, livro), e 'derivados', que se formaram dos primitivos (ex.: trovoada, de trovão; livraria, de livro). Em metatexto (nota), ressalva que, na prática, não convém levar ao exagero o rigor desse processo, pois alguns nomes ditos derivados derivam, em verdade, do latim diretamente (ex.: anual, que deriva de annualis, não de ano; pedreira, que deriva de petraria, não de pedra). Outra possibilidade é tomar por base de classificação a quantidade extensiva dos vocábulos, que podem ser ‘monossílabos' (uma sílaba - ex.: dor, mar), ‘dissílabos' (duas sílabas - ex.: pedra, casa) ou 'polissílabos' (muitas sílabas - ex.: socorro, extraordinário). Em metatexto (nota), afirma que existe ainda a denominação 'trissílabos' para os que têm três sílabas, e que esse processo de classificação é puramente material e não tem muitas aplicações fora da 'ortografia' e 'prosódia'.

Quando se toma por base as 'variações' que se observam em muitos vocábulos, diz que é possível classificá-los em dois grandes grupos. Um de 'palavras variáveis', são aquelas que sofrem diversas variações na 'terminação' para exprimir gênero, número, tempo etc., correspondem aos 'substantivo', 'artigos', 'adjetivos', 'pronomes' e 'verbos'. Outro de 'palavras invariáveis', aquelas cuja estrutura não aparece modificada, correspondem aos 'advérbios', 'preposições', 'interjeições' e 'conjunções'. Em metatexto (nota), emenda que o caráter de variabilidade não é muito fixo, visto que, por exemplo, 'advérbios' e 'preposições' tinham primitivamente variações de 'grau' (alguns ainda sobrevivem, ex.: certamente - certissimamente).

Tomando por base a comparação de vocábulos entre si, é possível classificá-los nos seguintes grupos: 'sinônimos', que têm mais ou menos a mesma significação (ex.: casa, mansão, lar, domicílio); 'antônimos', que têm significados opostos (ex.: luz, trevas; 
riso, lágrimas); homônimos, vocábulos semelhantes entre si (ex.: bota (calçado), bota (do verbo botar)) - acrescenta o metatexto (nota) dizendo que chamam-se 'homógrafos' quando se escreve com as mesmas letras, e 'homófonos' quando têm apenas a mesma 'prosódia' ou 'pronúncia' (ex.: cesta, sexta); e, finalmente, 'parônimos' que são palavras pouco diferentes entre si (ex.: relevar, revelar; diferir, deferir). Todas as classificações supracitadas, utilizadas frequentemente por gramáticos, são, entretanto, para o autor, imperfeitas, porque se baseiam em caracteres secundários. O caráter essencial de qualquer vocábulo é a ideia ou significação. Assim, no léxico de qualquer língua, encontramos palavras que indicam seres, como os 'substantivos', outras que indicam fatos e ações, como os 'verbos' etc.

Em seguida, inicia o tratamento do 'substantivo' e das demais classes de palavras, que são, em sua ordem de apresentação (a qual era determinada pela ordem dos pontos do Programa de Estudos de Fausto Barreto): 'substantivo', 'adjetivo', 'pronome', 'verbo', 'advérbio', 'preposição', 'conjunção', 'interjeição'.

Assim, podemos observar que o autor apresenta as metaclasses de palavras 'variáveis' e 'invariáveis', que juntas constam de nove classes de palavras; dessas, ele descreve apenas oito. A diferença se dá pela posterior ausência do 'artigo' na divisão das lições da gramática (a qual, como já mencionado, segue o programa de estudos). É curioso, como veremos adiante, que Ribeiro não apresenta os 'artigos' como espécie do 'adjetivo'. Ele tratará desse conceito apenas na lição 26, sobre a 'etimologia' do 'artigo' e do 'pronome'.

\subsubsection{Conceitos modificadores do nome}

O 'adjetivo' é definido, na lição VIII, como palavra que serve para qualificar ou determinar objetos. Em metatexto (nota de rodapé), coloca que a denominação latina dessa classe de palavra era 'nomen adjetctivum', que, por sua vez, era tradução do grego

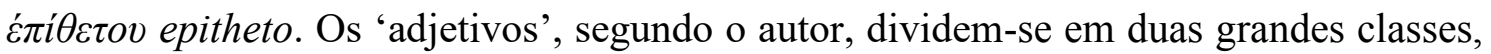
'nominais' ou 'qualificativos' e 'pronominais' ou 'determinativos'. Ele apresenta a seguinte organização:

\begin{tabular}{|l|l|l|}
\hline \multirow{2}{*}{ Adjetivos } & 1. Nominais ou qualificativos & \multirow{2}{*}{$\mathbf{c}$} \\
& & Possessivos \\
& & Demonstrativos \\
& Relativos & \\
\hline
\end{tabular}




\begin{tabular}{|l|l|l|l|}
\hline \multirow{2}{*}{ 2. Determinativos } & Interrogativos & \\
\cline { 3 - 4 } & & \multirow{2}{*}{ Quantitativos } & Numerais \\
\cline { 3 - 4 } & & Indefinidos \\
\hline
\end{tabular}

Ribeiro observa que 'indefinidos', ainda que não possam ser 'determinativos', exprimem uma determinação. Os interrogativos são definidos, sobretudo, pela você de quem fala e pela inflexão da voz do que pela natureza do vocábulo.

Define o 'adjetivo qualificativo (nominal)' como aquele que exprime a qualidade do objeto (il.: casa assoalhada). Em metatexto (nota), diz que a função do qualificativo é mostrar como são os objetos (ex.: grande, vermelho, prudente, luminoso). Entretanto, há momentos em que o qualificativo exerce função determinativa do objeto, distinguindo-o de outros, nesses casos vem ordinariamente anteposto (il.: São Pedro; a bela Helena). Em seguida, define as 'locuções adjetivas' como qualificativos expressos analiticamente por duas ou três palavras (ex.: quarto de dormir, mesa de mármore, vela de cera, navio de vela, navio de vapor, animal de dois pés) e que podem ser substituídos por um 'qualificativo'.

'Determinativos', que também podem chamar 'pronominais', marcam a referência dos 'nomes' sem indicar nenhuma qualidade. Em metatexto (nota), observa que, em verdade, 'adjetivos determinativos' são simultaneamente 'adjetivos' e 'pronomes'. As funções podem ser discriminadas apenas no texto da frase, pois o 'adjetivo' vem junto ao 'substantivo' (il.: que coisa?; meu tio), ao passo que o 'pronome' vem isoladamente (il.: o chapéu que achastes é meu). Pelas mesmas razões, diz o gramático, na frase "os soldados são sete" a palavra "sete" deveria ser considerada 'pronome'. Para evitar confusões como essa, segundo Ribeiro, muitos gramáticos judiciosamente só consideram a existência dos 'pronomes pessoais' ${ }^{124}$.

Ribeiro define cada uma das espécies de 'adjetivo determinativo', apresentamos um pequeno resumo de cada um adiante. O 'possessivo' é o que determina a pessoa gramatical a que pertencem os objetos (ex.: meu, teu, seu, nosso, vosso, seu, deles). Acrescenta que ‘adjetivos gentílicos' são uma espécie de 'possessivos' (ex.: brasileiro do Brasil; francês, de França). 'Demonstrativos' são os que determinam o lugar dos objetos no espaço, no tempo e no discurso (ex.: este, aquele). 'Relativos' referem-se a um nome ou pronome, que é determinado ou qualificado por uma proposição (il.: eu que sou

\footnotetext{
${ }^{124}$ Um dos gramáticos que analisamos que faz isso, embora não apresente tal justificativa, é Sotero dos Reis (1877) (cf. 4.6).
} 
criança; o qual homem já conheces). Em metatexto (nota), acrescenta que o 'relativo' substitui o 'nome' e ao mesmo tempo faz vezes de 'conjunção', ligando o nome determinado, chamado 'antecedente', com a proposição determinante que se segue, por isso, pode ser denominado também 'adjetivo conjuntivo'. O 'interrogativo' exprime indefinidamente os objetivos, como indagando a sua individualidade ou natureza (ex.: quanto?; que?; il.: que homem?). O ‘quantitativo' pode ser 'indefinido' ou 'positivo', este também chamado de 'numeral'. O primeiro dá aos nomes uma determinação, sem indicar o número ou a qualidade (ex.: muitos, poucos, diversos, diferentes, vários, alguns, algo, tantos, quantos, quais, todos, cada, nenhum, uns, outros). Os 'numerais' indicam números, determinando a quantidade exata (ex.: um, três, milésimo); é dividido em 'cardeais', que indicam números de unidades (ex.: um, dois, vinte e cinco), e 'ordinais', que exprimem o número conforme a ordem das coisas (ex.: primeiro, vigésimo), também podem exprimir frações (ex.: centésima, décima oitava parte).

Na lição IX, trata dos 'pronomes' e suas espécies. Define a classe de palavra como palavra que lembra o nome, em relação à sua pessoa gramática. Em metatexto (nota de rodapé), diz que o vocábulo formado de pro e nomen significa em lugar de nome. Em outro metatexto (nota), afirma que o 'pronome' é um simples 'determinativo', pois quando se diz "livro", este ser aparece como todos os seus atributos, ao passo que o 'pronome' "ele" pode designar qualquer indivíduo, independentemente dos atributos. De volta ao texto, afirma que 'pronomes pessoais' conservam os vestígios da 'declinação' que tinham no latim, por isso têm variações em todas as pessoas. Adiante, exemplo da primeira pessoa:

\begin{tabular}{|c|c|c|c|}
\hline & & Português & Latim \\
\hline \multirow[t]{4}{*}{ Sing. } & Nominativo & $\mathrm{Eu}$ & Ego \\
\hline & Dativo & Mim, me & Mihi \\
\hline & Acusativo & $\mathrm{Me}$ & $\mathrm{Me}$ \\
\hline & Ablativo & Comigo & Mecum \\
\hline \multirow[t]{3}{*}{ Pl. } & Nominativo & Nós & Nos \\
\hline & Acusativo & Nós & Nos \\
\hline & Ablativo & Conosco & Noscum \\
\hline
\end{tabular}

Quadro 85. 'Vestígios de declinação' em 'pronomes pessoais' em Ribeiro (1889)

Ribeiro usa a metalinguagem de descrição da língua latina por acreditar que, neste ponto, essa língua e o português se assemelham. Como vimos anteriormente, outros gramáticos eram contrários a essa prática.

Na lição XVI, chamada 'etimologia do artigo e do pronome', Ribeiro apresenta espécies de 'artigo', que não apresentou em capítulos anteriores. Divide-o em 'definito' e 'indefinito'. O último é aquele que, junto ao 'nome', não lhe determina a 'existência' 
ou 'posição' (il.: um homem). O 'definito', por sua vez, determina a 'espécie' (o homem é animal) ou o 'indivíduo’ (o homem que vimos).

\subsubsection{Conceito de verbo}

Verbo é uma palavra pela qual se pode atribuir a um ser uma ação, um estado ou uma qualidade (numa nota de rodapé, metatexto, acrescenta que o 'ser' citado é o 'sujeito' do 'verbo'). Em metatexto (nota de rodapé), divide o verbo em duas partes: o 'radical', que representa ideia principal, e a 'desinência', que é sempre variável e exprime a ideia acessória (ex.: am-ar, receb-er). Após falar a respeito de 'conjugações' e 'tempo', introduz, em texto, o 'verbo substantivo' (em nota de rodapé, afirma que também pode se chamar 'verbo abstrato'), que define como 'verbo único' que não tem 'ideia atributiva', isto é, o 'atributo' (que não havia sido definido anteriormente) está separado dele, e exprime apenas 'cópula' ou 'existência em absoluto' (ex.: ser). Todos os outros 'verbos' chamam-se 'atributivos' e encerram uma 'ideia predicativa' do 'sujeito'. Nota-se, portanto, que o 'verbo atributivo' está mais próximo da definição de 'verbo' de Ribeiro do que o 'verbo substantivo'.

Em seguida, apresenta outras espécies de 'verbo'. Os 'transitivos', que têm um 'complemento' no qual se emprega diretamente a 'ação predicativa' (il.: amo a virtude). 'Intransitivos' são os que exprimem uma 'predicação' por si só completa ou com um 'complemento indireto' (ex.: durmo; vou a Roma).

Em metatexto, acrescenta a observação de que todos os 'transitivos' como os 'intransitivos' podem entre si mudar de categoria. Assim, por essa 'virtualidade imanente', toda ação é possível (il.: chorei lágrimas; escrevo; leio). Há ainda 'verbos pronominais', que aparecem 'não casualmente', mas sempre com dois 'pronomes' (il.: eu me arrependo; arrepender-se). Fala também de 'verbos defectivos' ou 'impessoais', a que faltam alguns tempos ou pessoas da conjugação (ex.: chove, troveja). Em outra nota (metatexto), afirma que a omissão das flexões dos 'defectivos' explica-se, em geral, pela impossibilidade que as primeiras e segundas pessoas têm de receber certas atribuições (il.: eu trovejo, tu nevas - não se pode dizer, a não ser que em sentido figurado).

Ao final da lição Ribeiro fala, em metatexto (nota), da impossibilidade de dar uma definição suficiente do 'verbo', fazendo com que toda definição seja uma 'locução substantiva', entretanto, nenhum 'substantivo' poderia manter a equipolência com o 'verbo'. Finaliza a seção de tratamento do 'verbo', com a definição de 'verbo' de um 
gramático chamado Flores (do qual não temos informação) como ideal: "verbo é a palavra que significa ser, estar ou fazer qualquer coisa".

\subsubsection{Conceito de proposição e seus elementos}

Ribeiro define 'proposição' como todo agrupamento de palavras formando ‘juízo’ e que consiste sempre dois elementos indispensáveis, o 'sujeito' e o 'predicado'. O primeiro é o ser de que se afirma alguma coisa, o segundo aquilo que se afirma do 'sujeito' (il.: os pássaros / voam; a vida em Paris / é cara; o tempo / consome as coisas). Ambos podem ser 'lógicos', quando acompanhados das palavras que os completam, ou 'gramaticais' (ex.: lógicos - a vida em Paris / consome as coisas; gramaticais: vida / consome).

A respeito da organização dos elementos da 'proposição', Ribeiro cita três classes de 'relações' entre 'frase' e 'palavra': 'predicativa', 'atributiva', 'adverbial'. A 'relação predicativa' é a que existe entre os dois elementos essenciais de uma 'proposição', isto é, o ‘sujeito' e o 'predicado' (il.: Deus / existe; o homem / é mortal; Pedro e João / amam o estudo; a língua dos brasileiros / é a portuguesa). A 'relação atributiva' é toda aquela em

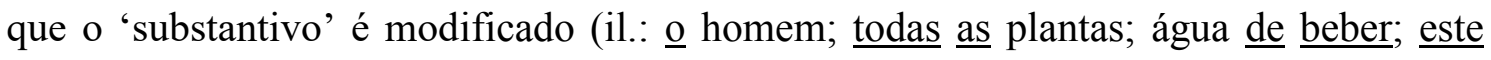
chapéu; a frase o amor tudo vence; o homem que é justo; o livro que escreveste; Sócrates, filósofo grego). Finalmente, a 'relação adverbial' é aquela que modifica ou limita o 'verbo' e o 'adjetivo' por meio de uma ou mais palavras (il.: Jantou como um gastrônomo; saiu às pressas; Júlia é perfeitamente educada; Educado com apuro; voltarei às dez horas). Acrescenta que há um caso especial digno de nota entre as 'relações adverbiais': a 'relação objetiva', que também modifica o 'verbo' (il.: Pedro ama a virtude). Diz ainda que 'objeto' é a palavra em que é empregada a ação do 'verbo', pode ser 'direto'. O primeiro exprime a coisa passiva, que recebe a ação (il.: Antonio matou um faisão) ou que exprime uma 'coisa fatativa', isto é, produto da ação (il.: Escreveu uma carta). O 'objeto indireto' exprime a coisa em vista da qual a ação se realiza (il.: deu um livro a Pedro; escreveu-me). Finalmente, trata dos 'adjuntos', que são elementos secundários que modificam os elementos principais da frase. Podem ser 'atributivos' quando modificam o 'substantivo' e ‘adverbiais' quando modificam o 'verbo' e o 'adjetivo'. No quadro adiante resumimos as quatro 'relações' apresentadas por Ribeiro. 


\begin{tabular}{|c|c|c|}
\hline Relação & Elementos envolvidos & Ilustração de uso $^{125}$ \\
\hline Predicativa & Sujeito e Predicado & $\begin{array}{l}\text { Deus / existe; o homem / é mortal; } \\
\text { Pedro e João / amam o estudo; a língua } \\
\text { dos brasileiros / é a portuguesa. }\end{array}$ \\
\hline Atributiva & $\begin{array}{l}\text { Substantivo e algo que o } \\
\text { modifica }\end{array}$ & 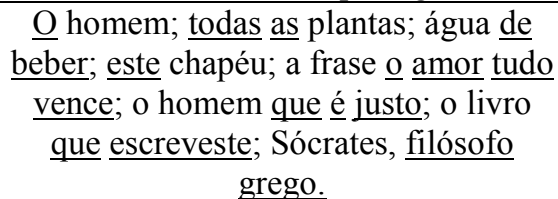 \\
\hline Adverbial & $\begin{array}{c}\text { Verbo ou Adjetivo e algo que } \\
\text { o modifica }\end{array}$ & $\begin{array}{l}\text { Jantou como um gastrônomo; saiu às } \\
\text { pressas; Júlia é perfeitamente educada; } \\
\text { Educado com } \underline{\text { apuro; }} \text {; voltarei às dez } \\
\text { horas. }\end{array}$ \\
\hline Objetiva (< Adverbial) & $\begin{array}{l}\text { Verbo e Objetivo (direto, } \\
\text { coisa fatativa, indireto) }\end{array}$ & $\begin{array}{l}\text { Pedro ama a virtude; Antônio matou } \\
\text { um faisão; Escreveu uma carta; Deu } \\
\text { um livro a Pedro; escreveu-me. }\end{array}$ \\
\hline
\end{tabular}

Quadro 86. Espécies de 'relação' e elementos 'da proposição' envolvidos em Ribeiro (1889)

Os 'sujeitos', 'predicados', 'objetos' e o fato de poderem ser 'simples', 'compostos' e 'complexos'. No quadro adiante, sintetizamos esses conceitos:

\begin{tabular}{|c|c|c|c|}
\hline & Simples & Composto & Complexo \\
\hline Sujeito & $\begin{array}{l}\text { É representado por um } \\
\text { substantivo, pronome, } \\
\text { infinito ou palavra } \\
\text { substantiva (il.: a vida é } \\
\text { breve; viver é necessário; } \\
\text { eu estudo; assaz é um } \\
\text { advérbio). }\end{array}$ & $\begin{array}{c}\text { É o que consta de dois } \\
\text { nomes ou palavras } \\
\text { substantivas (il.: o } \\
\text { nascimento e a morte são } \\
\text { dois termos da vida; eu e tu } \\
\text { estamos bons; ser e não ser } \\
\text { são coisas opostas) }\end{array}$ & $\begin{array}{c}\text { É representado por uma } \\
\text { proposição ou citação (il.: } \\
\text { "Deus e o meu direito" é a } \\
\text { sua dívida; que o trabalho } \\
\text { dá saúde é coisa certa; viver } \\
\text { sem pecado é a ambição do } \\
\text { justo) }\end{array}$ \\
\hline Predicado & $\begin{array}{l}\text { É expresso por um simples } \\
\text { verbo finito (il.: o mineral } \\
\text { cresce; o homem pensa; eu } \\
\text { leio) }\end{array}$ & 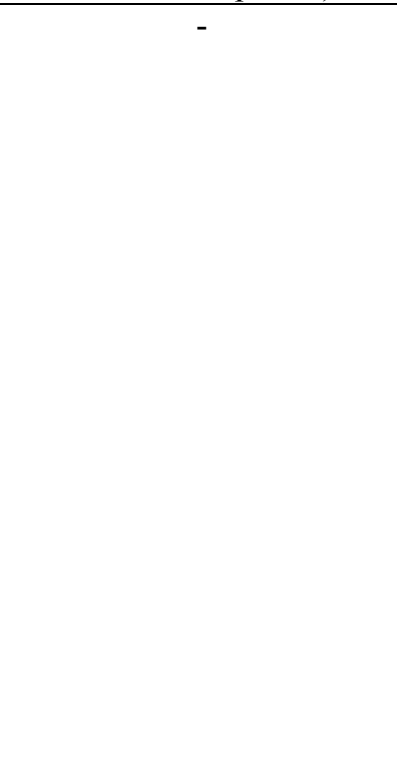 & $\begin{array}{l}\text { É o que se compõe de um } \\
\text { verbo de predicação } \\
\text { incompleta com o seu } \\
\text { ‘completivo’ necessário } \\
\text { (ex.: ser; tornar-se; parecer; } \\
\text { poder; il.: Pedro tornou-se } \\
\text { rico; Ele ficou doente; Ele } \\
\text { parece francês; Nós } \\
\text { podíamos estudar). O } \\
\text { completivo pode ser } \\
\text { ‘subjetivo' quando se refere } \\
\text { ao sujeito, o que se dá em } \\
\text { 'orações passivas' (il.: a } \\
\text { Áustria foi proclamada } \\
\text { nação livre), pode também } \\
\text { referir-se ao 'objetivo’ e } \\
\text { ser, então, 'objetivo' (il.: } \\
\text { Eu tornei o livro mais } \\
\text { volumoso). }\end{array}$ \\
\hline $\begin{array}{c}\text { Objeto } \\
\text { (caso de } \\
\text { 'relação } \\
\text { adverbial' }\end{array}$ & $\begin{array}{l}\text { Mesma definição de 'suj. } \\
\text { simples' aplicada ao } \\
\text { 'objeto' (il.: amo a justiça; } \\
\text { amo o justo; desejo viajar) }\end{array}$ & $\begin{array}{l}\text { Mesma definição de 'suj. } \\
\text { composto' aplicada ao } \\
\text { 'objeto' (il.: amo a justiça e } \\
\text { a clemência; amo os justos }\end{array}$ & $\begin{array}{l}\text { Mesma definição de 'suj. } \\
\text { complexo' aplicada ao } \\
\text { 'objeto' (il.: sei como } \\
\text { estudas; creio que estás }\end{array}$ \\
\hline
\end{tabular}

${ }^{125}$ Nas ilustrações de uso da 'relação predicativa', a barra separa o 'sujeito' do 'predicado', nas ilustrações seguintes, 'atributiva', 'adverbial' e 'objetiva', grifamos, respectivamente, aquilo que modifica o 'substantivo', aquilo que modifica o 'adjetivo' ou o 'verbo' e, finalmente, o 'objeto direito', 'coisa fatativa' ou 'objeto indireto' do 'verbo'. 


\begin{tabular}{|c|c|c|c|}
\hline & $\begin{array}{c}\text { e os clementes; quisera ler e } \\
\text { escrever). }\end{array}$ & $\begin{array}{c}\text { zombando; vi chover } \\
\text { pedras). }\end{array}$ \\
\hline
\end{tabular}

Quadro 87. Espécies de 'sujeito', 'predicado' e 'objeto' em Ribeiro (1889)

Na lição XXXI, apresenta espécies de 'proposição', que também podem ser 'simples', 'complexas' e 'compostas' e toca no tema da 'subordinação' e da 'classificação'. A 'proposição simples' é a aquela que se compõe unicamente de 'sujeito' e de 'predicado' (il.: Deus é onipotente, o poder de Deus é ilimitado; alguns animais vivem à custa de outros; os peixes respiram; Júlio Cesar venceu os bárbaros).

A 'proposição complexa' é aquela que, além de possuir 'sujeito' e 'predicado', contém outras proposições que são 'subordinadas', estas também se denominam 'cláusulas' e dividem-se em três classes. Há a 'cláusula substantiva', que tem função equivalente à de um substantivo (il.: notou que estava pálido (sua palidez); assegurou que eu viria (a minha vinda); quando eu vá é coisa incerta (o tempo da minha vida)); a 'cláusula adjetiva' que tem função de um adjetivo, isto é, modifica o substantivo (il.: vi o livro que tu escreveste (escrito por ti); os dedos que são cinco são os órgãos mais delicados do tato; palavras que ele pronuncia são sempre agradáveis; e, finalmente, as cláusulas adverbiais, que representam uma relação equivalente à do 'advérbio' (il.: ficou onde o deixaram; sairei quando todos saírem). As 'cláusulas advérbios' podem exprimir circunstâncias diversas de tempo, lugar, grau, causa, fim, condição, modo.

A 'proposição composta' é aquela que se compõe de várias proposições que têm a mesma função na 'frase', as proposições internas chamam-se 'coordenadas' e ligam-se pela simples sucessão, neste caso, chamam-se 'colaterais' (chegou, viu, venceu; Amo a virtude. Detesto o vício.), ou por 'conjunções de coordenação', que podem ser 'copulativas' (il.: Deus criou o homem e criou o mundo); 'adversativas' (il.: ele estuda, mas não aprende); 'disjuntivas' (venha ou mande); 'conclusivas' (il.: penso, logo existo). Aquelas que têm a 'conjunção' entre si são também chamadas 'sindéticas', enquanto que aquelas que não têm nada entre elas chamam-se 'assindéticas').

Há ainda outros dois tipos de 'proposição' de que fala Ribeiro. As 'contratas', que têm em comum o mesmo 'objeto', 'predicado' ou 'sujeito' (il.: os franceses e os russos são brancos; o livro que imaginaste e escreveste). Em metatexto (nota), observa que não são ‘contractas' aquelas 'proposições' irredutíveis à análise (il.: Pedro e Paulo são irmãos - Pedro é irmão, Paulo é irmão). As 'proposições elípticas' são aquelas que deixam subentender-se uma parte da frase que não é idêntica à similar já expressa (il.: ele é mais sábio que eu (sou sábio)). 
Ao final da lição, o gramático apresenta um esquema geral do conteúdo dado nela e também afirma que retirou o conteúdo apresentado de duas obras. A análise de proposições foi retirada da English Grammar de Mason e do texto Analyse de relações do Prof. A. Alexander ${ }^{126}$.

\subsubsection{Rede conceitual}

João Ribeiro menciona o 'verbo substantivo' (que também pode se chamar 'abstrato') ao tratar das espécies do 'verbo', definindo-o como 'verbo único' que não contém 'ideia atributiva', isto é, o 'atributo' está separado dele, e, por isso, exprime apenas 'cópula' ou 'existência em absoluto' ${ }^{127}$. Parece, entretanto, que esse conceito não se relaciona com outros - exceto pela distinção, indiretamente, relacionada a noções lógicas de intensão e extensão, entre 'adjetivo qualificativo' e 'adjetivo determinativo', que configuraria base teórica comum.

Em nota da primeira lição da obra, Ribeiro afirma que a 'gramatical geral' foi proscrita e, assim, que a base teórica abstrata, normalmente baseada em uma língua subjacente, da 'gramática geral' não era mais aceita, por isso, teria sido substituída por uma base teórica voltada para dados, em que a generalidade da gramática seria observada por razões históricas e relações genéticas entre línguas. $\mathrm{O}$ 'verbo' é definido como palavra pela qual se pode atribuir a um ser uma ação, um estado ou uma qualidade, aproximando-se mais da definição dada ao 'verbo atributivo'. A 'proposição' é constituída por 'sujeito' e 'predicado', sendo este último o 'verbos' e 'adjuntos'.

Concluímos, portanto, que a gramática de Ribeiro é eclética horizontalmente, pois apresenta os conceitos de 'verbo substantivo' sem relacioná-lo a outros conceitos da obra. Tal como vimos em outras gramáticas da década de 1880, esse pode ser um sintoma do período de transição por que passava a gramaticografia brasileira.

\subsection{Grammatica Portugueza (1895, [187]), de Alfredo Gomes}

\footnotetext{
${ }^{126}$ Não sabemos quem é Prof. Alexander. Mason é o mesmo autor citado por Ribeiro $(1881,1885)$ (cf. 4.8), do qual também tratamos no item 1.4.

127 Essa parece ser uma tendência para definir o 'verbo substantivo' no final do século, opondo duas maneiras de significá-lo: como cópula, que liga o sujeito ao atributo, ou como existência absoluta. Vemos isso também em Ribeiro (1881, cf. item 4.8) e Maciel (1887, cf. item 4.9). Nas gramáticas anteriores, o 'verbo substantivo' era definido, em geral, em relação ao ‘sujeito' e ao 'atributo', fosse como cópula ou existência, não se falava da 'existência em absoluto'.
} 


\subsubsection{Conceitos de gramática e de linguagem e organização da obra}

A gramática de Gomes é dividida em quarenta e nove pontos, os quais se assemelham, mas não são os mesmos do Programa de Estudos de Fausto Barreto, de 1887 - os quais, em número de quarenta e seis, foram usados como eixo organizador das gramáticas de Pacheco \& Lameira (1887) e de Ribeiro (1889), como vimos anterormente. Esses 49 pontos encontram-se integralmente no Apêndice B (cf. FD 13 e FD15). Apenas observaremos com mais tardar os pontos relativos aos itens de nossa análise adiante.

O primeiro ponto da gramática de Gomes chama-se "Grammatica geral e particular; seu objecto e divisões. Phonologia", diferentemente do primeiro ponto do Programa de Estudos de 1887, que citava outros tipos de gramática “Observações geraes sobre o que se entende por grammatica geral, por grammatica historica ou comparativa e por grammatica descriptiva ou expositiva". É nesse ponto que o gramático define gramática, na primeira página da obra como ciência dos fatos da linguagem. Divide-a, como já pressupomos pelo título do ponto, em 'geral' e 'particular', a primeira corresponde ao estudo de 'preceitos', 'leis' e 'anomalias' que regem a linguagem em qualquer idioma de um grupo. O autor não menciona 'princípios gerais', como era comum quando se tratava da grammaire générale, usa os termos 'leis' e 'anomalias' cujos conceitos eram mais aproximados do viés histórico e comparativista de então. A 'particular' é a mesma coisa, mas refere-se apenas à linguagem em um idioma determinado.

Ademais, apesar de não apresentá-la no título do ponto, define 'gramática histórica', como os estudos dos fatos de uma língua de sua origem até os dias atuais, e 'gramática comparativa', como estudo dos fatos de uma língua comparado ao de outras línguas. Define, ainda, o que seria a 'verdadeira gramática' como aquela que é ao mesmo tempo 'histórica' e 'comparativa'. Finalmente, apresenta a 'gramática descritiva' ou 'expositiva' como a que ensina as leis para bem falar e bem escrever.

Em seguida, afirma que o objeto da gramática portuguesa é o estudo dos fatos da língua portuguesa e que a gramática é dividida em duas partes, a 'morfologia', ou estudo da forma da palavra ou do vocábulo, e a 'sintaxe', ou estudo da função e boa disposição da palavra na frase. Entretanto, sua gramática é dividida em 49 pontos, como já dissemos.

Gomes não define linguagem, mas pelas suas definições de gramática, notamos que esta pode ser estuda por diferentes pontos de vista, os quais, em nenhum momento, referem-se à relação entre pensamento e linguagem (como vimos com frequência em 
gramáticas anteriores), mas referem-se a 'leis', 'anomalias' e 'fatos'. É notável que, sem o foco tocar no pensamento, o gramático tem apenas a língua como objeto. Nesse sentido, ao definir 'gramática', Gomes se aproxima do Programa Descritivista de Swiggers (cf. Quadro 2).

\subsubsection{Conceitos de metaclasses e classes de palavras}

Alfredo Gomes, no ponto IV da obra, denominado "Taxeonomia. Substantivos e suas espécies”, afirma que as palavras podem se agrupar em dez espécies, que são: 'substantivo', ‘artigo', ‘adjetivo', ‘pronome', ‘verbo', 'particípio', 'advérbio', 'preposição', 'conjunção' e 'interjeição'. Entretanto, racionalmente, essas espécies poderiam ser reduzidas a sete, visto que a ‘interjeição’ não pertence a gramática, o 'artigo' é um 'adjetivo determinativo' e o 'particípio' é ora 'adjetivo', ora 'verbo'. Apresenta, em seguida, as metaclasses possíveis de palavras 'invariáveis' e 'variáveis'. As últimas são divididas em 'radical', que permanece mais ou menos imutável, e 'flexão', que muda constantemente.

Ademais, apresenta outras classes de palavras: do ponto de vista formal, as palavras seriam 'simples' ou 'compostas' (ex.: bondade, expressão, verde-negro, ticotico); etimologicamente, elas seriam 'primitivas' ou 'derivadas; pela sua essência, elas seriam 'nominativas' também chamadas 'ideais', que exprimem substâncias imateriais ou reais, qualidades abstratas, ações personificadas, ou 'relativas' / 'conectivas', que exprimem laços ou relações entre aquelas. Há ainda a possibilidade de serem 'interjectivas' ('interjeição'), que expressam sentimento, ou 'analíticas', que exprimem atos ou relações intelectuais (todas as outras classes). Finalmente, diz que as palavras também podem ser divididas pela relação que mantêm entre si: 'sinônimas' (quase ou mesma significação), 'antônimas' (exprimem objetos, atos ou qualidades opostas), 'homônimas' (palavras semelhantes ou idênticas na pronúncia ou escrita) e 'parônimas' (são um pouco semelhantes na pronúncia).

\begin{tabular}{|c|c|c|c|c|}
\hline $\begin{array}{c}\text { Dez classes de } \\
\text { palavras }\end{array}$ & $\begin{array}{c}\text { Sete classes de } \\
\text { palavras (critério } \\
\text { racional) }\end{array}$ & Metaclasses 1 & $\begin{array}{c}\text { Metaclasses } 2 \\
\text { (suposição) }\end{array}$ & Metaclasses 3 \\
\hline Substantivo & Substantivo & \multirow{4}{*}{ Variáveis } & \multirow{4}{*}{$\begin{array}{c}\text { Nominativas / } \\
\text { ideais }\end{array}$} & \\
\hline Artigo & - & & & \\
\hline Adjetivo & Adjetivo & & & \\
\hline Pronome & Pronome & & & \\
\hline
\end{tabular}




\begin{tabular}{|c|c|c|c|c|}
\hline Verbo & Verbo & \multirow{2}{*}{ Analíticas } \\
\hline Particípio & - & & \\
\hline Advérbio & Advérbio & \multirow{2}{*}{ Invariáveis } & Relativas & \\
\cline { 1 - 1 } Preposição & Preposição & & Interjectivas \\
\hline Conjunção & Conjunção & & - & \\
\hline Interjeição & - & & & \\
\end{tabular}

Quadro 88. Metaclasses e classes de palavras em Gomes (1895)

É pelas metaclasses de palavras 'variáveis' e ‘invariáveis' que Gomes organiza a obra, já que os pontos de IV a VII tratam de palavras variáveis ('substantivo', 'pronome', 'adjetivo' e 'verbo') e o item VIII trata das outras classes de palavras 'invariáveis' ('advérbio', 'preposição', 'conjunção’ e ‘interjeição'). Ressaltamos, porém, outra divisão feita pelo gramático, nas quais relaciona a classe 'interjeição' a 'sentimentos' e, por isso, a coloca separada das outras classes, que, sendo 'analíticas', correspondem a 'relações intelectuais', pois nesse momento há certa relação, ainda que sutil, entre pensamento e linguagem.

\subsubsection{Conceitos modificadores do nome}

Os conceitos modificadores do nome são o 'pronome' e o 'adjetivo' na gramática de Gomes. 'Pronome' é definido como a palavra que substitui o 'nome', mas Gomes acrescenta, em metatexto ("observação"128), que eventualmente ele também substitui 'adjetivos', outro 'pronome', 'membros de frases' ou mesmo uma 'oração' inteira (il.: já fui bom, hoje não o sou; ontem vi-o alegre; fulano é o favorito, beltrano nunca o foi; fale a verdade, manda-o a consciência). Os 'pronomes' têm as seguintes espécies 'pessoais', 'demonstrativos', 'relativos' ou 'conjuntivos', 'absolutos' e 'indefinidos'. No quadro adiante, apresentamos seu conceito em maior detalhe:

\begin{tabular}{|c|c|}
\hline $\begin{array}{c}\text { Espécies de } \\
\text { 'pronome' (termo) }\end{array}$ & Conceito \\
\hline Pessoais & $\begin{array}{c}\text { Indicam as pessoas gramaticais, que são as diversas situações do indivíduo no } \\
\text { ato do discurso. No ato de falar, o indivíduo só pode ser o orador ou a pessoa } \\
\text { que fala (ex.: eu, me, mim; nós, nos), o interlocutor ou a pessoa com quem se } \\
\text { fala (ex.: tu, te, ti; vós, vos), ou o objeto de que se fala (ex.: ele, ela, lhe, o, a; } \\
\text { eles, elas, lhes, os, as). Há ainda um pronome pessoal que exerce função } \\
\text { 'reflexiva' (ex.: se), os outros também podem exercer essa função. }\end{array}$ \\
\hline Demonstrativos & $\begin{array}{c}\text { Substituem o nome demonstrando o lugar que os seres ocupam segundo as } \\
\text { pessoas gramaticais (isto, isso, aquilo). }\end{array}$ \\
\hline Relativos-conjuntivos & $\begin{array}{c}\text { Conjuntam orações, lembrando a ideia de um nome anterior (ex.: que, o qual, } \\
\text { quem, cujo, onde). }\end{array}$ \\
\hline Indefinidos & $\begin{array}{c}\text { Lembram o nome de modo vago e indeterminado (ex.: alguém, ninguém, } \\
\text { tudo, nada, outrem, fulano, sicrano, beltrano, outra coisa, cada um, cada qual). }\end{array}$ \\
\hline
\end{tabular}

${ }^{128}$ Item diagramado de maneira diferente, que o autor da gramática denomina “observação". 


\begin{tabular}{|c|c|}
\hline \multirow{2}{*}{ Absolutos } & $\begin{array}{r}\text { "Que, quem, qual" empregados em frases interrogativas ou sem referência a } \\
\text { termo anterior (il.: que fazes? quem disse isso?) } \\
\text { Metatexto: "onde" em interrogações ou sem referência é 'advérbio'. }\end{array}$ \\
\hline
\end{tabular}

Quadro 89. Espécies de 'pronome' em Gomes (1895)

Define 'adjetivo' como palavra que exprime 'qualidades' dos 'substantivos' ou os 'determina', por isso, são divididos em 'qualificativos' e 'determinativos'. Os primeiros exprimem qualidades dos seres (il.: casa boa), ao passo que os segundos os determinam (il.: meu chapéu). Há duas espécies de 'adjetivo qualificativo', que são 'restritivo' e 'qualificativo'; e há quatro espécies de 'adjetivos determinativos', a saber: 'articulares', 'demonstrativos', 'possessivos' e 'quantitativos'. No quadro adiante, apresentamos o conceito de cada uma das espécies.

\begin{tabular}{|c|c|c|}
\hline $\begin{array}{l}\text { Espécies de } \\
\text { adjetivo } \\
\text { (termo) }\end{array}$ & $\begin{array}{c}\text { Espécies de } \\
\text { (coluna anterior) } \\
\text { (termo) }\end{array}$ & Conceito \\
\hline \multirow{2}{*}{$\begin{array}{c}\text { Qualificativo / } \\
\text { Descritivo }\end{array}$} & Restritivo & $\begin{array}{l}\text { Exprimem qualidade acidental ao ser (il.: homem inteligente). } \\
\text { Necessário ao sentido do substantivo. Pode-se colocar a } \\
\text { expressão "nem todo" antes dele para checagem. }\end{array}$ \\
\hline & Explicativo & $\begin{array}{c}\text { Exprimem qualidade essencial ao ser (il.: Deus onipotente). } \\
\text { Dispensável ao sentido do 'substantivo'. Pode-se colocar a } \\
\text { expressão "todo" antes dele para checagem. }\end{array}$ \\
\hline \multirow{4}{*}{ Determinativo } & Articulares & $\begin{array}{l}\text { Limitam a significação dos 'substantivos', reduzem os ‘nomes } \\
\text { próprios' a ‘apelativos', 'substantivam' qualquer 'parte da } \\
\text { oração' (il.: o livro, um José Bonifácio, o porquê, o sim, o não). } \\
\text { Há dois artigos: ‘definido' (ex.: o, a, os, as) e ‘indefinido' (ex.: } \\
\text { um, uma) }\end{array}$ \\
\hline & Demonstrativos & $\begin{array}{c}\text { Designa o lugar que os seres ocupam no tempo ou no espaço em } \\
\text { relação às pessoas gramaticais (ex.: este, esta, estes, estas; esse, } \\
\text { essa, esses, essas; aquele, aquela, aqueles, aquelas) }\end{array}$ \\
\hline & Possessivos & $\begin{array}{l}\text { Indicam os seres com a ideia de posse em relação às pessoas } \\
\text { gramaticais (ex.: meu, minha, meus, minhas, nosso, nossa, } \\
\text { nossos, nossas; teu, tua, teus, tuas, vosso, vossa, vossos, vossas; } \\
\text { seu, sua, seus, suas). }\end{array}$ \\
\hline & Quantitativos & $\begin{array}{l}\text { Dão ideia de quantidade, ora quantidade fixa e numérica, feita } \\
\text { pelos 'numerais', ora indefinida e variável, feita pelos } \\
\text { 'indefinidos'. Os 'numerais' subdividem-se em ‘cardinais', que } \\
\text { indicam número simplesmente (ex.: três, oito), e 'ordinais', que } \\
\text { indicam número por ordem (ex.: primeiro, nono). Os } \\
\text { 'indefinidos' subdividem-se em 'universais', totalidade dos } \\
\text { seres (ex.: todo, nenhum), 'partitivos', porção maior ou menor } \\
\text { de seres (ex.: algum, pouco, muito, vários, diversos), } \\
\text { ‘distributivos', todos os seres, mas divididos um a um (ex.: } \\
\text { cada, outro, este, qualquer), 'multiplicativos', seres } \\
\text { multiplicados (ex.: duplo, triplo, décuplo). } \\
\text { Metatexto (parêntesis): o autor ressalta que “este” é um } \\
\text { determinativo que está em duas classes, 'demonstrativos' e } \\
\text { 'quantitativos'. }\end{array}$ \\
\hline
\end{tabular}

Como a maior parte dos autores já analisados, Gomes também apresenta o ‘artigo', ou 'adjetivo determinativo articular' como espécie do 'adjetivo'. Ademais, nota-se que 
Gomes é bastante direto quanto a classificação que faz dos modificadores do nome, sem hesitações ou metatextos que apresentem outros pontos de vista possíveis ou com os quais o autor discorda.

\subsubsection{Conceito de verbo}

O ‘verbo’ é definido como a palavra que exprime ação, qualidade ou estado. Logo em seguida, em metatexto (nota), afirma a respeito do 'verbo substantivo':

Não é acceita hoje a caduca divisão dos verbos em verbo substantivo e verbo adjetivo, só util para a metaphysica decomposição de todo verbo adjetivo no verbo substantivo SER e um adjetivo attributo, tirado do radical verbal; d'onde amar seria ser amante, crer-ser crente, etc. Ora isso poderá (?) ser philosophico, mas não é processo natural e a linguagem é sciencia natural de um lado e historica de outro, nem é tal decomposição testemunhada pela composição dos verbos adjectivos, que existiram antes do verbo substantivo ou abstrato. Este mesmo verbo substantivo é realmente adjetivo, isto é, encerra ideia de attributo na sua primitiva fórma, na sua raiz. (Gomes 1895: 35)

Sua argumentação, ressaltando que a 'linguagem' é 'ciência natural' e 'histórica', baseiase nas ideias de que os chamados 'verbos adjetivos' existiram antes do 'verbo substantivo' e que o verbo “ser" seria, em verdade, 'adjetivo', por ter um 'atributo' na sua forma primitiva.

Gomes distingue três espécies principais de 'verbos', que são 'ativos', 'inativos' e 'auxiliares', os quais colocamos no quadro abaixo:

\begin{tabular}{|c|c|}
\hline Espécie de verbo & Conceito \\
\hline \multirow{2}{*}{ 'Ativos' } & Exprime ação (ex.: dizer) \\
\cline { 2 - 2 } & \begin{tabular}{c} 
'Transitivos' ou 'de predicação incompleta': aqueles cuja ação passa do sujeito. \\
\cline { 2 - 2 } 'Intransitivos' ou 'de predicação completa': aqueles cuja ação não passa do sujeito.
\end{tabular} \\
\hline 'Inativos' & Exprimem estado, fenômeno (ex.: troveja, viver) \\
\hline 'Auxiliares' & $\begin{array}{c}\text { Auxiliam outros verbos em tempos compostos (ex.: ter, haver, ser; por vezes: estar, } \\
\text { andar, ir, vir, sair, deixar, começar, principiar, querer, entrar, tornar, por) (il.: tenho } \\
\text { feito, havia dito, ando pensando, vou abrindo, começo a entender, principia a } \\
\text { chover, entrou a dizer, tornou a chorar, estou refletindo, pôs-se a gritar, vou indo, } \\
\text { deixou-se estar, ele saiu graduado (Castilho), isto quer dizer). }\end{array}$ \\
Quadro 91. Principais espécies de 'verbo' em Gomes (1895)
\end{tabular}

Apresenta também uma divisão de verbos pela sua 'forma' em quatro espécies, 'passivo', 'reflexivo', 'recíproco', 'impessoal' ou 'unipessoal', cujo conceito apresentamos no quadro adiante. 


\begin{tabular}{|c|c|}
\hline Espécie de verbo & Conceito \\
\hline 'Passivo' & $\begin{array}{c}\text { Exprimem ação sofrida pelo sujeito (il.: Pedro foi ferido; a cadeira quebrou-se). } \\
\text { Os verbos passivos conjugam-se com o auxiliar "ser" ou com a partícula } \\
\text { apassivadora "se". }\end{array}$ \\
\hline 'Reflexivo' & $\begin{array}{c}\text { Exprimem ação feita e recebida pelo mesmo sujeito (il.: o menino pendurou-se na } \\
\text { árvore) }\end{array}$ \\
\hline $\begin{array}{c}\text { 'Recíproco' } \\
\text { 'Impessoal' ou } \\
\text { 'Unipelhor }\end{array}$ & $\begin{array}{c}\text { Só se conjugam nas terceiras pessoas de cada tempo (il.: chove, relampagueia). } \\
\text { eles se bateram e se feriram gravemente) }\end{array}$ \\
\hline
\end{tabular}

Gomes não apresenta o conceito de 'verbo substantivo' em texto, mas o critica, juntamente com o 'verbo adjetivo', em metatexto. Ademais, o autor apresenta um termo e um conceito incomuns: o 'verbo inativo'. Por outro lado, o autor mantém a categoria de 'verbo passivo’ em relação à ‘forma', algo que muitos gramáticos brasileiros rejeitam.

\subsubsection{Conceito de proposição ou oração e seus elementos}

Chama-se 'proposição' ou 'oração' o ‘enunciado verbal' de um 'juízo'. A ‘proposição' consta de dois elementos indispensáveis: ‘sujeito' e ‘predicado'. O primeiro é o ser a que se refere a ação, fenômeno ou estado expresso pelo 'predicado' (il.: Pedro é rico). Pode ser de várias espécies, que apresentamos no quadro adiante.

\begin{tabular}{|c|c|}
\hline $\begin{array}{c}\text { Espécie de } \\
\text { 'sujeito' (termo) }\end{array}$ & Conceito \\
\hline 'Lógico' & $\begin{array}{c}\text { Exprime o ser com todos os modificativos (il.: } \underline{\mathrm{O} \text { homem que é honesto merece }} \\
\text { a consideração de todos) }\end{array}$ \\
\hline 'Gramatical' & $\begin{array}{l}\text { Exprime o ser desprovido dos modificativos que possa ter (il.: (considerando } \\
\text { exemplo acima) homem) }\end{array}$ \\
\hline 'Simples' & $\begin{array}{l}\text { Representa um só ser ou uma coleção de seres da mesma espécie (il.: } \underline{\mathrm{A}} \\
\text { mangueira é forte; Os animais têm instintos muito diversos) }\end{array}$ \\
\hline 'Composto' & $\begin{array}{l}\begin{array}{l}\text { Representa mais de um ser separadamente (il.: o gato e o rato vivem sempre em } \\
\text { guerra aberta) }\end{array} \\
\end{array}$ \\
\hline 'Complexo' & É o sujeito modificado (il.: Tu, que és bom estudante, mereces ser aprovado \\
\hline 'Incomplexo' & É o que se apresenta sem modificativos (il.: Ele chorou amargamente) \\
\hline
\end{tabular}

'Predicado' é o que se afirma ou nega do sujeito. O predicado compreende o ‘verbo' e um 'predicativo' ou um 'objeto' (il.: Pedro é bom; o sábio merece o nosso respeito, mas não precisa dele). 'Predicados complexos' aparecem com 'modificativos',

\footnotetext{
129 Apresenta ainda os verbos 'frequentativos', 'incoativos' e 'diminutivos', que não estamos analisando
} neste trabalho. 
como o são os ilustrados acima. 'Predicados simples' não tem modificativos (il.: morreu o Neves).

Os 'modificativos' de 'sujeito' ou 'predicado' chamam-se 'adjuntos'. Quando exprime qualidade e modifica substantivo, chama-se ‘adjunto atributivo' (il.: um coração magoado; o copo de vidro dura pouco). Quando exprime circunstância modificadora de 'verbo', de 'adjetivo' ou de outro 'advérbio', chama-se 'adjunto adverbial' (il.: o velho caminha para a cova; a preguiça move-se com pasmosa lentidão; é digno de prêmio o estudante aplicado; fui passear juntamente com esse amigo). Em metatexto (observação), Gomes diz que há uma espécie de 'adjunto' que aparece modificando o verbo e que ocupa, pela sua significação e valor sintático, um lugar entre o 'adjunto adverbial' e o 'adjunto atributivo'. Este chama-se 'predicativo', que se define como 'adjetivo' ou 'substantivo adjetivado' que vem modificando certos verbos que exprimem estado, fenômeno, qualidade ou ação média ou passiva (il.: eu estou bom; ele caiu doente; este homem morreu impenitente; o menino é por natureza travesso; tu te julgas curado; esta senhora foi nomeada adjunta; chamo-me Alfredo); ele pode, por vezes, ser acidentalmente 'preposicional' (il.: este juiz passa por íntegro; eu o tenho como justo). Há espécies de 'predicativo', que expomos no quadro adiante:

\begin{tabular}{|c|c|}
\hline $\begin{array}{c}\text { Espécie de } \\
\text { 'predicativo' (termo) }\end{array}$ & Conceito \\
\hline Simples & Contém apenas uma qualidade (il.: o menino é estudioso) \\
\hline Composto & Encerra mais de uma qualidade (il.: este menino é estudioso e obediente) \\
\hline Complexo & Vem modificado (il.: este livro é digno de leitura) \\
\hline Incomplexo & Não vem modificado (il.: o meu livro está velho) \\
\hline
\end{tabular}

Finalmente, quanto à 'proposição', Gomes distingue oito espécies relacionadas à 'forma'; o conceito de cada uma delas é apresentado no quadro adiante:

\begin{tabular}{|c|c|}
\hline $\begin{array}{c}\text { Espécie de } \\
\text { 'proposição' quanto } \\
\text { à forma (termo) }\end{array}$ & Conceito \\
\hline Simples & $\begin{array}{c}\text { Aquela cujos ‘termos' são simples (il.: o dinheiro é às vezes fatal) } \\
\text { Metatexto (observação): os termos da 'proposição' são o ‘sujeito' e o } \\
\text { 'atributo' }\end{array}$ \\
\hline Composta & $\begin{array}{c}\text { Aquela cujos ‘termos' são compostos (il.: eu e Joaquim fomos ontem ao } \\
\text { Corcovado; o menino é por natureza leviano e irrefletido) }\end{array}$ \\
\hline Complexa & Que tem qualquer dos 'termos complexos' (il.: falar a verdade é dever de \\
todos)
\end{tabular}




\begin{tabular}{|c|c|}
\hline Negativa & Em que se nega uma qualidade atribuída ao sujeito (il.: o rato não tem \\
utilidade, nem sequer merece tolerância)
\end{tabular}

Quadro 95. Espécies de 'proposição' quanto à 'forma' em Gomes (1895)

As proposições podem, ainda, ser 'coordenadas' ou 'subordinadas' umas às outras dentro de 'períodos'. O 'período simples' consta somente de uma 'proposição', já o 'período composto' tem mais de uma 'proposição', e este pode ter proposições ligadas por 'coordenação' ou por 'subordinação'. A ‘coordenação' pode ser feita pelo sentido, sendo 'assindética', ou pela 'conjunção, sendo então 'sindética'. De acordo com a natureza da 'conjunção' (ou 'sindese') divide-se em 'coordenadas sindéticas': 'copulativas', 'disjuntivas', 'adversativas', 'continuativas', 'ilativas' ou 'conclusivas'. A 'subordinação' é feita por 'pronome relativo conjuntivo' ou por 'conjunções subordinativas. Dividem-se as 'proposições subordinadas' em ‘subordinadas': 'relativas' ('incidentes' ou não), 'causais', 'condicionais', ‘concessivas', 'circunstanciais de tempo', 'finais', 'integrantes' ('subjetiva', 'predicativa', 'objetiva', 'direta' ou 'indireta'). Não há definições ou ilustrações dessas espécies de proposições, Gomes apenas as lista, da mesma maneira que relatamos.

Em seguida, afirma que quanto à 'categoria mórfica' ou ao tipo 'formal' que apresentam, as 'proposições subordinadas' podem ser 'substantivas', 'adjetivas' ou 'adverbiais'. A primeira serve de 'sujeito', de 'predicativo' ou de 'objeto' de um 'verbo' e é por sua natureza redutível a um 'substantivo' (il.: dizem que isto é verdade). As 'adverbiais' são as que exprimem circunstância (il.: ao anoitecer... se chover... quando chegar... para que vissem) e corresponde a um 'advérbio'. Finalmente, a 'proposição adjetiva' restringe ou explica o sentido de algum 'substantivo' (il.: a pessoa que visitei ontem, falou a teu respeito; Deus, que é infinitamente misericordioso, concede sempre o perdão ao criminoso arrependido), formando, assim, claro paralelismo com as duas espécies de 'adjetivos qualificativos' ou 'descritivos', chamados 'restritivo' e 'explicativo'.

Ao tratar da 'regência', organiza e define os termos da 'oração': 'sujeito', 'predicativo', 'objeto direto', 'objeto indireto', 'adjunto atributivo'. No quadro abaixo, apresentamos o conceito de cada um deles:

\begin{tabular}{|c|c|}
\hline $\begin{array}{c}\text { Item } \\
\text { considerado na } \\
\text { regência (termo) }\end{array}$ & Conceito em texto \\
\hline Sujeito & $\begin{array}{c}\text { Pode ser ‘sujeito' em uma ‘oração' o ‘substantivo’ ou qualquer palavra ou } \\
\text { locução que lhe corresponda. Assim, aparecem como sujeito: 1) ‘substantivo' (il.: } \\
\text { amor é vida [Gonçalves Dias]); 2) 'pronome' (il.: eu cerro o peito à ventura [Th. }\end{array}$ \\
\hline
\end{tabular}




\begin{tabular}{|c|c|}
\hline & $\begin{array}{l}\text { Ribeiro]); 3) qualquer espécie de 'palavra substantivada' (il.: terrível palavra é um } \\
\text { não [P. Antono Vieira]); 4) um 'membro da frase' (il.: o o ser herói, Marília, não } \\
\text { consistem em queimar os impérios [Th. Gonzaga]); 5) uma 'oração inteira' (il.: } \\
\text { Dos cavalos o estrepito parece que faz que o chão deixado todo treme [Camões]). } \\
\text { MT: (Observação) Como se vê, o sujeito não pode ser regido de preposição. }\end{array}$ \\
\hline Predicativo & $\begin{array}{c}\text { Pode servir de 'predicativo' um 'adjetivo' uma qualquer palavra, uma 'locução } \\
\text { adjetivada' ou uma 'oração inteira' (il.: não me façais mais desgraçada [Garrett]; } \\
\text { senhora, parece-me aquela Filida [J. de Barros]; No céu temos as nossas Îndias, } \\
\text { chegar aí é salvar-se [M. Bernardes]). Por vezes, o ‘predicativo' vem regido de } \\
\text { 'preposição', quer seja expresso por 'substantivo', quer seja por 'adjetivo' (il.: } \\
\text { Na Igreja primitiva os cálices eram de pão [M. Bernardes]; qual vermelhas as } \\
\text { armas faz de Brancas [Camões]). }\end{array}$ \\
\hline Objeto direto & $\begin{array}{c}\text { O ‘objeto direto' é expresso por um substantivo, pronome, infinitivo de verbo ou } \\
\text { mesmo oração inteira (il.: Enfim tens coração de ver-me aflita [Santa Rita Durão]; } \\
\text { tomando de um cipó que desamarra, se atira n'agua a índia forasteira [Mello } \\
\text { Morais Filho]; mas viu esmorecido, em torno dos thuricremos altares, negra } \\
\text { escuma ferver nas ricas taças [Garção]. Pode, eventualmente, ser regido de } \\
\text { 'preposição' (il.: Arrancam das espadas de aço fino... [Camões]). Deve ser } \\
\text { preposicional quando exprime ser capaz de exercer a ação do 'verbo (il.: amo a } \\
\text { meus filhos; não: amo meus filhos). } \\
\text { MT: Citação de autor: É o que [objeto direto regido de preposição] Fausto Barreto } \\
\text { chama de 'objeto direto esporadicamente preposicional', verdadeiro 'objeto } \\
\text { indireto aparente'. } \\
\text { Essa regra é [do 'objeto direto preposicional'], porém, de rigor absoluto quando } \\
\text { da obscuridade. Assim, não imitaremos Camões quando disse "toda a corte } \\
\text { alvoroça a novidade”; diremos antes de maneira que não haja dúvida no sentido } \\
\text { "a novidade alvoroça a toda a corte" ou “toda a corte alvoroça-se com a } \\
\text { novidade". }\end{array}$ \\
\hline Objeto indireto & $\begin{array}{l}\text { Expresso por 'substantivo', por qualquer palavra ou locução substantiva regida de } \\
\text { 'preposição' (il.: gosto de ouvir; ele se aplica ao estudo). Note-se, porém, que as } \\
\text { flexões pronominais conjuntivas ao verbo "me, te, se, lhe, nos, vos, lhes", embora } \\
\text { sirvam de 'objeto indireto', dispensam a preposição que está incluída em sua } \\
\text { forma (il.: diga-lhe isto). O mesmo se dá com cláusulas do infinito e até com } \\
\text { orações integrantes ligada pela conjunção "que" e servindo de objeto indireto, que } \\
\text { por vezes dispensam a preposição (ill: preciso que me diga verdade; temos certa } \\
\text { que v. ex. virá; precisas estudar com coragem). } \\
\text { O ‘objeto direto' é, por vezes, aparente: na realidade é um 'adjunto atributivo' } \\
\text { mascarado com aquela forma. Neste exemplo de A. Ferreira "Eu também por que } \\
\text { lhe sei a condição, faço-me com ele um Hércules", "lhe” é 'adjunto atributivo' da } \\
\text { palavra "condição" (porque sei a condição dele). O mesmo nesse outro exemplo } \\
\text { de Camões "Tomé, barão sagrado, que a Jesus Cristo teve a mão no lado", onde } \\
\text { se deve entender "que teve a mão no lado de Jesus Cristo". }\end{array}$ \\
\hline $\begin{array}{l}\text { Adjunto } \\
\text { atributivo }\end{array}$ & $\begin{array}{l}\text { É expresso ordinariamente por adjetivo qualificativo, por substantivo regido de } \\
\text { preposição, por qualquer espécie de palavra substantiva e até por uma cláusula de } \\
\text { infinitivo ou oração sempre regida de preposição (il.: copo de barro; casa limpa; o } \\
\text { dia do Fico; a causa de serem tais fatos mal interpretados; o desejo de que tal se } \\
\text { dê). Pode ser expresso por 'substantivo' sem 'preposição' (il.: Epaminondas, } \\
\text { cidadão tebano, nem por gracejo mentia). Algumas vezes tem o termo principal } \\
\text { de uma locução tem forma de adjunto atributivo ficando o termo secundário com } \\
\text { a função de regente (il.: a cidade de Roma é a capital do mundo católico). }\end{array}$ \\
\hline Adjunto adverbial & $\begin{array}{l}\text { Expresso por 'advérbio' ou qualquer expressão adverbial', as quais pode ser um } \\
\text { substantivo ou palavra substantivada regida de preposição (il.: venho de casa, } \\
\text { tremo por ti); um infinitivo regido (il.: corro a vê-lo); uma oração ou cláusula de } \\
\text { particípio que exprima circunstância (il.: quando estiver alegre...; em sendo o dia } \\
\text { claro...). Por vezes, pode dispensar a preposição (il.: Os cavaleiros eram partidos } \\
\text { caminho de Zamora [A. de Castilho]; vou (para) jantar; venho (para) visitá-los). }\end{array}$ \\
\hline
\end{tabular}




\subsubsection{Rede conceitual}

Como vimos, Gomes não apresenta um conceito de 'verbo substantivo', pelo contrário, ele cita esse conceito e também o de ‘verbo adjetivo' para criticá-los. Algo que não era incomum na década de 1890, dada a transição epistemológica ocorrida na década anterior (que pudemos acompanhar nos itens anteriores, cf. itens 4.8 a 4.12). Assim, nossa busca não é exatamente por uma rede conceitual neste caso, mas observar como o autor trata os conceitos que, em geral, estavam conectados a essa rede quando o 'verbo susbtantivo' era assumido.

Na divisão de palavras na metaclasses 'nominativas' e 'relativas', Gomes insere o 'verbo' nas primeiras ${ }^{130}$. Assim, de certa forma, ele nega que dentro do conceito de 'verbo' haja alguma noção de relação. Sua 'proposição', ainda que definida como o “enunciado verbal de um juízo”, contém apenas dois "elementos indispensáveis”, o 'sujeito' e o 'predicado' - não há 'cópula' nem 'atributo'.

Os 'modificativos' são também chamados de 'adjuntos' e podem ser 'atributivos' ou 'adverbiais', assemelhando-se assim ao que outros gramáticos chamaram de 'complementos restritivos' e 'circunstanciais', os quais não eram obrigatórios para a regência regular. Não há, porém, 'adjuntos' que se assemelhem com os 'complementos' 'terminativo' e 'objetivo', os quais eram solicitados pelas palavras que os regiam, estão são similares ao que Gomes chama de 'objeto direto' e 'objeto indireto' do 'verbo' e, quando presentes, fazem parte do 'predicado'. O 'predicado' é aquilo que se diz do 'sujeito' e pode englobar várias palavras, além do 'verbo', poderiam fazer parte dele 'objeto direto', 'objeto indireto' ou um 'predicativo' - quando 'complexo' poderia haver nele também 'adjuntos'.

Os 'adjetivos' são organizados pelas duas oposições que Colombat (1992) diz ser proveniente da gramática escolar de Noël e Chapsal (cf. 1.4.2), o que gera a primeira oposição entre 'qualificativos' e 'determinativos', e uma segunda divisão dos 'qualificativos' em 'restritivos' e 'explicativos'. Essa segunda divisão aparece de forma idêntica quando o autor trata das 'proposições adjetivas', que podem explicar ou restringir o sentido de um 'substantivo'; o curioso é que o autor cita também a 'proposição incidente', sem, entretanto, defini-la - como faz também com outras espécies.

\footnotetext{
${ }^{130}$ De maneira similar a Pacheco e Lameira (1887) e a Maciel (1895), que, entretanto, em gramática anterior (Maciel 1887) entendia o 'verbo' como 'palavra conectiva'.
} 
Talvez por ter colocado o 'verbo' na metaclasse de 'palavras nominativas', seu significado é mais relevante do que sua ideia de 'ação'. Assim, os verbos são divididos inicialmente em 'inativos', que expressam 'estado' ou 'fenômeno', e 'ativos', que expressam 'ação', podendo estes últimos, por exprimir ação, transferi-la ou não a 'objetos' a depender de sua 'predicação' e, assim, sendo ‘transitivos' ou 'intransitivos'.

Em suma, vemos que os conceitos que teriam relações mais próximas e simples de destacar ao 'verbo substantivo', como 'verbo', 'proposição', têm definições e exemplos que já escapam da tradição. Há, entretanto, pontos mais distantes em que o autor se aproxima, como na distinção das espécies de 'adjetivo', quais estão claramente relacionadas a espécies de 'proposição'. 
Deixo aos vários futuros (não a todos) meu jardim das veredas que se bifurcam.

(Jorge Luis Borges) 


\section{CAPÍTULO 5 | Resultados e contribuições}

Neste capítulo, apresentamos resultados concernentes às análises realizadas nos capítulos 3 a 4 desta tese, as contribuições que tais analises podem ter tido para aprofundar o conhecimento sobre o objeto estudado e também perspectivas sobre as contribuições que a metodologia pode ter para área da Historiografia Linguística.

\subsection{Exame longitudinal de redes conceituais: continuidades e descontinuidades}

Realizar a longa análise orientada para o conteúdo de dezoito gramáticas brasileiras de língua portuguesa, publicadas ao longo do século XIX, separadamente por autor, nos permitiu chegar a dois resultados diferentes.

O primeiro, já apresentado no próprio capítulo 4, no final de cada item, é a rede conceitual particular de cada gramática e, quando analisamos mais de uma gramática de um mesmo autor, a comparação entre suas redes conceituais. Pudemos, com esse primeiro resultado, avaliar se as gramáticas eram ecléticas (horizontalmente e/ou verticalmente) no que diz respeito, pelo menos, aos conceitos que hipoteticamente formariam rede conceitual ao redor do conceito-chave, 'verbo substantivo'. No próximo item, 5.2, tratamos de possíveis relações entre ecletismo e agenda dos autores.

Outro resultado a que pudemos chegar diz respeito à comparação entre as redes conceituais observadas particularmente, o qual chamamos de exame longitudinal de redes conceituais. Esse exame permitiu que observássemos, justamente, continuidades e descontinuidades entre as obras. Como já dissemos anteriormente, selecionamos, para análise, uma metodologia que busca uma rede conceitual a fim de comparar as técnicas descritivas das obras, vendo nelas alguma homogeneidade ou, pelo menos, algo que poderia ir em direção a uma homogeneidade, isto é, a própria rede conceitual. Assim, procuramos compreender de que maneira os conceitos que, em algum momento, estiveram relacionados ao ‘verbo substantivo' deixam de sê-lo, quando isso se dá, e se a ruptura é gradual ou abrupta.

Ademais, após essa observação, pudemos também comparar aqueles conceitos que, em princípio, não pareciam tão conectados ao 'verbo substantivo', os quais não são incluídos em sua rede conceitual particular. Isso porque, ao fazer o exame longitudinal da análise realizada sobre cada obra, observamos que conceitos deixam de ser utilizados e/ou são substituídos por outros no mesmo momento em que o conceito 'verbo 
substantivo' e sua rede conceitual tornam-se mais frágeis e são eliminados das obras. Esse resultado nos permite hipotetizar que esses conceitos tinham alguma relação com o 'verbo substantivo', mesmo que esta não estivesse explícita na obra.

Adiante, apresentamos o primeiro resultado do exame longitudinal das redes conceituais, considerando somente as continuidades e descontinuidades das redes conceituais particulares, para, em seguida, incluir conceitos que não estavam explicitamente incluídos nas redes conceituais.

Como vimos, a tradição gramatical brasileira se inicia com gramáticas que não apresentam rede conceitual que tivesse como conceito-chave 'verbo substantivo'. Morais Silva (1806), embora apresente outros conceitos, como o de 'verbo' e de 'sentença' - que se vinculariam ao 'verbo substantivo' sustentado outras gramáticas brasileiras (como, por exemplo, o conceito de Costa Duarte (1829) e Bithencourt (1862)) -, define o 'verbo substantivo', simplesmente, como o 'verbo' "ser", apresentando, assim, como vimos, ecletismo horizontal. Ademais, é possível notar que o conceito de ‘verbo' de Morais Silva é subordinado ao de 'sentença', tal como há paralelismo entre as espécies de 'adjetivo', 'qualificativo' e 'determinativo', com as espécies de 'sentença incidente', 'explicativa' e 'determinativa'. Fortes (1816), por outro lado, baseia suas técnicas descritivas em gramáticas latinas, o que, certamente, é a razão de ele não apresentar nem o conceito de 'verbo substantivo', nem qualquer outro conceito que pudesse estar conectado a ele. Coruja (1835) não apresenta o conceito de 'verbo substantivo', define o 'verbo' como palavra que exprime 'ação', e no tratamento da sintaxe, pouco desenvolvido nessa edição, há um conceito de 'oração' cujos elementos são 'sujeito', 'verbo', 'predicado' e 'paciente'.

O Compendio de Costa Duarte (1829) é a primeira gramática analisada a apresentar uma rede conceitual do 'verbo substantivo'. Nela, este verbo é equivalente ao conceito de 'verbo', ao mesmo tempo que pode ser também subordinado a ele, e consequentemente à metaclasse do 'verbo', a qual diz respeito a 'relações de identidade'. É também subordinado aos conceitos de 'verbo adjetivo' e de 'oração' tripartite. Além disso, pode-se dizer que têm base teórica comum com os conceitos de espécies de 'adjetivo' e as 'proposições parciais', os quais têm entre si o paralelismo de serem 'explicativos' ou 'restritivos'. Finalmente, os próprios conceitos de gramática e de linguagem sustentados por esse gramático têm base teórica comum com 'verbo substantivo', na medida em que consideram dois níveis da linguagem, um subjacente e imutável, e outro expresso e variável, e que a 'gramática particular', que é o caso de seu 
compêndio, deve acomodar os princípios universais, apresentados na 'gramática universal', às línguas particulares. O 'verbo substantivo' faria parte do nível subjacente e imutável, o qual forma justamente os 'princípios universais'; e ao designá-lo como “ser", o gramático o acomoda à língua portuguesa. Na nova edição com título modificado do Compendio de Costa Duarte (1859), há em texto uma rede conceitual igual à de 1829; em metatexto, entretanto, o próprio conceito de 'verbo substantivo' é, depois de longa argumentação, eliminado; além disso, em metatexto, os conceitos de 'verbo' e de 'verbo adjetivo' são modificados, impossibilitando a subordinação do 'verbo substantivo' apresentado em texto a eles. Assim, consideramos a segunda gramática de Costa Duarte eclética verticalmente, na medida em que sustenta mais de um conceito para 'verbo', 'verbo substantivo' e 'verbo adjetivo'.

A rede conceitual de Costa Duarte (1829) é bastante similar àquela que vemos também em Bithencourt (1862), Sotero dos Reis (1877) Carneiro Ribeiro (1881, 1890), as duas últimas obras, porém, são ecléticas. No Epitome de Bithencourt (1862), o 'verbo substantivo' é subordinado à 'gramática filosófica', na medida em que é nela que se encontra a "relação da linguagem com os preceitos da lógica". Ainda que o autor não apresente metaclasses, afirma ao apresentar as classes de palavras que sua classificação não é mero arbítrio, mas é fruto de uma investigação verdadeira e genuína da aplicação dos 'vocábulos' segundo a ideia ou as ideias que representam. As espécies de 'adjetivo', 'explicativos' e 'restritivos', estão em paralelismo explícito (ressaltado pelo autor) com as espécies de 'oração parcial', também 'explicativas' e 'restritivas'. Assim, dado que ambos assumem dois níveis da linguagem, o 'verbo substantivo' tem relação de base teórica comum com esses itens. Tem, além disso, relação de subordinação com o 'verbo' e ‘oração' tripartite.

O conceito de 'gramática portuguesa' concebido por Sotero dos Reis é arte de aplicar aos princípios imutáveis e gerais da palavra aos usos e idiotismos da língua portuguesa, algo exposto no próprio título da obra. Não opera com metaclasses baseadas nessa informação, mas define 'verbo substantivo' como equivalente à classe 'verbo', pois é o 'verbo primitivo' e por isso próprio dos princípios imutáveis e gerais da palavra. Os outros 'verbos', 'atributivos' e 'auxiliares', estariam nos usos e idiotismos da língua. Apresenta a distinção entre 'adjetivo determinativo' e ‘adjetivo qualificativo', o qual, por sua vez, distingue-se em 'adjetivo explicativo' e 'adjetivo restritivo', mas não há equivalente nas espécies da 'proposição'. 
Como vimos, as duas gramáticas de Carneiro Ribeiro $(1881,1890)$ são bastante similares entre si. Em ambas as obras, a gramática é uma ciência que estuda a linguagem enquanto expressão do pensamento. Entretanto, o gramático apresenta espécies de gramática que se aproximariam do Programa Descritivista, mostrando eclético horizontalmente. Ademais, considera, em 1881, que as três metaclasses, 'denominativos', 'qualificativos' e 'conjuntivos', expressam aspectos das ideias e da realidade, a saber: os 'substância', 'qualidade' e 'relação', o que mostra que sua análise então é feita com base na relação entre pensamento e linguagem. Em 1890, não apresenta essa reflexão, mas mantém as metaclasses, substituindo apenas o termo 'qualificativo' por 'modificativo'. O 'verbo abstrato', que nas duas obras exprime a 'existência', é subordinado ao 'verbo' que está na metaclasse dos 'modificativos', porque sua ideia primordial e característica é a de existência, e esta é atributo universal dos seres. Assim, vemos que o 'verbo substantivo' é subordinado aos conceitos de linguagem e de gramática. É também subordinado à 'proposição' tripartite exposta pelo gramático - a qual, por sua vez, concorre com outro conceito de 'sentença' do autor, mostrando há em sua obra ecletismo vertical. Finalmente, não há paralelismo entre os conceitos das espécies de 'adjetivo' ('qualificativos' e 'determinativos) e de 'oração incidente' ('explicativas' e 'restritivas'). Assim, ainda que haja rede conceitual em torno do 'verbo abstrato', ela concorre com conceitos que distoam dela, o que faz as gramáticas de Carneiro Ribeiro serem ecléticas, tanto horizontalmente quanto verticalmente.

Coruja (1873) e Condurú (1888) apresentam o conceito de 'verbo substantivo' apenas em metatexto, e justificam essa escolha. Coruja (1873), reedição do texto de 1835 , afirma que não cabe a um compêndio tratar da 'linguagem subjetiva', Condurú (1888) propõe que o conceito de 'verbo lógico', que se divide em 'substantivo' e 'adjetivo', não é adequado à descrição dos ‘verbos portugueses' e impróprio à compreensão dos alunos. É curioso, porém, que ambas as obras apresentem alguma rede conceitual com o 'verbo substantivo'.

No caso de Coruja (1873), o 'verbo substantivo', que exprime a existência de uma qualidade ou 'atributo' no 'sujeito' da 'oração', é subordinado ao conceito de 'oração', que não tripartite, mas tem 'sujeito', 'verbo', 'atributo' e 'paciente'. Ademais, não há paralelismos entre as espécies de 'adjetivo' ('qualificativo' e 'determinativo') e as de 'proposição incidente' ('explicativa' e 'restritiva'). Condurú (1888), que define 'gramática' simplesmente como arte que ensina a falar, escrever e ler com acerto a língua portuguesa e não concebe metaclasses de palavras, apresenta em texto conceitos de 
'verbo' e de 'oração' bipartite ('sujeito' e ‘verbo') a que o 'verbo substantivo' não é subordinado, porém, em metatexto, trata do 'verbo lógico' e da 'oração' tripartite, aos quais o 'verbo substantivo' é subordinado. A rede está quase completamente em metatexto, em conceitos diferentes do que apresenta em texto, o que configura sua obra como eclética verticalmente. Ademais, o gramático maranhense rejeita a distinção dos 'adjetivos' em 'explicativo' e 'restritivo', mas distingue as 'orações incidentes' em 'explicativas' e 'restritivas'.

As gramáticas de Pacheco \& Lameira (1887) e Ribeiro (1889) não se assemelham apenas por terem sido escritas com base no Programa de Estudos de Fausto Barreto, mas também porque, apesar de, diferentemente das anteriores, apresentarem o 'verbo substantivo' ou 'abstrato' em texto, contêm, ou poucos conceitos relacionados a ele (no caso de Pacheco \& Lameira (1887)), ou nenhum, no caso de Ribeiro (1889). Pacheco \& Lameira (1887) definem 'verbo' como palavra que exprime 'ação' e 'afirmação' e que tem duas partes, o 'tema', que corresponde à 'ação', e a 'desinência', que corresponde à 'afirmação' ou 'cópula lógica'. Posteriormente, define ‘verbo abstrato' como aquele que apenas pode exprimir a simples 'relação' da 'proposição', só podendo formar 'cópula'; Eles se opõem aos 'verbos concretos', que exprimem uma ideia de ação (ex.: ler, matar) e podem formar a 'cópula' ou o 'predicado' de uma 'proposição'. Parece-nos, assim, que o 'verbo concreto' é subordinado ao conceito de 'verbo'.

Tratamos agora das obras de Ribeiro e Maciel, de 1881 e 1887 respectivamente, que são bastante similares entre si, por apresentarem o 'verbo substantivo', em texto, subordinado aos conceitos de 'verbo' (o qual, na gramática de Maciel, faz parte da metaclasse de 'palavras conectivas') e de 'sentença' ou 'proposição'. O conceito de 'verbo substantivo' de Ribeiro está também subordinado aos conceitos de espécies de 'verbo'. Entretanto, ambas as obras são ecléticas verticalmente, porque Ribeiro (1881) define 'verbo' de mais de uma maneira e Maciel (1887) apresenta mais de um conceito de 'proposição'.

Na segunda edição da gramática de Ribeiro (1885) e na segunda edição com título modificado da gramática de Maciel (1895), porém, o conceito de 'verbo substantivo' é eliminado e o 'verbo' passa a ser da metaclasse de 'palavras nominativas' em ambas as obras. Ademais, os conceitos de 'verbo' e 'proposição' são modificados nas duas obras (em Ribeiro há somente uma modificação de ilustração, mas que provoca distanciamento em relação ao 'verbo substantivo'). Os dois gramáticos parecem afastar-se conscientemente da assunção do 'verbo substantivo' e da rede conceitual que 
sustentavam em gramáticas anteriores. Finalmente, em Maciel (1895) há críticas à aplicação do 'verbo substantivo', tal qual há na gramática de Gomes (1895), que também apresenta o 'verbo' na metaclasse 'nominativa'.

Reunimos as gramáticas por semelhança de rede conceitual, mas muitas vezes elas também estão próximas cronologicamente. Há duas gramáticas que não apresentam o conceito 'verbo substantivo' ou e uma que o apresenta com um conceito incomum, as três são do início do século (Morais Silva 1806, Fortes 1816, Coruja 1835) - estas formam o que chamamos de bloco A. Parece-nos que os anos entre 1829 e 1877 (Costa Duarte 1829, 1859, Bithencourt 1862, Sotero dos Reis 1877) foi o período em que as redes conceituais em torno do 'verbo substantivo', com algumas diferenças entre si, obteve maior produtividade; entretanto, como vimos há em 1859 a crítica, realizada em metatexto, por Costa Duarte, a qual, como vimos, foi rebatida por Bithencourt 1862 estas obras formam o bloco B. No final desse período, porém, entre 1873 e 1890 (Coruja 1873, Carneiro Ribeiro 1881, Ribeiro 1881, Pacheco \& Lameira 1887, Maciel 1887, Condurú 1888, Ribeiro 1889, Carneiro Ribeiro 1890), ainda que o 'verbo substantivo' aparecesse nessas obras, sua rede conceitual era limitada a pouco conceitos ou conceitos apresentados apenas em metatexto, são gramáticas ecléticas - estas formam o bloco $C$. Finalmente, entre 1885 e 1890, temos o que chamamos de exclusão consciente do 'verbo substantivo', pois em 1885, temos a segunda edição da Grammatica Portugueza de Julio Ribeiro em que o conceito e sua rede são excluídos, e temos duas gramáticas que não apenas não aplicam o conceito, e sua rede conceitual, como também o criticam, de Gomes e Maciel - estas formam o bloco D.

\begin{tabular}{|c|c|c|c|}
\hline Bloco A & Bloco B & Bloco C & Bloco D \\
\hline \multirow{3}{*}{ Morais Silva 1806 } & Costa Duarte 1829 & Coruja 1873 & Ribeiro 1885 \\
Fortes 1816 & Costa Duarte 1859 & Ribeiro 1881 & Gomes 1895 \\
Coruja 1835 & Bithencourt 1862 & Maciel 1887 & Maciel 1895 \\
& Sotero dos Reis 1877 & Pacheco \& Lameira 1887 & \\
& & Condurú 1888 & \\
& & Ribeiro 1889 & \\
\hline
\end{tabular}

Quadro 97. As gramáticas de cada bloco

É notável, portanto, que a gramaticografia brasileira não tenha lidado com o conceito de verbo substantivo e sua rede conceitual logo em sua emergência, mas apenas após duas décadas da primeira gramática publicada. Depois disso, o conceito e sua rede conceitual que eram bastante similares, mas não completamente homogêneos entre as 
gramáticas, foi frequente até a penúltima década do século. Entretanto, entre a década de 1870 e 1890 que sua rede conceitual passa a perder espaço. Finalmente, nos últimos 15 anos do século passa a ser excluído conscientemente das obras, e, enfim, em 1895 passa a ser objeto de crítica. Ressaltamos, porém, que nossa análise se limitou a observar dezoito obras das duzentas e quatro gramaticas brasileiras oitocentistas de que temos conhecimento, o que a leva a ser uma amostra dessa produção, isto é, uma versão possível de sua história.

Quanto à homogeneidade parcial das redes conceituais sustentadas entre $1829 \mathrm{e}$ 1877, vemos que todos gramáticos do bloco $B$ apresentam a 'oração', 'sentença' ou 'proposição tripartite', isto é, composta por 'sujeito', 'verbo' e 'atributo' ou 'predicado', à qual o 'verbo substantivo' era subordinado, visto que seu conceito era, em todas essas obras, conectado ao ‘sujeito' e ao 'predicado'. No entanto, por vezes ele significa 'cópula' (Costa Duarte 1859, Sotero dos Reis 1877), em outros casos significava também 'existência' (Costa Duarte 1829, Bithencourt 1862). É notável que todos os gramáticos deste bloco também apresentem conceitos de 'linguagem' e 'gramática' que relacionem 'linguagem' e 'pensamento', aproximando-se apenas do Programa de Correspondência (Swiggers 2004 - cf. 1.2). Ademais, nem todos os gramáticos desse bloco fazem equivaler as espécies de 'adjetivo' e de 'proposição incidente' ou 'parcial', os que fazem isto são apenas Costa Duarte $(1829,1859)$ e Bithencourt (1862). Ressaltamos, porém, que todos descrevem as espécies 'adjetivos' em termos lógicos, trabalhando, ainda que não diretamente, com conceitos de 'intensão' e 'extensão'.

Os outros blocos são mais heterogêneos. A ‘oração' tripartite está em quatro das oito gramáticas do bloco $C$, mas aparece em competição com outras definições (ecletismo vertical). Na gramática de Condurú (1888), aparece apenas em metatexto, pois em texto sua ‘oração' divide-se em ‘sujeito' e ‘verbo'. Na gramática de Maciel (1887), compete com a 'proposição', que conteria sete 'funções' ambas apresentadas em texto. Nas gramáticas de Carneiro Ribeiro (1881, 1890), aparece em competição com a proposição gramatical que é análise pelo número de palavras que tiver, ambas também apresentadas em texto. Ademais, do bloco $C$, Coruja (1873) inclui o 'paciente' na 'oração', Ribeiro (1881) faz duas divisões binárias na 'sentença' (em ‘sujeito' e 'predicado', e depois divide o 'predicado' em 'cópula' e 'predicado propriamente dito') e Ribeiro (1889) e Pacheco \& Lameira (1887) dividem-na apenas em 'sujeito' e 'predicado'. No bloco A, apenas Morais Silva (1806) sustenta a 'sentença' tripartite, visto que Fortes (1816) não apresenta conceito de 'oração', Coruja (1835), tal como fez em (1873), inclui o 'paciente' na 
'oração' tripartite. Finalmente, como era de se esperar, dado que elas criticam o 'verbo substantivo' ou o excluem conscientemente, nenhuma gramática do bloco D apresenta a 'oração' ou 'proposição' tripartite, as três preferem a forma bipartite constituída por 'sujeito' e 'predicado' - entretanto, como vimos, Ribeiro (1881) ainda apresenta a cópula como parte do 'predicado'.

Quanto ao conceito de 'verbo', também bastante heterogêneo, no início do século, duas gramáticas do bloco $A$ o definem como palavra que significa ação (Coruja 1835) e também 'paixão' (Fortes 1816). Já Morais Silva (1806), também do bloco A, define 'verbo' como “palavra com que se declara o que a alma julga ou quer acerca dos 'sujeitos' e dos 'atributos' das 'sentenças"'. Outros dois gramáticos, do bloco $C$, que inserem a noção de 'relação' no conceito de 'verbo' são Maciel (1887), que define verbo como "palavra conjuntiva que sob a noção de tempo exprime a existência de um facto abstrato ou concreto", e Condurú (1888), em metatexto, onde define o 'verbo lógico' como "palavra que exprime a relação de conveniência entre os termos da proposição". Em texto, porém, a definição de Condurú é "palavra que exprime a existência, estado ou ato de algum sujeito", a qual é similar às definições de Ribeiro (1889 - bloco C) e Gomes (1895 - bloco D), que são respectivamente, "palavra pela qual se pode atribuir a um ser uma ação, um estado ou uma qualidade" e "palavra que exprime ação, qualidade ou estado". Finalmente, alguns gramáticos ressaltam a 'afirmação' e algum outro significado para definir o 'verbo'. Coruja (1873 - bloco C) define-o como "palavra com que na 'oração' significamos a ação 'afirmando' uma coisa de outra”, Ribeiro (1885), como "palavra que enuncia, diz ou declara alguma coisa e que implica sempre uma 'asserção' ou 'predicação"” e, finalmente, Maciel 1895, como "palavra de tempo destinada a afirmar e a exprimir simultaneamente os factos".

O conceito de 'gramática' e de espécies de 'gramática' é diferente entre as gramáticas dos blocos $A, C$ e $D$. Pacheco \& Lameira (1887 - bloco $C)$ não apresentam definição. Fortes (1816 - bloco A) e Condurú (1888 - bloco $C)$ ressaltam o aspecto normativo do manual, pois definem 'gramática', respectivamente como "arte que ensina a fazer sem erros a oração portuguesa" e "arte que ensina a falar, escrever e ler com acerto a língua portuguesa". Morais Silva (1806 - bloco A) e Coruja (1835 - bloco A; 1873 bloco $C$ ) definem, igualmente, gramática como "arte que ensina a declarar bem os nossos pensamentos por meio de palavras". As gramáticas de Ribeiro (1881 - bloco C; 1885 bloco A), Maciel (1895 - bloco D) e Ribeiro (1889 - bloco C) definem gramática como 'exposição metódica', 'sistematização lógica' ou 'coordenação' de 'fatos', 'normas', 
‘fórmulas', ‘leis' e 'regras' da 'linguagem' ou de uma 'língua qualquer'. Gomes (1895 bloco $D$ ) define gramática como "ciência dos fatos da linguagem”. Finalmente, Maciel $(1887$ - bloco $C)$ é o único a se aproximar do conceito sustentado pelas gramáticas do bloco $B$, mas inclui também a noção de 'fatos da linguagem', pois define gramática como "disciplina que trata das normas do pensamento humano pelo estudo analíticos dos fatos da linguagem”. Ressaltamos que a citação de 'fatos' é característica do final do século, visto que, ainda que variem entre os blocos definidos das redes conceituais do 'verbo substantivo', todas as gramáticas que usam esse termo foram publicadas entre 1881 e 1895.

Algumas gramáticas não apresentam espécies de 'gramática', como Fortes (1816), Coruja $(1835,1873)$ e Condurú (1888). Entre as que apresentam, é claro que até 1881, havia a oposição entre 'gramática particular' e 'gramática universal' ou 'geral', que se apresenta em Morais Silva (1806), Costa Duarte (1829, 1859), Sotero dos Reis (1877) e Ribeiro (1881, 1885). A única exceção do período é Bithencourt (1862) que diferencia a 'gramática geral' da 'gramática filosófica'. Salvo por Ribeiro (1881, 1885), todas relacionam a ideia de 'gramática geral' com princípios universais das línguas, os quais eram aplicados na 'gramática particular' - concepções, muitas vezes, estavam ligadas à conexão entre pensamento e linguagem. A partir da década de 1880, os gramáticos passam a também definir a 'gramática comparativa', a 'gramática histórica' e/ou a 'gramática histórico-comparativa', que é o caso de Carneiro Ribeiro (1881, 1890), Maciel (1887), Pacheco \& Lameira (1887), Ribeiro (1889), Gomes (1895) e Maciel (1895), que os aproxima de uma concepção de língua enquanto objeto comparável, mas mantêm - em geral - a definição de 'gramática geral', ainda que com divergências importantes.

Adiante esquematizamos as continuidades e descontinuidades da rede conceitual do 'verbo substantivo' no modelo Descontinuidade-e-Continuidade de Koerner (1989) (cf. 1.3). No seguinte esquema, considere que a linha que está no meio diz respeito à rede conceitual do 'verbo substantivo', a superior, a um tratamento anterior, que não considerava o 'verbo substantivo' e sua rede, como é o caso de Fortes (1816), típico da gramática latina estendida, e a linha inferior corresponde a uma superação consciente do 'verbo substantivo' e sua rede. 
Figura 11. Modelo de continuidade vs. descontinuidade das gramáticas brasileiras oitocentistas

Percebemos, no início do século, que, embora a gramática de Fortes (1816) use claramente outro modelo, esse modelo já estava em competição com uma incipiente rede conceitual do 'verbo substantivo', por conta da gramática eclética de Morais Silva (1806). Entre os anos 1829 e 1890, há gramáticas dos blocos $B$ e $C$, enquanto as do bloco $B$ estão espalhadas por um maior intervalo de tempo (de 1829 a 1877), as do bloco $C$ estão em maior número na seleção que fizemos. Elas aparecem após 1873, quando a rede conceitual do 'verbo substantivo' passa a perder importância. Há ainda nesse período de tempo, uma gramática do bloco A, ainda no início do século, em 1835. Vemos que a transição gradual, assim, a rede conceitual do 'verbo substantivo' tem um longo período hegemônico, de cerca de quatro décadas; depois, por duas décadas, compete com outras maneiras de descrever o 'verbo', a 'oração', e a 'gramática', e, finalmente, na última década do século, a rede conceitual torna-se razão de crítica, desaparecendo da descrição linguística, e tendo seu lugar tomado por outra forma de descrição.

Passemos à segunda etapa de nosso exame longitudinal, em que observaremos que conceitos, não captados na rede conceitual particular podem ser observados como comuns às gramáticas dos diferentes blocos.

É comum que as gramáticas do bloco B tratem dos outros itens da 'oração', 'sentença' ou 'proposição' que estavam além da sua divisão essencial tripatite como quatro 'complementos' ('objetivo', 'terminativo', 'restritivo', 'circunstancial'), como é o caso de Costa Duarte (1829, 1859), Bithencourt (1862), Sotero dos Reis (1877 - bloco B). Já Carneiro Ribeiro (1881, 1890 - bloco C) apresenta a noção de complemento, mas distingue apenas duas espécies, 'direto' ou 'indireto'. Maciel (1887 - bloco C), embora apresente três dos quatro 'complementos' como equivalente a algumas das 'funções'. As 'relações' e 'funções', diferentemente são exercidas por todos os elementos da 'sentença', inclusive os essenciais ('sujeito' e 'predicado'). Elas aparecem, em número diferente, nas gramáticas das últimas décadas do século de Ribeiro (1881 - bloco C, 1885 - bloco $D)$, Maciel (1887 - bloco B, 1895 - bloco D) e Ribeiro (1889 - bloco C). Alguns gramáticos 
preferem não se prender a uma terminologia específica, caso de Morais Silva (1806) e Coruja (1835), ambos do bloco A, Pacheco e Lameira (1887 - bloco C), e Gomes (1895 -bloco D). Finalmente, Fortes (1816 - bloco A) é o único a usar o conceito de ‘caso' para organizar as palavras sintaticamente, visto que não apresenta conceito de 'oração'. 'Complemento' parece, portanto, estar relacionado à rede conceitual do 'verbo substantivo', visto que é usado por todos os integrantes do bloco $B$ e alguns do bloco $C$.

É possível ver que, ainda que não apresentassem paralelismo entre espécies de 'adjetivo' e de 'oração', quase todas as gramáticas que tratam de 'orações incidentes' ou 'parciais' que podiam ser 'restritivas' ou 'explicativas' são do bloco B. A única deste bloco que não apresenta os conceitos é a de Sotero dos Reis (1877). Ademais, duas gramáticas de outros blocos também os apresentam: Morais Silva (1806 - bloco A), que, aliás, apresenta só essa espécie de 'sentença', e Condurú (1888 - bloco C), as duas, como vimos, ecléticas.

Finalmente, é notável que, exceto por Fortes (1816) e Coruja (1835), todos os gramáticos (dos quatro blocos) distingam nos 'adjetivos' espécies baseadas, mesmo que indiretamente, nas noções de intensão e extensão, seja pela dupla (1a) que modifica a compreensão do nome ('qualificativo') e (1b) que modifica a extensão do nome ('determinativo), seja pela dupla (em geral espécies do 'qualificativo'): (2a) que modifica a compreensão do nome ('restritivo') e ( 2 b) que não a modifica a compreensão do nome ('explicativo'), ou mesmo por ambas as duplas (cf. 1.4.2) - ainda que, por vezes, rejeitem uma das duplas, como foi o caso de Condurú (1888). Ademais, curiosamente, quase todos os gramáticos que consideraram a dupla de (1) e (2), ou incluíram o 'artigo' na classe dos 'adjetivos' ou (Morais Silva 1806, Costa Duarte 1829, 1859, Bithencourt 1862, Sotero dos Reis 1866, Carneiro Ribeiro 1881, 1890, Maciel 1887, 1895, Pacheco \& Lameira (1887), Condurú (1888) e Gomes (1895)) ou classificaram os 'artigos' das duas maneiras, como classe de palavra e como espécie de 'adjetivo' (Coruja 1873) - as exceções são Ribeiro (1881, 1885) e Ribeiro (1889).

Esse segundo exame nos mostra que o 'complemento' é preferido como conceito organizador dos elementos da 'proposição' pelos gramáticos do bloco $B$, isto, muito provavelmente, porque ele serve para complementar os elementos essenciais da 'oração' tripartite, a qual é apresentada por todas as gramáticas do bloco B. As 'orações incidentes' ou 'parciais' que tivessem distintas espécies baseadas, ainda que indiretamente, nos conceitos de intensão e extensão, apresentam-se sobretudo em gramáticas do bloco $B$ (com uma exceção: Sotero dos Reis (1877)). No entanto, vemos que essas noções lógicas 
são utilizadas ao longo de todo século para definir conceitos de diferentes espécies de 'adjetivo', por vezes, colocando o 'artigo' como uma espécie de 'adjetivo'. Dessa forma, embora estejam lidando com conceitos provenientes da Logique de Port-Royal (que foram adaptados pela tradição da grammaire générale (cf. 1.4.2)), as gramáticas brasileiras, diferentemente do que fizeram com o 'verbo substantivo' e sua rede conceitual, os mantêm durante todo o século para distinguir espécies de 'adjetivo', mas não para distinguir espécies de 'oração'. Isto nos leva a crer que a rejeição ao 'verbo substantivo' e sua rede conceitual no final do século dizia mais respeito à sua premissa de que a língua deve ser analisada por um nível subjacente do que por sua herança lógica, dado que conceitos lógicos não foram inteiramente rejeitados.

\subsection{Agendas e dois tipos de ecletismo}

Como pudemos ver na análise do capítulo 4, alguns gramáticos mostraram-se ecléticos de duas maneiras diferentes: alguns por apresentar conceitos que não tinham relação com outros da obra, o que chamamos de ecletismo horizontal, e outros por apresentarem duas definições e/ou ilustrações para um mesmo termo. Nestes resultados, observamos em que medida o tipo de ecletismo presente nas obras pode ter alguma relação com a agenda dos autores, a qual analisamos no capítulo 3 (item 3.2).

O primeiro gramático brasileiro conhecido é eclético. Notamos na gramática de Morais Silva ecletismo horizontal, pois seu conceito de 'verbo substantivo' não forma rede conceitual com outros conceitos da obra, sendo, como vimos, um conceito peculiar. Ademais, mesmo os conceitos de 'verbo' e de 'sentença' do autor coadunam definições de proveniência diferente. Sabemos, pela análise de sua agenda, que Morais Silva queria romper com os gramáticos anteriores, os quais, segundo ele, frequentemente baseavam a descrição do português numa metalinguagem própria para a língua latina, pois consideravam que as duas línguas tinham muitos aspectos em comum. O gramático brasileiro discorda dessa visão, como vimos por sua epígrafe e seu prólogo. Assim, Morais Silva autopercebia-se em um período de transição, no qual ele se via responsável por romper com modelos antigos. Talvez possamos relacionar esse ímpeto com seu ecletismo horizontal, visto que o autor, conhecendo uma série de doutrinas diferentes daquela que considera inadequada, pode, no ímpeto da mudança, ter recorrido a conceitos de proveniência diversa.

Na edição posterior com título modificado da gramática de Costa Duarte (1859), há um curioso ecletismo vertical. O gramático apresenta, em texto, o 'verbo substantivo' 
e sua rede conceitual de forma quase idêntica à que havia já apresentado em 1829, mas inclui longas notas de rodapé à seção de tratamento do 'verbo', que refutam os conceitos de 'verbo', 'verbo substantivo' e 'verbo adjetivo' apresentados em texto. Pouco sabemos da agenda desse gramático, a não ser que, em 1829, ele dedicava sua gramática ao então governador da província do Maranhão e solicitava que ele fizesse a ela as críticas necessárias. Em 1859, sua gramática, já com grande prestígio, era adotada no Liceu Maranhense e em aulas de primeiras letras de outras escolas da província. Não sabemos em que medida o gramático fez as modificações de acordo com críticas do governador da província ou se houve mudanças espontâneas em seu próprio pensamento. Vê-se, entretanto, que o gramático manteve o 'verbo substantivo' e sua rede conceitual no lugar de destaque, isto é, o texto, fazendo suas reflexões e críticas à parte dessa rede, em local de menos destaque, as notas de rodapé. Ressaltamos, porém, que o gramático não inseriu críticas ao conceito de 'oração' tripartite, nem aos 'complementos' ou à definição lógica dada às 'orações incidentes' e aos 'adjetivos' .

A Grammatica Elementar de Condurú (1888[1860]), da qual analisamos a décima terceira edição, apresenta ecletismo vertical. Mas, ao contrário do que faz Costa Duarte, coloca os conceitos de 'verbo substantivo' e de sua rede conceitual, isto é, 'verbo', 'oração' (e mesmo 'complemento') em metatexto, ao passo que apresenta conceitos diferentes para 'verbo' e 'oração' em texto. O gramático afirma em uma das notas de rodapé que esses os conceitos apresentados em metatexto não se adequam bem ao português e, por isso, são impróprios para o ensino. Ainda assim, ele os apresenta para que o leitor possa ter opção sobre qual seguir. Vemos, portanto, que há preocupação de Condurú com a didática de sua obra, que era adotada em escolas de primeiras letras das províncias do Maranhão e do Pará. Ademais, pelas informações que temos sobre o autor, ele teve carreira no magistério, o que pode ter influenciado essa opção.

As duas gramáticas de Carneiro Ribeiro (1881, 1890), que se assemelham bastante entre si (ao menos no que diz respeito aos aspectos analisados), apresentam também ecletismo vertical, o qual parece, porém, ser resultante de um plano consciente do autor. Não há prólogo em sua Grammatica Philosophica, mas há nos Serões, de 1890, e nele o autor ressalta que os estudos mais recentes ('naturalistas') não deveriam excluir os mais antigos ('lógicos'), mas, ao contrário, ambos deveriam se auxiliar e completar (cf. 3.2.7). Talvez por isso o autor exponha, por vezes, conceitos distintos para um mesmo termo que chama de 'lógicos', 'racionais' e 'filosóficas' em oposição aos que chama de 'gramaticais', como o faz em relação aos conceitos de espécies dos 'verbos' e de ‘oração'. 
Parece-nos que Pacheco \& Lameira (1887) seguem tendência similar, mas sua gramática apresenta ecletismo horizontal. Os dois autores eram educadores e tencionavam, como vemos em seu prólogo, escrever uma gramática que rompesse com a tradição; no entanto, ao definirem 'gramática geral' (ou 'glossologia') afirmam que devese examinar a linguagem tanto por meio de princípios a priori detectados na relação entre pensamento e linguagem, como por meio de análise mórfica do dado externo - tais princípios e dados, em vez de se polarizarem, devem, segundo os gramáticos, reuniremse, uma vez que a língua é 'ideia' e 'forma'. Talvez seja por sustentarem essa visão dos estudos da linguagem que definam o 'verbo' como palavra que exprime uma ação e uma afirmação e que consta de dois elementos, um 'material', o 'tema', que corresponde à 'ação enunciada', e um 'formal', a 'desinência', que se refere à 'afirmação' ou 'cópula lógica'. No entanto, os autores não analisam a 'proposição' considerando essa distinção, visto que a proposição é constituída apenas por 'sujeito' e 'predicado', sendo este um 'verbo de predicação completa' ou um 'verbo de predicação incompleta' acrescido de 'modificadores'.

Ribeiro (1881) e Maciel (1887), na primeira edição de suas gramáticas, por um lado, mantêm o 'verbo substantivo', mas apenas parte de sua rede conceitual; por outro lado, conceituam os mesmos segmentos de mais de uma forma. Ribeiro define 'verbo' em texto como "palavra que exprime a existência de uma relação entre duas ideias" e também como "palavra que diz ou declara” e, como já vimos, usa o conceito de 'função' para tratar dos elementos da 'sentença', mas não faz referência ao conceito de 'sentença' que havia apresentado anteriormente. Como sabemos por ampla literatura (cf. 1.5) e também pelos paratextos da gramática de Ribeiro (cf. 3.2.8), o gramático se autopercebia, tal como Morais Silva no início do século, num momento de transição, sentindo-se responsável por trazer novas maneiras de descrever a língua portuguesa em sua obra. Sendo assim, é possível que a rápida leitura de obras diversas, as quais, em alguns momentos tiveram seus trechos traduzidos e colocados diretamente na gramática (cf. Maciel 1910, Polachini 2013), tenha contribuído para o seu ecletismo vertical e horizontal.

Maciel avalia, no prólogo à sua Grammatica Analytica, de 1887, que é acomodada ao Programa de Estudo para exames de Fausto Barreto (1887), que todas as ciências passavam por grande progresso no século XIX, e que isso não era diferente para os estudos das línguas; assim, sua gramática baseava-se nas doutrinas modernas. Como sabemos, este foi seu primeiro livro publicado, o autor inclusive ressalta que terminou de 
escrevê-lo quando contava apenas vinte e dois anos. Concluímos, dessa forma, que o autor, tal como Morais Silva e Ribeiro, autopercebia-se num período de transição e igualmente se se sentia responsável por promover mudanças. Entretanto, talvez pela própria falta de experiência como gramático, visto que esse foi seu primeiro livro, há ecletismo vertical e horizontal na obra. O primeiro se dá porque o gramático define 'proposição' como sendo tripartite, isto é, constituída por 'sujeito', 'verbo' e 'predicado', e como sendo constituída por sete 'funções'. Ademais, faz equivaler três 'complementos' a três das sete 'funções'.

O ecletismo horizontal que vemos em Ribeiro (1889) é mais similar ao visto também em Ribeiro (1881) e Maciel (1887), porém mais simples. O autor, embora mencione os conceitos de 'verbo substantivo' e de 'verbo adjetivo', não dá qualquer continuidade ao seu tratamento, pois define 'verbo' como "uma palavra pela qual se pode atribuir a um ser uma ação, um estado ou uma qualidade” e 'oração' como constituída por 'sujeito' e 'predicado'. Parece-nos que sua citação daqueles conceitos é meramente protocolar. Quanto à sua agenda, em seu prólogo à primeira edição, apresentado na terceira que analisamos, o gramático, tal como fazem quase todos desse momento, relata a mudança por que passavam no período os estudos sobre a linguagem.

Em conclusão, percebemos que, por um lado, o que pode ter contribuído para o ecletismo dessas obras é a grande abertura que os gramáticos brasileiros tinham para conceitos já utilizados em gramáticas elaboradas em outros países, sobretudo, da Europa. Assim, vemos que Morais Silva (1806), Ribeiro (1881) e Maciel (1887) têm fontes diversas, de onde colhem boa parte de seus conceitos, mas, talvez, por conta do ímpeto que tinham de modificar o modo como se descrevia a língua portuguesa então, não tenham atentado à diversidade conceptual dessas fontes. Este, talvez, seja o mesmo caso de Ribeiro (1889), ainda se dê de forma mais sutil.

Há também ecletismo nas obras quando seus autores conscientemente desejam abordar os temas de mais de um ponto de vista, o que se dá nas gramáticas de Pacheco \& Lameira (1887), Carneiro Ribeiro (1881, 1890), Condurú (1888) e Costa Duarte (1859). A dupla de gramáticos prefere integrar nos conceitos de sua gramática, o que, ainda que as doutrinas da época considerassem opostos, eles consideravam constitutivo da linguagem. Carneiro Ribeiro faz algo similar, mas para isso prefere apresentar dois conceitos para um mesmo termo. Finalmente, Condurú e Costa Duarte discordam, pedagogicamente e/ou analiticamente, da maneira como certos conceitos são definidos e, portanto, apresentam uma alternativa a eles em nota, ou apresentam aqueles conceitos de 
que discordam com menos destaque. Em suma, vemos que o ecletismo que percebemos no aspecto que analisamos das obras não é fortuito, mas relaciona-se a causas contextuais que podem, muitas vezes, ser rastreadas.

\subsection{O 'verbo substantivo' e a língua portuguesa: o debate entre ser e estar}

$\mathrm{Na}$ análise realizada no Capítulo 4, foi comum ver que diversos gramáticos debatiam em metatexto, fosse a favor ou contra, a respeito da pertinência ou não de o 'verbo estar' ser um exemplo de 'verbo substantivo'. Tal debate não poderia ocorrer em qualquer língua. No francês, por exemplo, que era a primeira língua de diversos teóricos da grammaire générale não era um debate possível, dado que o verbo être significava tanto ser quanto estar. O grande agravante de se ter mais de um exemplo de 'verbo substantivo' seria não considerá-lo mais um 'verbo único', o que poderia ter consequências na teoria como um todo.

No início do século, não há menções a essa possibilidade. Todos os gramáticos que tratam, ainda que sumariamente, do 'verbo substantivo' apresentam apenas "ser" como exemplo. É a partir da década de 1850 que o debate começa a surgir nas obras, tomando as seguintes direções: (1) em metatexto é negada a possibilidade de "estar" ser 'verbo substantivo'; (2) em texto ou metatexto é feita uma análise linguística que procura justificar que o verbo "estar" seja ou possa ser exemplo do 'verbo substantivo'.

Os adeptos de (1) são Bithencourt (1862), Sotero dos Reis (1877), Ribeiro (1881), Carneiro Ribeiro (1881, 1890), Maciel (1887). É curioso que apenas as duas das primeiras gramáticas formam uma rede conceitual com o 'verbo substantivo' sem ter, ainda, influências do método histórico-comparativo. No entanto, essa polêmica não parece ter se iniciado com a introdução do nomo método de descrição e análise linguística, mas de possíveis anomalias que os dados de língua portuguesa geravam na teoria.

A primeira obra que conhecemos a fazer esse questionamento é a gramática de Costa Duarte (1859), que apresenta uma série de questionamentos sobre concepções da grammaire générale, os quais parecem sempre estar baseados nas dificuldades de se analisar a língua portuguesa com tal modelo. Como vimos, Costa Duarte não acrescentou apenas o 'verbo' “estar” como exemplo do 'verbo substantivo' (cf. 4.3), pois, ao que nos parece, o gramático desprendia-se das rédeas do modelo teórico usado para observar de fato os dados linguísticos - chegando, assim, à conclusão de que havia desencaixe entre 
eles. Crítica similar, mas muito menos detalhada, é feita por Condurú (1888) que também opta por apresentar o “estar” como 'verbo substantivo'. Este último, porém, já não considerava o modelo de descrição baseado no 'verbo substantivo' como principal, pois a apresenta somente em metatexto. Vemos, portanto, que, dentre as obras analisadas, a inserção do 'verbo' "estar" como substantivo aparece juntamente com uma crítica ao modelo de descrição.

Esse resultado mostra que a preocupação com o dado sobreposta à preocupação com a teoria é mais antiga do que a entrada do modelo histórico-comparativo no Brasil. Entretanto, mesmo com a entrada parcial desse modelo, que preconizava a observação atenta do dado, o respeito ao modelo de descrição baseado em um verbo único se manteve, como podemos ver nas críticas que são feitas nas gramáticas posteriores à década de 1880 à apresentação de "estar" como exemplo do 'verbo substantivo'.

\subsection{Resultados e contribuições da metodologia da História Serial}

Como já vimos nos Capítulos 1 e 2, a História Serial é uma metodologia que possibilita, a partir da análise de um material homogêneo, conceber eventos por meio observação em série de unidades. Nosso material homogêneo, a folha de rosto das obras ou suas informações catalográficas, permitiu, ao ser olhado em série, que concebêssemos diversos eventos, os quais expomos sumariamente no Capítulo 3. Neste item do capítulo de resultados e contribuições, intentamos, num primeiro momento, observar como tais eventos, específicos de nossa pesquisa, podem ser interpretados ao juntá-los a informações que obtivemos por outras análises ou por fontes secundárias. Posteriormente, apresentamos as contribuições que essa metodologia pode ter para a área de Historiografia Linguística como um todo.

Além de nos permitir ver a amplitude e diversidade da gramaticografia brasileira, que se formava naquele século, ela nos permitiu comprovar que é no Rio de Janeiro que se concentra a grande maior parte da produção gramatical, em relação ao número de autores, de gramáticas e de títulos, de que tivemos conhecimento. É fato que isso já era esperado, pois a cidade era então a capital do país recém-independente de Portugal. Com a vinda da família real portuguesa em 1808, foi no início do século, o primeiro local do Brasil a ter uma imprensa legalizada, a qual imprimiu a primeira gramática publicada em solo brasileiro (de que temos conhecimento), a saber, o Epitome de Fortes (1810, [2]). 
Logo, porém, como vimos, províncias do sul e do norte do país também começaram a publicar gramáticas. Chamam atenção a província do Maranhão, que tem publicações já na década de 1820 (Costa Duarte 1829, [10]), a Bahia e o Rio Grande do Sul, que publicam gramáticas na década de 1830 (César 1832, [11]; Coruja, 1835 [16]).

Essa metodologia nos possibilitou ver também que gramáticas não são, em geral, referidas pelas revisões históricas (cf. item 1.5) podem ter obtido bastante prestígio ao longo do século XIX, dado seus elevados números de reedições, como foi o caso de Fortes (1810, 1816, 1825, 1844, 1851, 1855, 1862), Condurú (1850, 1888), Albuquerque (1846, 1858, 1874), Ortiz \& Pardal (1871, 1873, 1876, 1884, 1888), Cruz (1853, 1863, 1865, 1879). O que nos faz concluir que há certa divergência entre a percepção que o século XX e início do XXI teve acerca da produção gramatical oitocentista e a maneira como ela era percebida então, dado que gramáticas de aparente prestígio na época não foram lembradas pelas revisões. Esse é um grande exemplo de contribuição da História Serial, visto que ela proporciona, como discutimos no Capítulo 1, a possibilidade de encontrar novos eventos justamente nos basearmos em algo que já foi estabelecido e interpretado anteriormente.

Pudemos, por meio dela, observar igualmente que é na década de 1860 que ocorre uma grande expansão na gramaticografia brasileira, momento também em que muitas obras oferecem subtítulos especificando: o conteúdo presente na obra ou se ela era baseada em um programa de estudos; os gramáticos, autores ou doutrinas em que a obra se baseia; sistemas ou teoria em que as obras têm seus fundamentos; modo de apresentação do conteúdo; e, finalmente, o material linguístico que é objeto da obra, como, por exemplo, textos literários clássicos. Tais subtítulos, parece-nos, expunham certa publicidade por explicitar algum atributo relativo ao seu conteúdo, formato ou objeto de análise ou qual era o público-alvo em diferentes partes do século. Esse grande aumento unido à publicidade pode ter tido por gatilho um maior interesse de colégios importantes do país no ensino de língua portuguesa, em detrimento do latim. Razzini (2000), explica que os programas de ensino de língua portuguesa do Colégio Pedro II surgem na década de 1850. É curioso também que o Epítome de Fortes, publicado pela primeira vez em 1810 e que, como pudemos ver no Capítulo 4, ensina a língua portuguesa por meio das relações que essa tem com o latim, tenha sido, de acordo com Sacramento Blake, publicado pela última vez em 1862; isto é, justamente quando o latim perde espaço para língua portuguesa no ensino. 
Ademais, é na década de 1880 que temos o maior número de gramáticas publicadas no século. Foram 53 gramática, sendo 32 delas edições específicas, isto é, títulos que vimos pela primeira vez. Nesse período, os subtítulos já não eram tão populares, mas é nesse momento que ocorrem outros dois eventos. O primeiro foi observado também em nossa História Serial, é a ascensão de títulos iniciados com o termo 'gramática' e a queda dos títulos iniciados pelo termo 'compêndio' (seja em número total de gramáticas, seja em edições específicas). Como vimos, essa mudança poderia estar associada a diferentes razões, uma delas é o aumento de obras gramaticais destinadas a níveis de ensino superiores à educação primária - foco da educação do país até o último quartel do século -, visto que 'compêndios' eram, pelos dados que temos, apenas destinados a esse nível de ensino.

A segunda razão está relacionada à transição epistemológica por que passava a gramaticografia brasileira naquele momento, pois, como é dito nas revisões históricas do período (cf. 1.5) e como pudemos ver em nossa análise orientada para o conteúdo (cf. Capítulo 4), é nos primeiros anos da década de 1880 que começam a entrar nas gramáticas brasileiras o método histórico-comparativo, ao mesmo tempo em que a tradição da grammaire générale perde prestígio - a não ser, como vimos no capítulo 4, quando aspectos dessa tradição estão de alguma maneira relacionados ao método históricocomparativo. Em 1887, seriam publicadas ao menos cinco gramáticas de acordo com o Programa de Estudos para o Colégio Pedro II, o qual preconizava a metodologia históricocomparativa para o ensino de alunos de nível médio, visto que seriam tais conhecimentos que permitiriam sua entrada em um curso superior. Assim, um momento de transição, a qual era vista frequentemente com muito bons olhos, como pudemos ver pelos prólogos dos autores dessa década (cf. 3.2), haveria maior estímulo para a publicação de gramáticas.

Entretanto, como podemos observar nas tabelas e nos gráficos, esse estímulo perdeu o viço muito rapidamente, dado que há queda na publicação de gramáticas na última década do século. As 53 gramáticas passam a ser 35, e as 32 edições específicas caem para 18. Um dos motivos possíveis para essa queda pode ser a transição política por que passou o pais, deixando de ser império para, depois da tomada de poder dos militares, tornar-se república. Pode também ter sido causado pelo reconhecimento das dificuldades de se absorver um novo modelo de análise. Vemos isso pelas mudanças que autores do período, que analisamos no Capítulo 4, promovem em suas gramáticas (cf. Ribeiro 1881, 1885 e Maciel 1887 e 1895), e pelo prólogo da gramática de Ribeiro (1889 - cf. 3.2.12), 
em que o autor critica a maneira como o método estava sendo usado pelas gramáticas brasileiras. Críticas similares seriam feitas no posfácio de Maciel (1918[1910]) que avalia a produção oitocentista, e essas críticas seriam repetidas em estudos e periodizações posteriores, como vimos ao revisitar os estudos sobre essa gramaticografia (cf. 1.5).

Dessa forma, a metodologia da História Serial que utilizamos em nosso mapeamento descritivo e interpretativo da produção gramatical brasileira permitiu enxergar eventos que muito provavelmente não seriam vistos a olho nu, isto é, sem a meticulosa metodologia da História Serial. Ela também motiva e solicita que haja uma organização do material analisado. Assim, organizamos as 204 gramáticas de que tivemos conhecimento ao expô-las em ordem cronológica crescente no Apêndice A, e também as distribuímos numericamente e, por vezes, nominalmente de acordo com as décadas do século e as unidades analisadas. Essa organização, inédita para a produção gramatical brasileira, possibilita que outras interpretações e insights sejam realizados por pesquisas posteriores, sobretudo ao relacionar os dados com eventos que aconteciam ao redor das publicações. Nesse sentido, cumprimos duas das propostas iniciais desse trabalho (cf. Introdução), de, primeiramente, organizar o material de que tivemos conhecimento e, posteriormente, de utilizá-lo como objeto de análise a fim de realizar um mapeamento inédito de nosso objeto, a produção gramatical brasileira oitocentista de língua portuguesa.

Quanto a contribuições que tal metodologia possa proporcionar para a área da Historiografia Linguística, entendemos que ela possa ser sempre o ponto de partida para uma análise orientada para o contexto panorâmica, pois ao se observar as informações contidas na folha de rosto das obras já é possível encontrar critérios interessantes para organizar o material que temos em mãos. No entanto, acreditamos que tal metodologia, baseada no estabelecimento de unidades em série, as quais podem, posteriormente, ser cruzadas a fim de obter diferentes resultados, possa ser usada também na análise orientada para o conteúdo, observando conceitos que se repetem ao longo das obras. Por exemplo, poder-se-ia utilizar essa metodologia para se observar quais são as metaclasses e classes de palavras utilizadas pelas 204 obras ${ }^{131}$ e como os gramáticos preferiram ordená-las, visto que classes de palavras são essenciais para o gênero textual que chamamos de gramática - desde o nascimento desse gênero com a Tékhne Grammatike de Dionísio da Trácia, do século 2 a.C. Tendo esses dados iniciais, seria possível uni-los a uma

\footnotetext{
${ }^{131}$ Infelizmente, porém, como já dissemos anteriormente, não tivemos acesso a todas as obras. Algumas
} conhecemos apenas pelo título. 
interpretação do próprio conceito de cada classe e observar as relações existentes, enfim, entre o conceito e a organização desses dados.

Assim, propomos que essa metodologia seja futuramente testada não apenas em análises orientadas para o contexto, mas também em análises orientadas para o conteúdo. Pois acreditamos que seja uma excelente ferramenta para organizar corpus muito extensos.

\subsection{Resultados e contribuições da metodologia da rede conceitual}

Como já dissemos na introdução deste trabalho, procuramos uma metodologia que tornasse a capa técnica (Swiggers 2004) mais homogênea. Dessa forma, juntamos aspectos da capa teórica (conceitualização de gramática e de linguagem) a aspectos relevantes das técnicas de análise usadas pelos autores analisados na metodologia da rede conceitual.

Por meio dessa metodologia, esforçamo-nos para compreender matizes da ruptura epistemológica ocorrida na tradição gramatical brasileira oitocentista, que já era atestada por ampla bibliografia, por meio do exame de um conceito e sua rede conceitual. Acreditamos que nossos resultados permitem observar a gradação da mudança em maior detalhe por três razões: (1) a possibilidade de acompanhar a gradual eliminação de conceitos atrelados ao conceito-chave, visto que os blocos de gramáticas se sobrepuseram em determinados períodos; (2) a escolha de avaliar reedições ou gramáticas diferentes de um mesmo autor permitiu que acompanhássemos essa gradação pela mudança de opinião dos gramáticos no período de transição (como os casos marcantes de Maciel $(1887,1895)$ e Ribeiro (1881, 1885)); (3) a avaliação que fizemos de dois tipos de ecletismos motivados pela agenda dos autores, tendo em conta a distinção entre texto e metatexto, permite observar diferentes estratégias utilizadas pelos gramáticos no período de transição.

Em nosso trabalho, relacionamos o conceito-chave 'verbo substantivo' aos conceitos (1) gramática e linguagem (2) classes e metaclasses de palavras (3) modificadores do nome (4) verbo (5) oração, sentença ou proposição, entendemos que outros conceitos poderiam ter sido relacionados, com vistas a um maior detalhamento quanto à rede conceitual, optamos por não fazê-lo devido ao tempo para realização da pesquisa e pelo já extenso grau de descrição apresentado nesse trabalho. Nesse sentido, sugerimos que desdobramentos possíveis desse trabalho relacionem outros conceitos ao 'verbo substantivo', como, por exemplo, o 'verbo impessoal', as 'conjunções', 
‘interjeição', outras classes de palavras e a descrição da ordem de palavras, pois eles poderiam elucidar outros aspectos da rede conceitual.

É claro, também, que neste trabalho analisamos um número reduzido de obras, e que o acréscimo de outras gramáticas poderia trazer mais detalhes e precisão aos nossos resultados, ainda que saibamos que sempre estamos realizando versões da história dessa produção. Ainda assim, acreditamos que esse trabalho seja uma descrição rigorosa de aspectos internos da gramaticografia oitocentista brasileira, permitindo uma nova interpretação desses fatos.

Ademais, acreditamos que essa metodologia seja bastante profícua para futuros trabalhos que tratem do estudo de metalinguagem, pois uma das grandes contribuições de nosso trabalho é o detalhamento da noção de conceito, a qual foi formalizada a partir da síntese de importantes estudos anteriores. Assim, de posse de nosso modelo de análise, os pesquisadores que se interessem por metalinguagem poderão ter uma visão completa do que é um conceito, podendo, então, decidir trabalhar com ele como um todo ou apenas parcialmente.

No que diz respeito à metodologia da rede conceitual, acreditamos que ela possa ser usada em trabalhos que visem um análise mais panorâmica, pois é uma metodologia que, ao relacionar diferentes conceitos, permite uma visão holística e interpretativa do objeto estudado, chegando à conclusão da unidade de sua rede e/ou do ecletismo. Assim, ao mesmo tempo em que a noção de conceito, juntamente com a distinção entre texto e metatexto, oferece uma análise detalhada e bastante analítica da metalinguagem, a noção de rede conceitual faz perguntas que permitem uma visão de conjunto do objeto. 


\section{REFERÊNCIAS BIBLIOGRÁFICAS}

\section{Fontes primárias}

BITHENCOURT, Raymundo Antonio Camara. 1862. Epitome da grammatica philosophica da lingua portuguesa. Rio de janeiro. Eduardo \& Henrique Laemmert.

CARNEIRO RIBEIRO, Ernersto. 1881. Grammatica Portugueza Philosophica. Bahia: Imprensa Economica.

CARNEIRO RIBEIRO, Ernesto. 1890. Seroes grammaticaes ou nova grammatica portugueza. Bahia: Imprensa Popular.

CONDURÚ, Fillippe Benicio de Oliveira Condurú. 1888. Grammatica Elementar da Lingua Portugueza. $1^{\mathrm{a}}$ ed. Maranhão.

CORUJA, Antonio Alvares Pereira. 1835. Compendio da Grammatica da Lingua Nacional, dedicado á mocidade rio-grandense. Porto Alegre : V.F. de Andrade.

CORUJA, Antonio Alvares Pereira. 1873. Compendio da grammatica da lingua nacional. Rio de janeiro : Esperanca.

COSTA DUARTE, Antonio da. 1829. Compendio de grammatica portugueza, para uso das Escolas de Primeiras Letras. Maranhão: Tipografia Nacional [Maranhão].

COSTA DUARTE, Antonio da. 1859. Compendio da grammatica philosophica da lingua portugueza Escolhida pela Congregação do Lycêo do Maranhão para o uso do mesmo Lycêo, e das aulas de primeiras lettras da provincia, pelo Padre /.../ Lente da grammatica. Maranhão : Tipografia do Frias.

FORTES, Padre Inácio Felizardo Fortes. 1816. Arte da grammatica portugueza, para uso dos seus discipulos. Rio de Janeiro: Imprensa Régia. $2^{\text {a }}$ edição.

GOMES, Alfredo. 1895. Grammatica Portugueza adoptada no Gymnasio Nacional, Escola Normal, Collegio Militar, Collegio Abilio, Collegio Moss. Rio de Janeiro: J. G. de Azevedo. 6a ed.

MACIEL, Maximino. 1887. Grammatica Analytica da Lingua Portugueza. Rio de janeiro, RJ : Typ. Central de Evaristo Rodrigues da Costa.

MACIEL, Maximino de Araújo (Sergipe ? - ?). 1895. Grammatica Descriptiva baseada nas doutrinas modernas Capital Federal. $2^{\mathrm{a}}$ ed.

MARTINHO, Marcos. 2007. "Dionísio da Trácia, Arte”. Revista de Estudos Clássicos do Programa de Pós-Graduação em Letras Clássicas da Universidade de São Paulo. n. 11, 2007.

MORAIS SILVA, Antonio. 1806. Epitome da Grammatica Portugueza. Lisboa: Off. de Simão Thadedeo Ferreira. 
PACHECO \& LAMEIRA (Pacheco da Silva Jr \& Lameira de Andrade). 1887. Grammatica da Lingua Portugueza. Rio de janeiro: J. G. de Azevedo.

RIBEIRO, João. Exames de Portuguez - Grammatica portugueza ( $3^{\circ}$ anno). 1889. Rio de janeiro : Francisco Alves.

RIBEIRO, Julio. 1881. Grammatica Portugueza. São Paulo: Jorge Seckler.

RIBEIRO, Julio. 1885. Grammatica Portugueza. São Paulo: Teixeira \& Irmão. 2. ed. ref. e muito aum.

SOTERO DOS REIS, Francisco. 1877. Grammatica portugueza accommodada aos principios geraes da palavra seguidos de immediata applicação pratica. Maranhão: Livraria de Magalhães. 3. ed. revista

\section{Fontes secundárias}

ALBUQUERQUE, Manoel M. de A.; REIS, Arthur Cezar Ferreira; CARVALHO, Carlos Delgado de. 1977. Atlas histórico escolar. $7^{\mathrm{a}}$ ed. rev. e atual. Rio de Janeiro: FENAME.

ALONSO, Miguel C. 2012. "Multidimensionalidad, Complejidad y Dinamismo em la historiografía lingüística y em su definición del concepto tradición" Todas as Letras $S$. v. 14. n.1. p.71-86.

ALTMAN, Cristina; COELHO, Olga. s/d. Documenta Grammaticae et Historiae: projeto de documentação linguística e historiográfica (séculos XVI-XIX). São Paulo, CEDOCH - DL - USP. (site: www.fflch.usp.br/dl/documenta)

ALTMAN, Cristina. 2012. "História, estórias e historiografia da linguística brasileira". TODAS AS LETRAS S, v. 14, n. 1, 2012.

ARENS, Hans. 1984. Aristotle's theory of language and its tradition: texts form 500 to 1750 - selection ans commentary by Hans Arens. Amsterdam: Benjamins.

ARGOTE, Jerónimo Contador de. 1725. Regras da Lingua Portugueza, Espelho da Lingua Latina, ou disposiçaõ para facilitar o ensino da lingua Latina pelas regras da Portugueza. Muyto accrecentada, e correcta. Segunda impressaõ. - Lisboa Occidental : na Officina da Musica.

ARISTÓTELES. 2013. Da Interpretação - tradução e comentários José Veríssimo Teixeira da Mata. São Paulo: UNESP.

ARNAULD, Antoine; LANCELOT, Claude. 1803[1660]. Grammaire Générale et Raisonnée de Port-Royal. Paris: de l'imprimerie de Munier.

AZEVEDO FILHO, Leodegário de. 2002. “Os estudos filológicos e linguísticos no Brasil - uma tentativa de periodização" In: Anais do Congresso Internacional de Lexicografia e Literaturas do mundo lusófono. Rio de Janeiro: Editora Ágora da Ilha.

AUROUX, Sylvain. 2009[1992]. A Revolução Tecnológica da Gramatização. 2a ed. [tradução do francês de Eni Puccinelli Orlandi]. São Paulo: Editora Unicamp. 
BEAUZÉE, Nicolas. 1767. Grammaire Générale ou Exposition raisonnée des éléments nécessaires du langage, pour servir de fondement à l'étude de toutes les langues. Tome Premier. Paris: J. Barbou.

BARROS, João de. 1540. Grammatica da lingua portugueza. Olyssipone: apud Lodouicum Rotorigiu[m], Typographum.

BARROS, José D’Assunção. 2004. Os Campos da História - uma introdução às especialidades da História. Revista HISTEDBR On-line. Campinas, n.16, p. 17 -35, dez. 2004 - ISSN: 1676-2584

BATTISTA, Emiliano. 2011. La Gramática castellana (1914) de Manuel de Montolíu. Un análisis de sus concepciones gramaticales y lingüísticas. RAHL, n. III, v. 1 pp. 1-28.

BECCARI, Alessandro J. 2013. "Uma tradução da Grammatica Speculativa, de Tomás de Erfurt, para o português: acompanhada de um estudo introdutório, notas e glossário. Tese de Doutorado. UFPR.

BECKER, Karl Ferdinand. 1845[1830]. A Grammar of the German Language. Second Edition: greatly improved. [Ed. by Bernhard Becker] London: Longman, Brown, Green, and Longmans.

BENVENISTE, Émile. 2005. “Categorias de pensamento e categorias de língua” In: Problemas de Linguística Geral. Campinas: Pontes.

BLOOMFIELD, Leonard. 1966[1933]. Language. New York: Holt, Rinehart and Wilson.

BORGES NETO, José. 2012. "Gramática Tradicional e Linguística Contemporânea: continuidade ou ruptura?” Todas as Letras - Revista de Língua e Literatura, v. 14, n.1.

BOUARD, Bérengère. 2007. "Structure de la proposition et construction verbale: régime, complément et transitivité dans les grammaires françaises 1651-1863". Thèse de Doctorat. Université Paris Diderot (Paris 7).

BURGRAFF, Pierre. 1863. Principes de grammaire générale, ou, Exposition raisonnée des éléments du langage. Liége: Imprimerie de H. Dessain.

BURKE, Peter. 1992. A escrita da história: novas perspectivas. São Paulo: Editora UNESP.

CAVALIERE, Ricardo. 2001. "Uma proposta de periodização dos estudos linguísticos no Brasil”. Alfa. v. 45. p. 49-69.

CASTILHO, Ataliba, T. de. 1962. Estudos Linguísticos no Brasil. Alfa 2. pp. 135-143.

CHAPANSKI, Gissele. 2003. Uma tradução da Tékhne Grammatiké, de Dionisio Trácio, para o português. Dissertação de Mestrado. Universidade Federal do Paraná. Curitiba.

CHEVALIER, Jean-Claude. Histoire de la syntaxe: naissance de la notion de complément dans la grammaire française (1530-1750). Genève : Librairie Droz, 1968. 
COELHO, Olga et al. 2010. Documenta Grammaticae et Historiae: projeto de documentação linguística e historiográfica do Português (séculos XVI-XIX). São Paulo, CEDOCH - DL - USP.

COELHO, Olga; DANNA, Stela M. D. G.; POLACHINI, Bruna S. 2013. Confluência: Revista do Instituto de Língua Portuguesa. "O português do Brasil em gramáticas brasileiras do século XIX.” n.43, v.46. Instituto de Língua Portuguesa do Liceu Literário Português, 2013.

COELHO, Olga; DANNA, Stela M. D. G. 2015. Confluência: Revista do Instituto de Língua Portuguesa. "História da língua portuguesa e historiografia linguística no Brasil em cinco gramáticas do século XIX”. 2015. N. 49. P. 215-245.

COLOMBAT, Bernard. 1992. "L'adjectif: perspectives historique et typologique" In: Histoire Épistémologia Langage. 1992. n. 14. v. 1, p. 5-23.

COXITO, Amândio A. 1981. Lógica, semântica e conhecimento: na escolástica peninsular pré-renascentista. Coimbra: Biblioteca Geral da Universidade.

ELIA, Silvio. 1975. "Os Estudos Filológicos no Brasil” In: Ensaios de Filologia e Linguística. Rio de Janeiro: Grifo. $2^{\mathrm{a}}$ ed. pp. 117-176. 1975.

FÁVERO, Leonor L.; MOLINA, Márcia. A. G. 2006. As Concepções Linguísticas no Século XIX: A gramática no Brasil. Rio de Janeiro: Editora Lucerna.

FOUCAULT, Michel. 2007. As palavras e as coisas: uma arqueologia das ciências humanas. São Paulo: Martins Fontes.

FURET, François. 1991. A Oficina da História. Lisboa: Gradiva. v. I.

GARCÍA, Ventura S. 2004. "El tratamiento de la cópula verbal em la historia del pensamiento lingüístico". Estudios de Lingüística: el verbo. p. 529-557.

GRAFFI, Giorgio. 2001. 200 years of syntax: a critical survey. Studies in the History of the Language Sciences 98. Amsterdam: John Benjamins.

HALLEWELL, Laurence. 2009. O Livro no Brasil: sua história. $2^{\mathrm{a}}$ edição revista e ampliada. São Paulo: Edusp.

HARRIS, James. 1806[1751]. Hermes or A Philosophical inqviry concerning vniversal grammar. The sixth edition. London: Printed for F. Wingrave.

HJELMSLEV, Louis. 2003. Prolegômenos a uma teoria da linguagem. São Paulo: Perspectiva.

HYMES, Dell H. 1983. "Traditions and Paradigms" In: Essays in the history of linguistic anthropology. Amsterdam/Philadelphia: John Benjamins Publishing Company.

ITKONEN, Esa. 1991. Universal history of linguistics: India, China, Arabia, Europe. Amsterdam: John Benjamins.

KEMMLER, Rolf. 2013. "A primeira gramática da língua portuguesa impressa no Brasil: a Arte de grammatica portugueza (1816) de Inácio Felizardo Fortes." Revista Confluência, n. 45, p. 61-82. 
KOERNER, Konrad. 1989a. "Models in Linguistic Historiography" In: 1989. Practicing Linguistic Historiography. Amsterdam/Philadelphia: John Benjamins Publishing Company. p.47-59.

KOERNER, Konrad. 1989b. "On the problem of "influence"” In: Practicing Linguistic Historiography. Series III - Studies in the history of the language sciences, v. 50. Amsterdam/Philadelphia: John Benjamins Publishing Company.

KOERNER, Konrad. 2014. "Questões que persistem na historiografia linguística” In: Quatro décadas de historiografia linguística: estudos selecionados Seleção e edição de textos de Rolf Kemmler e Cristina Altman. Coleção e Linguística 11 - Centro de Estudos em Letras, Universidade de Trás-os-montes e Alto Douro. Vila Real: MMXIV.

KUHN, Thomas S. 2009[1962]. A Estrutura das Revoluções Científicas. Editora Perspectiva, São Paulo.

LAUWERS, Peter. 2004. La description du français entre la tradition grammaticale et la modernite linguistique: étude historiographique et épistémologique de la grammaire française entre 1907 et 1948. Serie Orbis Supplementa v. 24. Leuven: Peeters.

LEROY, Maurice. 1977. As grandes correntes da linguística moderna. São Paulo: Cultrix.

MACIEL, Maximino. 1918[1910]. "Breve retrospecto sobre o ensino da língua portuguesa" In: .1918. Grammatica Descriptiva baseada nas doutrinas modernas. Rio de Janeiro: Francisco Alves. $7^{\mathrm{a}}$ ed.

MAGALHÃES, Pablo Antonio Iglesias. 2013. "A Palavra e o Império: Manoel de Freitas Brazileiro e a Nova Grammatica Ingleza e Portugueza". CLIO - Revista de Pesquisa Histórica. n. 31, v. 1.

MASON, Charles P. 1858. English Grammar - including the principles of grammatical analysis. Eighteenth Edition (revises and enlarged). London: Bell \& Daldy, York Street, Covent Garden.

MATTOSO CÂMARA, Joaquim. 1975. História da linguística. Petrópolis: Editora Vozes.

MORAES, Jorge Viana de. Arte de grammatica portugueza (1816) de Ignacio Felizardo Fortes: a construção teórica sobre as figuras de sintaxe $e$ as figuras de dicção. Cadernos de Pós-graduação em Letras do Mackenzie, 2015, volume 15, n¹, pp. 188-206.

MOUNIN, Georges. 1967. Histoire de la linguistique: des origines au XXe siècle. Paris: PUF.

MURAKAWA, Clotilde de A. A. 2006. António de Morais Silva: lexicógrafo de língua portuguesa. Araraquara, SP: Laboratório Editorial da FCL, UNESP: Cultura Acadêmica Editora.

MURRAY, Stephen O. 1994. "Chapter 1:Theory Groups in Science” In: Theory groups and the study of language in North America: a social history. (Studies in the history of the language sciences, 69.) Amsterdam: Benjamins. p. 1-26. 
NASCENTES, Antenor. “A filologia portuguesa no Brasil (esboço histórico)” In: Estudos Filologicos. Rio de Janeiro: Civilização Brasileira. p. 21-45. 1939.

NEBRIJA, Antonio. 1492. Grammatica de la lengua catellana.

NOGUEIRA, Sonia Maria. 2009. "Estudos Historiográficos e o Ensino de Língua Portuguesa." do CNLF, Vol. XIII, No 04.

OBREGÓN, Diana. 2002. "La construcción social del conocimiento: los casos de Kuhn y de Fleck" Revista Colombiana de Filosofia de la Ciencia, año/vol.3, número 6-7. Universidad El Bosque, Bogotá, Colombia, pp.41-68.

OLIVEIRA, Fernão. 1536. Grammatica da lingoagem portuguesa. Lixboa : e[m] casa d'Germão Galharde

PARREIRA, Andressa D. Contribución a la historia de la gramática brasileña del siglo XIX. Tesis Doctoral. Universidad de Salamanca. Faculdade de Filología. Julio de 2011.

PERCIVAL, Keith. 1976. "The applicability of Kuhn's Paradigms to the History of Linguistics". Language, Vol. 52, No. 2. p. 285-294.

PESSOA SANTOS, Maria Helena. 2010. As ideias linguística portuguesas na centúria de oitocentos. Fundação Calouste Gulbenkian: Fundação para a Ciência e Tecnologia, Ministério da Ciência, Tecnologia e Ensino Superior.

POLACHINI, Bruna S. 2013. "O tratamento da sintaxe em gramáticas brasileiras do português do século XIX: estudo historiográfico" Dissertação de Mestrado. FFLCH/USP. 2013.

POLACHINI, Bruna S. et al (Orgs.). 2015. Cadernos de Historiografia Linguística do $C E D O C H$ - vol. 1. São Paulo : FFLCH.

POLACHINI, Bruna S. 2016. "Difficulties in dealing with continuities and discontinuities in 19th-century Brazilian grammar's treatment of syntax: a 'complex' periodization”. In: ASSUNÇÃ̃, Carlos; FERNANDES; Gonçalo; KEMMLER, Rolf (Orgs.). Tradition and Innovation in the History of Linguistics. Münster: Nodus Publikationen. p.286-295

POLACHINI, Bruna S. ; DANNA, Stela M. G. D. 2016. "Dados sintáticos do português brasileiro em gramáticas brasileiras oitocentistas". Revista Estudos Linguísticos, São Paulo, n. 45, v.1, p. 192-202, 2016.

RABY, Valérie. 2000. "La proposition dans la grammaire generale francaise (16601803)" Thèse de Doctorat. Université Paris Diderot (Paris 7).

RAZZINI, Marcia de P. G. 2000. "O Espelho da nação: a antologia nacional e o ensino de português e de literatura (1838-1971)" Tese de Doutorado. UNICAMP, Intituto de Estudos da Linguagem.

REIS, José C. 2000. "Anos 1850: Varnhagen - O elogio da colonização portuguesa" In: . As identidades do Brasil: de Varnhagen a FHC. Rio de Janeiro: Fundação Getúlio Vargas Editora. p.23-50. 
REIS LOBATO, António José dos. 1770. Arte da grammatica da lingua portugueza. Lisboa: Na Regia Officina Typografica.

RIBEIRO, Julio. 2007. Cartas Sertanejas; Procellarias. São Paulo: Fundap / Imprensa Oficial.

ROBINS, Robert Henry. 1967. A short history of linguistics. London: Longmans.

ROBOREDO, Amaro. 1619. Methodo grammatical para todas as linguas. Salamanca. Edição de Marina A. Kossarik. Lisboa: Imprensa Nacional - Casa da Moeda.

ROSIELLO, Luigi. 1967. Linguistica Illuminista. Bologna: Il Mulino. 1967.

SACRAMENTO BLAKE, Augusto V. A. 1883. Diccionario Bibliographico Brazileiro. Primeiro volume. Rio de Janeiro: Typographia Nacional.

SACRAMENTO BLAKE, Augusto V. A. 1893. Diccionario Bibliographico Brazileiro. Segundo volume. Rio de Janeiro: Typographia Nacional.

SACRAMENTO BLAKE, Augusto V. A. 1895. Diccionario Bibliographico Brazileiro. Terceiro volume. Rio de Janeiro: Typographia Nacional.

SACRAMENTO BLAKE, Augusto V. A. 1898. Diccionario Bibliographico Brazileiro. Quarto volume. Rio de Janeiro: Typographia Nacional.

SACRAMENTO BLAKE, Augusto V. A. 1898. Diccionario Bibliographico Brazileiro. Quinto volume. Rio de Janeiro: Typographia Nacional.

SACRAMENTO BLAKE, Augusto V. A. 1899. Diccionario Bibliographico Brazileiro. Quinto volume. Rio de Janeiro: Typographia Nacional.

SACRAMENTO BLAKE, Augusto V. A. 1900. Diccionario Bibliographico Brazileiro. Sexto volume. Rio de Janeiro: Typographia Nacional.

SACRAMENTO BLAKE, Augusto V. A. 1902. Diccionario Bibliographico Brazileiro. Sétimo volume. Rio de Janeiro: Typographia Nacional.

SANCTIUS, Franciscus. 1587 Minerva sive de causis linguae latinae. Salamanca: Renaut.

SCHÄFER-PRIE $\boldsymbol{\beta}$, Barbara. 2002. "Entre a gramática filosófica e a linguística históricocomparativa: Francisco Solano Constâncio e sua Grammatica analytica da lingua portugueza de 1831" In:___ ; Rolf Kemmler \& Schönberger (eds.). 2002. Estudos de história da gramaticografia e lexicologia portuguesas. Frankfurt am Main: Domus Editoria Europaea.

SOARES BARBOSA, Jerônimo. Grammatica Philosophica da Lingua Portugueza ou principios da grammatica geral applicados á nossa linguagem. Lisboa: Typographia da Academia de Sciencias. 1822.

SILVA, Maria Beatriz Nizza da. S.D. Teoria da história. São Paulo: Cultrix.

SILVA, 2011. Maria Beatriz Nizza da. "Reflexões sobre a ciência histórica". Estado de São Paulo, 12/02/2011. Disponível em 
http://cultura.estadao.com.br/noticias/geral,reflexoes-sobre-a-ciencia-historica-imp, 678502 (Acessado em 08/2016)

SWIGGERS P.; DESMET P., JOOKEN L. 1996. "Metahistoriography meets (linguistic) historiography." In Schmitter, P. (Ed.), Van derWal, M. (Ed.), Metahistoriography: theoretical and methodological aspects in the historiography of linguistics. Special Conference on metahistoriography. Noordwijk, 11-12 April 1996 (pp. 2959). Münster: Nodus.

SWIGGERS, Pierre. 1990. Reflections on (models for) Linguistic Historiography. In: Hüllen (Ed. 1990) p. 21-34.

SWIGGERS, Pierre. 1997. Histoire de la pensée linguistique - analyse du langage et réflexion linguistique dans la culture occidentale, de l'Antiquité au XIX $X^{e}$ siècle. Paris : Presses Universitaires de France.

SWIGGERS, Pierre. 2004. "Modelos, Métodos y Problemas en la historiografía de la linguística". Nuevas Aportaciones a la historiografía lingüistica. Actas del IV Congresso Internacional de la SEHL. La Laguna (Tenerife), 22 al 25 de octubre de 2003. p.113-146.

SWIGGERS, Pierre. 2009. La historiografía de la lingüística: apuntes y reflexiones. Revista Argentina de Historiografia Lingüística, 1, 67-76.

SWIGGERS, Pierre. 2010a. "Le métalangage de la linguistique: reflexions à propos de la terminologie e de la terminographie linguistiques". Revista do GEL. v. 7, n. 2, p. 9-29.

SWIGGERS, Pierre. 2010b. "História e Historiografia de Linguística : Status, Modelo e Classificações" [trad. de Cristina Altman]. Eutomia. p.1-17.

SWIGGERS, Pierre. 2013. "A Historiografia da Linguística: Objeto, Objetivos, Organização" [trad. de Ricardo Cavaliere]. Revista Confluência. n.44/45. p. 39-50.

VAQUERA, María Luisa. 1986. Hitoria de la gramática española (1847-1920: de A. Bello a R. Lenz. Madrid: Gredos.

VIDAL NETO, José Bento Cardoso. 2008. A Grammatica portugueza, de Júlio Ribeiro: um corte epitemológico na gramaticografia brasileira e a questão da língua portuguesa no Brasil. Tese de Mestrado. FFLCH/USP, São Paulo.

VIVEIROS, Jerônimo de. S.D. Apontamentos para a História da Instrução Pública e Particular do Maranhão. Disponível em < http://www.cultura.ma.gov.br/portal/bpbl/acervodigital/ > (Acesso em 02/2017).

WHITNEY. William D. 1879[1877]. "Chapter I. Introductory: language and grammar" In: ___ Essentials of English Grammar: for the use of schools. Boston: Ginn and Heath. p. 1-5 


\section{APÊNDICE A | Referência completa das gramáticas}

\section{Referência completa das gramáticas encontradas em ordem cronológica ${ }^{132}$}

Os números nos nomes das gramáticas servem como índices para que se possa consultar sua referência completa sempre que for necessário. As categorias da referência completa são:

Ano de publicação. SOBRENOME, Nome do autor (Biodatas). Título e subtítulo da obra [sigla de tipo de título] [público-alvo/dedicatória-sigla]. Número da edição [tipo de edição, ver também [número de outras edições]]. Local de publicação: casa impressora. Número de páginas. - Citação e comentários em fontes secundárias: Sacramento Blake (1883:XX) [comentário]; Caveliere (2001:XX); Parreira (2011:XX).

Quando não tivemos acesso a algum(ns) dos itens da referência completa, este(s) será(ão) substituído(s) por hífen(s): -.

\section{0}

[1]. 1806. MORAIS SILVA, Antonio de (1757 Rio de Janeiro - 1824 Pernambuco). Epitome da grammatica portuguesa [Xgp] [-]. $1^{\mathrm{a}}$ edição [Edição mais antiga conhecida, ver também [3] [12]]. Lisboa: Off. de Simão Thaddeo Ferreira. 165p. Sacramento Blake (1883); Nascentes (1939); Cavaliere (2001); Azevedo Filho (2002); Parreira (2011); Polachini (2013).

\section{0}

[2]. 1810. FORTES, Padre Inácio Felizardo Fortes (último quartel do século XVIII 1856 Cabo Frio). Arte da grammatica portugueza, para uso dos seus discipulos [Xgp] [Alunos-A]. $1^{a}$ edição [Edição mais antiga conhecida, ver também [4] [7] [23] [31] [36] [53]]. Rio de Janeiro: Imp. Régia. -p. - Sacramento Blake (1895); Kemmler (2012).

[3]. 1813. MORAIS SILVA, Antonio de (1757 Rio de Janeiro - 1824 Pernambuco). Epitome da grammatica portuguesa [Xgp] [-] In Diccionario da Lingua Portugueza. $2^{\mathrm{a}}$ edição [edição posterior, ver também [1] [12]]. Lisboa: Typographia Lacerdena. 48p. - Sacramento Blake (1883).

[4]. 1816. FORTES, Padre Inácio Felizardo Fortes (último quartel do século XVIII 1856 Cabo Frio). Arte da grammatica portugueza, para uso dos seus discipulos [Xgp] [Alunos-A]. 2a edição [edição posterior, ver também [2] [7] [23] [31] [36] [53]]. Rio de Janeiro: Imp. Régia. -p. - Sacramento Blake (1895); Kemmler (2012).

[5]. 1823. TILBURY, Guilherme Paulo (? Inglaterra - 1862 Rio de Janeiro). Breve explicação sobre a grammatica, contendo quanto basta e o que é de absoluta necessidade saber da grammatica portugueza para aprender qualquer outra

\footnotetext{
${ }^{132}$ Quando duas gramáticas haviam sido publicadas no mesmo ano, organizamos de acordo com a ordem alfabética dos sobrenomes dos autores.
} 
lingua. [Xgpx] [-]. -ed. [Única edição conhecida]. Rio de Janeiro: -. -p. Sacramento Blake (1895).

\section{0}

[6]. 1824. MORAIS SILVA, Antonio de (1757 Rio de Janeiro - 1824 Pernambuco). Grammatica Portugueza [Gp] [-]. $1^{\mathrm{a}}$ ed. [Única edição conhecida]. Rio de Janeiro: Typographia de Silva Porto, e Comp. Xp. 91p. - Sacramento Blake (1883)

[7]. 1825. FORTES, Padre Inácio Felizardo Fortes (último quartel do século XVIII 1856 Cabo Frio). Arte da grammatica portugueza, para uso dos seus discipulos [Xgp] [Alunos-A]. $3^{\mathrm{a}}$ edição "mais correcta e augmentada". [edição posterior modificada, ver também [2] [4] [23] [31] [36] [53]]. Rio de Janeiro: -. -p. Sacramento Blake (1895);

[8]. 1828. ALENCASTRO. José Joaquim (?-?). Resumo das quatro partes da grammatica portugueza [Xgp] [-]. -ed. [Única edição conhecida]. Rio de Janeiro:-, -p. - Sem menção em fontes secundárias, localizada em catálogos de bibliotecas.

[9]. 1828. LOUREIRO, Lourenço Trido (1793 Portugal - 1870 Pernambuco). Grammatica razoavel da lingua portugueza, composta segundo a melhor doutrina dos grammaticos antigos e modernos de differentes idiomas [Gxlpx] [-]. -ed. [Única edição conhecida]. Rio de Janeiro: Typ. Imp. e Nac., XXXIX-362p. Sacramento Blake (1899)

[10]. 1829. COSTA DUARTE. Pa. Antonio da (17??-?). Compendio de grammatica portugueza para uso das escolas de primeiras letras, ordenado segundo a doutrina dos melhores grammaticos, offerecido ao illmo. e exmo. Senhor Cândido José de Araújo Vianna, presidente da provincia do Maranhão, deputado ás cortes legislativas, etc [Xgp] [Instrução Primária, Pessoa (dedicatória) - BI]. $1^{\text {a }}$ edição [Edição mais antiga conhecida, ver também [19] [33] [44] [51] [105]]. Maranhão: Tipografia Nacional. 98p. - Parreira (2011); Polachini (2013).

\section{0}

[11]. 1832. CÉSAR. Casimiro Ferreira (?-?). Manual pratico ou methodo resumido do ensino, recopilado dos mais adoptados e mais próprios para as aulas da lingua nacional do Brazil [Xln] [Alunos, Nacional - AF]. - ed. [Única edição conhecida]. Bahia: -. - p. - Sacramento Blake (1893).

[12]. 1832. MORAIS SILVA, Antonio de (1757 Rio de Janeiro - 1824 Pernambuco). Epitome da grammatica portuguesa agora mais resumido, e em fórma de dialogo, para uso de meninos. [Xgpx] [Alunos-A]. -ed. [Edição posterior com título modificado]. Porto Alegre: C. Dubreuil. 91p. - Sem menção em fontes secundárias, localizada em catálogos de bibliotecas.

[13]. 1833. PAZ, João Alexandre da Silva (Rio de Janeiro ? - ?). Grammatica elementar e methodica da lingua portugueza, composta e oferecida á mocidade fluminense [Gxlp] [Alunos, Regional - AE]. -ed. [Edição mais antiga conhecida, ver também [18]]. Rio de Janeiro:-. 163p. - Sacramento Blake (1895)

[14]. 1834. CÉSAR. Casimiro Ferreira (?-?). Grammatica Portugueza dada pela terceira vez á luz por C. F. César [Gp] [-]. 3ed. [Única edição conhecida]. Bahia:. - p. - Sacramento Blake (1893)

[15]. 1834. LOPES, Isidoro José (Rio Grande do Sul ? - ?). Compendio de grammatica da lingua portugueza ordenado segundo a doutrina dos melhores grammaticos [Xglpx] [-]. -ed. [Única edição conhecida]. Rio Grande:- . -p. - Sacramento Blake (1899). 
[16]. 1835. CORUJA, Antonio Alvares Pereira. (1806 Porto Alegre - 1889 Rio de Janeiro). Compendio da grammatica da lingua nacional, dedicado á mocidade riograndense [Xgln] [Alunos, Regional - $\mathrm{AE}$ ]. $1^{\mathrm{a}}$ ed. [Edição mais antiga conhecida, ver também [26] [27] [29] [52] [69] [87] [92] [172]]. Porto Alegre: V. F. de Andrade. 68p. - Sacramento Blake (1883); Nascentes (1939); Castilho (1962); Cavaliere (2001); Azevedo Filho (2002); Parreira (2011); Polachini (2013).

[17]. 1835. SOARES, Francisco José das Chagas (Rio de Janeiro ? - ?). Arte da Grammatica portugueza, composta e offerecida à Sociedade Promotora da Instrucção, na corte do Brazil. [Xgp] [Institucional - G]. -ed. [Única edição conhecida]. Rio de Janeiro:-. 112p. - Sacramento Blake (1895)

[18]. 1836. PAZ, João Alexandre da Silva (Rio de Janeiro ? - ?). Grammatica elementar e methodica da lingua portugueza [Gxlp] [-]. -ed. [edição posterior, ver também [13]]. Rio de Janeiro:-. -p. - Sem menção em fontes secundárias, localizada em catálogos de bibliotecas.

\section{0}

[19]. 1840. COSTA DUARTE. Pa. Antonio da (17??-?). Compendio de grammatica philosophica da lingua portugueza, escolhido pela congregação do Lyceu do Maranhão para uso do mesmo Lyceu. etc. [Xgxlp] [Regional, Institucional - EG]. $2^{\mathrm{a}}$ ed, segunda edição acrescentada. [Edição posterior com título modificado, ver também [10] [33] [44] [51] [105]]. Maranhão:-. p. -. Nascentes (1939), Castilho (1962), Azevedo Filho (2002).

[20]. 1841. ALBUQUERQUE, Salvador Henrique (1813 Paraíba - 1880 Pernambuco). Breve Compendio da Grammatica Portugueza [Xgp] [-]. -ed. [Edição mais antiga conhecida, ver também [21]]. Recife: Tip. do Santos. -p. - Sem menção em fontes secundárias, localizada em catálogos de bibliotecas.

[21]. 1844. ALBUQUERQUE, Salvador Henrique (1813 Paraíba - 1880 Pernambuco). Breve Compendio da Grammatica Portugueza [Xgp] [-]. -ed. [edição posterior, ver também [20]]. Recife: Tip. do Santos. -p. - Parreira (2011); Polachini (2013).

[22]. 1844. CORDEIRO, I. J. (? - ?). Nova grammatica de lingua portugueza [nGlp] []. -ed. [Única edição conhecida]. Rio de Janeiro: Col. B. Ottoni. -p. - Sem menção em fontes secundárias, localizada em catálogos de bibliotecas.

[23]. 1844. FORTES, Padre Inácio Felizardo Fortes (último quartel do século XVIII 1856 Cabo Frio). Arte da grammatica portugueza, para uso dos seus discipulos [Xgp] [Alunos-A]. 9a edição "mais correcta e augmentada" [edição posterior modificada ver também [2] [4] [7] [31] [36] [53]].]. Rio de Janeiro: -. -p Sacramento Blake (1895);

[24]. 1845. LOPES, Guilherme Antonio (? - ?). Lingua Portugueza. Resumo explicativo de grammatica portugueza para uso das escolas de instrucção primaria [Xgp] [Instrução Primária - B]. -ed. [Única edição conhecida]. Rio de Janeiro: Typ. do G. Globo. -p. - Sem menção em fontes secundárias, localizada em catálogos de bibliotecas.

[25]. 1846. ALBUQUERQUE, Salvador Henrique (1813 Paraíba - 1880 Pernambuco). Compendio de grammatica portugueza, extrahido de diversos autores e offerecido a seus alumnos [Xgpx] [Alunos]. $6^{\mathrm{a}}$ ed. [Edição mais antiga conhecida, ver também [42] [94]]. Pernambuco:-. 117p. - Sacramento Blake (1902)

[26]. 1846. CORUJA, Antonio Alvares Pereira. (1806 Porto Alegre - 1889 Rio de Janeiro). Compendio da grammatica da lingua nacional, dedicado á mocidade riograndense [Xgln] [Alunos, Regional - $\mathrm{AE}$ ]. 4a ed. "ampliada e mais correcta" 
[edição posterior modificada, ver também [16] [27] [29] [52] [69] [87] [92] [172]]. Rio de Janeiro: Tip. Francesa. 72p. - Sem menção em fontes secundárias, localizada em catálogos de bibliotecas.

[27]. 1847. CORUJA, Antonio Alvares Pereira. (1806 Porto Alegre - 1889 Rio de Janeiro). Compendio da grammatica da lingua nacional, dedicado á mocidade riograndense [Xgln] [Alunos, Regional - AE]. $5^{\mathrm{a}}$ ed. "ampliada, e mais correcta" [edição posterior modificada, ver também [16] [26] [29] [52] [69] [87] [92] [172]]. Rio de Janeiro: Tip. Francesa. -p. - Sem menção em fontes secundárias, localizada em catálogos de bibliotecas.

[28]. 1848. PASSOS, José Alexandre (1808 Alagoas - 1878 Alagoas). Compendio da grammatica portugueza pelo methodo analytico, recopilado especialmente das grammaticas de Moraes e Constancio, e accommodado á intelligencia dos meninos; dedicado á mocidade brazileira [Xgpx] [Alunos, Nacional - AF]. -ed. [Única edição conhecida]. Rio de Janeiro: Tip. De M. A. Silva Lima. 117p. Sacramento Blake (1906); Parreira (2011); Polachini (2013).

[29]. 1849. CORUJA, Antonio Alvares Pereira. (1806 Porto Alegre - 1889 Rio de Janeiro). Compendio da grammatica da lingua nacional, dedicado á mocidade riograndense [Xgln] [Alunos, Regional - AE]. 5 $5^{\text {a }}$ ed. [edição posterior, ver também [16] [26] [27] [52] [69] [87] [92] [172]]]. Rio de Janeiro:-. -p. Sacramento Blake (1883)

\section{0}

[30]. 1850. CONDURÚ, Fillippe Benicio de Oliveira Condurú (? - ?). Grammatica Elementar da Lingua Portugueza [Gxlp] [-]. $1^{\mathrm{a}}$ ed. [Edição mais antiga conhecida, ver também [157]]. -:-. p. - Nogueira (2009)

[31]. 1851. FORTES, Padre Inácio Felizardo Fortes (último quartel do século XVIII 1856 Cabo Frio). Arte da grammatica portugueza, para uso dos seus discipulos [Xgp] [Alunos-A]. 12a edição [edição posterior, ver também [2] [4] [7] [23] [36] [53]]. Rio de Janeiro: -. - p. - Sacramento Blake (1895);

[32]. 1851. SUSANO, Luís da Silva Alves de Azambuja (1791 Rio de Janeiro - 1873 Espírito Santo). Compendio da grammatica portugueza para uso das escholas primarias. Escripto. etc.[Xgp] [Instrução Primária - B]. -ed. [Única edição Conhecida]. Rio de Janeiro: Tip. de Laemmert. 54p. - Sacramento Blake (1899)

[33]. 1853. COSTA DUARTE. Pa. Antonio da (17??-?). Compendio da grammatica philosophica da lingua portugueza Escolhida pela Congregação do Lycêo do Maranhão para o uso do mesmo Lycêo, e das aulas de primeiras lettras da provincia. [Xgxlp] [Institucional, Instrução Primária, Regional - BEG]. $3^{\mathrm{a}}$ ed [edição posterior, ver também [10] [19] [44] [51] [105]]. Maranhão: Livraria do Editor F. Fructuoso Ferreira. 170p. - Sem menção em fontes secundárias, localizada em catálogos de bibliotecas.

[34]. 1853. CRUZ, Policarpo José Dias (? Rio de Janeiro - 1865 Rio de Janeiro). Compendio de grammatica portugueza [Xgp] [-]. -ed. [Edição mais antiga conhecida, ver também [62] [70] [110]]. Rio de Janeiro:-. -p. - Sem menção em fontes secundárias, localizada em catálogos de bibliotecas.

[35]. 1854. CAJA, Jose Ferreira Santos (Bahia ? - ?). Compendio da grammatica portugueza, resumido para uso das escolas de primeiras lettras, extraido dos autores de melhor nota e mais seguidos neste imperio do Brazil e reino de Portugal [Xgpx] [Instrução Primária - B]. 2a ed. [Única edição conhecida]. Salvador: A. J. N. Bandeira. -p. - Sacramento Blake (1898). 
[36]. 1855. FORTES, Padre Inácio Felizardo Fortes (último quartel do século XVIII 1856 Cabo Frio). Arte da grammatica portugueza, para uso dos seus discipulos [Xgp] [Alunos-A]. 13 edição [edição posterior, ver também [2] [4] [7] [23] [31] [53]]. Rio de Janeiro: -. - p. - Sacramento Blake (1895);

[37]. 1855. PASSOS, José Alexandre (1808 Alagoas - 1878 Alagoas). Resumo da grammatica portugueza para uso das escolas de primeiras lettras [Xgp] [Instrução Primária - B]. 2a ed. [Edição mais antiga conhecida, ver também [64] [84]]. Rio de Janeiro: Typ. do Commercio de Brito \& Braga. -p. - Nascentes (1939); Castilho (1962); Azevedo Filho (2002).

[38]. 1855. SILVEIRA, Cyrillo Dillermando da. (Ceará ? - Rio de Janeiro ?). Compendio de grammatica da lingua portugueza: obra adoptada pelo conselho de instrucção publica [Xglp] [Institucional - G]. -ed. [Edição mais antiga conhecida, ver também [58] [89] [138]]. Rio de Janeiro:-. 128p. - Sacramento Blake (1893)

[39]. 1856. ANDRADE, Joao Nunes de (1800 Beira (Portugal) - 1861 Rio de Janeiro Foi para RJ em 1843). Novo compêndio de eloqüencia grammatical da lingua portugueza por systema philosophico [nXglp] [-]. -ed. [Única edição conhecida]. Rio de Janeiro:-. -p. - Sacramento Blake (1898)

[40]. 1857. GRAÇA, Manoel Fernandes da Cunha. (1824 Portugal - ? Brasil). Elementos de grammatica portugueza, colligidos para uso de seus alumnos [Xgp] [Alunos - A]. -ed. [Única edição conhecida]. Rio de Janeiro:-. p. - Sacramento Blake (1900)

[41]. 1858. ALBERTO JUNIOR, Philippe Jose (? - ?). Grammatica ecleticorudimentaria da lingua portugueza [Gxlp] [-]. 5 $5^{\text {a }}$ ed. [Edição mais antiga conhecida, ver também [146]]. Bahia:-. -p. - Sem menção em fontes secundárias, localizada em catálogos de bibliotecas.

[42]. 1858. ALBUQUERQUE, Salvador Henrique (1813 Paraíba - 1880 Pernambuco). Compendio da grammatica portugueza [Xgp] [-]. -ed. [edição posterior, ver também ver também [20] [94]]. Recife: Tip. Universal. 143p. - Sem menção em fontes secundárias, localizada em catálogos de bibliotecas.

[43]. 1859. ALBERTO JUNIOR, Philippe Jose (? - ?). Grammatica da lingua portugueza [Glp] [-]. -ed. [Única edição conhecida]. Rio de Janeiro: Moderna. -p. - Sem menção em fontes secundárias, localizada em catálogos de bibliotecas.

[44]. 1859. COSTA DUARTE. Pa. Antonio da (17??-?). Compendio da grammatica philosophica da lingua portugueza Escolhida pela Congregação do Lycêo do Maranhão para o uso do mesmo Lycêo, e das aulas de primeiras lettras da provincia. [Xgxlp] [Institucional, Instrução Primária, Regional - BEG]. $5^{\mathrm{a}}$ ed, [edição posterior, ver também [10] [19] [33] [51] [105]] Maranhão: Tipografia do Frias. 121p. - Sem menção em fontes secundárias, localizada em catálogos de bibliotecas.

[45]. 1859. CRUZ, Policarpo José Dias (? Rio de Janeiro - 1865 Rio de Janeiro). Postillas de grammatica portugueza [Xgp] [-]. -ed. [Única edição conhecida] Rio de Janeiro:-. -p. - Sacramento Blake (1902)

\section{0}

[46]. 1860. BARKER, Antonio Maria (1792 Porto - 1853 Brasil [veio ao Brasil em 1810]). Grammatica da lingua portugueza em forma de dialogo, que para intelligencia da orthographia contem o que é absolutamente indipensavel, etc. [Glpx] [-]. $8^{\mathrm{a}}$ ed. [Única edição conhecida]. Rio de Janeiro:-. 59p. - Sacramento Blake (1883) 
[47]. 1860. BORGES, Abílio César (1824 Bahia - ?). Grammatica da lingua portugueza [Glp] [-]. $6^{\mathrm{a}}$ ed. [Edição posterior com título modificado, ver também [104] [206]]. -:- . -p. - Sacramento Blake (1883:3) ["A Grammatica da lingua portugueza, publicada com o titulo de « Epitome da grammatica portugueza » (ver [206]) até á quinta edição, foi publicada em edição posterior, dando-lhe o autor novo plano e desenvolvimento, do modo que se pôde considerar um trabalho inteiramente novo, como elle diz, mas com mudança de titulo, que se conserva na ultima edição, que é: - Resumo da grammatica portugueza. 7a edição, augmentada e melhorada segundo os grammaticos mais modernos, adoptada em varias escolas publicas do império do Brazil. Bruxellas, 1877 - Nesta edição foi o livro expurgado de alguns erros que ainda na anterior existiam."]

[48]. 1860. RUBIM, Joaquim Frederico Kiappe da Costa (1831 Porto - 1866 Corrientes (Argentina), naturalizado brasileiro). Novo methodo da grammatica portugueza composto em verso rimado, approvado e adoptado para as aulas da provincia do Ceará e pelo Conselho director da instrucção publica da mesma provincia [nXgp] [Regional, Institucional - EG]. -ed. [Edição mais antiga conhecida, ver também [56] [119]]. Rio de Janeiro:- 219p. - Sacramento Blake (1898)

[49]. 1861. BEZERRA, Manuel Soares da Silva (1810 Ceará - 1888 Fortaleza). Compendio da grammatica philosophica do lyceu provincial [Xgx] [Institucional, Regional - EG]. -ed. [Única edição conhecida]. Ceará: Tip. Social . IV-128p. Sacramento Blake (1900); Catálogo da BNP [“'Inoc. Anota o segunte: "No prefacio explica o auctor como pretendeu seguir uma vereda nova, não se limitando, como outros, "aos tratadinhos de palavras que estão em moda, com as novidades de algumas subtilezas e argucias"]

[50]. 1862. BITHENCOURT, Raimundo Câmara (Rio de Janeiro ? - ?). Epitome da grammatica philosophica da lingua portugueza [Xgxlp] [-]. 1ª ed. [Única edição conhecida]. Rio de Janeiro: Editores E. \& H. de Laemmert. vii-144p. Sacramento Blake (1902); Catálogo da BNP ["o auctor seguiu principalmente a doutrina de Jerónimo Soares Barbosa"].

[51]. 1862. COSTA DUARTE, Antonio. Compendio da grammatica philosophica da lingua portugueza escolhida pela congregação do licêo do Maranhão pára uso do mesmo, e das aulas de primeiras letras da provincia. [Xgxlp] [Institucional, Instrução Primária, Regional - BEG]. $5^{\mathrm{a}}$ ed. [edição posterior, ver também [10] [19] [33] [44] [105]]. Maranhão: Antonio Pereira Ramos D’Almeida. 152p. - Sem menção em fontes secundárias, localizada em catálogos de bibliotecas.

[52]. 1862. CORUJA, Antonio Alvares Pereira. (1806 Porto Alegre - 1889 Rio de Janeiro). Compendio da grammatica da lingua nacional, dedicado á mocidade riograndense [Xgln] [Alunos, Regional - $\mathrm{AE}$ ]. -ed. [edição posterior, ver também [16] [26] [27] [29] [69] [87] [92] [172]]]. Rio de Janeiro:-. -p. - Sacramento Blake (1883)

[53]. 1862. FORTES, Padre Inácio Felizardo Fortes (último quartel do século XVIII 1856 Cabo Frio). Arte da grammatica portugueza, para uso dos seus discipulos [Xgp] [Alunos-A]. 14 edição [edição posterior, ver também [2] [4] [7] [23] [31] [36]]. Rio de Janeiro: -. - p - Sacramento Blake (1895).

[54]. 1862. ORTIZ, José (? - ?); PARDAL, Candido Matheus de Faria (Rio Grande do Sul - 1888 Rio de Janeiro). Novo systema de estudar a grammatica portugueza por meio de memória, intelligencia e analyse, ajudando-se mutuamente [Xgpx] []. -ed. [Única edição conhecida]. Vitória:- . -p. - Sacramento Blake (1899); Nascentes (1939:24)

[55]. 1862. RIBEIRO, Joaquim Sabino Pinto (1812 Rio de Janeiro - 1863). Compendio de grammatica portugueza [Xgp] [-]. -ed. [Única edição conhecida]. Rio de Janeiro:-. -p. - Sacramento Blake (1899)

[56]. 1862. RUBIM, Joaquim Frederico Kiappe da Costa (1831 Porto - 1866 Corrientes (Argentina)). Novo methodo da grammatica portugueza composto em verso 
rimado, approvado e adoptado para as aulas da provincia do Ceará e pelo Conselho director da instrucção publica da mesma provincia [nXgp] [Regional, Institucional - EG]. -ed. [edição posterior, ver também [48] [119]]. Rio de Janeiro/Ceará: E. \& H. Laemmert. (RJ), mas impresso no Ceará: Typographia Cearense 219p. - Sacramento Blake (1898)

[57]. 1862. SENNA, José Bernardino de Senna (Pernambuco ? - ?). Lições de grammatica portugueza, destinadas ao uso dos alumnos de ambos os sexos que frequntam as aulas de primeiras lettras [Xgp] [Alunos, Instrução Primária - AB]. -ed. [Única edição conhecida]. Pernambuco:-. -p. - Sacramento Blake (1898)

[58]. 1862. SILVEIRA, Cyrillo Dillermando da. (Ceará ? - Rio de Janeiro ?). Compendio de grammatica da lingua portugueza: obra adoptada pelo conselho de instrucção publica [Xglp] [Institucional - G]. -ed. [edição posterior, ver também [38] [89] [138]]. -:-. -p. - Sacramento Blake (1893).

[59]. 1862. SOTERO DOS REIS, Francisco (1800 Maranhão - 1871 Maranhão). Postillas da grammatica geral applicada á lingua portugueza: pela analyse dos classicos, ou guia para a construcção portugueza [Xgx] [-]. $1^{\mathrm{a}}$ ed. [Edição mais antiga conhecida, ver também [77]]. Maranhão: s.n. -p. - Sacramento Blake (1895); Castilho (1862); Elia (1975); Azevedo Filho (2002).

[60]. 1862. TILBAULT, José Vicente (Rio Grande do Sul ? - ?). Grammatica elementar, methodica do Brazil para uso das aulas de ensino primario [Gxb] [Instrução Primária - B]. -ed. [Única edição conhecida]. Rio de Janeiro:-. 110p. Sacramento Blake (1899)

[61]. 1863. CARVALHO, Manoel Domingos (? - ?). Elementos de grammatica portugueza para uso dos alumnos do mesmo estabelecimento [Xgp] [Alunos, Institucional (?) - AG]. -ed. [Única edição conhecida]. Bahia: Tip. Poggetti. 46p. - Sem menção em fontes secundárias, localizada em catálogos de bibliotecas.

[62]. 1863. CRUZ, Policarpo José Dias (? Rio de Janeiro - 1865 Rio de Janeiro). Compendio da grammatica portugueza [Xgp] [-]. $3^{\mathrm{a}}$ ed. [edição posterior, ver também [34] [70] [110]]. Rio de Janeiro:-. -p. - Sacramento Blake (1902)

[63]. 1863. KOEFFER, Frederico Adão Carlos (1822 Prússia - ?). Resumo da grammatica nacional, adequado ao ensino methodico dos principiantes [Xgn] [Alunos, Instrução Primária - Ab]. -ed. [Única edição conhecida]. Porto Alegre:-. 64p. - Sacramento Blake (1895)

[64]. 1863. PASSOS, José Alexandre (1808 Alagoas - 1878 Alagoas). Resumo da grammatica portugueza. [Xgp] [-]. ed. [edição posterior, ver também [37] [84]]. Rio de Janeiro: Tip. Nacional. 163p. - Sem menção em fontes secundárias, localizada em catálogos de bibliotecas.

[65]. 1864. CASTILHO, Francisco Alves da Silva (Desterro ? - ?). Preliminares de grammatica, dispostos em leitura apropriada para exercitar a intelligencia dos principiantes e preparal-os para o estudo desta doutrina em obras de maior desenvolvimento, representando o systema grammatical figurado por meio da arvore da sciencia [Xg] [Instrução Primária - B]. -ed. [Única edição conhecida]. Rio de Janeiro:- . p. - Sacramento Blake (1899) [Grammatica pittoresca ou systema grammatical explicado pela arvore da sciencia: mappa appenso aos Preliminares de grammatica da Escola brazileira]

[66]. 1864. MURICI, João da Veiga (1806 Bahia - 1890). Grammatica Geral... [Gx] []. -ed. [Única edição conhecida]. Bahia: Typ. Constitucional de França Guerra. 59p. - Sacramento Blake (1898)

[67]. 1864. PINHEIRO, Joaquim Caetano Fernandes (1823 Rio de Janeiro - 1876). Grammatica da infância, dedicada aos senhores professores de instrucção 
primaria [Gx] [Instrução Primária, Professor - BJ]. ed. [Única edição conhecida]. Rio de Janeiro: B. L. Garnier. 150p. - Sacramento Blake (1898)

[68]. 1865. BEZERRA, Manuel Soares da Silva (1810 Ceará - 1888 Fortaleza). Compendio de grammatica portugueza para uso do atheneu cearense e das escolas primarias [Xgp] [Instrução Primária, Institucional, Regional - BEG]. -ed. [Única edição conhecida]. Ceará: Tip. Social. -p. - Sem menção em fontes secundárias, localizada em catálogos de bibliotecas.

[69]. 1865. CORUJA, Antonio Alvares Pereira. (1806 Porto Alegre - 1889 Rio de Janeiro). Compendio da grammatica da lingua nacional, dedicado á mocidade riograndense [Xgln] [Alunos, Regional - AE]. "Nova Edição ampliada" -ed. [edição posterior modificada, ver também [16] [26] [27] [29] [52] [87] [92] [172]]. Rio de Janeiro:-. 99p. - Sacramento Blake (1883)

[70]. 1865. CRUZ, Policarpo José Dias (? Rio de Janeiro - 1865 Rio de Janeiro). Compêndio de grammatica portugueza, corrigido e emendado de accordo com os bons professores públicos da corte, por autorisação do Exm. Sr. conselheiro de Estado, director da instrucção publica, para uso das escolas publicas deste município [Xgp] [Institucional, Regional - EG]. 4a ed "corrigida e emendada". [edição posterior modificada, ver também [34] [62] [110]] Rio de Janeiro:-. -p. Sacramento Blake (1902)

[71]. 1865. GRIVET, Charles Adrian (1816 Suíça - 1876 Rio de Janeiro). Grammatica analytica da lingua portuguesa [Gxlp] [-]. $1^{\mathrm{a}}$ ed. [Única edição conhecida]. Rio de Janeiro:-. p. - Nascentes (1939); Castilho (1962); Elia (1975); Cavaliere (2001); Azevedo Filho (2002); Polachini (2013).

[72]. 1865. IBIRAPITANGA, Antonio Gentil. (1805 Bahia - ?). Compendio grammatical, reduzido a dialogo, para uso dos principiantes do ensino das primeiras lettras $[\mathrm{Xg}$ ] [Alunos, Instrução Primária - AB]. -ed "nova edição". [Edição mais antiga conhecida, ver também [97]]. Bahia:-. -p. - Sacramento Blake () [Esta não é a primeira edição deste compêndio, entretanto nada se declara no frontispicio do livro, e ainda occorre á primeira folha o seguinte sob o titulo de Advertência : «O mundo marcha o com elle a civilisação e a seiencia. Os erros se emendam e os enganos se corrigem. Vendo que a grammatica de Gentil, impressa ultimamente na França, não só veiu pejada de erros (alguns dos quaes pareceram ser do autor e não da impressão) resolvi-me, baseado na mesma grammatica, e fazendo as alterações que a sciencia grammatical exige, fazer uma nova edição e publical-a para maior intelligencia dos meninos de primeiras lettras.» E esta advertência nenhuma assignatura traz, nem ha indicio de quem seja o autor della.]

[73]. 1866. d'ALMEIDA, F. M. Rapozo (? - ?). Elementos de grammatica portugueza segundo um systema mnemônico [Xgpx] [-]. 2a ed. [Única edição conhecida] Pernambuco:-. - p. - Sem menção em fontes secundárias, localizada em catálogos de bibliotecas.

[74]. 1866. MARTAGÃO, Bernadino Affonso (1815 Bahia - ? Bahia). Compendio da grammatica da lingua portugueza para uso das aulas de primeiras lettras, mais correcto, recopilado e extrahido das melhores grammaticas, até o presente conhecidas, posto em ordem e offerecidos a mocidade brazileira etc. [Xglpx] [Instrução Primária, Alunos, Nacional - ABF]. 8a ed. [Única edição conhecida]. Bahia:-. -p. - Sacramento Blake (1883) [Tenho presente a nona edição desta obra, de 1866. Têm havido outras posteriores, porque este compêndio ainda é adoptado na provincia]

[75]. 1866. SOTERO DOS REIS, Francisco (1800 Maranhão - 1871 Maranhão). Grammatica portugueza, accommodada aos principios geraes da palavra, seguidos de immediata applicação pratica, dedicada ao sr. Dr. Pedro Nunes de 
Leal [Gpx] [Pessoa (dedicatória) - I]. $1^{\mathrm{a}}$ ed. [Edição mais antiga conhecida, ver também [85] [85][106]]. Maranhão: Tip. de B. de Matos. XI-274p. - Sacramento Blake (1898); Nascentes (1939); Elia (1975); Azevedo Filho (2002); Parreira (2011); Polachini (2013).

[76]. 1868. SOARES, Vicente Rodrigues da Costa (? Portugal - 1884 Rio de Janeiro). Curso elementar e theorico-pratico da grammatica nacional, approvado pelo conselho director da instrucção publica [Xgn] [Institucional - G]. -ed. [Única edição conhecida]. Rio de Janeiro:-. 182p. - Sacramento Blake (1902)

[77]. 1868. SOTERO DOS REIS, Francisco (1800 Maranhão - 1871 Maranhão). Postillas da grammatica geral applicada á lingua portugueza: pela analyse dos classicos, ou guia para a construcção portugueza [Xgx] [-]. 2a ed. [edição posterior, ver também [59]]. Maranhão: s.n. -p. - Polachini (2013).

[78]. 1869. MORAIS, Alexandre José de Melo (1816 Alagoas - 1882 Rio de Janeiro). Grammatica analytica da lingua portugueza, ensinada por meio de quadros analyticos, methodo facilimo para aprender a lingua [Gxlpx] [-]. -ed. [Única edição conhecida]. Rio de Janeiro:-. -p. - Sacramento Blake (1883)

[79]. 1869. RABELLO, Laurindo José da Silva (1826 Rio de Janeiro - 1864). Compendio de grammatica da lingua portugueza [Xglp] [-]. 1 ${ }^{\mathrm{a}}$ ed. [Edição mais antiga conhecida, ver também [88]]. -:-. -p. - Sem menção em fontes secundárias, localizada em catálogos de bibliotecas.

\section{0}

[80]. 1870. PINHEIRO, Joaquim Caetano Fernandes (1823 Rio de Janeiro - 1876). Grammatica theorica e pratica da lingua portugueza [Gxlp] [-]. -ed. [Única edição conhecida]. Rio de Janeiro: Tip. De F. Alves da Sousa. 176p. - Sacramento Blake (1895)

[81]. 1870. VILLEROY, Frederico Ernesto Estrella (? - ?). Compendo da grammatica portugueza adoptado para uso das escolas da provincia do Rio Grande do Sul pelo respectivo Conselho Director da Instrucção Publica [Xgp] [Institucional, Regional - EG]. -ed. [Única edição conhecida]. Porto Alegre: Typ. do Riograndense. - 80p. - Sem menção em fontes secundárias, localizada em catálogos de bibliotecas.

[82]. 1871. FREIRE DA SILVA, Augusto (1836 S. Luiz do Maranhão - ?); LEAL, Pedro Nunes (? - ?). Noções de prosódia e orthographia para uso da infancia que frequenta as aulas do primeiro grau do instituto santista, intercaladas de um resumo da etymologia e syntaxe, extrahido da Grammatica portugueza de Francisco Sotero dos Reis pelo doutor Pedro Nunes Leal. [X] [Instrução Primária, Institucional, Regional]. $1^{\text {a }}$ ed. [Edição mais antiga conhecida, ver também [96] [111] [136] [145] [173] [180]]. São Luiz do Maranhão:-. p. - Sacramento Blake ()

[83]. 1871. ORTIZ, José (? - ?); PARDAL, Candido Matheus de Faria (1818 Rio de Janeiro - 1888). Grammatica analytica e explicativa da lingua portuguesa [Gxlp] [-]. $1^{\text {a }}$ ed. [Edição mais antiga conhecida, ver também [93] [102] [137] [162]]. Rio de Janeiro:-. p. - Sacramento Blake $(1893,1898)$

[84]. 1871. PASSOS, José Alexandre (1808 Alagoas - 1878 Alagoas). Resumo da grammatica portugueza para uso das escolas de primeiras lettras [Xgp] [Instrução Primária - B]. -ed. [edição posterior, ver também [37] [64]]. Maceió:-. 124p. - Sacramento Blake (1898).

[85]. 1871. SOTERO DOS REIS, Francisco (1800 Maranhão - 1871 Maranhão). Grammatica portugueza, accommodada aos principios geraes da palavra, 
seguidos de immediata applicação pratica, dedicada ao sr. Dr. Pedro Nunes de Leal [Gpx] [pessoa (dedicatória) - I]. $2^{\mathrm{a}}$ ed. [edição posterior modificada, ver também [75] [85][106]]. Maranhão: Typ. de R. d'Almeida \& C.. XI-304p. Sacramento Blake (1898);

[86]. 1871. TAYLOR, H. C (? - ?). Grammatica da lingua nacional. Compendio adaptado ao ensino nas aulas de instrucção primaria. [Gln] [Instrução Primária - B]. -ed. [Única edição conhecida]. Recife: Typ. de Santos \& C.a. 112p. - Sem menção em fontes secundárias, localizada em catálogos de bibliotecas.

[87]. 1872. CORUJA, Antonio Alvares Pereira. (1806 Porto Alegre - 1889 Rio de Janeiro). Compendio da grammatica da lingua nacional, dedicado á mocidade riograndense [Xgln] [Alunos, Regional - $\mathrm{AE}$ ]. -ed. [edição posterior, ver também [16] [26] [27] [29] [52] [69] [92] [172]]. Rio de Janeiro:-. -p. - Sacramento Blake (1883)

[88]. 1872. RABELLO, Laurindo José da Silva (1826 Rio de Janeiro - 1864). Compendio de grammatica da lingua portugueza: obra adoptada pelo governo imperial para uso das escolas regimentaes do exercito e para o ensino dos aprendizes artilheiros [Xglp] [Alunos, Institucional - AG]. 2 $2^{\mathrm{a}}$ ed. [edição posterior, ver também [79]]. Rio de Janeiro: Typographia Esperança de Gaspar João José Vellozo. 158p. - Sacramento Blake (1899), Parreira (2011), Polachini (2013).

[89]. 1872. SILVEIRA, Cyrillo Dillermando da. (Ceará ? - Rio de Janeiro ?). Compendio de grammatica da lingua portugueza: obra adoptada pelo conselho de instrucção publica [Xglp] [Institucional - G]. 4a ed. [edição posterior, ver também [38] [58] [138]]. Rio de Janeiro: Quirino \& Irmão. -p. - Sacramento Blake (1893)

[90]. 1872. SOUZA, Julio Cesar Ribeiro (1843 Acará (PA) - 1887). Grammatica portugueza para as escolas primarias, adoptada e premiada pelo conselho da instrucção publica da provincia do Pará [Gp] [Instrução Primária, Regional, Institucional - BEG]. -ed. [Única edição conhecida]. Pará:-- p. - Sacramento Blake (1899)

[91]. 1873. ALBUQUERQUE, Salvador Henrique (1813 Paraíba - 1880 Pernambuco). Rudimentos da grammatica portugueza [Xgp] [-]. ed. [Única edição conhecida]. Recife: Tip. Commercial. -p. - Sem menção em fontes secundárias, localizada em catálogos de bibliotecas.

[92]. 1873. CORUJA, Antonio Alvares Pereira. (1806 Porto Alegre - 1889 Rio de Janeiro). Compendio da grammatica da lingua nacional, dedicado á mocidade riograndense [Xgln] [Regional]. -ed. "Nova edição" [edição posterior modificada, ver também [16] [26] [27] [29] [52] [69] [87] [172]]. Rio de Janeiro: Esperança. 99p. - Polachini (2013)

[93]. 1873. ORTIZ, José (? - ?); PARDAL, Candido Matheus de Faria (1818 Rio de Janeiro - 1888). Grammatica analytica e explicativa da lingua portuguesa [Gxlp] [-]. $2^{\mathrm{a}}$ ed. [edição posterior, ver também [83] [102] [137] [162]]. Rio de Janeiro: Nicolau-Alves. -p. - Sacramento Blake (1893, 1898)

[94]. 1874. ALBUQUERQUE, Salvador Henrique (1813 Paraíba - 1880 Pernambuco). Compendio da grammatica portugueza [Xgp] [-]. "em edição posterior, dandolhe novo plano e desenvolvimento". [edição posterior, ver também ver também [25] [42]]. Rio de Janeiro:-. -p. - Sacramento Blake (1902).

[95]. 1874. FRAZÃO, Manuel José Pereira (1836 Rio de Janeiro - ?). Postillas de grammatica portugueza [Xgp] [-]. ed. [Única edição conhecida]. Rio de Janeiro:- 
. 103p. - Sem menção em fontes secundárias, localizada em catálogos de bibliotecas.

[96]. 1875. FREIRE DA SILVA, Augusto (1836 S. Luiz do Maranhão - ?). Compendio da grammatica portugueza [Xgp] [-]. 2a ed. "mais correcta e augmentada" [Edição Posterior com título modificado, ver também [82] [111] [136] [145] [173] [180]]. São Paulo: Tip. do Frias. 158p. - Sacramento Blake (1883); Castilho (1962); Parreira (2011); Polachini (2013)

[97]. 1875. IBIRAPITANGA, (1805 Bahia - ?). Compendio grammatical, reduzido a dialogo, para uso dos principiantes do ensino das primeiras lettras $[\mathrm{Xg}]$ [Instrução Primária]. -ed "nova edição". [edição posterior, ver também [72]]. Bahia (Salvador): Off. Litho-typ. de J. C. Tourinho. -p. - Sem menção em fontes secundárias, localizada em catálogos de bibliotecas.

[98]. 1875. MARQUES, Filipe Pinto (? - ?). Grammatica elementar da lingua portugueza extrahida dos melhores auctores e coordenada por... [Gxlp] [-]. $2^{\mathrm{a}} \mathrm{ed}$. [Edição mais antiga conhecida, ver também [128]]. Pará: C. Seidl. 152p. - Sem menção em fontes secundárias, localizada em catálogos de bibliotecas.

[99]. 1875. PIMENTEL, Francisco da Silveira da Ávila (? - ?). Explicador de portuguez de conformidade com o programma do $1^{\circ}$ anno do imperial collegio de Pedro II [Xp] [Programa, Institucional, Instrução Primária - BGH]. -ed. [Única edição conhecida]. Rio de Janeiro:-. 136p. - Sacramento Blake (1895)

[100]. 1876. CANECA, Frei Joaquim do Amor Divino (1779 Recife - 1824). Breve compêndio de grammatica portugueza, organisado em fôrma systematica, com adaptação á capacidade dos alumnos. In: "Obras políticas e litterarias de Frei Joaquim do Amor Divino Caneca, colleccionadas pelo Commendados Antonio Joauim de Mello, em virtude da lei provincial n. ${ }^{\circ} 900$ de 25 de junho de 1869 mandadas publicar pelo exm. Sr. Commendados Presidente da Provincia Desembargador Henrique Pereira de Lucena - Tomo II - [Xgpx] [Alunos - A]. $1^{\mathrm{a}}$ ed. [Única edição conhecida]. Recife: Typographia Mercantil. -p. - Sacramento Blake (1898); Parreira (2011); Polachini (2013).

[101]. 1876. COSTA, Manuel Olimpio Rodrigues da (Bahia - 1891 Bahia). Grammatica portugueza destinada ao curso do $1 .^{\circ}$ anno do Imperial Collegio Pedro Segundo [Gp] [Instrução Primária, Institucional - BG]. -ed. [Edição mais antiga conhecida, ver também [149]]. Rio de Janeiro: Tip. Escola / Cinco de março. 112p. - Sem menção em fontes secundárias, localizada em catálogos de bibliotecas.

[102]. 1876. ORTIZ, José (? - ?); PARDAL, Candido Matheus de Faria (1818 Rio de Janeiro - 1888). Grammatica analytica e explicativa da lingua portuguesa [Gxlp] [-]. 3 ed "aum". [edição posterior modificada, ver também [83] [93] [137] [162]]. Rio de Janeiro: Nicolau-Alves. 151p. - Sem menção em fontes secundárias, localizada em catálogos de bibliotecas.

[103]. 1877. BEZERRA, Manuel Soares da Silva (1810 Ceará - 1888 Fortaleza). Compendio de grammatica da lingua nacional [Xgln] [-]. -ed. [Única edição conhecida]. Fortaleza:-. 80p. - Sacramento Blake (1900)

[104]. 1877. BORGES, Abílio César (1824 Bahia - ?). Resumo da grammatica portugueza [Xgp] [Institucional - G]. $7^{\mathrm{a}}$ ed "augmentada e melhorada segundo as grammaticas mais modernas, adoptadas em varias escolas publicas do imperio do Brasil" [Edição posterior com título modificado, ver também [47] [206]]. Bruxelas: Typ. Guyot. -p. - Sacramento Blake (1883:3)

[105]. 1877. COSTA DUARTE. Pa. Antonio da (17??-?). Compendio da grammatica philosophica da lingua portugueza Escolhida pela Congregação do Lycêo do Maranhão para o uso do mesmo Lycêo, e das aulas de primeiras lettras da 
provincia. [Xgxlp] [Institucional, Instrução Primária, Regional - BEG]. $6^{\mathrm{a}}$ ed, [edição posterior, ver também [10] [19] [33] [44] [51]]. Maranhão:-. 121p. - Sem menção em fontes secundárias, localizada em catálogos de bibliotecas.

[106]. 1877. SOTERO DOS REIS, Francisco (1800 Maranhão - 1871 Maranhão). Grammatica portugueza, accommodada aos principios geraes da palavra, seguidos de immediata applicação pratica, dedicada ao sr. Dr. Pedro Nunes de Leal [Gpx] [Dedicado a pessoa]. $3^{\mathrm{a}}$ ed. [edição posterior modificada, ver também [75] [85][85]]. Maranhão: Livraria de Magalhães. - Sacramento Blake (1898); Cavaliere (2001).

[107]. 1877. VIEIRA, Joaquim José de Menezes Vieira (1851 Rio de Janeiro - ?). Primeiras noções de grammatica portugueza [Xgp] [-]. ${ }^{\text {a }}$ ed. [Edição mais antiga conhecida, ver também [124]]. Rio de Janeiro:-. -p. - Sacramento Blake (1898) [Este livro e os que o seguem pertencem à Bibliotheca da infância, collecção de Iivrinhos compilados especialmente para uso do collegio Menezes Vieira.]

[108]. 1878. PACHECO da Silva Junior, Manuel. Grammatica Historica da Lingua Portuguesa [Gxlp] [-]. $1^{\mathrm{a}}$ ed. [Única edição conhecida]. Rio de Janeiro:-. -p. Sacramento Blake (1900)

[109]. 1879. CARVALHO, Joaquim José de (1850 Rio de Janeiro - ?). Postillas de grammatica portuguesa [Xgp] [-]. -ed. [Única edição conhecida]. Rio de Janeiro:. -p. - Sacramento Blake (1898)

[110]. 1879. CRUZ, Policarpo José Dias (? Rio de Janeiro - 1865 Rio de Janeiro). Compêndio de grammatica portugueza [Xgp] [-]. $6^{\mathrm{a}}$ ed [Edição Posterior, ver também [34] [62] [70]]. Rio de Janeiro:-. -p. - Sacramento Blake (1902)

[111]. 1879. FREIRE DA SILVA, Augusto (1836 S. Luiz do Maranhão - ?). Compendio da grammatica portugueza: para uso de alunos de humanidades, que frequentam a aula de portugues [Xgp] [Alunos - A]. $3^{\mathrm{a}}$ ed. [edição posterior, ver também [82] [96] [136] [145] [173] [180]]. São Paulo: J. Sekler. -p. - Sacramento Blake (1883), Nascentes (1939)

[112]. 1879. FREIRE DA SILVA, Augusto (1836 S. Luiz do Maranhão - ?). Rudimentos da grammatica portugueza para uso dos alumnos de primeiras lettras [Xgp] [Alunos, Instrução Primária - AB]. $1^{\mathrm{a}}$ ed. [Edição mais antiga conhecida, ver também [158]]. São Paulo:-. -p. - Sacramento Blake (1883); Castilho (1962).

[113]. 1879. SANTOS, Hemetério José dos (Maranhão ? - ?). Grammatica elementar da lingua portugueza extrahida dos melhores auctores e.. [Gxlp] [-]. -ed. [Única edição conhecida]. Rio de Janeiro:-. p. - Sacramento Blake (1895).

[114]. 1879. SOUZA, José Martiniano de (Pernambuco ? - ?). Tratado de analyse phonetica grammatical, syntaxica e lógica com seus desenvolvimentos e applicações, seguido de um catalogo de palavras diversificaveis em significação, para complemento do mesmo assumpto [Xg] [-]. -ed. [Única edição conhecida]. Recife:-. -p. - Sacramento Blake (1898)

[115]. 1879. WALTER, Luiz Kraemer (Porto Alegre ? - ?). Segundo livro de grammatica, composto segundo o methodo Marcet [Xgx] [-]. -ed. [Única edição conhecida]. Pelotas:-. -p. - Sacramento Blake (1899)

[116]. 1879. WALTER, Luiz Kraemer (Porto Alegre ? - ?). Terceiro livro de grammatica, composto segundo o methodo Marcet [Xgx] [-]. $2^{\mathrm{a}}$ ed. [Única edição conhecida]. Pelotas:-. -p. - Sacramento Blake (1899) 
[117]. 1880. CARVALHO, Felisberto Rodrigues Pereira de (18?? Rio de Janeiro - ?). Elementos de grammatica portugueza para uso dos alumnos da instrucção primaria [Xgp] [Instrução Primária, Alunos - AB]. -ed. [Edição mais antiga conhecida, ver também [132] [191]]. Rio de Janeiro:-. -p. - Sacramento Blake (1893)

[118]. 1880. COSTA E CUNHA, Antonio Estevão da (Rio de Janeiro - ?). Grammatica elementar portugueza, adaptada ao ensino das escolas da instrucção primaria, quer dos menores, quer dos adultos, e bem assim dos collegios, lycêos, escolas normaes e aulas preparatórias [Gxp] [Alunos, Instrução Primária, Institucional $\mathrm{ABG}$ ]. -ed. [Edição mais antiga conhecida]. Rio de Janeiro:-. -p. - Sacramento Blake (1883)

[119]. 1880. RUBIM, Joaquim Frederico Kiappe da Costa (1831 Porto - 1866 Corrientes (Argentina)). Novo methodo da grammatica portugueza composto em verso rimado, approvado e adoptado para as aulas da provincia do Ceará e pelo Conselho director da instrucção publica da mesma provincia. Nova edição. [nXgp] [Regional, Institucional - EG]. -ed. [edição posterior, ver também ver também [48] [56]]. Porto: Tip. Comercial Portuense. XV-200p. - Sem menção em fontes secundárias, localizada em catálogos de bibliotecas.

[120]. 1881. CARNEIRO RIBEIRO, Ernesto (Bahia 1839 - 1920). Grammatica portugueza philosophica [Gpx] [-]. $1^{\mathrm{a}}$ ed. [Única edição conhecida]. Bahia:-. -p. - Sacramento Blake (1893); Nascentes (1939); Parreira (2011); Polachini (2013).

[121]. 1881. GRIVET, Charles Adrian (1816 Suíça - 1876 Rio de Janeiro). Nova grammatica de lingua portugueza [nGlp] [-]. $1^{\text {a }}$ ed. [Única edição conhecida]. Rio de Janeiro:-. -p. - Nascentes (1939); Castilho (1962); Elia (1975); Cavaliere (2001); Azevedo Filho (2002); Parreira (2011); Polachini (2013).

[122]. 1881. NOGUEIRA, Baptista Caetano de Almeida (1826 Jaguary (MG) - 1882 Rio de Janeiro). Rascunhos sobre a grammatica da lingua portugueza [Xglp] [-]. ed. [Edição mais antiga conhecida, ver também [130]]. Rio de Janeiro: Typ. de A. Santos. 222p. - Sem menção em fontes secundárias, localizada em catálogos de bibliotecas.

[123]. 1881. RIBEIRO, Julio Cesar Vaughan (Sabará MG 1845-1890 São Paulo). Grammatica Portugueza [Gp] [-]. 1 ${ }^{a}$ ed. [Edição mais antiga conhecida, ver também , ver também [143] [189] [177] [193] [204]]. São Paulo: Typ. Jorge Seckler. 229p. - Sacramento Blake (1899), Maciel (1910) [Mais ou menos por esta época apparecera a Grammatica de Julio Ribeiro, baseada nos trabalhos dos philologos allemães, inglezes e francezes. Tão de perto se lhes abeirava, porém, que se diria antes uma adaptação á lingua vernacula do que um trabalho onde transluzissem, com a individualidade do autor, os seus processos o seu methodo, emfim norteação propria, oriunda de um trabalho de assimilação. Até ponto havia em que o Sr. Julio Ribeiro se adscrevia a transcerter, quasi ipsis verbis, para ov ernaculo, as novas doutrinas dos autores extrangeiros, de Guardia, de Mason, de Bergmann. Além disso, resumbrava-lhe do estylo certo gráo de frouxidão e obscuridade; do methodo, certa desorientação; e, quanto á syntaxe, ao envez de exemplos hauridos aos monumentos literarios, dava-lh'os elle proprio, quasi sempre. O que nos afigura é que se apressurou o Sr. Julio Ribeiro a de chofre quebrar a rotina, fosse como fosse, embora inda não houvesse assimilado o qaunto lera nos philologos extrangeiros. Entretanto, ramanesce-lhe de certo o merito de haver sido o primeiro a trasladar para compendio didactivo a nova orientação, evertendo os alicerces da rotina e servindo de norma para algumas Grammaticas que se publicaram em S. Paulo.]; Nascentes (1939); Castilho (1962); Elia (1975); Guimarãoes (1996); Cavaliere (2001); Azevedo Filho (2002); Polachini (2013).

[124]. 1881. VIEIRA, Joaquim José de Menezes Vieira (1851 Rio de Janeiro - ?). Primeiras noções de grammatica portugueza [Xgp] [-]. $2^{\mathrm{a}}$ ed. [edição posterior, ver também [107]]. Rio de Janeiro:-. -p. - Sacramento Blake (1898) 
[125]. 1881. WALTER, Luiz Kraemer (Porto Alegre ? - ?). Primeiro livro de grammatica, composto segundo o methodo Marcet [Xgx] [-]. $4^{\mathrm{a}}$ ed. [Única edição conhecida]. Pelotas:-. -p. - Sacramento Blake (1899)

[126]. 1882. BRANDÃO, Thomaz da Silva (Minas Gerais ? - ?). Grammatica infantil da lingua portugueza, composta, etc. e adoptada pela Inspeciona geral da instrucção publica de Minas-Geraes para uso das escolas primarias [Gxlp] [Instrução Primária, Regional, Institucional - BEG]. 2a ed. [Única edição conhecida]. -:-. -p. - Sacramento Blake (1902)

[127]. 1882. FEITOSA, Miguel Alves (Alagoas ? - ?). Grammatica das escolas, dedicada à provincia de S. Paulo sobre o plano de Pierre Larousse. [Gx] [Regional - E]. -ed. [Edição mais antiga conhecida, ver também [135] [144]]. Campinas: Gazeta de Campinas. p. - Sacramento Blake (1900)

[128]. 1882. MARQUES, Filipe Pinto (? - ?). Grammatica elementar da lingua portugueza extrahida dos melhores auctores e coordenada por... [Gxlp] [-]. $4^{\mathrm{a}}$ ou

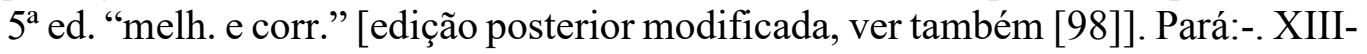
162p. - Sem menção em fontes secundárias, localizada em catálogos de bibliotecas.

[129]. 1882. MELLO, Silvino Soares de (? - ?). Grammatica portugueza [Gp] [-]. -ed. [Única edição conhecida]. Rio de Janeiro:-. -p. - Sacramento Blake (1902)

[130]. 1882. NOGUEIRA, Baptista Caetano de Almeida (1826 Jaguary (MG) - 1882 Rio de Janeiro). Rascunhos sobre a grammatica da lingua portugueza [Xglp] [-]. -ed. [edição posterior, ver também [122]]. Rio de Janeiro:-. cerca de 300p. Sacramento Blake (1883)

[131]. 1882. ANDRADE E SILVA, Hilario Ribeiro de (1847 Porto Alegre - 1886 Rio de Janeiro). Grammatica elementar e lições progressivas de composição, adoptada nas províncias do Rio Grande do Sul, Santa Catharina, Paraná, S. Paulo, Rio de Janeiro e município neutro. Terceira edição, melhorada e consideravelmente augmentada com novos exercicios de lexicologia, orthographia e linguagem; exercicios de invenção, estylo e sobre synonymos [Gx] [Regional]. $3^{\mathrm{a}}$ ed. [Edição mais antiga conhecida, ver também [147]]. Porto Alegre:-. 148p. - Sacramento Blake (1895) [Na corte foi mandada adoptar por aviso do Ministério do império de 22 de agosto desse anno.]

[132]. 1883. CARVALHO, Felisberto Rodrigues Pereira de (18?? Rio de Janeiro - ?). Elementos de grammatica portugueza para uso dos alumnos da instrucção primaria $[\mathrm{Xgp}]$ [Instrução Primária, Alunos - AB]. $5^{\mathrm{a}}$ ed. [edição posterior, ver também [117] [191]]. Rio de Janeiro:-. -p. - Sacramento Blake (1893)

[133]. 1883. COSTA E CUNHA, Antonio Estevão da (Rio de Janeiro ? - ?). Manual do examinando de portuguez: repertorio philologico grammatical e litterario da lingua materna [Xp] [Alunos - A]. $1^{\text {a }}$ ed. [Única edição conhecida]. Rio de Janeiro/Paris: Livraria Academica de J. de Azevedo. 416p. - Sacramento Blake (1883) [E' um compêndio das matérias indispensáveis para o estudo racional e methodico da lingua portugueza.]

[134]. 1883. COSTA E CUNHA, Antonio Estevão da (Rio de Janeiro ? - ?). Principios de Grammatica Historica e Comparada [Xgx] [-]. $1^{\mathrm{a}}$ ed. [Única edição conhecida]. -:-. Parreira (2011); Polachini (2013).

[135]. 1883. FEITOSA, Miguel Alves (Alagoas ? - ?). Grammatica das escolas, dedicada à provincia de S. Paulo sobre o plano de Pierre Larousse. [Gx] [Regional - E]. 2a ed. "consideravelmente melhorada" [edição posterior modificada, ver também [127] [144]]. Campinas: Gazeta de Campinas. 310p. Sem menção em fontes secundárias, localizada em catálogos de bibliotecas. 
[136]. 1883. FREIRE DA SILVA, Augusto (1836 São Luiz do Maranhão - ?). Compendio da grammatica portugueza: para uso de alunos de humanidades, que frequentam a aula de portugues [Xgp] [Alunos - A]. $4^{\mathrm{a}}$ ed. [edição posterior, ver também [82] [96] [111] [145] [173] [180]]. São Paulo: Jorge Seckler \& C.a. 238VIIp. - Sem menção em fontes secundárias, localizada em catálogos de bibliotecas.

[137]. [137]. 1884. ORTIZ, José (? - ?); PARDAL, Candido Matheus de Faria (1818 Rio de Janeiro - 1888). Grammatica analytica e explicativa da lingua portuguesa [Gxlp] [-]. 5a ed [edição posterior, ver também [83] [93] [102] [162]] Rio de Janeiro: Nicolau-Alves. -p. - Sacramento Blake $(1893,1898)$

[138]. 1884. SILVEIRA, Cyrillo Dolermando da. (Ceará ? - Rio de Janeiro ?). Compendio de grammatica da lingua portugueza: obra adoptada pelo conselho de instrucção publica [Xglp] [Institucional - G]. 9a ed. [edição posterior, ver também [38] [58] [89]]. -:-. -p. - Sacramento Blake (1893)

[139]. 1885. CARNEIRO RIBEIRO, Ernesto (Bahia 1839 - 1920). Elementos de grammatica portugueza [Xgp] [-]. $1^{\mathrm{a}}$ ed. [Edição mais antiga conhecida, ver também [149] [170] [179] [197]]. -: -. -p. - Souza (1957)

[140]. 1885. CARVALHO, Joaquim José de (1850 Rio de Janeiro - ?). Methodo de grammatica analytica [Xgx] [-]. ed. [Única edição conhecida]. Rio de Janeiro:-. p. - Sacramento Blake (1898) [E' um methodo de ensino intuitivo em cadernos apropriados à cópia ou ditado, facilitando o estudo da natureza de cada termo dado]

[141]. 1885. RABELO, Laurindo José da Silva (1826 Rio de Janeiro - 1864). Elementos de grammatica portugueza [Xgp] [-]. ed. [Única edição conhecida]. Rio de Janeiro:-. -p. - Sem menção em fontes secundárias, localizada em catálogos de bibliotecas.

[142]. 1885. RIBEIRO, Julio Cesar Vaughan (1845-1890). A grammatica analytica [Gp] [-]. -ed. [Única edição conhecida]. São Paulo: Ty. de Leroy King. 29p. - Sem menção em fontes secundárias, localizada em catálogos de bibliotecas.

[143]. 1885. RIBEIRO, Julio Cesar Vaughan (1845-1890). Grammatica Portugueza [Gp] [-]. $2^{a}$ ed. "ref. e muito aumentada" [edição posterior modificada, ver também [123] [189] [177] [193] [204]]. São Paulo: Teixeira \& Irmão. 362p. Nascentes (1939)

[144]. 1886. FEITOSA, Miguel Alves (Alagoas ? - ?). Grammatica das escolas, dedicada à provincia de S. Paulo sobre o plano de Pierre Larousse. [Gx] [Regional - E]. $3^{\mathrm{a}}$ ed. [edição posterior, ver também [127] [135]]. Campinas: Gazeta de Campinas. -p. - Sem menção em fontes secundárias, localizada em catálogos de bibliotecas.

[145]. 1886. FREIRE DA SILVA, Augusto (1836 São Luiz do Maranhão - ?). Compendio da grammatica portugueza: para uso de alunos de humanidades, que frequentam a aula de portugues [Xgp] [Alunos - A]. $5^{\mathrm{a}}$ ed. [edição posterior, ver também [82] [96] [111] [136] [173] [180]]. São Paulo: Typ. a vapor de Jorge. -p. - Sem menção em fontes secundárias, localizada em catálogos de bibliotecas.

[146]. 1887. ALBERTO JUNIOR, Philippe Jose (? - ?). Grammatica ecleticorudimentaria da lingua portugueza [Gxlp] [-]. - ed. [edição posterior, ver também [41]]. Rio de Janeiro: Typ. de Quirino \& Irmão. -p. - Sem menção em fontes secundárias, localizada em catálogos de bibliotecas.

[147]. 1887. ANDRADE E SILVA, Hilario Ribeiro de (1847 Porto Alegre - 1886 Rio de Janeiro). Grammatica elementar e lições progressivas de composição [Gx] [?] $7^{\mathrm{a}}$ ed [edição posterior, ver também [131]]. Rio de Janeiro:-. -p. - Sacramento Blake (1895). 
[148]. 1887. BOSCOLI, José Ventura (1855 Rio de Janeiro - ?); PAIO, João Zeferino Rangel de S. (? - ?). Grammatica portugueza [Gp] [-]. ed. [Única edição conhecida]. Rio de Janeiro:-. p. - Sem menção em fontes secundárias, localizada em catálogos de bibliotecas.

[149]. 1893. CARNEIRO RIBEIRO, Ernesto (Bahia 1839 - 1920). Elementos de grammatica portugueza [Xgp] [-]. $4^{\mathrm{a}}$ ed. [edição posterior, ver também [139] [170] [179] [197]]. -: -. -p. - Souza (1957)

[150]. 1887. COSTA, Manuel Olimpio Rodrigues da Costa (Bahia ? - Capital Federal 1891). Grammatica Portugueza [Gp] [-]. -ed. [edição posterior, ver também [101]]. Rio de Janeiro:Typ. da Escola. -p. - Sacramento Blake (1900)

[151]. 1887. GOMES, Alfredo (? - ?). Grammatica Portugueza (?) [Gp] [Programa - H]. $1^{a}$ ed. [Edição mais antiga conhecida, ver também [187] [196]]. -:-. -p. - Parreira (2011); Polachini (2013).

[152]. 1887. MACIEL, Maximino de Araújo (Sergipe ? - ?). Grammatica analytica baseada nas doutrinas modernas satisfazendo às condições do actual programma [Gx] [Programa - H]. $1^{\mathrm{a}}$ ed. [Edição mais antiga conhecida, ver também [188]]. Rio de Janeiro: Typ. Central de Evaristo Rodrigues da Costa. 316p. - Sacramento Blake (1900); Castilho (1962); Elia (1975); Parreira (2011); Polachini (2013).

[153]. 1887. PACHECO DA SILVA JR, Manuel (1843 Rio de Janeiro - 1900 Rio de Janeiro); LAMEIRA ANDRADE (? - ?). Noções da grammatica portugueza de accordo com o programma official para os exames geraes de preparatorios do corrente anno [nXgp] [Programa - G]. $1^{\mathrm{a}}$ ed. [Edição mais antiga conhecida, ver também [181]]. Rio de Janeiro: J. G. de Azevedo. 537p. - Sacramento Blake (1900) [A publicação foi feita em fasciculos e [por Pacheco Junior] em collaboração com o professor Lameira de Andrade. Teve segunda edição completamente refundida em 1894. Na primeira o livro foi escripto em fôrma de pontos, conforme os programmas de exames. Na segunda sob a fôrma moderna, baseada na historia e na comparação, e accrescentada da syntaxe.]; Castilho (1962); Parreira (2011); Polachini (2013).

[154]. 1887. RIBEIRO Fernandes, João (Sergipe 1860 - 1934). Exames de portuguez. Lições de grammatica portugueza, coordenadas segundo o programma de 1887 [Xgp] [Programa Institucional - H]. $1^{\mathrm{a}}$ ed. [Edição mais antiga conhecida, ver também [165] [167] [174] [176] [183] [198]]. Rio de Janeiro: Livraria Clássica de Alves \& Com. -p. - Parreira (2011); Polachini (2013).

[155]. 1887. RIBEIRO, Julio Cesar Vaughan (1845 Sabará (MG) - 1890 São Paulo). Holmer brazileiro ou grammatica da puericia. Tradução da "Introduction to English Grammar" de G. F. Holmer. [Xb ou Gx] [-]. -ed. [Única edição conhecida]. São Paulo:-. -p. - Sem menção em fontes secundárias, localizada em catálogos de bibliotecas.

[156]. 1888. BOSCOLI, José Ventura (1855 Rio de Janeiro - ?); PACHECO da Silva Junior, Manoel (1843 Rio de Janeiro - 1900 Rio de Janeiro). Noções de analyse grammatical, phonetica, etymologica e syntaxica [Xgx] [-]. -ed. [Única edição conhecida]. Rio de Janeiro:-. -p. - Sacramento Blake (1883)

[157]. 1888. CONDURÚ, Fillipe Benicio de Oliveira (? - ?). Grammatica Elementar da Lingua Portugueza; approvada pelo inspector da instrucção pública para uso das escolas de primeiras letras desta provincia e pelo conselho de instrucção publica para uso do lyceu, collegios e aulas de instrucção primaria [Gxlp] [Instrução primária, Institucional, Regional - BEG]. 13ª ed. [edição posterior modificada?, ver também [30]]. São Luiz do Maranhão: Typ. do Paiz. -p. -Nogueira ()

[158]. 1888. FREIRE DA SILVA, Augusto (1836 S. Luiz do Maranhão - ?). Rudimentos da grammatica portugueza para uso dos alumnos de primeiras lettras [Xgp] [Alunos, Instrução Primária - AB]. -ed. [edição posterior, ver também [112]]. São 
Paulo: Jorge Seckler. -p. - Sem menção em fontes secundárias, localizada em catálogos de bibliotecas.

[159]. 1888. LAPAGESSE, Leon Eugenio (1852 França - ? [casou em 1874 no Brasil, Santa Catarina]). Grammatica portugueza. Compêndio mandado adoptar pelo governo para uso das escolas publicas de Santa Catharina por acto de 26 de outubro de 1888, em virtude do parecer do Conselho de Instrucção publica. [Gp] [Institucional, Regional - EG]. $2^{\mathrm{a}}$ ed. [Única edição conhecida]. Desterro:-. 198p. - Sacramento Blake (1899)

[160]. 1888. LIMA, João Fernandes de (Bahia ? - ?). Resumo da grammatica portugueza. Pontos de portuguez, segundo o novo programma de exames [Xgp] [Programa H]. -ed. [Única edição conhecida]. Rio de Janeiro:-. -p. - Sacramento Blake (1898)

[161]. 1888. MASSA, José de Noronha Nápoles (1824 Bahia - 1890 Rio Grande do Sul). Grammatica analytica da lingua portugueza, composta e offerecida aos brazileiros... [Gxlp] [Nacional - F]. $1^{\text {a }}$ ed. [Única edição conhecida]. Rio de Janeiro: H. Lombaerts. 544p. - Nascentes (1939); Castilho (1962); Azevedo Filho (2002); Polachini (2013)

[162]. 1888. ORTIZ, José (? - ?); PARDAL, Candido Matheus de Faria (1818 Rio de Janeiro - 1888). Grammatica analytica e explicativa da lingua portuguesa [Gxlp] [-]. 6 ed corr. E augm. [edição posterior modificada, ver também [83] [93] [102] [137]]. Rio de Janeiro: Alves e Cia. -p. - Sem menção em fontes secundárias, localizada em catálogos de bibliotecas.

[163]. 1888. RIBEIRO Fernandes, João (Sergipe 1860 - 1934). Grammatica portugueza elementar [Gpx] [-]. -ed. [Única edição conhecida]. Rio de Janeiro: Livraria Classica de Alves \& Com. p. - Sem menção em fontes secundárias, localizada em catálogos de bibliotecas.

[164]. 1888. RIBEIRO Fernandes, João (Sergipe 1860 - 1934). Grammatica portugueza. Curso médio. $2 .^{\circ}$ anno de Portuguez [Gp] [Curso médio/2 $2^{\circ}$ ano]. ed. [Única edição conhecida]. Rio de Janeiro: Livraria Clássica . p. - Sacramento Blake (1898)

[165]. 1888. RIBEIRO Fernandes, João (Sergipe 1860 - 1934). Grammatica portugueza. Curso superior. $3 .^{\circ}$ anno de Portuguez. Com um complemento de anotações no texto [Gp] [Curso superior $/ 3^{\circ}$ ano - D]. $2^{\text {a }}$ ed. corr. E augm. [Edição posterior com título modificado, ver também [154] [167] [174] [176] [183] [198]]. Rio de Janeiro: Livraria Clássica / Alves. 347p. - Sacramento Blake (1898)

[166]. 1889. CARDOSO, Domiciano H. Perdigão (? - ?). Compendio de grammatica portugueza [Xgp] [-]. -ed. [Única edição conhecida]. Pará: Tavares Cardoso \& C.a. 148p. - Sem menção em fontes secundárias, localizada em catálogos de bibliotecas.

[167]. 1889. RIBEIRO Fernandes, João (Sergipe 1860 - 1934). Grammatica portugueza. (3. ${ }^{\circ}$ anno) $[\mathrm{Gp}]$ [Curso superior $/ 3^{\circ}$ ano - D]. $3^{\mathrm{a}}$ ed. [edição posterior, ver também [154] [165] [174] [176] [183] [198]] Rio de Janeiro: Francisco Alves. 326p. - Sem menção em fontes secundárias, localizada em catálogos de bibliotecas.

[168]. 1889. VIEIRA, Verissimo Ricardo (1855 São Luiz do Maranhão - ?). Grammatica elementar da lingua portugueza, dedicada á instrucção primaria e organisada de accordo com o programma vigente da instrucção primaria [Gpx] [Instrução primária, Programa - BH]. -ed. [Única edição conhecida]. Rio de Janeiro:-. 182p. - Sacramento Blake (1902)

[169]. 188?. LACERDA, Joaquim Maria de (? - ?). Pequena grammatica da infancia composta para uso das escolas primarias [Gx] [-]. "Nova edição" -ed. [Única 
edição conhecida]. Rio de Janeiro: Garnier. -p. - Sem menção em fontes secundárias, localizada em catálogos de bibliotecas.

\section{0}

[170]. 1890. CARNEIRO RIBEIRO, Ernesto (Bahia 1839 - 1920). Elementos de grammatica portugueza [Xgp] [-]. $2^{\mathrm{a}}$ ed. [edição posterior, ver também [139] [149] [179] [197]]. Salvador: Econômica. 167p. - Souza (1957)

[171]. 1890. CARNEIRO RIBEIRO, Ernesto (Bahia 1839 - 1920). Seroes grammaticaes ou nova grammatica portugueza, obra adaptada ao curso secundario da lingua portugueza e adaptada ao novo programma de exames [Xg/nGp] [Curso Médio/2 ${ }^{\circ}$ ano; Programa - $\mathrm{CH}$ ]. $1^{\mathrm{a}}$ ed. [Única edição conhecida]. Bahia: Imprensa Popular. 369p. - Nascentes (1939:26); Castilho (1962); Elia (1975: 121) [O livro que melhor simboliza o espírito vernaculista do período é, porém, os Serões Gramaticais de Ernesto Carneiro Ribeiro, 1.a ed. 1890; Trata-se de alentado volume de quase oitocentas páginas, onde se versam questões de fonética descritiva, de ortografia, de formação de palavras, de história da língua, de classificação de palavras, de etimologia, de sintaxe, de vício de linguagem, de figuras de sintaxe.]; Azevedo Filho (2002); Parreira (2011); Polachini (2013).

[172]. 1891. CORUJA, Antonio Alvares Pereira. (1806 Porto Alegre - 1889 Rio de Janeiro). Compendio da grammatica da lingua nacional, dedicado á mocidade riograndense [Xgln] [Alunos, Regional - AE]. -ed. [edição posterior, ver também [16] [26] [27] [29] [52] [69] [87] [92]]. Rio de Janeiro: Clássica. 101p. - Sem menção em fontes secundárias, localizada em catálogos de bibliotecas.

[173]. 1891. FREIRE DA SILVA, Augusto (1836 São Luiz do Maranhão - ?). Compendio da grammatica portugueza: para uso de alunos de humanidades, que frequentam a aula de portugues [Xgp] [Alunos -A]. - - ${ }^{\mathrm{a}}$ ed. [edição posterior, , ver também [82] [96] [111] [136] [145] [180]]. São Paulo:-. -p. - Sem menção em fontes secundárias, localizada em catálogos de bibliotecas.

[174]. 1891. RIBEIRO Fernandes, João (Sergipe 1860 - 1934). Grammatica portugueza. $\left(3 .^{\circ}\right.$ anno) [Gp] [Curso superior $/ 3^{\circ}$ ano - D]. $4^{\mathrm{a}}$ ed. [edição posterior, ver também [154] [165] [167] [176] [183] [198]]. Rio de Janeiro: Classica de Alves. 326p. Sem menção em fontes secundárias, localizada em catálogos de bibliotecas.

[175]. 1892. REIS, Luiz Augusto dos (Rio de Janeiro ? - ?). Grammatica portugueza [Gp] [-]. -ed. [Única edição conhecida]. -:-. -p. - Sacramento Blake (1899)

[176]. 1893. RIBEIRO Fernandes, João (Sergipe 1860 - 1934). Grammatica portugueza. (3. ${ }^{\circ}$ anno) $[\mathrm{Gp}]$ [Curso superior $/ 3^{\circ}$ ano - D]. $5^{\mathrm{a}}$ ed. [edição posterior, ver também [154] [165] [167] [174] [183] [198]]. Rio de Janeiro: Livraria Classica de Alves. -p. - Sem menção em fontes secundárias, localizada em catálogos de bibliotecas.

[177]. 1893. RIBEIRO, Julio Cesar Vaughan (1845-1890). Grammatica Portugueza [Gp] [-]. $3^{\mathrm{a}}$ ed. (póstuma) revisada por João Vieira de Almeida [edição posterior modificada, ver também [123] [143] [189] [193] [204]]. São Paulo: Teixeira \& Irmão. 362p. - Sem menção em fontes secundárias, localizada em catálogos de bibliotecas.

[178]. 1893-4. BOSCOLI, José Ventura (1855 Rio de Janeiro - ?). Grammatica Portugueza: estudo raciocinado segundo os principaes hodiernos da sciencia da linguagem [Gpx] [-]. -ed. [Edição mais antiga conhecida, ver também [201]]. Rio de Janeiro:-. - p. - Sacramento Blake (1899)

[179]. 1893. CARNEIRO RIBEIRO, Ernesto (Bahia 1839 - 1920). Elementos de grammatica portugueza [Xgp] [-]. $4^{\text {a }}$ ed. [edição posterior, ver também [139] [149] [170] [197]]. -: -. -p. - Souza (1957)

[180]. 1894. FREIRE DA SILVA, Augusto (1836 S. Luiz do Maranhão - ?). Grammatica portugueza [Gp] [-]. $8^{\mathrm{a}}$ ed. [Edição posterior com título modificado, ver também 
[82] [96] [111] [136] [145] [173]]. São Paulo: J. B. Endrizzi \& C. 442p. - Parreira (2011);

[181]. 1894. PACHECO DA SILVA JR, Manuel (1843 Rio de Janeiro - 1900 Rio de Janeiro); LAMEIRA ANDRADE (? - ?). Grammatica da lingua portugueza para uso dos gymnasios, lyceus e escolas normaes [Glp] [Institucional - G]. $2^{\mathrm{a}}$ ed. [Edição posterior com título modificado, ver também [153]]. Rio de Janeiro: Livraria Clássica de Alves. 737p. - Sem menção em fontes secundárias, localizada em catálogos de bibliotecas.

[182]. 1894. RIBEIRO Fernandes, João (Sergipe 1860 - 1934). Grammatica portugueza: curso primária, $1^{\circ}$ anno de portuguez [Gp] [Instrução Primária - B]. -ed. "nova edição" [Única edição conhecida]. Rio de Janeiro: Alves \& Cia. -p. - Sem menção em fontes secundárias, localizada em catálogos de bibliotecas.

[183]. 1894. RIBEIRO Fernandes, João (Sergipe 1860 - 1934). Grammatica portugueza. (3. ${ }^{\circ}$ anno) $[\mathrm{Gp}]$ [Curso superior $/ 3^{\circ}$ ano - D]. $6^{\mathrm{a}}$ ed. [edição posterior, ver também [154] [165] [167] [174] [176] [198]] Rio de Janeiro: Alves. 328p. - Sem menção em fontes secundárias, localizada em catálogos de bibliotecas.

[184]. 1895. ALVES, Francisco Ferreira de Vilhena (? - ?). Grammatica portugueza... (Curso Superior) [Gp] [Curso superior $/ 3^{\circ}$ ano - D]. -ed. [Única edição conhecida]. Pará: Typ. de Pinto Barbosa e Ca. 268p. - Sem menção em fontes secundárias, localizada em catálogos de bibliotecas.

[185]. 1895. BOSCOLI, José Ventura (1855 Rio de Janeiro - ?). Grammatica da Puericia (lingua vernácula)[Gx] [-]. $1^{a}$ ed. [Única edição conhecida]. Rio de Janeiro:-. p. - Sacramento Blake (1899)

[186]. 1895. COSTA E CUNHA, José Estevão da (Rio de Janeiro ? - ?). Grammatica Pratica do $1^{\circ}$ Gráo contendo muito e variados exercicios praticos de linguagem, lexiologia, syntaxe e recitação, regras de composição etc. Organisada de acordo com o novo plano de ensino primario do $1^{\circ}$ gráo. [Gx] [Instrução Primária, Programa - BH]. $4^{\mathrm{a}}$ ed. [Única edição conhecida]. Rio de Janeiro: J. G. de Azevedo. 141p. - Sacramento Blake (1883)

[187]. 1895. GOMES, Alfredo (? - ?). Grammatica Portugueza adoptada no Gymnasio Nacional, Escola Normal, Collegio Militar, Collegio Abilio, Collegio Moss [Gp] [Institucional - G]. 6a ed. [edição posterior, ver também [151] [196]]. Rio de Janeiro: J. G. de Azevedo. 215p. - Sem menção em fontes secundárias, localizada em catálogos de bibliotecas.

[188]. 1895. MACIEL, Maximino de Araújo (Sergipe ? - ?). Grammatica Descriptiva baseada nas doutrinas modernas [Gx] [-]. $2^{\mathrm{a}}$ ed. [Edição posterior com título modificado, ver também [152]]. Capital Federal:-. 316p. - Nascentes (1939); Castilho (1962); Elia (1975); Azevedo Filho (2002); Parreira (2011); Polachini (2013).

[189]. 1895. RIBEIRO, Julio Cesar Vaughan (1845-1890). Grammatica Portugueza [Gp] [-]. - -a ed. (póstuma) [edição posterior, ver também [123] [143] [177] [193] [204]]. São Paulo: Grande Livraria Paulista. -p. - Sem menção em fontes secundárias, localizada em catálogos de bibliotecas.

[190]. 1896. ALVES, Francisco Ferreira de Vilhena (? - ?). Primeira grammatica da infancia [Xgx] [-]. -ed. [Edição mais antiga conhecida]. Belém: Pacheco \& Barbosa. 84 p. - Sem menção em fontes secundárias, localizada em catálogos de bibliotecas.

[191]. 1896. CARVALHO, Felisberto Rodrigues Pereira de (18?? Rio de Janeiro - ?). Elementos de grammatica portugueza para uso dos alumnos da instrucção primaria [Xgp] [Instrução Primária, Alunos - AB]. -ed. [edição posterior, ver 
também [117] [132] [191]].Rio de Janeiro: Liv. Clássica de Alves. -p. - Sem menção em fontes secundárias, localizada em catálogos de bibliotecas.

[192]. 1896. LUZ, Sabino da (? - ?). Elementos de grammatica para uso das escolas primarias pelo professor [Xg] [Instrução Primária - B]. -ed. [Única edição conhecida]. Pará:-. -p. - Sacramento Blake (1902)

[193]. 1896. RIBEIRO, Julio Cesar Vaughan (1845-1890). Grammatica Portugueza [Gp] [-]. - -4a ed. (póstuma) [edição posterior, ver também [123] [143] [189] [177] [204]]. São Paulo: Teixeira. 364p. - Sem menção em fontes secundárias, localizada em catálogos de bibliotecas.

[194]. 1897. ALVES, Francisco Ferreira de Vilhena (? - ?). Primeira grammatica da infancia e Segunda grammatica da Infância [Xgx] [-]. -ed. [edição posterior modificada [181]] .-:- -p. - Polachini (2013)

[195]. 1897. BANDEIRA, Adelia Ennes (? - ?). Grammatica portugueza practica [Gpx] [-]. $1^{\mathrm{a}}$ ed. [Única edição conhecida]. -:-. -p. - Sem menção em fontes secundárias, localizada em catálogos de bibliotecas.

[196]. 1897. GOMES, Alfredo (? - ?). Grammatica Portugueza [Gp] [-]. 7a ed. "corr e aum" [edição posterior modificada, ver também [151] [187]]. Rio de Janeiro: J. G. de Azevedo. 324p. - Sem menção em fontes secundárias, localizada em catálogos de bibliotecas.

[197]. 1898. CARNEIRO RIBEIRO, Ernesto (Bahia 1839 - 1920). Elementos de grammatica portugueza [Xgp] [-]. $5^{\text {a }}$ ed. [edição posterior, ver também [139] [149] [170] [179]]. -: -. -p. - Souza (1957)

[198]. 1898. RIBEIRO Fernandes, João (Sergipe 1860 - 1934). Grammatica portugueza. $\left(3 .^{\circ}\right.$ anno) [Gp] [Curso superior $/ 3^{\circ}$ ano - D]. $8^{\mathrm{a}}$ ed. [edição posterior, ver também [154] [165] [167] [174] [176] [183]]. -:-. -p. - Sem menção em fontes secundárias, localizada em catálogos de bibliotecas.

[199]. 1898. VIEIRA, Verissimo Ricardo (1855 São Luiz do Maranhão - ?). Instrucção primaria. Grammatica portugueza: curso elementar [Gpx] [Instrução primária B]. -ed. [Única edição conhecida]. Rio de Janeiro:-. 182p. - Sacramento Blake (1902) [E' um livro de 182 pags. do qual disse uma folha do dia: «Resolve este livro, graças à reconhecida competência e longa pratica do magistério do autor, um dos maiores problemas do ensino. O árido estudo da grammatica acha-se alli amenisado e conscienciosamente adequado a capacidade intelloctual das crianças. Para que estas aprendam a matéria pelo methodo intuitivo, cada uma das lições começa por uma serie de phrases fáceis, a que se segue a parte theorica, abrangendo regras simples e claras, ao alcance de quem pela primeira vez vai estudar grammatica. $\mathrm{O}$ autor, como era natural, teve o cuidado de evitar os nomes arrevezados dessa falsa philologia que já foi moda e que difficultava o ensino em vez de facilital-o.»]

[200]. 1899. ALMEIDA, Bibiano Francisco (? - ?). Compêndio de grammatica da lingua portugueza: dedicado aos estudantes rio-grandenses [Xglp] [Alunos, Regional AE]. -ed. [Única edição conhecida]. Rio Grande do Sul: Livreiro Rodolpho José Machado. -p. - Sacramento Blake (1883)

[201]. 1899. BOSCOLI, José Ventura (1855 Rio de Janeiro - ?). Grammatica Portugueza [Gp] [-]. 2 a ed. "corrig. e aug." [edição posterior, ver também [178]]. Rio de Janeiro: Alves. -p. - Polachini (2013)

[202]. 1899. BRITO, Paulino de Almeida (Amazonas 1859 - ?). Grammatica primaria [Gx] [Instrução Primária - B]. -ed. [Única edição conhecida]. Pará:-. -p. Sacramento Blake (1900) [Foi mandada adoptar nas escolas da instrucção publica do estado]

[203]. 1899. MAIA, Zillah do Paço Mattoso Maia (Rio de Janeiro ? - ?). Grammatica da lingua portugueza [Glp] [-]. -ed. [Única edição conhecida]. Rio de Janeiro:-. -p. Sacramento Blake (1902); Polachini (2013) 
[204]. 1899. RIBEIRO, Julio Cesar Vaughan (1845-1890). Grammatica Portugueza [Gp] [-]. $5^{\mathrm{a}}$ ed. (póstuma) cuidadosamente revisada por João Vieira de Almeida [edição posterior, ver também [123] [143] [189] [177] [193], [204]]. São Paulo: Miguel Melillo. -p. - Sem menção em fontes secundárias, localizada em catálogos de bibliotecas.

\section{Sem data ${ }^{133}$}

[205]. s.d. ALBERTO JUNIOR, Philippe Jose (? - ?). Grammatica da Lingua Portugueza [Glp] [-]. -ed. [Outra edição conhecida, ver [43]]. Rio de Janeiro: Moderna. - p. - Sem menção em fontes secundárias, localizada em catálogos de bibliotecas.

[206]. s.d. BORGES, Abilio Cesar (Barão de Macahubas) (1824 Bahia - ?). Epitome da grammatica portugueza [Xgp] [-]. -ed. [Outras edições conhecidas (segundo Sacramento Blake), ver [47] [104]]. Rio de Janeiro:-. $5^{\mathrm{a}}$ p. - Sacramento Blake (1883)

[207]. s.d. (18--) CÂMARA, Paulo Perestrelo da (? - ?). Grammatica das grammaticas da lingua portugueza [Gglp] [-]. -ed. [Única edição conhecida]. Rio de Janeiro:-. -p. - Sem menção em fontes secundárias, localizada em catálogos de bibliotecas.

[208]. s.d. CONY, Augusto Candido Xavier (? - ?). Nova grammatica portugueza de Bento José de Oliveira, modificada e reduzida a compendio elementar: obra adoptada nas escolas publicas pelo governo imperial [Gp] [Institucional, Nacional - FG]. -ed. [Única edição conhecida]. Rio de Janeiro:-. p. - Sacramento Blake (1883)

[209]. s.d. COSTA, Manuel Olympio Rodrigues da (1815 Bahia - ? Bahia). Grammatica portugueza, destinada ao primeiro anno do imperial Collegio Pedro II, apresentada ao conselho director da instrução publica e adoptada nas escolas publicas pelo Governo imperial.. [Gg] [Instrução Primária, Institucional - BG]. ed. [Edição Posterior]. Rio de Janeiro:-. -p. - Sacramento Blake (1900)

[210]. s.d. LEAL, Pedro Nunes (1823 - ?). Noções grammaticaes para uso da infância que freqüenta as escolas do primeiro gráo, extrahidas da grammatica portugueza de Sotero. [Xg] [Instrução Primária - B]. -ed. [Única edição conhecida]. São Luiz do Maranhão:-. -p. - Sacramento Blake (1900)

[211]. s.d.(18--) MARTAGÃO, Bernadino Afonso (1815 Bahia - ? Bahia). Compêndio rudimental de grammatica da lingua portugueza [Xglp] [-]. -ed. [Única edição conhecida]. Bahia: Bahiana. 64p. - Sem menção em fontes secundárias, localizada em catálogos de bibliotecas.

[212]. s.d. MULLER, Daniel Pedro (1785-1841). Principios de grammatica da lingua portugueza [Xglp] [-]. -ed. [Única edição conhecida]. Rio de Janeiro:-. -p. Sacramento Blake (1893)

[213]. s.d. PERTENCE, Francisco Praxedes de Andrade (1823 Rio de Janeiro - 1886); VERGUEIRO, ?. Compendio de grammatica portugueza, accommodado ao uso das escolas [Xgp] [-]. -ed. [Única edição conhecida]. -:-. -p. - Sacramento Blake (1893)

[214]. S.d. PIMENTEL, Francisco da Silveira de Ávila (? - ?). Grammatica portugueza por Caldas Aulete, muito augmentada, principalmente na syntaxe, na orthographia e na prosódia, por F. S. A. Pimentel, adoptada pelo conselho da

\footnotetext{
${ }^{133}$ Não consideradas na análise, pois em geral ela envolve a data de publicação.
} 
instrucção publica para compendio do Io anno do imperial collegio de Pedro II e collegio naval. [Gp] [Instrução Primária, Institucional - BG]. -ed. [Única edição conhecida]. Rio de Janeiro:-. -p. - Sacramento Blake (1895)

[215]. s.d. SOUTO $2^{\circ}$, José Joaquim Vieira (1828 Rio de Janeiro - 1891). Grammatica da lingua portugueza para uso das escolas primarias [Glp] [Instrução Primária B]. $2^{\mathrm{a}}$ ed. [Única edição conhecida]. -:-. -p. - Sacramento Blake (1898)

[216]. s.d. TAVEIRA JÚNIOR, Bernardo (1836 Rio Grande do Sul - ?). Elementos de grammatica portugueza, segundo o systema de Pedro Larousse [Xgp] [-]. -ed. [Única edição conhecida]. -:-. -p. - Sacramento Blake (1893) 


\section{APENDICE B | Fichas Descritivas}

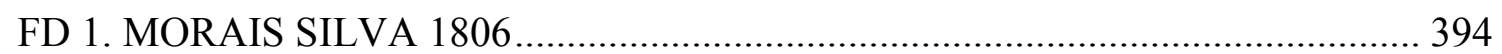

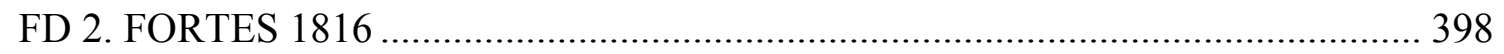

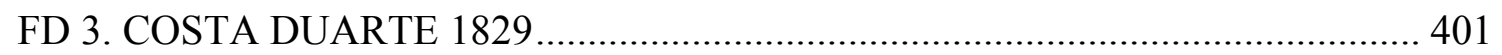

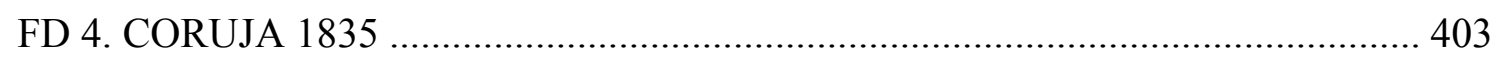

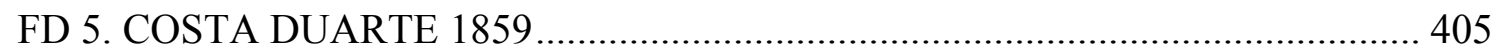

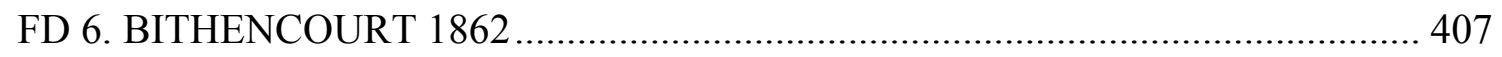

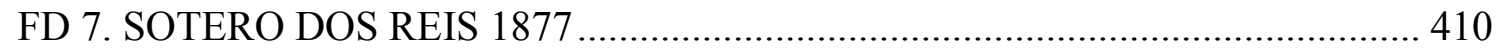

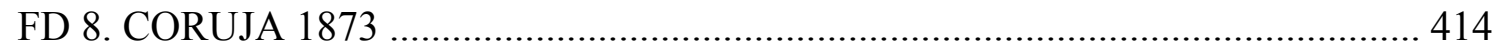

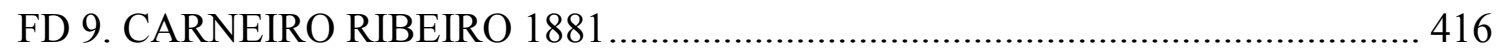

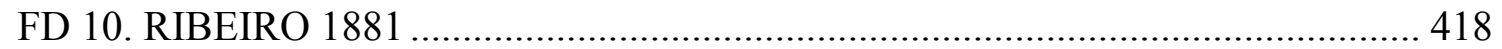

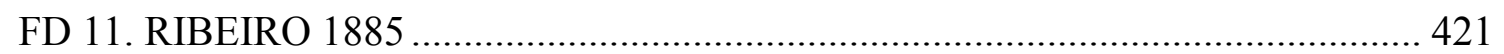

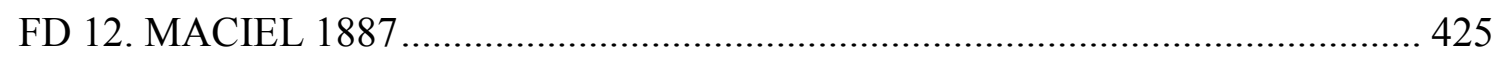

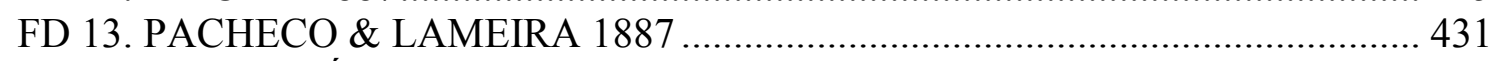

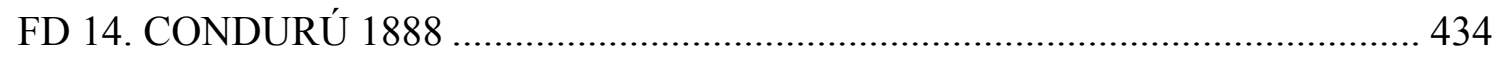

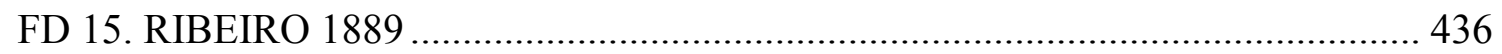

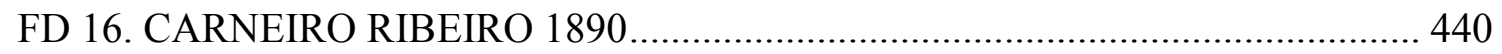

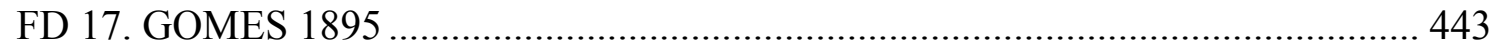

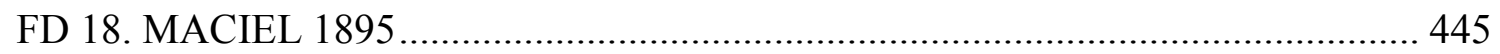




\begin{tabular}{|c|c|}
\hline Título & Epitome da gramática de lingua portugueza \\
\hline $\begin{array}{c}\text { Autor (biodatas e } \\
\text { locais) }\end{array}$ & Antonio de Morais Silva (1755 Rio de Janeiro - 1824 Pernambuco) \\
\hline Ano & 1806 \\
\hline $\begin{array}{c}\text { Local de } \\
\text { impressão }\end{array}$ & Lisboa \\
\hline Tipografia & Off. de Simão Thaddeo Ferreira \\
\hline $\begin{array}{c}\text { Edição / } \\
\text { Impressão }\end{array}$ & $1^{\mathrm{a}}$ \\
\hline $\begin{array}{c}\text { Outras } \\
\text { publicações do } \\
\text { autor }\end{array}$ & $\begin{array}{l}\mathbf{1 7 8 8} \text { - Tradução de História de Portugal, } 3 \text { volumes, "composta em inglez por } \\
\text { uma sociedade de litteratos, trasladada em vulgar com as addições da versão } \\
\text { franceza e notas do traductor portuguez Antônio de Moraes e Silva". Lisboa. Obra } \\
\text { que teve ainda três edições aumentadas: } 1802,1809,1828 \text {. (cf. Sacramento Blake) } \\
\mathbf{1 7 8 8 - 1 7 9 2 ~ - ~ T r a d u c ̧ a ̃ o ~ d e ~ R e c r e a c ̧ o ̃ e s ~ d o ~ h o m e m ~ s e n s i ́ v e l ~ o u ~ c o l l e c c ̧ a ̃ o ~ d e ~ e x e m p l o s ~} \\
\text { verdadeiros e patheticos, nos quaes se dá um curso de moral pratica, conforme as } \\
\text { máximas da sã philosophia. Traduzidos de Mr. Arnaud, } 5 \text { volumes. Teve segunda } \\
\text { edição em } 1821 \text {. Lisboa. } \\
\mathbf{1 7 8 9} \text { - Diccionario da Lingua Portugueza. Lisboa. } \\
\text { s/d - Historia de Portugal desde sua fundação até a convenção de Evora-Monte } \\
\text { com um resumo histórico dos acontecimentos, etc., } 10 \text { volumes, Escrita com José } \\
\text { Maria de Souza Monteiro. Lisboa. }\end{array}$ \\
\hline $\begin{array}{l}\text { Outras edições e } \\
\text { reimpressões } \\
\text { conhecidas }\end{array}$ & $\begin{array}{l}\mathbf{1 8 0 6} \text { - } 1^{\text {a }} \text { edição, publicada como volume independente. Lisboa. } \\
\mathbf{1 8 1 3} \text { - Epítome publicado anexo à } 2^{\mathrm{a}} \text { edição [1 }{ }^{\mathrm{a}} \text { de1789] do Diccionario da Lingua } \\
\text { Portugueza. Lisboa. } \\
\mathbf{1 8 2 3} \text { - Epitome publicado anexo à } 3^{\mathrm{a}} \text { edição do Diccionario da Lingua Portugueza. } \\
\text { Lisboa. } \\
\mathbf{1 8 2 4} \text { - } 1^{\mathrm{a}} \text { edição da Grammatica Portugueza, a qual se assemelha bastante em } \\
\text { conteúdo com o Epítome. Lisboa. } \\
\mathbf{1 8 3 1} \text { - Epítome publicado anexo à } 4^{\mathrm{a}} \text { edição do Diccionario da Lingua Portugueza. } \\
\text { Lisboa. } \\
\mathbf{1 8 3 2} \text { - Edição modificada em diálogo, sem referência a autor(es): Epitome da } \\
\text { grammatica portugueza, composto por Antonio de Morais Silva - E agora mais } \\
\text { resumido, e em fórma de Dialogo, para uso dos Meninos. Publicado em Porto Alegre. } \\
\text { Possivelmente, também se apresenta anexa a edições posteriores do Diccionario, de } \\
1844,1858,1877,1889 \text { e seguintes. } \\
\mathbf{1 9 2 2} \text { - Facsímile da } 2^{\mathrm{a}} \text { edição (1813) do Diccionario da Lingua Portugueza }\end{array}$ \\
\hline $\begin{array}{c}\text { Descrição da } \\
\text { edição consultada }\end{array}$ & $\begin{array}{l}\text { Folha de rosto: Epitome da Grammatica da Lingua Portugueza, composta por } \\
\text { Antonio de Moraes Silva, Natural do Rio de Janeiro. Lisboa. M. DCCCVL. Na Off. } \\
\text { De Simão Thaddeo Ferreira. Com licença da Meza de Desembargo do Paço. Vende- } \\
\text { se na loja Borel Borel, e Companhia. } \\
\text { Epígrafe: Nous avons complique nôtre Grammaire, parce que nous l'avons voulu } \\
\text { faire d'aprés les Grammaires Latines. Nous ne la simplifierons, qu'autant que nous } \\
\text { rappellerons les expressions aux élémens du discours. Condillac, Gramm. P. 2. Chap. } \\
\text { 21. Note (*) pag. 205. Édit. De 1780, á Genève. } \\
\text { Assinatura (última página): Acabou-se este Epitome da Grammatica Portugueza no } \\
\text { Engenho novo da Moribeca em Pernambuco, aos } 15 \text {. De Julho de } 1802 \text {. } \\
\text { Número de páginas: } 165\end{array}$ \\
\hline Sumário da obra & $\begin{array}{l}\text { Folha de rosto (p. I) } \\
\text { Epígrafe de Condillac (p. II) } \\
\text { Ao leitor benevolo (p. III - VIII) } \\
\text { Introducção - (p.9 - 15) } \\
\text { Livro I - Das palavras ou partes da Sentença (p. 15-82) } \\
\text { - Capitulo I - Dos Nomes, ou Substantivos. }(\mathrm{p} .18-21)\end{array}$ \\
\hline
\end{tabular}




\begin{tabular}{|c|c|}
\hline & $\begin{array}{l}\text { - Capitulo II - Dos Adjetivos Articulares. (p.21-30) } \\
\text { - Capitulo III - Dos Adjetivos Attributivos (p.30-33) } \\
\text { - Capitulo IV - De alguns accidentes communs aos nomes, e adjetivos (p.33-46) } \\
\text { §. I. Da formação dos Pluráes de Nomes, e Adjetivos. (p.33-38) } \\
\text { §. II. Dos Generos dos Nomes, e Variações dos Adjetivos respondentes a elles. } \\
\text { (p.39-46) } \\
\quad \text { Dos nomes próprios. (p.39-41) } \\
\quad \text { Dos nomes communs (p. 41-44) } \\
\quad \text { Das variações dos adjetivos accomodadas aos gêneros dos substantivos (p. 44- } \\
\text { 46) } \\
\text { - Capitulo V - Do Verbo, e Seus Modos, Attributos, Tempos, e pessoas (p.47-64) } \\
\text { - Capitulo VI - Dos Adverbios. (p.65-69) } \\
\text { - Capitulo VII - Das Preposições. (p.69-78) } \\
\text { - Capitulo VIII - Das Conjunções. (p.78-79) } \\
\text { - Capitulo IX - Das Interjeições (p.80-81) } \\
\text { Livro II - Da Composição das partes da Sentença entre si, ou Syntaxe. (p.83-121) } \\
\text { - Capitulo I - Introdução (p.83-85) } \\
\quad \text {.I. Da Syntaxe de Concordancia. (p.86-87) } \\
\text { §.II. Da Syntaxe de Regencia (p.88-102) } \\
\text { - Capitulo II - Da Syntaxa, ou Composição Figurada (p.103-114) } \\
\text { - Capitulo III - Das Composições viciosas. (p.115-119) } \\
\text { - Capitulo IV - Dos Sináes Ortograficos, e da Pontuação (p.199-121) } \\
\text { Taboas (p.122-163) } \\
\text { Assinatura: (p.163) } \\
\text { Índice (p.164-165) } \\
\text { Erratas (p.165) }\end{array}$ \\
\hline Objetivo do autor & 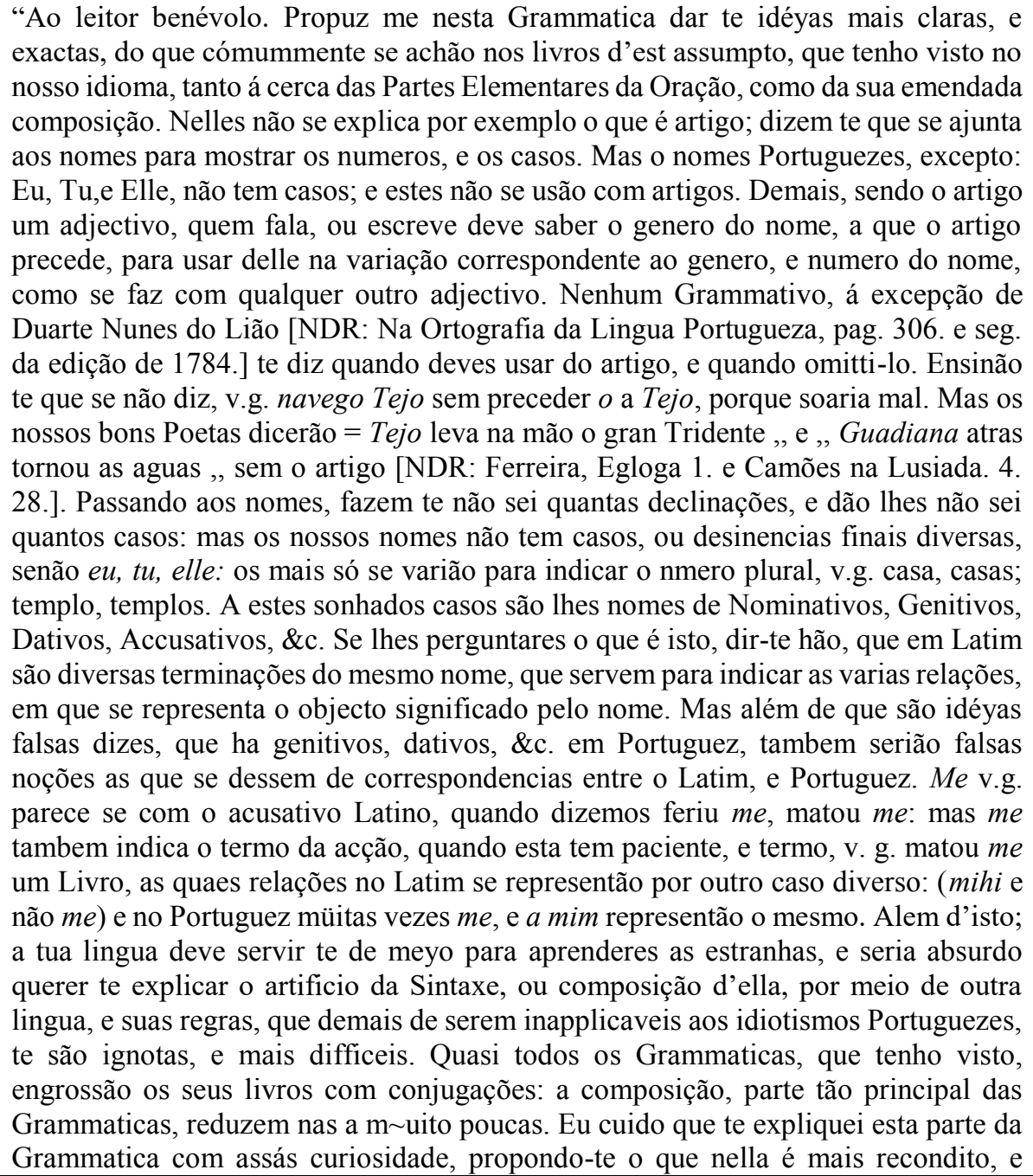 \\
\hline
\end{tabular}


muitos exemplos dos bons autores, que seguramente imites porque tambem a copia delles te fará caïr mais facilmente na intelligencia, e applicação das regras. Ajuntei alg uas observações á cerca de frases, e construcções erradas, ou menos seguidas, para que imitando o bom dos livros Classicos, não sigas tambem os erros, e descuidos, ou o que já hoje se não usa geralmente [NDR: Isto mesmo praticárão na lingua Ingleza o Bispo Lowth na sua Short Introduction to the English Grammar, o Dr. Priestley; e Mr. Wailly em Francez.]. charás neste Compendio alg uas palavras, conjugações, e frases, que te dou como antiquadas, para que não as estranhes nos bons autores, e não as imites. Não te contentes toda vida com as noções elementares deste compendio: Sirvão te sómente de guia para leres os bons autores, que desde os annos de 1500 fixárão, e aperfeiçoárão a nossa lingua, e começárão a escrever tão cultamente, ao menos os seus Dramas, como os Italianos que primeiro o fizerão na Europa moderna, antes que os Francesezes, Inglezes, e outros tivessem Poetas correctos, e elegantes, nem Historiadores, e Oradores dignos de se lerem como os nossos Castanheda, Barros, Couto, Antonio Pinto Pereira, Lucena, Diogo de Paiva d'Andrada, Gil Vicente, Francisco de Sá de Miranda, Antonio Ferreira, e a immortal Lusiada, tão superior aos nossos Epicos em invenção, grandeza e interesse do assumto, elegancia, pureza, e majestade d'estilo, e tão justamente invejada do grande Tasso [NDR: Voltaire diz que Tasso é mui superior a Camões, a pezar das invejas, que o nosso Epico fazia ao Italiano. Mas Voltaire nunca leu Camões senão na má traducção Ingleza do Fanshaw: e se entendia bem a Gerusaleme Liberata, entederia melhor Camões, do que o Tasso, que reconhece a propria inferioridade? Sei que Gabriel Pereira de Castro, na Ulissea, Vasco Mausinho de Quevedo, no Afonso Africano, e a Malaca Conquistada do Menezes tem m uito merecimento; mas estes tiverão em Camões um grande exemplar; e elle só pòde ler para formar o seu estilo, a Castanheda, e Barros; e Jorge Ferreira de Vasconcellos; poetas só a Gil Vicente, e Bernardim Ribeiro; e os do Cancioneiro de Resende; porque Sá de Miranda, e Ferreira \&c. sairão á luz depois de composto o seu poema, ou no mesmo anno, em que se imprimiu. A $1^{\mathrm{a}}$ e a $2^{\mathrm{a}}$ parte dos Palmeirins publicárão se em 1572, anno em que se fizerão as duas rimeiras edições da Lusiada: Camões formou se a si mesmo na sua lingua, e teve felicidade em todos os estilos, quando não foi grande, e sublime. A inveja, que o perseguíra na sua vida, resuscitou ha pouco, preferindo lhe a Ulissea de Gabriel Pereira, e até a Malaca Conquistada. Mas a Ulissea só tem o merecimento da dicção, em que Camões lhe foi mestre, e guia. A fabula é imitada, e copiada das de Homero e Virgilio, e despedia das bellezas dos Originaes, e das suas excellentes allegorias. Quanto á grandeza, e interesse dos assumtos, não é necessario gastar palavras. Se Camões introduziu nomes, e allegorias tiradas das Divindades do Paganismo, elle dá a sua descarga; e deviamos lembrar nos, que no seu tempo o Papa Clemente X., os Cardeaes, \&c. escrevião per Deos atque homines, e usavão os imitadores de Cicero, e Virgilio dos seus modos de dizer conformes á religião dos antigos Romanos. Voltaire censurava a Camões por ter falado ao Reis de Melinde nas navegações de Ulisses, e Eneas, como se um barbaro Africanos das Costas de Zanguebar tivesse lido Homero, e Virgilio. Mas elle mesmo não leu o que Camões diz na est. 111. do Canto 2, para prevenir esta censura; e não sabia, que na India, e especialmente em Ormuz, d'onde se navegava até á Costa de Zanguebar, os Reis ouvião ler Chronicas das historias Romana, e Grega; e não sabia, que pola India toda andavão obras dos Poetas de todas as idades, e de todas as nações, que trazião os Soldados e Elches Europeus, e m uitas vezes os nossos tomárão entre os despojos? Que inverisemelhança ha logo, ou impossibilidade de que um Reis tivesse noticia das navegações de Ulisses, e de Eneas? Quanto ao silencio dos Poetas seus contemporaneos, que todos se regalárão de elogios reciprocos, e nenhum (salvo Diogo Bernardes) derão a Camões, Horario nos predice ha m uito a causa destas desgraças (Epist. I. L. 2.). / Urit enim fulgore suo, qui praegravat artes / Infra se positas / Mas com quanta vergonha dos detractores do nosso Epico não se verifica a predicção do Lyrico Romano, extinctus amabitur idem.]. Delles tirei os exemplos, que te propuz; nelles te exercita; conversa-os de dia e de noite, porque se basta o estudo de um anno para saberes meyãmente um idioma estrangeiro, quando quizeres saber a lingua patria perfeita, e elegantemente, deves estudar toda a vida, e com $\mathrm{m} \sim$ uita reflexão os autores Classicos, notando principalmente as analogias peculiares ao genio do nosso idioma. E deste modo poderás imita los, não repetindo sempre 


\begin{tabular}{|l|l|}
\hline servilmente as suas palavras, e frazes, e remendando com ellas as tuas composições, \\
como alguns tem feito, mas dizendo coisas novas, sem barbarismos, sem \\
Gallicismos, Italianismos, e Anglicismos, como m ui vulgarmente se lem, e mais de \\
ordinarios nas traducções dos pouco versados nas linguas estrangeiras, e talvez \\
menos ainda na sua. Sigamos o exemplo dos bons ingenhos, que na Arcadia \\
Portugueza rescuscitárão as elegancias do idioma materno; aproveitemos as reflexões \\
sobre a lingua, que tem feito alguns membros da Real Academia das Sciencias de \\
Lisboa, e chegaremos a fazer nos capazes de produzir mais copiosas advertencias \\
sobre o artificio, purezas, e elegancias do nosso isioma, do que por hora temos, sendo \\
elle m $\sim$ uito digno de occupar os desvelos dos patriotas eruditos. Assim teremos quem \\
suppra as faltas d'esses Grammaticos, com quem Cesar, Augusto, e o mesmo Cicero \\
estudavão, e conferião, [NDR: V. o Tratado De Illustrib. Grammat. e Sueton nas \\
Vidas de Cesar, e Augusto.] depois de serem já m ui distinctos Oradores, porque \\
ainda que não tinhão em m uito o merecimento de falar correctamente, havião que \\
era grande torpeza não o saberem falar emendada, e puramente. Nam ipsum Latine \\
loqui est illud quidem in magna laude ponendum, sed non tam sua spoute, quam quod \\
est a plerisque neglectum. Non enunm tam praeclarum est scire Latine, quam turpe \\
nescire; neque tam id mihi Oratoris, quam Civis Romani proprium videtur. Cicero. \\
Vale.”
\end{tabular}




\begin{tabular}{|c|c|}
\hline \multicolumn{2}{|r|}{ FD 2. FORTES 1816} \\
\hline Título & Arte de grammatica portugueza que para o uso dos seus discipulos compoz o padre... \\
\hline $\begin{array}{l}\begin{array}{c}\text { Autor (biodatas e } \\
\text { locais) }\end{array} \\
\end{array}$ & $\begin{array}{l}\text { Ignacio Felizardo Fortes (nascido no último quartel do século XVIII, morto em } 1846 \\
\text { em Cabo Frio, província do Rio de Janeiro). }\end{array}$ \\
\hline Ano & 1816 \\
\hline $\begin{array}{l}\text { Local de } \\
\text { impressão }\end{array}$ & Rio de Janeiro \\
\hline Tipografia & Impressão Regia \\
\hline $\begin{array}{c}\text { Edição / } \\
\text { Impressão }\end{array}$ & $2^{\mathrm{a}}$ \\
\hline $\begin{array}{c}\text { Outras } \\
\text { publicações do } \\
\text { autor }\end{array}$ & $\begin{array}{l}\mathbf{1 8 1 8} \text { - Breve exame de pregadores pelo que pertence à arte de rhetorica, extrahido da } \\
\text { obra O pregador instruído. Rio de Janeiro, } 22 \text { pags. in- } 4 \text {. } \\
\mathbf{1 8 1 8 - 1 8 1 9} \text { - Historia do Brazil desde a sua descoberta até } 1810 \text {. Escripta em francez } \\
\text { por Mr. Affonso de Beauchamp e traduzida em portuguez, etc Rio de Janeiro, } 1 \text { o e } 20 \\
\text { tomos in-8" (seriam } 6 \text { tomos no total, de acordo com Sacramento Blake). } \\
\mathbf{1 8 3 4} \text { - Oração, que nas solemnes acções de graças que se celebraram na igreja } \\
\text { parochial de Nossa Senhora da Assumpção da cidado de Cabo Frio, no faustissimo } \\
\text { anniversario natalicio de S. M. I. o Senhor D. Pedro II, recitou, etc. Rio de Janeiro }\end{array}$ \\
\hline $\begin{array}{c}\text { Outras edições e } \\
\text { reimpressões } \\
\text { conhecidas }\end{array}$ & $\begin{array}{l}\text { 1810. Arte de grammatica portugueza, que para uso de seus discípulos compoz o padre } \\
\text { Ignacio Felizardo Fortes. Rio de Janeiro. } 1^{\mathrm{a}} \text {. ed. } \\
\text { 1825. Arte de grammatica portugueza, que para uso de seus discípulos compoz o padre } \\
\text { Ignacio Felizardo Fortes. Rio de Janeiro. } 3^{\mathrm{a}} \text { ed. mais correta e aumentada. } \\
\text { 1844. Arte de grammatica portugueza, que para uso de seus discípulos compoz o padre } \\
\text { Ignacio Felizardo Fortes. Rio de Janeiro. } 9^{\mathrm{a}} \text { ed. mais correta e aumentada } \\
\text { 1851. Arte de grammatica portugueza, que para uso de seus discípulos compoz o padre } \\
\text { Ignacio Felizardo Fortes. Rio de Janeiro. } 10^{\mathrm{a}} \text { ed. } \\
\text { 1855. Arte de grammatica portugueza, que para uso de seus discípulos compoz o padre } \\
\text { Ignacio Felizardo Fortes. Rio de Janeiro. } 12^{\mathrm{a}} \text { ed. } \\
\text { 1862. Arte de grammatica portugueza, que para uso de seus discípulos compoz o padre } \\
\text { Ignacio Felizardo Fortes. Rio de Janeiro. } 14^{\mathrm{a}} \text { ed. }\end{array}$ \\
\hline $\begin{array}{l}\text { Descrição da } \\
\text { edição consultada }\end{array}$ & $\begin{array}{l}\text { Folha de rosto: Arte de grammatica portugueza que para o uso dos seus discipulos } \\
\text { compoz o Padre Ignacio Felizardo Fortes, Professor de Lingua Latina. Rio de Janeiro. } \\
\text { Na impressão regia. 1816. Com Liçença da Mesa do Desembargo do Paço. } \\
\text { Dedicatória: Ao Illustrissimo Senhor Luiz José de Carvalho Mello, do Conselho de } \\
\text { Sua Magestade, seu Desembargador do Paço, Encarregado da direç̧ão geral dos } \\
\text { Estudos. Ill.mo Senhor. Os conhecimentos que enriquecem a alma de V. SENHORIA, } \\
\text { o amor, que V. SENHORIA tem ás Bellas Letras, e sobre tudo o ser V. SENHORIA o } \\
\text { Encarregado da direcção geral dos Estudos, são motivos cheios para que dedique a V. } \\
\text { SENHORIA a presente Arte de Grammatica Portugueza, que compuz para o uso dos } \\
\text { meus discipulos, e que pertendo dar á luz debaixo dos auspicios de V. SENHORIA. } \\
\text { As razões, que me movérão a compô-la, vão exprendidas no Prologo, que a precede; e } \\
\text { essas mesmas creio que são sufficientes, para que ella mereça a protecção de V. } \\
\text { SENHORIA. Deos guarde a V. SENHORIA por muitos annos. DE V. SENHORIA O } \\
\text { mais reverente venerador. Padre Ignacio Felizardo Fortes. } \\
\text { Número de páginas: } 95\end{array}$ \\
\hline Sumário da obra & $\begin{array}{l}\text { Folha de rosto (I) } \\
\text { Dedicatoria (III) } \\
\text { Prologo (V-VIII) } \\
\text { Livro I }(9-19) \\
\text { Capitulo I. Proemio (9-10) } \\
\text { Capitulo II. Da etimologia. Do nome substantivo (10-11) } \\
\text { Capitulo II. Do nome adjetivo (11-12) } \\
\text { Capitulo IV. Do Pronome (12-13) } \\
\text { Capitulo V. Do Participio (13) } \\
\text { Capitulo VI. Dos numeros, e dos casos (14) }\end{array}$ \\
\hline
\end{tabular}




\begin{tabular}{|c|c|}
\hline & $\begin{array}{l}\text { Capitulo VII. Do Artigo (14-15) } \\
\text { Capitulo VIII. Declinação dos nomes substantivos, e dos pronomes Eu, e Tu } \\
\text { Capitulo IX. Da formação do plural dos nomes (18-19) } \\
\text { Capitulo X. Da formação dos Comparativos, e Superlativos (19) } \\
\text { Livro II. Dos generos (20-24) } \\
\text { Capitulo I. Dos generos conhecidos pela significação (20-21) } \\
\text { Capitulo II. Dos generos conhecidos pela terminação (21-24) } \\
\text { Livro III. Dos verbos. (25-59) } \\
\text { Capitulo I. Verbos, e suas divisões (25-26) } \\
\text { Capitulo II. Conjugação do verbo Ter. (26-31) } \\
\text { Capitulo III. Conjugação do verbo Haver. (32-37) } \\
\text { Capitulo IV. Conjugação do verbo Ser. (37-42) } \\
\text { Capitulo V. Primeira Conjugação. Conjugação do verbo Louvar. (42-47) } \\
\text { Capitulo VI. Segunda Conjugação. Conjugação do verbo Combater. (48-53) } \\
\text { Capitulo VII. Terceira Conjugação. Conjugação do verbo Confundir. (54-59) } \\
\text { Livro IV. Preteritos, e participios dos verbos (60-63) } \\
\text { Capitulo I. Dos Preteritos, e participios dos preteritos [] verbos das primeira } \\
\text { Conjugação (60) } \\
\text { Capitulo II. Dos preteritos, e participios do preterito dos verbos da segunda } \\
\text { conjugação. (61-62) } \\
\text { Capitulo III. Dos preteritos, e participios do preteritos dos verbos da terceira } \\
\text { Conjugação. (62) } \\
\text { Capitulo IV. (63) } \\
\text { Livro V. Do adverbior, Conjungação, Interjeição, e Preposição. (64-68) } \\
\text { Capitulo I. Do adverbios (64-65) } \\
\text { Capitulo II. Da Conjunção (66) } \\
\text { Capitulo III. Da Interjeição (67) } \\
\text { Capitulo IV. Da Preposição (68) } \\
\text { Livro VI. Da Prosodia. (69-87) } \\
\text { Capitulo I. Das syllabas primeiras, e medias (69-70) } \\
\text { Capitulo II. Das ultimas syllabas (70-76) } \\
\text { Livro III. Da Syntaxe (77-87) } \\
\text { Capitulo I. Da syntaxe de concordancia (77-80) } \\
\text { Capitulo II. Da syntaxe de regencia (80-82) } \\
\text { Capitulo III. Do dativo (82-83) } \\
\text { Capitulo IV. Do Accusativo (83-84) } \\
\text { Capitulo V. Do Ablativo ( } 84-87) \\
\text { Livros III. Da syntaxe figurada (88-93) } \\
\text { Capitulo I. Das figuras das sentenças (88-92) } \\
\text { Capitulo II. Das figuras de dicção (92-93) } \\
\text { Errata (95) }\end{array}$ \\
\hline Objetivo do autor & $\begin{array}{l}\text { "PROLOGO Sendo o estudo da Lingua materna tão necessario, e tão recommendado } \\
\text { por tantos homens Sábios de todas as Nações cultas; e sendo por isso o da nossa Lingua } \\
\text { determinado nas Aulas de Gramatica Latina pelo Alvará do Senhor Rei D. José, } \\
\text { publicado aos } 30 \text { de Setembro de } 1770 \text {; e sendo igualmente certo, que o estado da } \\
\text { Lingua Latina entre nós he (como o da Grega entre os Romanos) por onde começamos } \\
\text { a carreira das Sciencia, e tão necessarios (por isso mesmo que a Lingua Portugueza he } \\
\text { quasi todos os seus vocabulos derivada da Latina) que por mais que qualquer se canse } \\
\text { em estudar só a Portugueza, jámais poderá nem fallá-a, nem escrevêl-a correctamente, } \\
\text { por não ter os conhecimentos etimologicos, que só se achão na Latina, não sendo ainda } \\
\text { bastantes as regras da Ortografia para escrever com inteira perfeição e vendo eu, que } \\
\text { as Artes POrtuguezas até aqui impressas, [sendo] algumas muito boas, são tão pouco } \\
\text { accommodadas ás Latinas, que conheço por expriencia, que os estudantes, de ordinario } \\
\text { impuberes, e por isso faltos de intelligencia para poderem combinar as regras } \\
\text { Grammaticaes de huma, e outra Lingua, passando a aprender as da Latina, [sendo] pela } \\
\text { maior parte as mesmas da Portugueza, se persuadem, que estão aprendendo regras } \\
\text { inteiramente novas: resolvi-me a reduzir as do grande Padre Antonio Pereira de } \\
\text { Figueiredo, hoje seguida nas Aulas de Grammatica Latina destes Reinos; resolvi-me, } \\
\text { digo, a fazer dellas huma Arte para o uso dos meus Discipulos, e dál-a á luz, tanto para } \\
\text { evitar o trabalho das copias manuscriptas, que sempre estão sujeitas a erros, e }\end{array}$ \\
\hline
\end{tabular}


necessitando de hum novo trabalho de correcção, como para utilidade tambem da mocidade Portugueza, que ella se quizer aproveitar. Segui por isso, o mais que me foi possivel, as mesmas definições, e regras, e até os mesmos exemplos do Padre Pereira. O tratado da etimologia he quasi todo o mesmo. Nas declinações dos nomes (não fallando na inteira differença, que há nas duas Linguas por attender á brevidade, omitti as declinações de adjectivos, e pronomes (excepto os pronomes $E u$, e $T u$ ) taanto por que com summa facilidade se declinão pelos dois substantivos, que servem de exemplo, quer com artigos, quer com proposições; co[] por que no uso quotidiano de declinar nomes (o que nas Aulas se chama fazer themas) fica-se sabendo com facilidade aquillo, que custaria mais tempo, e mais trabalho a decorar. O mesmo observei nos verbos pois só appresentos os tres auxiliares, e as tres conjugações regulares: os irregulares, sabidos aquelles, com muita facilidade se sabem, conjugandose em themas todos os dias, e na correcção delles mostrando o Mestre, onde se apartão da regularidade das conjugações. A syntaxe he quadi toda a mesma do Padre Pereira: e deste modo tendo hum estudante aprendido os preceitos Grammaticaes da Lingua Portugueza, e passando para a Latina, aprende os precietos desta em metade, e ainda [] menos de metade do tempo, em que alias os poderia aprender; e até com muito mais facilidade, e percepção, por ir entrando no conhecimento de huma Lingua estranha pelos mesmos principios, por onde aprendeo a sua. Conhecerá finalmente o Público respeitavel, que se não fiz huma ob[] inteiramente digna da sua acceitação, ao menos foi o meu trabalhos dirigido á sua utilidade." 


\begin{tabular}{|c|c|}
\hline \multicolumn{2}{|r|}{ FD 3. COSTA DUARTE 1829} \\
\hline Título & $\begin{array}{l}\text { Compendio da grammatica portugueza: para uso das escolas de primeiras } \\
\text { letras, ordenado segundo a doutrina dos melhores grammaticos e } \\
\text { offerecido... }\end{array}$ \\
\hline $\begin{array}{c}\text { Autor (biodatas e local de } \\
\text { nascimento e morte) }\end{array}$ & Padre Antonio da Costa Duarte (?-?) \\
\hline Ano & 1829 \\
\hline Local de impressão & Maranhão \\
\hline Tipografia & Typographia Nacional \\
\hline Edição / Impressão & $1^{\mathrm{a}}$ \\
\hline Acesso ao texto & $\begin{array}{l}\text { Biblioteca Brasiliana Mindlin - USP } \\
\text { CEDOCH (fotos) }\end{array}$ \\
\hline $\begin{array}{l}\text { Outras publicações do } \\
\text { autor }\end{array}$ & Não conhecemos. \\
\hline $\begin{array}{l}\text { Outras edições e } \\
\text { reimpressões conhecidas }\end{array}$ & $\begin{array}{l}\text { 1829. } 1^{\mathrm{a}} \text { edição: Compendio da grammatica portugueza: para uso das escolas } \\
\text { de primeiras letras, ordenado segundo a doutrina dos melhores gramáticos. } \\
\text { Maranhão: Tipografia Nacional. } \\
\text { 1840. } 2^{\mathrm{a}} \text { edição: Compêndio de grammatica philosophica da lingua } \\
\text { portugueza, escolhido pela congregaçâo do lyceu do Maranhão para uso do } \\
\text { mesmo lyceu. Maranhão. } \\
\text { 1853. } 3^{\mathrm{a}} \text { edição: Compendio da grammatica philosophica da lingua } \\
\text { portugueza, escolhida pela congregacao do lyceo do maranhao. Maranhao: } \\
\text { Na Livraria do Editor F Fructuoso Ferreira. } \\
\mathbf{1 8 5 9 .} 4^{\mathrm{a}} \text { edição: Compendio da grammatica philosophica da lingua } \\
\text { portugueza Escolhida pela Congregação do Lycêo do Maranhão para o uso } \\
\text { do mesmo Lycêo, e das aulas de primeiras lettras da provincia. Maranhão: } \\
\text { Tipografia do Frias } \\
\mathbf{1 8 7 7 .} 6^{\mathrm{a}} \text {. edição: Compendio da grammatica philosophica da lingua } \\
\text { portugueza Escolhida pela Congregação do Lycêo do Maranhão para o uso } \\
\text { do mesmo Lycêo, e das aulas de primeiras lettras da província. Maranhão: } \\
\text { Edictor Antonio Pereira Ramos D’Almeida. }\end{array}$ \\
\hline $\begin{array}{l}\text { Descrição da edição } \\
\text { consultada }\end{array}$ & 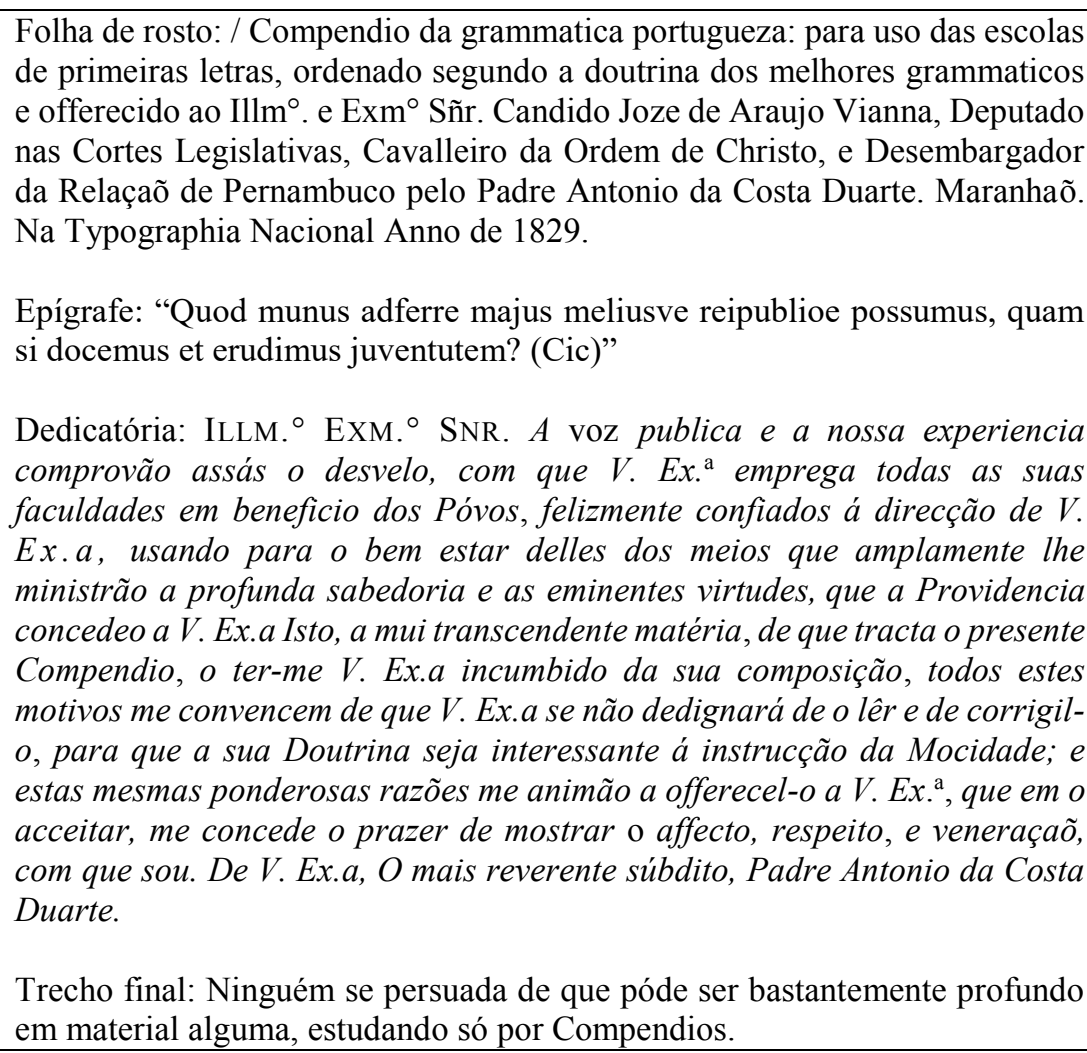 \\
\hline
\end{tabular}




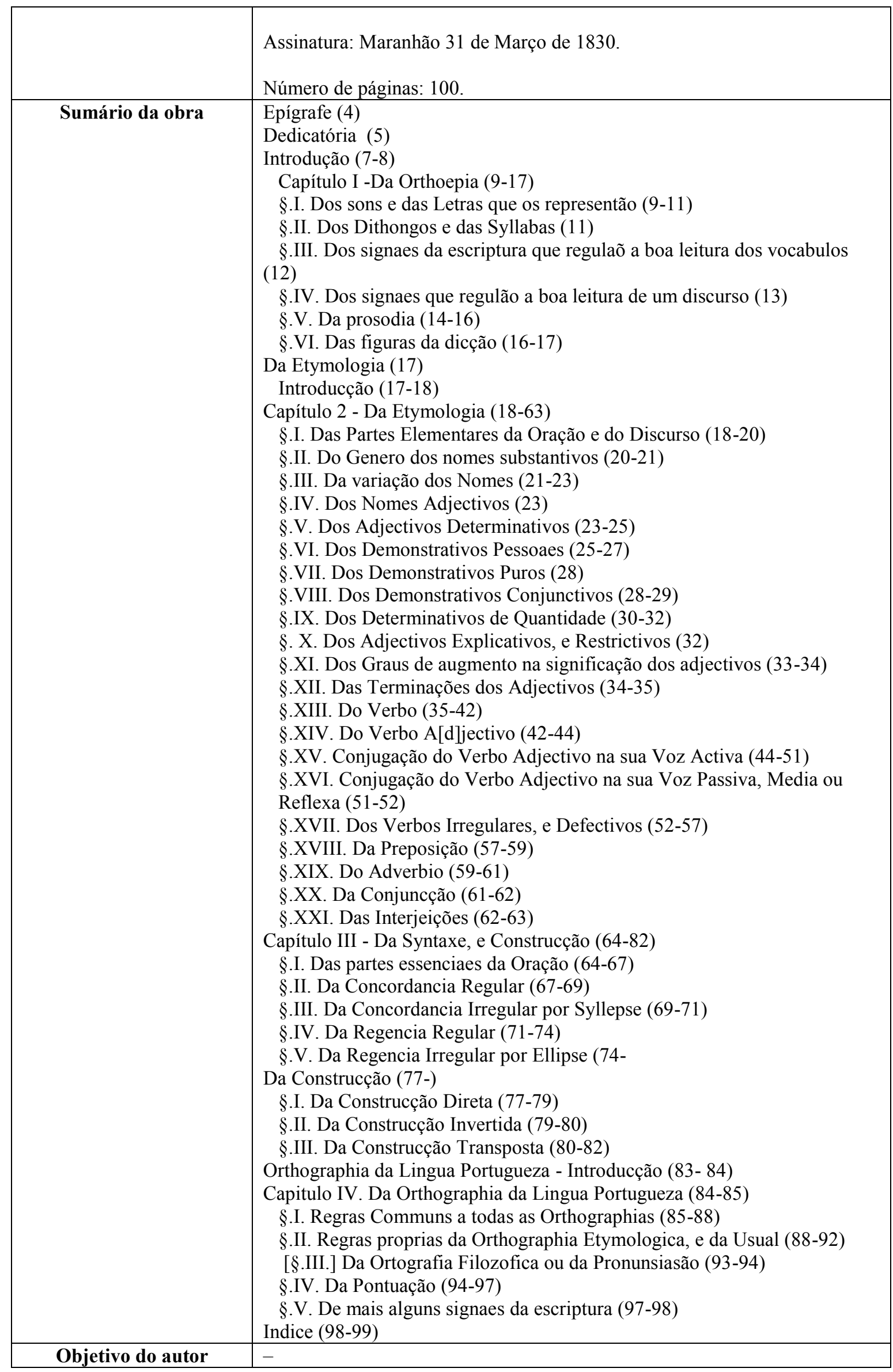




\begin{tabular}{|c|c|}
\hline \multicolumn{2}{|r|}{ FD 4. CORUJA 1835} \\
\hline Título & $\begin{array}{l}\text { Compendio da Grammatica da Lingua Nacional: dedicado á mocidade rio- } \\
\text { grandense }\end{array}$ \\
\hline $\begin{array}{l}\text { Autor (biodatas e local de } \\
\text { nascimento e morte) }\end{array}$ & Antonio Alvares Pereira Coruja (1806 Porto Alegre-1889 Rio de Janeiro) \\
\hline Ano & 1835 \\
\hline Local de impressão & Porto Alegre \\
\hline Tipografia & Typographia de V. F. de Andrade \\
\hline Edição / Impressão & $1^{\mathrm{a}}$ \\
\hline $\begin{array}{l}\text { Outras obras do mesmo } \\
\text { autor }\end{array}$ & $\begin{array}{l}\mathbf{1 8 3 8} \text { - Manual dos estudantes de latim, dedicado á mocidade brazileira. Rio } \\
\text { de Janeiro. "Foi depois adoptado no collegio de Pedro II. Idem, sendo } \\
\text { augmentado com um appendice de pretéritos e supinos." } \\
\mathbf{1 8 4 8} \text { - Compêndio de ortographia da lingua nacional, dedicado a sua } \\
\text { magestade o senhor dom Pedro II. Rio de Janeiro. } \\
\mathbf{1 8 5 0} \text { - Arithmetica para meninos, contendo Unicamente o que é necessário e } \\
\text { se pôde ensinar nas aulas de primeiras lettras. Rio de Janeiro. (segunda edição } \\
\text { de } 1861 \text {, segundo Sacramento Blake) } \\
\mathbf{1 8 5 2} \text { - Collecção dos vocábulos usados na provincia de S.Pedro do Rio } \\
\text { Grande do Sul. Revista do instituto histórico, tomo } 15^{\circ}, 1852 \text {, } \\
\mathbf{1 8 5 2} \text { - Manual de ortographia da lingua nacional. Rio de Janeiro. } \\
\text { (Sacramento Blake: "E' a mesma obra acima, porém resumida ás suas } \\
\text { principaes regras. Idem, sendo a segunda edição de } 1861 \text {, } 47 \text { pags. in- } 8^{\circ} \text {, e a } \\
\text { terceira de } 1866 . ") \\
\mathbf{1 8 5 5} \text { - Liçôes de historia do Brazil, adaptadas á leitura das escolas. Rio de } \\
\text { Janeiro. } \\
\mathbf{1 8 6 1} \text { - Compêndio da grammatica latina do padre Antônio Pereira de } \\
\text { Figueiredo com additamentos e notas. Rio de Janeiro. (Sacramento Blake: } \\
\text { "Segunda edição, } 1861 \text {, } 111 \text { pags. in- } 8^{\circ} \text { ") } \\
\mathbf{1 8 8 1} \text { - Antigudlhas e reminiscencias de Porto-Alegre. Rio de Janeiro. }\end{array}$ \\
\hline $\begin{array}{l}\text { Outras edições e } \\
\text { reimpressões conhecidas }\end{array}$ & 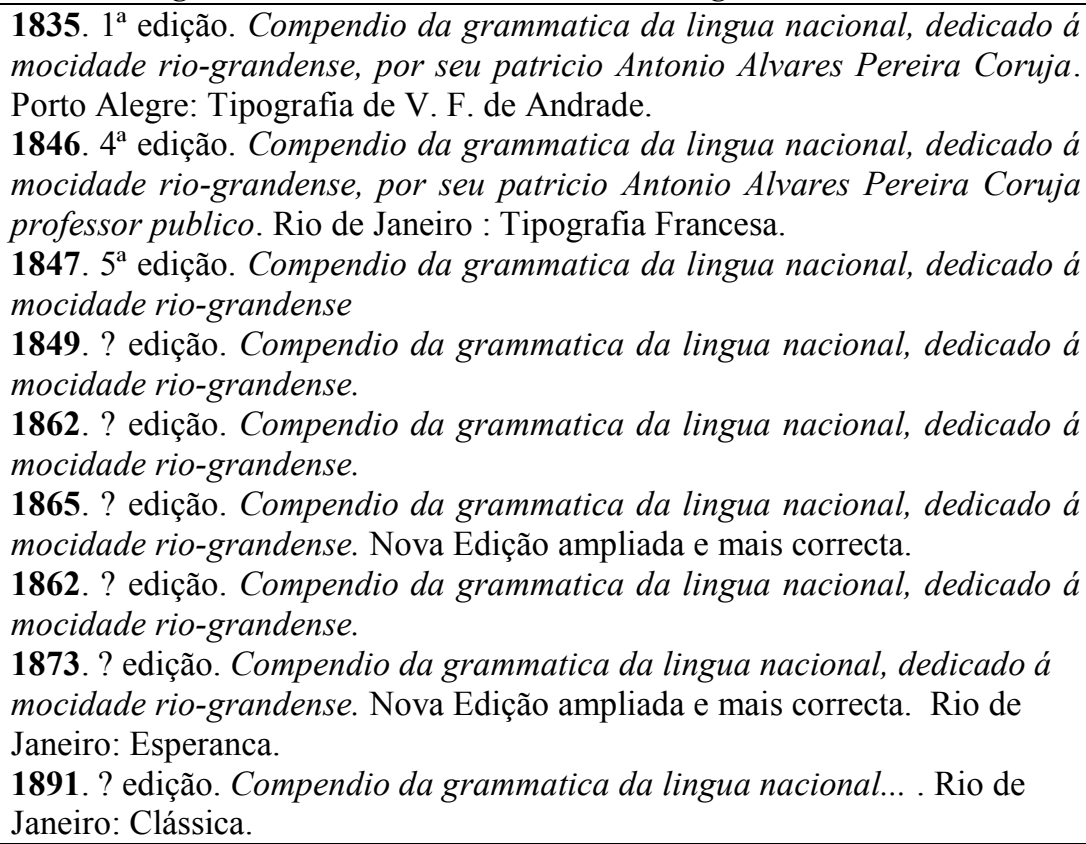 \\
\hline $\begin{array}{l}\text { Descrição da ediçãa } \\
\text { consultada }\end{array}$ & $\begin{array}{l}\text { Folha de rosto: Compendio da Grammatica da Lingua Nacional: dedicado á } \\
\text { mocidade rio-grandense por seu patrício Antonio Alvares Pereira Coruja. } \\
\text { Porto Alegre: } 1835 \text {. Typographia de V. F. de Andrade, Rua da Ponte. } \\
\text { Assinatura: Ponho este Compendio debaixo da proteção das Leis, que } \\
\text { garantem a propriedade aos Editores. Antonio Alvares Pereira Coruja. } \\
\text { Typographia de V. F. de Andrade. }\end{array}$ \\
\hline
\end{tabular}




\begin{tabular}{|l|l|}
\hline & Número de páginas: 68. \\
\hline Sumário da obra & Proemio (p.3-4) \\
& Parte Primeira - Da Etymologia (p.4-44) \\
& Artigo (4) \\
& Nome (4-9) \\
Do genero dos Nomes (9-10) \\
Verbo (10-39) \\
Conjugação dos verbos regulares (-38) \\
Dos verbos irregulares (38-39) \\
Participio (39-40) \\
Adverbio (40-42) \\
Conjunção (42-43) \\
Preposição (43-44) \\
Interjeição (44) \\
Parte Segunda - Syntaxe (45-59) \\
Circunstancias (46-51) \\
Verbo Passivo (51-52) \\
Syntaxe Figurada (52-55) \\
Observações necessarias aos principiantes para facilidade da regencia (55- \\
59) \\
& Parte terceira - Da prosodia (59-61) \\
& Figuras de dicção (60-61) \\
& Parte quarta - Da ortographia (62-68) \\
& Observação (65) \\
& Pontuação (66-68) \\
\hline
\end{tabular}




\begin{tabular}{|c|c|}
\hline \multicolumn{2}{|r|}{ FD 5. COSTA DUARTE 1859} \\
\hline Título & Compendio da grammatica philosophica da lingua portugueza \\
\hline $\begin{array}{l}\text { Autor (biodatas e local de } \\
\text { nascimento e morte) }\end{array}$ & Padre Antonio da Costa Duarte (?-?) \\
\hline Ano & 1859 \\
\hline Local de impressão & Maranhão \\
\hline Tipografia & Typ. do Frias \\
\hline Edição / Impressão & $4^{\mathrm{a}}$ \\
\hline Acesso ao texto & $\begin{array}{l}\text { Biblioteca Brasiliana Mindlin - USP } \\
\text { CEDOCH (fotos) }\end{array}$ \\
\hline $\begin{array}{c}\text { Outras obras do mesmo } \\
\text { autor }\end{array}$ & Não conhecemos. \\
\hline $\begin{array}{c}\text { Outras edições e } \\
\text { reimpressões conhecidas }\end{array}$ & $\begin{array}{l}\text { 1829. } 1^{\mathrm{a}} \text { edição: Compendio da grammatica portugueza: para uso das escolas } \\
\text { de primeiras letras, ordenado segundo a doutrina dos melhores gramáticos. } \\
\text { Maranhão: Tipografia Nacional. } \\
\text { 1840. } 2^{\mathrm{a}} \text { edição: Compêndio de grammatica philosophica da lingua } \\
\text { portugueza, escolhido pela congregaçâo do lyceu do Maranhão para uso do } \\
\text { mesmo lyceu. Maranhão. } \\
\text { 1853. } 3^{\mathrm{a}} \text { edição: Compendio da grammatica philosophica da lingua } \\
\text { portugueza, escolhida pela congregacao do lyceo do maranhao. Maranhao : } \\
\text { Na Livraria do Editor F Fructuoso Ferreira. } \\
\mathbf{1 8 5 9 .} 4^{\mathrm{a}} \text { edição: Compendio da grammatica philosophica da lingua } \\
\text { portugueza Escolhida pela Congregação do Lycêo do Maranhão para o uso } \\
\text { do mesmo Lycêo, e das aulas de primeiras lettras da província. Maranhão : } \\
\text { Tipografia do Frias } \\
\mathbf{1 8 7 7 .} 6^{\mathrm{a}} \text {. edição: Compendio da grammatica philosophica da lingua } \\
\text { portugueza Escolhida pela Congregação do Lycêo do Maranhão para o uso } \\
\text { do mesmo Lycêo, e das aulas de primeiras lettras da província. Maranhão: } \\
\text { Edictor Antonio Pereira Ramos D’Almeida. }\end{array}$ \\
\hline $\begin{array}{l}\text { Descrição da edição } \\
\text { consultada }\end{array}$ & $\begin{array}{l}\text { Folha de rosto: Compêndio da Grammatica Philosophica da Lingua } \\
\text { Portugueza escolhida pela Congregação do Lycêo do Maranhão para o uso } \\
\text { do mesmo Lycêo, e das aulas de primeiras lettras da provincia, pelo Padre } \\
\text { Antonio da Costa Duarte, lente da grammatica philosophica da lingua, e } \\
\text { analyse dos nossos classicos. } 4^{\text {a }} \text { edicção. Maranhão. Impressa na typ. e á } \\
\text { venda na livraria do Frias. 8. Rua dos Barbeiros, } 8.1859 . \\
\text { 121p. }\end{array}$ \\
\hline Sumário da obra & $\begin{array}{l}\text { Introdução (5-6) } \\
\text { Da Orthoepia (7-20) } \\
\text { §.I. Dos sons e das Letras que os representão (7-10) } \\
\text { §.II. Dos Dithongos e das Syllabas (10-13) } \\
\text { §.III. Dos signaes da escriptura que regulaõ a boa leitura dos vocabulos } \\
\text { (12) } \\
\text { §.IV. Dos signaes que regulão a boa leitura de um discurso (14-15) } \\
\text { §.V. Da prosodia (15-18) } \\
\text { §.VI. Das figuras da dicção (18-20) } \\
\text { Capítulo } 2 \text { - Da Etymologia (20-85) } \\
\text { §.I. Das Partes Elementares da Oração e do Discurso (20-24) } \\
\text { §.II. Do Genero dos nomes substantivos (24-25) } \\
\text { §.III. Da variação dos Nomes (25-27) } \\
\text { §.IV. Divisão dos Nomes Adjectivos (27-28) } \\
\text { §.V. Dos Adjectivos Determinativos (28-30) } \\
\text { §.VI. Dos Demonstrativos Pessoaes (30-32) } \\
\text { §.VII. Dos Demonstrativos Puros (32-33) } \\
\text { §.VIII. Dos Demonstrativos Conjunctivos (33-35) } \\
\text { §.IX. Dos Determinativos de Quantidade (35-37) } \\
\text { §.X. Dos Adjectivos Explicativos, e Restrictivos (37-38) } \\
\text { §.XI. Dos Graus de augmento na significação dos adjectivos (38-40) }\end{array}$ \\
\hline
\end{tabular}




\begin{tabular}{|c|c|}
\hline & $\begin{array}{l}\text { §.XII. Das Terminações dos Adjectivos (40-41) } \\
\text { §.XIII. Do Verbo (41-52) } \\
\text { Conjugação dos verbos ser, estar, haver e ter (52-60) } \\
\text { §.XIV. Do Verbo A[d]jectivo (61-65) } \\
\text { §.XV. Conjugação do Verbo Adjectivo na sua Voz Activa (66-74) } \\
\text { §.XVI. Conjugação do Verbo Adjectivo na sua Voz Passiva, Media ou } \\
\text { Reflexa (75-76) } \\
\text { §.XVII. Dos Verbos Irregulares, e Defectivos (77-78) } \\
\text { §.XVIII. Da Preposição (78-80) } \\
\text { §.XIX. Do Adverbio (80-83) } \\
\text { §.XX. Da Conjuncção (83-84) } \\
\text { §.XXI. Das Interjeições (84-85) } \\
\text { Da Syntaxe e Construção (85-105) } \\
\text { §.I. Dos elementos essenciaes da Oração (86-88) } \\
\text { §.II. Da Concordancia Regular (89-91) } \\
\text { §.III. Da Concordancia Irregular por Syllepse (91-93) } \\
\text { §.IV. Da Regencia Regular (93-96) } \\
\text { §.V. Da Regencia Irregular por Ellipse (96-99) } \\
\text { Da Construção (99-105) } \\
\text { §.I. Da Construçãa Direta (100-101) } \\
\text { §.II. Da Construcção Invertida (101-102) } \\
\text { §.III. Da Construcção Transposta (102-103) } \\
\text { Orthographia da Lingua Portuguesa (105) } \\
\text { Introdução (105-106) } \\
\text { Da orthographia da lingua portugueza (106- } \\
\text { §.I. Regras Communs a todas as Orthographias (107-111) } \\
\text { §.II. Regras proprias da Orthographia Etymologica, e da Usual (111-115) } \\
\text { [§.III.] Da Ortografia Filozofica ou da Pronunsiasão (116-117) } \\
\text { §.IV. Da Pontuação (117-120) } \\
\text { §.V. De mais alguns signaes da escriptura (120-121) } \\
\text { Indice (122-123) }\end{array}$ \\
\hline Objetivo do autor & - \\
\hline
\end{tabular}




\begin{tabular}{|c|c|}
\hline Título & Epitome da grammatica philosophica da lingua portugueza \\
\hline $\begin{array}{l}\text { Autor (biodatas e local de } \\
\text { nascimento e morte) }\end{array}$ & Raymundo Antonio da Camara Bithencourt \\
\hline Ano & 1862 \\
\hline Local de impressão & Rio de Janeiro \\
\hline Tipografia & Eduardo \& Henrique Laemmert \\
\hline Edição / Impressão & $1^{\mathrm{a}}$ \\
\hline Acesso ao texto & $\begin{array}{l}\text { IEL / Unicamp } \\
\text { CEDOCH (fotos) }\end{array}$ \\
\hline $\begin{array}{c}\text { Outras obras do mesmo } \\
\text { autor }\end{array}$ & $\begin{array}{l}\text { 1861. (Tradução). As azas da mosca: comédia em três atos de Victorien } \\
\text { Sardou. Rio de Janeiro. } \\
\text { 1862. (Tradução do francês) O alforge do contador. Biblioteca moral da } \\
\text { infância. Escolha de mais de cem contos, parabolas e historiazinhas para os } \\
\text { meninos de ambos os sexos, de A. Aveline. Rio de Janeiro. } \\
\text { 1862. (Tradução do francês). Legenda para os meninos, contendo: “O Judêo } \\
\text { errante, a Historia de Grisolides e o Bom rei Dagoberto", de P. de Boiteau. } \\
\text { Rio de Janeiro. } \\
\text { 1862. (Tradução do francês) Eustaquio: episódio dos primitivos tempos do } \\
\text { Cristianismo por Christovam Schimidt, seguido do conto moral "A família } \\
\text { christã". Rio de Janeiro. } \\
\text { 1862. (Tradução do francês) O fidalgo sem dinheiro: comédia em dois atos } \\
\text { de Dumanoir e Lafargue. Rio de Janeiro. } \\
\text { 1863. Trabalhos oratorios e litterarios de Frei Francisco de Monte-Alverne. } \\
\text { Rio de Janeiro. } \\
\text { s.d. (Tradução) O arrependimento: comédia em quatro atos de Edmond } \\
\text { About e E. M. Nojac. Rio de Janeiro. } \\
\text { 1892. (Tradução do Francês) Novo espelho de amor ou arte de fazer a corte } \\
\text { ás mulheres e conquistar-lher o coração. Conselhos aos homens para que } \\
\text { sejam victoriosos no amor e consigam concluir um feliz hymenêo. Rio de } \\
\text { Janeiro. }\end{array}$ \\
\hline $\begin{array}{c}\text { Outras edições e } \\
\text { reimpressões conhecidas }\end{array}$ & Não conhecemos. \\
\hline $\begin{array}{l}\text { Descrição da edição } \\
\text { consultada }\end{array}$ & $\begin{array}{l}\text { Folha de rosto: Epitome da grammatica philosophica da lingua portugueza } \\
\text { composto por Camara Bithencourt (Raymundo) natural do Rio de Janeiro - } \\
\text { Rio de Janeiro. Publicado e á venda em casa dos Editores-proprietarios. } \\
\text { Eduardo \& Henrique Laemmert - Rua da Quitanta, } 77-1862 \text {. } \\
\text { Número de páginas: } 144 \\
\text { Há ainda no final da obra um catálogo da E. \& H. Laemmert. }\end{array}$ \\
\hline Sumário da obra & $\begin{array}{l}\text { Prefácio (V-VIII) } \\
\text { Epitome da grammatica philosophica da lingua portuguesa }(1-4) \\
\text { Capítulo I - Da orthoepia }(5-21) \\
\S 1^{\circ} \text {. Dos sons e das letras que os representão }(5-6) \\
\S 2^{\circ} \text {. Dos diphthongos e das syllabas }(6-10) \\
\S 3^{\circ} \text {. Dos signaes da escriptura que determinão a boa leitura dos vocabuloa } \\
(10-13) \\
\S 4^{\circ} \text {. Dos signaes que regulão a boa leitura de um discurso }(13-14) \\
\S 5^{\circ} \text {. Da prosódia (14-17) } \\
\S 6^{\circ} \text {. Das figuras da dicção }(18-19) \\
\S 7^{\circ} \text {. Dos vicios da dicção }(20-21) \\
\text { Capitulo II - Orthographia (22-49) } \\
\S 1^{\circ} \text {. Regras communs aos tres systemas orthographicos }(24-33) \\
\S 2^{\circ} \text {. Regras proprias da Orthographia Etymologica e usual }(33-40) \\
\S 3^{\circ} \text {. Da ortografia ?lozo?ea ou da pronunciação }(40-43) \\
\S 4^{\circ} \text {. Da pontuação (44-49) } \\
\text { Capitulo III - Da Etymologia (50-) } \\
\S 1^{\circ} \text {. (p.50-56) }\end{array}$ \\
\hline
\end{tabular}




\begin{tabular}{|c|c|}
\hline & 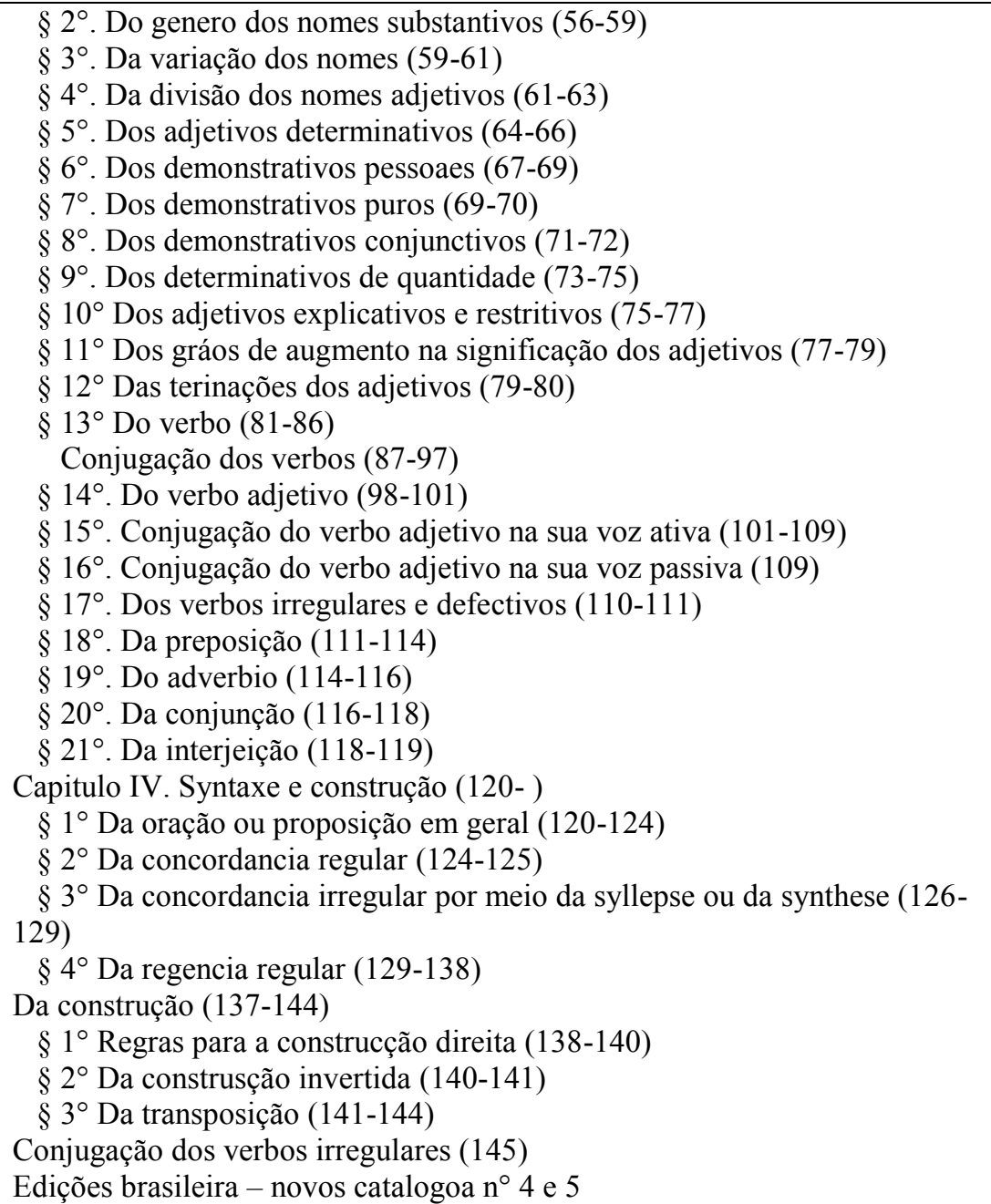 \\
\hline Objetivo do autor & $\begin{array}{l}\text { "PREFACIO O Epitome da Grammatica Philosophica da Lingua Portugueza } \\
\text { que organisamos, não é por certo um trabalho perfeito, temos consciencia } \\
\text { disto, mas tambem temos consciencia de que não é elle em nada somenos dos } \\
\text { que se tem publicado até agora. No Maranhão o Sr. padre Antonio da Costa } \\
\text { Duarte deu lume a um compendio que tem muitas cousas aproveitaveis, } \\
\text { algumas das quaes adoptamos no presente epitome; mas sem fazer injustiça } \\
\text { áquelle grammatico, é força reconhecer que grande numero das suas } \\
\text { definições, das suas doutrinas e opiniões, ao menos no nosso modo de pensar } \\
\text { merecem reparo e não podem ser aceitas. Quando o Sr. Costa Duarte se aparta } \\
\text { do insigne Soares Barbosa, sustenta doutrinas que nos parecem pouco } \\
\text { grammaticaes. Outros compendios temos examinado que não são mais } \\
\text { escoimados do que o de que tratamos. Nosso epitome não se aparta da } \\
\text { grammatica de Soares Barbosa, senão naquelles pontos em que o illustrado } \\
\text { philologo nos pareceu menos fundado: então em algumas notas damos a razão } \\
\text { da nossa discrepancia. Muitas das nossas definições e regras são extrahidas } \\
\text { textualmente daquella grammatica: nisto não sao menos inconveniente, } \\
\text { porque repetir o que é bom em materias de ensino, e adapta-lo a um } \\
\text { compendio é já fazer alguma coisa util. Dous motivos muito fortes levárão- } \\
\text { nos principalmente a organisar este epitome: o } 1^{\circ} \text {, achar-se esgotada toda a } \\
\text { edição da grammatica de S. Barbosa, e não ser esta encontrada á venda em } \\
\text { livraria alguma; e o } 2^{\circ} \text {, não se esssa mesma grammatica, por demasiado } \\
\text { diffusa, propria para o ensino nas aulas: será um excellente expositor, mas não } \\
\text { é compendio, e nas aulas cumpre que as materias sejão ensinadas em livros } \\
\text { onde os preceitos estejão compendiados. Um outro motivo, e perdôe-se-nos o } \\
\text { orgulho, actuou tambem poderosamente em nós na composição deste } \\
\text { epitome, a saber: a necessidade que tinhamos de provar solemnemente nossas } \\
\text { habilitações, para bem exercermos um emprego em qualquer Repartição }\end{array}$ \\
\hline
\end{tabular}


publica, um desses barateados á ignorancia, e arranjados pelo patronato; um emprego, emfim, que nos ponha a abrigo das primeiras necessidades da vida, já que o governo do paiz (não nos refirimos aos ministerios actual, ao qual por ora nada temos pedido) nunca se dignou de attender-nos. Acreditamos que o ministerio presidido pelo venerando Marquez de Olinda, tão amigo e protector das letras como é, nos fará justiça, e não consentirá que um moço que reune algumas habilitações, com as quaes póde até prestar bons serviões em uma secretaria d'estado, continue a viver sem um emprego e sem meios de prover á subsistencia de sua familia. A respeito da adopção deste compendio para as aulas publicas, esperamos que será decretada porque confiamos muito nas luzes do nosso conselho de instrucção. As pessoas doutas decidiráõ do merito desta publicação: quanto aos indoutos, sempre dispostos a censurar d'aquillo que não entendem, que esbravejem como lhes parecer, não lhes damos a menos consideração." 


\begin{tabular}{|c|c|}
\hline \multicolumn{2}{|r|}{ FD 7. SOTERO DOS REIS 1877} \\
\hline Título & $\begin{array}{l}\text { Grammatica Portugueza: accommodada aos principios geraes da palavra } \\
\text { seguidos de immediata applicação pratica }\end{array}$ \\
\hline $\begin{array}{l}\text { Autor (biodatas e local de } \\
\text { nascimento e morte) }\end{array}$ & $\begin{array}{l}\text { Francisco Sotero dos Reis (1800 S. Luiz do Maranhão - 1871 S. Luiz do } \\
\text { Maranhão) }\end{array}$ \\
\hline Ano & 1877 \\
\hline Local de impressão & Maranhão \\
\hline Tipografia & Typ. de R. d'Almeida \& C., Editores e proprietarios dessa edição. \\
\hline Edição / Impressão & $1^{\mathrm{a}}$ \\
\hline $\begin{array}{l}\text { Outras obras do mesmo } \\
\text { autor }\end{array}$ & $\begin{array}{l}\text { 1862. Postillas de Grammatica Geral applicada á lingua portugueza pela } \\
\text { analyse dos classicos. } \\
\text { 1863. Comentários sobre a Guerra Gálica, de Júlio César. Tradução. } \\
\text { 1868. Postillas de Grammatica Geral applicada á lingua portugueza pela } \\
\text { analyse dos classicos } \\
\text { 1866-1868. Curso de litteratura portugueza e brazileira. }\end{array}$ \\
\hline $\begin{array}{l}\text { Outras edições e } \\
\text { reimpressões conhecidas }\end{array}$ & $\begin{array}{l}\text { 1866. } 1^{\text {a }} \text { edição. Grammatica Portugueza: accommodada aos principios geraes } \\
\text { da palavra seguidos de immediata applicação pratica. Maranhão: [não } \\
\text { mencionado]. } \\
\text { 1871. } 2^{\mathrm{a}} \text { edição. Grammatica Portugueza: accommodada aos principios geraes } \\
\text { da palavra seguidos de immediata applicação pratica (revista, corrigida e } \\
\text { annotada). Maranhão: Typ. de R. d'Almeida \& C. } \\
\text { 1877. } 3^{\mathrm{a}} \text { edição. Grammatica Portugueza: accommodada aos principios } \\
\text { geraes da palavra seguidos de immediata applicação pratica (revista, } \\
\text { corrigida e annotada). Maranhão: Typ. de R. d'Almeida \& C. }\end{array}$ \\
\hline $\begin{array}{l}\text { Descrição da edição } \\
\text { consultada }\end{array}$ & $\begin{array}{l}\text { "Os herdeiros do auctor reservam-se, na forma da lei, o direito de proprieade, } \\
\text { por successão, desta e de todas as outras obras do mesmo auctor. Todos os } \\
\text { exemplares desta } 2^{\mathrm{a}} \text { edição vão rubricados pelo herdeiro Francisco Sotero dos } \\
\text { Reis Junior" } \\
\text { Folha de rosto: Grammatica Portugueza accommodada aos princípios geraes } \\
\text { da palavra seguidos de imediata aplicação pratica por Francisco Sotero dos } \\
\text { Reis, professor Jubilado de Lingua Latina e Professor da mesma Lingua e de } \\
\text { Litteratura no Instituto de Humanidades da Provincia do Maranhão, dedicada } \\
\text { pelo auctor ao ao Director do Mesmo Instituto, o Dr. Pedro Nunes Leal. } \\
\text { Segunda Edição, Revista, corrigida e annotada por Francisco Sotero dos Reis } \\
\text { Junior e Americo Vespucio dos Reis. Maranhão. Typ. de R. d'Almeida \& C., } \\
\text { Editores e proprietarios desta edição - Rua da Palma n. 3. } 1871 \text {. } \\
\text { Número de páginas: } 304\end{array}$ \\
\hline Sumário da obra & $\begin{array}{l}\text { "Ao público" (6 páginas) } \\
\text { Prolegomenos (V-XI) } \\
\text { Etymologia (p.1-147) } \\
\text { Nome substantivo (p.1-5) } \\
\text { Pronome pessoal (p.6-8) } \\
\text { Primeira pessoa (p.7) } \\
\text { Segunda pessoa (p.8) } \\
\text { Terceira pessoa (p.8) } \\
\text { Nome adjetivo (p.8-38) } \\
\text { Verbo (38-133) } \\
\text { Tempos do verbo (p.42-44) } \\
\text { Modos do verbo (p.44-45) } \\
\text { Verbo substantivo (p.45-50) } \\
\text { Modo indicativo (p.47-48) } \\
\text { Modo condicional (p.48) } \\
\text { Modo imperativo (p.48) } \\
\text { Modo conjuntivo (p.48-49) } \\
\text { Modo infinitivo impessoal (p.49) } \\
\text { Modo infinitivo pessoal (p.49-50) } \\
\text { Verbo auxiliar (p.50-60) }\end{array}$ \\
\hline
\end{tabular}




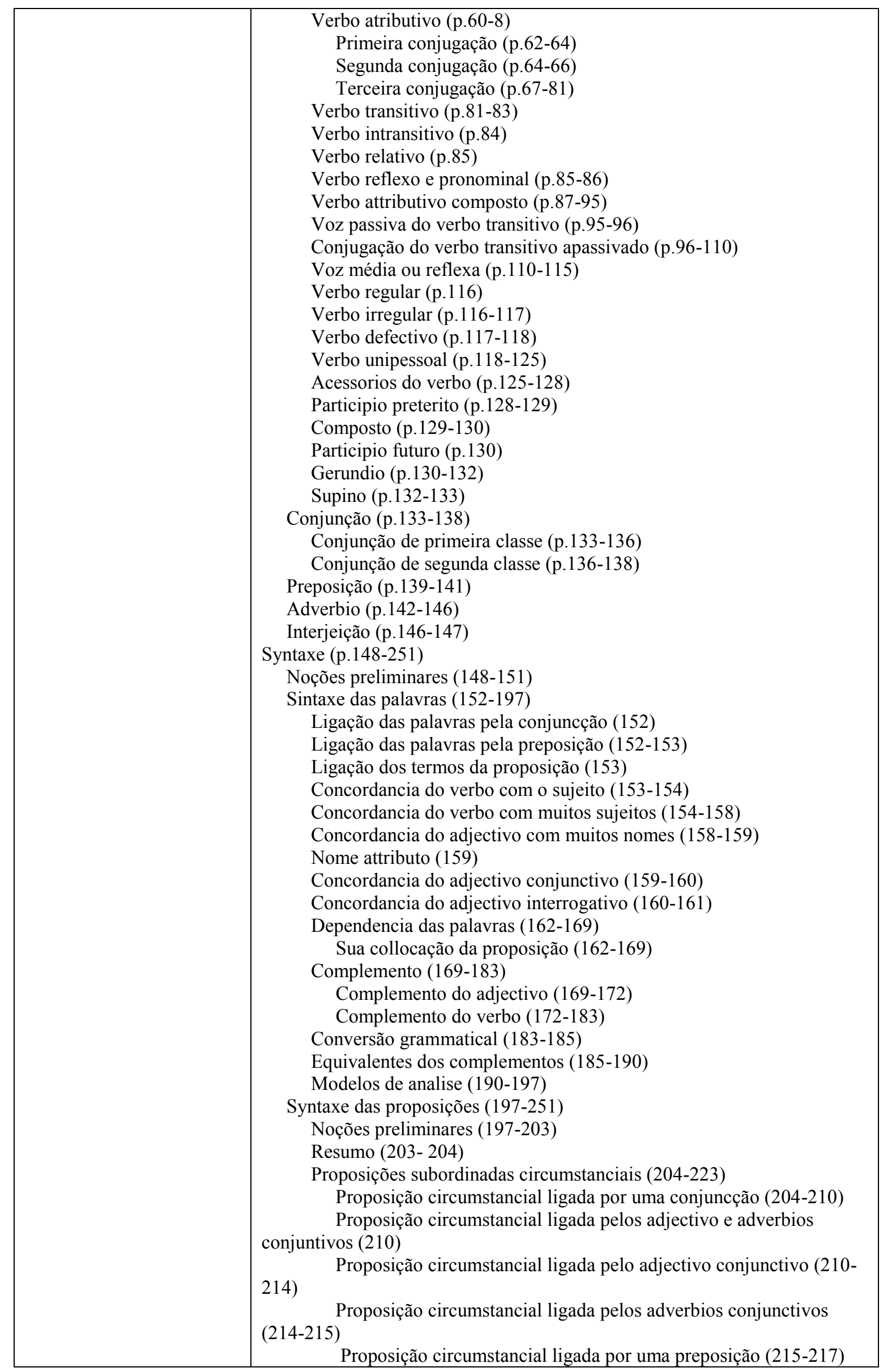




\begin{tabular}{|c|c|}
\hline & $\begin{array}{l}\text { Proposição circumstancial participio (218-223) } \\
\text { Proposição subordinadas completivas }(223-233) \\
\text { Proposição completiva ligada por uma conjuncção }(223-228) \\
\text { Proposição completiva ligada pelo adjectivo e adverbios } \\
\text { interrogativos (229) } \\
\text { Proposição completiva ligada pelo adjectivo interrogativo (229- } \\
\text { 231) Proposição completiva ligada pelos adverbios interrogativos (231- } \\
\text { 232) Proposição completiva do infinito (233) } \\
\text { Infinito pessoal (233-234) } \\
\text { Infinito impessoal (235-237) } \\
\text { Concordancia dos verbos das proposições do periodo grammatical } \\
\text { (237-244) } \\
\text { Relação de simultaneidade (237-240) } \\
\text { Relação de anterioridade (240-242) } \\
\text { Relação de posterioridade (242-244) } \\
\text { Modelo de analyse (245-251) } \\
\text { Ortographia (253-264) } \\
\text { Prosodia (265-272) } \\
\text { Errata (273) }\end{array}$ \\
\hline Objetivo do autor & 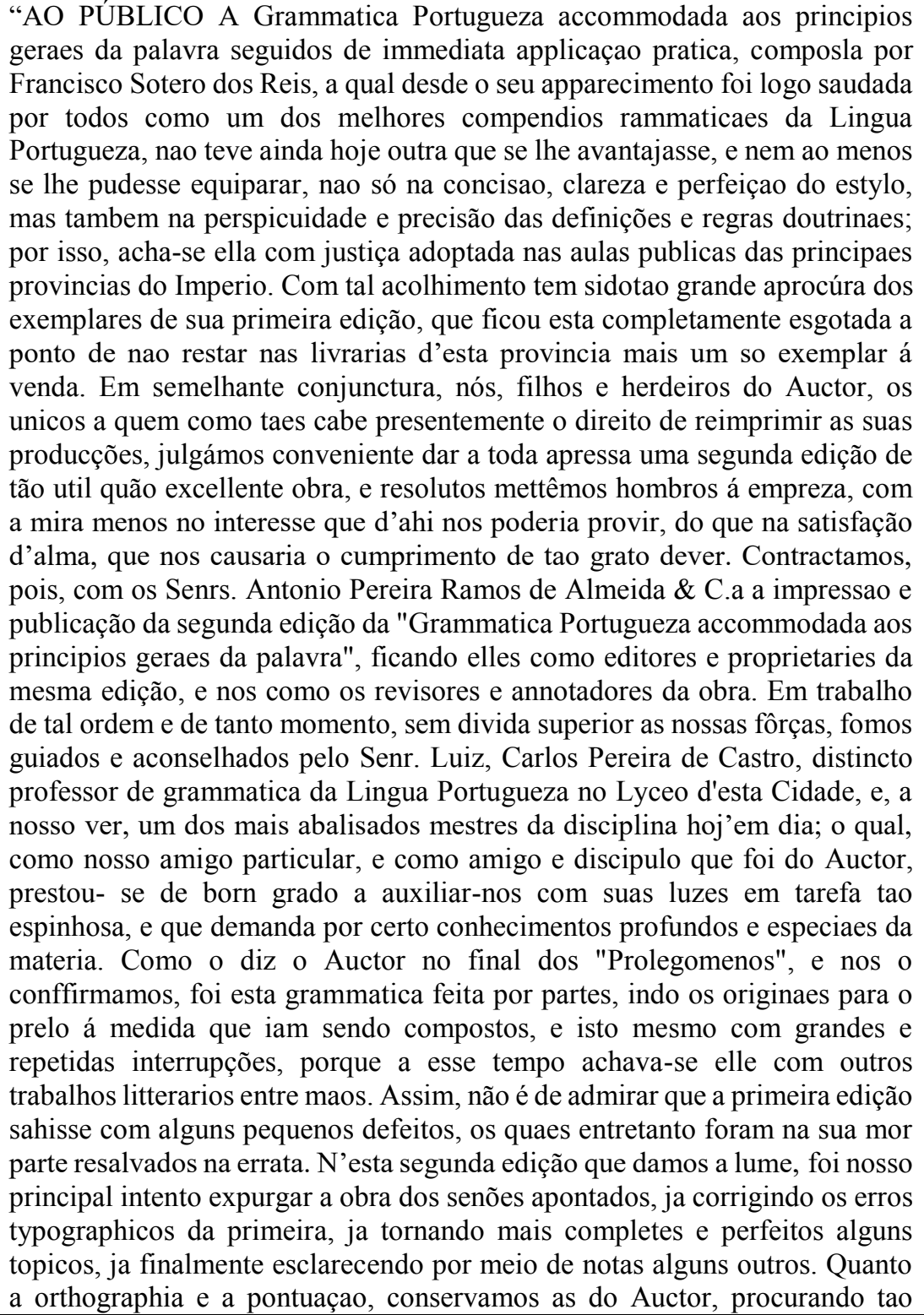 \\
\hline
\end{tabular}


somente uniformisal-as. Sob a poderosa egide do Senr. Luiz Carlos, com cuja auctoridade supprimos a nossa deficiencia, chegamos emfim ao cabo da empreza. Tanto n'uma, como n'outra d'aquellas partes, presumimos haver conseguido alguma cousa, melhorando a grammatica de que tractamos; si bem estejamos convencidos de que, no que respeita a orthographia e a pontuação, apesar dos nossos esforços, muito ha ainda que retocar, pois a urgencia e celeridade da impressao nao deram logar a uma revisao das provas mais demorada e reflectida, como era mister." 


\begin{tabular}{|c|c|}
\hline \multicolumn{2}{|r|}{ FD 8. CORUJA 1873} \\
\hline Título & $\begin{array}{l}\text { Compendio da Grammatica da Lingua Nacional: dedicado á mocidade rio- } \\
\text { grandense }\end{array}$ \\
\hline $\begin{array}{l}\text { Autor (biodatas e local de } \\
\text { nascimento e morte) }\end{array}$ & Antonio Alvares Pereira Coruja (1806 Porto Alegre-1889 Rio de Janeiro) \\
\hline Ano & 1873 \\
\hline Local de impressão & Rio de Janeiro \\
\hline Tipografia & Typ. Esperança, de Gaspar J. J. Vellozo \\
\hline Edição / Impressão & "Nova edição" \\
\hline $\begin{array}{l}\text { Outras obras do mesmo } \\
\text { autor }\end{array}$ & $\begin{array}{l}\mathbf{1 8 3 8} \text { - Manual dos estudantes de latim, dedicado á mocidade brazileira. Rio } \\
\text { de Janeiro. "Foi depois adoptado no collegio de Pedro II. Idem, sendo } \\
\text { augmentado com um appendice de pretéritos e supinos." } \\
\mathbf{1 8 4 8} \text { - Compêndio de ortographia da língua nacional, dedicado a sua } \\
\text { magestade o senhor dom Pedro II. Rio de Janeiro. } \\
\mathbf{1 8 5 0} \text { - Arithmetica para meninos, contendo Unicamente o que é necessário e } \\
\text { se pôde ensinar nas aulas de primeiras lettras. Rio de Janeiro. "sendo a } \\
\text { segunda edição de } 1861 \text { " } \\
\mathbf{1 8 5 2} \text { - "Collecção dos vocábulos usados na provincia de S.Pedro do Rio } \\
\text { Grande do Sul. Revista do instituto histórico, tomo } 15^{\circ}, 1852 \text {, } \\
\mathbf{1 8 5 2} \text { - Manual de ortographia da lingua nacional. Rio de Janeiro. "E' a } \\
\text { mesma obra acima, porém resumida ás suas principaes regras. Idem, sendo a } \\
\text { segunda edição de 1861, } 47 \text { pags. in- } 8^{\circ} \text {, e a terceira de } 1866 \text {." (Sacramento } \\
\text { Blake) } \\
\mathbf{1 8 5 5} \text { - Lições de historia do Brazil, adaptadas á leitura das escolas. Rio de } \\
\text { Janeiro. } \\
\mathbf{1 8 6 1} \text { - Compêndio da grammatica latina do padre Antônio Pereira de } \\
\text { Figueiredo com additamentos e notas. Rio de Janeiro. "Segunda edição, 1861, } \\
111 \text { pags. in- } 8^{\circ} \text { " (Sacramento Blake) } \\
\mathbf{1 8 8 1} \text { - Antigudlhas e reminiscencias de Porto-Alegre. Rio de Janeiro. }\end{array}$ \\
\hline $\begin{array}{l}\text { Outras edições e } \\
\text { reimpressões conhecidas }\end{array}$ & $\begin{array}{l}\text { 1846. } 4^{\text {a }} \text { edição. Compendio da grammatica da lingua nacional, dedicado á } \\
\text { mocidade rio-grandense, por seu patricio Antonio Alvares Pereira Coruja } \\
\text { professor publico. Rio de Janeiro : Tipografia Francesa. } \\
\mathbf{1 8 4 7 .} 5^{\text {a }} \text { edição. Compendio da grammatica da lingua nacional, dedicado á } \\
\text { mocidade rio-grandense } \\
\mathbf{1 8 4 9} \text { ? edição. Compendio da grammatica da lingua nacional, dedicado á } \\
\text { mocidade rio-grandense. } \\
\mathbf{1 8 6 2} \text { ? edição. Compendio da grammatica da lingua nacional, dedicado á } \\
\text { mocidade rio-grandense. } \\
\mathbf{1 8 6 5 .} \text { ? edição. Compendio da grammatica da lingua nacional, dedicado á } \\
\text { mocidade rio-grandense. Nova Edição ampliada e mais correcta. } \\
\mathbf{1 8 6 2} \text { ? edição. Compendio da grammatica da lingua nacional, dedicado á } \\
\text { mocidade rio-grandense. } \\
\mathbf{1 8 7 3 .} \text { ? edição. Compendio da grammatica da lingua nacional, dedicado á } \\
\text { mocidade rio-grandense. Nova Edição ampliada e mais correcta. Rio de } \\
\text { Janeiro: Esperanca. } \\
\mathbf{1 8 9 1 . ? ~ e d i c ̧ a ̃ o . ~ C o m p e n d i o ~ d a ~ g r a m m a t i c a ~ d a ~ l i n g u a ~ n a c i o n a l , ~ d e d i c a d o ~ a ́ ~} \\
\text { mocidade rio-grandense. Rio de Janeiro: Clássica. }\end{array}$ \\
\hline $\begin{array}{l}\text { Descrição da edição } \\
\text { consultada }\end{array}$ & $\begin{array}{l}\text { Obras do mesmo autor } \\
\text { Collecção de } 8 \text { grandes Exemplares de Leitura progressivos desde }-a b c- \\
\text { até carta de nomes inclusive, impressos em grandes caractéres, proprios para } \\
\text { quadros ou para grudar em papelão: a } 320 \text { rs. a colleç̧ão. } \\
\text { Paulas para bastardo, bastardinho, e cursivo, com linhas de inclinação: a } 80 \\
\text { rs. cada uma. } \\
\text { Arithmetica para Meninos, contendo unicamente o que é indispensavel, e se } \\
\text { póde ensinar nas escolas de primeiras letras: a } 320 \text { rs. } \\
\text { Manual da Orthografia da Lingua Nacional, extrahido do seu Compendio de } \\
\text { Orthographia: a } 320 \text { rs. }\end{array}$ \\
\hline
\end{tabular}




\begin{tabular}{|c|c|}
\hline & $\begin{array}{l}\text { Compendio da Grammatica da Lingua Nacional: a } 1 \$ 000 \text {. } \\
\text { Compendio da Grammatica Latina, com additamentos e notas, organisado } \\
\text { sobre o Epitome da Grammmatica do Padre Antonio Pereira: a } 1 \$ 000 \text { réis. } \\
\text { Manual dos Estudantes de latim, approvado para o uso do collegio D. Pedro } \\
\text { II; contém a declinação dos nomes greco-latinos, conjugação de muitos } \\
\text { verbos irregulares, impessoaes e defectivos, ampliação das regras de sintaxe, } \\
\text { figuras de sentença e de dicção, regras da metrificação latina, e outras muitas } \\
\text { explicações necessarias aos estudantes, e que não vem na Arte do Padre } \\
\text { Antonio Pereira; com umAppendice dos preteritos e supinos mais difficeis de } \\
\text { procurar-se: a } 1 \$ 000 \text { réis. } \\
\text { Liçções da Historia do brasil, adaptadas á leitura das escolas, e seguidas de } \\
\text { um Appendice contendo noticias de casa uma das provincias do Imperio; a } \\
2 \$ 000 \text { réis. } \\
\text { Compendio da Orthographia da lingua Nacional, impressoa em 1848, } \\
\text { dedicado a S. M. I., e precedido do parecer de uma Comissão nomeada pelo } \\
\text { governo para informar sobre o seu merecimento: contém um Vocabulario á } \\
\text { semelhança do da Orthografia do Padre Madureira: a } 4 \$ 000 \text { réis. } \\
\text { Vendem-se no Rio de Janeiro, em casa do autor, rua da Assemblea n. } 88 \text {, na } \\
\text { rua da Quitanda ns. } 70 \text { e } 124 \text {. Em Porto Alegre, rua de Bragança n. } 51 . \\
\text { Folha de rosto: compendio da grammatica da lingua nacional dedicada á } \\
\text { mocidade rio-grandense por seu patricio Antonio Alvares Pereira Coruja } \\
\text { professor publico. Nova edição ampliada e mais correcta. Rio de Janeiro. } \\
1873 \text {. } \\
\text { Typographia - Esperança - de Garpar João José Vellozo Rua de S. José, } 11 \text {. } \\
\text { Número de páginas: } 99\end{array}$ \\
\hline Sumário da obra & $\begin{array}{l}\text { Folha de rosto (3) } \\
\text { Proemio (5-6) } \\
\text { Parte Primeira - Da Etymologia (6-45) } \\
\text {-Artigo (6) } \\
\text {-Nome (6-9) } \\
\text {-Pronome (9-13) } \\
\text {-Verbo (13-39) } \\
\text {-Participio (41) } \\
\text {-Adverbio (41-43) } \\
\text {-Conjunção (42-43) } \\
\text {-Preposição (44) } \\
\text {-Interjeição (45) } \\
\text { Parte Segunda - Da Syntaxe (45-59) } \\
\text {-Circunstancia (47-50) } \\
\text {-Verbo Passivo (51) } \\
\text { - Das orações (51-53) } \\
\text {-Sintaxe Figurada (52-55) } \\
\text { - Observações necessarias aos principiantes para faculdade da analyse (55- } \\
\text { 60) } \\
\text { Parte Terceira - Da Prosodia (60-62) } \\
\text {-Figuras de dicção (61-62) } \\
\text { Parte Quarta - Da Orthographia (62-72) } \\
\text { - Palavras de pronuncia semelhantes, que se escrevem diversamente (67-70) } \\
\text {-Pontuação (70-72) }\end{array}$ \\
\hline Objetivo do autor & - \\
\hline
\end{tabular}




\begin{tabular}{|c|c|}
\hline Título & Grammatica Portugueza Philosophica \\
\hline $\begin{array}{l}\text { Autor (biodatas e local de } \\
\text { nascimento e morte) }\end{array}$ & Ernesto Carneiro Ribeiro (1839-1920) \\
\hline Ano & 1881 \\
\hline Local de impressão & Bahia \\
\hline Tipografia & Imprensa Econômica \\
\hline Edição / Impressão & $1^{\mathrm{a}}$ \\
\hline Acesso ao texto & $\begin{array}{l}\text { FFLCH / USP } \\
\text { CEDOCH (fotos) }\end{array}$ \\
\hline $\begin{array}{c}\text { Outras obras do mesmo } \\
\text { autor }\end{array}$ & $\begin{array}{l}\mathbf{1 8 6 4} \text { - Relações da medicina com as sciencias philosophicas; Como obra, o } \\
\text { sulfato de quinino nas febres intermittentes. Do centeio espigado e sua } \\
\text { applicação na obstetrícia; Theoria da respiração vegetal: these que sustenta } \\
\text { para obter o grau de doutor, etc. Bahia. } \\
\mathbf{1 8 8 5} \text { - Perturbações psychicas no domínio da hysteria : these de concurso da } \\
\text { cadeira de clinica obstetrica e gynecologica. Bahia. } \\
\mathbf{1 8 9 0} \text { - Serões Grammaticaes ou Nova Grammatica Portugueza. Bahia. }\end{array}$ \\
\hline $\begin{array}{c}\text { Outras edições e } \\
\text { reimpressões conhecidas }\end{array}$ & Não temos conhecimento de reedições. \\
\hline $\begin{array}{l}\text { Descrição da edição } \\
\text { consultada }\end{array}$ & $\begin{array}{l}\text { Folha de rosto: Grammatica Portugueza Philosophica pelo Dr. Ernesto } \\
\text { Carneiro Ribeiro professor de grammatica philosophica no Lyceo da Bahia - } \\
\text { Obra approvada pelo conselho Superior de Instrucção Publica. } \\
\text { Epígrafe: Lex sum sermonis, linguarum regula certa; qui me non dedict } \\
\text { coetera aulla pelat. BACON. } \\
\text { - Bahia, Imprensa Economica, } 16 \text { - Rua Nova das Princezas - } 16-1887 \text { / } \\
\text { 1881. } \\
\text { Dedicatória: Á memoria de Dr. Guilherme Pereira Rebello. O.D.C. - O } \\
\text { Auctor. } \\
\text { Número de páginas: } 447\end{array}$ \\
\hline Sumário da obra & $\begin{array}{l}\text { Parecer (4-6) } \\
\text { Introdução (7-13) } \\
\text { Livro I - Phonologia (15-61) } \\
\text { Capitulo I (15-25) } \\
\text { Capitulo II (25-29) } \\
\text { Capitulo III - Syllabas (29-38) } \\
\text { Capitulo IV - Da quantidade do accento (38-57) } \\
\text { Capitulo V - Dos principais vicios da pronunciação (57-61) } \\
\text { Livro II - Orthographia (63-199) } \\
\text { Capitulo I (63-68) } \\
\text { Capitulo II - Da escriptura em geral e especialmente da escriptura } \\
\text { alphabetica (69-73) } \\
\text { Capitulo III - Regras: relativas ao emprego da vogal Y e observações } \\
\text { sobre cada uma das consoantes (73-92) } \\
\text { Capitulo IV - Divisão das Syllabas dos vocabulos (92-94) } \\
\text { Capitulo V - Principaes Abbreviações portuguezas (94-96) } \\
\text { Capitulo VI - Das Lettras Capitaes (97) } \\
\text { Capitulo VII - Pontuação (97-114) } \\
\text { Capitulo VIII - De outros signaes orthographicos (115-116) } \\
\text { Capitulo IX - Emprego das maiusculas e minusculas (116-119) } \\
\text { Livro III - Lexicologia (121-367) } \\
\text { Capitulo I (121-129) } \\
\text { Capitulo II - Interjeições (128-134) }\end{array}$ \\
\hline
\end{tabular}




\begin{tabular}{|l|l|}
\hline & Capitulo III - Substantivos (134-172) \\
& Capitulo IV - Pronome (172-205) \\
& Capitulo V - Adjectivos (205-248) \\
& Capitulo VI - Verbos (248-314) \\
& Capitulo VII - Preposições (314-328) \\
& Capitulo VIII - Conjuncção (328-339) \\
& Capitulo IX - Adverbio (340-353) \\
Capitulo X - Preficas e Suffixas (353-367) \\
Livro IV - Phraseologia (369-447) \\
Capitulo I (369-287) \\
Capitulo II - Concordância (386-406) \\
Capitulo III - Regência (406- \\
Capitulo IV - Das figuras de syntaxe (416-432) \\
Capitulo V - Dos vicios da linguagem (432-439) \\
\hline Capitulo VI - Dos tropos (439-447) \\
\hline Objetivo do autor & Errata \\
\hline
\end{tabular}




\begin{tabular}{|c|c|}
\hline Título & Grammatica Portugueza \\
\hline $\begin{array}{l}\text { Autor (biodatas e local de } \\
\text { nascimento e morte) }\end{array}$ & Julio Cezar Ribeiro Vaughan (1845 Sabará, MG - 1890 Santos, SP) \\
\hline Ano & 1881 \\
\hline Local de impressão & São Paulo \\
\hline Tipografia & Typ. De Jorge Seckler, Rua Direita, 15 \\
\hline Edição / Impressão & $1^{\mathrm{a}}$ \\
\hline $\begin{array}{c}\text { Outras obras do mesmo } \\
\text { autor }\end{array}$ & $\begin{array}{l}\text { 1876-1877. O padre Belchior Pontes } \\
\text { 1880. Traços gerais de Linguística } \\
\text { 1885. Grammatica Analytica } \\
\text { 1887. Holmes Brasileiro ou Grammatica da Puericia } \\
\text { 1888. A Carne } \\
\text { 1895. Nova Grammatica de Lingua Latina }\end{array}$ \\
\hline $\begin{array}{c}\text { Outras edições e } \\
\text { reimpressões conhecidas }\end{array}$ & $\begin{array}{l}\text { 1885. Grammatica Portugueza. } 2^{\mathrm{a}} \mathrm{ed} \text {. } \\
\text { 1893. Grammatica Portugueza. } 3^{\mathrm{a}} \mathrm{ed} \text {. } \\
\text { 1896. Grammatica Portugueza. } 4^{\mathrm{a}} \mathrm{ed} \text {. } \\
\text { 1899. Grammatica Portugueza. } 5^{\mathrm{a}} \mathrm{ed} .\end{array}$ \\
\hline $\begin{array}{l}\text { Descrição da edição } \\
\text { consultada }\end{array}$ & $\begin{array}{l}\text { Capa: Grammatica Portugueza, por Julio Ribeiro. Epig.: Tentei ensinar aos } \\
\text { meus naturaes o que eu de outrem não pude apprendrer. DUARTE NUNES } \\
\text { DE LEÃO. - Pour les langes, la methode essentielle est dans la comparaison } \\
\text { et la filiation. - Rien n'est explicable dans notre grammaire moderne si nous } \\
\text { ne connaisons notre grammaire ancienne. LITTRE - En aucune chose, peut- } \\
\text { êtrê, il n'est donné à l'homme d'arriver au but: su gloire est d'y avoir marché. } \\
\text { GUIZOT.) São Paulo: Typ. de Jorge Seckler, Rua Direita, 15. } 1881 \text {. } \\
\text { Folha de rosto: (igual à capa) } \\
\text { Dedicatória: A Friederich Diez e Émile Littré, de saudosa memoria; aos } \\
\text { Senhores William Dwight Whitney, Mas Müller, Auguste Branchet, Gaston } \\
\text { Paris, Michel Bréal, Theophilo Braga, Adolpho Coelho, Paulino de Souza, } \\
\text { Pacheco Junior, Sylvio Romério, Capistrano de Abreu; Voi duchi, voi signori, } \\
\text { voi maestri. Dante, Inferno, II, 140. --- A Manoel José da Fonseca e á Exm.a } \\
\text { Sra. D. Carolina Florence: vulgare amici nomen, sed rara est fides. Phaedrus, } \\
\text { Lib. III, Fab. 9. } \\
\text { Advertência: "Peço á critica illustrada e honesta o que ella não pode recusar } \\
\text { - toda a severidade para com esta Grammatica. Não é um orgulho tolo que } \\
\text { me leva a fazer tal pedido: é o desejo de melhorar o meu trabalho em bem dos } \\
\text { que estudam Portuguez. Dos directores da imprensa espero uma fineza-que } \\
\text { me sejam enviados todos os exemplares das suas folhas em que saiam noticias } \\
\text { e apreciações desta obra. Endereço: Julio Ribeiro. Collegio "Culto á } \\
\text { Sciencia". Campinas. Província de São Paulo. } \\
\text { Número de páginas: } 298\end{array}$ \\
\hline Sumário da obra & $\begin{array}{l}\text { Introducção (1-2) } \\
\text { Parte Primeira - Lexeologia (3-192) } \\
\text { Livro Primeiro - Elementos Materiaes das Palavras (3-51) } \\
\text { Seção Primeira - Phonetica (3-10) } \\
\text { Seção Segunda - Prosodia (10-22) } \\
\text { Seção Terceira - Orthographia (22-51) } \\
\text { Livro Segundo - Elemento Morphicos das Palavras (51- } \\
\text { Secção Primeira - Taxeonomia (51-73) } \\
\text { I Substantivo (53-55) } \\
\text { II Artigo (55-56) } \\
\text { III Adjectivo (56-59) }\end{array}$ \\
\hline
\end{tabular}




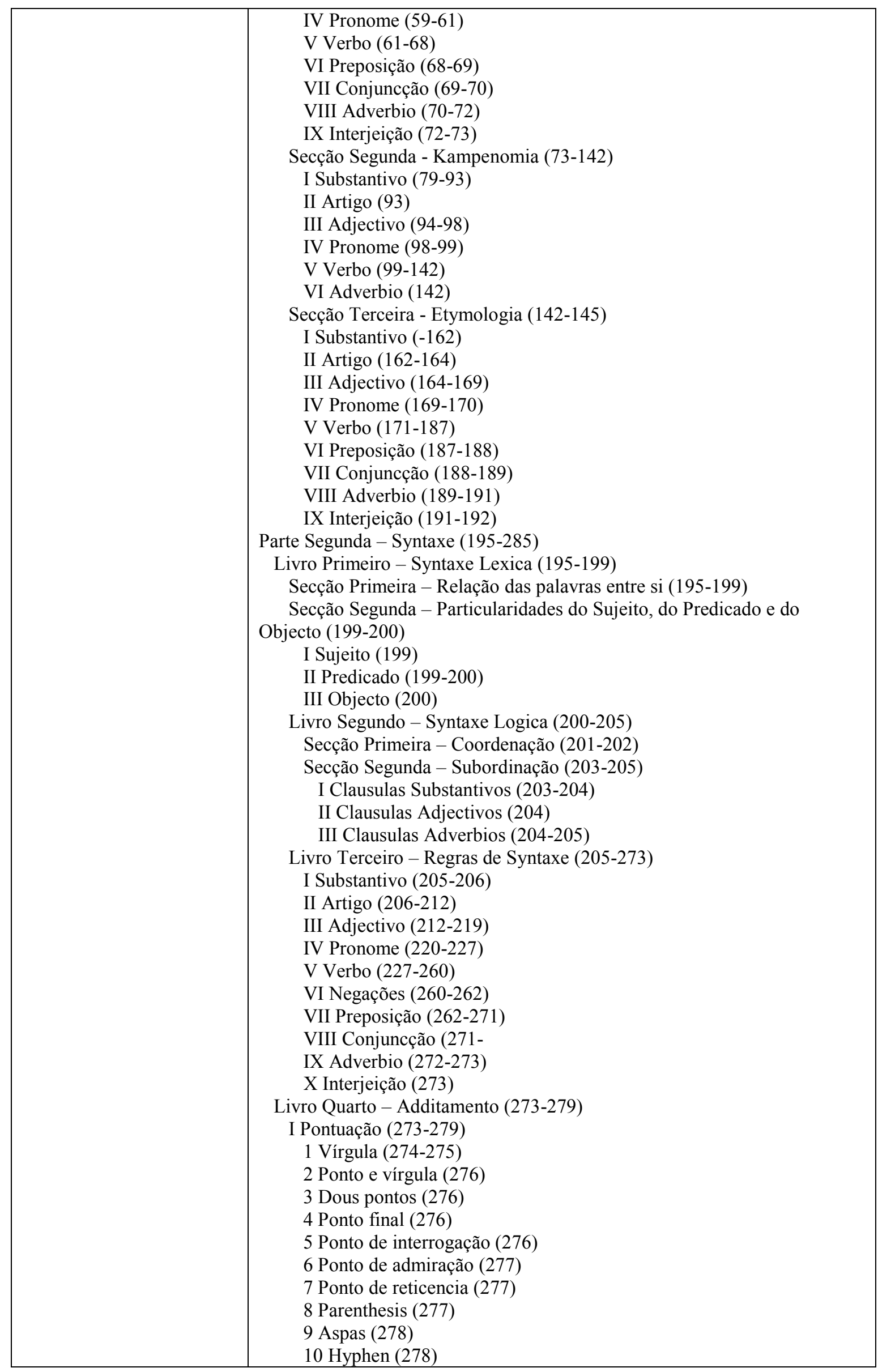




\begin{tabular}{|c|l|}
\hline & 11 Travessão (278) \\
& 12 Paragrapho (279) \\
II Emprego das Lettras Maiusculas (279-280) \\
III Ordem das palavras e phrases na construção de sentenças simples \\
(281) \\
IV Ordem dos membros e clausulas na construção de sentenças \\
compostas (281-283) \\
V Estylo (283-284) \\
VI Vicios (284-285) \\
Annexo (286-291) \\
& Errata (293-4) \\
\hline Objetivo do autor & Indice (295-299) \\
\hline
\end{tabular}




\begin{tabular}{|c|c|}
\hline \multicolumn{2}{|r|}{ FD 11. RIBEIRO 1885} \\
\hline Título & Grammatica Portugueza \\
\hline $\begin{array}{c}\text { Autor (biodatas e local de } \\
\text { nascimento e morte) }\end{array}$ & Julio Cezar Ribeiro Vaughan (1845 Sabará, MG - 1890 Santos, SP) \\
\hline Ano & 1885 \\
\hline Local de impressão & São Paulo \\
\hline Tipografia & Teixeira \& Irmão, Editores, Rua S. Bento 54A \\
\hline Edição / Impressão & Segunda edição, refundida e muito augmentada \\
\hline $\begin{array}{c}\text { Outras obras do mesmo } \\
\text { autor }\end{array}$ & $\begin{array}{l}\text { 1876-1877. O padre Belchior Pontes } \\
\text { 1880. Traços gerais de Linguística } \\
\text { 1885. Grammatica Analytica } \\
\text { 1887. Holmes Brasileiro ou Grammatica da Puericia } \\
\text { 1888. A Carne } \\
\text { 1895. Nova Grammatica de Lingua Latina }\end{array}$ \\
\hline $\begin{array}{c}\text { Outras edições e } \\
\text { reimpressões conhecidas }\end{array}$ & $\begin{array}{l}\text { 1881. Grammatica Portugueza. } 1^{\text {a }} \text { ed. } \\
\text { 1893. Grammatica Portugueza. } 3^{\mathrm{a}} \text { ed. } \\
\text { 1896. Grammatica Portugueza. } 4^{\mathrm{a}} \text { ed. } \\
\text { 1899. Grammatica Portugueza. } 5^{\mathrm{a}} \text { ed. }\end{array}$ \\
\hline $\begin{array}{c}\text { Descrição da edição } \\
\text { consultada }\end{array}$ & $\begin{array}{l}\text { Capa: Grammatica Portugueza, por Julio Ribeiro. Epig.: Tentei ensinar aos } \\
\text { meus naturaes o que eu de outrem não pude apprendrer. DUARTE NUNES } \\
\text { DE LEÃO. - Pour les langes, la methode essentielle est dans la comparaison } \\
\text { et la filiation. - Rien n'est explicable dans notre grammaire moderne si nous } \\
\text { ne connaisons notre grammaire ancienne. LITTRE - En aucune chose, peut- } \\
\text { êtrê, il n'est donné à l'homme d'arriver au but: su gloire est d'y avoir marché. } \\
\text { GUIZOT.) Segunda edição, refundida e muito augmentada. São Paulo: } \\
\text { Teixeira \& Irmão, Editores, Rua de S. Bento, 54A. 1885. } \\
\text { Dedicatória: Á memoria veneranda de Luiz de Camões, Friederich Diez e } \\
\text { Émile Littré; áos colendos mestres André Lefèvre, Michel Bréal e Adolpho } \\
\text { Coelho; ao eruditissimo polugrapho Theophilo Braga; ao mais robusto } \\
\text { manejador actual da Lingua Portugueza, Camillo Castello Branco; á maior } \\
\text { gloria do magisterio official brazileiro, Capistrano de Abreu; aos } \\
\text { distinctissimos professores Vieira de Almeira (Campinas), Thomaz Galhardo } \\
\text { (S. Paulo) e Serafim de Mello (Capivary) dedica esta segunda edição da } \\
\text { Grammatica Portugueza. O auctor. } \\
\text { Advertência: "Peço á critica illustrada e hones o que ella não pode recusar - } \\
\text { toda a severidade para com esta Grammatica. Não é um orgulho tolo que me } \\
\text { leva a fazer tal pedido: é o desejo de melhorar o meu trabalho em bem dos } \\
\text { que estudam Portuguez. Dos directores da imprensa espero uma fineza-que } \\
\text { me sejam enviados todos os exemplares das suas folhas em que saiam noticias } \\
\text { e apreciações desta obra. Endereço: Julio Ribeiro. S. João de Capivary, } \\
\text { Província de São Paulo. Brazil. } \\
\text { Número de páginas: } 298\end{array}$ \\
\hline Sumário da obra & $\begin{array}{l}\text { Introducção (1-2) } \\
\text { Parte Primeira - Lexeologia (3-192) } \\
\text { Livro Primeiro - Elementos Materiaes das Palavras (3-51) } \\
\text { Seção Primeira - Phonetica (3-10) } \\
\text { Seção Segunda - Prosodia (10-22) } \\
\text { Seção Terceira - Orthographia (22-51) } \\
\text { Livro Segundo - Elemento Morphicos das Palavras (51-192) } \\
\text { Secção Primeira - Taxeonomia (51-73) } \\
\text { I Substantivo (53-55) } \\
\text { II Artigo (55-56) } \\
\text { III Adjectivo (56-59) } \\
\text { IV Pronome (59-61) }\end{array}$ \\
\hline
\end{tabular}




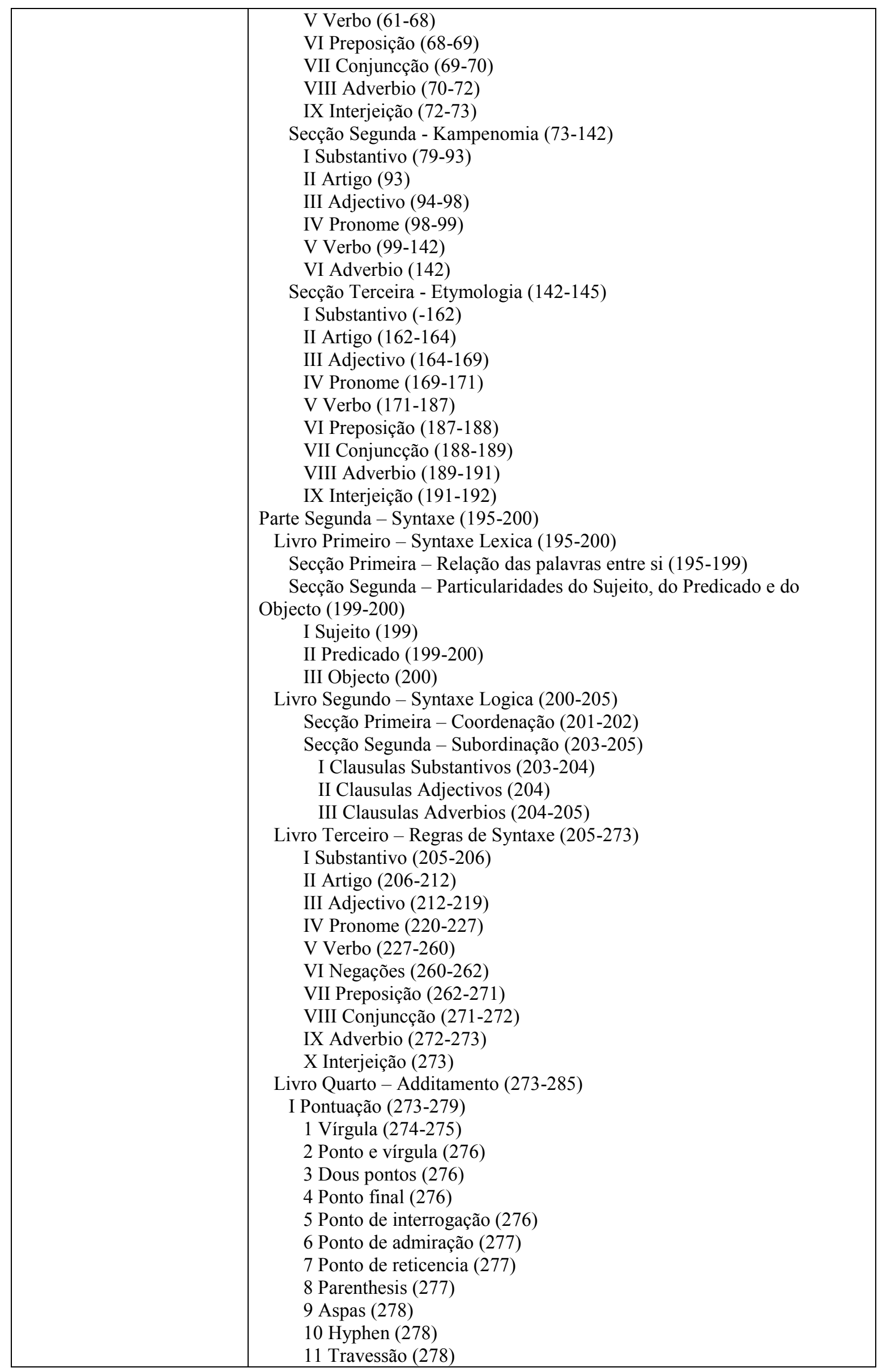




\begin{tabular}{|c|c|}
\hline & $\begin{array}{l}\text { 12 Paragrapho (279) } \\
\text { II Emprego das Lettras Maiusculas (279-280) } \\
\text { III Ordem das palavras e phrases na construção de sentenças simples } \\
\text { (281) } \\
\text { IV Ordem dos membros e clausulas na construção de sentenças } \\
\text { compostas }(281-283) \\
\quad \text { V Estylo }(283-284) \\
\text { VI Vicios }(284-285) \\
\text { Annexo }(286-291) \\
\text { Errata }(293-4) \\
\text { Indice }(295-299)\end{array}$ \\
\hline Objetivo do autor & 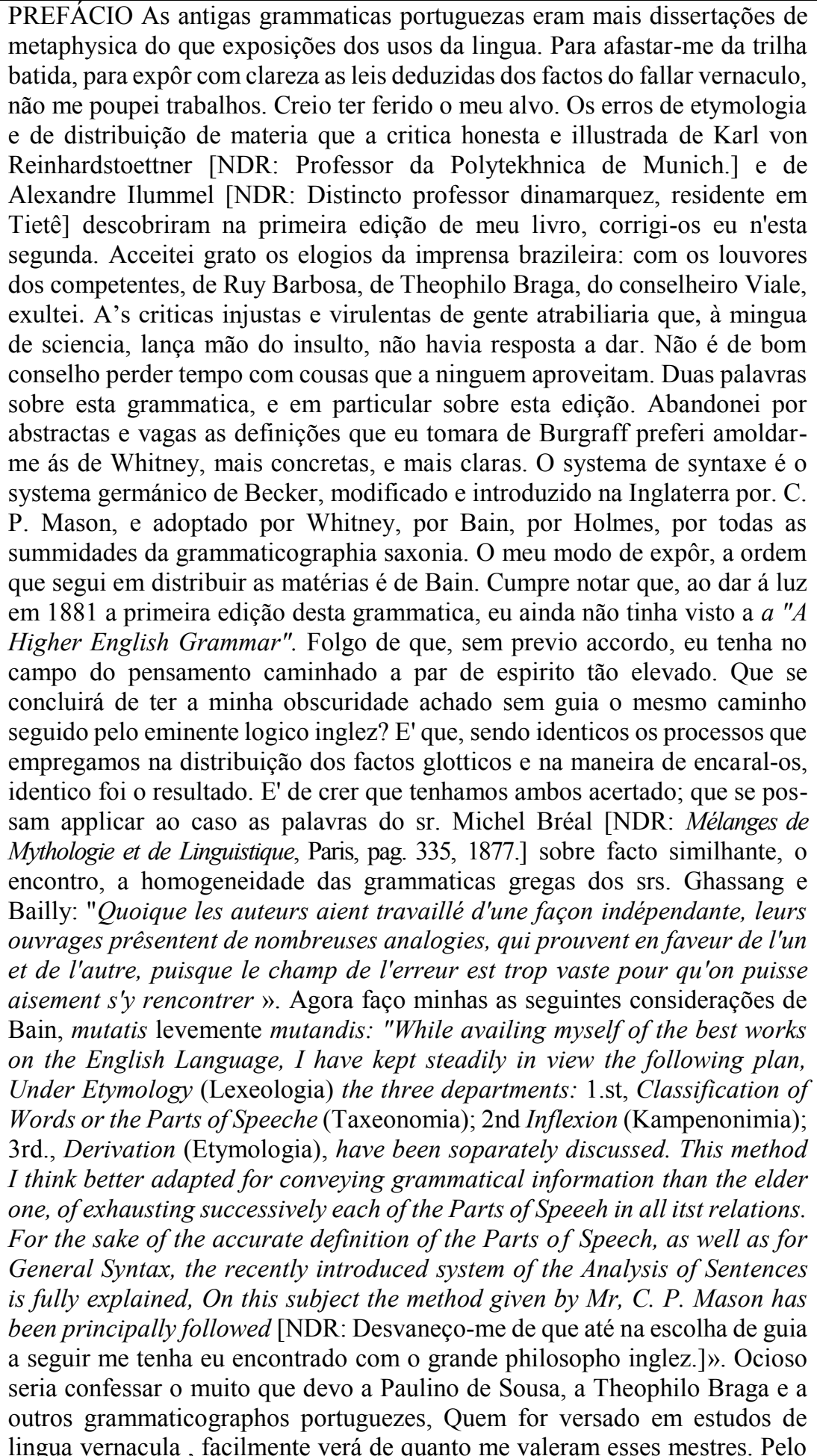 \\
\hline
\end{tabular}




\begin{tabular}{|c|c|}
\hline & 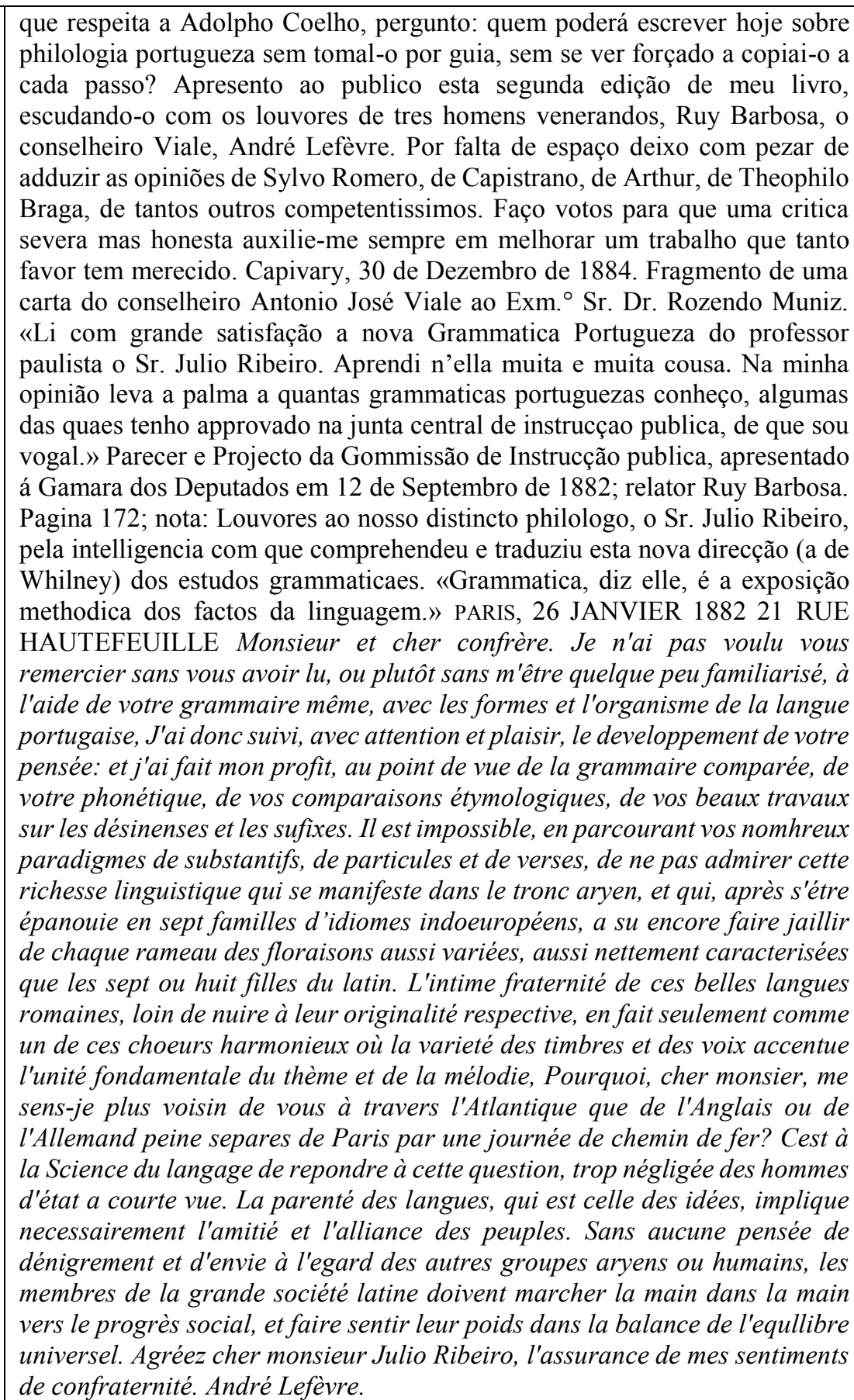 \\
\hline
\end{tabular}




\begin{tabular}{|c|c|}
\hline \multicolumn{2}{|r|}{ FD 12. MACIEL 1887} \\
\hline Título & $\begin{array}{l}\text { Grammatica analytica baseada nas doutrinas modernas, satisfazendo ás } \\
\text { condições do actual programma }\end{array}$ \\
\hline $\begin{array}{c}\text { Autor (biodatas e local de } \\
\text { nascimento e morte) }\end{array}$ & Maximino de Araújo Maciel (1865 Larangeiras - 1923 Rio de Janeiro) \\
\hline Ano & 1887 \\
\hline Local de impressão & Rio de Janeiro \\
\hline Tipografia & Typ. Central, de Evaristo Rodrigues da Costa \\
\hline Edição / Impressão & $1^{\mathrm{a}}$ \\
\hline $\begin{array}{l}\text { Outras obras do mesmo } \\
\text { autor }\end{array}$ & $\begin{array}{l}1889 \text { - Philologia Portugueza, Rio de Janeiro. } \\
1901 \text { - Noções geraes de agronomia. Rio de Janeiro: Garnier. } \\
1903 \text { - Lições de botânica geral. Rio de Janeiro: Garnier. } \\
1913 \text { - Elementos de chimica geral. Rio de Janeiro: Francisco Alves. }\end{array}$ \\
\hline $\begin{array}{l}\text { Outras edições e } \\
\text { reimpressões conhecidas }\end{array}$ & 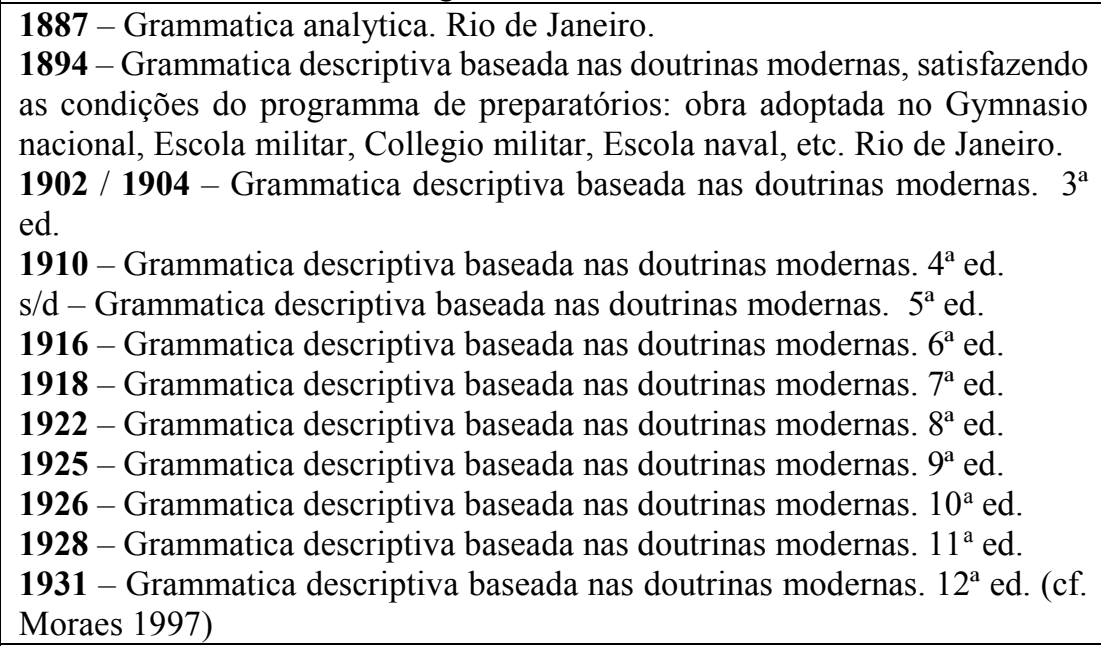 \\
\hline $\begin{array}{l}\text { Descrição da edição } \\
\text { consultada }\end{array}$ & $\begin{array}{l}\text { Folha de rosto: Grammatica analytica baseada nas doutrinas modernas, } \\
\text { satisfazendo ás condições do actual programma por Maximino de Araújo } \\
\text { Maciel, natural de sergire, estudante do curso medico. Professor de Linguas } \\
\text { no collegio Augusto, professor livre de philosophia, ex-professor de } \\
\text { portuguez e frances da Associação Promotora da Instrucção, etc. A' venda em } \\
\text { casa de B. L. Garnier, rua do Ouvidor n. 71. Rio de Janeiro, Typ. Central, de } \\
\text { Evaristo Rodrigues da Costa, travessa do Ouvidor, 7. 1887 - Direitos } \\
\text { reservados. } \\
\text { Número de páginas 215. }\end{array}$ \\
\hline Sumário da obra & $\begin{array}{l}\text { Grammatica (1-2) } \\
\text { Parte Primeira - Phonologia (3-43) } \\
\text { Phonetica (Phonemas) (3-13) } \\
\text { Classificação physiologica (6-7) } \\
\text { Diphthongos (7-8) } \\
\text { Categorias dos diphtongos oraes (9-10) } \\
\text { Triphthongos (10-11) } \\
\text { Syllabas (11-12) } \\
\text { Tautosyllabas (13) } \\
\text { Prosodia (13-30) } \\
\text { Accentuação Prosódica (15-16) } \\
\text { Oxytonos (17) } \\
\text { Proparoxytonos (17-18) } \\
\text { Proparoxytonos (18-19) } \\
\text { Alterações fonéticas (19-20) } \\
\text { Metaplasmo prosódico (21-23) } \\
\text { Assimilação (23-24) } \\
\text { Assimilação de prefixos (24-25) } \\
\end{array}$ \\
\hline
\end{tabular}




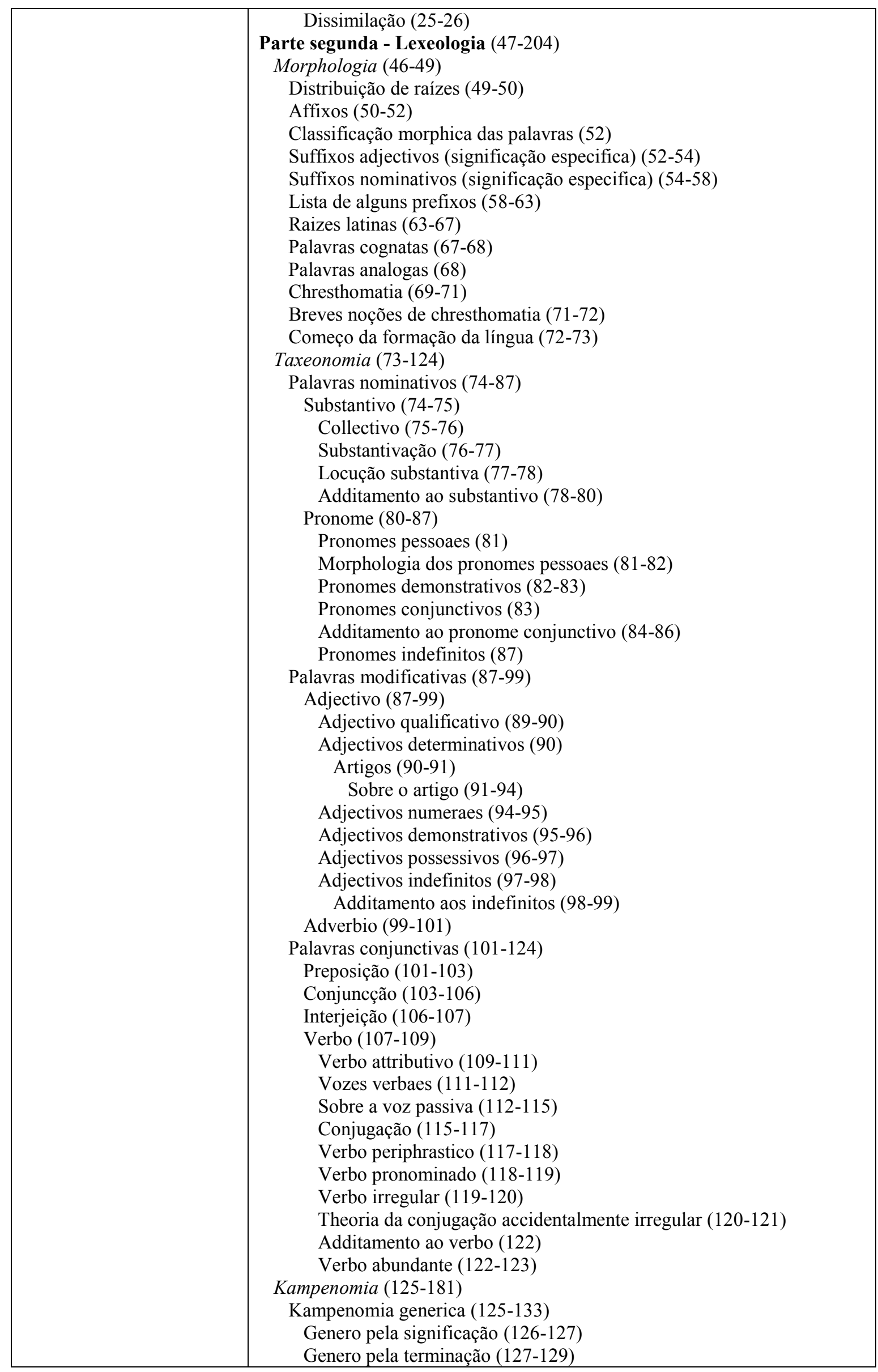




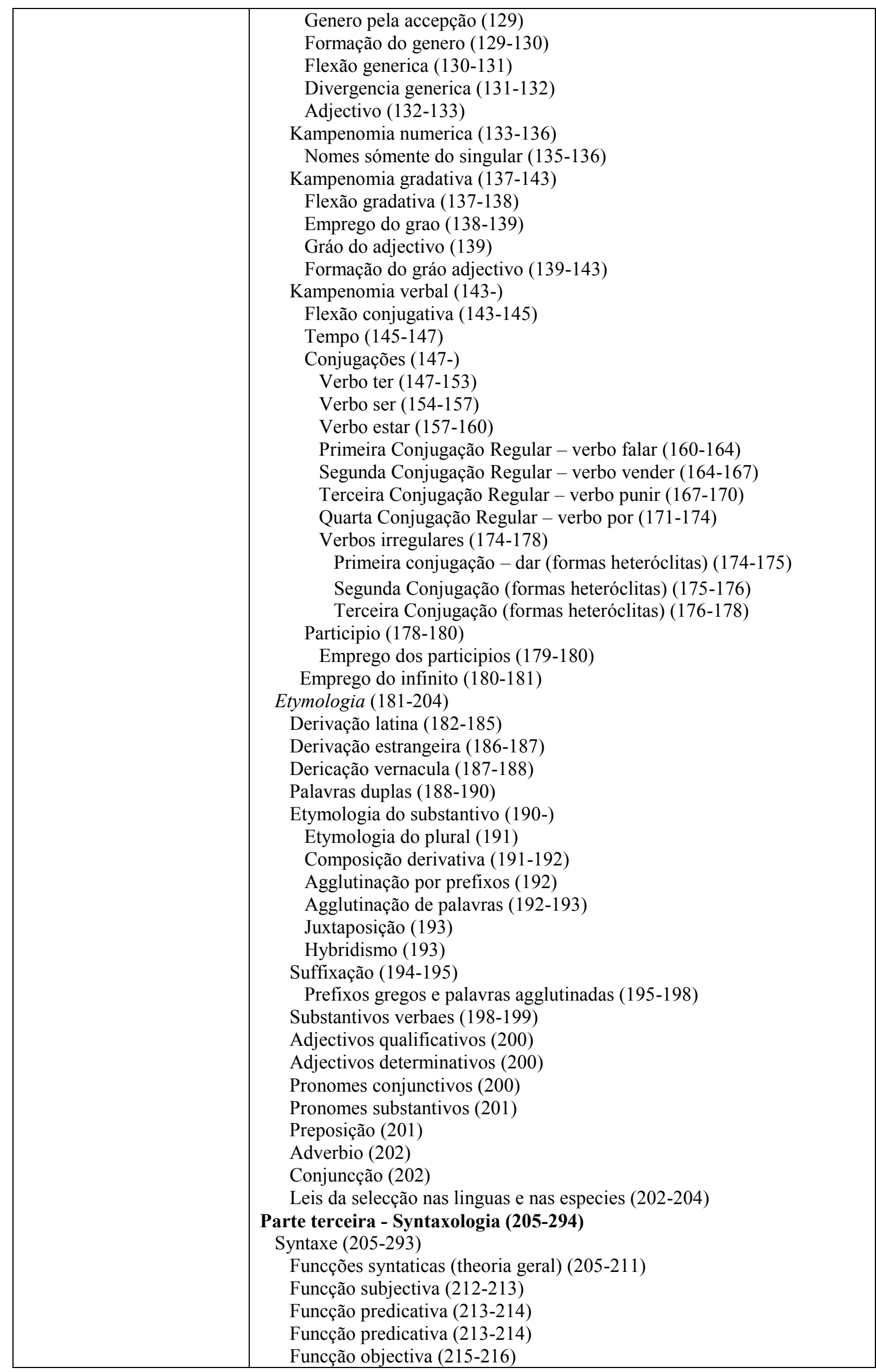




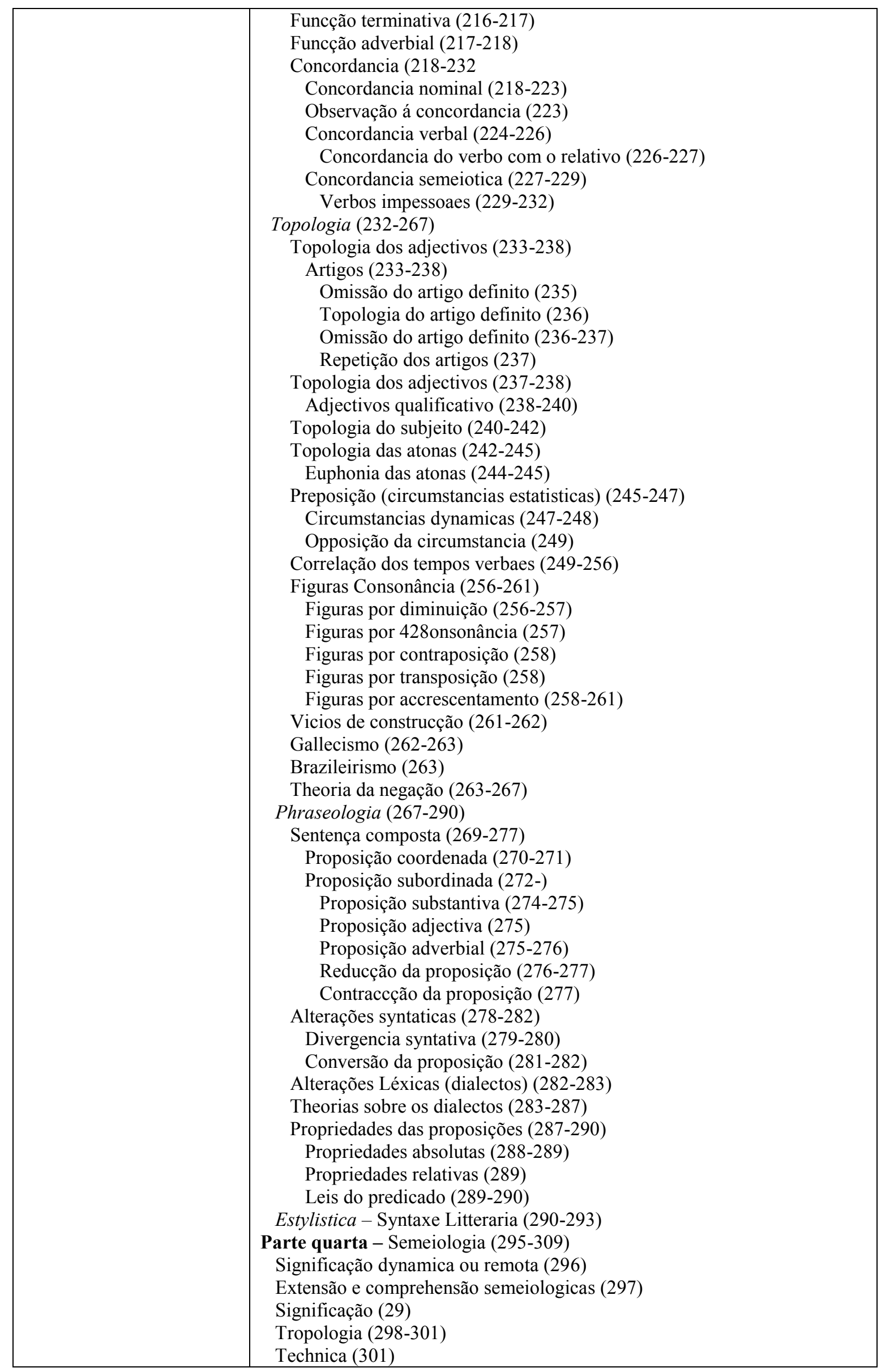




\begin{tabular}{|c|c|}
\hline & $\begin{array}{l}\text { Virgula (301-303) } \\
\text { Poncto e virgula (303-304) } \\
\text { Dous ponctos (304-305) } \\
\text { Poncto final (305) } \\
\text { Poncto interjectivo ou admirativo (305) } \\
\text { Poncto interrogativo (306) } \\
\text { Ponctos reticentes ou suspensivos (306) } \\
\text { Parenthesis (306) } \\
\text { Virgulas dobradas (307) } \\
\text { Travessão (307-308) } \\
\text { Outros signaes technicos (308-309) }\end{array}$ \\
\hline Objetivo do autor & 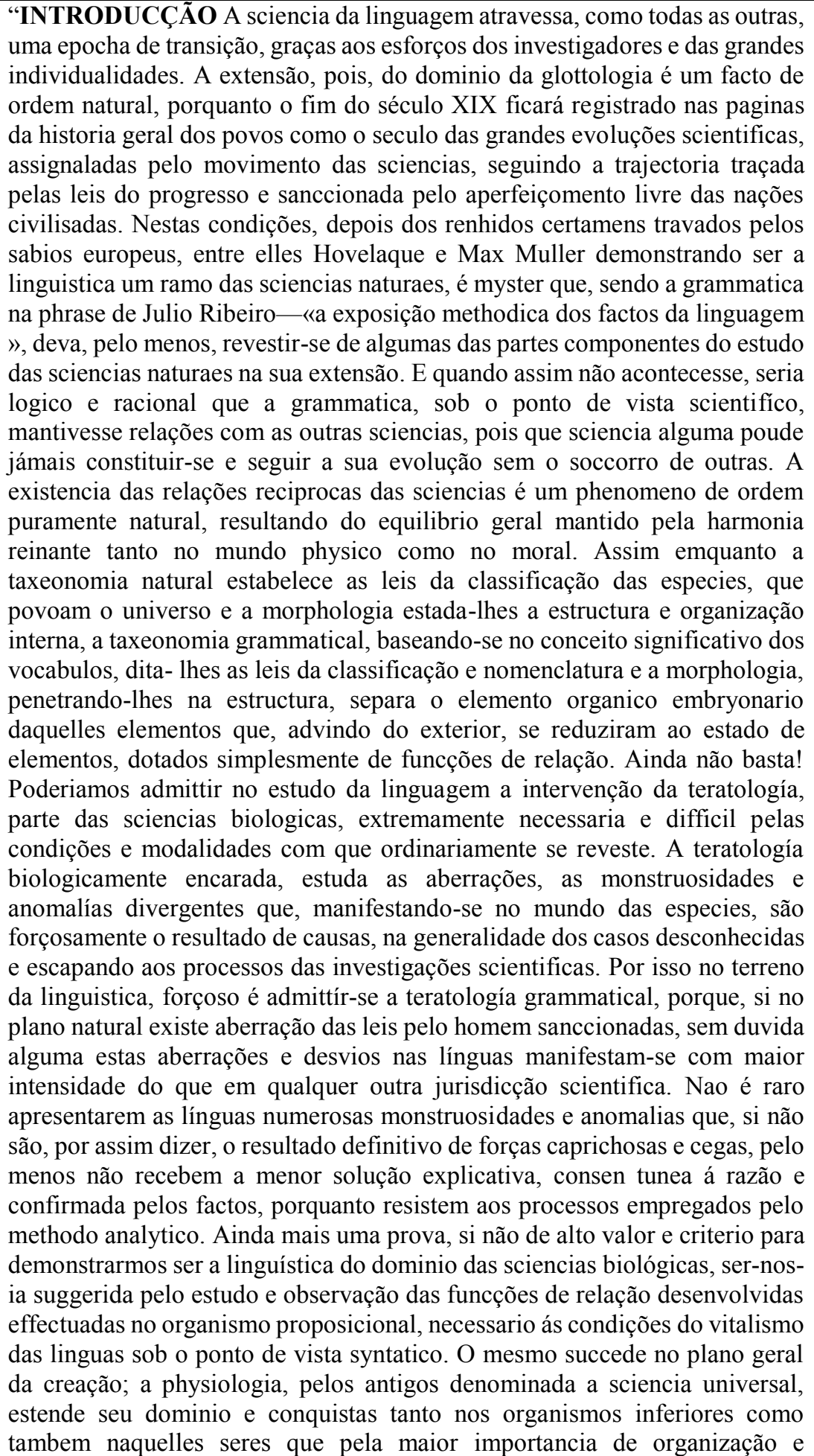 \\
\hline
\end{tabular}




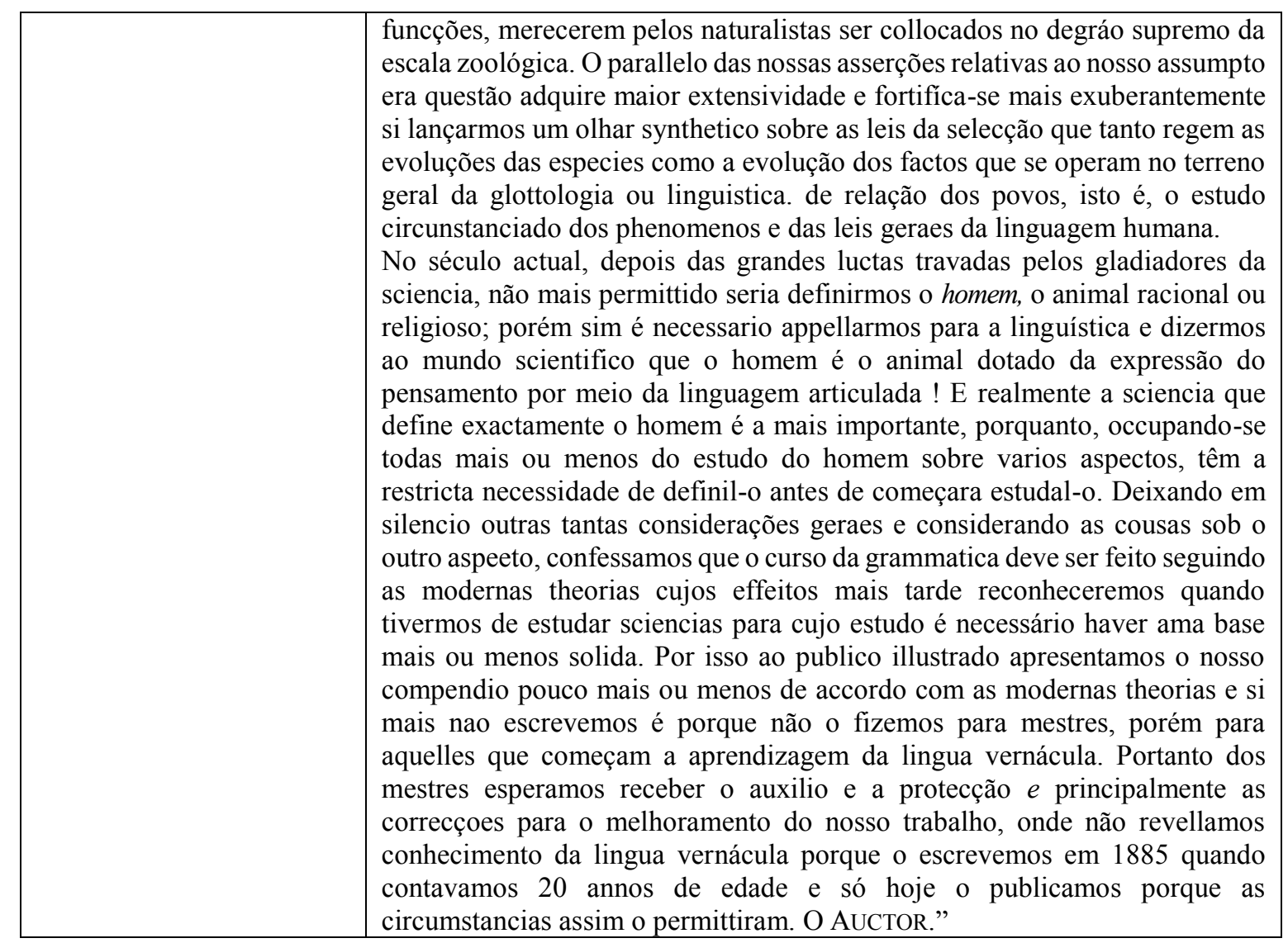




\begin{tabular}{|c|c|}
\hline \multicolumn{2}{|c|}{ FD 13. PACHECO \& LAMEIRA 1887} \\
\hline Título & $\begin{array}{l}\text { Noções de grammatica portugueza de accordo com o programma official } \\
\text { para os exames geraes de preparatorios do corrente anno }\end{array}$ \\
\hline $\begin{array}{l}\text { Autor (biodatas e local de } \\
\text { nascimento e morte) }\end{array}$ & $\begin{array}{l}\text { Pacheco da Silva Junior (? -? ) e Boaventura Plácido Lameira de Andrade (? } \\
\text {-?) }\end{array}$ \\
\hline Ano & 1887 \\
\hline Local de impressão & Rio de Janeiro \\
\hline Tipografia & J. G. de Azevedo - Editor \\
\hline Edição / Impressão & $1^{\mathrm{a}}$ \\
\hline $\begin{array}{l}\text { Outras obras do mesmo } \\
\text { autor. }\end{array}$ & $\begin{array}{l}\text { PACHECO: } \\
\text { 1876. Novo methodo facil e pratico para aprender a linguage ingleza. } \\
\text { 1877. Estudo da lingua vernacula. Phonologia. } \\
\text { 1878. Grammatica litteraria da lingua portugueza. } \\
\text { 1880. O collegio Pedro II, seu passado, presente e futuro. } \\
\text { 1883. Diccionario etymologico da lingua portugueza, } \\
\text { 1888. Noçós de analyse grammatical, phonetica, etymologica e syntaxica, } \\
\text { em co-autoria com Boscoli. }\end{array}$ \\
\hline $\begin{array}{l}\text { Outras edições e } \\
\text { reimpressões conhecidas }\end{array}$ & $\begin{array}{l}\text { 1894. Grammatica da lingua portugueza para uso dos gymnasios, lyceus e } \\
\text { escolas normaes. }\end{array}$ \\
\hline $\begin{array}{l}\text { Descrição da edição } \\
\text { consultada }\end{array}$ & $\begin{array}{l}\text { Folha de rosto: grammatica portugueza de accordo com o programma } \\
\text { official para os exames geraes de preparatorios do corrente anno pelos } \\
\text { professores Pacheco da Silva Junior e Lameira de Andrade. Epígrafe: Ainda } \\
\text { quando a grammatica historica só désse em resultado tornar as grammaticas } \\
\text { ordinarias mais logicas e mais simples, já não prestava pequeno serviço. Rio } \\
\text { de Janeiro. J. G. de Azevedo - Editor. Rua da Uruguayana, } 33 \text { - } 1887 \text {. } \\
\text { Número de páginas: } 537\end{array}$ \\
\hline Sumário da obra & $\begin{array}{l}\text { Primeira Lição - Observaçães geraes sobre o que se entende por grammatica } \\
\text { geral, por grammatica historica ou comprativa e por grammatica descriptiva } \\
\text { ou expositiva. Objecto da grammatica portugueza e divisão do seu estudo. } \\
\text { Phonologia: os sons e as lettras; classificaçãoi dos sons e das lettras; vogaes; } \\
\text { grupos vocaliscos; copnsoantes; grupos consonantaes; syllabas; grupos } \\
\text { syllabicos; vocabulos; notações lexicas. (5-16) } \\
\text { Segunda Lição - Accentuaço e quantidade. (17-26) } \\
\text { Terceira Lição - Origem das lettras portuguezas; leis que presidem á permuta } \\
\text { das lettras; importancia destas transformaçõe sphonicas no processo de } \\
\text { derivação das palavras (27-41) } \\
\text { Quarta Lição - Metaplasmos (43-50) } \\
\text { Quinta Lição - Dos systemas de ortographia; das causas de sua irregularidade. } \\
\text { (51-55) } \\
\text { Sexta Lição. Morphologia: estructura da palavra; raiz; thema; terminação; } \\
\text { affixos. Do sentido das palavras deduzido dos elementos morphicos que as } \\
\text { constituem; desenvolvimento de sentidos novos nas palavras. (57-75) } \\
\text { Sétima Lição - Da classificação das palavras. Do substantivo e suas especies. } \\
\text { (76-85) } \\
\text { Oitava Lição - Da classificação das palavras. Do adjetivo e suas especies. (86- } \\
\text { 90) } \\
\text { Nona Lição - Classificação das palavras. Do pronome e suas especies. (91- } \\
94) \\
\text { Décima Lição - Classificação das palavras. Do verbo e suas especies. (95- } \\
\text { 105) } \\
\text { Décima Primeira Lição - Classificação das palavras. Das palavras invariáveis } \\
\text { (106-120) } \\
\text { Décima Segunda Lição - Agrupamentos de palavras por familias e por } \\
\text { associação de idéias. Dos synonymos, homonymos e paronymos. (121-140) } \\
\text { Décima Terceira Lição - Flexão dos nomes: genero; numero; caso. Noções } \\
\text { de declinação latina. Desapparecimento do neuto latino em Portuguez; }\end{array}$ \\
\hline
\end{tabular}


vestigios de neutro em Portuguez; vestigios da declinação em Portuguez. Origem do $s$ do plural. (142-180)

Décima Quarta Lição - Flexão dos nomes: grau do substantivo e do adjectivo; comparativos e superlativos analyticos. (182-198)

Décima Quinta Lição - Flexão dos nomes; flexão do pronome; declinação dos pronomes pessoaes. (199-210)

Décima Sexta Lição - Flexão dos verbos; conjugação; fórmas de consjugação. (211-248)

Décima Sétima Lição - Formação das palavras em geral: composição por prefixos e por juxtaposição. Estudos dos prefixos. (249-280)

Décima Oitava Lição - Formação das palavras em geral: derivação propria (por suffixos); derivação impropria (sem sufficos). Estudos dos suffixos. (281-308)

Décima Nona Lição - Das palavras variaveis formadas no proprio seio da lingua portugueza. (309-311)

Vigésima Lição - Das palavras invariaveis formadas no proprio seio da lingua portugueza. (312 - 314)

Vigésima Primeira Lição -. Etymologia portugueza; principios em que se baseia a etymologia. Leis que presidiram á formação do lexico portuguez. (315-321)

Vigésima Segunda Lição - Da constituição do lexico portuguez. Linguas que maior contingente forneceram ao vocabulario portuguez. (322-335)

Vigésima Terceira Lição - Caracter differencial entre os vocabulos de origem popular e os de formação erudita; duplas ou forma divergentes. (336-347)

Vigésima Quarta Lição - Da creação de palavras novas. Hybridismos. (348354)

Vigésima Quinta Lição - Etymoologia do substantivo e do adjectivo. Influencia dos casos na etymologia dos nomes. (355-370)

Vigésima Sexta Lição - Etymologia do artigo e do pronome. (371-384)

Vigésima Sétima Lição - Etymologia das fórmas verb aes; comparação da conjugação latina com a portugueza. (385-396). Vigésima Oitava Lição Etymologia das palavras. (397-414)

Vigésima Nona Lição - Da syntaxe em geral. Breves noções sobre a estructura oracional, do Latim popular e do Latim culto. Typos syntaxicos divergentes na lingua portugueza (415-419)

Trigésima Lição - Syntaxe da proposição simples. Especies de proposição simples quanto á forma e á significação. Dos membros da proposição simples (420-421)

Trigésima Primeira Lição - Syntaxe da proposição composta ou do periodo composto. Coordenação. Subordinação. Classificação das proposições (422424)

Trigésima Segunda Lição - Regras de syntaxe relativas a cada um dos termos ou membros da composição (425-429)

Trigésima Terceira Lição - Regras de syntaxe relativas ao substantivo e ao adjectivo (430-442)

Trigésima Quarta Lição - Regras de syntaxe relativas ao pronome (443-448) Trigésima Quinta Lição - Regras de syntaxe relativas ao verbo. Do emprego dos modos e tempos, correspondencia dos tempos dos verbos nas proposições coordenadas e nas proposições subordinadas (449-460)

Trigésima Sexta Lição - Regras de syntaxe relativas ás fórmas nominaes do verbo (461-467)

Trigésima Sétima Lição - Regras de syntaxe relativas ás palavras invariaveis (468-480)

Trigésima Oitava Lição - Syntaxe do verbo haver e do pronome se (481-482) Trigésima Nona Lição - Da construcção: ordem das palavras na proposição simples e das proposições simples no periodo composto. (483-490)

Quadragésima Lição - Da collocação dos pronomes pessoaes. (491-493)

Quadragésima Primeira Lição - Das notações syntaxicas; pontuação; emprego de lettras maiusculas. (494-497) 


\begin{tabular}{|c|c|}
\hline & $\begin{array}{l}\text { Quadragésima Segunda Lição - Figuras de syntaxe. Particulas de realce. } \\
\text { (494-497) } \\
\text { Quadragésima Terceira Lição - Dos vicios de linguagem. (498-502) } \\
\text { Quadragésima Quarta Lição -. Das anomalias grammaticaes; idiotismos; } \\
\text { provincialismos; brasileirismos e dialecto. (503-522) } \\
\text { Quadragésima Quinta Lição - Das alterações lexicas e syntaxicas; archaismo } \\
\text { e neologismo. (523-526) } \\
\text { Quadragésima Sexta Lição - A syntaxe e o estylo (527-537) }\end{array}$ \\
\hline Objetivo do autor & $\begin{array}{l}\text { "Tinhamos emprehendido escrever uma grammatica completa da lingua } \\
\text { portugueza, rompendo em lucta a tradição, e fazíamos fundamento de } \\
\text { entregal-a em breve á publicidade. O novo programma para os exames geraes } \\
\text { de preparatorios, porem, veio fazer-nos mudar do proposito. E' que muitos } \\
\text { dos pontos nelle exigidos para os exames de portuguez não se encontrando } \\
\text { nas grammaticas que por ahi correm impressas, e os alumnos não tendo fontes } \\
\text { onde possam haurir a instrucção de que carecem, resolvemos vir ainda uma } \\
\text { vez em auxilio da mocidade estudiosa. Não apresentamos este trabalho como } \\
\text { merecedor de gabos de excellente nem no intuito de nos revelarmos } \\
\text { professores de sciencia jubilada. O tempo urgia; bosquejamos apenas o } \\
\text { assumpto. Nem sempre o nosso parecer coincidiu com a indicação do } \\
\text { programma official; seguimos todavia, para maior segurança dos viajantes } \\
\text { novéis, o roteiro apresentado pelo governo. A unica difificuldade, e não } \\
\text { pequena, com que tivemos de pleitear, foi a dosagem. Acertadamente } \\
\text { escreveu o illustre pedagogista Alberto Brandão: A grande difficuldade com } \\
\text { que vão arcar os professores é a dosagem, porquanto, como disse Michel } \\
\text { Bréal, não ha methodo mais perigoso do que o historico, quando mal } \\
\text { applicado, e os autores do livro a apparecer têm de pôr de parte a vaidade } \\
\text { natural aos que muito estudam para formularem um livro modesto e } \\
\text { comprehendido pelos que começam a estudar. E isso, parece, ficará de } \\
\text { accôrdo com os organi- sadores do programma, que levem saber que muitos } \\
\text { dos pontos exigidos só poderiam ser tratados em theses, não de exames de } \\
\text { preparatórios, mas de concurso no imperial Collegio. Seguindo esse conselho } \\
\text { de mestre, fizemos o que deviamos; se o nosso trabalho, porem, não agradar } \\
\text { a alguns, escrevam elles um outro - a maior aproveitamento dos } \\
\text { estudantes-, e mostrem o que sabem e o que podem. NotA. - A matéria } \\
\text { que o alumno é obrigado a encerebrar vae impressa em typo maior; as notas } \\
\text { encasadas no texto, e as que vão embaixo da pagina são destinadas aos que } \\
\text { mais desejam aprender. Entendemos dever forrar-nos á tarefa de nos } \\
\text { occuparmos de definições e outras cousas elementares, que o alumno já deve } \\
\text { conhecer desde a escola primaria." }\end{array}$ \\
\hline
\end{tabular}




\begin{tabular}{|c|c|}
\hline \multicolumn{2}{|r|}{ FD 14. CONDURÚ 1888} \\
\hline Título & Grammatica elementar da lingua portugueza \\
\hline $\begin{array}{c}\text { Autor (biodatas e local de } \\
\text { nascimento e morte) }\end{array}$ & Fillippe Benicio de Oliveira Condurú (1818 - 1879 Maranhão) \\
\hline Ano & 1888 (cf. Nogueira) \\
\hline Local de impressão & São Luiz do Maranhão \\
\hline Tipografia & Typ. do Paiz. Largo do Palacio, n. 45. Impresso por M. F. Vianna Pires. \\
\hline Edição / Impressão & $13^{\mathrm{a}}$ \\
\hline $\begin{array}{c}\text { Outras edições e } \\
\text { reimpressões conhecidas }\end{array}$ & 1850. Grammatica elementar da lingua portugueza. (cf. Nogueira 2009) \\
\hline $\begin{array}{c}\text { Descrição da edição } \\
\text { consultada }\end{array}$ & $\begin{array}{l}\text { Folha de rosto: Grammatica elementar da lingua portugueza por Filippe } \\
\text { Benicio de Oliveria Condurú, profesor da Escola Normal do Maranhão, } \\
\text { approvada pelo Inspector da Intrucção publica para uso das escolas de } \\
\text { primeiras letras desta provincia e pelo conselho de instrucção publica par } \\
\text { uso do lyceu, collegios e aulas de instrucção primaria na provincia do Pará. } \\
\text { XIII. Edição. Á venda. Em casa do Sr. Manoel Joaquim Fernandes. R. de } \\
\text { Nazareth. Preço } 1 \$ 000 \text { réis. } \\
\text { Pagina seguinte: Advertencia - O autor previne que os exemplaes desta obra } \\
\text { impressos por seu consentimento leverão esta marca autographa. () San luiz } \\
\text { - Typ. do PAIZ. Largo de Palacio. n. 15. Impresso por M. F. Vianna Pires. } \\
\text { Última página: Advertencia. Os exemplares desta edição levarão, em vez da } \\
\text { marca authographa do costuma na 2a pagina, o nome do auctr em letras } \\
\text { brancas em relevo. }\end{array}$ \\
\hline Sumário da obra & $\begin{array}{l}\text { Folha de rosto (2) } \\
\text { Advertencia (3) } \\
\text { Introdução (4-5) } \\
\text { Capitulo I - Da Etymologia (6-70) } \\
\text { I - Do substantivo (6-7) } \\
\text { II - Do genero do substantivo (7-8) } \\
\text { III - Do adjectivo (8-17) } \\
\text { IV. Das variações dos nomes (17-21) } \\
\text { V. Do verbo (21-35) } \\
\text { VI. Da conjugação dos verbos auxiliares (28-35) } \\
\text { VII. Da conjugação dos verbos (35-41) } \\
\text { VIII. Da conjugação activa dos verbos regulares (41-46) } \\
\text { IX. Conjugação activa do verbo unir para modelo dos da terceira } \\
\text { conjugação, e do verbo por para modelo de seus compostos (46-51) } \\
\text { X. Da conjugação da voz reflexa e da passiva dos verbos (51-56) } \\
\text { XI. Da formação dos tempo e dos verbos irregulares (56-66) } \\
\text { XII. Da preposição (66-67) } \\
\text { XIII. Do adverbio (67-68) } \\
\text { XIV. Da conjuncção (68-69) } \\
\text { XV. Da interjeição (69-70) } \\
\text { Capitulo II - Da Prosodia (70-75) } \\
\text { I. Do som (70-71) } \\
\text { II. Do accento (72-73) } \\
\text { III. Da quantidade das syllabas (73-74) } \\
\text { IV. Das figuras de dicção (74-75) } \\
\text { Capitulo III - Da orthographia (75- } \\
\text { I. Das vogaes (76-77) } \\
\text { II. Das consoantes (78-80) } \\
\text { III. Das letras dobradas (80-81) } \\
\text { IV. Do emprego das letras maiusculas, do uso do hyphen e do apostropho } \\
\text { (81-83) } \\
\text { V. Da pontuação (83-85) } \\
\text { Capitulo IV - Da syntaxe (86-103) } \\
\text { I. Da oração e suas partes essenciais (86-88) } \\
\end{array}$ \\
\hline
\end{tabular}




\begin{tabular}{|l|l|}
\hline & II. Do periodo e orações que o compõem (89-91) \\
& III. Da syntaxe de concordancia (91-93) \\
& IV. Da syntaxe de regencia (93-97) \\
& V. Da construção (97-99) \\
& VI. Das figuras de syntaxe (99-103) \\
& Advertencia (103) \\
\hline Objetivo do autor & - \\
\hline
\end{tabular}




\begin{tabular}{|c|c|}
\hline \multicolumn{2}{|r|}{ FD 15. RIBEIRO 1889} \\
\hline Título & Exames de Portuguez - Grammatica Portugueza ( $3^{\circ}$ anno) \\
\hline $\begin{array}{c}\text { Autor (biodatas e local de } \\
\text { nascimento e morte) }\end{array}$ & João Ribeiro Fernandes (Sergipe 1860 - 1934 Rio de Janeiro) \\
\hline Ano & 1889 \\
\hline Local de impressão & Rio de Janeiro \\
\hline Tipografia & Livraria Classica de ALVEZ \& C. \\
\hline Edição / Impressão & $3^{\mathrm{a}}$ ed. \\
\hline Acesso ao texto & $\begin{array}{l}\text { IEB / USP } \\
\text { CEDOCH (fotos) } \\
\text { Coleção "Gramáticas" da UNICAMP (gramática digitalizada) }\end{array}$ \\
\hline $\begin{array}{c}\text { Outras obras do mesmo } \\
\text { autor }\end{array}$ & $\begin{array}{l}\text { 1880. Idilios Modernos } \\
\text { 1888. Grammatica portugueza elementar } \\
\text { 1888. Grammatica portugueza. Curso médio. } 2 .^{\circ} \text { anno de Portuguez } \\
\text { 1884. Estudos philologicos: morphologia e funcciologia } \\
\text { 1889. Diccionario Grammatical } \\
\text { 1890. Versos } \\
\text { 1923. Autores contemporâneos } \\
\text { 1921. A lingua nacional }\end{array}$ \\
\hline $\begin{array}{c}\text { Outras edições e } \\
\text { reimpressões conhecidas }\end{array}$ & $\begin{array}{l}\text { 1887. Exames de Portuguez - Grammatica Portugueza ( } 3^{\circ} \text { anno) } \\
\text { 1888. Exames de Portuguez }- \text { Grammatica Portugueza }\left(3^{\circ} \text { anno) }\right. \\
\text { 1891. Grammatica Portugueza }\left(3^{\circ} \text { anno) }\right. \\
\text { 1893. Grammatica Portugueza }\left(3^{\circ} \text { anno) }\right. \\
\text { 1894. Grammatica Portugueza }\left(3^{\circ} \text { anno) }\right. \\
\text { 1898. Grammatica Portugueza }\left(3^{\circ} \text { anno) }\right.\end{array}$ \\
\hline $\begin{array}{l}\text { Descrição da edição } \\
\text { consultada }\end{array}$ & 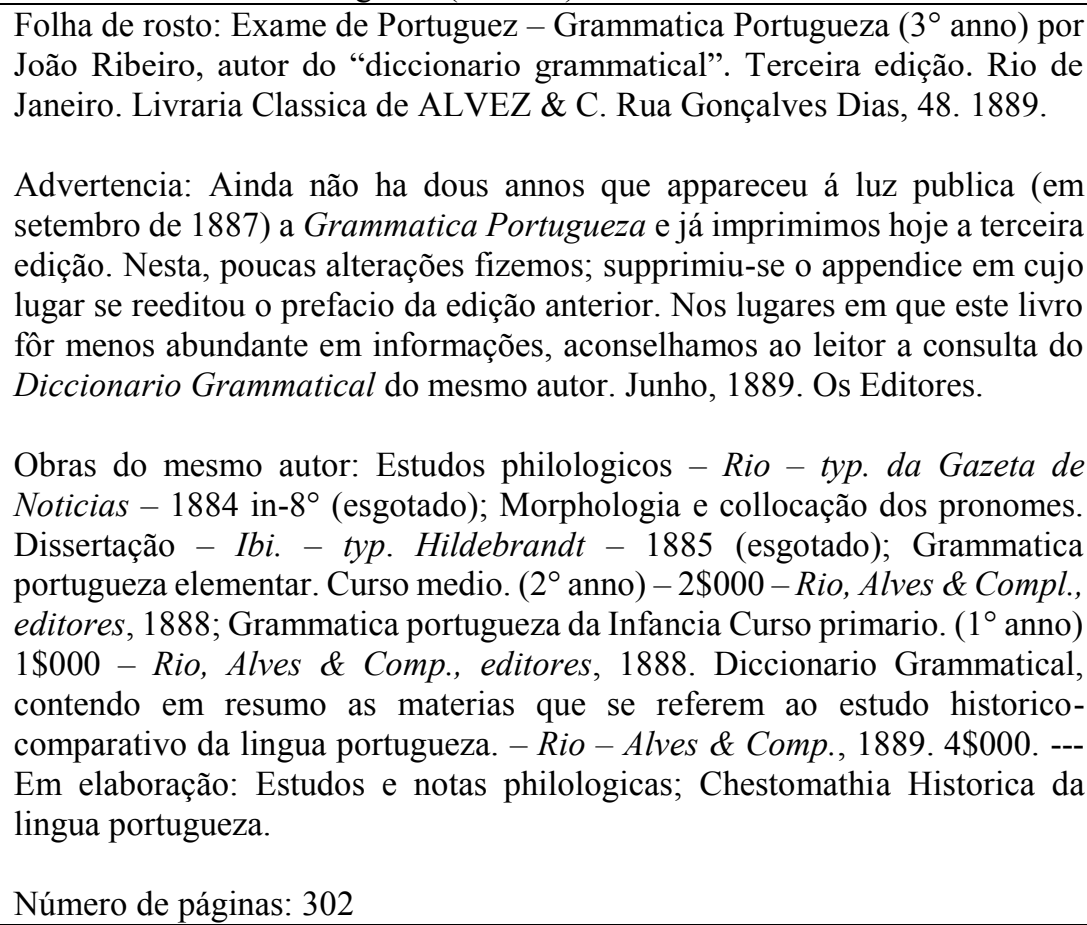 \\
\hline Sumário da obra & $\begin{array}{l}\text { 1. Observações geraes sobre o que se entende por grammatica geral, por } \\
\text { grammatica historica ou comprativa e por grammatica descriptiva ou } \\
\text { expositiva. Objecto da grammatica portugueza e divisão do seu estudo. } \\
\text { Phonologia: os sons e as lettras; classificaçãoi dos sons e das lettras; vogaes; } \\
\text { grupos vocaliscos; copnsoantes; grupos consonantaes; syllabas; grupos } \\
\text { syllabicos; vocabulos; notações lexicas. (1-15) } \\
\text { 2. De Accentuaço e quantidade. (15-27) }\end{array}$ \\
\hline
\end{tabular}


3. Origem das lettras portuguezas; leis que presidem á permuta das lettras; importancia destas transformaçõe sphonicas no processo de derivação das palavras (27-51)

4. Das metaplasmas (52-56)

5. Dos systemas de ortographia; das causas de sua irregularidade. (57-68)

6. Morphologia: estructura da palavra; raiz; thema; terminação; affixos. Do sentido das palavras deduzido dos elementos morphicos que as constituem; desenvolvimento de sentidos novos nas palavras. (69-75)

7. Da classificação das palavras. Do substantivo e suas especies. (76-83)

8. Da classificação das palavras. Do adjetivo e suas especies. (84-90)

9. Classificação das palavras. Do pronome e suas especies. (91-94)

10. Classificação das palavras. Do verbo e suas especies. (95-99)

11. Classificação das palavras. Das palavras invariáveis (100-104)

12. Agrupamentos de palavras por familias e por associação de idéias. Dos synonymos, homonymos e paronymos. (121-140)

13. Flexão dos nomes: genero; numero; caso. Noções de declinação latina. Desapparecimento do neuto latino em Portuguez; vestigios de neutro em Portuguez; vestigios da declinação em Portuguez. Origem do $s$ do plural. (142-180)

14. Flexão dos nomes: grau do substantivo e do adjectivo; comparativos e superlativos analyticos. (182-198)

15. Flexão dos nomes; flexão do pronome; declinação dos pronomes pessoaes. (199-210)

16. Flexão dos verbos; conjugação; fórmas de consjugação. (211-248)

17. Formação das palavras em geral: composição por prefixos e por juxtaposição. Estudos dos prefixos. (249-280)

18. Formação das palavras em geral: derivação propria (por suffixos); derivação impropria (sem sufficos). Estudos dos suffixos. (281-308)

19. Das palavras variaveis formadas no proprio seio da lingua portugueza. (309-311)

20. Das palavras invariaveis formadas no proprio seio da lingua portugueza. $(312-314)$

21. Etymologia portugueza; principios em que se baseia a etymologia. Leis que presidiram á formação do lexico portuguez. (315-321)

22. Da constituição do lexico portuguez. Linguas que maior contingente forneceram ao vocabulario portuguez. (322-335)

23. Caracter differencial entre os vocabulos de origem popular e os de formação erudita; duplas ou forma divergentes. (336-347)

24. Da creação de palavras novas. Hybridismos. (348-354)

25. Etymoologia do substantivo e do adjectivo. Influencia dos casos na etymologia dos nomes. (355-370)

26. Etymologia do artigo e do pronome. (371-384)

27. Etymologia das fórmas verb aes; comparação da conjugação latina com a portugueza. (385-396).

28. Etymologia das palavras. (397-414)

29. Da syntaxe em geral. Breves noções sobre a estructura oracional, do Latim popular e do Latim culto. Typos syntaxicos divergentes na lingua portugueza (415-419)

30. Syntaxe da proposição simples. Especies de proposição simples quanto á forma e á significação. Dos membros da proposição simples (420-421)

31. Syntaxe da proposição composta ou do periodo composto. Coordenação. Subordinação. Classificação das proposições (422-424)

32. Regras de syntaxe relativas a cada um dos termos ou membros da composição (425-429)

33. Regras de syntaxe relativas ao substantivo e ao adjectivo (430-442)

34. Regras de syntaxe relativas ao pronome (443-448)

35. Regras de syntaxe relativas ao verbo. Do emprego dos modos e tempos, correspondencia dos tempos dos verbos nas proposições coordenadas e nas proposições subordinadas (449-460)

36. Regras de syntaxe relativas ás fórmas nominaes do verbo (461-467) 


\begin{tabular}{|c|c|}
\hline & $\begin{array}{l}\text { 37. Regras de syntaxe relativas ás palavras invariaveis (468-480) } \\
\text { 38. Syntaxe do verbo haver e do pronome se (481-482) } \\
\text { 39. Da construcção: ordem das palavras na proposição simples e das } \\
\text { proposições simples no periodo composto. (483-490) } \\
\text { 40. Da collocação dos pronomes pessoaes. (491-493) } \\
\text { 41. Das notações syntaxicas; pontuação; emprego de lettras maiusculas. (494- } \\
\text { 497) } \\
\text { 42. Figuras de syntaxe. Particulas de realce. (494-497) } \\
\text { 43. Dos vicios de linguagem. (498-502) } \\
\text { 44. Das anomalias grammaticaes; idiotismos; provincialismos; brasileirismos } \\
\text { e dialecto. (503-522) } \\
\text { 45. Das alterações lexicas e syntaxicas; archaismo e neologismo. (523-526) } \\
\text { 46. A syntaxe e o estylo (527-537) }\end{array}$ \\
\hline Objetivo do autor & 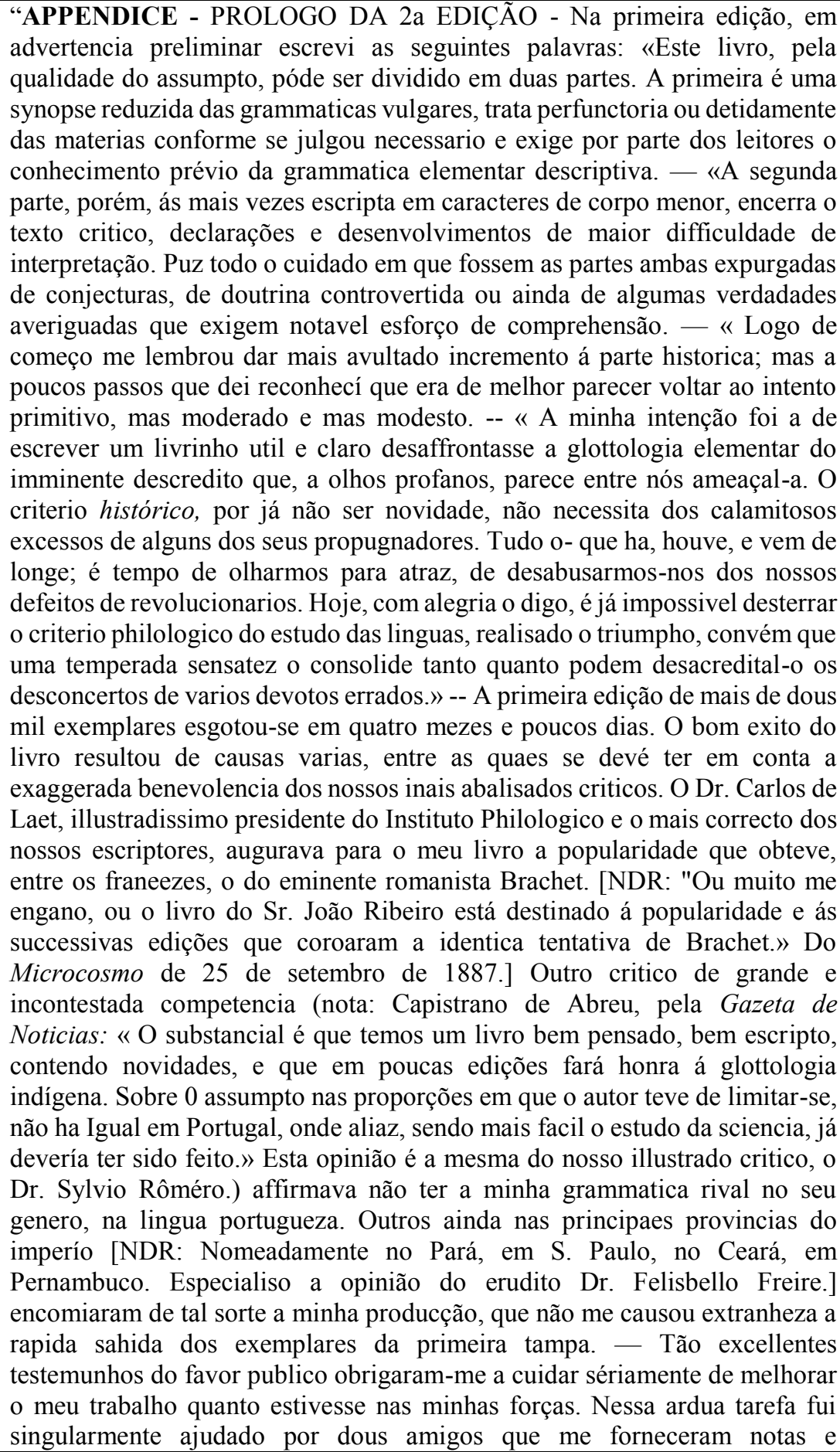 \\
\hline
\end{tabular}




\begin{tabular}{|l|l|}
\hline & corrigendas: que aceitei com verdadeiro jubilo. O illustrâdíssimo Sr. \\
Aureliano Pimentel, honra do professorado do Collegio de D. Pedro II, \\
propoz-me algumas observações que, por muito conformes á razão, aceitei \\
sem escrupulos; as notas versavam sobre a etymologia de cigarra, sobre os \\
prefixos de, dis, des, in e os suffixos izar, ela, acrescimo de exemplos de \\
futuros que se differençaram das fórmas infinitivas e sobre a correcção do \\
genéro latino de fons, manus, etc. O nosso americanista e esclarecido \\
phliologo, o Dr. Macedo Soares, notou alguns erros - concernentes ás \\
linguas tupi e africana, que me apressei em corrigir com o reconhecimento \\
que devo ao mais habilitado dos que, entre nós, estudam o dialecto brasileiro. \\
Por mim mesmo reparei e emendei tudo o que me pareceu erroneo ou mal \\
feito e com o intuito de tornar o meu trabalho mais digno da aceitação publica, \\
fiz accrescísmos notaveis e dei capitulos novos de materias essenciaes á \\
disciplina grammatical. Entre os capitulos novos chamarei a attenção dos \\
competentes para os que se intitulam: Analyse das proposiçóes -- baseado nos \\
trabalhos de Latham e Mason; - Concordancia - complexo de regras \\
extrahidas integral mente, com alguns retoques, do vigoroso compêndio \\
castelhano de Andres Bello;- Verbos irregulares, capitulo necessario á \\
etymologia dos verbos:- Theoria da, phonetica, estudo doutrinario cuja \\
cópia de exemplos foi toda bebida nos trabalhos de A. Coelho e Karl von \\
Reinhard Stoettner. -- A lingua portugueza nos últimos quinze annos tem tido \\
estudiosos de mérito e no estrangeiro basta lembrar os nomes de \\
Reinhadstcettner (Gramm. der portugieschen Sprache) Carolina Michaelis \\
(Studien, edições philologicas e artigos no Zeitschrift für rom. Phil.) Cornu \\
(artigos na Romania, Muséon etc.) D'Ovidio e Monaci (edição do Canc,, e \\
Manualetti neo-lat,-Portoghese) Hugo Schuchardt (varios estudos de \\
dialectologia) e outros mais. No Brazil existe uma pleiade notabilissima de \\
philologos, cuja manifestação collectiva mais importante é o Instituto \\
Philologico. Em Portugal basta o nome unico de Adolpho Coelho. - Possa \\
este livro encontrar o apoio que merecem os esforços do mais humilde \\
discipulo da nova escola.
\end{tabular}




\begin{tabular}{|c|c|}
\hline \multicolumn{2}{|r|}{ FD 16. CARNEIRO RIBEIRO 1890} \\
\hline Título & Serões Grammaticaes ou Nova Grammatica Portugueza \\
\hline $\begin{array}{c}\text { Autor (biodatas e local de } \\
\text { nascimento e morte) }\end{array}$ & Ernesto Carneiro Ribeiro (Bahia 1839-1920) \\
\hline Ano & 1890 \\
\hline Local de impressão & Bahia \\
\hline Tipografia & Imprensa Popular \\
\hline Edição / Impressão & $1^{\mathrm{a}}$ \\
\hline $\begin{array}{c}\text { Outras obras do mesmo } \\
\text { autor }\end{array}$ & $\begin{array}{l}\mathbf{1 8 6 4} \text { - Relações da medicina com as sciencias philosophicas; Como obra, o } \\
\text { sulfato de quinino nas febres intermittentes }{ }^{\wedge} \text { Do centeio espigado e sua } \\
\text { applicação na obstetrícia; Theoria da respiração vegetal: these que sustenta } \\
\text { para obter o grau de doutor, etc. Bahia. } \\
\mathbf{1 8 8 5} \text { - Perturbações psychicas no domínio da hysteria : these de concurso da } \\
\text { cadeira de clinica obstetrica e gynecologica. Bahia. } \\
\mathbf{1 8 8 1} \text { - Grammatica portugueza philosophica. Bahia. }\end{array}$ \\
\hline $\begin{array}{c}\text { Outras edições e } \\
\text { reimpressões conhecidas }\end{array}$ & $\begin{array}{l}\text { 1915. Serões grammaticaes ou Nova grammatica portugueza, pelo Dr. } \\
\text { Ernesto Carneiro Ribeiro. Bahia: Livraria Catilina. } 2^{\mathrm{a}} \text { ed. } \\
\text { 1919. Serões grammaticaes ou Nova grammatica portugueza, pelo Dr. } \\
\text { Ernesto Carneiro Ribeiro. Bahia: Livraria Catilina. } 3^{\mathrm{a}} \text { ed. } \\
\text { 1950. Seroes grammaticaes ou Nova grammatica portugueza. Bahia: } \\
\text { Progresso. } 5^{\mathrm{a}} \text { ed. } \\
\text { 1956. Serões grammaticais ou Nova gramática portuguesa. Bahia: } \\
\text { Progresso. } 6^{\mathrm{a}} \text { ed. }\end{array}$ \\
\hline $\begin{array}{l}\text { Descriçãa da edição } \\
\text { consultada }\end{array}$ & $\begin{array}{l}\text { Folha de rosto: Serões Grammaticaes ou Nova Grammatica Portugueza pelo } \\
\text { Dr. Ernesto Carneiro Ribeiro, professor do Lyceo da Bahia. Obra } \\
\text { especialmente destinada ao curso secundario da lingua portugueza e } \\
\text { adaptada ao novo programma de exames. Non ut laudemur, sed ut prosimus. } \\
\text { Bahia. Imprensa Popular. Rua do Coberto Grande, } 48.1890 \text {. } \\
\text { Número de páginas: } 369\end{array}$ \\
\hline Sumário da obra & $\begin{array}{l}\text { Prólogo } \\
\text { Introdução (1-5) } \\
\text { Parte } 1 \text { - Phonologia (7-42) } \\
\text { Capitulo I (7-11) } \\
\text { Capitulo II (11-21) } \\
\text { Capitulo III Quantidade e accento (21-26) } \\
\text { Capitulo IV Origem das lettras portuguezas, permutas e suas leis (27-42) } \\
\text { Parte II - Orthographia (43-56) } \\
\text { Capitulo I (43-48) } \\
\text { Capitulo II Divisão das syllabas, abreviaturas, lettras capitaes } \\
\text { representativas de numeros (49-54) } \\
\text { Capitulo III Signaes orthographicos ou notações lexicas (54-56) } \\
\text { Parte III - Lexicologia (57-231) } \\
\text { Secção I - Formação das palavras (57-101) } \\
\text { Capitulo I Das palavras e seos elementos morphicos (57-83) } \\
\text { Capitulo II Vocabulos de origem popular e de origem erudita; duplas ou } \\
\text { formas divergentes (83-88) } \\
\text { Capitulo III Vocabulos reunidos por uma analogia de sentido, por uma } \\
\text { relação de contraste ou por mera semelhança phonica ou orthographica. } \\
\text { Palvras de sentido proprio e de sentido translato. (88-91) } \\
\text { Capitulo IV Constituição do lexico ou vocabulario portuguez (91-97) } \\
\text { Capitulo V Alterações das lingaos. Lingoa, idioma e dialectos: alterações } \\
\text { lexicas: archaismos, neologismos e hybridismos (97-102) } \\
\text { Secção II (102-231) } \\
\text { Capitulo I - Interjeição (102-106) } \\
\text { Capitulo II Dos substantivos (106-127) } \\
\text { Capitulo III Dos pronomes (127-130) }\end{array}$ \\
\hline
\end{tabular}




\begin{tabular}{|c|c|}
\hline & $\begin{array}{l}\text { Capitulo IV Dos adjectivos (130-149) } \\
\text { Capitulo V Dos verbos (150-210) } \\
\text { Capitulo V Das preposições (210-214) } \\
\text { Capitulo VI Das conjunções (215-221) } \\
\text { Capitulo VII Dos adverbios (222-225) } \\
\text { Capitulo VIII Origens latinas das preposições, das conjuncções e dos } \\
\text { adverbios (225-228) } \\
\text { Capitulo IX Etymologia em geral e principios em que se fundamenta } \\
\text { (228-231) } \\
\text { Parte IV - Phraseologia ou Syntaxe (233-369) } \\
\text { Capitulo I - Phraseologia em geral; syntaxe e contrucção; proposição ou } \\
\text { oração, seos elementos logicos; complementos, apposto e formula vocativa } \\
\text { ou compellativo. Divisão das orações, periodo e seos membros. (233-252) } \\
\text { Capitulo II Concordancia (253-273) } \\
\text { Capitulo III Observações sobre o emprego dos modos (273-281) } \\
\text { Capitulo IV Correspondencia dos tempos (282-286) } \\
\text { Capitulo V Do emprego do substantivo, do pronome, do artigo indicativo e } \\
\text { de alguns outros determinativos. Desdobramento do substantivo synthetivo } \\
\text { ou vocabulo complexo “quem" (286-300) } \\
\text { Capitulo VI Syntaxe das partes invariaveis (301-309) } \\
\text { Capitulo VII Regencia (309-321) } \\
\text { Capitulo VIII Pontuação (322-328) } \\
\text { Capitulo IX Alterações syntacticas (328-329) } \\
\text { Capitulo X Construcção: ordem das palavras nas proposições e das } \\
\text { proposições no periodo (330-342) } \\
\text { Capitulo XI Differença de estructura entre as orações no latim popular e } \\
\text { no latim classico ou litterario. Typos syntacticos divergentes (342-346) } \\
\text { Capitulo XII Vicios de linguagem (346-350) } \\
\text { Capitulo XIII Idiotismos, brazileirismos, provincianismos (350-356) } \\
\text { Capitulo XIV Figuras de syntaxe (356-364) } \\
\text { Capitulo XV A syntaxe e o estylo (364-368) } \\
\text { Observação supplementar (368-369) } \\
\text { Indice } \\
\text { Erratas }\end{array}$ \\
\hline Objetivo do autor & $\begin{array}{l}\text { "Prologo: O desenvolvimento que nestes ultimos annos têm tido os estudos } \\
\text { grammaticaes, esclarecidos pela grammatica comparada, levou-nos a } \\
\text { emprehender este nosso trabalho, que não é senão a grammatica portugueza a } \\
\text { que damos uma feição historica, ampliando-lhe mais a base, e enriquecendo- } \\
\text { a de novas observações, que a longa pratica é o estudo da lingoa, que com } \\
\text { tanto amor cultivamos, nos têm suggerido e ensinado. Hoje todo o estudo da } \\
\text { grammatica a que não acompanham as observações sbre a historia da lingoa } \\
\text { em sua evolução progressiva, como um organismo vivo, e que não se pode } \\
\text { subtrahir ás leis a que está sujeito tudo o que vive, é incompleto e repellido } \\
\text { para o puro dominio dos estudos abstractos e metaphysicos, em nada } \\
\text { consoantes á esphera em que deve girar e se deve manter toda a sciencia que } \\
\text { aspira a uma utilidade pratica e real, e se harmonisa e concerta com os sellos } \\
\text { que em todos os trabalhos cientificos vae imprimindo e gravando o seculo que } \\
\text { atravessamos. Neguem-se todos os meritos aos estudos positivos, tão } \\
\text { ardentemente sustentados e pleiteados por Comte e Littré, e complementados } \\
\text { pela orientação que lhes dá a escola ingleza contemporanea não se lhes poderá } \\
\text { contestar o merito de ter tenaz e intantemente chamado a attenção dos } \\
\text { espiritos do ermo sombrio e intrincados das abstrações, vagas e ociosas, para } \\
\text { o campo largo e fecundo da observação, aturda e reflectida, que dornece á } \\
\text { sciencia o seo ponto de partida, sua base e substratus. Todos os trabalhos } \\
\text { grammaticaes de algum merecimento attestam esta nova tendencia no estudo } \\
\text { da grammatica. Para o estudo da nossa lingoa e de todas as lingoas romanicas, } \\
\text { foi a grammatica de Frederico Diez o ponto de partida de todos os trabalhos } \\
\text { sobre o mesmo assumpto; a grammaticas historica de Branchet, em França, } \\
\text { os estudos criteriosos de Adolpho Coelho, em Portugal, e no Brazil os estudos } \\
\text { de Pacheco Junior e a nova grammatica portugueza de João Ribeiro, são }\end{array}$ \\
\hline
\end{tabular}




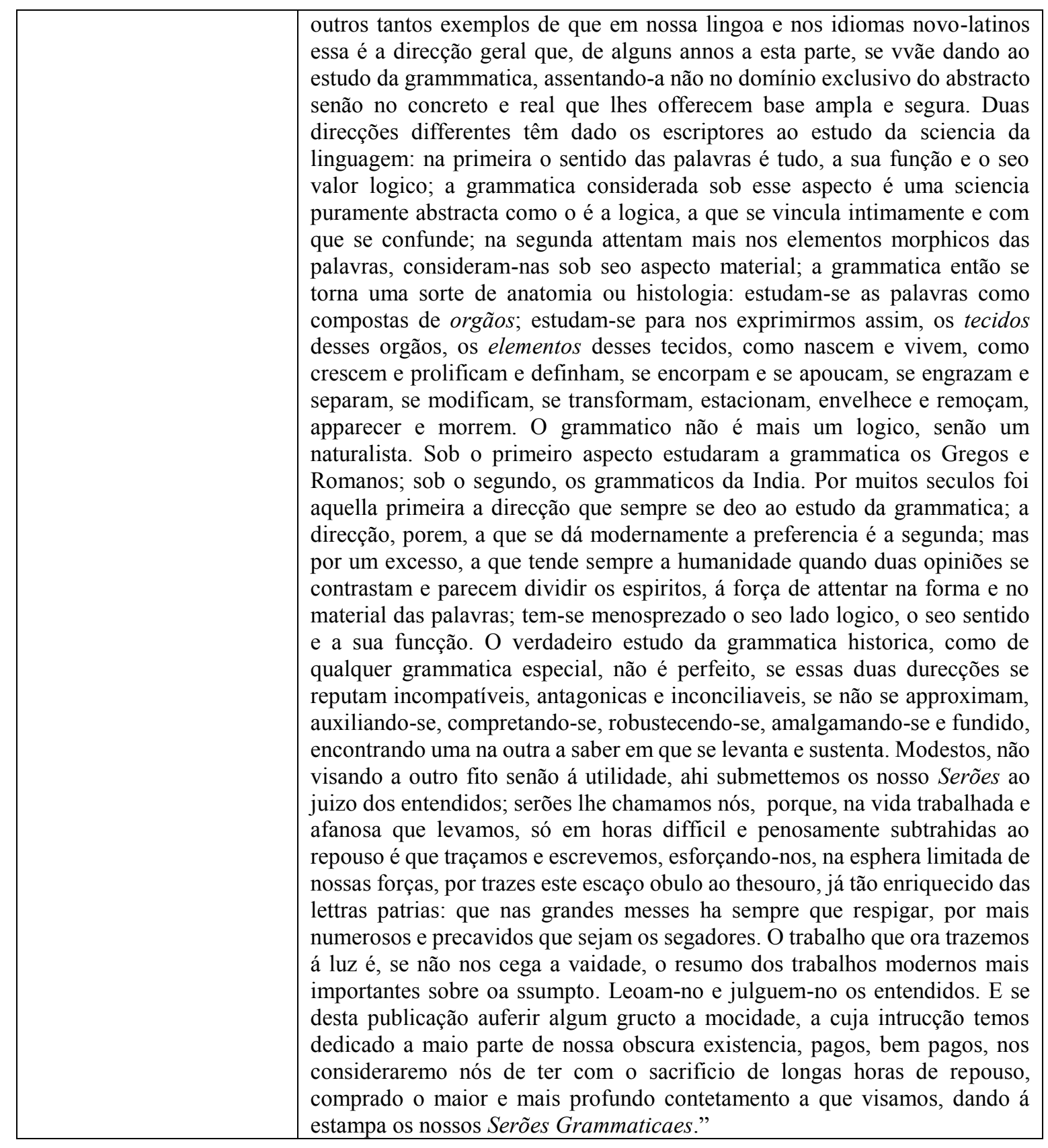




\begin{tabular}{|c|c|}
\hline \multicolumn{2}{|r|}{ FD 17. GOMES 1895} \\
\hline Título & Grammatica Portugueza \\
\hline $\begin{array}{l}\text { Autor (biodatas e local de } \\
\text { nascimento e morte) }\end{array}$ & Alfredo Gomes (? - ?) \\
\hline Ano & 1895 \\
\hline Local de impressão & Rio de Janeiro \\
\hline Tipografia & Typ. Moreira Maximino, Chagas \& C. / J. G. de Azevedo \\
\hline Edição / Impressão & $6^{\mathrm{a}}$ edição correcta e augmentada \\
\hline $\begin{array}{c}\text { Outras obras do mesmo } \\
\text { autor }\end{array}$ & - \\
\hline $\begin{array}{c}\text { Outras edições e } \\
\text { reimpressões conhecidas }\end{array}$ & $\begin{array}{l}\text { 1887. Grammatica Portugueza. } 1^{\mathrm{a}} \text { ed. } \\
\text { 1915. Grammatica Portugueza. Rio de Janeiro: Francisco Alvez. } 15^{\mathrm{a}} \text { ed. }\end{array}$ \\
\hline $\begin{array}{l}\text { Descrição da edição } \\
\text { consultada }\end{array}$ & $\begin{array}{l}\text { Folha de rosto: Grammatica Portugueza pelo Dr. Alfredo Gomes (da Escola } \\
\text { Normal). Adopatada no Gymnasio Nacional, Escola Normal, Collegio } \\
\text { Militar, Collegio Abilio, Collegio Moss, etc. - } 6^{\text {a }} \text { edição Correcta e } \\
\text { Augmentada - Capital Federal. Na livraria de J. G. de Azevedo, editor. } 33 \\
\text { Rua da Uruguayana - } 1895 . \\
\text { Número de páginas: } 215\end{array}$ \\
\hline Sumário da obra & $\begin{array}{l}\text { I. Grammatica geral e particular; seu objecto e divisões. Phonologia. (3-6) } \\
\text { II. Prosodia. Accentuação e quantidade. (7-12) } \\
\text { III. Graphica. Notações vocabulares (13-23) } \\
\text { IV. Taxeonomia. Substantivo e suas especies (24- } \\
\text { V. Pronome: suas especies (28-30) } \\
\text { VI. Adjetivo: suas especies (31-33) } \\
\text { VII. Verbo: suas especies (34-36) } \\
\text { VIII. Adverbo, preposição, conjunção e interjeição. Suas especies. (37-42) } \\
\text { IX. Kampenomia. Flexões nominaes. Genero, numero. Vestigio de casos em } \\
\text { portuguez (43-47) } \\
\text { X. Flexões nominaes: fráo (48-51) } \\
\text { XI. Pronome. Sua flexão. (52-53) } \\
\text { XII. Flexões verbaes; conjugação (54-57) } \\
\text { XIII. Verbos apparentemente irregulares (58-60) } \\
\text { XIV. Principaes verbos irregulares (61-67) } \\
\text { XV. Conjungações periphrasticas (68-71) } \\
\text { XVI. Etymologia: seus processos (72-16) } \\
\text { XVII. Familia de palavras. Paronymos, homonymos, synonymos, } \\
\text { antonymos. (77-80) } \\
\text { XVIII. Composição de palavras (81-84) } \\
\text { XIX. Derivação de palavras (85-88) } \\
\text { XX. Formação vernacula (89-91) } \\
\text { XXI. Historia da lingua portuguesa (92-96) } \\
\text { XXII. Formação do lexico portuguez (97-98) } \\
\text { XXIII. Permutas (99-104) } \\
\text { XXIV. Metaplasmos (105-107) } \\
\text { XXV. Corrente erudita. Corrente popular. Discplina grammatical no XVI } \\
\text { seculo (108-109) } \\
\text { XXVI. Fórmas divergentes e convergentes (110-112) } \\
\text { XXVII. Etymologia dos substantivos. Caso formador da desinencia } \\
\text { vocabular portugueza (113-115) } \\
\text { XXVIII. Etymologia do artigo, dor pronome e adjectivoss determinativos } \\
\text { em geral (116-118) } \\
\text { XXIX. Etymologia das formas verbaes (119-122) } \\
\text { XXX. Etymologia das palavras invariaveis (123-124) } \\
\text { XXXI. Syntaxe (125-128) } \\
\text { XXXII. Coordenação e subordinação dos periodos (129-130) } \\
\text { XXXIII. Syntaxe dos termos da oração (concordancia e regencia) (131-138) }\end{array}$ \\
\hline
\end{tabular}




\begin{tabular}{|l|l|}
\hline & XXXIV. Syntaxe dos termos da oração (construção da oração e do periodo) \\
& (139-144) \\
& XXXV. Syntaxe do substantivo (145-148) \\
XXXVI. Syntaxe do pronome (149-154) & XXXVII. Collocação dos pronomes pessoaes (155-157) \\
& XXXVIIII. Syntaxe de adjectivo e do artigo em especial (158-165) \\
& XXXIX. Syntaxe do verbo. (166-173) \\
& XL. Fórmas nominaes do verbo (174-177) \\
& XLI. Syntaxe das palavras invariaveis (178-187) \\
& XLII. Syntaxe do verbo haver e do pronome se (188-190) \\
& XLIII. Figuras de syntaxe. Particulas de realce (191-183) \\
& XLIV. Vicio de linguagem (194-196) \\
& XLV. Anomalias grammaticaes (197-198) \\
& XLVI. Typos syntacticos divergentes e convergentes (199-202) \\
& XLVII. Alerações lexias e syntacticas (203-205) \\
& XLVIII. Noções syntacticas. Uso do maiusculo (206-208) \\
XLIX. Differenças principaes entre o latim classico e o latim popular (209- & 211) \\
& Modelo de analyse syntactica (212-215) \\
\hline Objetivo do autor & - \\
\hline
\end{tabular}




\begin{tabular}{|c|c|}
\hline \multicolumn{2}{|r|}{ FD 18. MACIEL 1895} \\
\hline Título & Grammatica Descriptiva baseada nas doutrinas modernas \\
\hline $\begin{array}{c}\text { Autor (biodatas e local de } \\
\text { nascimento e morte) }\end{array}$ & Maximino de Araújo Maciel (1865 Larangeiras - 1923 Rio de Janeiro) \\
\hline Ano & 1895 \\
\hline Local de impressão & Capital Federal \\
\hline Typ. & Typ. do Pazo \& C. \\
\hline Edição / Impressão & $2^{\mathrm{a}} ?$ \\
\hline $\begin{array}{c}\text { Outras obras do mesmo } \\
\text { autor }\end{array}$ & $\begin{array}{l}1889 \text { - Philologia Portugueza, Rio de Janeiro. } \\
1901 \text { - Noções geraes de agronomia. Rio de Janeiro: Garnier. } \\
1903 \text { - Lições de botânica geral. Rio de Janeiro: Garnier. } \\
1913 \text { - Elementos de chimica geral. Rio de Janeiro: Francisco Alves. }\end{array}$ \\
\hline $\begin{array}{c}\text { Outras edições e } \\
\text { reimpressões conhecidas }\end{array}$ & 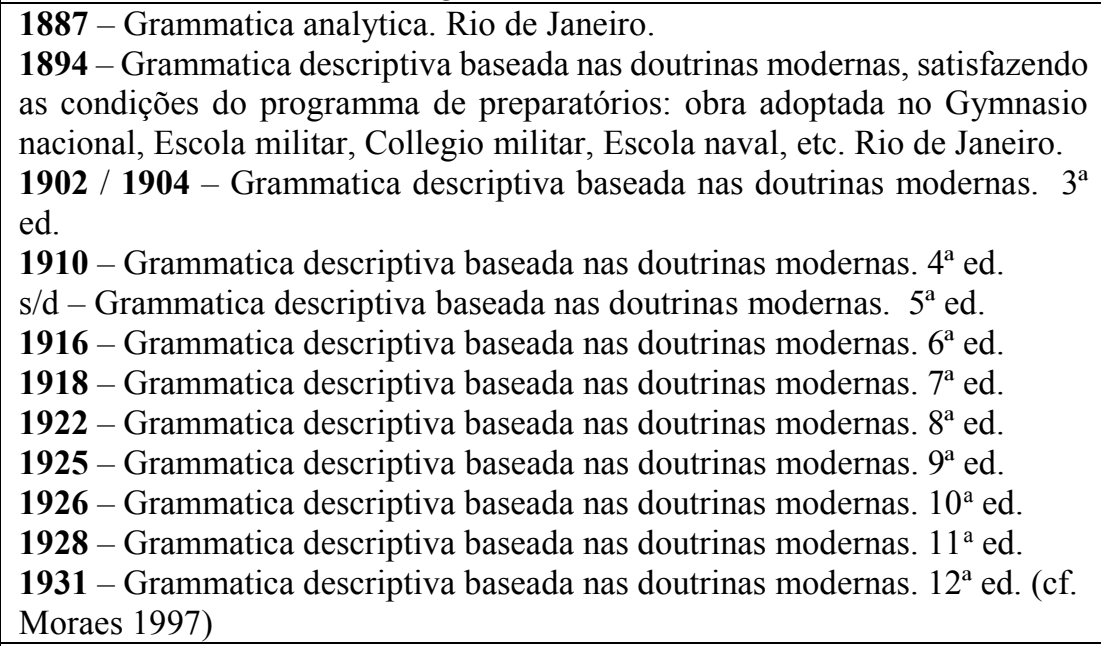 \\
\hline $\begin{array}{l}\text { Descrição da edição } \\
\text { consultada }\end{array}$ & $\begin{array}{l}\text { Folha de rosto: } \\
\text { Língua Portugueza - Grammatica Descriptiva baseada nas doutrinas } \\
\text { modernas por Maximino de Araujo Maciel / Natural de Sergipe / Formado } \\
\text { em direito e em sciencias sociaes, professor cathedratico no Collegio } \\
\text { Militar. } \\
\text { Epígrafe: "Lex sum sermonis, linguarum regula certa, qui me non didicit, } \\
\text { caetera nulla petat" (Bacon) } \\
\text { Capital Federal / Typ. de Pazo \& C., rua Sete de Setembro } 83 \text { / } 1895 . \\
\text { Outra página: } \\
\text { (Dedicatória) Aos meus amigos Drs. Joaquim Abilio Borges e José } \\
\text { Domingues de Andrade. } \\
\text { Outra página: } \\
\text { (Agradecimento) Ao meu amigo Heliodoro Pereira agradeço o auxilio que } \\
\text { me prestou na revisão d'este trabalho. } \\
\text { Número de páginas: } 333\end{array}$ \\
\hline Sumário da obra & \begin{tabular}{|l} 
Noções propedeuticas (1) \\
Pronologia e sua subdivisão (4-59) \\
Phonetica (4-17) \\
Phonemas (5) \\
Classificação physiologica (8) \\
Grupos fonéticos (9) \\
Diphtongos (9) \\
Triphtongos (12) \\
Grupos consonantaes (13) \\
Syllabismo (15) \\
Phonographia (17-27) \\
\end{tabular} \\
\hline
\end{tabular}




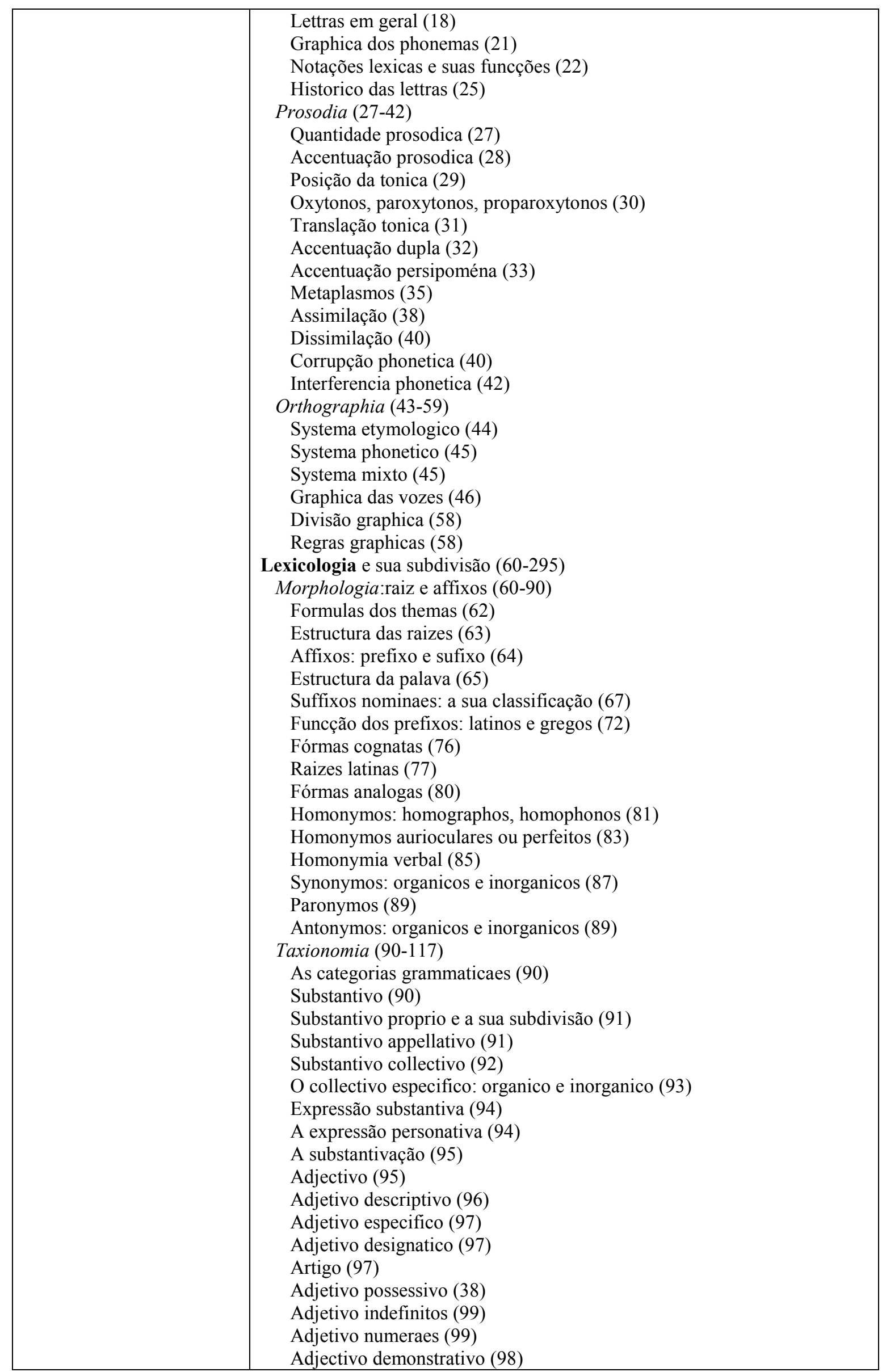




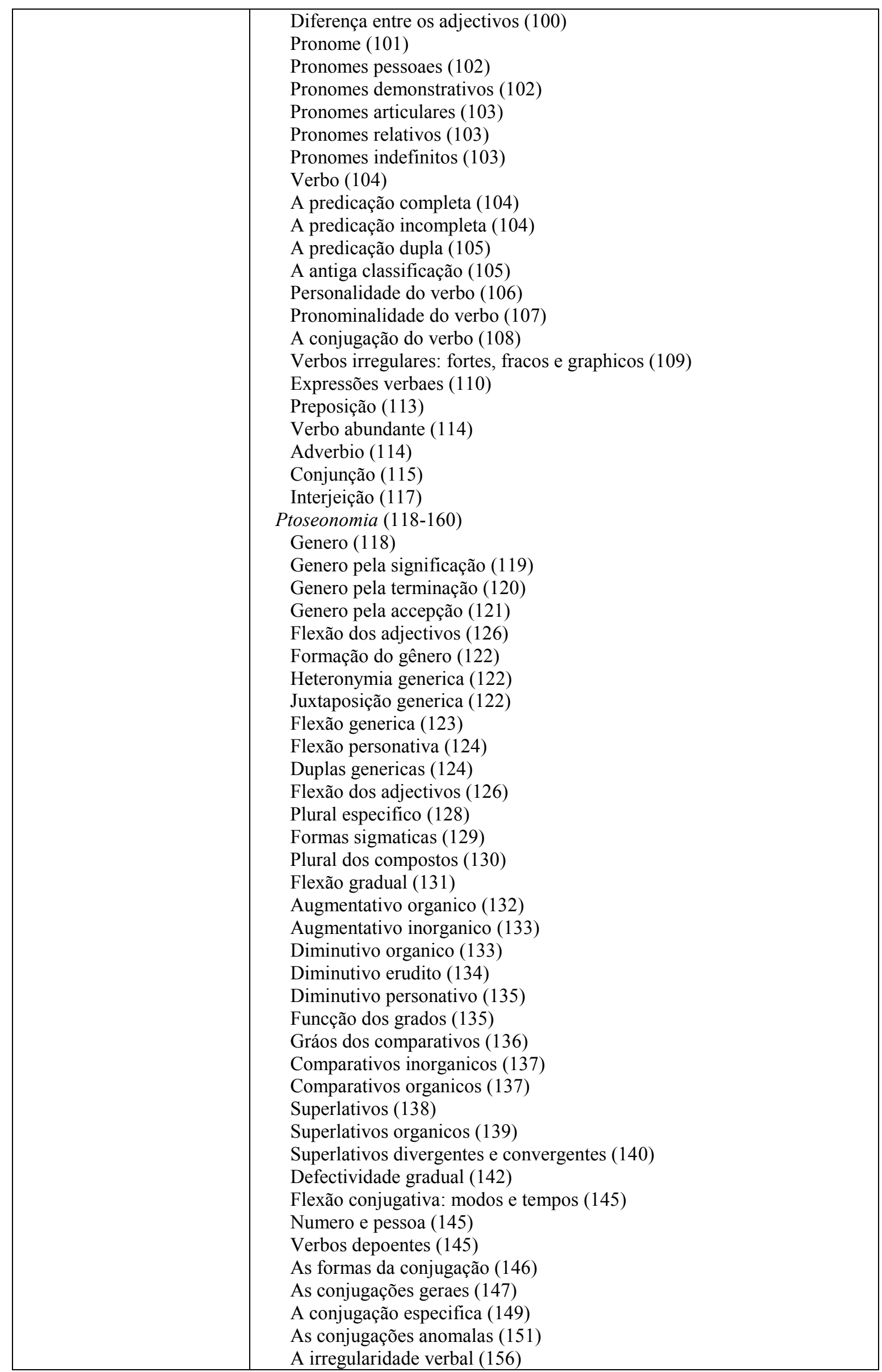




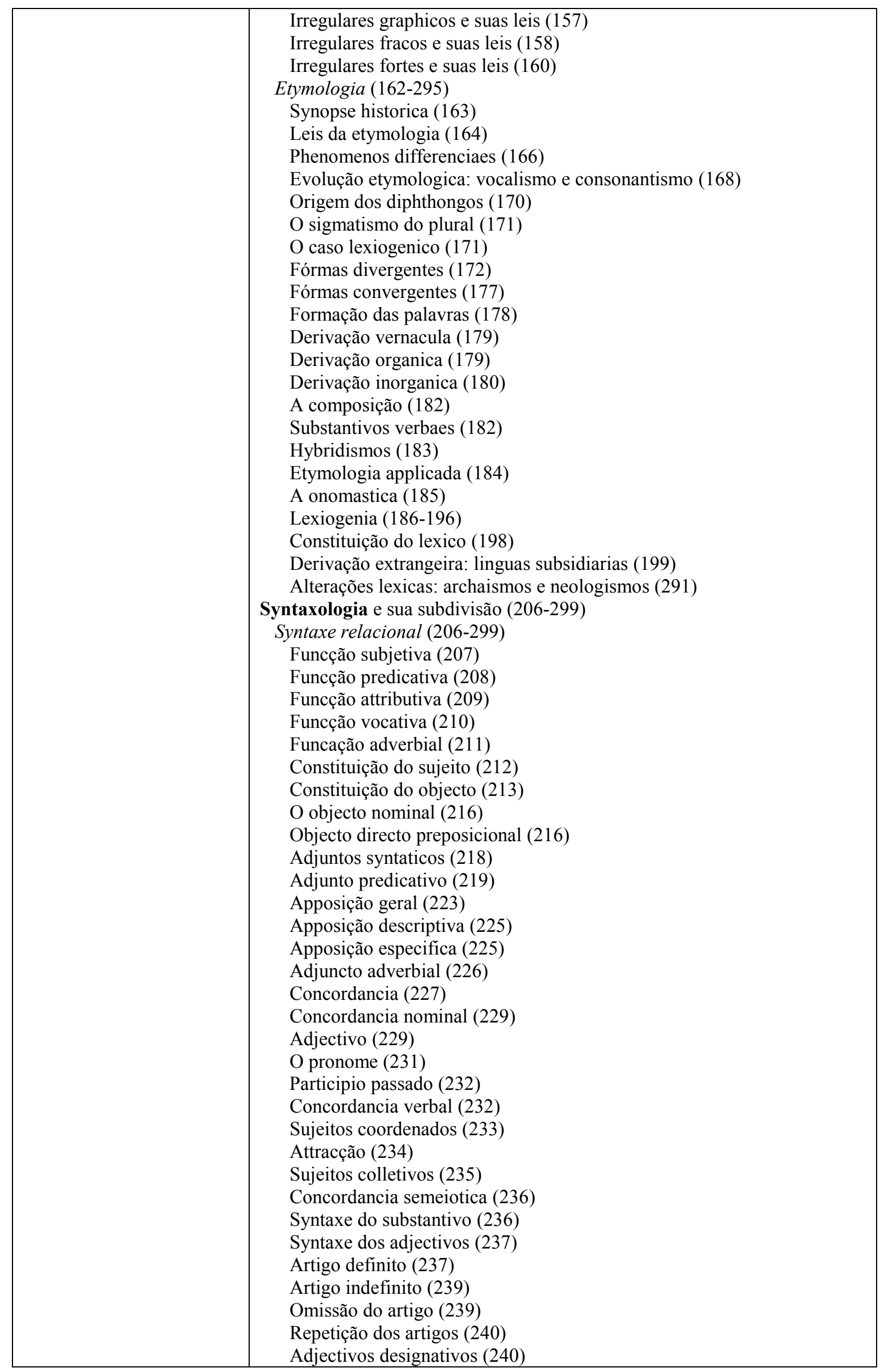




\begin{tabular}{|c|c|}
\hline & 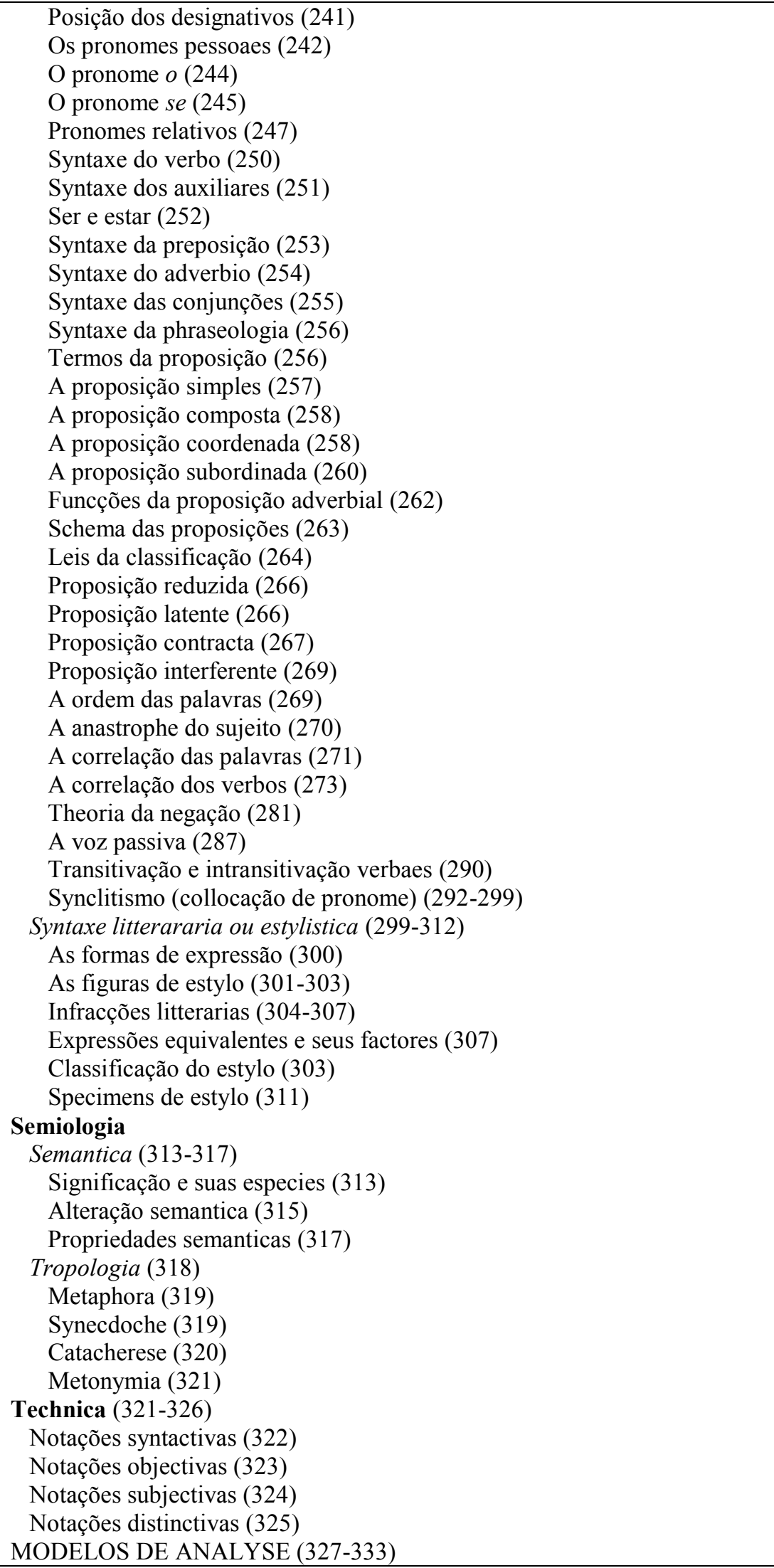 \\
\hline Objetivo do autor & $\begin{array}{l}\text { "PROLOGO. Em } 1887 \text { publicámos o nosso primeiro trabalho - Grammatica } \\
\text { Analytica em que, baseando-nos nas doutrinas modernas, concorremos de } \\
\text { algum modo para romper com a velha tradição, quebrando os antigos moldes } \\
\text { em que se vasava a grammaticographia. E' certo que esse trabalho nosso a } \\
\text { que alludímos, posto que houvesse sido acceito pelos competentes e exaltado }\end{array}$ \\
\hline
\end{tabular}




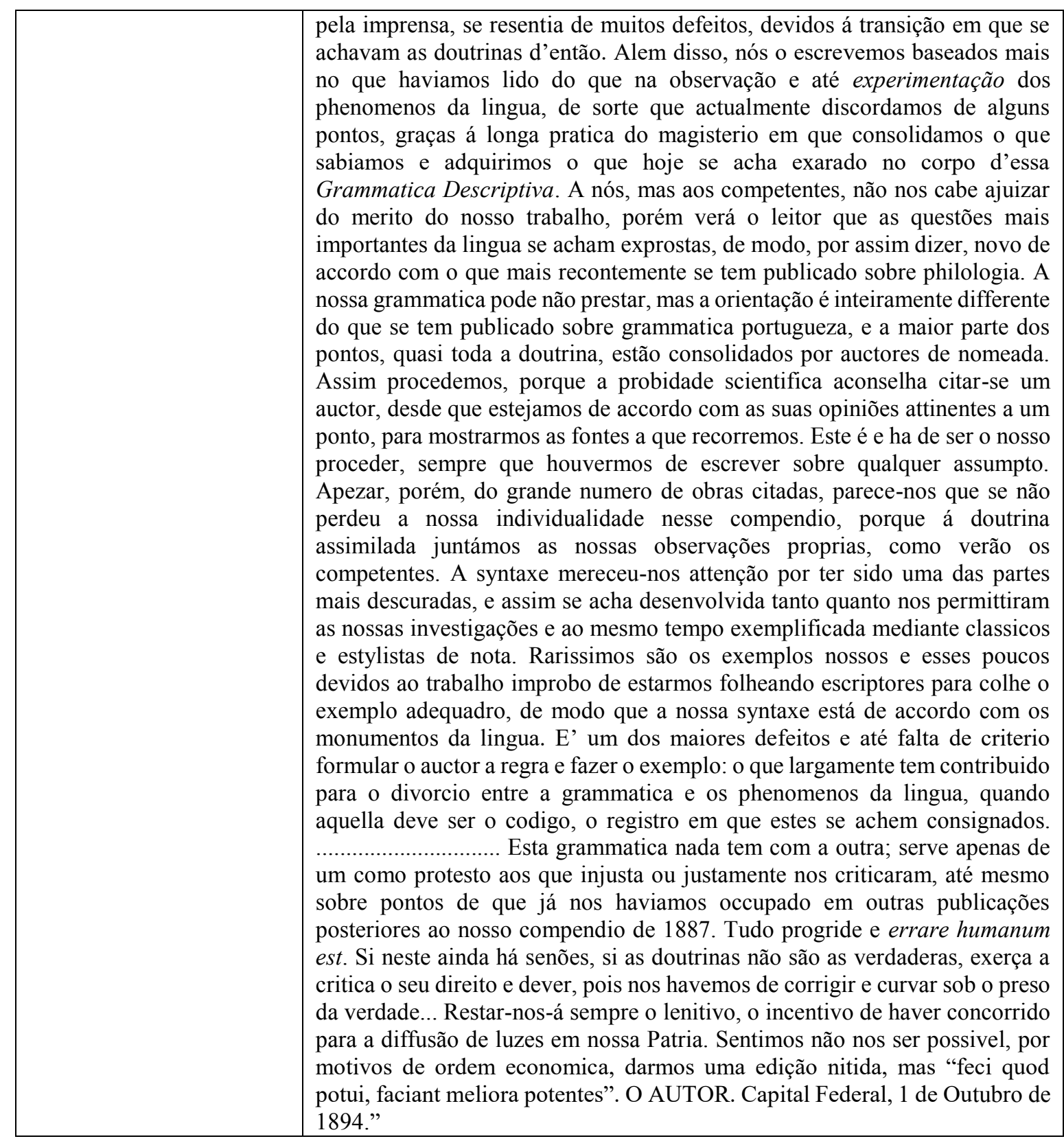

